\title{
Fifty State Survey of Mandatory Reporting Statutes
}

\section{NIC/WCL Project on Addressing Prison Rape}

\begin{tabular}{|c|c|}
\hline \multicolumn{2}{|r|}{ ALABAMA } \\
\hline $\begin{array}{l}\text { Mandatory Reporting } \\
\text { Statute } \\
\text { (Alabama) }\end{array}$ & $\begin{array}{l}\text { AGAINST A CHILD } \\
\text { ALA. CODE } 1975 \text { § 26-14-3 (West 2008) }\end{array}$ \\
\hline $\begin{array}{l}\text { What has to be } \\
\text { reported? } \\
\text { (Alabama) }\end{array}$ & $\begin{array}{l}\text { ALA. CODE } 1975 \text { § 26-14-3 (West 2008) } \\
\text { (a) When the child is known or suspected to be a victim of child abuse or neglect. }\end{array}$ \\
\hline $\begin{array}{l}\text { Relevant Definitions } \\
\text { (Alabama) }\end{array}$ & $\begin{array}{l}\text { ALA. CODE } 1975 \text { § 26-14-1 (West 2008) } \\
\text { (3) Child means a person under the age of } 18 \text { years. } \\
\text { ALA. CODE } 1975 \text { § 26-14-1 (West 2008) } \\
\text { (1) Abuse means harm or threatened harm to a child's health or welfare. Harm or threatened harm to a child's health or welfare can } \\
\text { occur through nonaccidental physical or mental injury, sexual abuse or attempted sexual abuse or sexual exploitation or attempted } \\
\text { sexual exploitation. "Sexual abuse" includes the employment, use, persuasion, inducement, enticement, or coercion of any child to } \\
\text { engage in, or having a child assist any other person to engage in any sexually explicit conduct or any simulation of the conduct for } \\
\text { the purpose of producing any visual depiction of the conduct; or the rape, molestation, prostitution, or other form of sexual } \\
\text { exploitation of children, or incest with children as those acts are defined by Alabama law. "Sexual exploitation" includes allowing, } \\
\text { permitting, or encouraging a child to engage in prostitution and allowing, permitting, encouraging or engaging in the obscene or } \\
\text { pornographic photographing, filming, or depicting of a child for commercial purposes. } \\
\text { (2) Neglect means negligent treatment or maltreatment of a child, including the failure to provide adequate food, medical }\end{array}$ \\
\hline
\end{tabular}

NOTE:

** For purposes of this chart, corrections officers, police officers, peace officers, probation officers or "catch-all” phrases such as "all persons" have been bolded. However, many mandatory reporters include professionals who may have contact or work in correctional facilities. Such individuals include physicians, nurses, dentists, teachers and social workers. These statutes can be used as a tool to require staff other than correctional officers to report sexual misconduct with inmates.

This publication is developed by the NIC/WCL Project on Addressing Prison Rape under NIC Cooperative Agreement 06S20GJJ1.

This is not to be reproduced or cited without permission from the authors.

American University, Washington College of Law

Current as of May 7, 2009 


\section{Fifty State Survey of Mandatory Reporting Statutes}

\section{NIC/WCL Project on Addressing Prison Rape}

\begin{tabular}{|c|c|}
\hline $\begin{array}{l}\text { Relevant Definitions } \\
\text { Cont'd } \\
\text { (Alabama) }\end{array}$ & $\begin{array}{l}\text { treatment, supervision, clothing, or shelter. } \\
\text { (4) Duly constituted authority means the chief of police of a municipality or municipality and county; or the } \\
\text { sheriff, if the observation of child abuse or neglect is made in an unincorporated territory; or the Department of Human } \\
\text { Resources; or any person, organization, corporation, group, or agency authorized and designated by the Department of } \\
\text { Human Resources to receive reports of child abuse and neglect; provided that a "duly constituted authority" shall not include an } \\
\text { agency involved in the acts or omissions of the reported child abuse or neglect. }\end{array}$ \\
\hline $\begin{array}{l}\text { Persons Required to } \\
\text { Report } \\
\text { (Alabama) }\end{array}$ & $\begin{array}{l}\text { ALA. CoDE } 1975 \text { § 26-14-3 (West 2008) } \\
\text { (a) All: } \\
\text { - Law enforcement officials; } \\
\text { - Peace officers; } \\
\text { - Hospitals; } \\
\text { - Clinics; } \\
\text { - Sanitariums; } \\
\text { - Doctors; } \\
\text { - Physicians; } \\
\text { - Surgeons; } \\
\text { - Medical examiners; } \\
\text { - Coroners; } \\
\text { - Dentists; } \\
\text { - Osteopaths; } \\
\text { - Optometrists; } \\
\text { - Chiropractors; } \\
\text { - Podiatrists; }\end{array}$ \\
\hline
\end{tabular}

NOTE:

** For purposes of this chart, corrections officers, police officers, peace officers, probation officers or "catch-all” phrases such as "all persons" have been bolded. However, many mandatory reporters include professionals who may have contact or work in correctional facilities. Such individuals include physicians, nurses, dentists, teachers and social workers. These statutes can be used as a tool to require staff other than correctional officers to report sexual misconduct with inmates.

This publication is developed by the NIC/WCL Project on Addressing Prison Rape under NIC Cooperative Agreement 06S20GJJ1.

This is not to be reproduced or cited without permission from the authors.

American University, Washington College of Law

Current as of May 7, 2009 


\section{Fifty State Survey of Mandatory Reporting Statutes}

\section{NIC/WCL Project on Addressing Prison Rape}

\begin{tabular}{|c|c|}
\hline $\begin{array}{l}\text { Persons Required to } \\
\text { Report Cont'd } \\
\text { (Alabama) }\end{array}$ & $\begin{array}{l}\text { - Nurses; } \\
\text { - School teachers and officials; } \\
\text { - } \text { Pharmacists; } \\
\text { - Social workers; } \\
\text { - } \text { Day care workers or employees; } \\
\text { - } \text { Mental health professionals; } \\
\text { - } \text { Members of the clergy; } \\
\text { - } \text { Any other person called upon to render aid or medical assistance to any child. Private mental health center was not state actor } \\
\text { for purposes of } 42 \text { U.S.C.A. § } 1983 \text { where it reported allegations made by plaintiff's ex-wife that plaintiff had abused his } \\
\text { children; center was required by state law to report such allegations. Barber v. Dale County Mental Health Center, } 898 \text { F.Supp. } \\
832 \text { (M.D.Ala.1995), affirmed } 98 \text { F.3d } 1353 \text {. }\end{array}$ \\
\hline $\begin{array}{l}\text { Reporting } \\
\text { Procedures } \\
\text { (Alabama) }\end{array}$ & $\begin{array}{l}\text { ALA. CODE } 1975 \text { § 26-14-3 (West 2008) } \\
\text { (a) [A mandatory reporter] shall be required to report, or cause a report to be made of the same, orally, either by telephone or } \\
\text { direct communication immediately, followed by a written report, to a duly constituted authority. }\end{array}$ \\
\hline $\begin{array}{l}\text { Penalty for Failure to } \\
\text { Report } \\
\text { (Alabama) }\end{array}$ & $\begin{array}{l}\text { ALA. CODE } 1975 \S 26-14-13 \text { (West 2008) } \\
\text { Any person who shall knowingly fail to make the report required by this chapter shall be guilty of a misdemeanor and shall be } \\
\text { punished by a sentence of not more than six months' imprisonment or a fine of not more than } \$ 500.00 \text {. }\end{array}$ \\
\hline $\begin{array}{l}\text { Mandatory } \\
\text { Reporting Statute } \\
\text { (Alabama) }\end{array}$ & $\begin{array}{l}\text { AGAINST AN ADULT } \\
\text { ALA. CODE } 1975 \text { § 38-9-8 (West 2008) }\end{array}$ \\
\hline
\end{tabular}

NOTE:

** For purposes of this chart, corrections officers, police officers, peace officers, probation officers or "catch-all” phrases such as “all persons” have been bolded. However, many mandatory reporters include professionals who may have contact or work in correctional facilities. Such individuals include physicians, nurses, dentists, teachers and social workers. These statutes can be used as a tool to require staff other than correctional officers to report sexual misconduct with inmates.

This publication is developed by the NIC/WCL Project on Addressing Prison Rape under NIC Cooperative Agreement 06S20GJJ1.

This is not to be reproduced or cited without permission from the authors.

American University, Washington College of Law

Current as of May 7, 2009 


\section{Fifty State Survey of Mandatory Reporting Statutes}

\section{NIC/WCL Project on Addressing Prison Rape}

\begin{tabular}{|c|c|}
\hline $\begin{array}{l}\text { What has to be } \\
\text { reported? } \\
\text { (Alabama) }\end{array}$ & $\begin{array}{l}\text { ALA. CODE } 1975 \S 38-9-8 \text { (West 2008) } \\
\text { (a) Reasonable cause to believe that any protected person has been subjected to physical abuse, neglect, exploitation, sexual abuse, } \\
\text { or emotional abuse. } \\
\text { ALA. CODE } 1975 \S 38-9-8 \text { (West 2008) } \\
\text { (c) The county department of human resources shall not be required to investigate any report of abuse, neglect, exploitation, sexual } \\
\text { abuse, or emotional abuse that occurs in any facility owned and operated by the Alabama Department of Corrections or the } \\
\text { Alabama Department of Mental Health and Mental Retardation. }\end{array}$ \\
\hline $\begin{array}{l}\text { Relevant Definitions } \\
\text { (Alabama) }\end{array}$ & $\begin{array}{l}\text { ALA. CODE } 1975 \text { § 38-9-2 (West 2008) } \\
\text { (1) “Abuse” means the infliction of physical pain, injury, or the willful deprivation by a caregiver or other person of services } \\
\text { necessary to maintain mental and physical health. } \\
\text { (2) Adult in need of protective services is a person } 18 \text { years of age or older whose behavior indicates that he or she is mentally } \\
\text { incapable of adequately caring for himself or herself and his or her interests without serious consequences to himself or herself or } \\
\text { others, or who, because of physical or mental impairment, is unable to protect himself or herself from abuse, neglect, exploitation, } \\
\text { sexual abuse, or emotional abuse by others, and who has no guardian, relative, or other appropriate person able, willing, and } \\
\text { available to assume the kind and degree of protection and supervision required under the circumstances. } \\
\text { (8) "Exploitation” means the expenditure, diminution, or use of the property, assets, or resources of a protected person without the } \\
\text { express voluntary consent of that person or his or her legally authorized representative. } \\
\text { (12) "Neglect” means the failure of a caregiver to provide food, shelter, clothing, medical services, or health care for the person } \\
\text { unable to care for himself or herself; or the failure of the person to provide these basic needs for himself or herself when the failure } \\
\text { is the result of the person's mental or physical inability. } \\
\text { (17) "Protected person” means any person over } 18 \text { years of age subject to protection under this chapter or any person, including, } \\
\text { but not limited to, persons who are senile, mentally ill, developmentally disabled, or mentally retarded, or any person over } 18\end{array}$ \\
\hline
\end{tabular}

\section{NOTE:}

(17) "Protected person” means any person over 18 years of age subject to protection under this chapter or any person, includin

** For purposes of this chart, corrections officers, police officers, peace officers, probation officers or “catch-all” phrases such as “all persons” have been bolded. However, many mandatory reporters include professionals who may have contact or work in correctional facilities. Such individuals include physicians, nurses, dentists, teachers and social workers. These statutes can be used as a tool to require staff other than correctional officers to report sexual misconduct with inmates.

This publication is developed by the NIC/WCL Project on Addressing Prison Rape under NIC Cooperative Agreement 06S20GJJ1.

This is not to be reproduced or cited without permission from the authors.

American University, Washington College of Law

Current as of May 7, 2009 


\section{Fifty State Survey of Mandatory Reporting Statutes}

\section{NIC/WCL Project on Addressing Prison Rape}

\begin{tabular}{|c|c|}
\hline $\begin{array}{l}\text { Relevant Definitions } \\
\text { Cont'd } \\
\text { (Alabama) }\end{array}$ & $\begin{array}{l}\text { years of age that is mentally or physically incapable of adequately caring for himself or herself and his or her interests without } \\
\text { serious consequences to himself or herself or others. } \\
\text { (22) "Sexual abuse" means any conduct that is a crime including rape, sexual torture, sexual misconduct, sodomy, and sexual } \\
\text { abuse. }\end{array}$ \\
\hline $\begin{array}{l}\text { Persons Required to } \\
\text { Report } \\
\text { (Alabama) }\end{array}$ & $\begin{array}{l}\text { ALA. CODE } 1975 \S 38-9-8 \text { (West 2008) } \\
\text { (a) All physicians and other practitioners of the healing arts or any caregiver }\end{array}$ \\
\hline $\begin{array}{l}\text { Reporting } \\
\text { Procedures } \\
\text { (Alabama) }\end{array}$ & $\begin{array}{l}\text { ALA. CODE } 1975 \text { § 38-9-8 (West 2008) } \\
\text { (a)(1) An oral report, by telephone or otherwise, shall be made immediately, followed by a written report, to the county } \\
\text { department of human resources or to the chief of police of the city or city and county, or to the sheriff of the county if the } \\
\text { observation is made in an unincorporated territory, except that reports of a nursing home employee who abuses, neglects, or } \\
\text { misappropriates the property of a nursing home resident shall be made to the Department of Public Health. The requirements to } \\
\text { report suspicion of suspected abuse, neglect, or misappropriation of property of a nursing home resident by an employee of a } \\
\text { nursing home shall be deemed satisfied if the report is made in accordance with the rules of the State Board of Health. } \\
\text { (a)(2) Within seven days following an oral report, an investigation of any alleged abuse, neglect, exploitation, sexual abuse, or } \\
\text { emotional abuse shall be made by the county department of human resources or the law enforcement official, whichever receives } \\
\text { the report, and a written report prepared which includes the following: } \\
\text { a. Name, age, and address of the person. } \\
\text { b. Nature and extent of injury suffered by the person. } \\
\text { c. Any other facts or circumstances known to the reporter which may aid in the determination of appropriate action. } \\
\text { (b) All reports prepared by a law enforcement official shall be forwarded to the county department of human resources within } 24 \\
\text { hours. }\end{array}$ \\
\hline
\end{tabular}

NOTE:

** For purposes of this chart, corrections officers, police officers, peace officers, probation officers or "catch-all” phrases such as “all persons” have been bolded. However, many mandatory reporters include professionals who may have contact or work in correctional facilities. Such individuals include physicians, nurses, dentists, teachers and social workers. These statutes can be used as a tool to require staff other than correctional officers to report sexual misconduct with inmates.

This publication is developed by the NIC/WCL Project on Addressing Prison Rape under NIC Cooperative Agreement 06S20GJJ1.

This is not to be reproduced or cited without permission from the authors.

American University, Washington College of Law

Current as of May 7, 2009 


\section{Fifty State Survey of Mandatory Reporting Statutes}

\section{NIC/WCL Project on Addressing Prison Rape}

\begin{tabular}{|c|c|}
\hline $\begin{array}{l}\text { Penalty for Failure to } \\
\text { Report } \\
\text { (Alabama) }\end{array}$ & $\begin{array}{l}\text { ALA. CODE } 1975 \S 38-9-10 \text { (West 2008) } \\
\text { Any physician or other practitioner of the healing arts knowingly failing to make the report required by this chapter shall be guilty } \\
\text { of a misdemeanor and shall, upon conviction, be punished by imprisonment for not more than six months or a fine of not more } \\
\text { than } \$ 500.00 \text {. }\end{array}$ \\
\hline & ALASKA \\
\hline $\begin{array}{l}\text { Mandatory } \\
\text { Reporting Statute } \\
\text { (Alaska) }\end{array}$ & $\begin{array}{l}\text { AGAINST A CHILD } \\
\text { AS } \S 47.17 .020 \text { (West 2008) }\end{array}$ \\
\hline $\begin{array}{l}\text { What has to be } \\
\text { reported? } \\
\text { (Alaska) }\end{array}$ & $\begin{array}{l}\text { AS } \S 47.17 .020 \text { (West 2008) } \\
\text { (a) Reasonable cause to suspect that a child has suffered harm as a result of child abuse or neglect. }\end{array}$ \\
\hline $\begin{array}{l}\text { Relevant Definitions } \\
\text { (Alaska) }\end{array}$ & $\begin{array}{l}\text { AS } § 47.17 .290 \text { (West 2008) } \\
\text { (2) Child abuse or neglect means the physical injury or neglect, mental injury, sexual abuse, sexual exploitation, or maltreatment } \\
\text { of a child under the age of } 18 \text { by a person under circumstances that indicate that the child's health or welfare is harmed or } \\
\text { threatened thereby; in this paragraph, "mental injury" means an injury to the emotional well-being, or intellectual or psychological } \\
\text { capacity of a child, as evidenced by an observable and substantial impairment in the child's ability to function. }\end{array}$ \\
\hline $\begin{array}{l}\text { Persons Required to } \\
\text { Report } \\
\text { (Alaska) }\end{array}$ & $\begin{array}{l}\text { AS } \S 47.17 .020 \text { (West 2008) } \\
\text { (a)(1-8): } \\
\text { (1) Practitioners of the healing arts; } \\
\text { (2) Peace officers and officers of the Department of Corrections; }\end{array}$ \\
\hline
\end{tabular}

\section{NOTE:}

** For purposes of this chart, corrections officers, police officers, peace officers, probation officers or "catch-all” phrases such as “all persons” have been bolded. However, many mandatory reporters include professionals who may have contact or work in correctional facilities. Such individuals include physicians, nurses, dentists, teachers and social workers. These statutes can be used as a tool to require staff other than correctional officers to report sexual misconduct with inmates.

This publication is developed by the NIC/WCL Project on Addressing Prison Rape under NIC Cooperative Agreement 06S20GJJ1.

This is not to be reproduced or cited without permission from the authors.

American University, Washington College of Law

Current as of May 7, 2009 


\section{Fifty State Survey of Mandatory Reporting Statutes}

\section{NIC/WCL Project on Addressing Prison Rape}

\begin{tabular}{|c|c|}
\hline $\begin{array}{l}\text { Persons Required to } \\
\text { Report Cont'd } \\
\text { (Alaska) }\end{array}$ & $\begin{array}{l}\text { (3) School teachers and school administrative staff members of public and private schools; } \\
\text { (4) Administrative officers of institutions; } \\
\text { (5) Child care providers; } \\
\text { (6) Paid employees of domestic violence and sexual assault programs, and crisis intervention and prevention programs; } \\
\text { (7) Paid employees of an organization that provides counseling or treatment to individuals seeking to control their use of drugs } \\
\text { or alcohol; } \\
\text { (8) Members of a child fatality review team or the multidisciplinary child protection team. } \\
\text { (b) This section does not prohibit the named persons from reporting cases that have come to their attention in their non- } \\
\text { occupational capacities, nor does it prohibit any other person from reporting a child's harm that the person has reasonable cause } \\
\text { to suspect is a result of child abuse or neglect. These reports shall be made to the nearest office of the department. }\end{array}$ \\
\hline $\begin{array}{l}\text { Reporting } \\
\text { Procedures } \\
(\text { Alaska) }\end{array}$ & $\begin{array}{l}\text { AS } \S 47.17 .020 \text { (West 2008) } \\
\text { (a) A mandatory reporter shall immediately report the harm to the nearest office of the department. } \\
\text { (c) If the person making a report of harm under this section cannot reasonably contact the nearest office of the department and } \\
\text { immediate action is necessary for the well-being of the child, the person shall make the report to a peace officer. The peace officer } \\
\text { shall immediately take action to protect the child and shall, at the earliest opportunity, notify the nearest office of the department. } \\
\text { (e) The department shall immediately notify the nearest law enforcement agency if the department } \\
\text { (1) concludes that the harm was caused by a person who is not responsible for the child's welfare; } \\
\text { (2) is unable to determine } \\
\text { (A) who caused the harm to the child; or } \\
\text { (B) whether the person who is believed to have caused the harm has responsibility for the child's welfare; or } \\
\text { (3) concludes that the report involves } \\
\text { (A) possible criminal conduct under AS } 11.41 .410--11.41 .458 \text {; or } \\
\text { (B) abuse or neglect that results in the need for medical treatment of the child. }\end{array}$ \\
\hline
\end{tabular}

** For purposes of this chart, corrections officers, police officers, peace officers, probation officers or "catch-all” phrases such as “all persons” have been bolded. However, many mandatory reporters include professionals who may have contact or work in correctional facilities. Such individuals include physicians, nurses, dentists, teachers and social workers. These statutes can be used as a tool to require staff other than correctional officers to report sexual misconduct with inmates.

This publication is developed by the NIC/WCL Project on Addressing Prison Rape under NIC Cooperative Agreement 06S20GJJ1.

This is not to be reproduced or cited without permission from the authors.

American University, Washington College of Law

Current as of May 7, 2009 


\section{Fifty State Survey of Mandatory Reporting Statutes}

\section{NIC/WCL Project on Addressing Prison Rape}

\begin{tabular}{|c|c|}
\hline $\begin{array}{l}\text { Penalty for Failure to } \\
\text { Report } \\
\text { (Alaska) }\end{array}$ & $\begin{array}{l}\text { AS } \S 47.17 .068 \text { (West 2008) } \\
\text { Class A Misdemeanor } \\
\text { AS } \S 12.55 .135 \text { (West 2008) } \\
\text { Maximum of } 1 \text { year imprisonment } \\
\text { AS } \S 12.55 .035 \text { (West } 2008 \text { ) } \\
\text { (b)(5)Maximum of } \$ 10,000 \text { fine }\end{array}$ \\
\hline $\begin{array}{l}\text { Mandatory } \\
\text { Reporting Statute } \\
\text { (Alaska) }\end{array}$ & $\begin{array}{l}\text { AGAINST AN ADULT } \\
\text { AS } \S 47.24 .010 \text { (West 2008) }\end{array}$ \\
\hline $\begin{array}{l}\text { What has to be } \\
\text { reported? } \\
\text { (Alaska) }\end{array}$ & $\begin{array}{l}\text { AS } \S 47.24 .010 \text { (West 2008) } \\
\text { (a) Reasonable cause to believe that in the performance of their professional duties a vulnerable adult suffers from abandonment, } \\
\text { exploitation, abuse, neglect, or self-neglect. }\end{array}$ \\
\hline $\begin{array}{l}\text { Relevant Definitions } \\
\text { (Alaska) }\end{array}$ & $\begin{array}{l}\text { AS § 47.24.900 (West 2008) } \\
\text { (1) Abandonment means desertion of a vulnerable adult by a caregiver. } \\
\text { (2) “Abuse” means: } \\
\text { (A) the willful, intentional, or reckless nonaccidental, and nontherapeutic infliction of physical pain, injury, or mental distress; or } \\
\text { (B) sexual assault. } \\
\text { (7) Exploitation means unjust or improper use of another person or another person's resources for one's own profit or advantage. } \\
\text { (8) Incapacitated person means a person whose ability to receive and evaluate information or to communicate decisions is }\end{array}$ \\
\hline
\end{tabular}

NOTE:

** For purposes of this chart, corrections officers, police officers, peace officers, probation officers or "catch-all” phrases such as "all persons" have been bolded. However, many mandatory reporters include professionals who may have contact or work in correctional facilities. Such individuals include physicians, nurses, dentists, teachers and social workers. These statutes can be used as a tool to require staff other than correctional officers to report sexual misconduct with inmates.

This publication is developed by the NIC/WCL Project on Addressing Prison Rape under NIC Cooperative Agreement 06S20GJJ1.

This is not to be reproduced or cited without permission from the authors.

American University, Washington College of Law

Current as of May 7, 2009 


\section{Fifty State Survey of Mandatory Reporting Statutes}

\section{NIC/WCL Project on Addressing Prison Rape}

\begin{tabular}{|c|c|}
\hline $\begin{array}{l}\text { Relevant Definitions } \\
\text { Cont'd } \\
\text { (Alaska) }\end{array}$ & $\begin{array}{l}\text { impaired to the extent that the person lacks the ability to provide or arrange for the essential requirements for the person's physical } \\
\text { health or safety without court-ordered assistance. } \\
\text { (9) Neglect means the intentional failure by a caregiver to provide essential care or services necessary to maintain the physical and } \\
\text { mental health of the vulnerable adult. } \\
\text { (16) Vulnerable adult means a person } 18 \text { years of age or older who, because of physical or mental impairment, is unable to meet } \\
\text { the person's own needs or to seek help without assistance. }\end{array}$ \\
\hline $\begin{array}{l}\text { Persons Required to } \\
\text { Report } \\
\text { (Alaska) }\end{array}$ & $\begin{array}{l}\text { AS § } 47.24 .010 \text { (West 2008) } \\
\text { (a): } \\
\text { (1) A physician or other licensed health care provider; } \\
\text { (2) A mental health professional; } \\
\text { (3) A pharmacist; } \\
\text { (4) An administrator of a nursing home, residential care or health care facility; } \\
\text { (5) A guardian or conservator; } \\
\text { (6) A police officer; } \\
\text { (7) A village public safety officer; } \\
\text { (8) A village health aide; } \\
\text { (9) A social worker; } \\
\text { (10) A member of the clergy; } \\
\text { (11) A staff employee of a project funded by the Department of Administration for the provision of services to older Alaskans, } \\
\text { the Department of Health and Social Services, or the Council on Domestic Violence and Sexual Assault; } \\
\text { (12) An employee of a personal care or home health aide program; } \\
\text { (13) An emergency medical technician or a mobile intensive care paramedic; } \\
\text { (14) A caregiver of the vulnerable adult; } \\
\text { (15) A certified nurse aide. }\end{array}$ \\
\hline
\end{tabular}

NOTE:

** For purposes of this chart, corrections officers, police officers, peace officers, probation officers or "catch-all” phrases such as "all persons" have been bolded. However, many mandatory reporters include professionals who may have contact or work in correctional facilities. Such individuals include physicians, nurses, dentists, teachers and social workers. These statutes can be used as a tool to require staff other than correctional officers to report sexual misconduct with inmates.

This publication is developed by the NIC/WCL Project on Addressing Prison Rape under NIC Cooperative Agreement 06S20GJJ1.

This is not to be reproduced or cited without permission from the authors.

American University, Washington College of Law

Current as of May 7, 2009 


\section{Fifty State Survey of Mandatory Reporting Statutes}

\section{NIC/WCL Project on Addressing Prison Rape}

\begin{tabular}{|c|c|}
\hline $\begin{array}{l}\text { Reporting } \\
\text { Procedures } \\
\text { (Alaska) }\end{array}$ & $\begin{array}{l}\text { AS } § 47.24 .010 \text { (West } 2008 \text { ) } \\
\text { (a) Not later than } 24 \text { hours after first having cause for the belief, report the belief to the department's central information and } \\
\text { referral service for vulnerable adults. }\end{array}$ \\
\hline $\begin{array}{l}\text { Penalty for Failure to } \\
\text { Report } \\
\text { (Alaska) }\end{array}$ & $\begin{array}{l}\text { AS } \S 12.55 .135 \text { (West } 2008 \text { ) } \\
\text { (b) Any Defendant convicted of a class B misdemeanor may be sentenced to a definite term of imprisonment not more than } 90 \\
\text { days unless otherwise specified in the provision of law defining the offense. } \\
\text { AS } \S 12.55 .035 \text { (West } 2008 \text { ) } \\
\text { (b)(6) Maximum of } \$ 2,000 \text { fine }\end{array}$ \\
\hline & ARIZONA \\
\hline $\begin{array}{l}\text { Mandatory } \\
\text { Reporting Statute } \\
\text { (Arizona) }\end{array}$ & 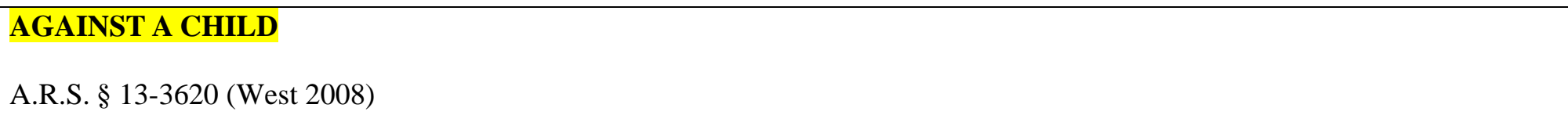 \\
\hline $\begin{array}{l}\text { What has to be } \\
\text { reported? } \\
\text { (Arizona) }\end{array}$ & $\begin{array}{l}\text { A.R.S. } \S 13-3620 \text { (West 2008) } \\
\text { (A) Any person who reasonably believes that a minor is or has been the victim of physical injury, abuse, child abuse, a reportable } \\
\text { offense or neglect that appears to have been inflicted on the minor by other than accidental means or that is not explained by the } \\
\text { available medical history as being accidental in nature or who reasonably believes there has been a denial or deprivation of } \\
\text { necessary medical treatment or surgical care or nourishment with the intent to cause or allow the death of an infant who is } \\
\text { protected under } \S 36-2281 \text { shall immediately report or cause reports to be made of this information to a peace officer or to child } \\
\text { protective services in the department of economic security, except if the report concerns a person who does not have care, custody }\end{array}$ \\
\hline
\end{tabular}

NOTE:

** For purposes of this chart, corrections officers, police officers, peace officers, probation officers or “catch-all” phrases such as “all persons” have been bolded. However, many mandatory reporters include professionals who may have contact or work in correctional facilities. Such individuals include physicians, nurses, dentists, teachers and social workers. These statutes can be used as a tool to require staff other than correctional officers to report sexual misconduct with inmates.

This publication is developed by the NIC/WCL Project on Addressing Prison Rape under NIC Cooperative Agreement 06S20GJJ1.

This is not to be reproduced or cited without permission from the authors.

American University, Washington College of Law

Current as of May 7, 2009 


\title{
Fifty State Survey of Mandatory Reporting Statutes
}

\section{NIC/WCL Project on Addressing Prison Rape}

\begin{tabular}{|c|c|}
\hline $\begin{array}{l}\text { What has to be } \\
\text { reported? Cont'd } \\
\text { (Arizona) }\end{array}$ & $\begin{array}{l}\text { or control of the minor, the report shall be made to a peace officer only. } \\
\text { (B) A report is not required under this section for sexual abuse and sexual conduct if the conduct involves only minors who are } \\
\text { fourteen, fifteen, sixteen or seventeen years of age and there is nothing to indicate that the conduct is other than consensual. }\end{array}$ \\
\hline $\begin{array}{l}\text { Relevant Definitions } \\
\text { (Arizona) }\end{array}$ & 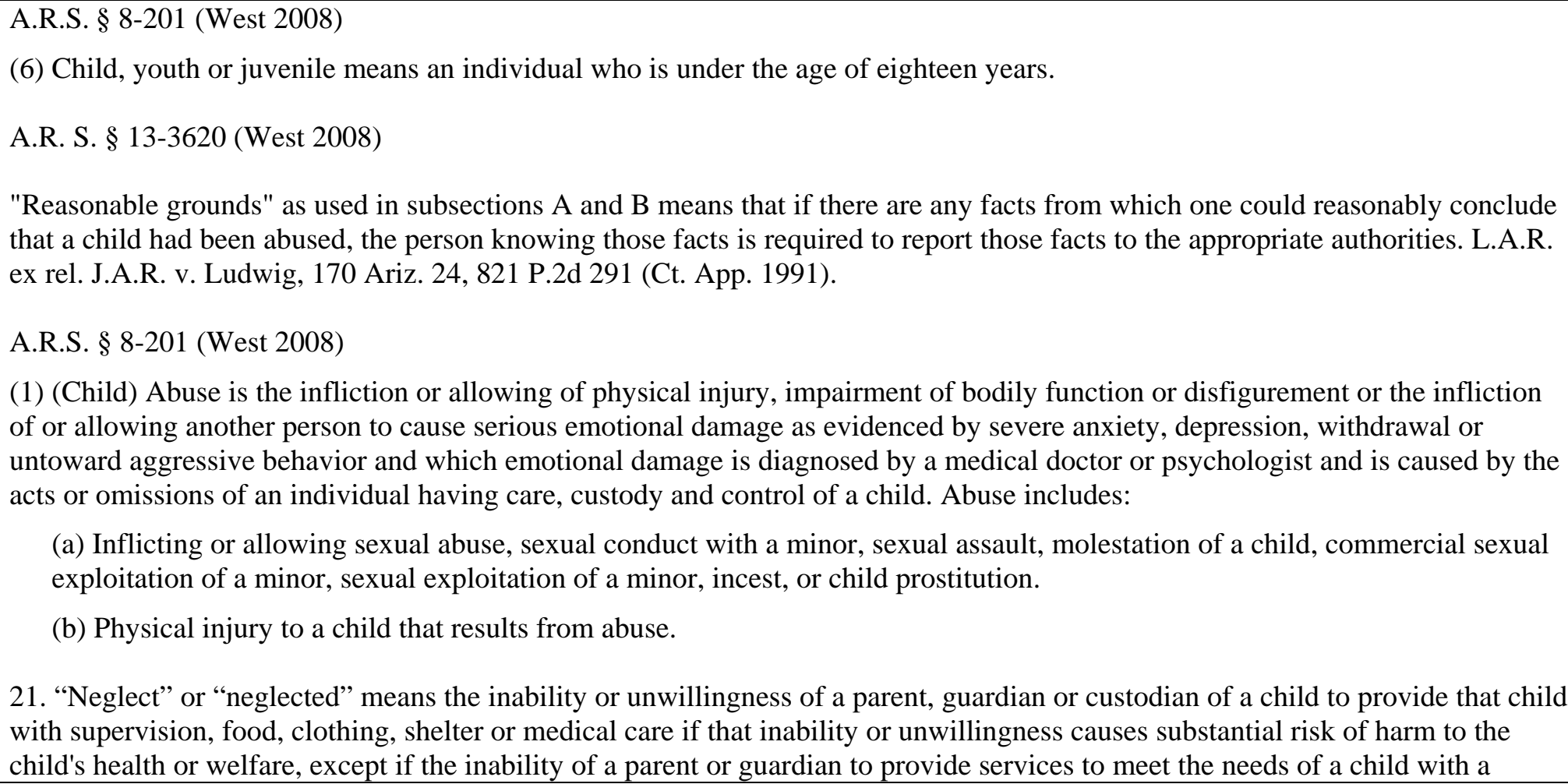 \\
\hline
\end{tabular}

\section{NOTE:}

\begin{abstract}
** For purposes of this chart, corrections officers, police officers, peace officers, probation officers or "catch-all” phrases such as "all persons" have been bolded. However, many mandatory reporters include professionals who may have contact or work in correctional facilities. Such individuals include physicians, nurses, dentists, teachers and social workers. These statutes can be used as a tool to require staff other than correctional officers to report sexual misconduct with inmates.
\end{abstract}

This publication is developed by the NIC/WCL Project on Addressing Prison Rape under NIC Cooperative Agreement 06S20GJJ1.

This is not to be reproduced or cited without permission from the authors.

American University, Washington College of Law

Current as of May 7, 2009 


\section{Fifty State Survey of Mandatory Reporting Statutes}

\section{NIC/WCL Project on Addressing Prison Rape}

\begin{tabular}{|c|c|}
\hline $\begin{array}{l}\text { Relevant Definitions } \\
\text { Cont'd } \\
\text { Arizona) }\end{array}$ & 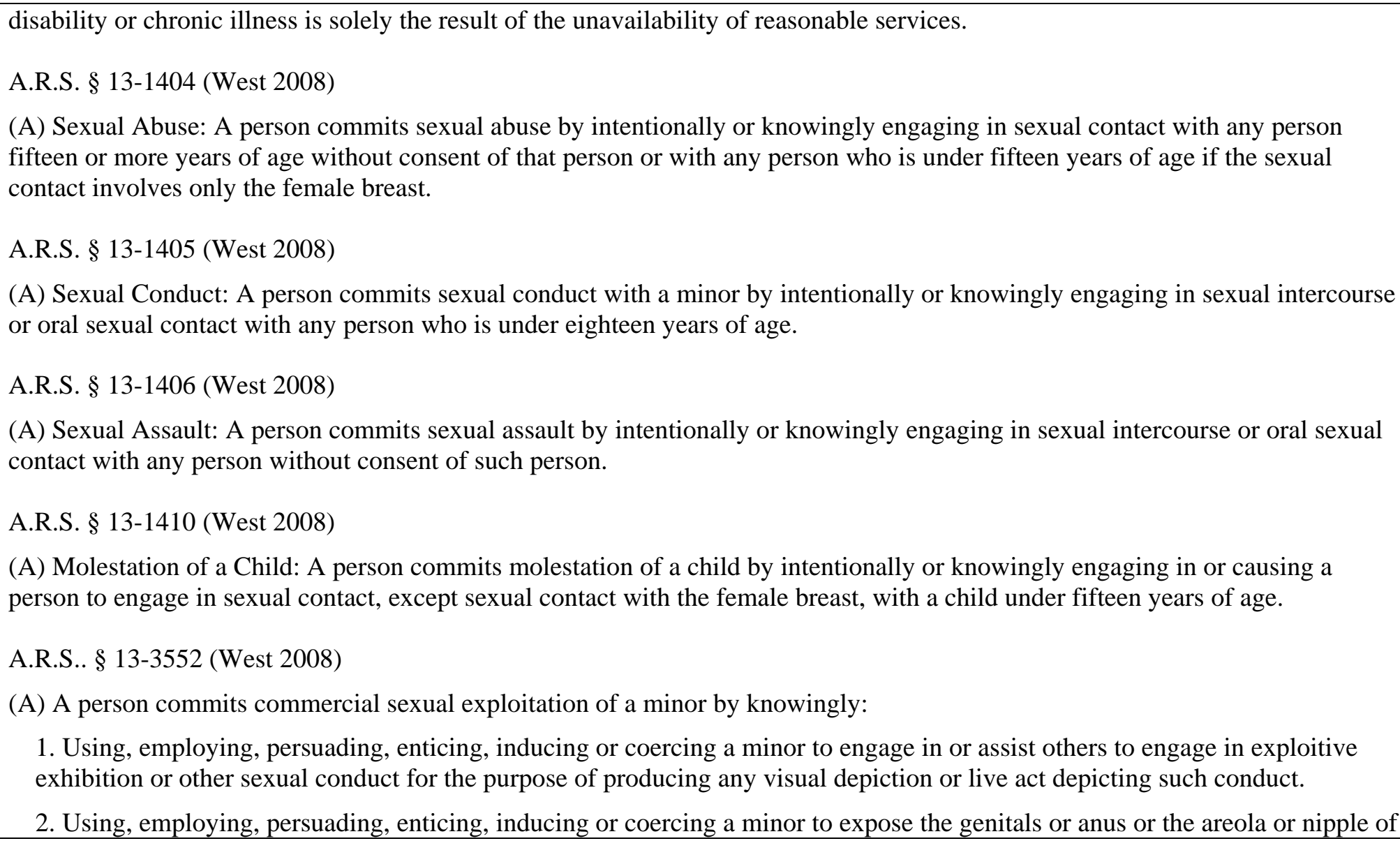 \\
\hline
\end{tabular}

\section{NOTE:}

** For purposes of this chart, corrections officers, police officers, peace officers, probation officers or “catch-all” phrases such as “all persons” have been bolded. However, many mandatory reporters include professionals who may have contact or work in correctional facilities. Such individuals include physicians, nurses, dentists, teachers and social workers. These statutes can be used as a tool to require staff other than correctional officers to report sexual misconduct with inmates.

This publication is developed by the NIC/WCL Project on Addressing Prison Rape under NIC Cooperative Agreement 06S20GJJ1.

This is not to be reproduced or cited without permission from the authors.

American University, Washington College of Law

Current as of May 7, 2009 


\section{Fifty State Survey of Mandatory Reporting Statutes}

\section{NIC/WCL Project on Addressing Prison Rape}

\begin{tabular}{|c|c|}
\hline $\begin{array}{l}\text { Relevant Definitions } \\
\text { Cont'd } \\
\text { (Arizona) }\end{array}$ & $\begin{array}{l}\text { the female breast for financial or commercial gain. } \\
\text { 3. Permitting a minor under the person's custody or control to engage in or assist others to engage in exploitive exhibition or } \\
\text { other sexual conduct for the purpose of producing any visual depiction or live act depicting such conduct. } \\
\text { 4. Transporting or financing the transportation of any minor through or across this state with the intent that the minor engage in } \\
\text { prostitution, exploitive exhibition or other sexual conduct for the purpose of producing a visual depiction or live act depicting } \\
\text { such conduct. } \\
\text { A.R.S. § 13-3553 (West 2008) } \\
\text { (A) Sexual Exploitation of a Minor: A person commits sexual exploitation of a minor by knowingly } \\
\text { 1. Recording, filming, photographing, developing or duplicating any visual depiction in which a minor is engaged in exploitive } \\
\text { exhibition or other sexual conduct. } \\
\text { 2. Distributing, transporting, exhibiting, receiving, selling, purchasing, electronically transmitting, possessing or exchanging } \\
\text { any visual depiction in which a minor is engaged in exploitive exhibition or other sexual conduct. } \\
\text { A.R.S. § 13-3212 (West 2008) } \\
\text { (A) Child Prostitution: A person commits child prostitution by knowingly: } \\
\text { 1. Causing any minor to engage in prostitution. } \\
\text { 2. Using any minor for purposes of prostitution. } \\
\text { 3. Permitting a minor under such person's custody or control to engage in prostitution. } \\
\text { 4. Receiving any benefit for or on account of procuring or placing a minor in any place or in the charge or custody of any person } \\
\text { for the purpose of prostitution. } \\
\text { 5. Receiving any benefit pursuant to an agreement to participate in the proceeds of prostitution of a minor. } \\
\text { 6. Financing, managing, supervising, controlling or owning, either alone or in association with others, prostitution activity } \\
\text { involving a minor. }\end{array}$ \\
\hline
\end{tabular}

NOTE:

** For purposes of this chart, corrections officers, police officers, peace officers, probation officers or "catch-all” phrases such as "all persons" have been bolded. However, many mandatory reporters include professionals who may have contact or work in correctional facilities. Such individuals include physicians, nurses, dentists, teachers and social workers. These statutes can be used as a tool to require staff other than correctional officers to report sexual misconduct with inmates.

This publication is developed by the NIC/WCL Project on Addressing Prison Rape under NIC Cooperative Agreement 06S20GJJ1.

This is not to be reproduced or cited without permission from the authors.

American University, Washington College of Law

Current as of May 7, 2009 


\section{Fifty State Survey of Mandatory Reporting Statutes}

\section{NIC/WCL Project on Addressing Prison Rape}

\begin{tabular}{|c|c|}
\hline $\begin{array}{l}\text { Relevant Definitions } \\
\text { Cont'd } \\
\text { (Arizona) }\end{array}$ & $\begin{array}{l}\text { 7. Transporting or financing the transportation of any minor through or across this state with the intent that such minor engage } \\
\text { in prostitution. } \\
\text { 8. Engaging in prostitution with a minor. } \\
\text { A.R.S. § } 13-3620 \text { (West 2008) } \\
\text { (P)(4) Reportable Offense means: } \\
\text { 1. Sexual Offenses } \\
\text { 2. Surreptitious photographing, videotaping, filming or digitally recording of a minor } \\
\text { 3. Child prostitution } \\
\text { 4. Incest }\end{array}$ \\
\hline $\begin{array}{l}\text { Persons Required to } \\
\text { Report } \\
\text { (Arizona) }\end{array}$ & $\begin{array}{l}\text { A.R.S. } § \text { 13-3620 (West 2008) } \\
\text { (A): } \\
\text { (1) Any physician, physician's assistant, optometrist, dentist, osteopath, chiropractor, podiatrist, behavioral health } \\
\text { professional, Nurse, psychologist, counselor or social worker who develops the reasonable belief in the course of treating } \\
\text { a patient; } \\
\text { (2) Any peace officer; } \\
\text { (3) Member of the clergy, priest or Christian science practitioner; } \\
\text { (4) The parent, stepparent or guardian of the minor; } \\
\text { (5) School personnel or domestic violence victim advocate who develops the reasonable belief in the course of their } \\
\text { employment; } \\
\text { (6) Any other person who has responsibility for the care or treatment of the minor. } \\
\text { (E) A health care professional who is regulated pursuant to title } 32 \text { and who, after a routine newborn physical assessment of a } \\
\text { newborn infant's health status or following notification of positive toxicology screens of a newborn infant, reasonably believes that } \\
\text { the newborn infant may be affected by the presence of alcohol or a drug listed in } \S 13 \text {-3401 shall immediately report this } \\
\text { information, or cause a report to be made, to child protective services in the department of economic security. For the purposes of }\end{array}$ \\
\hline
\end{tabular}

NOTE:

** For purposes of this chart, corrections officers, police officers, peace officers, probation officers or “catch-all” phrases such as “all persons” have been bolded. However, many mandatory reporters include professionals who may have contact or work in correctional facilities. Such individuals include physicians, nurses, dentists, teachers and social workers. These statutes can be used as a tool to require staff other than correctional officers to report sexual misconduct with inmates.

This publication is developed by the NIC/WCL Project on Addressing Prison Rape under NIC Cooperative Agreement 06S20GJJ1.

This is not to be reproduced or cited without permission from the authors.

American University, Washington College of Law

Current as of May 7, 2009 


\section{Fifty State Survey of Mandatory Reporting Statutes}

\section{NIC/WCL Project on Addressing Prison Rape}

\begin{tabular}{|c|c|}
\hline $\begin{array}{l}\text { Persons Required to } \\
\text { Report Cont'd } \\
\text { (Arizona) }\end{array}$ & this subsection, "newborn infant" means a newborn infant who is under thirty days of age. \\
\hline $\begin{array}{l}\text { Reporting } \\
\text { Procedures } \\
\text { (Arizona) }\end{array}$ & $\begin{array}{l}\text { A.R.S. } \S 13-3620 \text { (West 2008) } \\
\text { (A) A mandatory reporter shall immediately report or cause reports to be made to a peace officer or to child protective services in } \\
\text { the department of economic security, except if the report concerns a person who does not have care, custody or control of the } \\
\text { minor, the report shall be made to a peace officer only. } \\
\text { (D) Reports shall be made immediately by telephone or in person and shall be followed by a written report within seventy-two } \\
\text { hours. The reports shall contain: } \\
\text { 1. The names and addresses of the minor and the minor's parents or the person or persons having custody of the minor, if } \\
\text { known. } \\
\text { 2. The minor's age and the nature and extent of the minor's abuse, child abuse, physical injury or neglect, including any } \\
\text { evidence of previous abuse, child abuse, physical injury or neglect. } \\
\text { 3. Any other information that the person believes might be helpful in establishing the cause of the abuse, child abuse, physical } \\
\text { injury or neglect. }\end{array}$ \\
\hline $\begin{array}{l}\text { Penalty for Failure to } \\
\text { Report } \\
\text { (Arizona) }\end{array}$ & $\begin{array}{l}\text { A.R.S. } \S 13-3620 \text { (West 2008) } \\
\text { (O) A person who violates this section is guilty of a class } 1 \text { misdemeanor, except if the failure to report involves a reportable } \\
\text { offense, the person is guilty of a class } 6 \text { felony. } \\
\text { A.R.S. } \S 13-802 \text { (West } 2008 \text { ) } \\
\text { (A) Max of } \$ 2,500 \text { fine. }\end{array}$ \\
\hline
\end{tabular}

NOTE:

** For purposes of this chart, corrections officers, police officers, peace officers, probation officers or “catch-all” phrases such as “all persons” have been bolded. However, many mandatory reporters include professionals who may have contact or work in correctional facilities. Such individuals include physicians, nurses, dentists, teachers and social workers. These statutes can be used as a tool to require staff other than correctional officers to report sexual misconduct with inmates.

This publication is developed by the NIC/WCL Project on Addressing Prison Rape under NIC Cooperative Agreement 06S20GJJ1.

This is not to be reproduced or cited without permission from the authors.

American University, Washington College of Law

Current as of May 7, 2009 


\section{Fifty State Survey of Mandatory Reporting Statutes}

\section{NIC/WCL Project on Addressing Prison Rape}

\begin{tabular}{|c|c|}
\hline $\begin{array}{l}\text { Penalty for Failure to } \\
\text { Report Cont'd } \\
\text { (Arizona) }\end{array}$ & $\begin{array}{l}\text { A.R.S. § 13-707 (West 2008) } \\
\text { (A)(1) Maximum of six months imprisonment. }\end{array}$ \\
\hline $\begin{array}{l}\text { Mandatory } \\
\text { Reporting Statute } \\
\text { (Arizona) }\end{array}$ & $\begin{array}{l}\text { AGAINST AN ADULT } \\
\text { A.R.S. } \S 46-454 \text { (West 2008) }\end{array}$ \\
\hline $\begin{array}{l}\text { What has to be } \\
\text { reported? } \\
\text { (Arizona) }\end{array}$ & $\begin{array}{l}\text { A.R.S. § 46-454 (West 2008) } \\
\text { Reasonable basis to believe that abuse or neglect of the adult has occurred. }\end{array}$ \\
\hline $\begin{array}{l}\text { Relevant Definitions } \\
\text { (Arizona) }\end{array}$ & $\begin{array}{l}\text { A.R.S. § 46-451 (West 2008) } \\
\text { 1. Abuse means: } \\
\text { (a) Intentional infliction of physical harm. } \\
\text { (b) Injury caused by negligent acts or omissions. } \\
\text { (c) Unreasonable confinement. } \\
\text { (d) Sexual abuse or sexual assault. } \\
\text { 4. Exploitation means the illegal or improper use of an incapacitated or vulnerable adult or his resources for another's profit or } \\
\text { advantage. } \\
\text { 5. Incapacity means an impairment by reason of mental illness, mental deficiency, mental disorder, physical illness or disability, } \\
\text { advanced age, chronic use of drugs, chronic intoxication or other cause to the extent that the person lacks sufficient understanding } \\
\text { or capacity to make or communicate informed decisions concerning his person. } \\
\text { 7. Neglect means a pattern of conduct without the person's informed consent resulting in deprivation of food, water, medication, } \\
\text { medical services, shelter, cooling, heating or other services necessary to maintain minimum physical or mental health. }\end{array}$ \\
\hline
\end{tabular}

NOTE:

** For purposes of this chart, corrections officers, police officers, peace officers, probation officers or "catch-all” phrases such as “all persons” have been bolded. However, many mandatory reporters include professionals who may have contact or work in correctional facilities. Such individuals include physicians, nurses, dentists, teachers and social workers. These statutes can be used as a tool to require staff other than correctional officers to report sexual misconduct with inmates.

This publication is developed by the NIC/WCL Project on Addressing Prison Rape under NIC Cooperative Agreement 06S20GJJ1.

This is not to be reproduced or cited without permission from the authors.

American University, Washington College of Law

Current as of May 7, 2009 


\section{Fifty State Survey of Mandatory Reporting Statutes}

\section{NIC/WCL Project on Addressing Prison Rape}

\begin{tabular}{|c|c|}
\hline $\begin{array}{l}\text { Persons Required to } \\
\text { Report } \\
\text { (Arizona) }\end{array}$ & $\begin{array}{l}\text { A.R.S. § 46-454 (West 2008) } \\
\text { (A) } \\
\text { - Peace officer; } \\
\text { - Physician; } \\
\text { - Registered nurse practitioner; } \\
\text { - Hospital intern or resident; } \\
\text { - Surgeon; } \\
\text { - Dentist; } \\
\text { - Psychologist; } \\
\text { - Social worker; or } \\
\text { - Other person who has the responsibility for the care of an incapacitated or vulnerable adult. }\end{array}$ \\
\hline $\begin{array}{l}\text { Reporting } \\
\text { Procedures } \\
\text { (Arizona) }\end{array}$ & $\begin{array}{l}\text { A.R.S. } § 46-454 \text { (West 2008) } \\
\text { (A) Immediately report or cause reports to be made of such reasonable basis to a peace officer or to a protective services worker. } \\
\text { The guardian or conservator of an incapacitated or vulnerable adult shall immediately report or cause reports to be made of such } \\
\text { reasonable basis to the superior court. All of the above reports shall be made immediately in person or by telephone and shall be } \\
\text { followed by a written report mailed or delivered within forty-eight hours or on the next working day if the forty-eight hours expire } \\
\text { on a weekend or holiday. } \\
\text { (C) Reports pursuant to subsection A shall contain: } \\
\text { 1. The names and addresses of the adult and any persons having control or custody of the adult, if known. } \\
\text { 2. The adult's age and the nature and extent of his incapacity or vulnerability. } \\
\text { 3. The nature and extent of the adult's injuries or physical neglect or of the exploitation of the adult's property. } \\
\text { 4. Any other information that the person reporting believes might be helpful in establishing the cause of the adult's injuries or } \\
\text { physical neglect or of the exploitation of the adult's property. }\end{array}$ \\
\hline
\end{tabular}

** For purposes of this chart, corrections officers, police officers, peace officers, probation officers or "catch-all” phrases such as “all persons” have been bolded. However, many mandatory reporters include professionals who may have contact or work in correctional facilities. Such individuals include physicians, nurses, dentists, teachers and social workers. These statutes can be used as a tool to require staff other than correctional officers to report sexual misconduct with inmates.

This publication is developed by the NIC/WCL Project on Addressing Prison Rape under NIC Cooperative Agreement 06S20GJJ1.

This is not to be reproduced or cited without permission from the authors.

American University, Washington College of Law

Current as of May 7, 2009 


\section{Fifty State Survey of Mandatory Reporting Statutes}

\section{NIC/WCL Project on Addressing Prison Rape}

\begin{tabular}{|c|c|}
\hline $\begin{array}{l}\text { Penalty for Failure to } \\
\text { Report } \\
\text { (Arizona) }\end{array}$ & $\begin{array}{l}\text { A.R.S. } \S 46-454 \text { (West 2008) } \\
\text { K. A person who violates any provision of this section is guilty of a class } 1 \text { misdemeanor. } \\
\text { ARIZ. REV. STAT. ANN. } § 13-802 \text { (West } 2008 \text { ) } \\
\text { (A) A sentence to pay a fine for a class } 1 \text { misdemeanor shall be a sentence to pay an amount, fixed by the court, not more than two } \\
\text { thousand five hundred dollars.. } \\
\text { A.R.S. } \S 13-707 \text { (West 2008) } \\
\text { (A)(1) Maximum of six months imprisonment }\end{array}$ \\
\hline & ARKANSAS \\
\hline $\begin{array}{l}\text { Mandatory } \\
\text { Reporting Statute } \\
\text { (Arkansas) }\end{array}$ & $\begin{array}{l}\text { AGAINST A CHILD } \\
\text { A.C.A. § 12-12-507 (West 2008) }\end{array}$ \\
\hline $\begin{array}{l}\text { What has to be } \\
\text { reported? } \\
\text { (Arkansas) }\end{array}$ & $\begin{array}{l}\text { A.C.A. } \S 12-12-507 \text { (West 2008) } \\
\text { (a) Any person with reasonable cause to suspect child maltreatment or that a child has died as a result of child maltreatment, or } \\
\text { who observes a child being subjected to conditions or circumstances that would reasonably result in child maltreatment, may } \\
\text { immediately notify the child abuse hotline. }\end{array}$ \\
\hline
\end{tabular}

NOTE:

** For purposes of this chart, corrections officers, police officers, peace officers, probation officers or "catch-all” phrases such as "all persons" have been bolded. However, many mandatory reporters include professionals who may have contact or work in correctional facilities. Such individuals include physicians, nurses, dentists, teachers and social workers. These statutes can be used as a tool to require staff other than correctional officers to report sexual misconduct with inmates.

This publication is developed by the NIC/WCL Project on Addressing Prison Rape under NIC Cooperative Agreement 06S20GJJ1.

This is not to be reproduced or cited without permission from the authors.

American University, Washington College of Law

Current as of May 7, 2009 


\section{Fifty State Survey of Mandatory Reporting Statutes}

\section{NIC/WCL Project on Addressing Prison Rape}

\begin{tabular}{|c|c|}
\hline $\begin{array}{l}\text { Relevant Definitions } \\
\text { (Arkansas) }\end{array}$ & $\begin{array}{l}\text { A.C.A. § 12-12-503 (West 2008) } \\
\text { (1)(A) Abandonment means: } \\
\text { (i) Failure of a parent to: } \\
\text { (a) Provide reasonable support and to maintain regular contact with a juvenile through statement or contact when the failure is } \\
\text { accompanied by an intention on the part of the parent to permit the condition to continue for an indefinite period in the future; } \\
\text { (b) Support or maintain regular contact with a juvenile without just cause; or } \\
\text { (ii) An articulated intent to forego parental responsibility. } \\
\text { (2)(A) Abuse means any of the following acts or omissions by a parent, guardian, custodian, foster parent, person eighteen (18) } \\
\text { years of age or older living in the home with a child whether related or unrelated to the child, or any person who is entrusted with } \\
\text { the juvenile's care by a parent, guardian, custodian, or foster parent, including, but not limited to, an agent or employee of a public } \\
\text { or private residential home, child care facility, public or private school, or any person legally responsible for the juvenile's welfare, } \\
\text { but excluding the spouse of a minor: } \\
\text { (i) Extreme or repeated cruelty to a juvenile } \\
\text { (ii) Engaging in conduct creating a realistic and serious threat of death, permanent or temporary disfigurement, or impairment of } \\
\text { any bodily organ } \\
\text { (iii) Injury to a juvenile's intellectual, emotional, or psychological development as evidenced by observable and substantial } \\
\text { impairment of the juvenile's ability to function within the juvenile's normal range of performance and behavior } \\
\text { (iv) Any injury that is at variance with the history given } \\
\text { (v) Any nonaccidental physical injury } \\
\text { (vi) Any of the following intentional or knowing acts, with physical injury and without justifiable cause: } \\
\text { (a) Throwing, kicking, burning, biting, or cutting a child; } \\
\text { (b) Striking a child with a closed fist; } \\
\text { (c) Shaking a child; or } \\
\text { (d) Striking a child on the face or head; or } \\
\text { (vii) Any of the following intentional or knowing acts, with or without physical injury: }\end{array}$ \\
\hline
\end{tabular}

NOTE:

** For purposes of this chart, corrections officers, police officers, peace officers, probation officers or "catch-all” phrases such as "all persons" have been bolded. However, many mandatory reporters include professionals who may have contact or work in correctional facilities. Such individuals include physicians, nurses, dentists, teachers and social workers. These statutes can be used as a tool to require staff other than correctional officers to report sexual misconduct with inmates.

This publication is developed by the NIC/WCL Project on Addressing Prison Rape under NIC Cooperative Agreement 06S20GJJ1.

This is not to be reproduced or cited without permission from the authors.

American University, Washington College of Law

Current as of May 7, 2009 


\section{Fifty State Survey of Mandatory Reporting Statutes}

\section{NIC/WCL Project on Addressing Prison Rape}

\begin{tabular}{|c|c|}
\hline $\begin{array}{l}\text { Relevant Definitions } \\
\text { Cont'd } \\
\text { (Arkansas) }\end{array}$ & 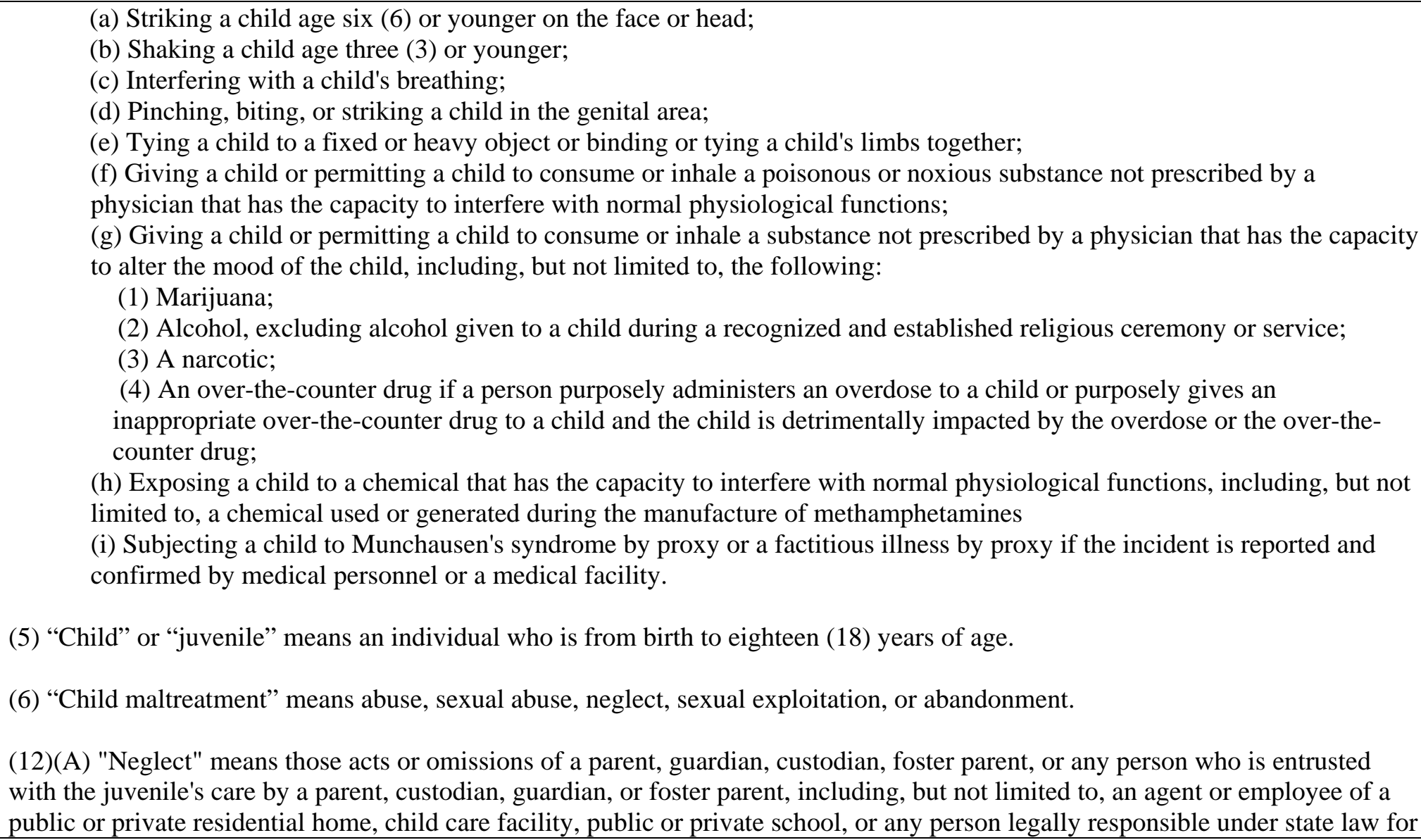 \\
\hline
\end{tabular}

NOTE:

** For purposes of this chart, corrections officers, police officers, peace officers, probation officers or “catch-all” phrases such as “all persons” have been bolded. However, many mandatory reporters include professionals who may have contact or work in correctional facilities. Such individuals include physicians, nurses, dentists, teachers and social workers. These statutes can be used as a tool to require staff other than correctional officers to report sexual misconduct with inmates.

This publication is developed by the NIC/WCL Project on Addressing Prison Rape under NIC Cooperative Agreement 06S20GJJ1.

This is not to be reproduced or cited without permission from the authors.

American University, Washington College of Law

Current as of May 7, 2009 


\section{Fifty State Survey of Mandatory Reporting Statutes}

\section{NIC/WCL Project on Addressing Prison Rape}

\begin{tabular}{|c|c|}
\hline $\begin{array}{l}\text { Relevant Definitions } \\
\text { Cont'd } \\
\text { (Arkansas) }\end{array}$ & 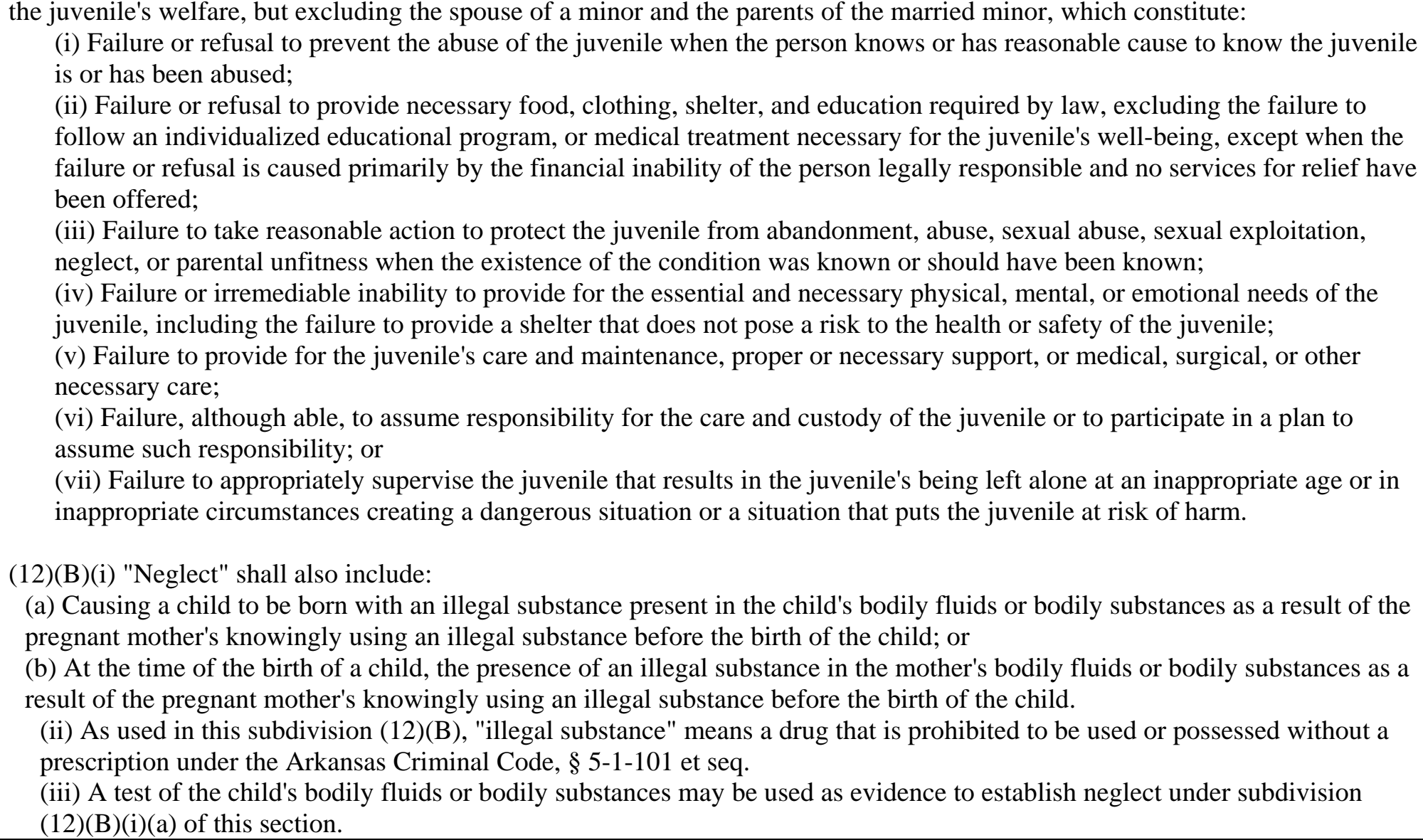 \\
\hline
\end{tabular}

NOTE:

** For purposes of this chart, corrections officers, police officers, peace officers, probation officers or “catch-all” phrases such as “all persons” have been bolded. However, many mandatory reporters include professionals who may have contact or work in correctional facilities. Such individuals include physicians, nurses, dentists, teachers and social workers. These statutes can be used as a tool to require staff other than correctional officers to report sexual misconduct with inmates.

This publication is developed by the NIC/WCL Project on Addressing Prison Rape under NIC Cooperative Agreement 06S20GJJ1.

This is not to be reproduced or cited without permission from the authors.

American University, Washington College of Law

Current as of May 7, 2009 


\section{Fifty State Survey of Mandatory Reporting Statutes}

\section{NIC/WCL Project on Addressing Prison Rape}

\begin{tabular}{|c|c|}
\hline $\begin{array}{l}\text { Relevant Definitions } \\
\text { Cont'd } \\
\text { (Arkansas) }\end{array}$ & 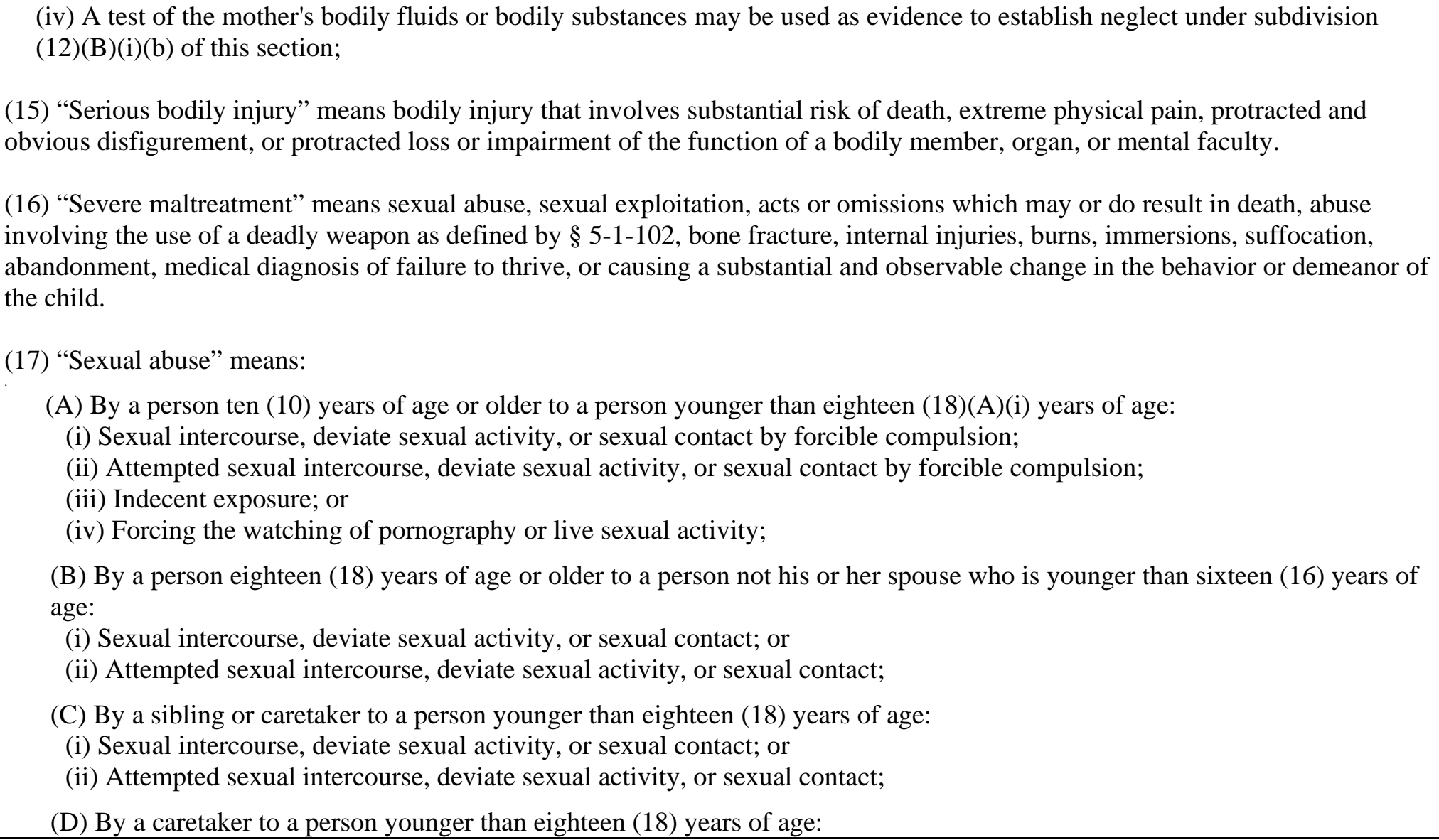 \\
\hline
\end{tabular}

NOTE:

** For purposes of this chart, corrections officers, police officers, peace officers, probation officers or "catch-all” phrases such as “all persons” have been bolded. However, many mandatory reporters include professionals who may have contact or work in correctional facilities. Such individuals include physicians, nurses, dentists, teachers and social workers. These statutes can be used as a tool to require staff other than correctional officers to report sexual misconduct with inmates.

This publication is developed by the NIC/WCL Project on Addressing Prison Rape under NIC Cooperative Agreement 06S20GJJ1.

This is not to be reproduced or cited without permission from the authors.

American University, Washington College of Law

Current as of May 7, 2009 


\section{Fifty State Survey of Mandatory Reporting Statutes}

\section{NIC/WCL Project on Addressing Prison Rape}

\begin{tabular}{|c|c|}
\hline $\begin{array}{l}\text { Relevant Definitions } \\
\text { Cont'd } \\
\text { (Arkansas) }\end{array}$ & $\begin{array}{l}\text { (i) Forcing or encouraging the watching of pornography; } \\
\text { (ii) Forcing, permitting, or encouraging the watching of live sexual activity; } \\
\text { (iii) Forcing listening to a phone sex line; or } \\
\text { (iv)An act of voyeurism as defined under § 5-16-102; or } \\
\text { (E) By a person younger than ten (10) years of age to a person younger than eighteen (18) years of age: } \\
\text { (i) Sexual intercourse, deviate sexual activity, or sexual contact by forcible compulsion; or } \\
\text { (ii) Attempted sexual intercourse, deviate sexual activity, or sexual contact by forcible compulsion; } \\
\text { (18)(A)(i) “Sexual contact” means any act of sexual gratification involving: } \\
\text { (a) The touching, directly or through clothing, of the sex organs, buttocks, or anus of a person or the breast of a female; } \\
\text { (b) The encouraging of a child to touch the offender in a sexual manner; or } \\
\text { (c) The offender requesting to touch a child in a sexual manner. } \\
\text { (ii) Evidence of sexual gratification may be inferred from the attendant circumstances surrounding the specific complaint of } \\
\text { child maltreatment. } \\
\text { (B) However, nothing in this section shall permit normal affectionate hugging to be construed as sexual contact; } \\
\text { (19) Sexual exploitation means: } \\
\text { (A) Allowing, permitting, or encouraging participation or depiction of the child in: } \\
\text { (i) Prostitution; } \\
\text { (ii) Obscene photography; } \\
\text { (iii) Obscene filming; or } \\
\text { (B) Obscenely depicting, obscenely posing, or obscenely posturing a child for any use or purpose. }\end{array}$ \\
\hline $\begin{array}{l}\text { Persons Required to } \\
\text { Report } \\
\text { (Arkansas) }\end{array}$ & $\begin{array}{l}\text { A.C.A. § 12-12-507 (West 2008) } \\
\text { (b)(4) } \\
\text { • A law enforcement official; }\end{array}$ \\
\hline
\end{tabular}

NOTE:

** For purposes of this chart, corrections officers, police officers, peace officers, probation officers or "catch-all” phrases such as “all persons” have been bolded. However, many mandatory reporters include professionals who may have contact or work in correctional facilities. Such individuals include physicians, nurses, dentists, teachers and social workers. These statutes can be used as a tool to require staff other than correctional officers to report sexual misconduct with inmates.

This publication is developed by the NIC/WCL Project on Addressing Prison Rape under NIC Cooperative Agreement 06S20GJJ1.

This is not to be reproduced or cited without permission from the authors.

American University, Washington College of Law

Current as of May 7, 2009 


\section{Fifty State Survey of Mandatory Reporting Statutes}

\section{NIC/WCL Project on Addressing Prison Rape}

\begin{tabular}{|c|c|}
\hline $\begin{array}{l}\text { Persons Required to } \\
\text { Report Cont'd } \\
\text { (Arkansas) }\end{array}$ & 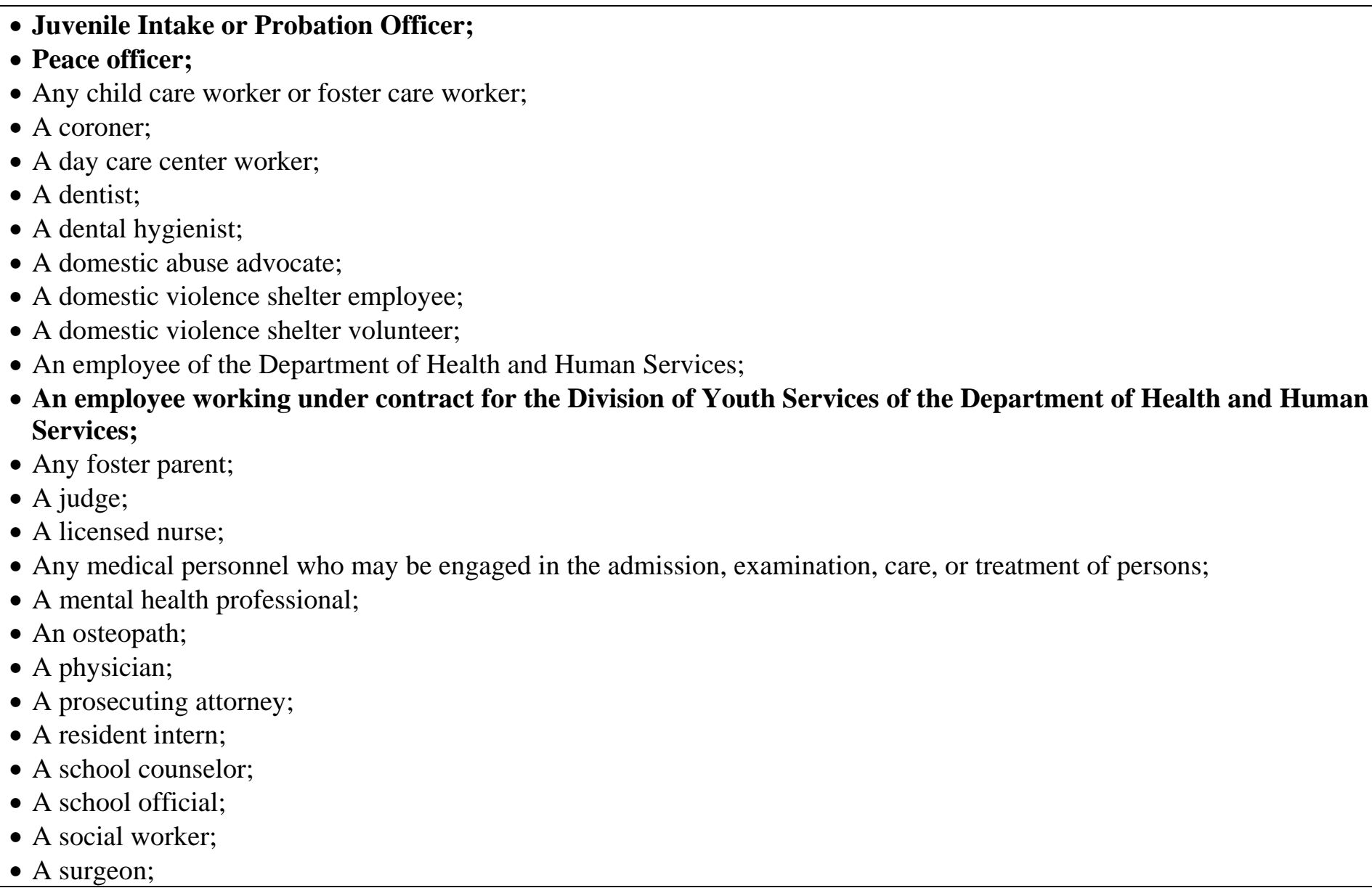 \\
\hline
\end{tabular}

** For purposes of this chart, corrections officers, police officers, peace officers, probation officers or "catch-all” phrases such as "all persons" have been bolded. However, many mandatory reporters include professionals who may have contact or work in correctional facilities. Such individuals include physicians, nurses, dentists, teachers and social workers. These statutes can be used as a tool to require staff other than correctional officers to report sexual misconduct with inmates.

This publication is developed by the NIC/WCL Project on Addressing Prison Rape under NIC Cooperative Agreement 06S20GJJ1.

This is not to be reproduced or cited without permission from the authors.

American University, Washington College of Law

Current as of May 7, 2009 


\section{Fifty State Survey of Mandatory Reporting Statutes}

\section{NIC/WCL Project on Addressing Prison Rape}

\begin{tabular}{|c|c|}
\hline $\begin{array}{l}\text { Persons Required to } \\
\text { Report Cont'd } \\
\text { (Arkansas) }\end{array}$ & $\begin{array}{l}\text { - A teacher; } \\
\text { - A court-appointed special advocate program staff member or volunteer; } \\
\text { - Any clergyman, which includes a minister, priest, rabbi, accredited Christian Science practitioner, or other similar functionary } \\
\text { of a religious organization, or an individual reasonably believed to be so by the person consulting him or her (unless covered by } \\
\text { privilege); or } \\
\text { - An employee of a child advocacy center. } \\
\text { Proposed statutory language: } 2009 \text { Arkansas Laws Act } 629 \text { (H.B. 1715) } \\
\text { (EE) A sexual abuse advocate or sexual abuse volunteer; } \\
\text { (FF) A rape crisis advocate or rape crisis volunteer; } \\
\text { (GG) A child abuse advocate or child abuse volunteer; } \\
\text { (HH) A victim/witness coordinator; } \\
\text { (II) A victim advocate; or } \\
\text { (JJ) A victim assistance professional or victim assistance volunteer. } \\
\text { (c) No privilege or contract shall prevent anyone from reporting child maltreatment when he or she is a mandated reporter as } \\
\text { required by this section. }\end{array}$ \\
\hline $\begin{array}{l}\text { Reporting } \\
\text { Procedures } \\
\text { (Arkansas) }\end{array}$ & $\begin{array}{l}\text { A.C.A. } § 12-12-507 \text { (West 2008) } \\
\text { (b)(1) When any individual listed in subdivision (b)(4) of this section has reasonable cause to suspect that a child has been } \\
\text { subjected to child maltreatment or has died as a result of child maltreatment or observes a child being subjected to conditions or } \\
\text { circumstances that would reasonably result in child maltreatment, he or she shall immediately notify the child abuse hotline by } \\
\text { telephone call, facsimile transmission, or online reporting. }\end{array}$ \\
\hline
\end{tabular}

NOTE:

** For purposes of this chart, corrections officers, police officers, peace officers, probation officers or “catch-all” phrases such as “all persons” have been bolded. However, many mandatory reporters include professionals who may have contact or work in correctional facilities. Such individuals include physicians, nurses, dentists, teachers and social workers. These statutes can be used as a tool to require staff other than correctional officers to report sexual misconduct with inmates.

This publication is developed by the NIC/WCL Project on Addressing Prison Rape under NIC Cooperative Agreement 06S20GJJ1.

This is not to be reproduced or cited without permission from the authors.

American University, Washington College of Law

Current as of May 7, 2009 


\section{Fifty State Survey of Mandatory Reporting Statutes}

\section{NIC/WCL Project on Addressing Prison Rape}

\begin{tabular}{|c|c|}
\hline $\begin{array}{l}\text { Penalty for Failure to } \\
\text { Report } \\
\text { (Arkansas) }\end{array}$ & 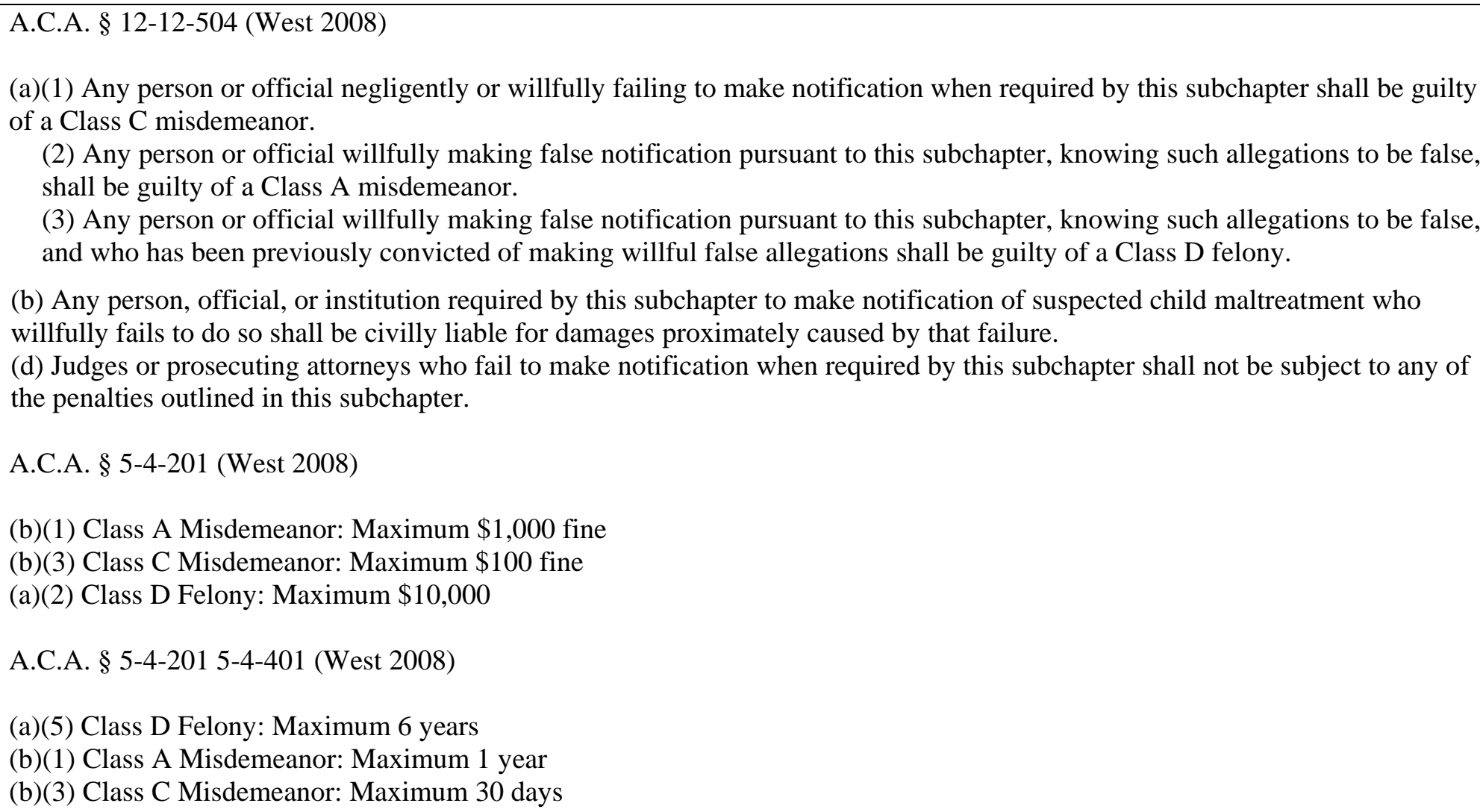 \\
\hline
\end{tabular}

NOTE:

** For purposes of this chart, corrections officers, police officers, peace officers, probation officers or "catch-all” phrases such as “all persons” have been bolded. However, many mandatory reporters include professionals who may have contact or work in correctional facilities. Such individuals include physicians, nurses, dentists, teachers and social workers. These statutes can be used as a tool to require staff other than correctional officers to report sexual misconduct with inmates.

This publication is developed by the NIC/WCL Project on Addressing Prison Rape under NIC Cooperative Agreement 06S20GJJ1.

This is not to be reproduced or cited without permission from the authors.

American University, Washington College of Law

Current as of May 7, 2009 


\section{Fifty State Survey of Mandatory Reporting Statutes}

\section{NIC/WCL Project on Addressing Prison Rape}

\begin{tabular}{|c|c|}
\hline $\begin{array}{l}\text { Mandatory } \\
\text { Reporting Statute } \\
\text { (Arkansas) }\end{array}$ & $\begin{array}{l}\text { AGAINST AN ADULT } \\
\text { A.C.A. } \S 12-12-1708 \text { (West 2008) }\end{array}$ \\
\hline $\begin{array}{l}\text { What has to be } \\
\text { reported? } \\
\text { (Arkansas) }\end{array}$ & $\begin{array}{l}\text { A.C.A. } \S 12-12-1708 \text { (West 2008) } \\
\text { (a)(1) Observed or has reasonable cause to suspect that an endangered person or an impaired person has been subjected to } \\
\text { conditions or circumstances that constitute adult maltreatment or long-term care facility resident maltreatment. }\end{array}$ \\
\hline $\begin{array}{l}\text { Relevant Definitions } \\
\text { (Arkansas) }\end{array}$ & $\begin{array}{l}\text { A.C.A. } § \text { 12-12-1703 (West 2008) } \\
\text { (1)(A) Abuse means with regard to any long-term care facility resident or any patient at the Arkansas State Hospital by a } \\
\text { caregiver: } \\
\text { (i) Any intentional and unnecessary physical act that inflicts pain on or causes injury to an endangered person or an impaired } \\
\text { person, excluding court-ordered medical care or medical care requested by the patient or long-term care facility resident or a } \\
\text { person legally authorized to make medical decisions on behalf of the patient or long-term care facility resident; } \\
\text { (ii) Any intentional act that a reasonable person would believe subjects an endangered person or an impaired person, regardless } \\
\text { of age, ability to comprehend, or disability, to ridicule or psychological injury in a manner likely to provoke fear or alarm, } \\
\text { excluding necessary care and treatment provided in accordance with generally recognized professional standards of care; } \\
\text { (iii) Any intentional threat that a reasonable person would find credible and nonfrivolous to inflict pain on or cause injury to an } \\
\text { endangered person or an impaired person except in the course of medical treatment or for justifiable cause; or } \\
\text { (iv) Any willful infliction of injury, unreasonable confinement, intimidation, or punishment with resulting physical harm, pain, } \\
\text { or mental anguish. } \\
\text { (B) Abuse means with regard to any person who is not a long-term care facility resident or a patient at the Arkansas State Hospital: }\end{array}$ \\
\hline
\end{tabular}

NOTE:

** For purposes of this chart, corrections officers, police officers, peace officers, probation officers or “catch-all” phrases such as “all persons” have been bolded. However, many mandatory reporters include professionals who may have contact or work in correctional facilities. Such individuals include physicians, nurses, dentists, teachers and social workers. These statutes can be used as a tool to require staff other than correctional officers to report sexual misconduct with inmates.

This publication is developed by the NIC/WCL Project on Addressing Prison Rape under NIC Cooperative Agreement 06S20GJJ1.

This is not to be reproduced or cited without permission from the authors.

American University, Washington College of Law

Current as of May 7, 2009 


\section{Fifty State Survey of Mandatory Reporting Statutes}

\section{NIC/WCL Project on Addressing Prison Rape}

\begin{tabular}{|c|c|}
\hline $\begin{array}{l}\text { Relevant Definitions } \\
\text { Cont'd } \\
\text { (Arkansas) }\end{array}$ & 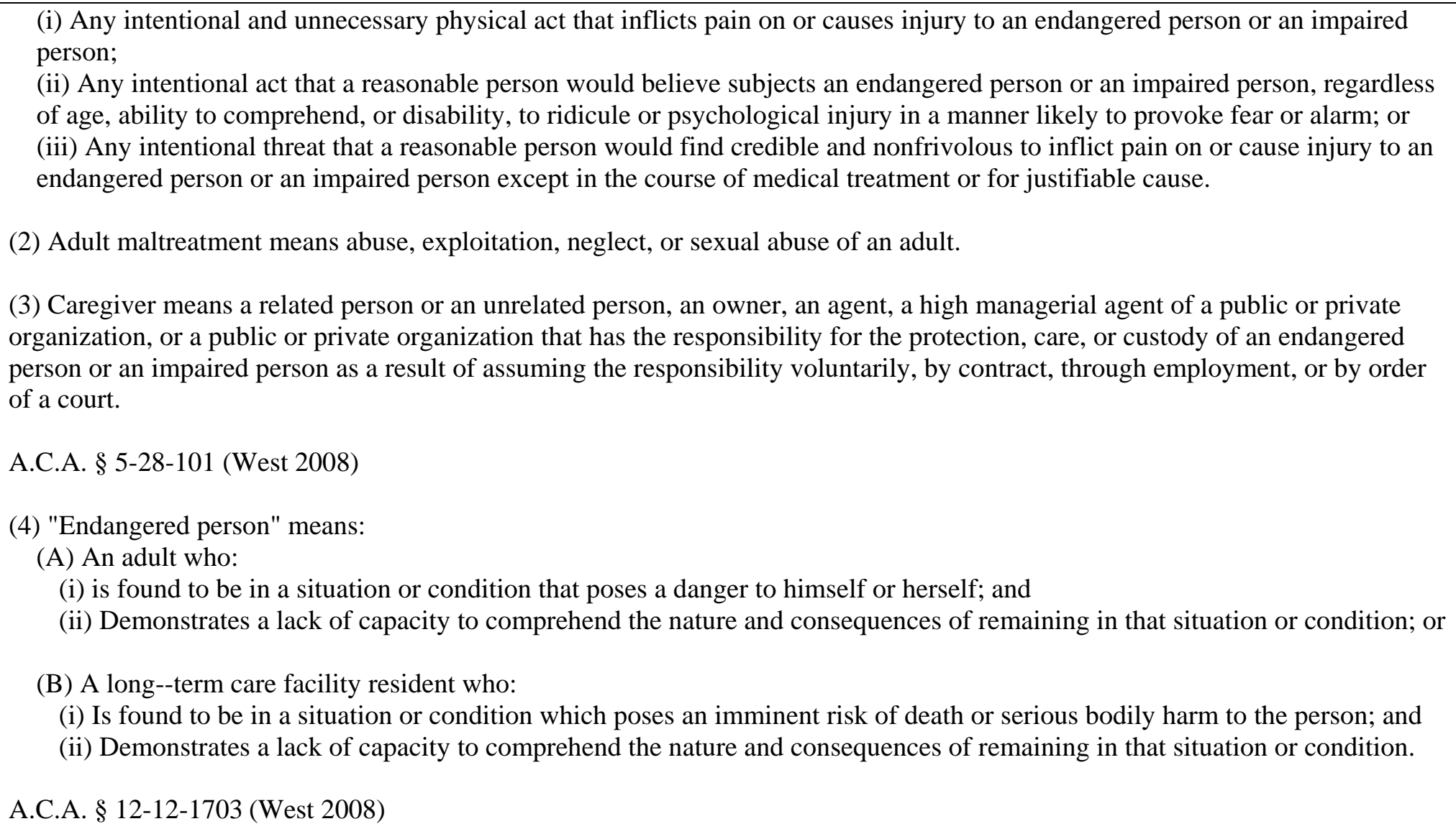 \\
\hline
\end{tabular}

NOTE:

** For purposes of this chart, corrections officers, police officers, peace officers, probation officers or "catch-all” phrases such as “all persons” have been bolded. However, many mandatory reporters include professionals who may have contact or work in correctional facilities. Such individuals include physicians, nurses, dentists, teachers and social workers. These statutes can be used as a tool to require staff other than correctional officers to report sexual misconduct with inmates.

This publication is developed by the NIC/WCL Project on Addressing Prison Rape under NIC Cooperative Agreement 06S20GJJ1.

This is not to be reproduced or cited without permission from the authors.

American University, Washington College of Law

Current as of May 7, 2009 


\section{Fifty State Survey of Mandatory Reporting Statutes}

\section{NIC/WCL Project on Addressing Prison Rape}

\begin{tabular}{|c|c|}
\hline $\begin{array}{l}\text { Relevant Definitions } \\
\text { Cont'd } \\
\text { (Arkansas) }\end{array}$ & 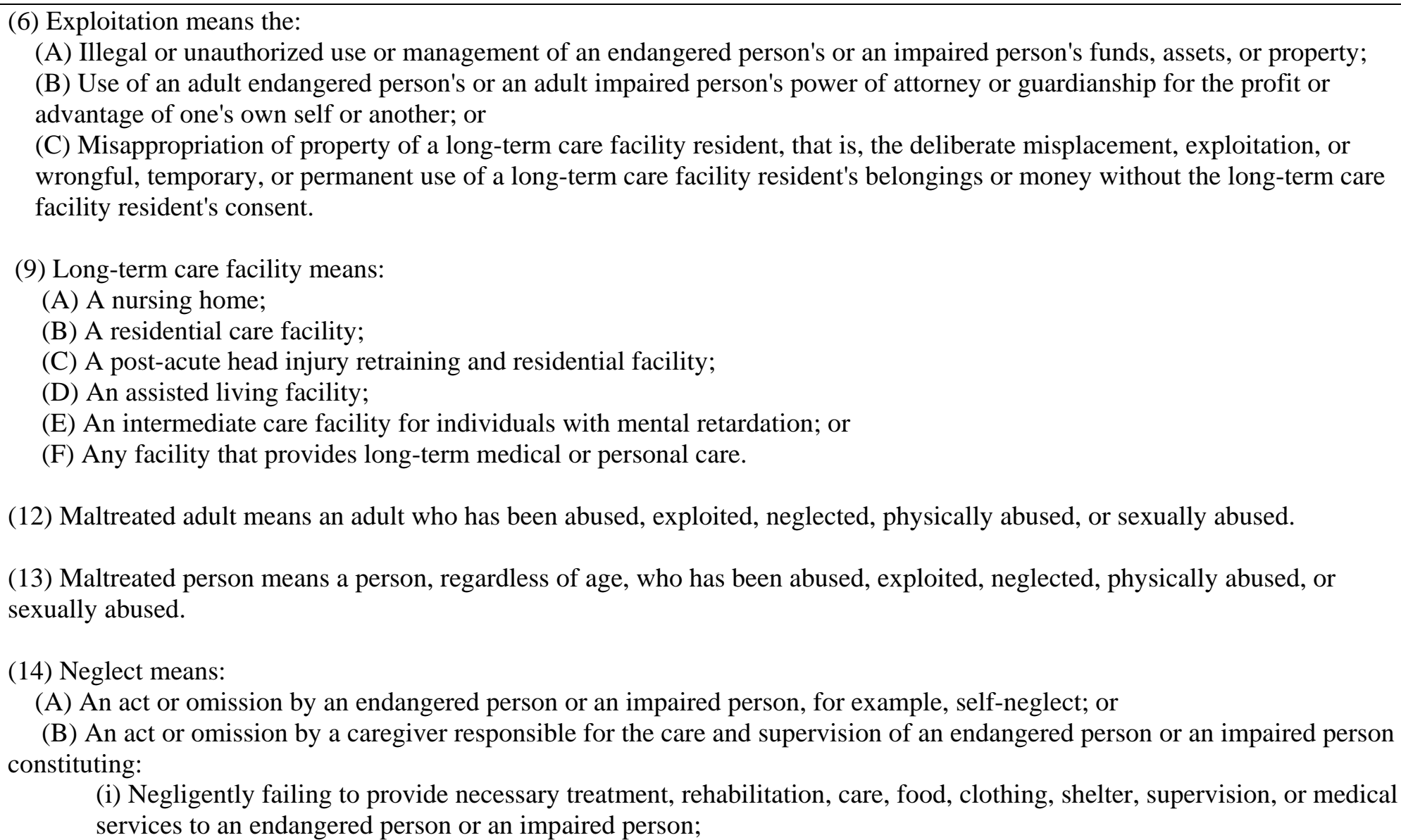 \\
\hline
\end{tabular}

NOTE:

** For purposes of this chart, corrections officers, police officers, peace officers, probation officers or "catch-all” phrases such as “all persons” have been bolded. However, many mandatory reporters include professionals who may have contact or work in correctional facilities. Such individuals include physicians, nurses, dentists, teachers and social workers. These statutes can be used as a tool to require staff other than correctional officers to report sexual misconduct with inmates.

This publication is developed by the NIC/WCL Project on Addressing Prison Rape under NIC Cooperative Agreement 06S20GJJ1.

This is not to be reproduced or cited without permission from the authors.

American University, Washington College of Law

Current as of May 7, 2009 


\section{Fifty State Survey of Mandatory Reporting Statutes}

\section{NIC/WCL Project on Addressing Prison Rape}

\begin{tabular}{|c|c|}
\hline $\begin{array}{l}\text { Relevant Definitions } \\
\text { Cont'd } \\
\text { (Arkansas) }\end{array}$ & $\begin{array}{l}\text { (ii) Negligently failing to report health problems or changes in health problems or changes in the health condition of an } \\
\text { endangered person or an impaired person to the appropriate medical personnel; } \\
\text { (iii) Negligently failing to carry out a prescribed treatment plan; or } \\
\text { (iv) Negligently failing to provide goods or services to a long-term care facility resident necessary to avoid physical harm, } \\
\text { mental anguish, or mental illness as defined in regulations promulgated by the Office of Long-Term Care. } \\
\text { (16) Serious bodily harm means sexual abuse, physical injury, or serious physical injury. } \\
\text { (17) Serious physical injury means physical injury to an endangered person or an impaired person that creates a substantial risk of } \\
\text { death or that causes protracted disfigurement, protracted impairment of health, or loss or protracted impairment of the function of } \\
\text { any bodily member or organ. } \\
\text { (18) Sexual abuse means deviate sexual activity, sexual contact, or sexual intercourse, with another person who is not the actor's } \\
\text { spouse and who is incapable of consent because he or she is mentally defective, mentally incapacitated, or physically helpless. }\end{array}$ \\
\hline $\begin{array}{l}\text { Persons Required to } \\
\text { Report } \\
\text { (Arkansas) }\end{array}$ & $\begin{array}{l}\text { A.C.A. } § 12-12-1708 \text { (West 2008) } \\
\text { (a)(1): } \\
\text { A. A law enforcement officer; } \\
\text { B. A peace officer; } \\
\text { C. A physician; } \\
\text { D. Surgeon; } \\
\text { E. A coroner; } \\
\text { F. A dentist; } \\
\text { G. A dental hygienist; } \\
\text { H. An osteopath; } \\
\text { I. A resident intern; }\end{array}$ \\
\hline
\end{tabular}

NOTE:

** For purposes of this chart, corrections officers, police officers, peace officers, probation officers or “catch-all” phrases such as “all persons” have been bolded. However, many mandatory reporters include professionals who may have contact or work in correctional facilities. Such individuals include physicians, nurses, dentists, teachers and social workers. These statutes can be used as a tool to require staff other than correctional officers to report sexual misconduct with inmates.

This publication is developed by the NIC/WCL Project on Addressing Prison Rape under NIC Cooperative Agreement 06S20GJJ1.

This is not to be reproduced or cited without permission from the authors.

American University, Washington College of Law

Current as of May 7, 2009 


\section{Fifty State Survey of Mandatory Reporting Statutes}

\section{NIC/WCL Project on Addressing Prison Rape}

\begin{tabular}{|c|c|}
\hline $\begin{array}{l}\text { Persons Required to } \\
\text { Report } \\
\text { (Arkansas) }\end{array}$ & $\begin{array}{l}\text { J. A nurse; } \\
\text { K. A member of a hospital's personnel who is engaged in the administration, examination, care, or treatment of persons; } \\
\text { L. A social worker; } \\
\text { M. A case manager; } \\
\text { N. A home health worker; } \\
\text { O. A mental health professional; } \\
\text { P. A facility administrator or owner; } \\
\text { Q. An employee in a facility; } \\
\text { R. An employee of the Department of Health and Human Services; } \\
\text { S. A firefighter; } \\
\text { T. An emergency medical technician; } \\
\text { U. An employee of a bank or other financial institution; } \\
\text { V. An employee of the United States Postal Service; } \\
\text { W. An employee or volunteer of a program or organization funded partially or wholly by the Department of Health and } \\
\text { Xuman Services who enters the home of or has contact with an elderly person; } \\
\text { Y. A person associated with the care and treatment of animals, such as animal control officers and humane society officials; } \\
\text { Z. Any clergyman, including without limitation a minister, a priest, a rabbi, an accredited Christian Science Practitioner, or } \\
\text { any other similarly functionary of a religious organization, or an individual believed to be a minister, a priest, a rabbi, an } \\
\text { accredited Christina Science Practitioner, or any other similarly functionary of a religious organization (except privilege } \\
\text { or where knowledge of suspected maltreatment was received from offender in the context of a statement of admission). }\end{array}$ \\
\hline $\begin{array}{l}\text { Reporting } \\
\text { Procedures } \\
\text { (Arkansas) }\end{array}$ & $\begin{array}{l}\text { A.C.A. } \S 12-12-1708 \text { (West 2008) } \\
\text { (a)(2) Whenever a person is required to report under this subchapter in his or her capacity as a member of the staff, an employee in } \\
\text { or owner of a facility, or an employee of the department, he or she shall immediately notify the person in charge of the institution, } \\
\text { facility, or agency, or that person's designated agent, who shall then become responsible for making a report or cause a report to be }\end{array}$ \\
\hline
\end{tabular}

NOTE:

** For purposes of this chart, corrections officers, police officers, peace officers, probation officers or “catch-all” phrases such as “all persons” have been bolded. However, many mandatory reporters include professionals who may have contact or work in correctional facilities. Such individuals include physicians, nurses, dentists, teachers and social workers. These statutes can be used as a tool to require staff other than correctional officers to report sexual misconduct with inmates.

This publication is developed by the NIC/WCL Project on Addressing Prison Rape under NIC Cooperative Agreement 06S20GJJ1.

This is not to be reproduced or cited without permission from the authors.

American University, Washington College of Law

Current as of May 7, 2009 


\section{Fifty State Survey of Mandatory Reporting Statutes}

\section{NIC/WCL Project on Addressing Prison Rape}

\begin{tabular}{|c|c|}
\hline $\begin{array}{l}\text { Reporting } \\
\text { Procedures Cont'd } \\
\text { (Arkansas) }\end{array}$ & $\begin{array}{l}\text { made within twenty-four (24) hours or on the next business day, whichever is earlier. } \\
\text { (b)(1) A report for a long-term care facility resident shall be made: } \\
\text { (A) Immediately to the local law enforcement agency for the jurisdiction in which the long-term care facility is located; and } \\
\text { (B) To the Office of Long-Term Care, under regulations of that office. } \\
\text { (b)(2) A report of a maltreated adult who does not reside in a long-term care facility shall be made to the adult and long-term care } \\
\text { facility maltreatment hotline provided in } \S 12-12-1707 \text {. }\end{array}$ \\
\hline $\begin{array}{l}\text { Penalty for Failure to } \\
\text { Report } \\
\text { (Arkansas) }\end{array}$ & $\begin{array}{l}\text { A.C.A. } \S 5-28-110 \text { (West 2008) } \\
\text { (a) Any person or caregiver required by the Adult and Long-Term Care Facility Resident Maltreatment Act, } \S 12-12-1701 \text { et seq., } \\
\text { to report a case of suspected adult maltreatment or long-term care facility resident maltreatment who purposely fails to do so is: } \\
\text { (1) Guilty of a Class B misdemeanor; and } \\
\text { (2) Civilly liable for damages proximately caused by the failure. } \\
\text { A.C.A. } \S 5-4-201 \text { (West 2008) } \\
\text { (b) A defendant convicted of a misdemeanor may be sentenced to pay a fine: } \\
\text { (2) Not exceeding five hundred dollars (\$500) if the conviction is of a Class B misdemeanor; } \\
\text { A.C.A. } \S 5-4-401 \text { (West 2008) } \\
\text { (b) A defendant convicted of a misdemeanor may be sentenced according to the following limitations: } \\
\text { (2) For a Class B misdemeanor, the sentence shall not exceed ninety (90) days. }\end{array}$ \\
\hline
\end{tabular}

NOTE:

** For purposes of this chart, corrections officers, police officers, peace officers, probation officers or “catch-all” phrases such as “all persons” have been bolded. However, many mandatory reporters include professionals who may have contact or work in correctional facilities. Such individuals include physicians, nurses, dentists, teachers and social workers. These statutes can be used as a tool to require staff other than correctional officers to report sexual misconduct with inmates.

This publication is developed by the NIC/WCL Project on Addressing Prison Rape under NIC Cooperative Agreement 06S20GJJ1.

This is not to be reproduced or cited without permission from the authors.

American University, Washington College of Law

Current as of May 7, 2009 


\section{Fifty State Survey of Mandatory Reporting Statutes}

\section{NIC/WCL Project on Addressing Prison Rape}

\begin{tabular}{|c|c|}
\hline $\begin{array}{l}\text { Penalty for Failure to } \\
\text { Report Cont'd } \\
\text { (Arkansas) }\end{array}$ & $\begin{array}{l}\text { A.C.A. § 5-28-110 (West 2008) } \\
\text { (e) Any person required to report suspected adult maltreatment or long-term care facility resident maltreatment who knowingly } \\
\text { fails to make a report within twenty-four }(24) \text { hours or on the next business day, whichever is earlier, is guilty of a Class C } \\
\text { misdemeanor. } \\
\text { A.C.A. § 5-4-401 (West 2008) } \\
\text { (b)(3) For a Class C misdemeanor, the sentence shall not exceed thirty (30) days. } \\
\text { A.C.A. } \S 5-4-201 \text { (West } 2008) \\
\text { (b)(3) Not exceeding one hundred dollars }(\$ 100) \text { if the conviction is of a Class C misdemeanor }\end{array}$ \\
\hline & CALIFORNIA \\
\hline $\begin{array}{l}\text { Mandatory } \\
\text { Reporting Statute } \\
\text { (California) }\end{array}$ & $\begin{array}{l}\text { AGAINST A CHILD } \\
\text { CA. PENAL CODE } \S 11166 \text { (West 2008) }\end{array}$ \\
\hline $\begin{array}{l}\text { What has to be } \\
\text { reported? } \\
\text { (California) }\end{array}$ & $\begin{array}{l}\text { CA. PENAL CODE } § 11166 \text { (West 2008) } \\
\text { (a) Whenever the mandated reporter, in his or her professional capacity or within the scope of his or her employment, has } \\
\text { knowledge of or observes a child whom the mandated reporter knows or reasonably suspects has been the victim of child abuse or } \\
\text { neglect. }\end{array}$ \\
\hline
\end{tabular}

NOTE:

** For purposes of this chart, corrections officers, police officers, peace officers, probation officers or “catch-all” phrases such as “all persons” have been bolded. However, many mandatory reporters include professionals who may have contact or work in correctional facilities. Such individuals include physicians, nurses, dentists, teachers and social workers. These statutes can be used as a tool to require staff other than correctional officers to report sexual misconduct with inmates.

This publication is developed by the NIC/WCL Project on Addressing Prison Rape under NIC Cooperative Agreement 06S20GJJ1.

This is not to be reproduced or cited without permission from the authors.

American University, Washington College of Law

Current as of May 7, 2009 


\section{Fifty State Survey of Mandatory Reporting Statutes}

\section{NIC/WCL Project on Addressing Prison Rape}

\begin{tabular}{|c|c|}
\hline & 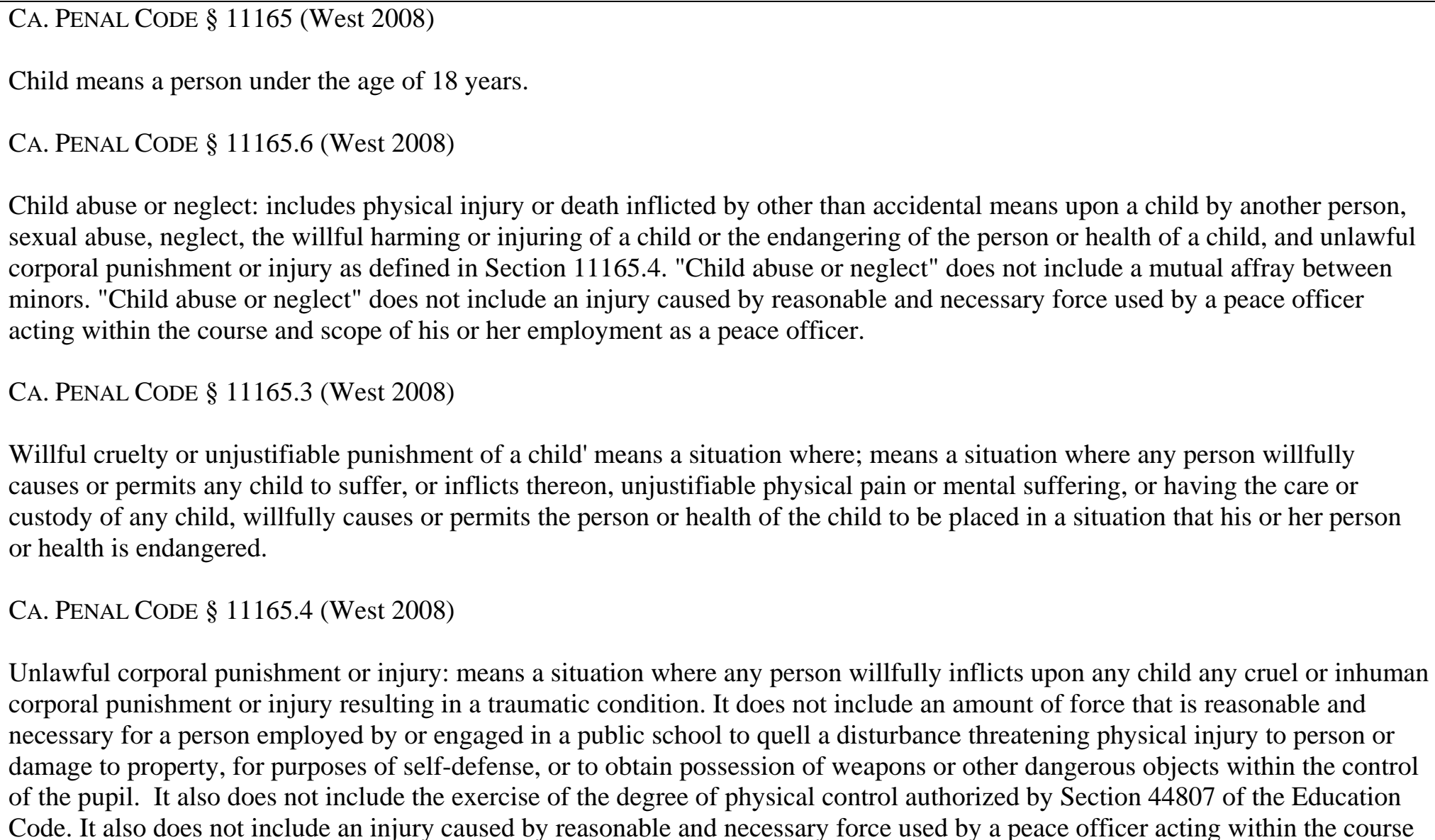 \\
\hline
\end{tabular}

NOTE:

** For purposes of this chart, corrections officers, police officers, peace officers, probation officers or “catch-all” phrases such as “all persons” have been bolded. However, many mandatory reporters include professionals who may have contact or work in correctional facilities. Such individuals include physicians, nurses, dentists, teachers and social workers. These statutes can be used as a tool to require staff other than correctional officers to report sexual misconduct with inmates.

This publication is developed by the NIC/WCL Project on Addressing Prison Rape under NIC Cooperative Agreement 06S20GJJ1.

This is not to be reproduced or cited without permission from the authors.

American University, Washington College of Law

Current as of May 7, 2009 


\section{Fifty State Survey of Mandatory Reporting Statutes}

\section{NIC/WCL Project on Addressing Prison Rape}

\begin{tabular}{|c|c|}
\hline $\begin{array}{l}\text { Relevant Definitions } \\
\text { Cont'd } \\
\text { (California) }\end{array}$ & 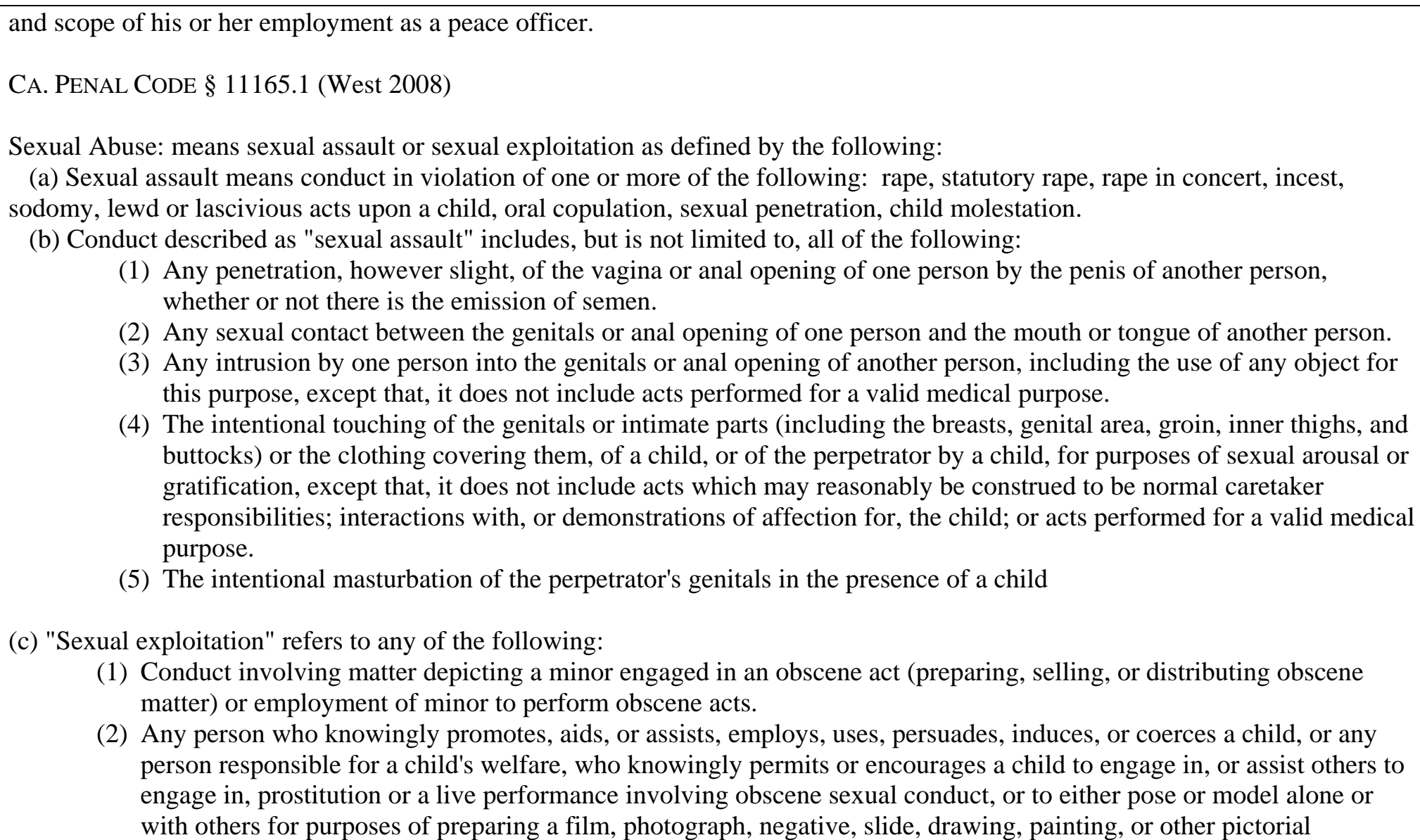 \\
\hline
\end{tabular}

NOTE:

** For purposes of this chart, corrections officers, police officers, peace officers, probation officers or “catch-all” phrases such as “all persons” have been bolded. However, many mandatory reporters include professionals who may have contact or work in correctional facilities. Such individuals include physicians, nurses, dentists, teachers and social workers. These statutes can be used as a tool to require staff other than correctional officers to report sexual misconduct with inmates.

This publication is developed by the NIC/WCL Project on Addressing Prison Rape under NIC Cooperative Agreement 06S20GJJ1.

This is not to be reproduced or cited without permission from the authors.

American University, Washington College of Law

Current as of May 7, 2009 


\section{Fifty State Survey of Mandatory Reporting Statutes}

\section{NIC/WCL Project on Addressing Prison Rape}

\begin{tabular}{|c|c|}
\hline $\begin{array}{l}\text { Relevant Definitions } \\
\text { Cont'd } \\
\text { (California) }\end{array}$ & 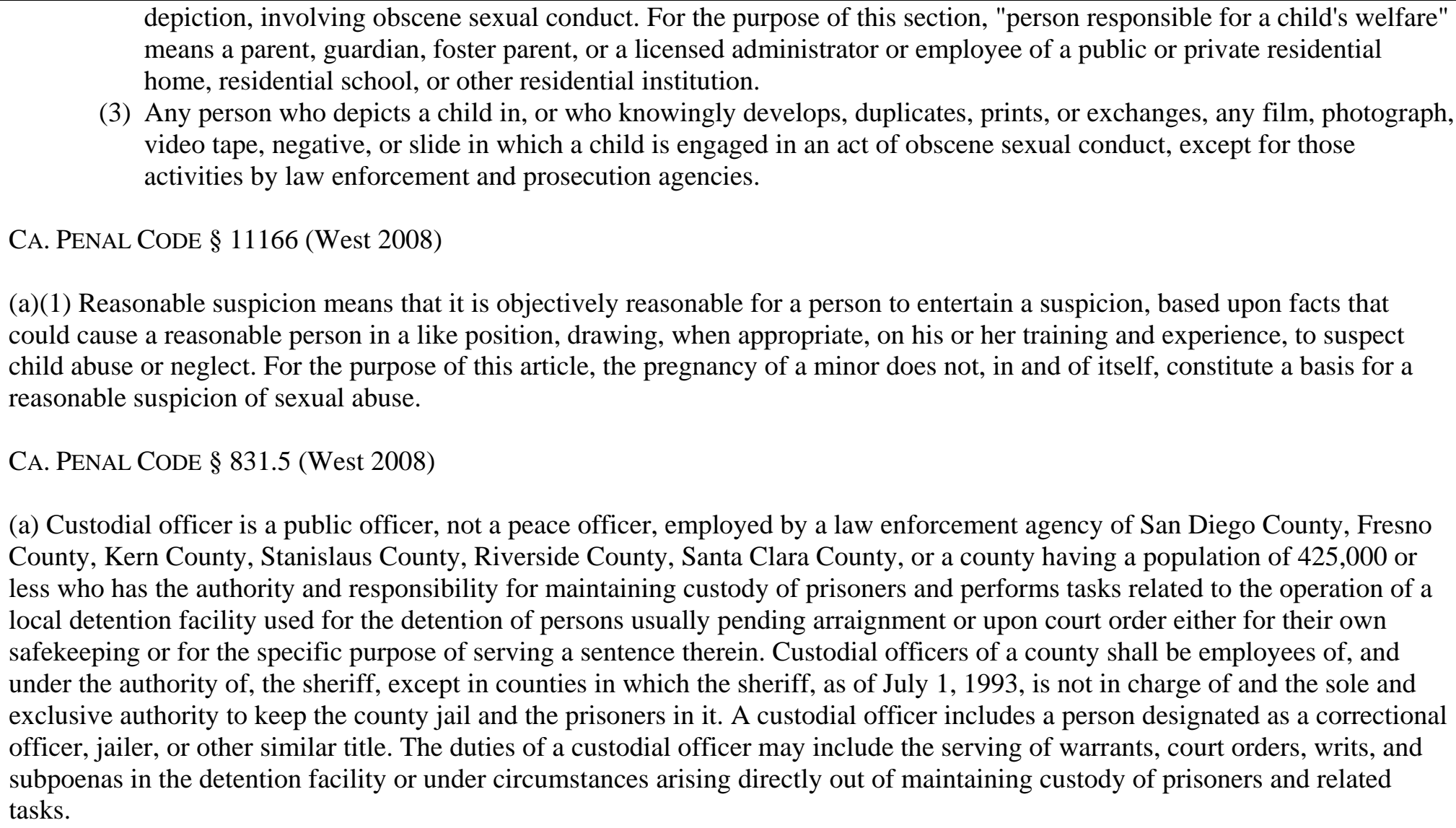 \\
\hline
\end{tabular}

** For purposes of this chart, corrections officers, police officers, peace officers, probation officers or "catch-all” phrases such as “all persons” have been bolded. However, many mandatory reporters include professionals who may have contact or work in correctional facilities. Such individuals include physicians, nurses, dentists, teachers and social workers. These statutes can be used as a tool to require staff other than correctional officers to report sexual misconduct with inmates.

This publication is developed by the NIC/WCL Project on Addressing Prison Rape under NIC Cooperative Agreement 06S20GJJ1.

This is not to be reproduced or cited without permission from the authors.

American University, Washington College of Law

Current as of May 7, 2009 


\section{Fifty State Survey of Mandatory Reporting Statutes}

\section{NIC/WCL Project on Addressing Prison Rape}

\begin{tabular}{|c|c|}
\hline $\begin{array}{l}\text { Relevant Definitions } \\
\text { Cont'd } \\
\text { (California) }\end{array}$ & $\begin{array}{l}\text { CA. PENAL CODE } \S 11166 \text { (West 2008) } \\
\text { (g) For the purposes of this section, “any other person” includes a mandated reporter who acts in his or her private capacity and } \\
\text { not in his or her professional capacity or within the scope of his or her employment. }\end{array}$ \\
\hline $\begin{array}{l}\text { Persons Required to } \\
\text { Report } \\
\text { (California) }\end{array}$ & $\begin{array}{l}\text { CA. PENAL CODE } § 11165.7 \text { (West 2008) } \\
\text { (a) “Mandated Reporter” is defined as any of the following: } \\
\text { (1) A teacher; } \\
\text { (2) An instructional aide; } \\
\text { (3) A teacher's aide or teacher's assistant employed by any public or private school; } \\
\text { (4) A classified employee of any public school; } \\
\text { (5) An administrative officer or supervisor of child welfare and attendance, or a certificated pupil personnel employee of any } \\
\text { (6) An administrator of a public or private day camp; } \\
\text { (7) An administrator or employee of a public or private youth center, youth recreation program, or youth organization; } \\
\text { (8) An administrator or employee of a public or private organization whose duties require direct contact and supervision of } \\
\text { (9) Any employee of a county office of education or California Department of Education, whose duties bring the employee } \\
\text { (10) A licensee, an administrator, or an employee of a licensed community care or child day care facility; } \\
\text { (11) A Head Start program teacher; } \\
\text { (12) A licensing worker or licensing evaluator employed by a licensing agency; } \\
\text { (13) A public assistance worker; } \\
\text { (14) An employee of a child care institution, including, but not limited to, foster parents, group home personnel, and } \\
\text { (15) A social worker, probation officer, or parole officer; }\end{array}$ \\
\hline
\end{tabular}

NOTE:

** For purposes of this chart, corrections officers, police officers, peace officers, probation officers or “catch-all” phrases such as “all persons” have been bolded. However, many mandatory reporters include professionals who may have contact or work in correctional facilities. Such individuals include physicians, nurses, dentists, teachers and social workers. These statutes can be used as a tool to require staff other than correctional officers to report sexual misconduct with inmates.

This publication is developed by the NIC/WCL Project on Addressing Prison Rape under NIC Cooperative Agreement 06S20GJJ1.

This is not to be reproduced or cited without permission from the authors.

American University, Washington College of Law

Current as of May 7, 2009 


\section{Fifty State Survey of Mandatory Reporting Statutes}

\section{NIC/WCL Project on Addressing Prison Rape}

\begin{tabular}{|c|c|c|}
\hline $\begin{array}{l}\text { Persons Required to } \\
\text { Report Cont'd } \\
\text { (California) }\end{array}$ & $\begin{array}{l}(16) \\
(17) \\
(18) \\
\\
(19) \\
(20) \\
(21) \\
\\
(22) \\
(23) \\
(24) \\
(25) \\
(26) \\
(27) \\
(28) \\
(29) \\
(30) \\
(32) \\
(33) \\
(34) \\
(35)\end{array}$ & 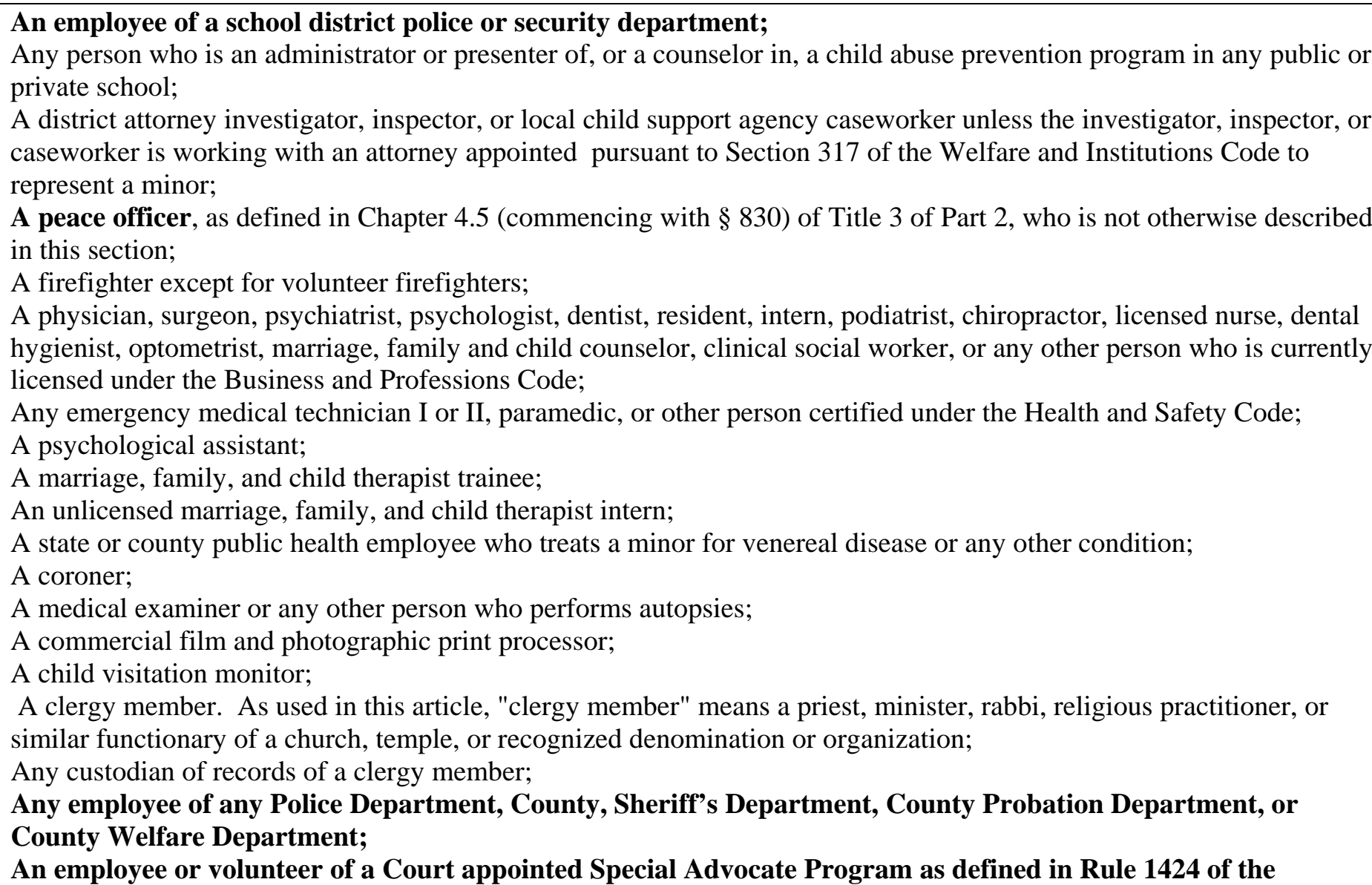 \\
\hline
\end{tabular}

NOTE:

** For purposes of this chart, corrections officers, police officers, peace officers, probation officers or "catch-all” phrases such as “all persons” have been bolded. However, many mandatory reporters include professionals who may have contact or work in correctional facilities. Such individuals include physicians, nurses, dentists, teachers and social workers. These statutes can be used as a tool to require staff other than correctional officers to report sexual misconduct with inmates.

This publication is developed by the NIC/WCL Project on Addressing Prison Rape under NIC Cooperative Agreement 06S20GJJ1.

This is not to be reproduced or cited without permission from the authors.

American University, Washington College of Law

Current as of May 7, 2009 


\section{Fifty State Survey of Mandatory Reporting Statutes}

\section{NIC/WCL Project on Addressing Prison Rape}

\begin{tabular}{|c|c|}
\hline $\begin{array}{l}\text { Persons Required to } \\
\text { Report Cont'd } \\
\text { (California) }\end{array}$ & $\begin{array}{l}\text { California Rules of Court; } \\
\text { (37) Any person providing services to a minor child. }\end{array}$ \\
\hline $\begin{array}{l}\text { Reporting } \\
\text { Procedures } \\
\text { (California) }\end{array}$ & 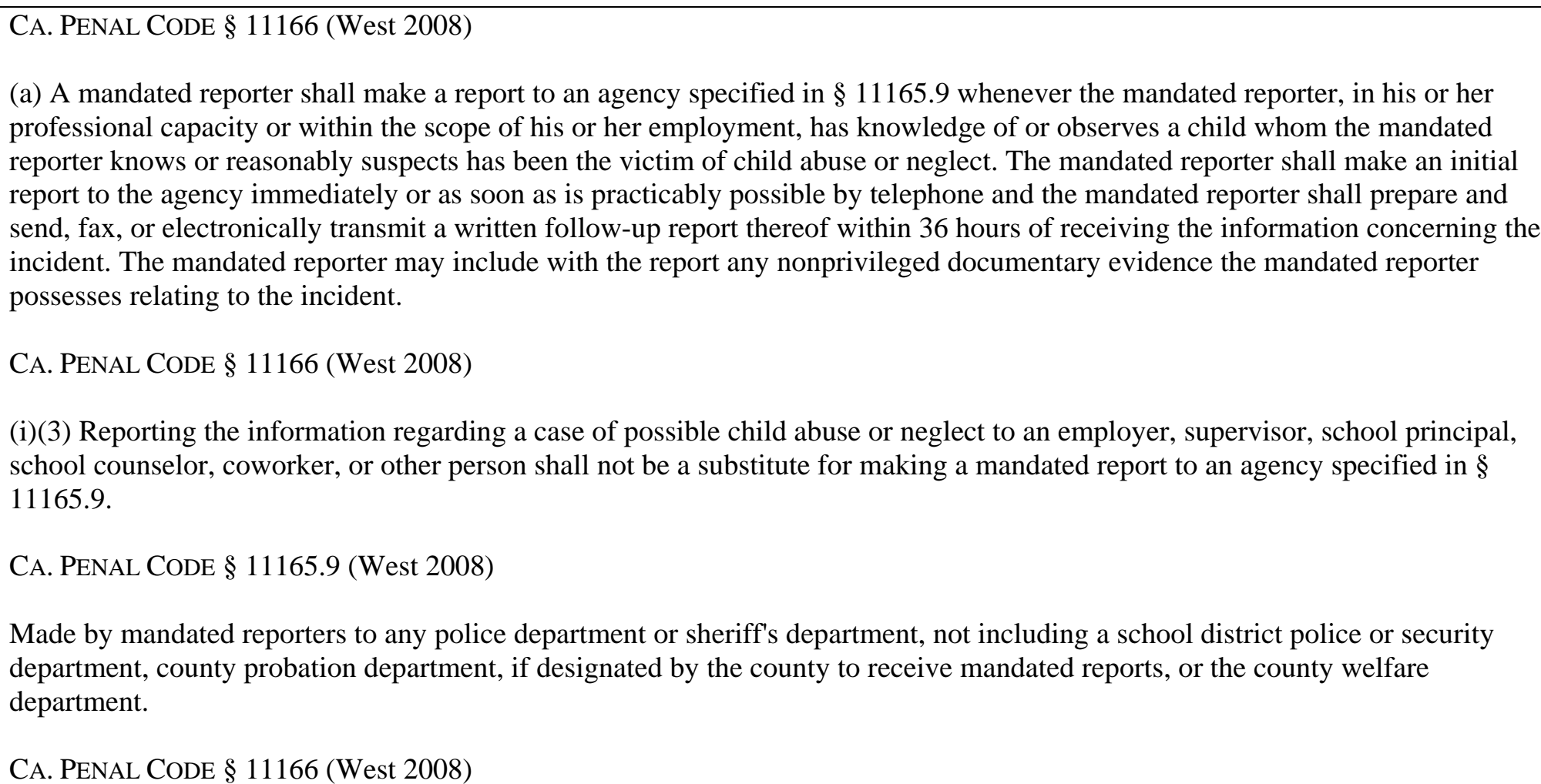 \\
\hline
\end{tabular}

NOTE:

** For purposes of this chart, corrections officers, police officers, peace officers, probation officers or "catch-all” phrases such as “all persons” have been bolded. However, many mandatory reporters include professionals who may have contact or work in correctional facilities. Such individuals include physicians, nurses, dentists, teachers and social workers. These statutes can be used as a tool to require staff other than correctional officers to report sexual misconduct with inmates.

This publication is developed by the NIC/WCL Project on Addressing Prison Rape under NIC Cooperative Agreement 06S20GJJ1.

This is not to be reproduced or cited without permission from the authors.

American University, Washington College of Law

Current as of May 7, 2009 


\section{Fifty State Survey of Mandatory Reporting Statutes}

\section{NIC/WCL Project on Addressing Prison Rape}

\begin{tabular}{|c|c|}
\hline $\begin{array}{l}\text { Reporting } \\
\text { Procedures Cont'd } \\
\text { (California) }\end{array}$ & $\begin{array}{l}\text { (b) If after reasonable efforts a mandated reporter is unable to submit an initial report by telephone, he or she shall immediately or } \\
\text { as soon as is practicably possible, by fax or electronic transmission, make a one-time automated written report on the form } \\
\text { prescribed by the Department of Justice, and shall also be available to respond to a telephone follow-up call by the agency with } \\
\text { which he or she filed the report. A mandated reporter who files a one-time automated written report because he or she was unable } \\
\text { to submit an initial report by telephone is not required to submit a written follow-up report. } \\
\text { CA. PENAL CODE } § 11166 \text { (West 2008) } \\
\text { (k) A law enforcement agency shall immediately, or as soon as practicably possible, report by telephone, fax, or electronic } \\
\text { transmission to the agency given responsibility for investigation of cases and to the district attorney's office every known or } \\
\text { suspected instance of child abuse or neglect reported to it, except acts or omissions which shall be reported only to the county } \\
\text { welfare or probation department. } \\
\text { CA. PENAL CoDE } § 11165.7 \text { (West 2008) } \\
\text { (e) Unless otherwise specifically provided, the absence of training shall not excuse a mandated reporter from the duties imposed } \\
\text { by this article. }\end{array}$ \\
\hline $\begin{array}{l}\text { Penalty for Failure to } \\
\text { Report } \\
\text { (California) }\end{array}$ & $\begin{array}{l}\text { CA. PENAL CODE } § 11166 \text { (West 2008) } \\
\text { (c) Any mandated reporter who fails to report an incident of known or reasonably suspected child abuse or neglect as required by } \\
\text { this section is guilty of a misdemeanor punishable by up to six months confinement in a county jail or by a fine of one thousand } \\
\text { dollars ( } \$ 1,000) \text { or by both that imprisonment and fine. If a mandated reporter intentionally conceals his or her failure to report an } \\
\text { incident known by the mandated reporter to be abuse or severe neglect under this section, the failure to report is a continuing } \\
\text { offense until an agency specified in } \S 11165.9 \text { discovers the offense. }\end{array}$ \\
\hline
\end{tabular}

NOTE:

** For purposes of this chart, corrections officers, police officers, peace officers, probation officers or “catch-all” phrases such as “all persons” have been bolded. However, many mandatory reporters include professionals who may have contact or work in correctional facilities. Such individuals include physicians, nurses, dentists, teachers and social workers. These statutes can be used as a tool to require staff other than correctional officers to report sexual misconduct with inmates.

This publication is developed by the NIC/WCL Project on Addressing Prison Rape under NIC Cooperative Agreement 06S20GJJ1.

This is not to be reproduced or cited without permission from the authors.

American University, Washington College of Law

Current as of May 7, 2009 


\section{Fifty State Survey of Mandatory Reporting Statutes}

\section{NIC/WCL Project on Addressing Prison Rape}

\begin{tabular}{|c|c|}
\hline $\begin{array}{l}\text { Mandatory } \\
\text { Reporting Statute } \\
\text { (California) }\end{array}$ & $\begin{array}{l}\text { AGAINST AN ADULT } \\
\text { CA. WEL \& INST } \S 15630 \text { (West 2008) }\end{array}$ \\
\hline $\begin{array}{l}\text { What has to be } \\
\text { reported? } \\
\text { (California) }\end{array}$ & $\begin{array}{l}\text { CA. WEL \& INST } \S 15630 \text { (West 2008) } \\
\text { (b)(1) Any mandated reporter who, in his or her professional capacity, or within the scope of his or her employment, has observed } \\
\text { or has knowledge of an incident that reasonably appears to be physical abuse. }\end{array}$ \\
\hline $\begin{array}{l}\text { Relevant Definitions } \\
\text { (California) }\end{array}$ & $\begin{array}{l}\text { CA. WEL \& INST } § 15610.23 \text { (West 2008) } \\
\text { (a) Dependent adult means any person between the ages of } 18 \text { and } 64 \text { years who resides in this state and who has physical or } \\
\text { mental limitations that restrict his or her ability to carry out normal activities or to protect his or her rights, including, but not } \\
\text { limited to, persons who have physical or developmental disabilities, or whose physical or mental abilities have diminished because } \\
\text { of age. } \\
\text { CA. WEL \& INST } \S 15610.63 \text { (West 2008) } \\
\text { "Physical abuse” means any of the following: } \\
\text { (a) Assault } \\
\text { (b) Battery } \\
\text { (c) Assault with a deadly weapon or force likely to produce great bodily injury (d) Unreasonable physical constraint, or prolonged } \\
\text { or continual deprivation of food or water. } \\
\text { (e) Sexual assault, that means any of the following: } \\
\text { (1) Sexual battery } \\
\text { (2) Rape } \\
\text { (3) Rape in concert }\end{array}$ \\
\hline
\end{tabular}

NOTE:

** For purposes of this chart, corrections officers, police officers, peace officers, probation officers or "catch-all” phrases such as "all persons" have been bolded. However, many mandatory reporters include professionals who may have contact or work in correctional facilities. Such individuals include physicians, nurses, dentists, teachers and social workers. These statutes can be used as a tool to require staff other than correctional officers to report sexual misconduct with inmates.

This publication is developed by the NIC/WCL Project on Addressing Prison Rape under NIC Cooperative Agreement 06S20GJJ1.

This is not to be reproduced or cited without permission from the authors.

American University, Washington College of Law

Current as of May 7, 2009 


\section{Fifty State Survey of Mandatory Reporting Statutes}

\section{NIC/WCL Project on Addressing Prison Rape}

\begin{tabular}{|c|c|}
\hline $\begin{array}{l}\text { Relevant Definitions } \\
\text { Cont'd } \\
\text { (California) }\end{array}$ & $\begin{array}{l}\text { (4) Spousal rape } \\
\text { (5) Incest } \\
\text { (6) Sodomy } \\
\text { (7) Oral copulation } \\
\text { (8) Sexual penetration } \\
\text { (9) Lewd or lascivious acts. }\end{array}$ \\
\hline $\begin{array}{l}\text { Persons Required to } \\
\text { Report } \\
\text { (California) }\end{array}$ & $\begin{array}{l}\text { CA. WEL \& INST } \S 15630 \text { (West 2008) } \\
\text { (a) Any person who has assumed full or intermittent responsibility for the care or custody of an elder or dependent adult, } \\
\text { whether or not he or she receives compensation, including administrators, supervisors, and any licensed staff of a public or private } \\
\text { facility that provides care or services for elder or dependent adults, or any elder or dependent adult care custodian, health } \\
\text { practitioner, clergy member, or employee of a county adult protective services agency or a local law enforcement agency. }\end{array}$ \\
\hline $\begin{array}{l}\text { Reporting } \\
\text { Procedures } \\
\text { (California) }\end{array}$ & $\begin{array}{l}\text { CA. WEL \& INST } § 15630 \text { (West 2008) } \\
\text { (b)(1)(A) If the abuse has occurred in a long-term care facility, except a state mental health hospital or a state developmental } \\
\text { center, the report shall be made to the local ombudsperson or the local law enforcement agency.... Except in an emergency, the } \\
\text { local ombudsperson and the local law enforcement agency shall, as soon as practicable, do all of the following: } \\
\text { (i) Report to the State Department of Health Services any case of known or suspected abuse occurring in a long-term health } \\
\text { care facility, as defined in subdivision (a) of Section } 1418 \text { of the Health and Safety Code. } \\
\text { (ii) Report to the State Department of Social Services any case of known or suspected abuse occurring in a residential care } \\
\text { facility for the elderly, as defined in Section } 1569.2 \text { of the Health and Safety Code, or in an adult day care facility, as defined } \\
\text { in paragraph (2) of subdivision (a) of Section } 1502 \text {. } \\
\text { (iii) Report to the State Department of Health Services and the California Department of Aging any case of known or } \\
\text { suspected abuse occurring in an adult day health care center, as defined in subdivision (b) of Section } 1570.7 \text { of the Health } \\
\text { and Safety Code. }\end{array}$ \\
\hline
\end{tabular}

** For purposes of this chart, corrections officers, police officers, peace officers, probation officers or "catch-all” phrases such as "all persons" have been bolded. However, many mandatory reporters include professionals who may have contact or work in correctional facilities. Such individuals include physicians, nurses, dentists, teachers and social workers. These statutes can be used as a tool to require staff other than correctional officers to report sexual misconduct with inmates.

This publication is developed by the NIC/WCL Project on Addressing Prison Rape under NIC Cooperative Agreement 06S20GJJ1.

This is not to be reproduced or cited without permission from the authors.

American University, Washington College of Law

Current as of May 7, 2009 


\section{Fifty State Survey of Mandatory Reporting Statutes}

\section{NIC/WCL Project on Addressing Prison Rape}

\begin{tabular}{|c|c|}
\hline $\begin{array}{l}\text { Reporting } \\
\text { Procedures Cont'd } \\
\text { (California) }\end{array}$ & $\begin{array}{l}\text { (iv) Report to the Bureau of Medi-Cal Fraud and Elder Abuse any case of known or suspected criminal activity. } \\
\text { (b)(1)(B) If the suspected or alleged abuse occurred in a state mental hospital or a state developmental center, the report shall be } \\
\text { made to designated investigators of the State Department of Mental Health or the State Department of Developmental Services, or } \\
\text { to the local law enforcement agency..... Except in an emergency, the local law enforcement agency shall, as soon as practicable, } \\
\text { report any case of known or suspected criminal activity to the Bureau of Medi-Cal Fraud and Elder Abuse. } \\
\text { (b)(1)(C) The report shall be made to the adult protective services agency or the local law enforcement agency. } \\
\text { (e) A telephone report of a known or suspected instance of elder or dependent adult abuse shall include, if known, the name of the } \\
\text { person making the report, the name and age of the elder or dependent adult, the present location of the elder or dependent adult, } \\
\text { the names and addresses of family members or any other adult responsible for the elder's or dependent adult's care, the nature and } \\
\text { extent of the elder's or dependent adult's condition, the date of the incident, and any other information, including information that } \\
\text { led that person to suspect elder or dependent adult abuse, as requested by the agency receiving the report. }\end{array}$ \\
\hline $\begin{array}{l}\text { Penalty for Failure to } \\
\text { Report } \\
\text { (California) }\end{array}$ & $\begin{array}{l}\text { CA. WEL \& INST } \S 15630 \text { (West 2008) } \\
\text { (h) Misdemeanor, punishable by not more than six months in the county jail, by a fine of not more than one thousand dollars } \\
(\$ 1,000) \text {, or by both that fine and imprisonment. Willful failure to report, or impedes or inhibits a report of, physical abuse, } \\
\text { abandonment, abduction, isolation, financial abuse, or neglect of an elder or dependent adult, in violation of this section, where } \\
\text { that abuse results in death or great bodily injury, shall be punished by not more than one year in a county jail, by a fine of not more } \\
\text { than five thousand dollars ( } \$ 5,000) \text {, or by both that fine and imprisonment. }\end{array}$ \\
\hline & COLORADO \\
\hline
\end{tabular}

NOTE:

** For purposes of this chart, corrections officers, police officers, peace officers, probation officers or “catch-all” phrases such as “all persons” have been bolded. However, many mandatory reporters include professionals who may have contact or work in correctional facilities. Such individuals include physicians, nurses, dentists, teachers and social workers. These statutes can be used as a tool to require staff other than correctional officers to report sexual misconduct with inmates.

This publication is developed by the NIC/WCL Project on Addressing Prison Rape under NIC Cooperative Agreement 06S20GJJ1.

This is not to be reproduced or cited without permission from the authors.

American University, Washington College of Law

Current as of May 7, 2009 


\section{Fifty State Survey of Mandatory Reporting Statutes}

\section{NIC/WCL Project on Addressing Prison Rape}

\begin{tabular}{|c|c|}
\hline $\begin{array}{l}\text { Mandatory } \\
\text { Reporting Statute } \\
\text { (Colorado) }\end{array}$ & $\begin{array}{l}\text { AGAINST A CHILD } \\
\text { C.R.S.A. § 19-3-304 (West 2008) }\end{array}$ \\
\hline $\begin{array}{l}\text { What has to be } \\
\text { reported? } \\
\text { (Colorado) }\end{array}$ & $\begin{array}{l}\text { C.R.S.A. } \S 19-3-304 \text { (West 2008) } \\
\text { (1) Reasonable cause to know or suspect that a child has been subjected to abuse or neglect or who has observed the child } \\
\text { being subjected to circumstances or conditions which would reasonably result in abuse or neglect. }\end{array}$ \\
\hline $\begin{array}{l}\text { Relevant Definitions } \\
\text { (Colorado) }\end{array}$ & $\begin{array}{l}\text { C.R.S.A. § 19-1-103 (West 2008) } \\
\text { (1)(a) Abuse or child abuse or neglect: means an act or omission in one of the following categories that threatens the health or } \\
\text { welfare of a child: } \\
\text { (I) Any case in which a child exhibits evidence of skin bruising, bleeding, malnutrition, failure to thrive, burns, fracture of } \\
\text { any bone, subdural hematoma, soft tissue swelling, or death and either: Such condition or death is not justifiably } \\
\text { explained; the history given concerning such condition is at variance with the degree or type of such condition or } \\
\text { death; or the circumstances indicate that such condition may not be the product of an accidental occurrence; } \\
\text { Any case in which a child is subjected to unlawful sexual behavior; } \\
\text { (II) Any case in which a child is a child in need of services because the child's parents, legal guardian, or custodian fails to } \\
\text { (III) would take. } \\
\text { Any case in which a child is subjected to emotional abuse. As used in this subparagraph (IV), "emotional abuse" means } \\
\text { an identifiable and substantial impairment of the child's intellectual or psychological functioning or development or a } \\
\text { substantial risk of impairment of the child's intellectual or psychological functioning or development. } \\
\text { Any act or omission described in section 19-3-102(1)(a), (1)(b), or (1)(c); } \\
\text { (V) Any case in which, in the presence of a child, or on the premises where a child is found, or where a child resides, a } \\
\text { (VI) controlled substance, is manufactured or attempted to be manufactured; }\end{array}$ \\
\hline
\end{tabular}

NOTE:

** For purposes of this chart, corrections officers, police officers, peace officers, probation officers or “catch-all” phrases such as “all persons” have been bolded. However, many mandatory reporters include professionals who may have contact or work in correctional facilities. Such individuals include physicians, nurses, dentists, teachers and social workers. These statutes can be used as a tool to require staff other than correctional officers to report sexual misconduct with inmates.

This publication is developed by the NIC/WCL Project on Addressing Prison Rape under NIC Cooperative Agreement 06S20GJJ1.

This is not to be reproduced or cited without permission from the authors.

American University, Washington College of Law

Current as of May 7, 2009 


\section{Fifty State Survey of Mandatory Reporting Statutes}

\section{NIC/WCL Project on Addressing Prison Rape}

\begin{tabular}{|c|c|}
\hline $\begin{array}{l}\text { Relevant Definitions } \\
\text { Cont'd } \\
\text { (Colorado) }\end{array}$ & 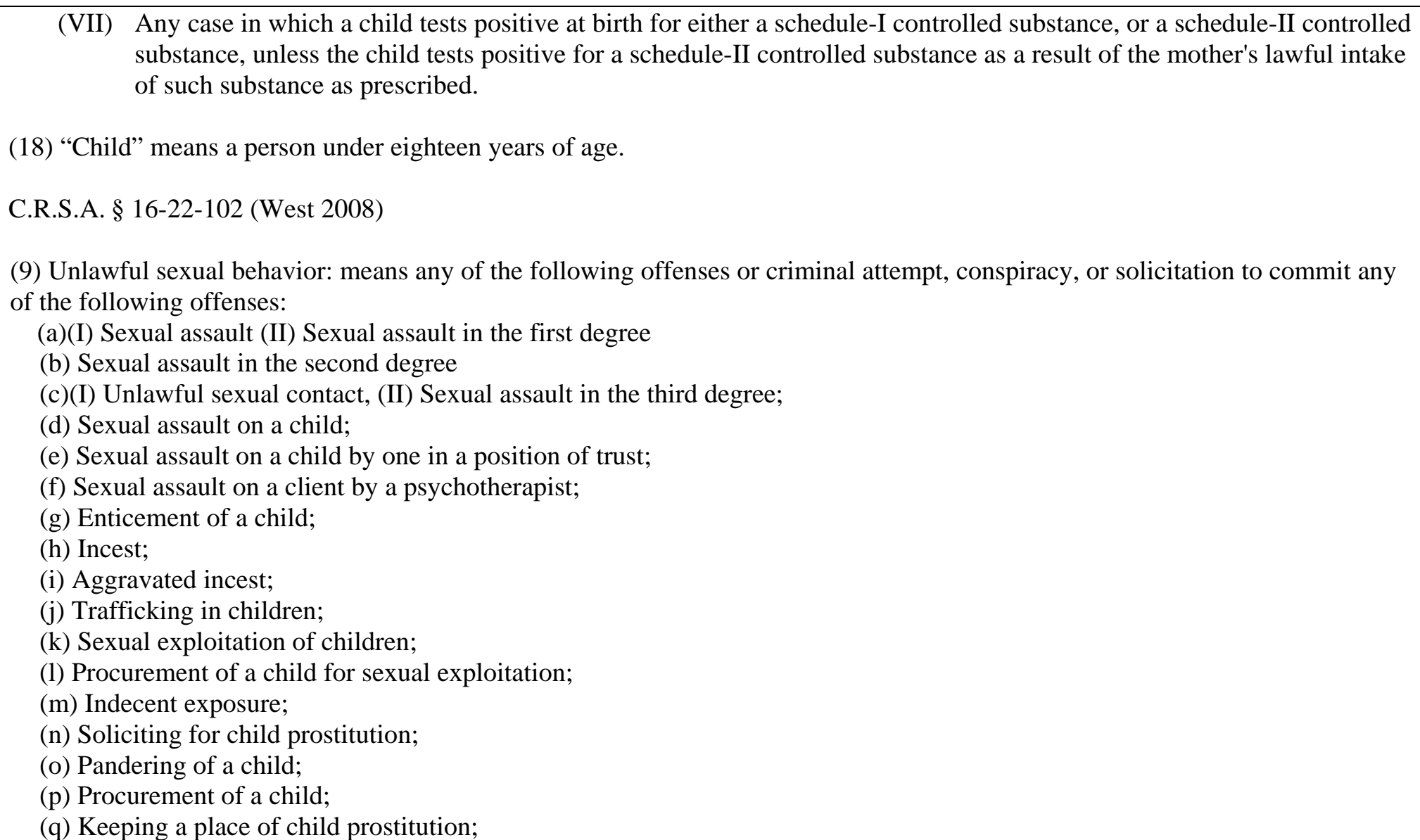 \\
\hline
\end{tabular}

NOTE:

** For purposes of this chart, corrections officers, police officers, peace officers, probation officers or "catch-all” phrases such as “all persons” have been bolded. However, many mandatory reporters include professionals who may have contact or work in correctional facilities. Such individuals include physicians, nurses, dentists, teachers and social workers. These statutes can be used as a tool to require staff other than correctional officers to report sexual misconduct with inmates.

This publication is developed by the NIC/WCL Project on Addressing Prison Rape under NIC Cooperative Agreement 06S20GJJ1.

This is not to be reproduced or cited without permission from the authors.

American University, Washington College of Law

Current as of May 7, 2009 


\section{Fifty State Survey of Mandatory Reporting Statutes}

\section{NIC/WCL Project on Addressing Prison Rape}

\begin{tabular}{|c|c|}
\hline $\begin{array}{l}\text { Relevant Definitions } \\
\text { Cont'd } \\
\text { (Colorado) }\end{array}$ & $\begin{array}{l}\text { (r) Pimping of a child; } \\
\text { (s) Inducement of child prostitution; } \\
\text { (t) Patronizing a prostituted child; } \\
\text { (u) Engaging in sexual conduct in a penal institution, } \\
\text { (v) Wholesale promotion of obscenity to a minor, } \\
\text { (w) Promotion of obscenity to a minor. } \\
\text { (x) Class } 4 \text { felony internet luring of a child; } \\
\text { (y) Internet sexual exploitation of a child. } \\
\text { C.R.S.A. } § 19-3-102(1)(a) \text {; (1)(b); (1)(c) (West 2008) } \\
\text { (1) A child is neglected or dependent if: } \\
\text { (a) A parent, guardian, or legal custodian has abandoned the child or has subjected him or her to mistreatment or abuse or a } \\
\text { parent, guardian, or legal custodian has suffered or allowed another to mistreat or abuse the child without taking lawful } \\
\text { means to stop such mistreatment or abuse and prevent it from recurring } \\
\text { (b) The child lacks proper parental care through the actions or omissions of the parent, guardian, or legal custodian } \\
\text { (c) The child's environment is injurious to his or her welfare. }\end{array}$ \\
\hline $\begin{array}{l}\text { Persons Required to } \\
\text { Report } \\
\text { (Colorado) }\end{array}$ & $\begin{array}{l}\text { C.R.S.A. § 19-3-304 (West 2008) } \\
\text { (2) A person required to report such abuse or neglect or circumstances or conditions shall include any } \\
\text { (a) Physician or surgeon, including a physician in training; } \\
\text { (b) Child health associate; } \\
\text { (c) Medical examiner or coroner; } \\
\text { (d) Dentist; }\end{array}$ \\
\hline
\end{tabular}

NOTE:

** For purposes of this chart, corrections officers, police officers, peace officers, probation officers or "catch-all” phrases such as “all persons” have been bolded. However, many mandatory reporters include professionals who may have contact or work in correctional facilities. Such individuals include physicians, nurses, dentists, teachers and social workers. These statutes can be used as a tool to require staff other than correctional officers to report sexual misconduct with inmates.

This publication is developed by the NIC/WCL Project on Addressing Prison Rape under NIC Cooperative Agreement 06S20GJJ1.

This is not to be reproduced or cited without permission from the authors.

American University, Washington College of Law

Current as of May 7, 2009 


\section{Fifty State Survey of Mandatory Reporting Statutes}

\section{NIC/WCL Project on Addressing Prison Rape}

\begin{tabular}{|c|c|c|}
\hline $\begin{array}{l}\text { Persons Required to } \\
\text { Report Cont'd } \\
\text { (Colorado) }\end{array}$ & 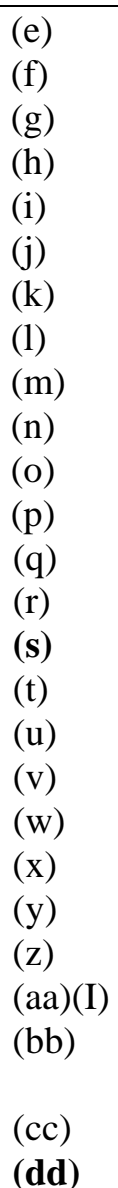 & 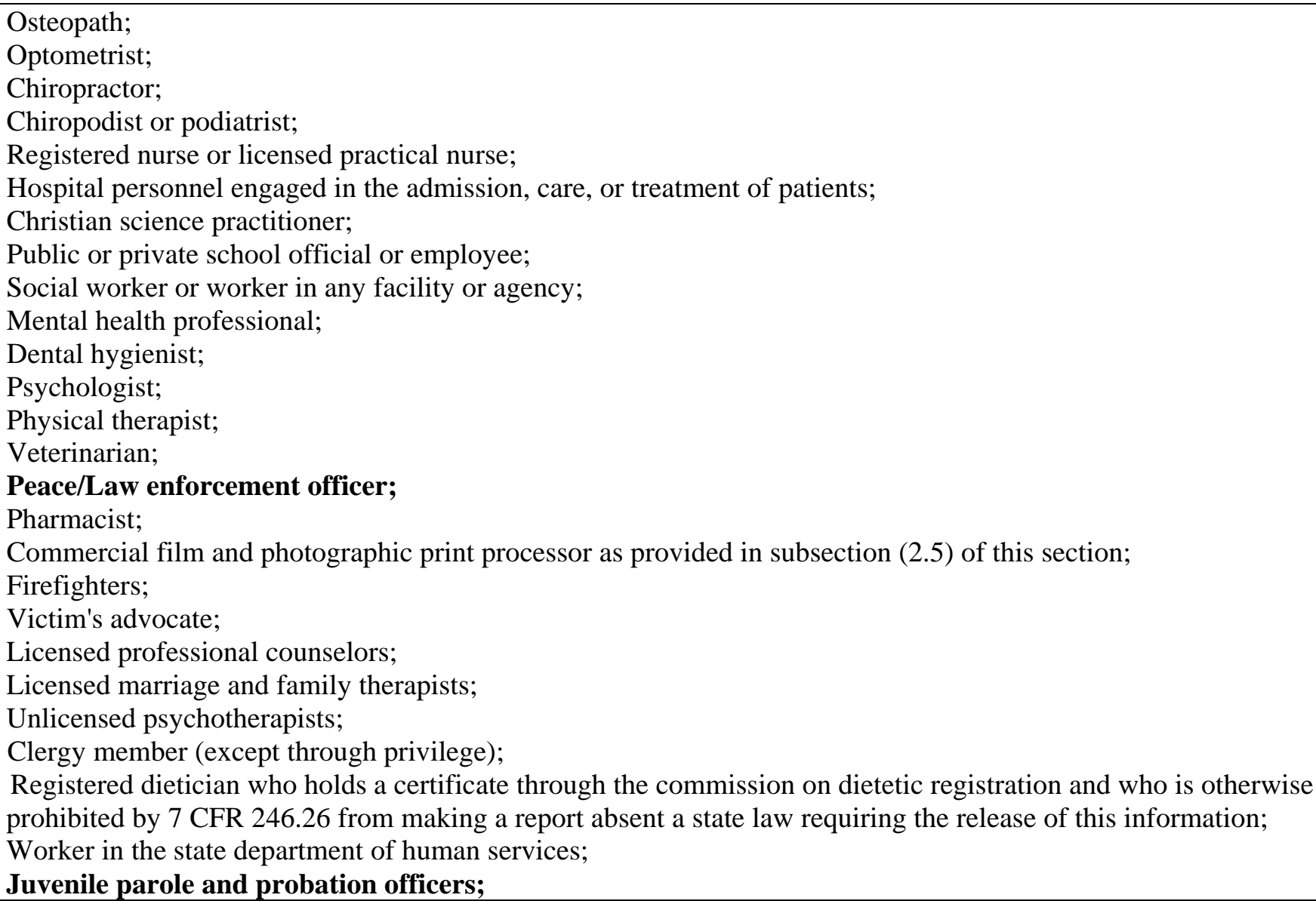 \\
\hline
\end{tabular}

NOTE:

** For purposes of this chart, corrections officers, police officers, peace officers, probation officers or "catch-all” phrases such as “all persons” have been bolded. However, many mandatory reporters include professionals who may have contact or work in correctional facilities. Such individuals include physicians, nurses, dentists, teachers and social workers. These statutes can be used as a tool to require staff other than correctional officers to report sexual misconduct with inmates.

This publication is developed by the NIC/WCL Project on Addressing Prison Rape under NIC Cooperative Agreement 06S20GJJ1.

This is not to be reproduced or cited without permission from the authors.

American University, Washington College of Law

Current as of May 7, 2009 


\section{Fifty State Survey of Mandatory Reporting Statutes}

\section{NIC/WCL Project on Addressing Prison Rape}

\begin{tabular}{|c|c|}
\hline $\begin{array}{l}\text { Persons Required to } \\
\text { Report Cont'd } \\
\text { (Colorado) }\end{array}$ & $\begin{array}{l}\text { (ee) Child and family investigators; } \\
\text { (ff) } \quad \text { Officers and agents of the state bureau of animal protection, and animal control officers. }\end{array}$ \\
\hline $\begin{array}{l}\text { Reporting } \\
\text { Procedures } \\
\text { (Colorado) }\end{array}$ & $\begin{array}{l}\text { C.R.S.A. § 19-3-304 (West 2008) } \\
\qquad \begin{array}{l}\text { (1) A mandatory reporter shall immediately upon receiving such information report or cause a report to be made of } \\
\text { such fact to the county department or local law enforcement agency. }\end{array}\end{array}$ \\
\hline $\begin{array}{l}\text { Penalty for Failure to } \\
\text { Report } \\
\text { (Colorado) }\end{array}$ & $\begin{array}{l}\text { C.R.S.A. } § 19-3-304 \text { (West 2008) } \\
\text { (4)(a) Class } 3 \text { Misdemeanor. } \\
\text { (4)(b) Liable for damages proximately caused thereby. } \\
\text { COLO. REV. STAT. } § 18-1.3-501 \text { (West 2008) } \\
\text { Maximum of } 6 \text { months in prison and/or maximum of } \$ 750 \text { fine }\end{array}$ \\
\hline $\begin{array}{l}\text { Mandatory } \\
\text { Reporting Statute } \\
\text { (Colorado) }\end{array}$ & $\begin{array}{l}\text { AGAINST AN ADULT } \\
\text { C.R.S.A. § 26-3.1-102 (West 2008) }\end{array}$ \\
\hline $\begin{array}{l}\text { What has to be } \\
\text { reported? } \\
\text { (Colorado) }\end{array}$ & $\begin{array}{l}\text { C.R.S.A. § 26-3.1-102 (West 2008) } \\
\text { (1)(a) Observed the mistreatment or self-neglect of an at-risk adult or who has reasonable cause to believe that an at-risk adult has } \\
\text { been mistreated or is self-neglected and is at imminent risk of mistreatment or self-neglect. }\end{array}$ \\
\hline
\end{tabular}

NOTE:

** For purposes of this chart, corrections officers, police officers, peace officers, probation officers or “catch-all” phrases such as “all persons” have been bolded. However, many mandatory reporters include professionals who may have contact or work in correctional facilities. Such individuals include physicians, nurses, dentists, teachers and social workers. These statutes can be used as a tool to require staff other than correctional officers to report sexual misconduct with inmates.

This publication is developed by the NIC/WCL Project on Addressing Prison Rape under NIC Cooperative Agreement 06S20GJJ1.

This is not to be reproduced or cited without permission from the authors.

American University, Washington College of Law

Current as of May 7, 2009 


\section{Fifty State Survey of Mandatory Reporting Statutes}

\section{NIC/WCL Project on Addressing Prison Rape}

\begin{tabular}{|c|c|}
\hline $\begin{array}{l}\text { Relevant Definitions } \\
\text { (Colorado) }\end{array}$ & $\begin{array}{l}\text { C.R.S.A. § 26-3.1-101 (West 2008) } \\
\text { (1) At-risk adult means an individual eighteen years of age or older who is susceptible to mistreatment as such term is defined in } \\
\text { subsection (4) of this section or self-neglect as such term is defined in subsection (7) of this section because the individual is } \\
\text { unable to perform or obtain services necessary for the individual's health, safety, or welfare or lacks sufficient understanding or } \\
\text { capacity to make or communicate responsible decisions concerning the individual's person or affairs. } \\
\text { (2) Caretaker means a person, as such term is defined in subsection (5) of this section, who is responsible for the care of an at-risk } \\
\text { adult, as such term is defined in subsection (1) of this section, as a result of a family or legal relationship or who has assumed } \\
\text { responsibility for the care of an at-risk adult. } \\
\text { (4) Mistreatment means an act or omission which threatens the health, safety, or welfare of an at-risk adult... or which exposes the } \\
\text { adult to a situation or condition that poses an imminent risk of death, serious bodily injury, or bodily injury to the adult. } \\
\text { "Mistreatment" includes, but is not limited to: } \\
\text { (a) Abuse which occurs: } \\
\text { (I) Where there is infliction of physical pain or injury, as demonstrated by, but not limited to, substantial or multiple skin } \\
\text { bruising, bleeding, malnutrition, dehydration, burns, bone fractures, poisoning, subdural hematoma, soft tissue swelling, or } \\
\text { suffocation; } \\
\text { (II) Where unreasonable confinement or restraint is imposed; or } \\
\text { (III) Where there is subjection to nonconsensual sexual conduct or contact; } \\
\text { (b) Caretaker neglect which occurs when adequate food, clothing, shelter, psychological care, physical care, medical care, or } \\
\text { supervision is not secured for the at-risk adult or is not provided by a caretaker in a timely manner and with the degree of care } \\
\text { that a reasonable person in the same situation would exercise; except that the withholding of artificial nourishment shall not be } \\
\text { considered as abuse; } \\
\text { (c) Exploitation which is the illegal or improper use of an at-risk adult for another person's advantage. }\end{array}$ \\
\hline
\end{tabular}

NOTE:

** For purposes of this chart, corrections officers, police officers, peace officers, probation officers or "catch-all” phrases such as "all persons" have been bolded. However, many mandatory reporters include professionals who may have contact or work in correctional facilities. Such individuals include physicians, nurses, dentists, teachers and social workers. These statutes can be used as a tool to require staff other than correctional officers to report sexual misconduct with inmates.

This publication is developed by the NIC/WCL Project on Addressing Prison Rape under NIC Cooperative Agreement 06S20GJJ1.

This is not to be reproduced or cited without permission from the authors.

American University, Washington College of Law

Current as of May 7, 2009 


\section{Fifty State Survey of Mandatory Reporting Statutes}

\section{NIC/WCL Project on Addressing Prison Rape}

\begin{tabular}{|c|c|}
\hline $\begin{array}{l}\text { Persons Required to } \\
\text { Report } \\
\text { (Colorado) }\end{array}$ & 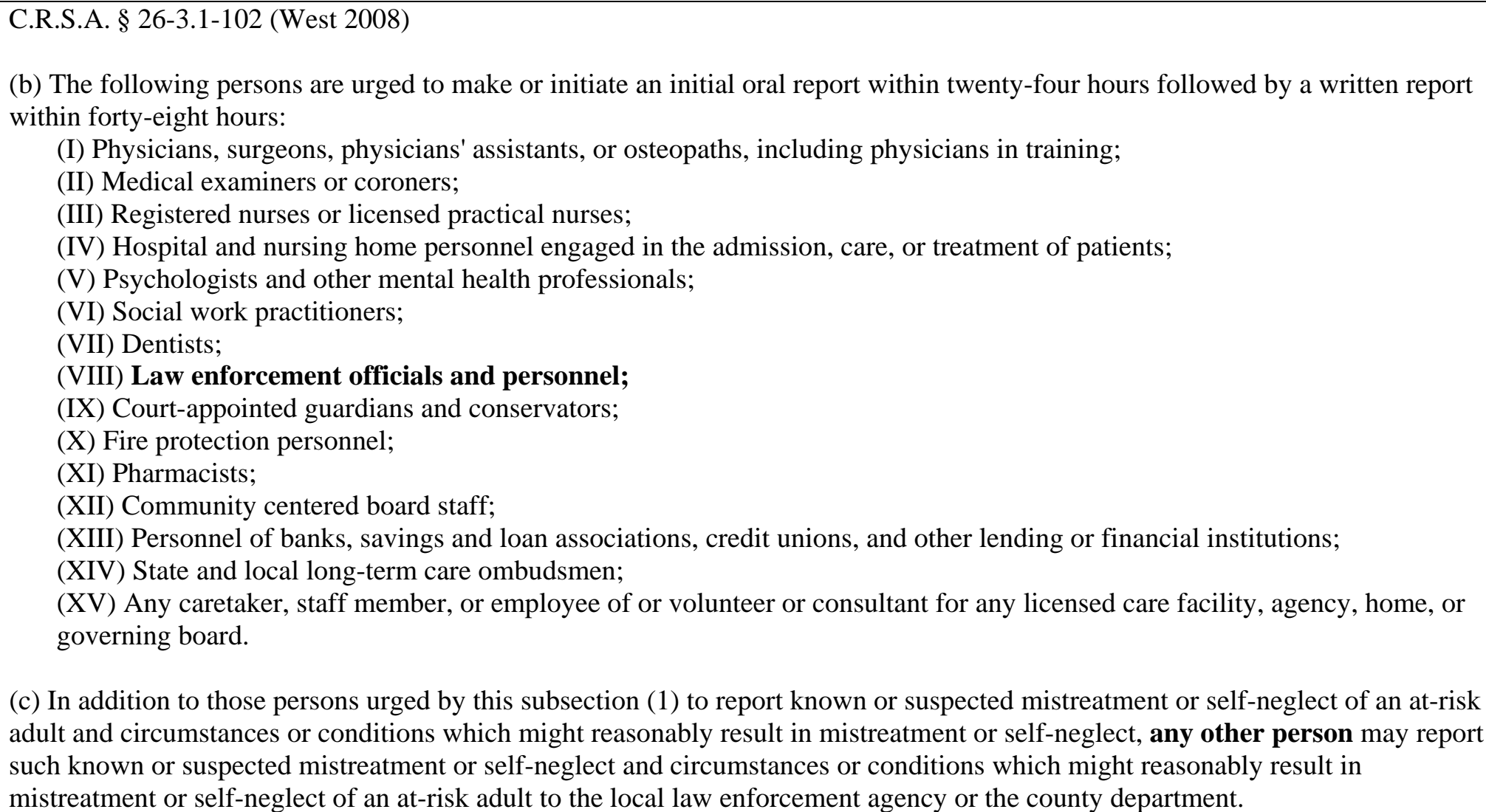 \\
\hline
\end{tabular}

NOTE:

** For purposes of this chart, corrections officers, police officers, peace officers, probation officers or "catch-all” phrases such as "all persons" have been bolded. However, many mandatory reporters include professionals who may have contact or work in correctional facilities. Such individuals include physicians, nurses, dentists, teachers and social workers. These statutes can be used as a tool to require staff other than correctional officers to report sexual misconduct with inmates.

This publication is developed by the NIC/WCL Project on Addressing Prison Rape under NIC Cooperative Agreement 06S20GJJ1.

This is not to be reproduced or cited without permission from the authors.

American University, Washington College of Law

Current as of May 7, 2009 


\section{Fifty State Survey of Mandatory Reporting Statutes}

\section{NIC/WCL Project on Addressing Prison Rape}

\begin{tabular}{|c|c|}
\hline $\begin{array}{l}\text { Reporting } \\
\text { Procedures } \\
\text { (Colorado) }\end{array}$ & $\begin{array}{l}\text { C.R.S.A. } § \text { 26-3.1-102 (West 2008) } \\
\text { (1)(a) Immediate oral report of abuse should be made or caused to be made within twenty-four hours to the county department or } \\
\text { during non-business hours to a local law enforcement agency responsible for investigating violations of state criminal laws } \\
\text { protecting at-risk adults. } \\
\text { C.R.S.A. } § \text { 26-3.1-102 (West 2008) } \\
\text { (2) The report shall include: The name and address of the at-risk adult; the name and address of the at-risk adult's caretaker, if any; } \\
\text { the age, if known, of such at-risk adult; the nature and extent of such at-risk adult's injury, if any; the nature and extent of the } \\
\text { condition that will reasonably result in mistreatment or self-neglect; and any other pertinent information. }\end{array}$ \\
\hline $\begin{array}{l}\text { Penalty for Failure to } \\
\text { Report } \\
\text { (Colorado) }\end{array}$ & $\begin{array}{l}\text { C.R.S.A. § 26-3.1-102 (West 2008) } \\
\text { (1)(b) No enumerated sanctions; reporting is “urged,” not required. }\end{array}$ \\
\hline & CONNECTICUT \\
\hline $\begin{array}{l}\text { Mandatory } \\
\text { Reporting Statute } \\
\text { (Connecticut) }\end{array}$ & $\begin{array}{l}\text { AGAINST A CHILD } \\
\text { C.G.S.A. } \S 17 a-101 a \text { (West 2008) }\end{array}$ \\
\hline $\begin{array}{l}\text { What has to be } \\
\text { reported? } \\
\text { (Connecticut) }\end{array}$ & $\begin{array}{l}\text { C.G.S.A. } § 17 a-101 a \text { (West 2008) } \\
\text { In the ordinary course of such person's employment or profession has reasonable cause to suspect or believe that any child under } \\
\text { the age of eighteen years (1) has been abused or neglected, }(2) \text { has had nonaccidental physical injury, or injury which is at variance } \\
\text { with the history given of such injury, inflicted upon such child, or (3) is placed at imminent risk of serious harm, shall report or }\end{array}$ \\
\hline
\end{tabular}

\section{NOTE:}

** For purposes of this chart, corrections officers, police officers, peace officers, probation officers or “catch-all” phrases such as “all persons” have been bolded. However, many mandatory reporters include professionals who may have contact or work in correctional facilities. Such individuals include physicians, nurses, dentists, teachers and social workers. These statutes can be used as a tool to require staff other than correctional officers to report sexual misconduct with inmates.

This publication is developed by the NIC/WCL Project on Addressing Prison Rape under NIC Cooperative Agreement 06S20GJJ1.

This is not to be reproduced or cited without permission from the authors.

American University, Washington College of Law

Current as of May 7, 2009 


\section{Fifty State Survey of Mandatory Reporting Statutes}

\section{NIC/WCL Project on Addressing Prison Rape}

\begin{tabular}{|c|c|}
\hline $\begin{array}{l}\text { What has to be } \\
\text { reported? } \\
\text { (Connecticut) }\end{array}$ & cause a report to be made. \\
\hline $\begin{array}{l}\text { Relevant Definitions } \\
\text { (Connecticut) }\end{array}$ & 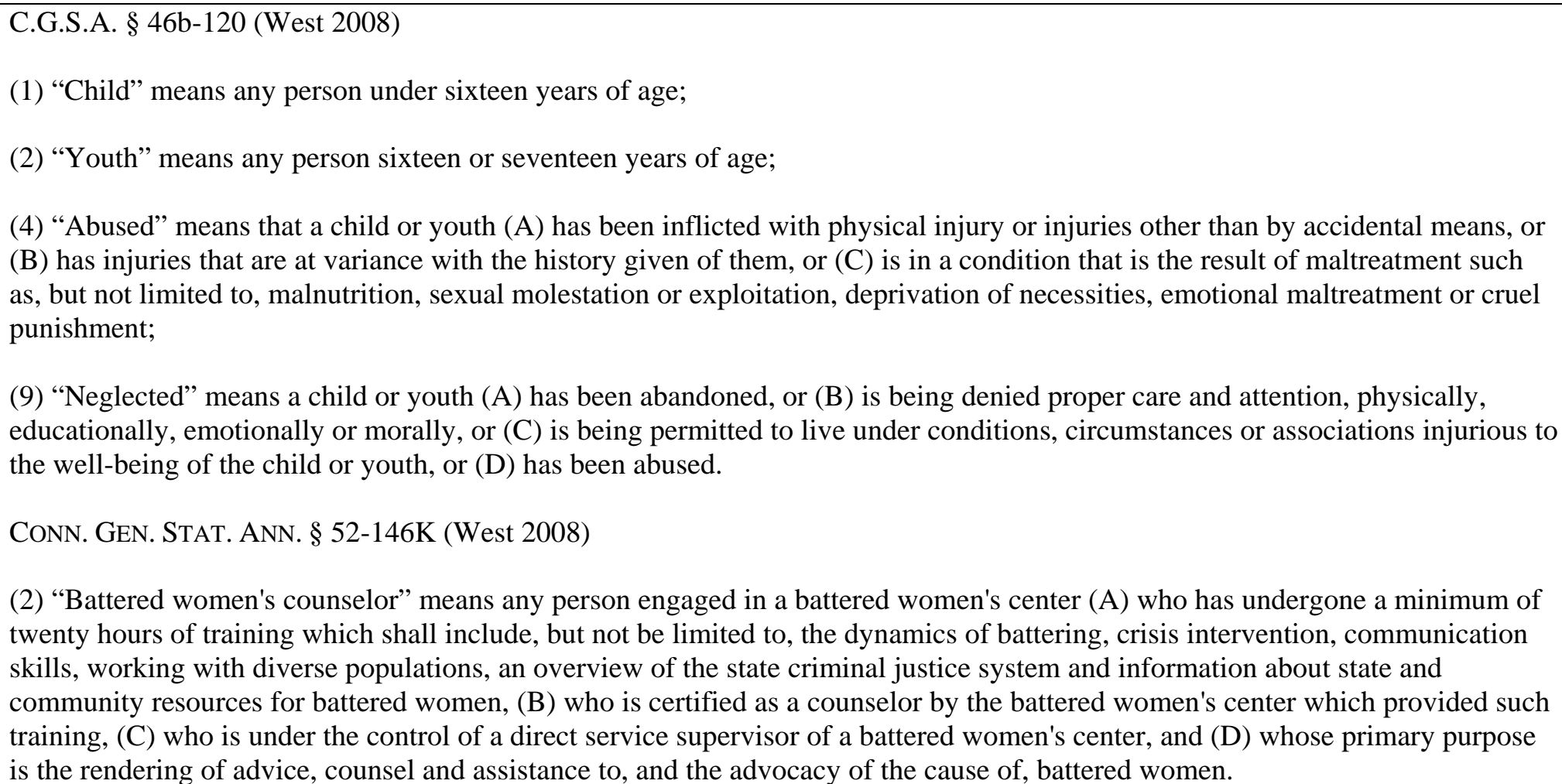 \\
\hline
\end{tabular}

NOTE:

** For purposes of this chart, corrections officers, police officers, peace officers, probation officers or “catch-all” phrases such as “all persons” have been bolded. However, many mandatory reporters include professionals who may have contact or work in correctional facilities. Such individuals include physicians, nurses, dentists, teachers and social workers. These statutes can be used as a tool to require staff other than correctional officers to report sexual misconduct with inmates.

This publication is developed by the NIC/WCL Project on Addressing Prison Rape under NIC Cooperative Agreement 06S20GJJ1.

This is not to be reproduced or cited without permission from the authors.

American University, Washington College of Law

Current as of May 7, 2009 


\section{Fifty State Survey of Mandatory Reporting Statutes}

\section{NIC/WCL Project on Addressing Prison Rape}

\begin{tabular}{|c|c|}
\hline $\begin{array}{l}\text { Persons Required to } \\
\text { Report } \\
\text { (Connecticut) }\end{array}$ & 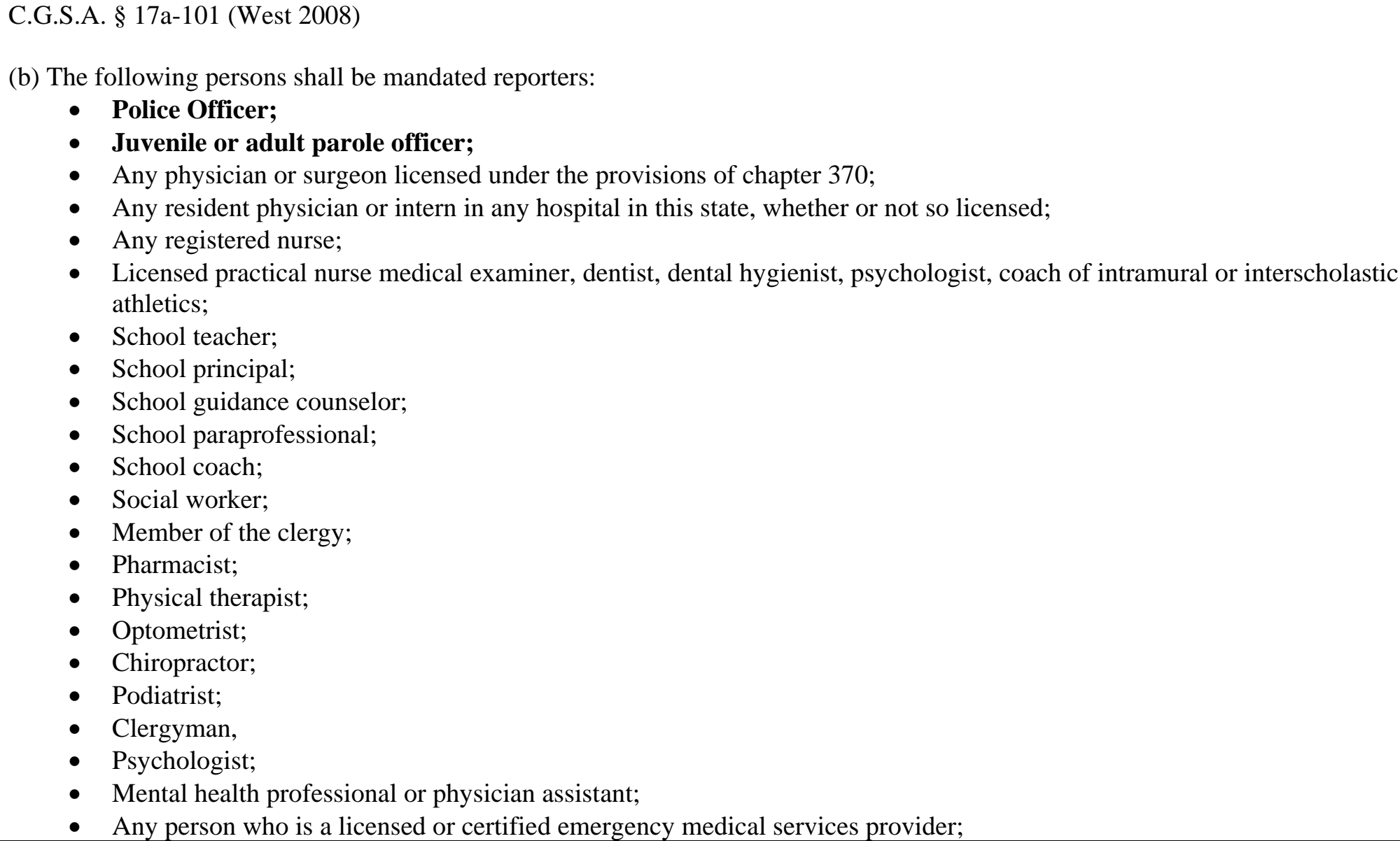 \\
\hline
\end{tabular}

NOTE:

** For purposes of this chart, corrections officers, police officers, peace officers, probation officers or "catch-all” phrases such as "all persons" have been bolded. However, many mandatory reporters include professionals who may have contact or work in correctional facilities. Such individuals include physicians, nurses, dentists, teachers and social workers. These statutes can be used as a tool to require staff other than correctional officers to report sexual misconduct with inmates.

This publication is developed by the NIC/WCL Project on Addressing Prison Rape under NIC Cooperative Agreement 06S20GJJ1.

This is not to be reproduced or cited without permission from the authors.

American University, Washington College of Law

Current as of May 7, 2009 


\section{Fifty State Survey of Mandatory Reporting Statutes}

\section{NIC/WCL Project on Addressing Prison Rape}

\begin{tabular}{|c|c|}
\hline $\begin{array}{l}\text { Persons Required to } \\
\text { Report Cont'd } \\
\text { (Connecticut) }\end{array}$ & $\begin{array}{l}\text { - Any person who is a licensed or certified alcohol and drug counselor; } \\
\text { - Any person who is a licensed marital and family therapist; } \\
\text { - Any person who is a sexual assault counselor or a battered women's counselor; } \\
\text { - Any person who is a licensed professional counselor; } \\
\text { - A child day care center, group day care home or family day care home licensed by the state; } \\
\text { - Any employee of the Department of Children and Families; } \\
\text { - Any employee of the Department of Public Health who is responsible for the licensing of child day care centers, group } \\
\text { - Any care homes, family day care homes or youth camps, the Child Advocate; } \\
\text { - Any employee of the Office of Child Advocate; }\end{array}$ \\
\hline $\begin{array}{l}\text { Reporting } \\
\text { Procedures } \\
\text { (Connecticut) }\end{array}$ & $\begin{array}{l}\text { C.G.S.A. } \S 17 a-101 b \text { (West 2008) } \\
\text { (a) An oral report shall be made by a mandated reporter as soon as practicable but not later than twelve hours after the mandated } \\
\text { reporter has reasonable cause to suspect or believe that a child has been abused or neglected or placed in imminent risk of serious } \\
\text { harm, by telephone or in person to the Commissioner of Children and Families or a law enforcement agency. If a law enforcement } \\
\text { agency receives an oral report, it shall immediately notify the Commissioner of Children and Families. }\end{array}$ \\
\hline $\begin{array}{l}\text { Penalty for Failure to } \\
\text { Report } \\
\text { (Connecticut) }\end{array}$ & $\begin{array}{l}\text { C.G.S.A. } \S 17 a-101 \text { (West 2008) } \\
\text { (d) Any mandated reporter who fails to report to the Commissioner of Children and Families shall be required to participate in an } \\
\text { educational and training program established by the commissioner. } \\
\text { C.G.S.A. } \S \S 17 a-101 a \text { (West 2008) }\end{array}$ \\
\hline
\end{tabular}

NOTE:

** For purposes of this chart, corrections officers, police officers, peace officers, probation officers or “catch-all” phrases such as “all persons” have been bolded. However, many mandatory reporters include professionals who may have contact or work in correctional facilities. Such individuals include physicians, nurses, dentists, teachers and social workers. These statutes can be used as a tool to require staff other than correctional officers to report sexual misconduct with inmates.

This publication is developed by the NIC/WCL Project on Addressing Prison Rape under NIC Cooperative Agreement 06S20GJJ1.

This is not to be reproduced or cited without permission from the authors.

American University, Washington College of Law

Current as of May 7, 2009 


\section{Fifty State Survey of Mandatory Reporting Statutes}

\section{NIC/WCL Project on Addressing Prison Rape}

\begin{tabular}{|c|c|}
\hline $\begin{array}{l}\text { Penalty for Failure to } \\
\text { Report Cont'd } \\
\text { (Connecticut) }\end{array}$ & Fine of no more than $\$ 2,500$ \\
\hline $\begin{array}{l}\text { Mandatory } \\
\text { Reporting Statute } \\
\text { (Connecticut) }\end{array}$ & $\begin{array}{l}\text { AGAINST AN ADULT } \\
\text { CONN. GEN. STAT. ANN. } \S 17 b-451 \text { (West 2008) }\end{array}$ \\
\hline $\begin{array}{l}\text { What has to be } \\
\text { reported? } \\
\text { (Connecticut) }\end{array}$ & $\begin{array}{l}\text { C.G.S.A. } § 17 b-451 \text { (West 2008) } \\
\text { (a) Reasonable cause to suspect or believe that any elderly person has been abused, neglected, exploited or abandoned, or is in a } \\
\text { condition which is the result of such abuse, neglect, exploitation or abandonment, or is in need of protective services. }\end{array}$ \\
\hline $\begin{array}{l}\text { Relevant Definitions } \\
\text { (Connecticut) }\end{array}$ & $\begin{array}{l}\text { C.G.S.A. § 17b-450 (West 2008) } \\
\text { (1) Elderly person means any resident of Connecticut who is sixty years of age or older. }\end{array}$ \\
\hline $\begin{array}{l}\text { Persons Required to } \\
\text { Report } \\
\text { (Connecticut) }\end{array}$ & 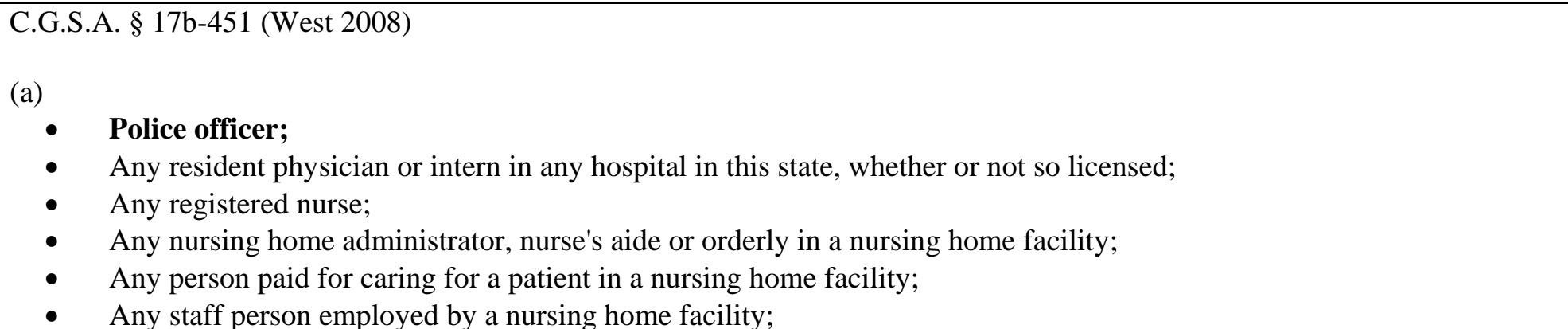 \\
\hline
\end{tabular}

NOTE:

** For purposes of this chart, corrections officers, police officers, peace officers, probation officers or "catch-all” phrases such as "all persons" have been bolded. However, many mandatory reporters include professionals who may have contact or work in correctional facilities. Such individuals include physicians, nurses, dentists, teachers and social workers. These statutes can be used as a tool to require staff other than correctional officers to report sexual misconduct with inmates.

This publication is developed by the NIC/WCL Project on Addressing Prison Rape under NIC Cooperative Agreement 06S20GJJ1.

This is not to be reproduced or cited without permission from the authors.

American University, Washington College of Law

Current as of May 7, 2009 


\section{Fifty State Survey of Mandatory Reporting Statutes}

\section{NIC/WCL Project on Addressing Prison Rape}

\begin{tabular}{|c|c|}
\hline $\begin{array}{l}\text { Persons Required to } \\
\text { Report Cont'd } \\
\text { (Connecticut) }\end{array}$ & $\begin{array}{l}\text { - } \quad \text { Any patients' advocate and any licensed practical nurse, medical examiner, dentist, optometrist, chiropractor; podiatrist; } \\
\text { - } \quad \text { Social worker; } \\
\text { - } \quad \text { Clergyman, } \\
\text { - } \quad \text { Psychochogist; } \\
\text { - } \quad \text { Physical therapist. }\end{array}$ \\
\hline $\begin{array}{l}\text { Reporting } \\
\text { Procedures } \\
\text { (Connecticut) }\end{array}$ & $\begin{array}{l}\text { C.G.S.A. § § 17b-451 (West 2008) } \\
\text { (a) Not later than seventy-two hours after such suspicion or belief arose, report such information or cause a report to be made in } \\
\text { any reasonable manner to the Commissioner of Social Services or to the person or persons designated by the commissioner to } \\
\text { receive such reports. } \\
\text { C.G.S.A. § 17b-451 (West 2008) } \\
\text { (b) Such report shall contain the name and address of the involved elderly person, information regarding the nature and extent of } \\
\text { the abuse, neglect, exploitation or abandonment, and any other information which the reporter believes might be helpful in an } \\
\text { investigation of the case and the protection of such elderly person. }\end{array}$ \\
\hline
\end{tabular}

NOTE:

** For purposes of this chart, corrections officers, police officers, peace officers, probation officers or "catch-all” phrases such as "all persons" have been bolded. However, many mandatory reporters include professionals who may have contact or work in correctional facilities. Such individuals include physicians, nurses, dentists, teachers and social workers. These statutes can be used as a tool to require staff other than correctional officers to report sexual misconduct with inmates.

This publication is developed by the NIC/WCL Project on Addressing Prison Rape under NIC Cooperative Agreement 06S20GJJ1.

This is not to be reproduced or cited without permission from the authors.

American University, Washington College of Law

Current as of May 7, 2009 


\section{Fifty State Survey of Mandatory Reporting Statutes}

\section{NIC/WCL Project on Addressing Prison Rape}

\begin{tabular}{|c|c|}
\hline $\begin{array}{l}\text { Penalty for Failure to } \\
\text { Report } \\
\text { (Connecticut) }\end{array}$ & $\begin{array}{l}\text { C.G.S.A. } § 17 b-451 \text { (West 2008) } \\
\text { (a) Any person required to report under the provisions of this section who fails to make such report within the prescribed time } \\
\text { period shall be fined not more than } \$ 500.00 \text {, except that, if such person intentionally fails to make such report within the } \\
\text { prescribed time period, such person shall be guilty of a class } C \text { misdemeanor for the first offense and a class A misdemeanor for } \\
\text { any subsequent offense. } \\
\text { C.G.S.A. } § 53 a-26 \text { (West 2008) } \\
\text { (a) An offense for which a person may be sentenced to a term of imprisonment of not more than one year is a misdemeanor. } \\
\text { (b) Misdemeanors are classified for the purposes of sentence as follows: (1) Class A, (2) class B, (3) class C and (4) unclassified. }\end{array}$ \\
\hline & DELEWARE \\
\hline $\begin{array}{l}\text { Mandatory } \\
\text { Reporting Statute } \\
\text { (Delaware) }\end{array}$ & $\begin{array}{l}\text { AGAINST A CHILD } \\
16 \text { DEL.C. } \S 903 \text { (West 2008) }\end{array}$ \\
\hline $\begin{array}{l}\text { What has to be } \\
\text { reported? } \\
\text { (Delaware) }\end{array}$ & $\begin{array}{l}16 \text { DEL.C. § } 903 \text { (West 2008) } \\
\text { Knowledge or good faith suspicion of child abuse or neglect. }\end{array}$ \\
\hline $\begin{array}{l}\text { Relevant Definitions } \\
\text { (Delaware) }\end{array}$ & 16 DEL.C. § 902 (West 2008) \\
\hline
\end{tabular}

NOTE:

** For purposes of this chart, corrections officers, police officers, peace officers, probation officers or “catch-all” phrases such as “all persons” have been bolded. However, many mandatory reporters include professionals who may have contact or work in correctional facilities. Such individuals include physicians, nurses, dentists, teachers and social workers. These statutes can be used as a tool to require staff other than correctional officers to report sexual misconduct with inmates.

This publication is developed by the NIC/WCL Project on Addressing Prison Rape under NIC Cooperative Agreement 06S20GJJ1.

This is not to be reproduced or cited without permission from the authors.

American University, Washington College of Law

Current as of May 7, 2009 


\section{Fifty State Survey of Mandatory Reporting Statutes}

\section{NIC/WCL Project on Addressing Prison Rape}

\begin{tabular}{|c|c|}
\hline $\begin{array}{l}\text { Relevant Definitions } \\
\text { Cont'd } \\
\text { (Delaware) }\end{array}$ & $\begin{array}{l}\text { (3) “Child” shall mean any person who has not reached his or her 18th birthday. } \\
10 \text { DEL.C. § } 901 \text { (West 2008) } \\
\text { (1) “Abuse” or “abused child” shall mean any physical injury to a child by those responsible for the care, custody and control of } \\
\text { the child, through unjustified force, emotional abuse, torture, criminally negligent treatment, sexual abuse, exploitation, } \\
\text { maltreatment or mistreatment. } \\
\text { (18) "Neglect” or "neglected child” means that a person: } \\
\text { (a) is responsible for the care, custody, and/or control of the child; and } \\
\text { (b) has the ability and financial means to provide for the care of the child; and } \\
\text { 1. fails to provide necessary care with regard to: food, clothing, shelter, education, health, medical or other care necessary } \\
\text { for the child's emotional, physical, or mental health, or safety and general well-being; or } \\
\text { 2. chronically and severely abuses alcohol or a controlled substance, is not active in treatment for such abuse, and the } \\
\text { abuse threatens the child's ability to receive care necessary for his or her safety and general well-being, or } \\
\text { 3. fails to provide necessary supervision appropriate for a child when the child is unable to care for his or her own basic } \\
\text { needs or safety, after considering such factors as the child's age, mental ability, physical condition, the length of the } \\
\text { caretaker's absence, and the context of the child's environment. }\end{array}$ \\
\hline $\begin{array}{l}\text { Persons Required to } \\
\text { Report } \\
\text { (Delaware) }\end{array}$ & $\begin{array}{l}\text { 16 DEL.C. § } 903 \text { (West 2008) } \\
\text { - Any physician } \\
\text { - Any other person in the healing arts including any person licensed to render services in medicine, osteopathy, dentistry, any } \\
\text { intern, resident, nurse, school employee, social worker, psychologist, medical examiner or any other person who knows of or } \\
\text { suspects child abuse or neglect. }\end{array}$ \\
\hline
\end{tabular}

NOTE:

** For purposes of this chart, corrections officers, police officers, peace officers, probation officers or "catch-all” phrases such as "all persons" have been bolded. However, many mandatory reporters include professionals who may have contact or work in correctional facilities. Such individuals include physicians, nurses, dentists, teachers and social workers. These statutes can be used as a tool to require staff other than correctional officers to report sexual misconduct with inmates.

This publication is developed by the NIC/WCL Project on Addressing Prison Rape under NIC Cooperative Agreement 06S20GJJ1.

This is not to be reproduced or cited without permission from the authors.

American University, Washington College of Law

Current as of May 7, 2009 


\section{Fifty State Survey of Mandatory Reporting Statutes}

\section{NIC/WCL Project on Addressing Prison Rape}

\begin{tabular}{|c|c|}
\hline $\begin{array}{l}\text { Reporting } \\
\text { Procedures } \\
\text { (Delaware) }\end{array}$ & $\begin{array}{l}16 \text { DEL.C. } \S 903 \text { (West 2008) } \\
\text { Any mandatory reporter shall make a report in accordance with } \S 904 \text { of this title. In addition to and not in lieu of reporting to the } \\
\text { Division of Family Services, any such person may also give oral or written notification of said knowledge or suspicion to any } \\
\text { police officer who is in the presence of such person for the purpose of rendering assistance to the child in question or investigating } \\
\text { the cause of the child's injuries or condition. } \\
16 \text { DEL.C. } \S 904 \text { (West 2008) } \\
\text { Any report required to be made under this chapter shall be made to the Division of Child Protective Services of the Department of } \\
\text { Services for Children, Youth and Their Families. An immediate oral report shall be made by telephone or otherwise. Reports and } \\
\text { the contents thereof including a written report, if requested, shall be made in accordance with the rules and regulations of the } \\
\text { Division of Child Protective Services, or in accordance with the rules and regulations adopted by the Division. }\end{array}$ \\
\hline $\begin{array}{l}\text { Penalty for Failure to } \\
\text { Report } \\
\text { (Delaware) }\end{array}$ & $\begin{array}{l}16 \text { DEL.C. } \S 905 \text { (West 2008) } \\
\text { Fine of not to exceed more than } \$ 1,000 \text { or imprisonment not to exceed more than } 15 \text { days, or both. }\end{array}$ \\
\hline $\begin{array}{l}\text { Mandatory } \\
\text { Reporting Statute } \\
\text { (Delaware) }\end{array}$ & $\begin{array}{l}\text { AGAINST AN ADULT } \\
31 \text { DEL.C. } \S 3910 \text { (West 2008) }\end{array}$ \\
\hline $\begin{array}{l}\text { What has to be } \\
\text { reported? } \\
\text { (Delaware) }\end{array}$ & $\begin{array}{l}31 \text { DEL.C. } \S 3910 \text { (West 2008) } \\
\text { (a) Reasonable cause to believe that an adult person is infirm or incapacitated and is in need of protective services. }\end{array}$ \\
\hline
\end{tabular}

NOTE:

** For purposes of this chart, corrections officers, police officers, peace officers, probation officers or “catch-all” phrases such as “all persons” have been bolded. However, many mandatory reporters include professionals who may have contact or work in correctional facilities. Such individuals include physicians, nurses, dentists, teachers and social workers. These statutes can be used as a tool to require staff other than correctional officers to report sexual misconduct with inmates.

This publication is developed by the NIC/WCL Project on Addressing Prison Rape under NIC Cooperative Agreement 06S20GJJ1.

This is not to be reproduced or cited without permission from the authors.

American University, Washington College of Law

Current as of May 7, 2009 


\section{Fifty State Survey of Mandatory Reporting Statutes}

\section{NIC/WCL Project on Addressing Prison Rape}

\begin{tabular}{|c|c|}
\hline $\begin{array}{l}\text { Relevant Definitions } \\
\text { (Delaware) }\end{array}$ & $\begin{array}{l}31 \text { DEL.C. } \S 3902 \text { (West 2008) } \\
\text { (1) “Infirm adult” shall mean any person } 18 \text { years of age or over who, because of physical or mental disability, is substantially } \\
\text { impaired in the ability to provide adequately for the person's own care and custody. } \\
\text { (5) "Exploitation means” the illegal or improper use or abuse of an infirm person, the infirm person's resources or the infirm } \\
\text { person's rights, by another person, whether for profit or other advantage. } \\
\text { (6) “Incapacitated person” means a person for whom a guardian of person or property, or both, shall be appointed, under } \S 3914(a) \\
\text { of Title } 12 \text {. } \\
\text { (16) “Abuse” means: } \\
\text { a. Physical abuse by unnecessarily inflicting pain or injury on an infirm adult; or } \\
\text { b. A pattern of emotional abuse, which includes, but is not limited to, ridiculing or demeaning an infirm adult making } \\
\text { derogatory remarks to an infirm adult or cursing or threatening to inflict physical or emotional harm on an infirm adult. } \\
\text { (17) "Caregiver” means any adult who has assumed the permanent or temporary care, custody or responsibility for the supervision } \\
\text { of an infirm adult. } \\
\text { (18) "Mistreatment” means the failure to provide appropriate physical or emotional care to an infirm adult, including the } \\
\text { inappropriate use of medications, isolation or physical or chemical restraints on or of an infirm adult. } \\
\text { (19) "Neglect” means: } \\
\text { a. Lack of attention by a caregiver to physical needs of an infirm adult including but not limited to toileting, bathing, meals and } \\
\text { safety; } \\
\text { b. Failure by a caregiver to carry out a treatment plan prescribed by a health care professional for an infirm adult; or } \\
\text { c. Intentional and permanent abandonment or desertion in any place of an infirm adult by a caregiver who does not make } \\
\text { reasonable efforts to ensure that essential services, as defined in this section, will be provided for said infirm adult. }\end{array}$ \\
\hline $\begin{array}{l}\text { Persons Required to } \\
\text { Report } \\
\text { (Delaware) }\end{array}$ & $\begin{array}{l}31 \text { DEL.C. } § 3910 \text { (West 2008) } \\
\text { (a) Any person having reasonable cause to believe that an adult person is infirm or incapacitated and is in need of protective } \\
\text { services. }\end{array}$ \\
\hline
\end{tabular}

\section{NOTE:}

** For purposes of this chart, corrections officers, police officers, peace officers, probation officers or “catch-all” phrases such as “all persons” have been bolded. However, many mandatory reporters include professionals who may have contact or work in correctional facilities. Such individuals include physicians, nurses, dentists, teachers and social workers. These statutes can be used as a tool to require staff other than correctional officers to report sexual misconduct with inmates.

This publication is developed by the NIC/WCL Project on Addressing Prison Rape under NIC Cooperative Agreement 06S20GJJ1.

This is not to be reproduced or cited without permission from the authors.

American University, Washington College of Law

Current as of May 7, 2009 


\section{Fifty State Survey of Mandatory Reporting Statutes}

\section{NIC/WCL Project on Addressing Prison Rape}

\begin{tabular}{|c|c|}
\hline $\begin{array}{l}\text { Reporting } \\
\text { Procedures } \\
\text { (Delaware) }\end{array}$ & $\begin{array}{l}31 \text { DEL.C. } § 3910 \text { (West 2008) } \\
\text { (a) Report such information to the Department of Health and Social Services. }\end{array}$ \\
\hline $\begin{array}{l}\text { Penalty for Failure to } \\
\text { Report } \\
\text { (Delaware) }\end{array}$ & No enumerated sanctions. \\
\hline & DISTRICT OF COLUMBIA \\
\hline $\begin{array}{l}\text { Mandatory } \\
\text { Reporting Statute } \\
\text { (District of Columbia) }\end{array}$ & $\begin{array}{l}\text { AGAINST A CHILD } \\
\text { DC ST } \S 4-1321.02 \text { (West 2008) }\end{array}$ \\
\hline $\begin{array}{l}\text { What has to be } \\
\text { reported? } \\
\text { (District of Columbia) }\end{array}$ & $\begin{array}{l}\text { DC ST § 4-1321.02 (West 2008) } \\
\text { (a) Knowledge or reasonable cause to suspect that a child known to him or her in his or her professional or official capacity has } \\
\text { been or is in immediate danger of being a mentally or physically abused or neglected child. }\end{array}$ \\
\hline $\begin{array}{l}\text { Relevant Definitions } \\
\text { (District of Columbia) }\end{array}$ & $\begin{array}{l}\text { DC ST § 4-1341.01 (West 2008) } \\
\text { (1) “Child” means a person under } 18 \text { years of age. } \\
\text { (2) "Child abuse” means harm or threatened harm to a child's health or welfare by a person responsible for the child's health or } \\
\text { welfare, which occurs through the intentional infliction of physical or emotional injury or an act of sexual abuse, which } \\
\text { includes a violation of any provision of subchapter of this chapter. }\end{array}$ \\
\hline
\end{tabular}

\section{NOTE:}

** For purposes of this chart, corrections officers, police officers, peace officers, probation officers or “catch-all” phrases such as “all persons” have been bolded. However, many mandatory reporters include professionals who may have contact or work in correctional facilities. Such individuals include physicians, nurses, dentists, teachers and social workers. These statutes can be used as a tool to require staff other than correctional officers to report sexual misconduct with inmates.

This publication is developed by the NIC/WCL Project on Addressing Prison Rape under NIC Cooperative Agreement 06S20GJJ1.

This is not to be reproduced or cited without permission from the authors.

American University, Washington College of Law

Current as of May 7, 2009 


\section{Fifty State Survey of Mandatory Reporting Statutes}

\section{NIC/WCL Project on Addressing Prison Rape}

\begin{tabular}{|c|c|}
\hline $\begin{array}{l}\text { Relevant Definitions } \\
\text { Cont'd } \\
\text { (District of Columbia) }\end{array}$ & $\begin{array}{l}\text { DC ST § 14-310 (West 2008) } \\
\text { (2) Domestic violence counselor means an employee, contractor, or volunteer of a domestic violence program who: } \\
\text { (A) Is rendering support, counseling, or assistance to a victim; } \\
\text { (B) Has undergone not less than } 40 \text { hours of domestic violence counselor training conducted by a domestic violence program } \\
\text { that includes dynamics of domestic violence, trauma resulting from domestic violence, crisis intervention, personal safety, } \\
\text { risk management, criminal and civil court processes, and resources available to victims; an } \\
\text { (C) (i) Is or is under the supervision of a licensed social worker, nurse, physician, psychologist, or psychotherapist; or } \\
\text { (ii) Is or is under the supervision of a person who has a minimum of } 5 \text { years of experience rendering support, counseling, or } \\
\text { assistance to persons against whom severe emotional abuse or a criminal offense has been committed or is alleged to have } \\
\text { been committed, of which at least } 2 \text { years of experience involves victims. } \\
\text { DC ST § 7-1201.01 (West 2008) } \\
\text { (11) Mental health professional means any of the following persons engaged in the provision of professional services: } \\
\text { (A) A person licensed to practice medicine; } \\
\text { (B) A person licensed to practice psychology; } \\
\text { (C) A licensed social worker; } \\
\text { (D) A professional marriage, family, or child counselor; } \\
\text { (E) A rape crisis or sexual abuse counselor who has undergone at least } 40 \text { hours of training and is under the supervision of a } \\
\text { licensed social worker, nurse, psychiatrist, psychologist, or psychotherapist; } \\
\text { (F) A licensed nurse who is a professional psychiatric nurse; or } \\
\text { (G) Any person reasonably believed by the client to be a mental health professional within the meaning of subparagraphs (A) } \\
\text { through (F) of this paragraph. }\end{array}$ \\
\hline
\end{tabular}

** For purposes of this chart, corrections officers, police officers, peace officers, probation officers or "catch-all” phrases such as "all persons" have been bolded. However, many mandatory reporters include professionals who may have contact or work in correctional facilities. Such individuals include physicians, nurses, dentists, teachers and social workers. These statutes can be used as a tool to require staff other than correctional officers to report sexual misconduct with inmates.

This publication is developed by the NIC/WCL Project on Addressing Prison Rape under NIC Cooperative Agreement 06S20GJJ1.

This is not to be reproduced or cited without permission from the authors.

American University, Washington College of Law

Current as of May 7, 2009 


\section{Fifty State Survey of Mandatory Reporting Statutes}

\section{NIC/WCL Project on Addressing Prison Rape}

\begin{tabular}{|c|c|}
\hline $\begin{array}{l}\text { Persons Required to } \\
\text { Report } \\
\text { (District of Columbia) }\end{array}$ & $\begin{array}{l}\text { DC ST § 4-1321.02 (West 2008) } \\
\text { (b) Every: } \\
\text { - Law enforcement officer; }{ }^{2} \\
\text { - } \quad \text { Child and Family Services Agency employees, agents and contractors; } \\
\text { - } \quad \text { Physician; } \\
\text { - Psychologist; } \\
\text { - } \quad \text { Medical examiner; } \\
\text { - Dentist; } \\
\text { - Chiropractor; } \\
\text { - Registered nurse; } \\
\text { - Licensed practical nurse; } \\
\text { - Person involved in the care and treatment of patients; } \\
\text { - School official; } \\
\text { - Teacher; } \\
\text { - Athletic coach; } \\
\text { - Department of Parks and Recreation employee; } \\
\text { - } \quad \text { Public housing resident manager; } \\
\text { - Social service worker; } \\
\text { - Day care worker; } \\
\text { - Mental health professional; and } \\
\text { - Domestic violence counselor. }\end{array}$ \\
\hline $\begin{array}{l}\text { Reporting } \\
\text { Procedures } \\
\text { (District of Columbia) }\end{array}$ & $\begin{array}{l}\text { DC ST § 4-1321.02(a) (West 2008) } \\
\text { (a) Immediately report or have a report made of such knowledge or suspicion to either the Metropolitan Police Department of the }\end{array}$ \\
\hline
\end{tabular}

NOTE:

** For purposes of this chart, corrections officers, police officers, peace officers, probation officers or “catch-all” phrases such as “all persons” have been bolded. However, many mandatory reporters include professionals who may have contact or work in correctional facilities. Such individuals include physicians, nurses, dentists, teachers and social workers. These statutes can be used as a tool to require staff other than correctional officers to report sexual misconduct with inmates.

This publication is developed by the NIC/WCL Project on Addressing Prison Rape under NIC Cooperative Agreement 06S20GJJ1.

This is not to be reproduced or cited without permission from the authors.

American University, Washington College of Law

Current as of May 7, 2009 


\title{
Fifty State Survey of Mandatory Reporting Statutes
}

\section{NIC/WCL Project on Addressing Prison Rape}

\begin{tabular}{|c|c|}
\hline $\begin{array}{l}\text { Reporting } \\
\text { Procedures Cont'd } \\
\text { (District of Columbia) }\end{array}$ & $\begin{array}{l}\text { District of Columbia or the Child and Family Services Agency } \\
\text { (b) Whenever a person is required to report in his or her capacity as a member of the staff of a hospital, school, social agency or } \\
\text { similar institution, he or she shall immediately notify the person in charge of the institution or his or her designated agent who } \\
\text { shall then be required to make the report. }\end{array}$ \\
\hline $\begin{array}{l}\text { Penalty for Failure to } \\
\text { Report } \\
\text { (District of Columbia) }\end{array}$ & $\begin{array}{l}\text { DC ST § 4-1321.07 (West 2008) } \\
\text { Any person required to make a report under this subchapter who willfully fails to make such a report shall be fined not more than } \\
\$ 100 \text { or imprisoned for not more than } 30 \text { days or both. }\end{array}$ \\
\hline $\begin{array}{l}\text { Mandatory } \\
\text { Reporting Statute } \\
\text { (District of Columbia) }\end{array}$ & $\begin{array}{l}\text { AGAINST AN ADULT } \\
\text { DC ST § 7-1903 (West 2008) }\end{array}$ \\
\hline $\begin{array}{l}\text { What has to be } \\
\text { reported? } \\
\text { (District of Columbia) }\end{array}$ & $\begin{array}{l}\text { DC ST § 7-1903 (West 2008) } \\
\text { (a)(1) A mandatory reporter who as a result of his or her appointment, employment, or practice has cause to believe that an adult is } \\
\text { in need of protective services because of abuse, neglect or exploitation by another. }\end{array}$ \\
\hline $\begin{array}{l}\text { Relevant Definitions } \\
\text { (District of Columbia) }\end{array}$ & $\begin{array}{l}\text { DC ST § 7-1901 (West 2008) } \\
\text { (1)(A) “Abuse” means: } \\
\text { (i) The intentional or reckless infliction of serious physical pain or injury; } \\
\text { (ii) The use or threatened use of violence to force participation in "sexual conduct," } \\
\text { (iii) The repeated, intentional imposition of unreasonable confinement or threats to impose unreasonable confinement, } \\
\text { resulting in severe mental distress; } \\
\text { (iv) The repeated use of threats or violence, resulting in shock or an intense, expressed fear for one's life or of serious }\end{array}$ \\
\hline
\end{tabular}

\section{NOTE:}

(iv) The repeated use of threats or violence, resulting in shock or an intense, expressed fear for one's life or of serious

\begin{abstract}
** For purposes of this chart, corrections officers, police officers, peace officers, probation officers or "catch-all” phrases such as "all persons" have been bolded. However, many mandatory reporters include professionals who may have contact or work in correctional facilities. Such individuals include physicians, nurses, dentists, teachers and social workers. These statutes can be used as a tool to require staff other than correctional officers
\end{abstract} to report sexual misconduct with inmates.

This publication is developed by the NIC/WCL Project on Addressing Prison Rape under NIC Cooperative Agreement 06S20GJJ1.

This is not to be reproduced or cited without permission from the authors.

American University, Washington College of Law

Current as of May 7, 2009 


\section{Fifty State Survey of Mandatory Reporting Statutes}

\section{NIC/WCL Project on Addressing Prison Rape}

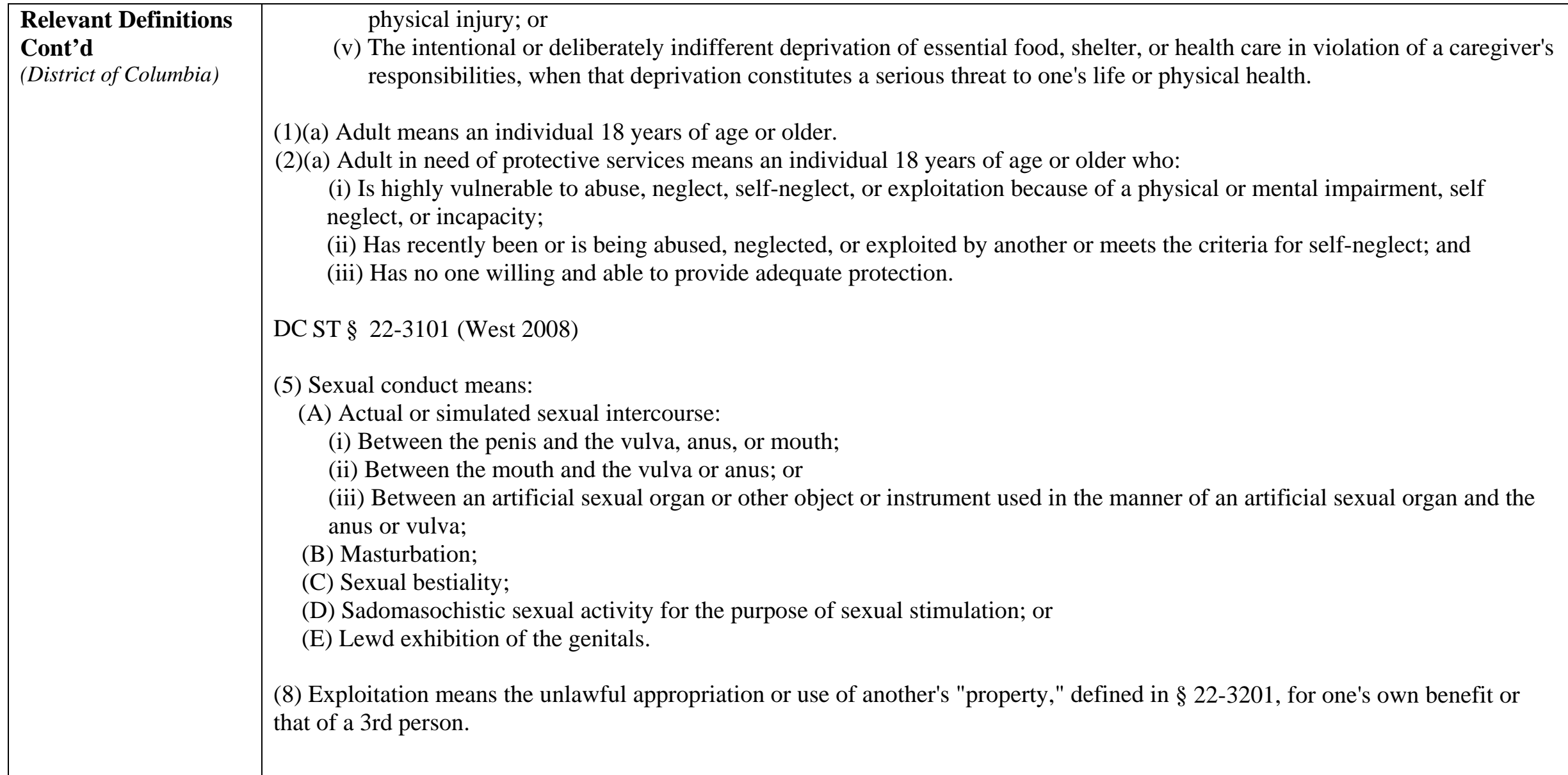

NOTE:

** For purposes of this chart, corrections officers, police officers, peace officers, probation officers or "catch-all” phrases such as “all persons” have been bolded. However, many mandatory reporters include professionals who may have contact or work in correctional facilities. Such individuals include physicians, nurses, dentists, teachers and social workers. These statutes can be used as a tool to require staff other than correctional officers to report sexual misconduct with inmates.

This publication is developed by the NIC/WCL Project on Addressing Prison Rape under NIC Cooperative Agreement 06S20GJJ1.

This is not to be reproduced or cited without permission from the authors.

American University, Washington College of Law

Current as of May 7, 2009 


\section{Fifty State Survey of Mandatory Reporting Statutes}

\section{NIC/WCL Project on Addressing Prison Rape}

\begin{tabular}{|c|c|}
\hline $\begin{array}{l}\text { Relevant Definitions } \\
\text { Cont'd } \\
\text { (District of Columbia) }\end{array}$ & $\begin{array}{l}\text { (9)(A) Neglect means: } \\
\text { (i) The repeated, careless infliction of serious physical pain or injury; } \\
\text { (ii) The repeated failure of a caregiver to take reasonable steps, within the purview of his or her responsibilities, to protect } \\
\text { against acts of abuse described in paragraph (1)(B) of this section; } \\
\text { (iii) The repeated, careless imposition of unreasonable confinement, resulting in severe mental distress; or } \\
\text { (iv) The careless deprivation of essential food, shelter, or health care in violation of a caregiver's responsibilities, when that } \\
\text { deprivation constitutes a serious threat to one's life or physical health. } \\
\text { (B) An adult shall not be considered neglected under this chapter for the sole reason that he or she seeks, or his or her caregiver } \\
\text { provides or permits to be provided, with the express consent or in accordance with the practice of the adult, treatment by spiritual } \\
\text { means through prayer alone in accordance with a religious method of healing, in lieu of medical treatment. } \\
\text { (13)(A) Self-neglect means the failure of an adult, due to physical or mental impairments or incapacity, to perform essential self- } \\
\text { care tasks, including: } \\
\text { (i) Providing essential food, clothing, shelter, or medical care; } \\
\text { (ii) Obtaining goods or services necessary to maintain physical health, mental health, emotional well-being, and general safety; } \\
\text { or } \\
\text { (iii) Managing his or her financial affairs. } \\
\text { (B) An adult shall not be considered to be committing self-neglect under this chapter for the sole reason that he or she seeks } \\
\text { treatment by spiritual means through prayer alone in accordance with a religious method of healing, in lieu of medical treatment. }\end{array}$ \\
\hline $\begin{array}{l}\text { Persons Required to } \\
\text { Report } \\
\text { (District of Columbia) }\end{array}$ & 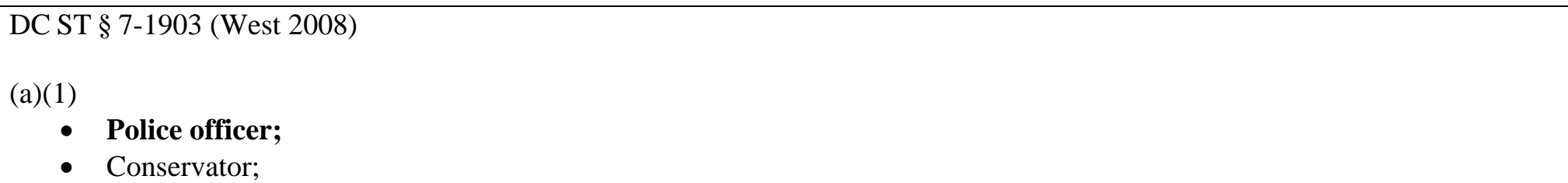 \\
\hline
\end{tabular}

NOTE:

** For purposes of this chart, corrections officers, police officers, peace officers, probation officers or “catch-all” phrases such as “all persons” have been bolded. However, many mandatory reporters include professionals who may have contact or work in correctional facilities. Such individuals include physicians, nurses, dentists, teachers and social workers. These statutes can be used as a tool to require staff other than correctional officers to report sexual misconduct with inmates.

This publication is developed by the NIC/WCL Project on Addressing Prison Rape under NIC Cooperative Agreement 06S20GJJ1.

This is not to be reproduced or cited without permission from the authors.

American University, Washington College of Law

Current as of May 7, 2009 


\section{Fifty State Survey of Mandatory Reporting Statutes}

\section{NIC/WCL Project on Addressing Prison Rape}

\begin{tabular}{|c|c|}
\hline $\begin{array}{l}\text { Persons Required to } \\
\text { Report Cont'd } \\
\text { (District of Columbia) }\end{array}$ & $\begin{array}{l}\text { - Court-appointed mental retardation advocate; } \\
\text { - Guardian; } \\
\text { - Health-care administrator; } \\
\text { - Bicensed health professional; } \\
\text { - Financial manager; or } \\
\text { - Social worker. }\end{array}$ \\
\hline $\begin{array}{l}\text { Reporting } \\
\text { Procedures } \\
\text { (District of Columbia) }\end{array}$ & $\begin{array}{l}\text { DC ST § 7-1903 (West 2008) } \\
\text { (a)(1) Immediately report this belief. } \\
\text { (c) A report made pursuant to this section may be either oral or written and shall be transmitted to the division within the } \\
\text { Department designated by the Mayor to receive these reports. Each report shall include, if known: The name, age, physical } \\
\text { description, and location of the adult alleged to be in need of protective services; the name and location of the person(s) allegedly } \\
\text { responsible for the abuse, neglect, or exploitation; the nature and extent of the abuse, neglect, self-neglect, or exploitation; the } \\
\text { basis of the reporter's knowledge; and any other information the reporter believes might be helpful to an investigation. A reporter } \\
\text { may be required to identify himself or herself only when obliged to report under subsection (a)(1) of this section. }\end{array}$ \\
\hline $\begin{array}{l}\text { Penalty for Failure to } \\
\text { Report } \\
\text { (District of Columbia) }\end{array}$ & $\begin{array}{l}\text { DC ST } \S 7-1912 \text { (West 2008) } \\
\text { Any person required to report under } \S 7-1903(a)(1) \text { who willfully fails to do so shall be guilty of a misdemeanor and, upon } \\
\text { conviction, subject to a fine not exceeding } \$ 300 \text {. }\end{array}$ \\
\hline
\end{tabular}

NOTE:

** For purposes of this chart, corrections officers, police officers, peace officers, probation officers or "catch-all” phrases such as "all persons" have been bolded. However, many mandatory reporters include professionals who may have contact or work in correctional facilities. Such individuals include physicians, nurses, dentists, teachers and social workers. These statutes can be used as a tool to require staff other than correctional officers to report sexual misconduct with inmates.

This publication is developed by the NIC/WCL Project on Addressing Prison Rape under NIC Cooperative Agreement 06S20GJJ1.

This is not to be reproduced or cited without permission from the authors.

American University, Washington College of Law

Current as of May 7, 2009 


\section{Fifty State Survey of Mandatory Reporting Statutes}

\section{NIC/WCL Project on Addressing Prison Rape}

\begin{tabular}{|c|c|}
\hline \multicolumn{2}{|r|}{ FLORIDA } \\
\hline $\begin{array}{l}\text { Mandatory } \\
\text { Reporting Statute } \\
\text { (Florida) }\end{array}$ & $\begin{array}{l}\text { AGAINST A CHILD } \\
\text { FL ST § } 39.201 \text { (West 2008) }\end{array}$ \\
\hline $\begin{array}{l}\text { What has to be } \\
\text { reported? } \\
\text { (Florida) }\end{array}$ & $\begin{array}{l}\text { FL ST § } 39.201 \text { (West 2008) } \\
\text { (1)(a) Any person that has reasonable cause to suspect, that a child is abused, abandoned, or neglected by a parent, legal custodian, } \\
\text { caregiver, or other person responsible for the child's welfare. }\end{array}$ \\
\hline $\begin{array}{l}\text { Relevant Definitions } \\
\text { (Florida) }\end{array}$ & $\begin{array}{l}\text { FL ST § } 39.01 \text { (West 2008) } \\
\text { (1) “Abandoned” means a situation in which the parent or legal custodian of a child or, in the absence of a parent or legal } \\
\text { custodian, the caregiver responsible for the child's welfare, while being able, makes no provision for the child's support and makes } \\
\text { no effort to communicate with the child, which situation is sufficient to evince a willful rejection of parental obligations. If the } \\
\text { efforts of the parent or legal custodian, or caregiver primarily responsible for the child's welfare, to support and communicate with } \\
\text { the child are, in the opinion of the court, only marginal efforts that do not evince a settled purpose to assume all parental duties, the } \\
\text { court may declare the child to be abandoned. The term "abandoned” does not include an abandoned newborn infant as described in } \\
\text { s. } 383.50 \text {, a "child in need of services” as defined in chapter 984, or a "family in need of services” as defined in chapter } 984 \text {. The } \\
\text { incarceration of a parent, legal custodian, or caregiver responsible for a child's welfare may support a finding of abandonment. } \\
\text { (2) “Abuse” means any willful act or threatened act that results in any physical, mental, or sexual injury or harm that causes or is } \\
\text { likely to cause the child's physical, mental, or emotional health to be significantly impaired. Abuse of a child includes acts or } \\
\text { omissions. Corporal discipline of a child by a parent or legal custodian for disciplinary purposes does not in itself constitute abuse }\end{array}$ \\
\hline
\end{tabular}

NOTE:

** For purposes of this chart, corrections officers, police officers, peace officers, probation officers or "catch-all” phrases such as "all persons" have been bolded. However, many mandatory reporters include professionals who may have contact or work in correctional facilities. Such individuals include physicians, nurses, dentists, teachers and social workers. These statutes can be used as a tool to require staff other than correctional officers to report sexual misconduct with inmates.

This publication is developed by the NIC/WCL Project on Addressing Prison Rape under NIC Cooperative Agreement 06S20GJJ1.

This is not to be reproduced or cited without permission from the authors.

American University, Washington College of Law

Current as of May 7, 2009 


\section{Fifty State Survey of Mandatory Reporting Statutes}

\section{NIC/WCL Project on Addressing Prison Rape}

\begin{tabular}{|c|c|}
\hline $\begin{array}{l}\text { Relevant Definitions } \\
\text { Cont'd } \\
\text { (Florida) }\end{array}$ & 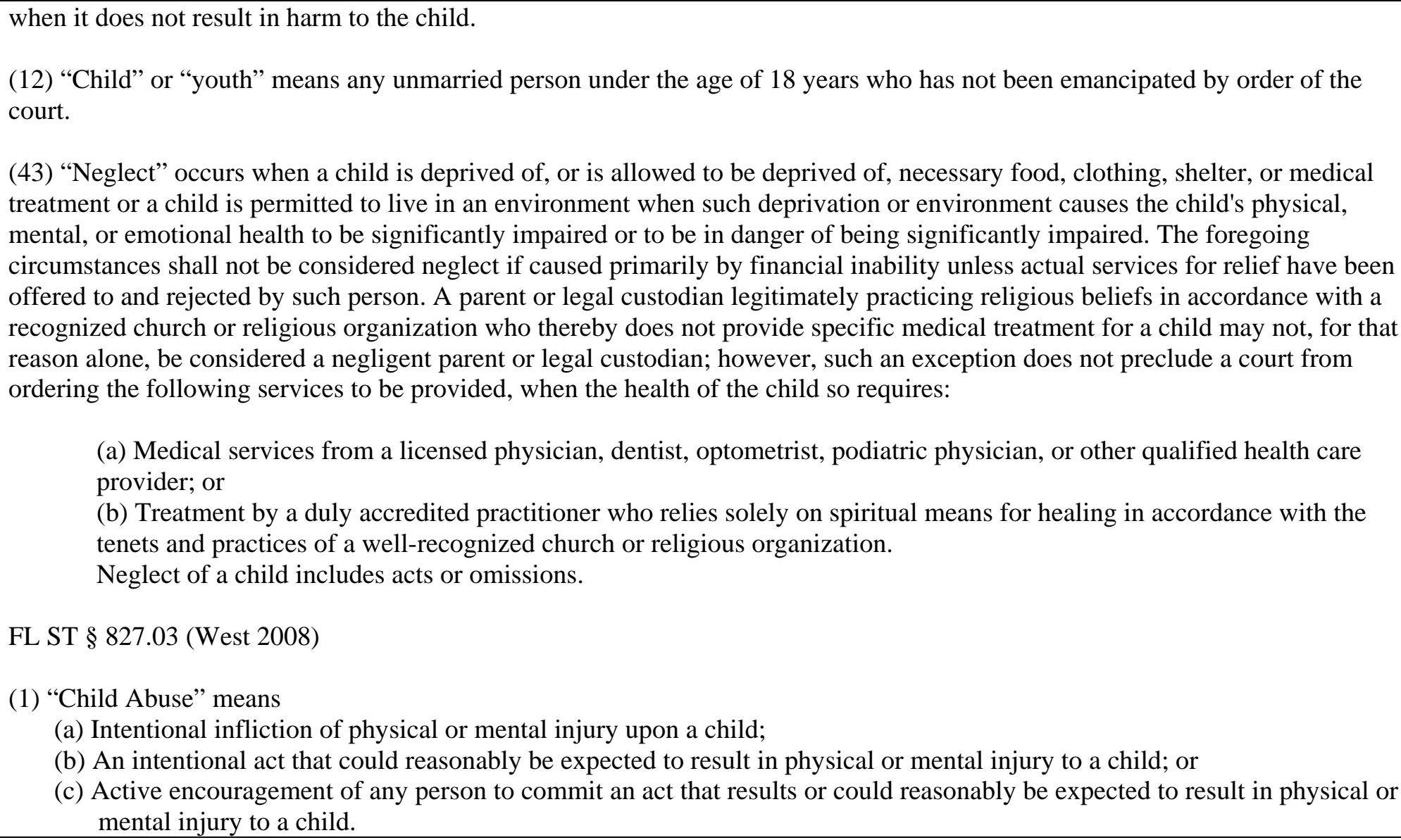 \\
\hline
\end{tabular}

NOTE:

** For purposes of this chart, corrections officers, police officers, peace officers, probation officers or “catch-all” phrases such as “all persons” have been bolded. However, many mandatory reporters include professionals who may have contact or work in correctional facilities. Such individuals include physicians, nurses, dentists, teachers and social workers. These statutes can be used as a tool to require staff other than correctional officers to report sexual misconduct with inmates.

This publication is developed by the NIC/WCL Project on Addressing Prison Rape under NIC Cooperative Agreement 06S20GJJ1.

This is not to be reproduced or cited without permission from the authors.

American University, Washington College of Law

Current as of May 7, 2009 


\section{Fifty State Survey of Mandatory Reporting Statutes}

\section{NIC/WCL Project on Addressing Prison Rape}

\begin{tabular}{|c|c|}
\hline $\begin{array}{l}\text { Relevant Definitions } \\
\text { Cont'd } \\
\text { (Florida) }\end{array}$ & $\begin{array}{l}\text { (3)(a) "Neglect of a child" means } \\
\text { 1. A caregiver's failure or omission to provide a child with the care, supervision, and services necessary to maintain the child's } \\
\text { physical and mental health, including, but not limited to, food, nutrition, clothing, shelter, supervision, medicine, and } \\
\text { medical services that a prudent person would consider essential for the well-being of the child; or } \\
\text { 2. A caregiver's failure to make a reasonable effort to protect a child from abuse, neglect, or exploitation by another person. } \\
\text { Neglect of a child may be based on repeated conduct or on a single incident or omission that results in, or could reasonably } \\
\text { be expected to result in, serious physical or mental injury, or a substantial risk of death, to a child. } \\
\text { (b) A person who willfully or by culpable negligence neglects a child and in so doing causes great bodily harm, permanent } \\
\text { disability, or permanent disfigurement to the child commits a felony of the second degree. } \\
\text { (c) A person who willfully or by culpable negligence neglects a child without causing great bodily harm, permanent disability, } \\
\text { or permanent disfigurement to the child commits a felony of the third degree. }\end{array}$ \\
\hline $\begin{array}{l}\text { Persons Required to } \\
\text { Report } \\
\text { (Florida) }\end{array}$ & $\begin{array}{l}\text { FL ST § } 39.201 \text { (West 2008) } \\
\text { (b): } \\
\text { (1) Physician, osteopathic physician, medical examiner, chiropractic physician, nurse, or hospital personnel engaged in the } \\
\text { admission, examination, care, or treatment of persons; } \\
\text { (2) Health or mental health professional other than one listed in the preceding paragraph; } \\
\text { (3) Practitioner who relies solely on spiritual means for healing; } \\
\text { (4) School teacher or other school official or personnel; } \\
\text { (5) Social worker, day care center worker, or other professional child care, foster care, residential, or institutional worker; } \\
\text { (6) Law enforcement officer; or } \\
\text { (7) Judge. }\end{array}$ \\
\hline
\end{tabular}

** For purposes of this chart, corrections officers, police officers, peace officers, probation officers or “catch-all” phrases such as “all persons” have been bolded. However, many mandatory reporters include professionals who may have contact or work in correctional facilities. Such individuals include physicians, nurses, dentists, teachers and social workers. These statutes can be used as a tool to require staff other than correctional officers to report sexual misconduct with inmates.

This publication is developed by the NIC/WCL Project on Addressing Prison Rape under NIC Cooperative Agreement 06S20GJJ1.

This is not to be reproduced or cited without permission from the authors.

American University, Washington College of Law

Current as of May 7, 2009 


\section{Fifty State Survey of Mandatory Reporting Statutes}

\section{NIC/WCL Project on Addressing Prison Rape}

\begin{tabular}{|c|c|}
\hline $\begin{array}{l}\text { Reporting } \\
\text { Procedures } \\
\text { (Florida) }\end{array}$ & $\begin{array}{l}\text { FL ST } \S 39.201 \text { (West 2008) } \\
\text { (2)(a) Each report of known or suspected child abuse, abandonment, or neglect by a parent, legal custodian, caregiver, or other } \\
\text { person responsible for the child's welfare as defined in this chapter, except those solely under s. 827.04(3), and each report that a } \\
\text { child is in need of supervision and care and has no parent, legal custodian, or responsible adult relative immediately known and } \\
\text { available to provide supervision and care shall be made immediately to the department's central abuse hotline on the single } \\
\text { statewide toll-free telephone number. Personnel at the department's central abuse hotline shall determine if the report received } \\
\text { meets the statutory definition of child abuse, abandonment, or neglect. Any report meeting one of these definitions shall be } \\
\text { accepted for the protective investigation pursuant to part III of this chapter. } \\
\text { FL ST § } 39.201 \text { (West 2008) } \\
\text { (3) Any person required to report or investigate cases of suspected child abuse, abandonment, or neglect who has reasonable cause } \\
\text { to suspect that a child died as a result of child abuse, abandonment, or neglect shall report his or her suspicion to the appropriate } \\
\text { medical examiner. The medical examiner shall accept the report for investigation and shall report his or her findings, in writing, to } \\
\text { the local law enforcement agency, the appropriate state attorney, and the department. Autopsy reports maintained by the medical } \\
\text { examiner are not subject to the confidentiality requirements. }\end{array}$ \\
\hline $\begin{array}{l}\text { Penalty for Failure to } \\
\text { Report } \\
\text { (Florida) }\end{array}$ & $\begin{array}{l}\text { FL ST } § 39.205 \text { (West 2008) } \\
\text { (1) First degree misdemeanor (maximum of } \$ 1,000 \text { fine and maximum imprisonment of } 1 \text { year). } \\
\text { FL ST } § 775.082 \text { (West 2008) } \\
\text { (3) A person who has been convicted of a designated misdemeanor may be sentenced as follows: } \\
\text { (a) For a misdemeanor of the first degree, by a definite term of imprisonment not exceeding } 1 \text { year. }\end{array}$ \\
\hline
\end{tabular}

NOTE:

** For purposes of this chart, corrections officers, police officers, peace officers, probation officers or “catch-all” phrases such as “all persons” have been bolded. However, many mandatory reporters include professionals who may have contact or work in correctional facilities. Such individuals include physicians, nurses, dentists, teachers and social workers. These statutes can be used as a tool to require staff other than correctional officers to report sexual misconduct with inmates.

This publication is developed by the NIC/WCL Project on Addressing Prison Rape under NIC Cooperative Agreement 06S20GJJ1.

This is not to be reproduced or cited without permission from the authors.

American University, Washington College of Law

Current as of May 7, 2009 


\section{Fifty State Survey of Mandatory Reporting Statutes}

\section{NIC/WCL Project on Addressing Prison Rape}

\begin{tabular}{|c|c|}
\hline $\begin{array}{l}\text { Penalty for Failure to } \\
\text { Report Cont'd } \\
\text { (Florida) }\end{array}$ & $\begin{array}{l}\text { FL ST } \S 775.083 \text { (West } 2008 \text { ) } \\
\text { (1)(d) } \$ 1,000 \text {, when the conviction is of a misdemeanor of the first degree. }\end{array}$ \\
\hline $\begin{array}{l}\text { Mandatory } \\
\text { Reporting Statute } \\
\text { (Florida) }\end{array}$ & $\begin{array}{l}\text { AGAINST AN ADULT } \\
\text { FL ST § 944.35 (West 2008) } \\
\text { F.S.A § 415.1034(West 2008) }\end{array}$ \\
\hline $\begin{array}{l}\text { What has to be } \\
\text { reported? } \\
\text { (Florida) }\end{array}$ & $\begin{array}{l}\text { FL ST } § 944.35 \text { (West 2008) } \\
\text { (4)(d) Witnessing, or reasonable cause to suspect, that an inmate or an offender under the supervision of the department in the } \\
\text { community has been unlawfully abused or is the subject of sexual misconduct. } \\
\text { F.S.A § 415.1034(West 2008) } \\
\text { (1)(a) Knows, or has reasonable cause to suspect, that a vulnerable adult has been or is being abused, neglected, or } \\
\text { exploited shall immediately report such knowledge or suspicion to the central abuse hotline. }\end{array}$ \\
\hline $\begin{array}{l}\text { Relevant Definitions } \\
\text { (Florida) }\end{array}$ & $\begin{array}{l}\text { FL ST § } 944.35 \text { (West 2008) } \\
\text { (3)(b)(1) “Sexual misconduct” means the oral, anal, or vaginal penetration by, or union with, the sexual organ of another or the } \\
\text { anal or vaginal penetration of another by any other object, but does not include an act done for a bona fide medical purpose or an } \\
\text { internal search conducted in the lawful performance of the employee's duty. }\end{array}$ \\
\hline
\end{tabular}

NOTE:

** For purposes of this chart, corrections officers, police officers, peace officers, probation officers or “catch-all” phrases such as “all persons” have been bolded. However, many mandatory reporters include professionals who may have contact or work in correctional facilities. Such individuals include physicians, nurses, dentists, teachers and social workers. These statutes can be used as a tool to require staff other than correctional officers to report sexual misconduct with inmates.

This publication is developed by the NIC/WCL Project on Addressing Prison Rape under NIC Cooperative Agreement 06S20GJJ1.

This is not to be reproduced or cited without permission from the authors.

American University, Washington College of Law

Current as of May 7, 2009 


\section{Fifty State Survey of Mandatory Reporting Statutes}

\section{NIC/WCL Project on Addressing Prison Rape}

\begin{tabular}{|c|c|}
\hline $\begin{array}{l}\text { Persons Required to } \\
\text { Report } \\
\text { (Florida) }\end{array}$ & $\begin{array}{l}\text { FL ST } § 944.35 \text { (West 2008) } \\
\text { (3)(d) Each employee who witnesses, or has reasonable cause to suspect, that an inmate or an offender under the supervision of } \\
\text { the department in the community has been unlawfully abused or is the subject of sexual misconduct. } \\
\text { F.S.A } § 415.1034 \text { (West 2008) } \\
\text { (1)(a) Any person, including, but not limited to, any: } \\
\text { 1. Physician, osteopathic physician, medical examiner, chiropractic physician, nurse, paramedic, emergency medical } \\
\text { 2. Health professional or mental health professional other than one listed in subparagraph 1; } \\
\text { 3. Practitioner who relies solely on spiritual means for healing; } \\
\text { 4. Nursing home staff; assisted living facility staff; adult day care center staff; adult family-care home staff; social worker; or } \\
\text { other professional adult care, residential, or institutional staff; } \\
\text { 5. State, county, or municipal criminal justice employee or law enforcement officer; } \\
\text { 6. An employee of the Department of Business and Professional Regulation conducting inspections of public lodging } \\
\text { 7. Florida advocacy council member or long-term care ombudsman council member; or } \\
\text { 8. Bank, savings and loan, or credit union officer, trustee, or employee. }\end{array}$ \\
\hline $\begin{array}{l}\text { Reporting } \\
\text { Procedures } \\
\text { (Florida) }\end{array}$ & $\begin{array}{l}\text { FL ST } § 944.35 \text { (West 2008) } \\
\text { (3)(d) Immediately prepare, date, and sign an independent report specifically describing the nature of the force used or the nature } \\
\text { of the sexual misconduct, the location and time of the incident, and the persons involved. The report shall be delivered to the } \\
\text { inspector general of the department with a copy to be delivered to the warden of the institution or the regional administrator. The } \\
\text { inspector general shall immediately conduct an appropriate investigation, and, if probable cause is determined that a violation of } \\
\text { this subsection has occurred, the respective state attorney in the circuit in which the incident occurred shall be notified. }\end{array}$ \\
\hline
\end{tabular}

NOTE:

** For purposes of this chart, corrections officers, police officers, peace officers, probation officers or “catch-all” phrases such as “all persons” have been bolded. However, many mandatory reporters include professionals who may have contact or work in correctional facilities. Such individuals include physicians, nurses, dentists, teachers and social workers. These statutes can be used as a tool to require staff other than correctional officers to report sexual misconduct with inmates.

This publication is developed by the NIC/WCL Project on Addressing Prison Rape under NIC Cooperative Agreement 06S20GJJ1.

This is not to be reproduced or cited without permission from the authors.

American University, Washington College of Law

Current as of May 7, 2009 


\section{Fifty State Survey of Mandatory Reporting Statutes}

\section{NIC/WCL Project on Addressing Prison Rape}

\begin{tabular}{|c|c|}
\hline $\begin{array}{l}\text { Reporting } \\
\text { Procedures Cont'd } \\
\text { (Florida) }\end{array}$ & $\begin{array}{l}\text { F.S.A § } 415.1034 \text { (West 2008) } \\
\text { (1)(b) To the extent possible, a report made pursuant to paragraph (a) must contain, but need not be limited to, the } \\
\text { following information: } \\
\text { 1. Name, age, race, sex, physical description, and location of each victim alleged to have been abused, neglected, or exploited. } \\
\text { 2. Names, addresses, and telephone numbers of the victim's family members. } \\
\text { 3. Name, address, and telephone number of each alleged perpetrator. } \\
\text { 4. Name, address, and telephone number of the caregiver of the victim, if different from the alleged perpetrator. } \\
\text { 5. Name, address, and telephone number of the person reporting the alleged abuse, neglect, or exploitation. } \\
\text { 6. Description of the physical or psychological injuries sustained. } \\
\text { 7. Actions taken by the reporter, if any, such as notification of the criminal justice agency. } \\
\text { 8. Any other information available to the reporting person which may establish the cause of abuse, neglect, or exploitation that occurred } \\
\text { or is occurring. }\end{array}$ \\
\hline $\begin{array}{l}\text { Penalty for Failure to } \\
\text { Report } \\
\text { (Florida) }\end{array}$ & $\begin{array}{l}\text { FL ST § 775.082(4)(a); FL ST § 775.083(1)(d); \& FL ST § 944.35(4)(a) (West 2008) } \\
\text { First degree misdemeanor } \\
\text { (maximum of } \$ 1,000 \text { fine and maximum imprisonment of } 1 \text { year). }\end{array}$ \\
\hline & GEORGIA \\
\hline $\begin{array}{l}\text { Mandatory } \\
\text { Reporting Statute } \\
\text { (Georgia) }\end{array}$ & $\begin{array}{l}\text { AGAINST A CHILD } \\
\text { GA. CODE ANN } \S 19-7-5 \text { (West 2008) }\end{array}$ \\
\hline
\end{tabular}

NOTE:

** For purposes of this chart, corrections officers, police officers, peace officers, probation officers or “catch-all” phrases such as “all persons” have been bolded. However, many mandatory reporters include professionals who may have contact or work in correctional facilities. Such individuals include physicians, nurses, dentists, teachers and social workers. These statutes can be used as a tool to require staff other than correctional officers to report sexual misconduct with inmates.

This publication is developed by the NIC/WCL Project on Addressing Prison Rape under NIC Cooperative Agreement 06S20GJJ1.

This is not to be reproduced or cited without permission from the authors.

American University, Washington College of Law

Current as of May 7, 2009 


\section{Fifty State Survey of Mandatory Reporting Statutes}

\section{NIC/WCL Project on Addressing Prison Rape}

\begin{tabular}{|c|c|}
\hline $\begin{array}{l}\text { What has to be } \\
\text { reported? } \\
\text { (Georgia) }\end{array}$ & $\begin{array}{l}\text { GA. CODE ANN. } \S 19-7-5 \text { (West 2008) } \\
\text { (c)(1) Reasonable cause to believe that a child has been abused. } \\
\text { GA. CODE ANN. } § 19-7-5 \text { (West 2008) } \\
\text { (g) Suspected child abuse which is required to be reported by any person pursuant to this Code section shall be reported } \\
\text { notwithstanding that the reasonable cause to believe such abuse has occurred or is occurring is based in whole or in part upon any } \\
\text { communication to that person which is otherwise made privileged or confidential by law. }\end{array}$ \\
\hline $\begin{array}{l}\text { Relevant Definitions } \\
\text { (Georgia) }\end{array}$ & $\begin{array}{l}\text { GA. CODE ANN § 19-7-5 (West 2008) } \\
\text { (b)(2) Child means any person under } 18 \text { years of age. } \\
\text { (b)(3) Child abuse: } \\
\text { (A) Physical injury or death inflicted upon a child by a parent or caretaker thereof by other than accidental means; provided, } \\
\text { however, physical forms of discipline may be used as long as there is no physical injury to the child; } \\
\text { (B) Neglect or exploitation of a child by a parent or caretaker thereof; } \\
\text { (C) Sexual abuse of a child; or } \\
\text { (D) Sexual exploitation of a child. } \\
\text { (b)(3.1) “Sexual abuse” means a person's employing, using, persuading, inducing, enticing, or coercing any minor who is not that } \\
\text { person's spouse to engage in any act which involves: } \\
\text { (A) Sexual intercourse, including genital-genital, oral-genital, anal-genital, or oral-anal, whether between persons of the } \\
\text { same or opposite sex; } \\
\text { (B) Bestiality; } \\
\text { (C) Masturbation; }\end{array}$ \\
\hline
\end{tabular}

NOTE:

** For purposes of this chart, corrections officers, police officers, peace officers, probation officers or "catch-all” phrases such as "all persons" have been bolded. However, many mandatory reporters include professionals who may have contact or work in correctional facilities. Such individuals include physicians, nurses, dentists, teachers and social workers. These statutes can be used as a tool to require staff other than correctional officers to report sexual misconduct with inmates.

This publication is developed by the NIC/WCL Project on Addressing Prison Rape under NIC Cooperative Agreement 06S20GJJ1.

This is not to be reproduced or cited without permission from the authors.

American University, Washington College of Law

Current as of May 7, 2009 


\section{Fifty State Survey of Mandatory Reporting Statutes}

\section{NIC/WCL Project on Addressing Prison Rape}

\begin{tabular}{|c|c|}
\hline $\begin{array}{l}\text { Relevant Definitions } \\
\text { Cont'd } \\
\text { (Georgia) }\end{array}$ & $\begin{array}{l}\text { (D) Lewd exhibition of the genitals or pubic area of any person; } \\
\text { (E) Flagellation or torture by or upon a person who is nude; } \\
\text { (F) Condition of being fettered, bound, or otherwise physically restrained on the part of a person who is nude; } \\
\text { (G) Physical contact in an act of apparent sexual stimulation or gratification with any person's clothed or unclothed } \\
\text { genitals, pubic area, or buttocks or with a female's clothed or unclothed breasts; } \\
\text { (H) Defecation or urination for the purpose of sexual stimulation; or } \\
\text { (I) Penetration of the vagina or rectum by any object except when done as part of a recognized medical procedure. } \\
\text { Sexual abuse shall not include consensual sex acts involving persons of the opposite sex when the sex acts are between minors or } \\
\text { between a minor and an adult who is not more than five years older than the minor. This provision shall not be deemed or } \\
\text { construed to repeal any law concerning the age or capacity to consent. } \\
\text { (b)(4) "Sexual exploitation" means conduct by a child's parent or caretaker who allows, permits, encourages, or requires that child } \\
\text { to engage in: } \\
\text { (A) Prostitution, or } \\
\text { (B) Sexually explicit conduct for the purpose of producing any visual or print medium depicting such conduct,. }\end{array}$ \\
\hline $\begin{array}{l}\text { Persons Required to } \\
\text { Report } \\
\text { (Georgia) }\end{array}$ & $\begin{array}{l}\text { GA. CODE ANN § 19-7-5 (West 2008) } \\
\text { (c)(1) } \\
\text { (A) Physicians licensed to practice medicine, interns, or residents; } \\
\text { (B) Hospital or medical personnel; } \\
\text { (C) Dentists; } \\
\text { (D) Licensed psychologists and persons participating in internships to obtain licensing; } \\
\text { (E) Podiatrists; } \\
\text { (F) Registered professional nurses or licensed practical nurses; }\end{array}$ \\
\hline
\end{tabular}

NOTE:

** For purposes of this chart, corrections officers, police officers, peace officers, probation officers or “catch-all” phrases such as “all persons” have been bolded. However, many mandatory reporters include professionals who may have contact or work in correctional facilities. Such individuals include physicians, nurses, dentists, teachers and social workers. These statutes can be used as a tool to require staff other than correctional officers to report sexual misconduct with inmates.

This publication is developed by the NIC/WCL Project on Addressing Prison Rape under NIC Cooperative Agreement 06S20GJJ1.

This is not to be reproduced or cited without permission from the authors.

American University, Washington College of Law

Current as of May 7, 2009 


\section{Fifty State Survey of Mandatory Reporting Statutes}

\section{NIC/WCL Project on Addressing Prison Rape}

\begin{tabular}{|c|c|}
\hline $\begin{array}{l}\text { Persons Required to } \\
\text { Report Cont'd } \\
\text { (Georgia) }\end{array}$ & $\begin{array}{l}\text { (G) Professional counselors, social workers, or marriage and family therapists; } \\
\text { (H) School teachers; } \\
\text { (I) School administrators; } \\
\text { (J) School guidance counselors, visiting teachers, school social workers, or school psychologists; } \\
\text { (K) Child welfare agency personnel; } \\
\text { (L) Child-counseling personnel; } \\
\text { (M) Child service organization personnel; or } \\
\text { (N) Law enforcement personnel. }\end{array}$ \\
\hline $\begin{array}{l}\text { Reporting } \\
\text { Procedures } \\
\text { (Georgia) }\end{array}$ & $\begin{array}{l}\text { GA. CODE ANN § 19-7-5 (West 2008) } \\
\text { (e) An oral report shall be made as soon as possible by telephone or otherwise and followed by a report in writing, if requested, to } \\
\text { a child welfare agency providing protective services, as designated by the Department of Human Resources, or, in the absence of } \\
\text { such agency, to an appropriate police authority or district attorney. Such reports shall contain the names and addresses of the child } \\
\text { and the child's parents or caretakers, if known, the child's age, the nature and extent of the child's injuries, including any evidence } \\
\text { of previous injuries, and any other information that the reporting person believes might be helpful in establishing the cause of the } \\
\text { injuries and the identity of the perpetrator. }\end{array}$ \\
\hline $\begin{array}{l}\text { Penalty for Failure to } \\
\text { Report } \\
\text { (Georgia) }\end{array}$ & $\begin{array}{l}\text { GA. CODE ANN } \S \S 19-7-5 \text { (West 2008) } \\
\text { (h) Any person or official required by subsection (c) of this Code section to report a suspected case of child abuse who knowingly } \\
\text { and willfully fails to do so shall be guilty of a misdemeanor. } \\
\text { GA. CODE ANN. } \S 17-10-3 \text { (West 2008) } \\
\text { (a)(1)Maximum fine of } \$ 1,000 \text { and maximum imprisonment of } 12 \text { months. }\end{array}$ \\
\hline
\end{tabular}

NOTE:

** For purposes of this chart, corrections officers, police officers, peace officers, probation officers or "catch-all” phrases such as "all persons" have been bolded. However, many mandatory reporters include professionals who may have contact or work in correctional facilities. Such individuals include physicians, nurses, dentists, teachers and social workers. These statutes can be used as a tool to require staff other than correctional officers to report sexual misconduct with inmates.

This publication is developed by the NIC/WCL Project on Addressing Prison Rape under NIC Cooperative Agreement 06S20GJJ1.

This is not to be reproduced or cited without permission from the authors.

American University, Washington College of Law

Current as of May 7, 2009 


\section{Fifty State Survey of Mandatory Reporting Statutes}

\section{NIC/WCL Project on Addressing Prison Rape}

\begin{tabular}{|c|c|}
\hline $\begin{array}{l}\text { Mandatory } \\
\text { Reporting Statute } \\
\text { (Georgia) }\end{array}$ & $\begin{array}{l}\text { AGAINST AN ADULT } \\
\text { GA. CODE ANN. § 30-5-4 (West 2008) }\end{array}$ \\
\hline $\begin{array}{l}\text { What has to be } \\
\text { reported? } \\
\text { (Georgia) }\end{array}$ & $\begin{array}{l}\text { GA. CODE ANN § 30-5-4 (West 2008) } \\
\text { (a)(1)(A) Reasonable cause to believe that a disabled adult or elder person has had a physical injury or injuries inflicted upon such } \\
\text { disabled adult or elder person, other than by accidental means, or has been neglected or exploited. }\end{array}$ \\
\hline $\begin{array}{l}\text { Relevant Definitions } \\
\text { (Georgia) }\end{array}$ & $\begin{array}{l}\text { GA. CODE ANN § 30-5-3 (West 2008) } \\
\text { (1) Abuse means the willful infliction of physical pain, physical injury, mental anguish, unreasonable confinement, or the willful } \\
\text { deprivation of essential services to a disabled adult or elder person. } \\
\text { (6) Disabled adult means a person } 18 \text { years of age or older who is not a resident of a long-term care facility, but who is mentally or } \\
\text { physically incapacitated. } \\
\text { (7.1) Elder person means a person } 65 \text { years of age or older who is not a resident of a long-term care facility. } \\
\text { (9) Exploitation means the illegal or improper use of a disabled adult or elder person or that person's resources through undue } \\
\text { influence, coercion, harassment, duress, deception, false representation, false pretense, or other similar means for another's profit } \\
\text { or advantage. } \\
\text { (10) Neglect means the absence or omission of essential services to the degree that it harms or threatens with harm the physical or } \\
\text { emotional health of a disabled adult or elder person. }\end{array}$ \\
\hline $\begin{array}{l}\text { Persons Required to } \\
\text { Report } \\
\text { (Georgia) }\end{array}$ & $\begin{array}{l}\text { GA. CODE ANN § 30-5-4 (West 2008) } \\
\text { (a)(1)A) Any } \\
\text { - Law enforcement personnel; } \\
\text { - Physician; }\end{array}$ \\
\hline
\end{tabular}

NOTE:

** For purposes of this chart, corrections officers, police officers, peace officers, probation officers or "catch-all” phrases such as "all persons" have been bolded. However, many mandatory reporters include professionals who may have contact or work in correctional facilities. Such individuals include physicians, nurses, dentists, teachers and social workers. These statutes can be used as a tool to require staff other than correctional officers to report sexual misconduct with inmates.

This publication is developed by the NIC/WCL Project on Addressing Prison Rape under NIC Cooperative Agreement 06S20GJJ1.

This is not to be reproduced or cited without permission from the authors.

American University, Washington College of Law

Current as of May 7, 2009 


\section{Fifty State Survey of Mandatory Reporting Statutes}

\section{NIC/WCL Project on Addressing Prison Rape}

\begin{tabular}{|c|c|}
\hline $\begin{array}{l}\text { Persons Required to } \\
\text { Report Cont'd } \\
\text { (Georgia) }\end{array}$ & $\begin{array}{l}\text { - Osteopath; } \\
\text { - Intern; } \\
\text { - Resident; } \\
\text { - Other hospital or medical personnel; } \\
\text { - Dentist; } \\
\text { - Psychologist; } \\
\text { - Chiropractor; } \\
\text { - Podiatrist; } \\
\text { - Pharmacist; } \\
\text { - Physical therapist; } \\
\text { - Occupational therapist; } \\
\text { - Licensed professional counselor; } \\
\text { - Nursing personnel; } \\
\text { - Social work personnel; } \\
\text { - Day-care personnel; } \\
\text { - Coroner, medical examiner; } \\
\text { - Employee of a public or private agency engaged in professional health related services to elder persons or disabled adults. }\end{array}$ \\
\hline $\begin{array}{l}\text { Reporting } \\
\text { Procedures } \\
\text { (Georgia) }\end{array}$ & $\begin{array}{l}\text { GA. CODE ANN § 30-5-4 (West 2008) } \\
\text { (b)(2) The report may be made by oral or written communication. The report shall include the name and address of the disabled } \\
\text { adult or elder person and should include the name and address of the disabled adult's or elder person's caretaker, the age of the } \\
\text { disabled adult or elder person, the nature and extent of the disabled adult's or elder person's injury or condition resulting from } \\
\text { abuse, exploitation, or neglect, and other pertinent information. All such reports prepared by a law enforcement agency shall be } \\
\text { forwarded to the director within } 24 \text { hours. }\end{array}$ \\
\hline
\end{tabular}

** For purposes of this chart, corrections officers, police officers, peace officers, probation officers or "catch-all” phrases such as “all persons” have been bolded. However, many mandatory reporters include professionals who may have contact or work in correctional facilities. Such individuals include physicians, nurses, dentists, teachers and social workers. These statutes can be used as a tool to require staff other than correctional officers to report sexual misconduct with inmates.

This publication is developed by the NIC/WCL Project on Addressing Prison Rape under NIC Cooperative Agreement 06S20GJJ1.

This is not to be reproduced or cited without permission from the authors.

American University, Washington College of Law

Current as of May 7, 2009 


\section{Fifty State Survey of Mandatory Reporting Statutes}

\section{NIC/WCL Project on Addressing Prison Rape}

\begin{tabular}{|c|c|}
\hline $\begin{array}{l}\text { Penalty for Failure to } \\
\text { Report } \\
\text { (Georgia) }\end{array}$ & $\begin{array}{l}\text { GA. CODE ANN § 30-5-8 (West 2008) } \\
\text { (b)(2) Misdemeanor } \\
\text { GA. CODE ANN. § 17-10-3 (West 2008) } \\
\text { (a)(1)Maximum fine of } \$ 1,000 \text { and maximum imprisonment of } 12 \text { months. }\end{array}$ \\
\hline & GUAM \\
\hline $\begin{array}{l}\text { Mandatory } \\
\text { Reporting Statute } \\
\text { (Guam) }\end{array}$ & $\begin{array}{l}\text { AGAINST A CHILD } \\
19 \text { G.C.A. § } 13201 \text { (West 2008) }\end{array}$ \\
\hline $\begin{array}{l}\text { What has to be } \\
\text { reported? } \\
\text { (Guam) }\end{array}$ & $\begin{array}{l}19 \text { G.C.A. } § 13201 \text { (West 2008) } \\
\text { (a) Reason to suspect in course of employment and on the basis of his medical, professional or other training and experience that a } \\
\text { child is an abused or neglected child. } \\
\text { No person may claim "privileged communications" as a basis for his or her refusal or failure to report suspected child abuse or } \\
\text { neglect or to provide Child Protective Services or the Guam Police Department with required information. }\end{array}$ \\
\hline $\begin{array}{l}\text { Relevant Definitions } \\
\text { (Guam) }\end{array}$ & 19 G.C.A. § 13101 (West 2008) \\
\hline
\end{tabular}

NOTE:

** For purposes of this chart, corrections officers, police officers, peace officers, probation officers or “catch-all” phrases such as “all persons” have been bolded. However, many mandatory reporters include professionals who may have contact or work in correctional facilities. Such individuals include physicians, nurses, dentists, teachers and social workers. These statutes can be used as a tool to require staff other than correctional officers to report sexual misconduct with inmates.

This publication is developed by the NIC/WCL Project on Addressing Prison Rape under NIC Cooperative Agreement 06S20GJJ1.

This is not to be reproduced or cited without permission from the authors.

American University, Washington College of Law

Current as of May 7, 2009 


\section{Fifty State Survey of Mandatory Reporting Statutes}

\section{NIC/WCL Project on Addressing Prison Rape}

\begin{tabular}{|c|c|}
\hline $\begin{array}{l}\text { Relevant Definitions } \\
\text { Cont'd } \\
\text { (Guam) }\end{array}$ & $\begin{array}{l}\text { (a) "Abandonment” means the desertion or willful forsaking of a minor by the person responsible for the child's welfare under } \\
\text { circumstances in which a reason able person would continue to provide care or custody; } \\
\text { (b) “Abused” or "neglected child” means a child whose physical or mental health or welfare is harmed or threatened with harm by } \\
\text { the acts or omissions of the person(s) responsible for the child's welfare; } \\
\text { (d) "Child" means a person under the age of } 18 \text { years. } \\
19 \text { G.C.A. } § 13201 \text { (West 2008) } \\
\text { (c) As used in this section, sexual conduct means any of the following: } \\
\text { (1) Sexual intercourse, including genital-genital, oral-genital, anal-genital or oral-anal, whether between persons of the same or } \\
\text { opposite sex or between humans and animals; } \\
\text { (2) Penetration of the vagina or rectum by any object; } \\
\text { (3) Masturbation, for the purpose of sexual stimulation or the viewer; } \\
\text { (4) Sadomasochistic abuse for the purpose of sexual stimulation of the viewer; or } \\
\text { (5) Exhibition of the genitals, pubic or rectal areas of any person for the purpose of sexual stimulation to the viewer. }\end{array}$ \\
\hline $\begin{array}{l}\text { Persons Required to } \\
\text { Report } \\
\text { (Guam) }\end{array}$ & $\begin{array}{l}19 \text { G.C.A. } § 13201 \text { (West 2008) } \\
\text { (a) Mandated reporter shall report when he or she has reason to suspect on the basis of his medical, professional or other training } \\
\text { and experience that a child is an abused or neglected child. } \\
\text { (c) Persons required to report suspected child abuse include but are not limited to any: } \\
\text { - Law enforcement official; } \\
\text { - Peace officer; } \\
\text { - Licensed physician; }\end{array}$ \\
\hline
\end{tabular}

NOTE:

** For purposes of this chart, corrections officers, police officers, peace officers, probation officers or "catch-all” phrases such as "all persons" have been bolded. However, many mandatory reporters include professionals who may have contact or work in correctional facilities. Such individuals include physicians, nurses, dentists, teachers and social workers. These statutes can be used as a tool to require staff other than correctional officers to report sexual misconduct with inmates.

This publication is developed by the NIC/WCL Project on Addressing Prison Rape under NIC Cooperative Agreement 06S20GJJ1.

This is not to be reproduced or cited without permission from the authors.

American University, Washington College of Law

Current as of May 7, 2009 


\section{Fifty State Survey of Mandatory Reporting Statutes}

\section{NIC/WCL Project on Addressing Prison Rape}

\begin{tabular}{|c|c|}
\hline $\begin{array}{l}\text { Persons Required to } \\
\text { Report Cont'd } \\
\text { (Guam) }\end{array}$ & $\begin{array}{l}\text { - Medical examiner; } \\
\text { - Dentist; } \\
\text { - Osteopath; } \\
\text { - Optometrist; } \\
\text { - Phiropractor; } \\
\text { - Intern; } \\
\text { - Registered nurse; } \\
\text { - Licensed practical nurse; } \\
\text { - Hospital personnel engaged in the admission, examination, care or treatment of persons; } \\
\text { - Christian Science practitioner; } \\
\text { - School administrator, school teacher, school nurses, school counselor; } \\
\text { - Social services worker; } \\
\text { - Day care center worker or any other child care or foster care worker; } \\
\text { - Mental health professional. } \\
\text { (c) Any commercial film and photographic print processor who has knowledge of or observes, within the scope of his or her } \\
\text { professional capacity or employment, any film, photograph, video tape, negative or slide depicting a child under the age of } 18 \\
\text { engaged in an act of sexual conduct shall report such instances of suspected child abuse to Child Protective Services immediately } \\
\text { or as soon as practically possible by telephone and shall prepare and send a written report of it with a copy of the film, } \\
\text { photograph, video tape, negative or slide attached within } 48 \text { hours of receiving the information concerning the incident. }\end{array}$ \\
\hline $\begin{array}{l}\text { Reporting } \\
\text { Procedures } \\
\text { (Guam) }\end{array}$ & $\begin{array}{l}19 \text { G.C.A. } § 13203 \text { (West 2008) } \\
\text { (a) Reports suspected child abuse or neglect from persons required to report shall be made immediately by telephone and followed }\end{array}$ \\
\hline
\end{tabular}

NOTE:

** For purposes of this chart, corrections officers, police officers, peace officers, probation officers or “catch-all” phrases such as “all persons” have been bolded. However, many mandatory reporters include professionals who may have contact or work in correctional facilities. Such individuals include physicians, nurses, dentists, teachers and social workers. These statutes can be used as a tool to require staff other than correctional officers to report sexual misconduct with inmates.

This publication is developed by the NIC/WCL Project on Addressing Prison Rape under NIC Cooperative Agreement 06S20GJJ1.

This is not to be reproduced or cited without permission from the authors.

American University, Washington College of Law

Current as of May 7, 2009 


\section{Fifty State Survey of Mandatory Reporting Statutes}

\section{NIC/WCL Project on Addressing Prison Rape}

\begin{tabular}{|c|c|}
\hline $\begin{array}{l}\text { Reporting } \\
\text { Procedures Cont'd } \\
\text { (Guam) }\end{array}$ & $\begin{array}{l}\text { up in writing within } 48 \text { hours after the oral report. Oral reports shall be made to Child Protective Services or to the Guam Police } \\
\text { Department. }\end{array}$ \\
\hline $\begin{array}{l}\text { Penalty for Failure to } \\
\text { Report } \\
\text { (Guam) }\end{array}$ & $\begin{array}{l}19 \text { G.C.A. } § 13207 \text { (West 2008) } \\
\text { Any person required to report who fails to report an instance of child abuse which he or she knows to exist or reasonably should } \\
\text { know to exist is guilty of a misdemeanor and is punishable by confinement for a term not to exceed six months, by a fine of not } \\
\text { more than } \$ 1,000 \text { or by both. A second or subsequent conviction shall be a felony in the third degree. }\end{array}$ \\
\hline $\begin{array}{l}\text { Mandatory } \\
\text { Reporting Statute } \\
\text { (Guam) }\end{array}$ & $\begin{array}{l}\text { AGAINST AN ADULT } \\
10 \text { G.C.A. § } 2952 \text { (West 2008) }\end{array}$ \\
\hline $\begin{array}{l}\text { What has to be } \\
\text { reported? } \\
\text { (Guam) }\end{array}$ & $\begin{array}{l}10 \text { G.C.A. § } 2952 \text { (West 2008) } \\
\text { (a) Actual knowledge or reasonable cause to believe that an elderly or disabled adult is suffering from or has died as a result of } \\
\text { abuse }\end{array}$ \\
\hline $\begin{array}{l}\text { Relevant Definitions } \\
\text { (Guam) }\end{array}$ & $\begin{array}{l}10 \text { G.C.A. } § 2951 \text { (West 2008) } \\
\text { (a) Abandonment refers to the desertion or willful forsaking of an elderly or disabled adult by his or her caregiver under } \\
\text { circumstances in which a reasonable person would continue to provide care or custody. } \\
\text { (f) Elderly or disabled adult abuse means any one (1) or more of the following acts inflicted on an elderly or disabled adult by } \\
\text { other than accidental means by another person: physical abuse, neglect, abandonment or self neglect. }\end{array}$ \\
\hline
\end{tabular}

NOTE:

** For purposes of this chart, corrections officers, police officers, peace officers, probation officers or “catch-all” phrases such as “all persons” have been bolded. However, many mandatory reporters include professionals who may have contact or work in correctional facilities. Such individuals include physicians, nurses, dentists, teachers and social workers. These statutes can be used as a tool to require staff other than correctional officers to report sexual misconduct with inmates.

This publication is developed by the NIC/WCL Project on Addressing Prison Rape under NIC Cooperative Agreement 06S20GJJ1.

This is not to be reproduced or cited without permission from the authors.

American University, Washington College of Law

Current as of May 7, 2009 


\section{Fifty State Survey of Mandatory Reporting Statutes}

\section{NIC/WCL Project on Addressing Prison Rape}

\begin{tabular}{|c|c|}
\hline $\begin{array}{l}\text { Relevant Definitions } \\
\text { Cont'd } \\
\text { (Guam) }\end{array}$ & $\begin{array}{l}\text { (i) Neglect means the failure of a caregiver to provide for the physical, mental or emotional health and well-being of the elderly or } \\
\text { disabled adult and includes but is not limited to: } \\
\text { (1) Failure to assist or provide personal hygiene for the elderly or disabled adult. } \\
\text { (2) Failure to provide adequate food, water, clothing or shelter. } \\
\text { (3) Failure to provide medical care for the physical and mental health of the elderly or disabled adult. No person shall be } \\
\text { deemed neglected or abused for the sole reason that he or she voluntarily relies on treatment by spiritual means through } \\
\text { prayer alone in lieu of medical treatment. } \\
\text { (4) Failure to protect an elderly or disabled adult from health and safety hazards. } \\
\text { (j) Physical Abuse means the willful infliction of injury which results in physical harm. It includes but is not limited to cruel } \\
\text { punishment resulting in physical harm or pain or mental anguish, such as direct beatings, slapping, kicking, biting, choking, } \\
\text { burning, sexual assault or molestation, or unreasonable physical restraint or confinement resulting in physical injury. } \\
\text { (k) Physical Harm means bodily pain, injury, impairment or disease. } \\
\text { (n) Disabled Adult is any person over the age of eighteen (18) years who: } \\
\text { (1) Has a physical or mental impairment which substantially limits one (1) or more major life activities; or } \\
\text { (2) Has a history of, or has been classified as having an impairment which substantially limits one or more major life activities. }\end{array}$ \\
\hline $\begin{array}{l}\text { Persons Required to } \\
\text { Report } \\
\text { (Guam) }\end{array}$ & $\begin{array}{l}10 \text { G.C.A. } § 2952 \text { (West 2008) } \\
\text { (a) Any person who, in the course of his or her employment, occupation or professional practice comes into contact with elderly or } \\
\text { disabled adults. } \\
\text { (b) Persons required to report abuse include but are not limited to: } \\
\text { - Police officers; } \\
\text { - Probation officers; }\end{array}$ \\
\hline
\end{tabular}

NOTE:

** For purposes of this chart, corrections officers, police officers, peace officers, probation officers or "catch-all” phrases such as “all persons” have been bolded. However, many mandatory reporters include professionals who may have contact or work in correctional facilities. Such individuals include physicians, nurses, dentists, teachers and social workers. These statutes can be used as a tool to require staff other than correctional officers to report sexual misconduct with inmates.

This publication is developed by the NIC/WCL Project on Addressing Prison Rape under NIC Cooperative Agreement 06S20GJJ1.

This is not to be reproduced or cited without permission from the authors.

American University, Washington College of Law

Current as of May 7, 2009 


\section{Fifty State Survey of Mandatory Reporting Statutes}

\section{NIC/WCL Project on Addressing Prison Rape}

\begin{tabular}{|c|c|}
\hline $\begin{array}{l}\text { Persons Required to } \\
\text { Report Cont'd } \\
\text { (Guam) }\end{array}$ & $\begin{array}{l}\text { - } \text { Physicians; } \\
\text { - Medical interns; } \\
\text { - } \text { Medical examiners; } \\
\text { - Chiropractors; } \\
\text { - Hospital personnel engaged in the admission, examination, care or treatment of persons; } \\
\text { - } \quad \text { Employees of nursing homes and adult day care facilities. }\end{array}$ \\
\hline $\begin{array}{l}\text { Reporting } \\
\text { Procedures } \\
\text { (Guam) }\end{array}$ & $\begin{array}{l}10 \text { G.C.A. § } 2952 \text { (West 2008) } \\
\text { (a) Immediately make a verbal report of such information or cause a report to be made to the Adult Protective Services Unit and } \\
\text { shall, within forty-eight (48) hours, make a written report to the unit. } \\
\text { (b) Oral or written reports from persons required to report under subsection A and B shall include the following information, } \\
\text { if available: } \\
\text { (1) The name of the person making the report and where he or she can be reached. The identity of the person making } \\
\text { the report shall be confidential, but made available to an agency contracted by the Adult Protective Services to } \\
\text { provide case investigation; } \\
\text { (2) The name, address and approximate age of the elderly or disabled adult; } \\
\text { (3) Information regarding the nature and extent of the abuse, the name of the person's caretaker, if known, and any } \\
\text { medical treatment being received or immediately required, if known; } \\
\text { (4) The name of the person or persons responsible for causing the suspected abuse; } \\
\text { (5) The source of the report; } \\
\text { (6) Any other information which may assist in the investigation of the suspected abuse. The identity of the person } \\
\text { making the report shall be confidential. }\end{array}$ \\
\hline
\end{tabular}

NOTE:

** For purposes of this chart, corrections officers, police officers, peace officers, probation officers or "catch-all” phrases such as “all persons” have been bolded. However, many mandatory reporters include professionals who may have contact or work in correctional facilities. Such individuals include physicians, nurses, dentists, teachers and social workers. These statutes can be used as a tool to require staff other than correctional officers to report sexual misconduct with inmates.

This publication is developed by the NIC/WCL Project on Addressing Prison Rape under NIC Cooperative Agreement 06S20GJJ1.

This is not to be reproduced or cited without permission from the authors.

American University, Washington College of Law

Current as of May 7, 2009 


\section{Fifty State Survey of Mandatory Reporting Statutes}

\section{NIC/WCL Project on Addressing Prison Rape}

\begin{tabular}{|c|c|}
\hline $\begin{array}{l}\text { Penalty for Failure to } \\
\text { Report } \\
\text { (Guam) }\end{array}$ & $\begin{array}{l}10 \text { G.C.A. } § 2954 \text { (West 2008) } \\
\text { Liable for a fine of not more than } \$ 500 \text {, except that for a second or subsequent offense, such person shall be guilty of a } \\
\text { misdemeanor. }\end{array}$ \\
\hline & HAWAII \\
\hline $\begin{array}{l}\text { Mandatory } \\
\text { Reporting Statute } \\
\text { (Hawaii) }\end{array}$ & $\begin{array}{l}\text { AGAINST A CHILD } \\
\text { HRS } \S 350-1.1 \text { (West 2008) }\end{array}$ \\
\hline $\begin{array}{l}\text { What has to be } \\
\text { reported? } \\
\text { (Hawaii) }\end{array}$ & $\begin{array}{l}\text { HRS § 350-1.1 (West 2008) } \\
\text { (a) Persons who, in their professional or official capacity, have reason to believe that child abuse or neglect has occurred or that } \\
\text { there exists a substantial risk that child abuse or neglect may occur in the reasonably foreseeable future. }\end{array}$ \\
\hline $\begin{array}{l}\text { Relevant Definitions } \\
\text { (Hawaii) }\end{array}$ & $\begin{array}{l}\text { HRS § 350-1 (West 2008) } \\
\text { Child abuse or Neglect: means the acts or omissions of any person who, or legal entity which, is in any manner or degree related to } \\
\text { the child, is residing with the child, or is otherwise responsible for the child's care, that have resulted in the physical or } \\
\text { psychological health or welfare of the child, who is under the age of eighteen, to be harmed, or to be subject to any reasonably } \\
\text { foreseeable, substantial risk of being harmed. The acts or omissions are indicated for the purposes of reports by circumstances that } \\
\text { include but are not limited to: } \\
\text { (1) When the child exhibits evidence of: }\end{array}$ \\
\hline
\end{tabular}

NOTE:

** For purposes of this chart, corrections officers, police officers, peace officers, probation officers or “catch-all” phrases such as “all persons” have been bolded. However, many mandatory reporters include professionals who may have contact or work in correctional facilities. Such individuals include physicians, nurses, dentists, teachers and social workers. These statutes can be used as a tool to require staff other than correctional officers to report sexual misconduct with inmates.

This publication is developed by the NIC/WCL Project on Addressing Prison Rape under NIC Cooperative Agreement 06S20GJJ1.

This is not to be reproduced or cited without permission from the authors.

American University, Washington College of Law

Current as of May 7, 2009 


\section{Fifty State Survey of Mandatory Reporting Statutes}

\section{NIC/WCL Project on Addressing Prison Rape}

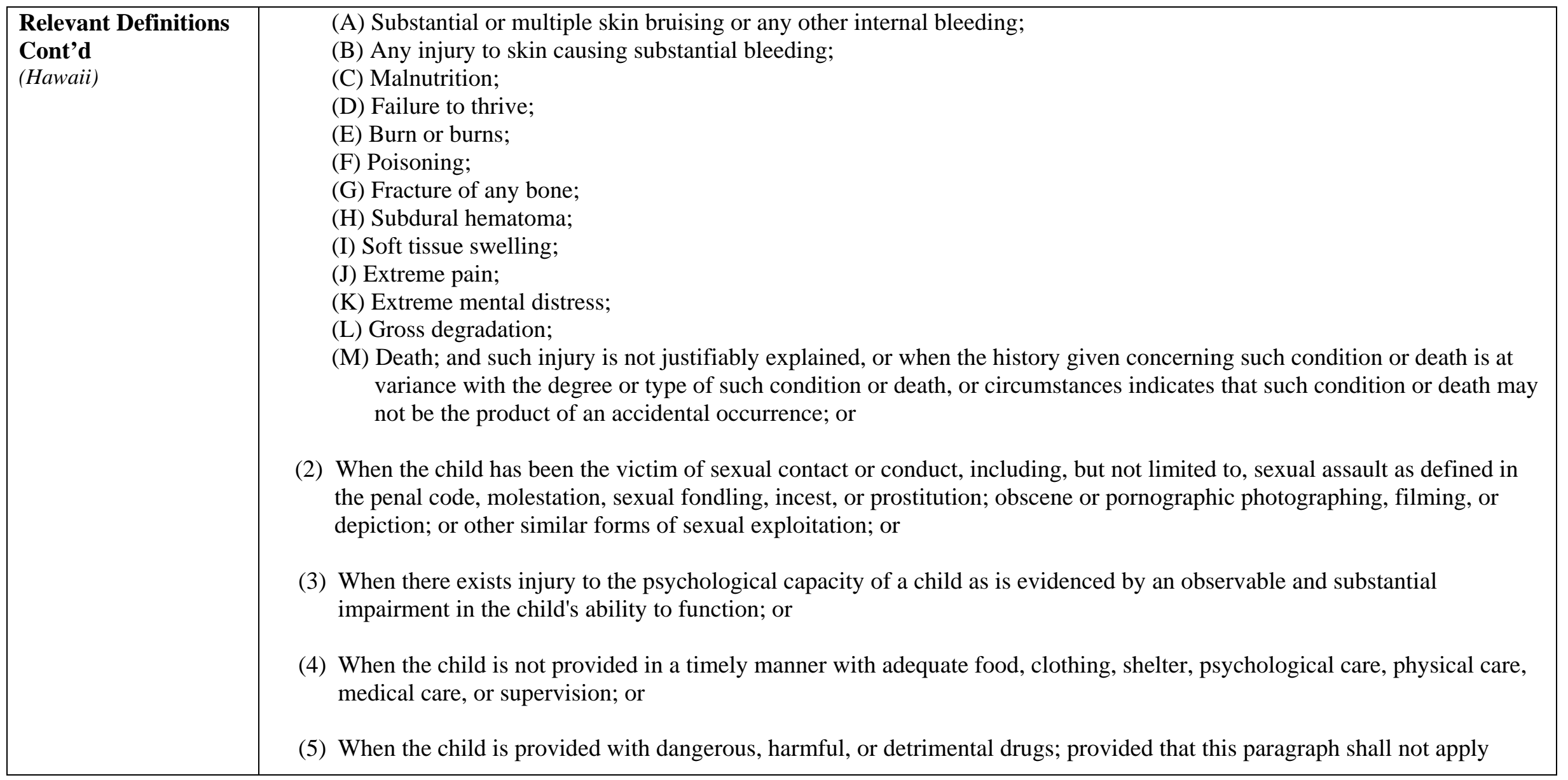

NOTE:

** For purposes of this chart, corrections officers, police officers, peace officers, probation officers or “catch-all” phrases such as “all persons” have been bolded. However, many mandatory reporters include professionals who may have contact or work in correctional facilities. Such individuals include physicians, nurses, dentists, teachers and social workers. These statutes can be used as a tool to require staff other than correctional officers to report sexual misconduct with inmates.

This publication is developed by the NIC/WCL Project on Addressing Prison Rape under NIC Cooperative Agreement 06S20GJJ1.

This is not to be reproduced or cited without permission from the authors.

American University, Washington College of Law

Current as of May 7, 2009 


\section{Fifty State Survey of Mandatory Reporting Statutes}

\section{NIC/WCL Project on Addressing Prison Rape}

\begin{tabular}{|c|c|}
\hline $\begin{array}{l}\text { Relevant Definitions } \\
\text { Cont'd } \\
\text { (Hawaii) }\end{array}$ & when such drugs are provided to the child pursuant to the direction or prescription of a practitioner. \\
\hline $\begin{array}{l}\text { Persons Required to } \\
\text { Report } \\
\text { (Hawaii) }\end{array}$ & $\begin{array}{l}\text { HRS § 350-1.1 (West 2008) } \\
\text { (a) } \\
\text { (2) Licensed or registered professional of the healing arts or any health-related occupation who examines, attends, treats, or } \\
\text { provides other professional or specialized services, including but not limited to physicians, including physicians in training, } \\
\text { psychologists, dentists, nurses, osteopathic physicians and surgeons, optometrists, chiropractors, podiatrists, pharmacists, } \\
\text { and other health-related professionals; } \\
\text { (3) Employees or officers of any public or private school; } \\
\text { (4) Employees or officers of any public or private agency or institution, or other individuals, providing social, medical, } \\
\text { hospital, or mental health services, including financial assistance; } \\
\text { (5) Employees or officers of any law enforcement agency, including but not limited to the courts, police departments, } \\
\text { department of public safety correctional institutions, and parole or probation offices; } \\
\text { (6) Individual providers of child care, or employees or officers of any licensed or registered child care facility, foster home, or } \\
\text { similar institution; } \\
\text { (7) Medical examiners or coroners; and } \\
\text { (8) Employees of any public or private agency providing recreational or sports activities. }\end{array}$ \\
\hline $\begin{array}{l}\text { Reporting } \\
\text { Procedures } \\
\text { (Hawaii) }\end{array}$ & $\begin{array}{l}\text { HRS § 350-1.1 (West 2008) } \\
\text { (a) A mandatory reporter shall immediately report the matter orally to the department of social services or to the police } \\
\text { department. } \\
\text { (c) The initial oral report shall be followed as soon as possible by a report in writing to the department.... All written reports shall } \\
\text { contain the name and address of the child and the child's parents or other persons responsible for the child's care, if known, the }\end{array}$ \\
\hline
\end{tabular}

NOTE:

** For purposes of this chart, corrections officers, police officers, peace officers, probation officers or “catch-all” phrases such as “all persons” have been bolded. However, many mandatory reporters include professionals who may have contact or work in correctional facilities. Such individuals include physicians, nurses, dentists, teachers and social workers. These statutes can be used as a tool to require staff other than correctional officers to report sexual misconduct with inmates.

This publication is developed by the NIC/WCL Project on Addressing Prison Rape under NIC Cooperative Agreement 06S20GJJ1.

This is not to be reproduced or cited without permission from the authors.

American University, Washington College of Law

Current as of May 7, 2009 


\section{Fifty State Survey of Mandatory Reporting Statutes}

\section{NIC/WCL Project on Addressing Prison Rape}

\begin{tabular}{|c|c|}
\hline $\begin{array}{l}\text { Reporting } \\
\text { Procedures Cont'd } \\
\text { (Hawaii) }\end{array}$ & $\begin{array}{l}\text { child's age, the nature and extent of the child's injuries, and any other information that the reporter believes might be helpful or } \\
\text { relevant to the investigation of the child abuse or neglect. This subsection shall not be construed to serve as a cause of action } \\
\text { against the department or the police. }\end{array}$ \\
\hline $\begin{array}{l}\text { Penalty for Failure to } \\
\text { Report } \\
\text { (Hawaii) }\end{array}$ & $\begin{array}{l}\text { HRS } \S 350-1.2 \text { (West 2008) } \\
\text { Petty misdemeanor: (For knowingly preventing another person from reporting, or who knowingly fails to provide information as } \\
\text { required) } \\
\text { HRS } \S 706-640 \text { (West 2008) } \\
\text { Maximum fine of } \$ 1000 \text { when the conviction is a petty misdemeanor or a violation } \\
\text { HRS } \S 706-663 \\
\text { The court may sentence a person who has been convicted of a petty misdemeanor to imprisonment for a definite term to be fixed } \\
\text { by the court and not to exceed a maximum of } 30 \text { days imprisonment. }\end{array}$ \\
\hline $\begin{array}{l}\text { Mandatory } \\
\text { Reporting Statute } \\
\text { (Hawaii) }\end{array}$ & $\begin{array}{l}\text { AGAINST AN ADULT } \\
\text { HRS § 346-224 (West 2008) }\end{array}$ \\
\hline
\end{tabular}

NOTE:

** For purposes of this chart, corrections officers, police officers, peace officers, probation officers or “catch-all” phrases such as “all persons” have been bolded. However, many mandatory reporters include professionals who may have contact or work in correctional facilities. Such individuals include physicians, nurses, dentists, teachers and social workers. These statutes can be used as a tool to require staff other than correctional officers to report sexual misconduct with inmates.

This publication is developed by the NIC/WCL Project on Addressing Prison Rape under NIC Cooperative Agreement 06S20GJJ1.

This is not to be reproduced or cited without permission from the authors.

American University, Washington College of Law

Current as of May 7, 2009 


\section{Fifty State Survey of Mandatory Reporting Statutes}

\section{NIC/WCL Project on Addressing Prison Rape}

\begin{tabular}{|c|c|}
\hline $\begin{array}{l}\text { What has to be } \\
\text { reported? } \\
\text { (Hawaii) }\end{array}$ & $\begin{array}{l}\text { HRS § 346-224 (West 2008) } \\
\text { (a) A mandatory reporter in the performance of their professional or official duties who has reason to believe that a dependent } \\
\text { adult has been abused and is threatened with imminent abuse. }\end{array}$ \\
\hline $\begin{array}{l}\text { Relevant Definitions } \\
\text { (Hawaii) }\end{array}$ & 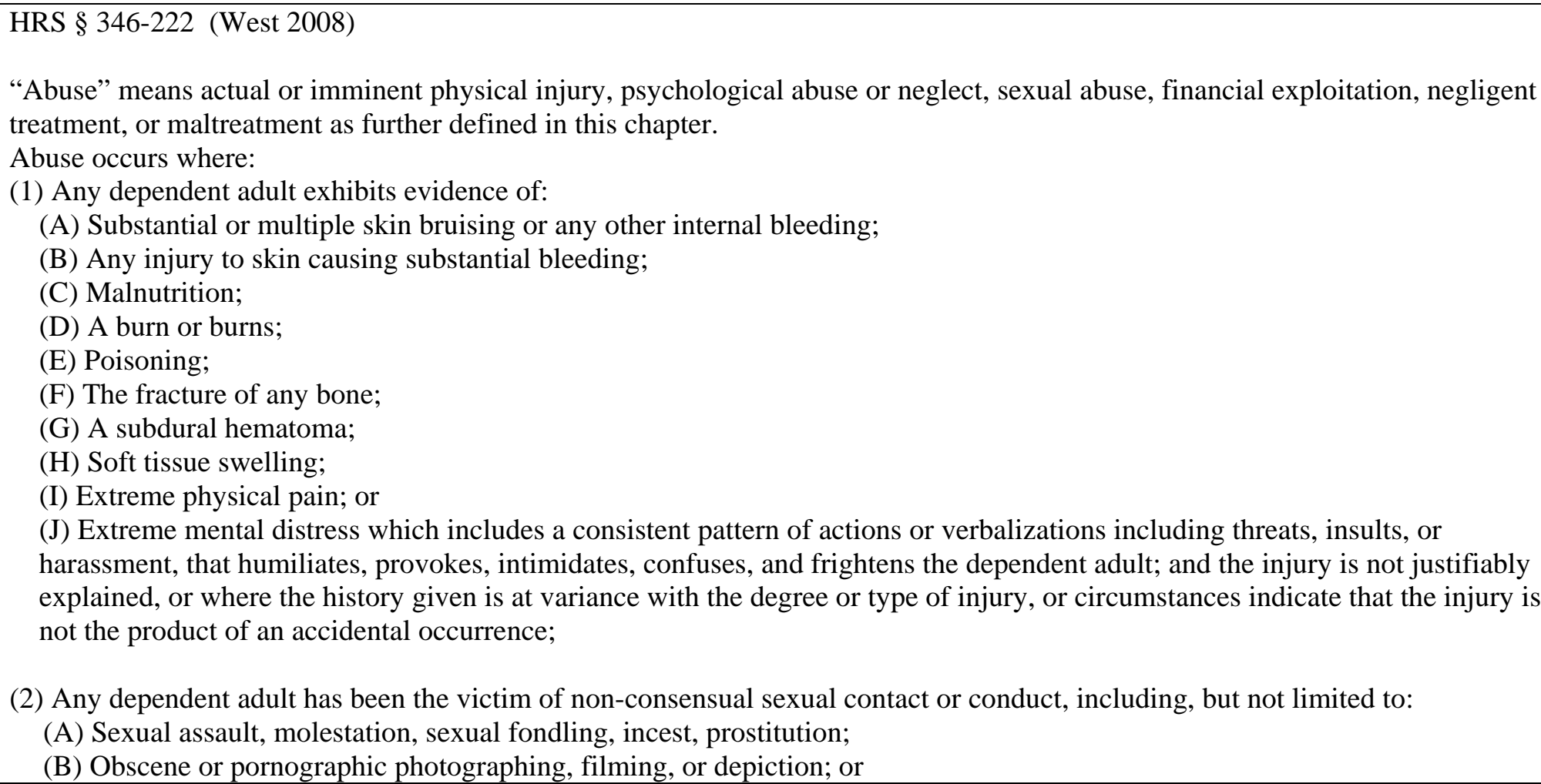 \\
\hline
\end{tabular}

NOTE:

** For purposes of this chart, corrections officers, police officers, peace officers, probation officers or “catch-all” phrases such as “all persons” have been bolded. However, many mandatory reporters include professionals who may have contact or work in correctional facilities. Such individuals include physicians, nurses, dentists, teachers and social workers. These statutes can be used as a tool to require staff other than correctional officers to report sexual misconduct with inmates.

This publication is developed by the NIC/WCL Project on Addressing Prison Rape under NIC Cooperative Agreement 06S20GJJ1.

This is not to be reproduced or cited without permission from the authors.

American University, Washington College of Law

Current as of May 7, 2009 


\section{Fifty State Survey of Mandatory Reporting Statutes}

\section{NIC/WCL Project on Addressing Prison Rape}

\begin{tabular}{|c|c|}
\hline $\begin{array}{l}\text { Relevant Definitions } \\
\text { Cont'd } \\
\text { (Hawaii) }\end{array}$ & 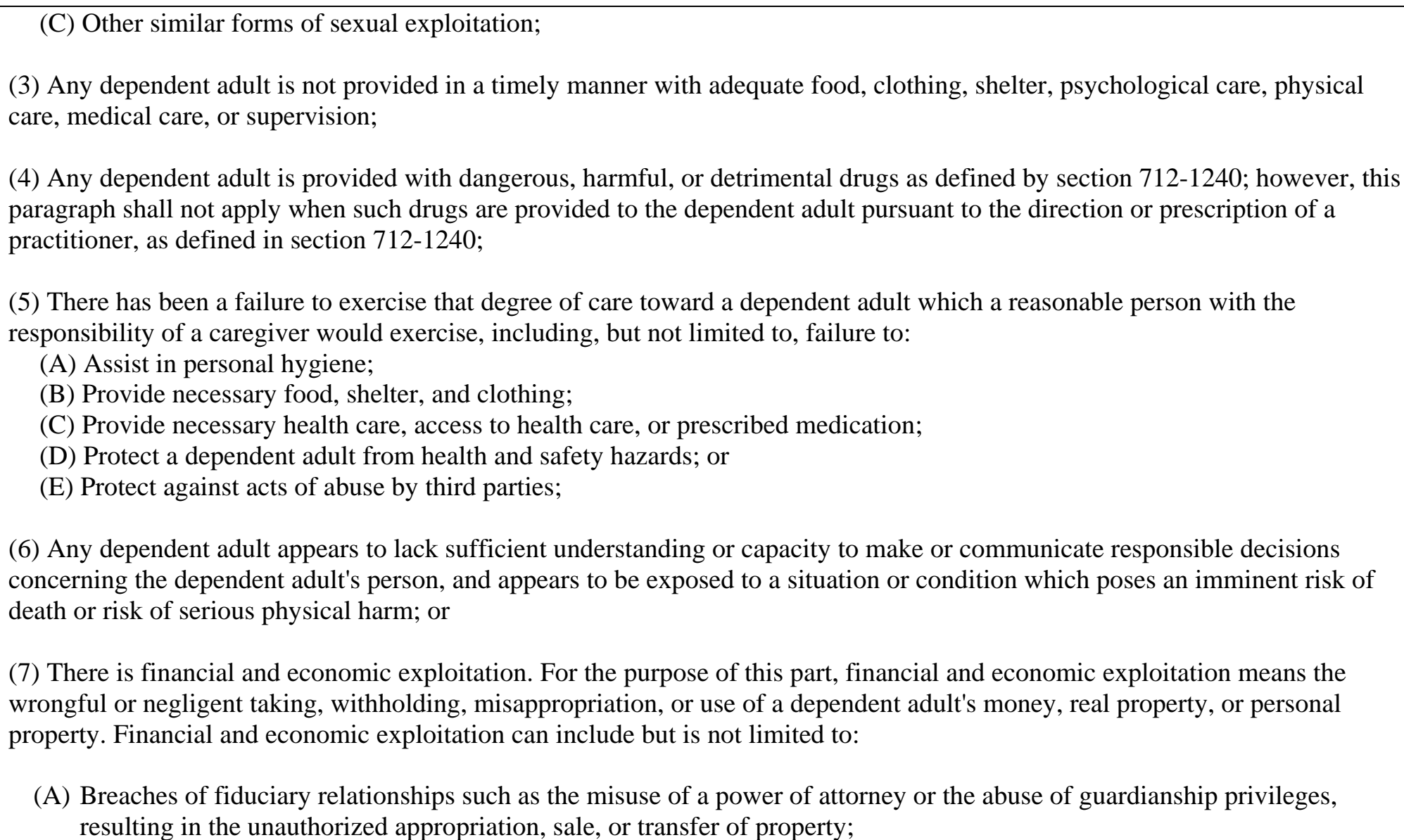 \\
\hline
\end{tabular}

NOTE:

** For purposes of this chart, corrections officers, police officers, peace officers, probation officers or “catch-all” phrases such as “all persons” have been bolded. However, many mandatory reporters include professionals who may have contact or work in correctional facilities. Such individuals include physicians, nurses, dentists, teachers and social workers. These statutes can be used as a tool to require staff other than correctional officers to report sexual misconduct with inmates.

This publication is developed by the NIC/WCL Project on Addressing Prison Rape under NIC Cooperative Agreement 06S20GJJ1.

This is not to be reproduced or cited without permission from the authors.

American University, Washington College of Law

Current as of May 7, 2009 


\section{Fifty State Survey of Mandatory Reporting Statutes}

\section{NIC/WCL Project on Addressing Prison Rape}

\begin{tabular}{|c|c|}
\hline $\begin{array}{l}\text { Relevant Definitions } \\
\text { Cont'd } \\
\text { (Hawaii) }\end{array}$ & $\begin{array}{l}\text { (B) The unauthorized taking of personal assets; } \\
\text { (C) The misappropriation, misuse, or transfer of moneys belonging to the dependent adult from a personal or joint account; or } \\
\text { (D) The intentional or negligent failure to effectively use a dependent adult's income and assets for the necessities required for } \\
\text { the person's support and maintenance. The exploitation may involve coercion, manipulation, threats, intimidation, } \\
\text { misrepresentation, or exertion of undue influence. } \\
\text { "Dependent adult" means any adult who, because of mental or physical impairment is dependent upon another person, a care } \\
\text { organization, or a care facility for personal health, safety, or welfare. }\end{array}$ \\
\hline $\begin{array}{l}\text { Persons Required to } \\
\text { Report } \\
\text { (Hawaii) }\end{array}$ & $\begin{array}{l}\text { HRS § 346-224 (West 2008) } \\
\text { (a) } \\
\text { (1) Any licensed or registered professional of the healing arts and any health-related occupation who examines, treats, or } \\
\text { provides other professional or specialized services to dependent adults, including, but not limited to, physicians, physicians } \\
\text { in training, psychologists, dentists, nurses, osteopathic physicians and surgeons, optometrists, chiropractors, podiatrists, } \\
\text { pharmacists, and other health-related professionals; } \\
\text { (2) Employees or officers of any public or private agency or institution providing social, medical, hospital or mental health } \\
\text { services, including financial assistance; } \\
\text { (3) Employees or officers of any law enforcement agency including, but not limited to, the courts, police departments, } \\
\text { correctional institutions, and parole or probation offices; } \\
\text { (4) Employees or officers of any adult residential care home, adult day care center, or similar institution; and } \\
\text { (5) Medical examiners or coroners. }\end{array}$ \\
\hline $\begin{array}{l}\text { Reporting } \\
\text { Procedures } \\
\text { (Hawaii) }\end{array}$ & $\begin{array}{l}\text { HRS } \S 346-224 \text { (West 2008) } \\
\text { (a) Shall promptly report the matter orally to the department of human services. } \\
\text { (b) The initial oral report required by subsection (a) shall be followed as soon as possible by a written report to the department; }\end{array}$ \\
\hline
\end{tabular}

NOTE:

** For purposes of this chart, corrections officers, police officers, peace officers, probation officers or “catch-all” phrases such as “all persons” have been bolded. However, many mandatory reporters include professionals who may have contact or work in correctional facilities. Such individuals include physicians, nurses, dentists, teachers and social workers. These statutes can be used as a tool to require staff other than correctional officers to report sexual misconduct with inmates.

This publication is developed by the NIC/WCL Project on Addressing Prison Rape under NIC Cooperative Agreement 06S20GJJ1.

This is not to be reproduced or cited without permission from the authors.

American University, Washington College of Law

Current as of May 7, 2009 


\section{Fifty State Survey of Mandatory Reporting Statutes}

\section{NIC/WCL Project on Addressing Prison Rape}

\begin{tabular}{|c|c|}
\hline $\begin{array}{l}\text { Reporting } \\
\text { Procedures Cont'd } \\
\text { (Hawaii) }\end{array}$ & $\begin{array}{l}\text { provided that where a police department is the initiating agency, a written report shall not be required unless the police department } \\
\text { has declined to take further action and the department informs the police department that it intends to pursue the matter of the } \\
\text { orally reported incident of abuse. All written reports shall contain the name and address of the dependent adult and the person who } \\
\text { or care organization or care facility which is alleged to have committed or been responsible for the dependent adult abuse, if } \\
\text { known; the nature and extent of the dependent adult's injury or harm; and any other information the reporter believes might be } \\
\text { helpful in establishing the cause of the dependent adult abuse. }\end{array}$ \\
\hline $\begin{array}{l}\text { Penalty for Failure to } \\
\text { Report } \\
\text { (Hawaii) }\end{array}$ & $\begin{array}{l}\text { HRS § 346-224 (West 2008) } \\
\text { (e) Any person who knowingly fails to report as required by this section or who willfully prevents another person from reporting } \\
\text { pursuant to this section shall be guilty of a petty misdemeanor. } \\
\text { HRS § 706-663 (West 2008) } \\
\text { The court may sentence a person who has been convicted of a petty misdemeanor to imprisonment for a definite term to be fixed } \\
\text { by the court and not to exceed a maximum of } 30 \text { days imprisonment. } \\
\text { HRS § 706-640 (West 2008) } \\
\text { When the conviction is for a petty misdemeanor the maximum fine is } \$ 1000\end{array}$ \\
\hline & IDAHO \\
\hline
\end{tabular}

NOTE:

** For purposes of this chart, corrections officers, police officers, peace officers, probation officers or "catch-all” phrases such as "all persons" have been bolded. However, many mandatory reporters include professionals who may have contact or work in correctional facilities. Such individuals include physicians, nurses, dentists, teachers and social workers. These statutes can be used as a tool to require staff other than correctional officers to report sexual misconduct with inmates.

This publication is developed by the NIC/WCL Project on Addressing Prison Rape under NIC Cooperative Agreement 06S20GJJ1.

This is not to be reproduced or cited without permission from the authors.

American University, Washington College of Law

Current as of May 7, 2009 


\section{Fifty State Survey of Mandatory Reporting Statutes}

\section{NIC/WCL Project on Addressing Prison Rape}

\begin{tabular}{|c|c|}
\hline $\begin{array}{l}\text { Mandatory } \\
\text { Reporting Statute } \\
\text { (Idaho) }\end{array}$ & $\begin{array}{l}\text { AGAINST A CHILD } \\
\text { I.C. } \S 16-1605 \text { (West 2008) }\end{array}$ \\
\hline $\begin{array}{l}\text { What has to be } \\
\text { reported? } \\
\text { (Idaho) }\end{array}$ & $\begin{array}{l}\text { I.C. } § 16-1605 \text { (West 2008) } \\
\text { (1) Reason to believe that a child under the age of eighteen (18) years has been abused, abandoned or neglected or who observes } \\
\text { the child being subjected to conditions or circumstances which would reasonably result in abuse, abandonment or neglect. }\end{array}$ \\
\hline $\begin{array}{l}\text { Relevant Definitions } \\
\text { (Idaho) }\end{array}$ & $\begin{array}{l}\text { I.C. } \$ 16-1602 \text { (West 2008) } \\
\text { (7) “Child” means an individual who is under the age of eighteen (18) years. } \\
\text { (1) “Abused” means any case in which a child has been the victim of: } \\
\text { (a) Conduct or omission resulting in skin bruising, bleeding, malnutrition, burns, fracture of any bone, subdural hematoma, soft } \\
\text { tissue swelling, failure to thrive or death, and such condition or death is not justifiably explained, or where the history given } \\
\text { concerning such condition or death is at variance with the degree or type of such condition or death, or the circumstances } \\
\text { indicate that such condition or death may not be the product of an accidental occurrence; or } \\
\text { (b) Sexual conduct, including rape, molestation, incest, prostitution, obscene or pornographic photographing, filming or } \\
\text { depiction for commercial purposes, or other similar forms of sexual exploitation harming or threatening the child's health or } \\
\text { welfare or mental injury to the child. } \\
\text { (2) “Abandoned” means the failure of the parent to maintain a normal parental relationship with his child including, but not limited } \\
\text { to, reasonable support or regular personal contact. Failure to maintain this relationship without just cause for a period of one (1) } \\
\text { year shall constitute prima facie evidence of abandonment. } \\
\text { (13) “Department” means the department of health and welfare and its authorized representatives. }\end{array}$ \\
\hline
\end{tabular}

NOTE:

** For purposes of this chart, corrections officers, police officers, peace officers, probation officers or “catch-all” phrases such as “all persons” have been bolded. However, many mandatory reporters include professionals who may have contact or work in correctional facilities. Such individuals include physicians, nurses, dentists, teachers and social workers. These statutes can be used as a tool to require staff other than correctional officers to report sexual misconduct with inmates.

This publication is developed by the NIC/WCL Project on Addressing Prison Rape under NIC Cooperative Agreement 06S20GJJ1.

This is not to be reproduced or cited without permission from the authors.

American University, Washington College of Law

Current as of May 7, 2009 


\section{Fifty State Survey of Mandatory Reporting Statutes}

\section{NIC/WCL Project on Addressing Prison Rape}

\begin{tabular}{|c|c|}
\hline $\begin{array}{l}\text { Relevant Definitions } \\
\text { Cont'd } \\
\text { (Idaho) }\end{array}$ & $\begin{array}{l}\text { (22) "Law enforcement agency" means a city police department, the prosecuting attorney of any county, state law enforcement } \\
\text { officers, or the office of a sheriff of any county. } \\
\text { (25) "Neglected" means a child: } \\
\text { (a) Who is without proper parental care and control, or subsistence, medical or other care or control necessary for his well- } \\
\text { being because of the conduct or omission of his parents, guardian or other custodian or their neglect or refusal to provide } \\
\text { them; however, no child whose parent or guardian chooses for such child treatment by prayers through spiritual means alone } \\
\text { in lieu of medical treatment- shall be deemed for that reason alone to be neglected or lack parental care necessary for his } \\
\text { health and well-being, but this subsection shall not prevent the court from acting pursuant to section } 16-1627 \text {, Idaho Code; or } \\
\text { (b) Whose parents, guardian or other custodian are unable to discharge their responsibilities to and for the child and, as a } \\
\text { result of such inability, the child lacks the parental care necessary for his health, safety or well-being; or } \\
\text { (c) Who has been placed for care or adoption in violation of law; or } \\
\text { (d) Who is without proper education because of the failure to comply with section 33-202, Idaho Code. }\end{array}$ \\
\hline $\begin{array}{l}\text { Persons Required to } \\
\text { Report } \\
\text { (Idaho) }\end{array}$ & $\begin{array}{l}\text { I.C. } § 16-1605 \text { (West 2008) } \\
\text { (1) Any: } \\
\text { - Physician, resident on a hospital staff, intern, nurse, coroner; } \\
\text { - School teacher; } \\
\text { - Day care personnel; } \\
\text { - Social worker; or } \\
\text { - Other person having reason to believe that a child under the age of eighteen (18) years has been abused, abandoned or } \\
\text { neglected or who observes the child being subjected to conditions or circumstances which would reasonably result in abuse, } \\
\text { abandonment or neglect. }\end{array}$ \\
\hline
\end{tabular}

NOTE:

** For purposes of this chart, corrections officers, police officers, peace officers, probation officers or "catch-all” phrases such as “all persons” have been bolded. However, many mandatory reporters include professionals who may have contact or work in correctional facilities. Such individuals include physicians, nurses, dentists, teachers and social workers. These statutes can be used as a tool to require staff other than correctional officers to report sexual misconduct with inmates.

This publication is developed by the NIC/WCL Project on Addressing Prison Rape under NIC Cooperative Agreement 06S20GJJ1.

This is not to be reproduced or cited without permission from the authors.

American University, Washington College of Law

Current as of May 7, 2009 


\section{Fifty State Survey of Mandatory Reporting Statutes}

\section{NIC/WCL Project on Addressing Prison Rape}

\begin{tabular}{|c|c|}
\hline $\begin{array}{l}\text { Reporting } \\
\text { Procedures } \\
\text { (Idaho) }\end{array}$ & $\begin{array}{l}\text { I.C. } § 16-1605 \text { (West 2008) } \\
\text { (1) A mandatory reporter shall report or cause to be reported within twenty-four (24) hours such conditions or circumstances to the } \\
\text { proper law enforcement agency or the department. }\end{array}$ \\
\hline $\begin{array}{l}\text { Penalty for Failure to } \\
\text { Report } \\
\text { (Idaho) }\end{array}$ & $\begin{array}{l}\text { I.C. } § 16-1605 \text { (West 2008) } \\
\text { (4) Misdemeanor } \\
\text { IDAHO CoDE ANN. } § 16-1607 \text { (West 2008) } \\
\text { Civil penalties: Any person who makes a report or allegation of child abuse, abandonment or neglect knowing the same to be false } \\
\text { or who reports or alleges the same in bad faith or with malice shall be liable to the party or parties against whom the report was } \\
\text { made for the amount of actual damages sustained or statutory damages of five hundred dollars (\$ 2,500), whichever is greater, plus } \\
\text { attorney's fees and costs of suit. If the court finds that the defendant acted with malice or oppression, the } \\
\text { court may award treble actual damages or treble statutory damages, whichever is greater. } \\
\text { I.C. } § 18-113 \text { (West 2008) } \\
\text { (1) Except in cases where a different punishment is prescribed in this code, every offense declared to be a misdemeanor, is } \\
\text { punishable by imprisonment in a county jail not exceeding six (6) months, or by a fine not exceeding one thousand dollars } \\
\text { (\$1,000), or by both. }\end{array}$ \\
\hline $\begin{array}{l}\text { Mandatory } \\
\text { Reporting Statute } \\
\text { (Idaho) }\end{array}$ & $\begin{array}{l}\text { AGAINST AN ADULT } \\
\text { I.C. } \S 39-5303 \text { (West 2008) }\end{array}$ \\
\hline
\end{tabular}

NOTE:

** For purposes of this chart, corrections officers, police officers, peace officers, probation officers or “catch-all” phrases such as “all persons” have been bolded. However, many mandatory reporters include professionals who may have contact or work in correctional facilities. Such individuals include physicians, nurses, dentists, teachers and social workers. These statutes can be used as a tool to require staff other than correctional officers to report sexual misconduct with inmates.

This publication is developed by the NIC/WCL Project on Addressing Prison Rape under NIC Cooperative Agreement 06S20GJJ1.

This is not to be reproduced or cited without permission from the authors.

American University, Washington College of Law

Current as of May 7, 2009 


\section{Fifty State Survey of Mandatory Reporting Statutes}

\section{NIC/WCL Project on Addressing Prison Rape}

\begin{tabular}{|c|c|}
\hline $\begin{array}{l}\text { What has to be } \\
\text { reported? } \\
\text { (Idaho) }\end{array}$ & $\begin{array}{l}\text { I.C. } \S 39-5303 \text { (West 2008) } \\
\text { (1) Reasonable cause to believe that a vulnerable adult is being or has been abused, neglected or exploited. }\end{array}$ \\
\hline $\begin{array}{l}\text { Relevant Definitions } \\
\text { (Idaho) }\end{array}$ & $\begin{array}{l}\text { I.C. § 39-5302 (West 2008) } \\
\text { (10) Vulnerable adult means a person eighteen (18) years of age or older who is unable to protect himself from abuse, neglect or } \\
\text { exploitation due to physical or mental impairment which affects the person's judgment or behavior to the extent that he lacks } \\
\text { sufficient understanding or capacity to make or communicate or implement decisions regarding his person. } \\
\text { (1) Abuse means the intentional or negligent infliction of physical pain, injury or mental injury. } \\
\text { (3) Commission means the Idaho commission on aging. }\end{array}$ \\
\hline $\begin{array}{l}\text { Persons Required to } \\
\text { Report } \\
\text { (Idaho) }\end{array}$ & $\begin{array}{l}\text { I.C. } § 39-5303 \text { (West 2008) } \\
\text { (1) Any: } \\
\text { - Police officer; } \\
\text { - } \quad \text { Physician; } \\
\text { - Nurse; } \\
\text { - } \quad \text { Employee of a public or private health facility, or a state licensed or certified residential facility serving vulnerable adults, } \\
\text { - Dentist; } \\
\text { - Ombudsman for the elderly; } \\
\text { - Osteopath; }\end{array}$ \\
\hline
\end{tabular}

NOTE:

** For purposes of this chart, corrections officers, police officers, peace officers, probation officers or “catch-all” phrases such as “all persons” have been bolded. However, many mandatory reporters include professionals who may have contact or work in correctional facilities. Such individuals include physicians, nurses, dentists, teachers and social workers. These statutes can be used as a tool to require staff other than correctional officers to report sexual misconduct with inmates.

This publication is developed by the NIC/WCL Project on Addressing Prison Rape under NIC Cooperative Agreement 06S20GJJ1.

This is not to be reproduced or cited without permission from the authors.

American University, Washington College of Law

Current as of May 7, 2009 


\section{Fifty State Survey of Mandatory Reporting Statutes}

\section{NIC/WCL Project on Addressing Prison Rape}

\begin{tabular}{|c|c|}
\hline $\begin{array}{l}\text { Persons Required to } \\
\text { Report Cont'd } \\
\text { (Idaho) }\end{array}$ & $\begin{array}{l}\text { - Chiropractor; } \\
\text { - Podiatrist; } \\
\text { - Social worker; } \\
\text { - Pharmacist; } \\
\text { - Physical therapist; or } \\
\text { - Home care worker. }\end{array}$ \\
\hline $\begin{array}{l}\text { Reporting } \\
\text { Procedures } \\
\text { (Idaho) }\end{array}$ & $\begin{array}{l}\text { I.C. § 39-5303 (West 2008) } \\
\text { (1) Immediately report such information to the commission. When there is reasonable cause to believe that abuse or sexual assault } \\
\text { has resulted in death or serious physical injury jeopardizing the life, health or safety of a vulnerable adult, any person required to } \\
\text { report under this section shall also report such information within four (4) hours to the appropriate law } \\
\text { enforcement agency. }\end{array}$ \\
\hline $\begin{array}{l}\text { Penalty for Failure to } \\
\text { Report } \\
\text { (Idaho) }\end{array}$ & $\begin{array}{l}\text { I.C. § 39-5303 (West 2008) } \\
\text { (2) Misdemeanor } \\
\text { I.C. § 18-113 (West 2008) } \\
\text { (1) Punishable by imprisonment in a county jail not exceeding six (6) months or by a fine not exceeding one thousand dollars } \\
\text { (\$1,000), or by both. }\end{array}$ \\
\hline
\end{tabular}

NOTE:

** For purposes of this chart, corrections officers, police officers, peace officers, probation officers or "catch-all” phrases such as "all persons" have been bolded. However, many mandatory reporters include professionals who may have contact or work in correctional facilities. Such individuals include physicians, nurses, dentists, teachers and social workers. These statutes can be used as a tool to require staff other than correctional officers to report sexual misconduct with inmates.

This publication is developed by the NIC/WCL Project on Addressing Prison Rape under NIC Cooperative Agreement 06S20GJJ1.

This is not to be reproduced or cited without permission from the authors.

American University, Washington College of Law

Current as of May 7, 2009 


\section{Fifty State Survey of Mandatory Reporting Statutes}

\section{NIC/WCL Project on Addressing Prison Rape}

\begin{tabular}{|c|c|}
\hline $\begin{array}{l}\text { Mandatory } \\
\text { Reporting Statute } \\
\text { (Illinois) }\end{array}$ & $\begin{array}{l}\text { AGAINST A CHILD } \\
325 \text { I.L.C.S. 5/4 (West 2008) }\end{array}$ \\
\hline $\begin{array}{l}\text { What has to be } \\
\text { reported? } \\
\text { (Illinois) }\end{array}$ & $\begin{array}{l}325 \text { I.L.C.S. } 5 / 4 \text { (West 2008) } \\
\text { §4: } \\
\text { Reasonable cause to believe a child known to them in their professional or official capacity may be an abused child or a neglected } \\
\text { child. } \\
\text { The privileged quality of communication between any professional person required to report and his patient or client shall not } \\
\text { apply to situations involving abused or neglected children and shall not constitute grounds for failure to report as required by this } \\
\text { Act. } \\
\text { A member of the clergy may claim the privilege. }\end{array}$ \\
\hline $\begin{array}{l}\text { Relevant Definitions } \\
\text { (Illinois) }\end{array}$ & $\begin{array}{l}325 \text { I.L.C.S. 5/3 (West 2008) } \\
\S 3 \text { : } \\
\text { "Child” means any person under the age of } 18 \text { years, unless legally emancipated by reason of marriage or entry into a branch of } \\
\text { the United States armed services. } \\
\text { "Department” means Department of Children and Family Services. } \\
\text { "Abused child” means a child whose parent or immediate family member, or any person responsible for the child's welfare, or any }\end{array}$ \\
\hline
\end{tabular}

NOTE:

** For purposes of this chart, corrections officers, police officers, peace officers, probation officers or “catch-all” phrases such as “all persons” have been bolded. However, many mandatory reporters include professionals who may have contact or work in correctional facilities. Such individuals include physicians, nurses, dentists, teachers and social workers. These statutes can be used as a tool to require staff other than correctional officers to report sexual misconduct with inmates.

This publication is developed by the NIC/WCL Project on Addressing Prison Rape under NIC Cooperative Agreement 06S20GJJ1.

This is not to be reproduced or cited without permission from the authors.

American University, Washington College of Law

Current as of May 7, 2009 


\section{Fifty State Survey of Mandatory Reporting Statutes}

\section{NIC/WCL Project on Addressing Prison Rape}

\begin{tabular}{|c|c|}
\hline $\begin{array}{l}\text { Relevant Definitions } \\
\text { Cont'd } \\
\text { (Illinois) }\end{array}$ & 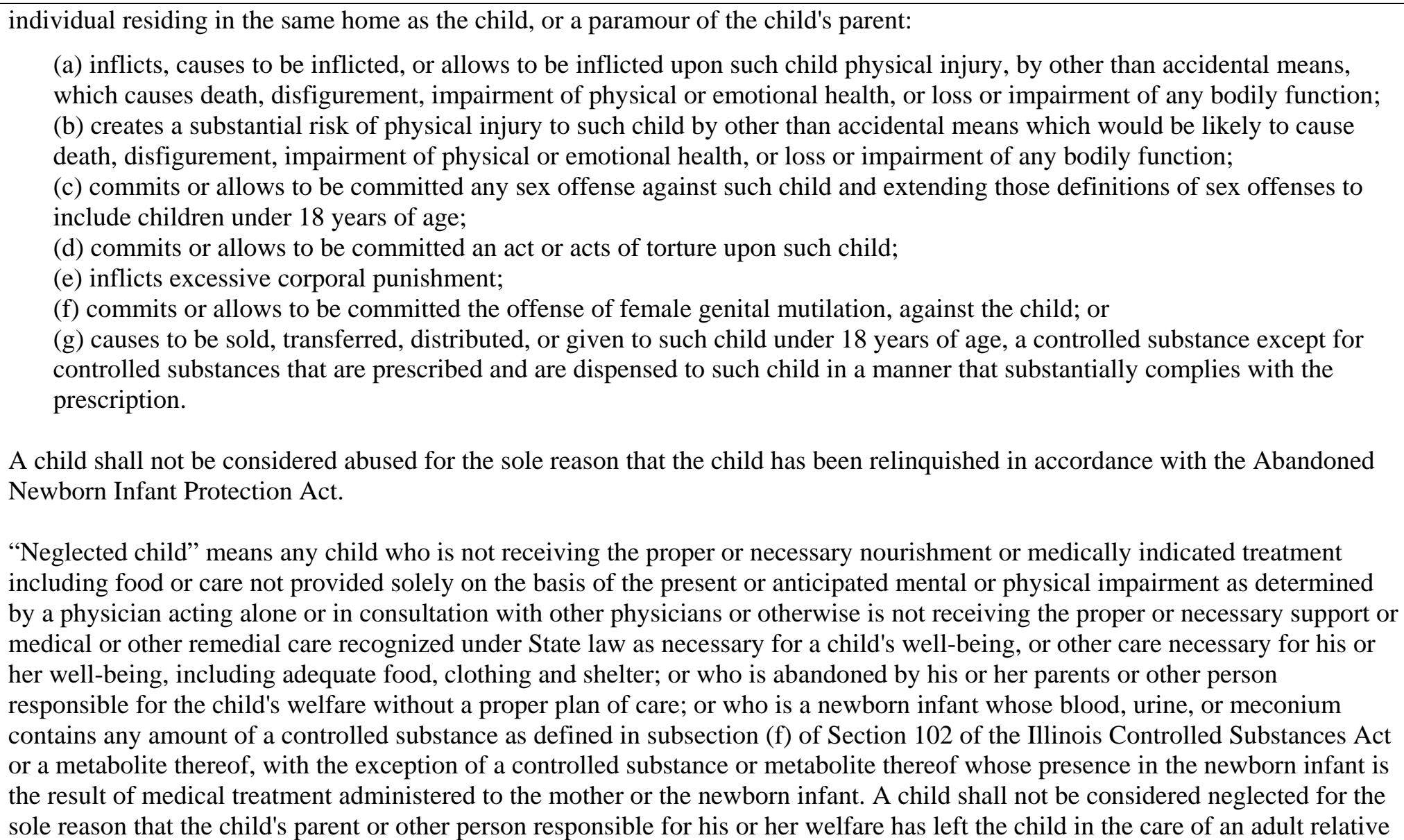 \\
\hline
\end{tabular}

NOTE:

** For purposes of this chart, corrections officers, police officers, peace officers, probation officers or “catch-all” phrases such as “all persons” have been bolded. However, many mandatory reporters include professionals who may have contact or work in correctional facilities. Such individuals include physicians, nurses, dentists, teachers and social workers. These statutes can be used as a tool to require staff other than correctional officers to report sexual misconduct with inmates.

This publication is developed by the NIC/WCL Project on Addressing Prison Rape under NIC Cooperative Agreement 06S20GJJ1.

This is not to be reproduced or cited without permission from the authors.

American University, Washington College of Law

Current as of May 7, 2009 


\section{Fifty State Survey of Mandatory Reporting Statutes}

\section{NIC/WCL Project on Addressing Prison Rape}

\begin{tabular}{|c|c|}
\hline $\begin{array}{l}\text { Relevant Definitions } \\
\text { Cont'd } \\
\text { (Illinois) }\end{array}$ & $\begin{array}{l}\text { for any period of time. A child shall not be considered neglected for the sole reason that the child has been relinquished in } \\
\text { accordance with the Abandoned Newborn Infant Protection Act. A child shall not be considered neglected or abused for the sole } \\
\text { reason that such child's parent or other person responsible for his or her welfare depends upon spiritual means through prayer } \\
\text { alone for the treatment or cure of disease or remedial care as provided under Section } 4 \text { of this Act. A child shall not be considered } \\
\text { neglected or abused solely because the child is not attending school in accordance with the requirements of Article } 26 \text { of The } \\
\text { School Code, as amended.... or who has been provided with interim crisis intervention services under Section } 3 \text { - } 5 \text { of the Juvenile } \\
\text { Court Act of } 1987 \text { and whose parent, guardian, or custodian refuses to permit the child to return home and no other living } \\
\text { arrangement agreeable to the parent, guardian, or custodian can be made, and the parent, guardian, or custodian has not made any } \\
\text { other appropriate living arrangement for the child }\end{array}$ \\
\hline $\begin{array}{l}\text { Persons Required to } \\
\text { Report } \\
\text { (Illinois) }\end{array}$ & $\begin{array}{l}325 \text { I.L.C.S. } 5 / 4 \text { (West 2008) } \\
\text { § 4: } \\
\text { Persons required to report: } \\
\text { - Law enforcement officer; } \\
\text { - Probation officer; } \\
\text { - Field personnel of the Illinois Department of Public Aid, Public Health, Human Services (acting as successor to the } \\
\text { Department of Mental Health and Developmental Disabilities, Rehabilitation Services, or Public Aid), Corrections, Human } \\
\text { Rights, or Children and Family Services, Juvenile Justice; } \\
\text { - Physician; } \\
\text { - Resident; } \\
\text { - Intern; } \\
\text { - Hospital; } \\
\text { - Hospital administrator and personnel engaged in examination, care and treatment of persons; } \\
\text { - Surgeon; }\end{array}$ \\
\hline
\end{tabular}

** For purposes of this chart, corrections officers, police officers, peace officers, probation officers or "catch-all” phrases such as “all persons” have been bolded. However, many mandatory reporters include professionals who may have contact or work in correctional facilities. Such individuals include physicians, nurses, dentists, teachers and social workers. These statutes can be used as a tool to require staff other than correctional officers to report sexual misconduct with inmates.

This publication is developed by the NIC/WCL Project on Addressing Prison Rape under NIC Cooperative Agreement 06S20GJJ1.

This is not to be reproduced or cited without permission from the authors.

American University, Washington College of Law

Current as of May 7, 2009 


\section{Fifty State Survey of Mandatory Reporting Statutes}

\section{NIC/WCL Project on Addressing Prison Rape}

\begin{tabular}{|c|c|}
\hline $\begin{array}{l}\text { Persons Required to } \\
\text { Report Cont'd } \\
\text { (Illinois) }\end{array}$ & $\begin{array}{l}\text { - Dentist; } \\
\text { - Dentist hygienist; } \\
\text { - Osteopath; } \\
\text { - Chiropractor; } \\
\text { - Podiatrist; } \\
\text { - Physician assistant; } \\
\text { - Substance abuse treatment personnel; } \\
\text { - Funeral home director or employee; } \\
\text { - Coroner; } \\
\text { - Medical examiner; } \\
\text { - Emergency medical technician; } \\
\text { - Acupuncturist; } \\
\text { - Crisis line or hotline personnel; } \\
\text { - School personnel; } \\
\text { - Educational advocate assigned to a child pursuant to the School Code; } \\
\text { - Truant officers; } \\
\text { - Social worker } \\
\text { - Social services administrator; } \\
\text { - Domestic violence program personnel; } \\
\text { - Registered nurse; } \\
\text { - Licensed practical nurse; } \\
\text { - Genetic counselor; } \\
\text { - Respiratory care practitioner; } \\
\text { - Advanced practice nurse; } \\
\text { - Home health aide; }\end{array}$ \\
\hline
\end{tabular}

** For purposes of this chart, corrections officers, police officers, peace officers, probation officers or "catch-all” phrases such as “all persons” have been bolded. However, many mandatory reporters include professionals who may have contact or work in correctional facilities. Such individuals include physicians, nurses, dentists, teachers and social workers. These statutes can be used as a tool to require staff other than correctional officers to report sexual misconduct with inmates.

This publication is developed by the NIC/WCL Project on Addressing Prison Rape under NIC Cooperative Agreement 06S20GJJ1.

This is not to be reproduced or cited without permission from the authors.

American University, Washington College of Law

Current as of May 7, 2009 


\section{Fifty State Survey of Mandatory Reporting Statutes}

\section{NIC/WCL Project on Addressing Prison Rape}

\begin{tabular}{|c|c|}
\hline $\begin{array}{l}\text { Persons Required to } \\
\text { Report Cont'd } \\
\text { (Illinois) }\end{array}$ & $\begin{array}{l}\text { - Director or staff assistant of a nursery school or a child day care center; } \\
\text { - Recreational program or facility personnel; } \\
\text { - Licensed professional counselor; } \\
\text { - Licensed clinical professional counselor; } \\
\text { - Registered psychologist and assistants working under the direct supervision of a psychologist, psychiatrist; } \\
\text { - Supervisor and administrator of general assistance under the Illinois Public Aid Code; } \\
\text { - Or any other foster parent, homemaker or child care worker. }\end{array}$ \\
\hline $\begin{array}{l}\text { Reporting } \\
\text { Procedures } \\
\text { (Illinois) }\end{array}$ & $\begin{array}{l}325 \text { I.L.C.S. } 5 / 4 \text { (West 2008) } \\
\text { § } 4 \text { : } \\
\text { Immediately report or cause a report to be made to the Department. } \\
325 \text { I.L.C.S. } 5 / 7 \text { (West 2008) } \\
\S 7 \text { : } \\
\text { All reports of suspected child abuse or neglect made under this Act shall be made immediately by telephone to the central } \\
\text { register...on the single, State-wide, toll-free telephone number (800-25-ABUSE)..., or in person or by telephone through the } \\
\text { nearest Department office. }\end{array}$ \\
\hline $\begin{array}{l}\text { Penalty for Failure to } \\
\text { Report } \\
\text { (Illinois) }\end{array}$ & $\begin{array}{l}325 \text { I.L.C.S. } 5 / 4 \text { (West 2008) } \\
\S 4:\end{array}$ \\
\hline
\end{tabular}

NOTE:

** For purposes of this chart, corrections officers, police officers, peace officers, probation officers or “catch-all” phrases such as “all persons” have been bolded. However, many mandatory reporters include professionals who may have contact or work in correctional facilities. Such individuals include physicians, nurses, dentists, teachers and social workers. These statutes can be used as a tool to require staff other than correctional officers to report sexual misconduct with inmates.

This publication is developed by the NIC/WCL Project on Addressing Prison Rape under NIC Cooperative Agreement 06S20GJJ1.

This is not to be reproduced or cited without permission from the authors.

American University, Washington College of Law

Current as of May 7, 2009 


\section{Fifty State Survey of Mandatory Reporting Statutes}

\section{NIC/WCL Project on Addressing Prison Rape}

\begin{tabular}{|c|c|}
\hline $\begin{array}{l}\text { Penalty for Failure to } \\
\text { Report Cont'd } \\
\text { (Illinois) }\end{array}$ & $\begin{array}{l}\text { Any person required by this Act to report suspected child abuse and neglect who willfully fails to report such is guilty of a Class A } \\
\text { misdemeanor for a first violation and a Class } 4 \text { felony for a second or subsequent violation. } \\
325 \text { I.L.C.S. 5/4.02 (West 2008) } \\
\text { § 4.02: } \\
\text { Any physician who willfully fails to report suspected child abuse or neglect as required by this Act shall be referred to the Illinois } \\
\text { State Medical Disciplinary Board for action. Any dentist or dental hygienist who willfully fails to report suspected child abuse or } \\
\text { neglect as required by this Act shall be referred to the Department of Professional Regulation for action. }\end{array}$ \\
\hline $\begin{array}{l}\text { Mandatory } \\
\text { Reporting Statute } \\
\text { (Illinois) }\end{array}$ & $\begin{array}{l}\text { AGAINST AN ADULT } \\
320 \text { I.L.C.S. 20/4 (West 2008) }\end{array}$ \\
\hline $\begin{array}{l}\text { What has to be } \\
\text { reported? } \\
\text { (Illinois) }\end{array}$ & $\begin{array}{l}320 \text { I.L.C.S. 20/4 (West 2008) } \\
\text { (a) Suspicion of abuse, neglect, financial exploitation, or self-neglect of an eligible adult. }\end{array}$ \\
\hline $\begin{array}{l}\text { Relevant Definitions } \\
\text { (Illinois) }\end{array}$ & $\begin{array}{l}320 \text { I.L.C.S. 20/4 (West 2008) } \\
\text { (a) “Abuse” means causing any physical, mental or sexual injury to an eligible adult, including exploitation of such adult's } \\
\text { financial resources. } \\
\text { (e) "Eligible adult” means a person } 60 \text { years of age or older who resides in a domestic living situation and is, or is alleged to be, } \\
\text { abused, neglected, or financially exploited by another individual. }\end{array}$ \\
\hline
\end{tabular}

** For purposes of this chart, corrections officers, police officers, peace officers, probation officers or “catch-all” phrases such as “all persons” have been bolded. However, many mandatory reporters include professionals who may have contact or work in correctional facilities. Such individuals include physicians, nurses, dentists, teachers and social workers. These statutes can be used as a tool to require staff other than correctional officers to report sexual misconduct with inmates.

This publication is developed by the NIC/WCL Project on Addressing Prison Rape under NIC Cooperative Agreement 06S20GJJ1.

This is not to be reproduced or cited without permission from the authors.

American University, Washington College of Law

Current as of May 7, 2009 


\section{Fifty State Survey of Mandatory Reporting Statutes}

\section{NIC/WCL Project on Addressing Prison Rape}

\begin{tabular}{|c|c|}
\hline $\begin{array}{l}\text { Relevant Definitions } \\
\text { Cont'd } \\
\text { (Illinois) }\end{array}$ & $\begin{array}{l}\text { (g) "Neglect" means another individual's failure to provide an eligible adult with or willful withholding from an eligible adult the } \\
\text { necessities of life including, but not limited to, food, clothing, shelter or health care. This subsection does not create any new } \\
\text { affirmative duty to provide support to eligible adults. Nothing in this Act shall be construed to mean that an eligible adult is a } \\
\text { victim of neglect because of health care services provided or not provided by licensed health care professionals. } \\
\text { (i-5) "Self-neglect" means a condition that is the result of an eligible adult's inability, due to physical or mental impairments, or } \\
\text { both, or a diminished capacity, to perform essential self-care tasks that substantially threaten his or her own health, including: } \\
\text { providing essential food, clothing, shelter, and health care; and obtaining goods and services necessary to maintain physical health, } \\
\text { mental health, emotional well-being, and general safety. }\end{array}$ \\
\hline $\begin{array}{l}\text { Persons Required to } \\
\text { Report } \\
\text { (Illinois) }\end{array}$ & $\begin{array}{l}320 \text { I.L.C.S. 20/4 (West 2008) } \\
\text { (a) Any person who suspects the abuse, neglect, financial exploitation, or self-neglect of an eligible adult. } \\
320 \text { I.L.C.S. 20/2 (West 2008) } \\
\text { (f-5) Specific mandated reporters are: } \\
\text { (1) A professional or professional's delegate while engaged in: (i) social services, (ii) law enforcement, (iii) education, (iv) } \\
\text { the care of an eligible adult or eligible adults, or (v) any of the occupations required to be licensed under the Clinical } \\
\text { Psychologist Licensing Act, the Clinical Social Work and Social Work Practice Act, the Illinois Dental Practice Act, the } \\
\text { Dietetic and Nutrition Services Practice Act, the Marriage and Family Therapy Licensing Act, the Medical Practice Act of } \\
\text { 1987, the Naprapathic Practice Act, the Nursing and Advanced Practice Nursing Act, the Nursing Home Administrators } \\
\text { Licensing and Disciplinary Act, the Illinois Occupational Therapy Practice Act, the Illinois Optometric Practice Act of } \\
\text { 1987, the Pharmacy Practice Act of the Illinois Physical Therapy Act, the Physician Assistant Practice Act of 1987, the } \\
\text { Podiatric Medical Practice Act of 1987, the Respiratory Care Practice, the Professional Counselor and Clinical } \\
\text { Professional Counselor Licensing Act, the Illinois Speech-Language Pathology and Audiology Practice Act, the }\end{array}$ \\
\hline
\end{tabular}

** For purposes of this chart, corrections officers, police officers, peace officers, probation officers or “catch-all” phrases such as “all persons” have been bolded. However, many mandatory reporters include professionals who may have contact or work in correctional facilities. Such individuals include physicians, nurses, dentists, teachers and social workers. These statutes can be used as a tool to require staff other than correctional officers to report sexual misconduct with inmates.

This publication is developed by the NIC/WCL Project on Addressing Prison Rape under NIC Cooperative Agreement 06S20GJJ1.

This is not to be reproduced or cited without permission from the authors.

American University, Washington College of Law

Current as of May 7, 2009 


\section{Fifty State Survey of Mandatory Reporting Statutes}

\section{NIC/WCL Project on Addressing Prison Rape}

\begin{tabular}{|c|c|}
\hline $\begin{array}{l}\text { Persons Required to } \\
\text { Report } \\
\text { (Illinois) }\end{array}$ & $\begin{array}{l}\text { Veterinary Medicine and Surgery Practice Act of 2004, and the Illinois Public Accounting Act; } \\
\text { (2) An employee of a vocational rehabilitation facility prescribed or supervised by the Department of Human Services; } \\
\text { (3) An administrator, employee, or person providing services in or through an unlicensed community based facility; } \\
\text { (5) Field personnel of the Department of Public Health, and Department of Human Services, Department of Public Aid, and } \\
\text { any county or municipal health department; } \\
\text { (6) Personnel of the Department of Human Services, the Guardianship and Advocacy Commission, the State Fire Marshal, } \\
\text { local fire departments, the Department on Aging and its subsidiary Area Agencies on Aging and provider agencies, and } \\
\text { the Office of State Long Term Care Ombudsman; or } \\
\text { (9) A person who performs the duties of a coroner or medical examiner; } \\
\text { (10)A person who performs the duties of a paramedic or an emergency medical technician. }\end{array}$ \\
\hline $\begin{array}{l}\text { Reporting } \\
\text { Procedures } \\
\text { (Illinois) }\end{array}$ & $\begin{array}{l}320 \text { I.L.C.S. 20/4 (West 2008) } \\
\text { (a-5) If any mandated reporter has reason to believe that an eligible adult, who because of dysfunction is unable to seek assistance } \\
\text { for himself or herself, has, within the previous } 12 \text { months, been subjected to abuse, neglect, or financial exploitation, the mandated } \\
\text { reporter shall, within } 24 \text { hours after developing such belief, report this suspicion to an agency designated to receive such reports } \\
\text { under this Act or to the Department on Aging of the State of Illinois. Whenever a mandated reporter is required to report under this } \\
\text { Act in his or her capacity as a member of the staff of a medical or other public or private institution, facility, board and care home, } \\
\text { or agency, he or she shall make a report to an agency designated to receive such reports under this Act or to the Department in } \\
\text { accordance with the provisions of this Act and may also notify the person in charge of the institution, facility, board and care } \\
\text { home, or agency or his or her designated agent that the report has been made. }\end{array}$ \\
\hline
\end{tabular}

NOTE:

** For purposes of this chart, corrections officers, police officers, peace officers, probation officers or “catch-all” phrases such as “all persons” have been bolded. However, many mandatory reporters include professionals who may have contact or work in correctional facilities. Such individuals include physicians, nurses, dentists, teachers and social workers. These statutes can be used as a tool to require staff other than correctional officers to report sexual misconduct with inmates.

This publication is developed by the NIC/WCL Project on Addressing Prison Rape under NIC Cooperative Agreement 06S20GJJ1.

This is not to be reproduced or cited without permission from the authors.

American University, Washington College of Law

Current as of May 7, 2009 


\section{Fifty State Survey of Mandatory Reporting Statutes}

\section{NIC/WCL Project on Addressing Prison Rape}

\begin{tabular}{|c|c|}
\hline $\begin{array}{l}\text { Reporting } \\
\text { Procedures Cont'd } \\
\text { (Illinois) }\end{array}$ & $\begin{array}{l}\text { Under no circumstances shall any person in charge of such institution, facility, board and care home, or agency, or his or her } \\
\text { designated agent to whom the notification has been made, exercise any control, restraint, modification, or other change in the } \\
\text { report or the forwarding of the report to an agency designated to receive such reports under this Act or to the Department. The } \\
\text { privileged quality of communication between any professional person required to report and his or her patient or client shall not } \\
\text { apply to situations involving abused, neglected, or financially exploited eligible adults and shall not constitute grounds for failure } \\
\text { to report as required by this Act. }\end{array}$ \\
\hline $\begin{array}{l}\text { Penalty for Failure to } \\
\text { Report } \\
\text { (Illinois) }\end{array}$ & $\begin{array}{l}320 \text { I.L.C.S. 20/4 (West 2008) } \\
\text { (e) Any physician who willfully fails to report as required by this Act shall be referred to the Illinois State Medical Disciplinary } \\
\text { Board. Any dentist or dental hygienist who willfully fails to report as required by this Act shall be referred to the Department of } \\
\text { Professional Regulation. Any other mandated reporter required by this Act to report suspected abuse, neglect, or financial } \\
\text { exploitation who willfully fails to report the same is guilty of a Class A misdemeanor. }\end{array}$ \\
\hline & INDIANA \\
\hline $\begin{array}{l}\text { Mandatory } \\
\text { Reporting Statute } \\
\text { (Indiana) }\end{array}$ & $\begin{array}{l}\text { AGAINST A CHILD } \\
\text { I.C. } \S 31-33-5-1 \text { (West 2008) }\end{array}$ \\
\hline $\begin{array}{l}\text { What has to be } \\
\text { reported? } \\
\text { (Indiana) }\end{array}$ & $\begin{array}{l}\text { I.C. } \S 31-33-5-1 \text { (West 2008) } \\
\text { Sec. } 1 \text { Reason to believe that a child is a victim of child abuse or neglect. }\end{array}$ \\
\hline
\end{tabular}

NOTE:

** For purposes of this chart, corrections officers, police officers, peace officers, probation officers or “catch-all” phrases such as “all persons” have been bolded. However, many mandatory reporters include professionals who may have contact or work in correctional facilities. Such individuals include physicians, nurses, dentists, teachers and social workers. These statutes can be used as a tool to require staff other than correctional officers to report sexual misconduct with inmates.

This publication is developed by the NIC/WCL Project on Addressing Prison Rape under NIC Cooperative Agreement 06S20GJJ1.

This is not to be reproduced or cited without permission from the authors.

American University, Washington College of Law

Current as of May 7, 2009 


\section{Fifty State Survey of Mandatory Reporting Statutes}

\section{NIC/WCL Project on Addressing Prison Rape}

\begin{tabular}{|c|c|}
\hline $\begin{array}{l}\text { Relevant Definitions } \\
\text { (Indiana) }\end{array}$ & 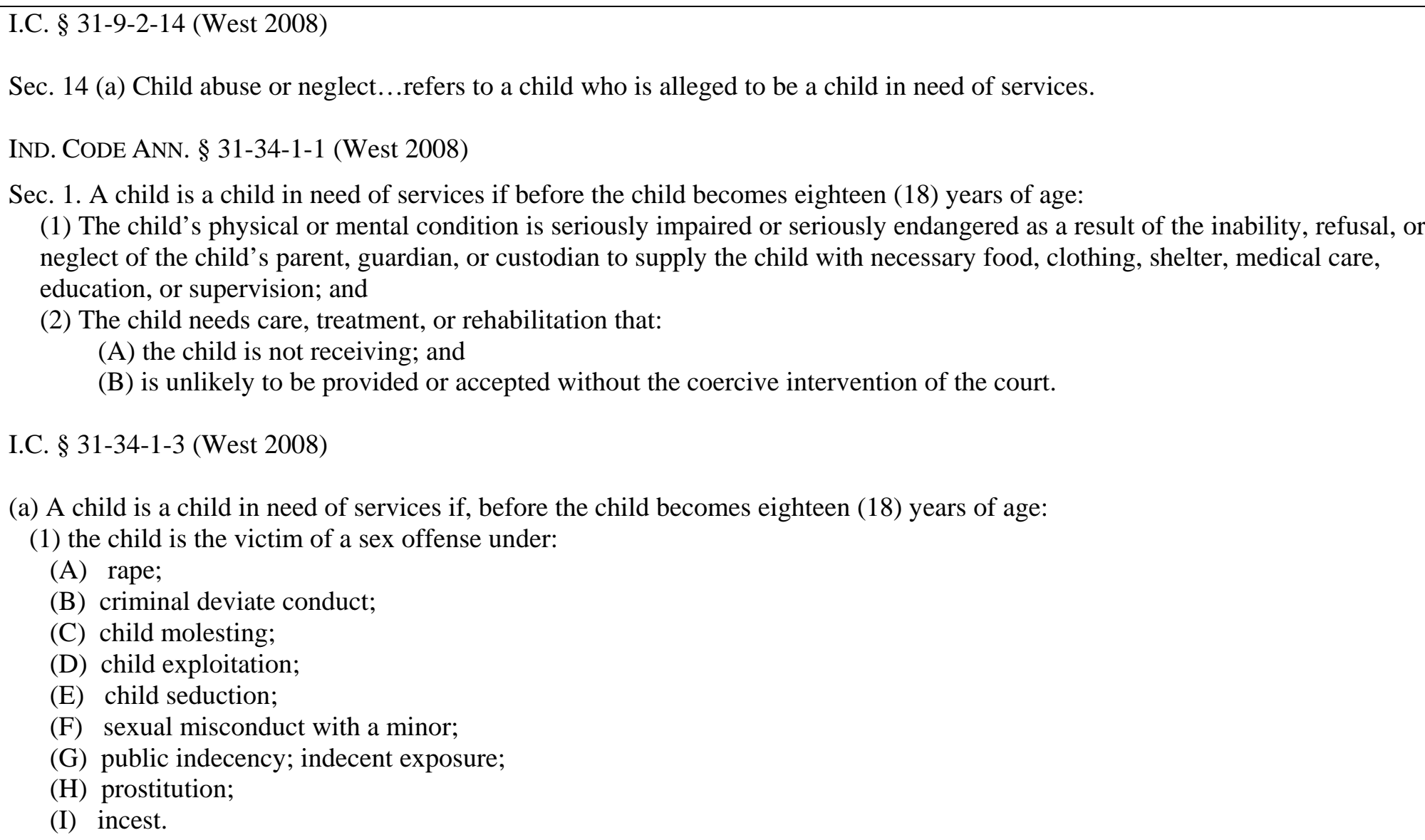 \\
\hline
\end{tabular}

NOTE:

** For purposes of this chart, corrections officers, police officers, peace officers, probation officers or "catch-all” phrases such as “all persons” have been bolded. However, many mandatory reporters include professionals who may have contact or work in correctional facilities. Such individuals include physicians, nurses, dentists, teachers and social workers. These statutes can be used as a tool to require staff other than correctional officers to report sexual misconduct with inmates.

This publication is developed by the NIC/WCL Project on Addressing Prison Rape under NIC Cooperative Agreement 06S20GJJ1.

This is not to be reproduced or cited without permission from the authors.

American University, Washington College of Law

Current as of May 7, 2009 


\section{Fifty State Survey of Mandatory Reporting Statutes}

\section{NIC/WCL Project on Addressing Prison Rape}

\begin{tabular}{|c|c|}
\hline $\begin{array}{l}\text { Persons Required to } \\
\text { Report } \\
\text { (Indiana) }\end{array}$ & $\begin{array}{l}\text { I.C. } § 31-33-5-1 \text { (West 2008) } \\
\text { An individual who has reason to believe that a child is a victim of child abuse. }\end{array}$ \\
\hline $\begin{array}{l}\text { Reporting } \\
\text { Procedures } \\
\text { (Indiana) }\end{array}$ & $\begin{array}{l}\text { I.C. } \S 31-33-5-4 \text { (West 2008) } \\
\text { Sec. 1. A person who has a duty under this chapter to report that a child may be a victim of child abuse or neglect shall } \\
\text { immediately make an oral report to: } \\
\text { (1) the department; or } \\
\text { (2) the local law enforcement agency. }\end{array}$ \\
\hline $\begin{array}{l}\text { Penalty for Failure to } \\
\text { Report } \\
\text { (Indiana) }\end{array}$ & $\begin{array}{l}\text { I.C. } \S \text { 31-33-22-1 (West 2008) } \\
\text { Sec. 1. (a) A person who knowingly fails to make a report required by IC } 31-33-5-1 \text { commits a Class B misdemeanor. } \\
\text { (b) A person who knowingly fails to make a report required by IC 31-33-5-2 commits a Class B misdemeanor. This penalty } \\
\text { is in addition to the penalty imposed by subsection (a). } \\
\text { I.C. § 35-50-3-3 (West 2008) } \\
\text { Class B misdemeanor } \\
\text { Sec. 3. A person who commits a Class B misdemeanor shall be imprisoned for a fixed term of not more than one hundred eighty } \\
\text { (180) days; in addition, he may be fined not more than one thousand dollars }(\$ 1,000) \text {. }\end{array}$ \\
\hline
\end{tabular}

NOTE:

** For purposes of this chart, corrections officers, police officers, peace officers, probation officers or "catch-all” phrases such as "all persons" have been bolded. However, many mandatory reporters include professionals who may have contact or work in correctional facilities. Such individuals include physicians, nurses, dentists, teachers and social workers. These statutes can be used as a tool to require staff other than correctional officers to report sexual misconduct with inmates.

This publication is developed by the NIC/WCL Project on Addressing Prison Rape under NIC Cooperative Agreement 06S20GJJ1.

This is not to be reproduced or cited without permission from the authors.

American University, Washington College of Law

Current as of May 7, 2009 


\section{Fifty State Survey of Mandatory Reporting Statutes}

\section{NIC/WCL Project on Addressing Prison Rape}

\begin{tabular}{|c|c|}
\hline $\begin{array}{l}\text { Mandatory } \\
\text { Reporting Statute } \\
\text { (Indiana) }\end{array}$ & $\begin{array}{l}\text { AGAINST AN ADULT } \\
\text { I.C. § 35-46-1-13 (West 2008) }\end{array}$ \\
\hline $\begin{array}{l}\text { What has to be } \\
\text { reported? } \\
\text { (Indiana) }\end{array}$ & $\begin{array}{l}\text { I.C. § 35-46-1-13 (West 2008) } \\
\text { (a)(1) Believes or has reason to believe that an endangered adult is the victim of battery, neglect, or exploitation. }\end{array}$ \\
\hline $\begin{array}{l}\text { Relevant Definitions } \\
\text { (Indiana) }\end{array}$ & $\begin{array}{l}\text { I.C. § 12-10-3-2 (West 2008) } \\
\text { (b) Endangered Adult means an individual who is: } \\
\text { (1) at least eighteen (18) years of age; } \\
\text { (2) incapable by reason of mental illness, mental retardation, dementia, or other physical or mental incapacity of managing or } \\
\text { directing the management of the individual's property or providing or directing the provision of self-care; and } \\
\text { (3) harmed or threatened with harm as a result of: } \\
\text { (A) neglect; or } \\
\text { (B) battery } \\
\text { (c) An individual is not an endangered adult solely: } \\
\text { (1) for the reason that the individual is being provided spiritual treatment in accordance with a recognized religious method of } \\
\text { healing instead of specified medical treatment if the individual would not be considered to be an endangered adult if the } \\
\text { individual were receiving the medical treatment; or } \\
\text { (2) on the basis of being physically unable to provide self care when appropriate care is being provided. }\end{array}$ \\
\hline $\begin{array}{l}\text { Persons Required to } \\
\text { Report } \\
\text { (Indiana) }\end{array}$ & $\begin{array}{l}\text { I.C. § 35-46-1-13 (West 2008) } \\
\text { (a)(1) A person who believes or has reason to believe that an endangered adult is the victim of battery, neglect, or exploitation. }\end{array}$ \\
\hline
\end{tabular}

NOTE:

** For purposes of this chart, corrections officers, police officers, peace officers, probation officers or "catch-all” phrases such as "all persons" have been bolded. However, many mandatory reporters include professionals who may have contact or work in correctional facilities. Such individuals include physicians, nurses, dentists, teachers and social workers. These statutes can be used as a tool to require staff other than correctional officers to report sexual misconduct with inmates.

This publication is developed by the NIC/WCL Project on Addressing Prison Rape under NIC Cooperative Agreement 06S20GJJ1.

This is not to be reproduced or cited without permission from the authors.

American University, Washington College of Law

Current as of May 7, 2009 


\section{Fifty State Survey of Mandatory Reporting Statutes}

\section{NIC/WCL Project on Addressing Prison Rape}

\begin{tabular}{|c|c|}
\hline $\begin{array}{l}\text { Reporting } \\
\text { Procedures } \\
\text { (Indiana) }\end{array}$ & $\begin{array}{l}\text { I.C. } \S 35-46-1-13 \text { (West 2008) } \\
\text { (a)(2) Report the facts supporting that belief to the division of disability, aging, and rehabilitative services, the adult protective } \\
\text { services unit, or a law enforcement agency having jurisdiction over battery, neglect, or exploitation of an endangered adult. }\end{array}$ \\
\hline $\begin{array}{l}\text { Penalty for Failure to } \\
\text { Report } \\
\text { (Indiana) }\end{array}$ & $\begin{array}{l}\text { I.C. } \S 35-46-1-13 \text { (West 2008) } \\
\text { (a)(2) Class B Misdemeanor } \\
\text { I.C. } § 35-50-3-3 \text { (West 2008) } \\
\text { Class B Misdemeanor: } \\
\text { Maximum of } 180 \text { days and a maximum of } \$ 1,000 \text { fine. } \\
\text { I.C. } \S 35-46-1-13 \text { (West 2008) } \\
\text { (d) An individual who discharges, demotes, transfers, prepares a negative work performance evaluation, reduces benefits, pay or } \\
\text { work privileges, or takes other action to retaliate against an individual who in good faith makes a report concerning an endangered } \\
\text { individual commits a Class A infraction. }\end{array}$ \\
\hline & IOWA \\
\hline $\begin{array}{l}\text { Mandatory } \\
\text { Reporting Statute } \\
\text { (Iowa) }\end{array}$ & $\begin{array}{l}\text { AGAINST A CHILD } \\
\text { I.C.A. } \S 232.69 \text { (West 2008) }\end{array}$ \\
\hline
\end{tabular}

NOTE:

** For purposes of this chart, corrections officers, police officers, peace officers, probation officers or “catch-all” phrases such as “all persons” have been bolded. However, many mandatory reporters include professionals who may have contact or work in correctional facilities. Such individuals include physicians, nurses, dentists, teachers and social workers. These statutes can be used as a tool to require staff other than correctional officers to report sexual misconduct with inmates.

This publication is developed by the NIC/WCL Project on Addressing Prison Rape under NIC Cooperative Agreement 06S20GJJ1.

This is not to be reproduced or cited without permission from the authors.

American University, Washington College of Law

Current as of May 7, 2009 


\section{Fifty State Survey of Mandatory Reporting Statutes}

\section{NIC/WCL Project on Addressing Prison Rape}

\begin{tabular}{|c|c|}
\hline $\begin{array}{l}\text { What has to be } \\
\text { reported? } \\
\text { (Iowa) }\end{array}$ & $\begin{array}{l}\text { I.C.A. } § 232.69 \text { (West 2008) } \\
\text { (1)The person enumerated in this section shall make a report of cases of child abuse. In addition, the classes of persons } \\
\text { enumerated in this subsection shall make a report of abuse of a child who is under twelve years of age and may make a report of } \\
\text { abuse of a child who is twelve years of age or older. }\end{array}$ \\
\hline $\begin{array}{l}\text { Relevant Definitions } \\
\text { (Iowa) }\end{array}$ & $\begin{array}{l}\text { I.C.A. } § 232.68 \text { (West 2008) } \\
\text { (1) "Child" means any person under the age of eighteen years. } \\
\text { (2) "Child Abuse” or "Abuse" means: } \\
\text { a. Any nonaccidental physical injury, or injury which is at variance with the history given of it, suffered by a child as the result } \\
\text { of the acts or omissions of a person responsible for the care of the child. } \\
\text { b. Any mental injury to a child's intellectual or psychological capacity as evidenced by an observable and substantial } \\
\text { impairment in the child's ability to function within the child's normal range of performance and behavior as the result of the acts } \\
\text { or omissions of a person responsible for the care of the child, if the impairment is diagnosed and confirmed by a licensed } \\
\text { physician or qualified mental health professional. } \\
\text { c. The commission of a sexual offense with or to a child as a result of the acts or omissions of the person responsible for the } \\
\text { care of the child. The commission of a sexual offense under this paragraph includes any sexual offense referred to in this } \\
\text { paragraph with or to a person under the age of eighteen years. } \\
\text { d. The failure on the part of a person responsible for the care of a child to provide for the adequate food, shelter, clothing or } \\
\text { other care necessary for the child's health and welfare when financially able to do so or when offered financial or other } \\
\text { reasonable means to do so. A parent or guardian legitimately practicing religious beliefs who does not provide specified } \\
\text { medical treatment for a child for that reason alone shall not be considered abusing the child, however this provision shall not } \\
\text { preclude a court from ordering that medical service be provided to the child where the child's health requires it. } \\
\text { e. The acts or omissions of a person responsible for the care of a child which allow, permit, or encourage the child to engage in } \\
\text { acts prohibited. Acts or omissions under this paragraph include an act or omission referred to in this paragraph with or to a } \\
\text { person under the age of eighteen years. }\end{array}$ \\
\hline
\end{tabular}

NOTE:

** For purposes of this chart, corrections officers, police officers, peace officers, probation officers or "catch-all” phrases such as “all persons” have been bolded. However, many mandatory reporters include professionals who may have contact or work in correctional facilities. Such individuals include physicians, nurses, dentists, teachers and social workers. These statutes can be used as a tool to require staff other than correctional officers to report sexual misconduct with inmates.

This publication is developed by the NIC/WCL Project on Addressing Prison Rape under NIC Cooperative Agreement 06S20GJJ1.

This is not to be reproduced or cited without permission from the authors.

American University, Washington College of Law

Current as of May 7, 2009 


\section{Fifty State Survey of Mandatory Reporting Statutes}

\section{NIC/WCL Project on Addressing Prison Rape}

\begin{tabular}{|c|c|}
\hline $\begin{array}{l}\text { Relevant Definitions } \\
\text { Cont'd } \\
(\text { Iowa) }\end{array}$ & $\begin{array}{l}\text { f. An illegal drug is present in a child's body as a direct and foreseeable consequence of the acts or omissions of the person } \\
\text { responsible for the care of the child. } \\
\text { g. The person responsible for the care of a child has, in the presence of the child, manufactured a dangerous substance, or in the } \\
\text { presence of the child possesses a product containing ephedrine, its salts, optical isomers, salts of optical isomers, or } \\
\text { pseudoephedrine, its salts, optical isomers, salts of optical isomers, with the intent to use the product as a precursor or an } \\
\text { intermediary to a dangerous substance. } \\
\text { h. The commission of bestiality in the presence of a minor by a person who resides in a home with a child, as a result of the acts } \\
\text { or omissions of a person responsible for the care of the child. } \\
\text { i. Cohabitation with a person on the sex offender registry. }\end{array}$ \\
\hline $\begin{array}{l}\text { Persons Required to } \\
\text { Report } \\
(\text { Iowa) }\end{array}$ & $\begin{array}{l}\text { I.C.A. § } 232.69 \text { (West 2008) } \\
\text { (1)(b)Any of the following persons who, in the scope of professional practice or in their employment responsibilities, examines, } \\
\text { attends, counsels, or treats a child and reasonably believes a child has suffered abuse: } \\
\text { (1) A social worker; } \\
\text { (2) An employee or operator of a public or private health care facility; } \\
\text { (3) A certified psychologist; } \\
\text { (4) A licensed school employee, certified para-educator, holder of a coaching authorization, or an instructor employed } \\
\text { (5) An employee or operator of a licensed child care center, registered child development home, head start program, } \\
\text { family development and self-sufficiency grant program or healthy opportunities for parents to experience success- } \\
\text { (6) An employee or operator of a substance abuse program or facility; } \\
\text { (7) An employee of a department of human services institution; } \\
\text { (8) An employee or operator of a juvenile detention or juvenile shelter care facility; } \\
\text { (9) An employee or operator of a foster care facility; }\end{array}$ \\
\hline
\end{tabular}

** For purposes of this chart, corrections officers, police officers, peace officers, probation officers or "catch-all” phrases such as “all persons” have been bolded. However, many mandatory reporters include professionals who may have contact or work in correctional facilities. Such individuals include physicians, nurses, dentists, teachers and social workers. These statutes can be used as a tool to require staff other than correctional officers to report sexual misconduct with inmates.

This publication is developed by the NIC/WCL Project on Addressing Prison Rape under NIC Cooperative Agreement 06S20GJJ1.

This is not to be reproduced or cited without permission from the authors.

American University, Washington College of Law

Current as of May 7, 2009 


\section{Fifty State Survey of Mandatory Reporting Statutes}

\section{NIC/WCL Project on Addressing Prison Rape}

\begin{tabular}{|c|c|}
\hline $\begin{array}{l}\text { Persons Required to } \\
\text { Report Cont'd } \\
\text { (Iowa) }\end{array}$ & $\begin{array}{l}\text { (10)An employee or operator of a mental health center; } \\
\text { (11)A peace officer; } \\
\text { (12)A counselor or mental health professional; } \\
\text { (13)An employee or operator of a provider of services to children funded under a federally approved medical } \\
\text { assistance home and community-based services waiver. } \\
\text { (1)(a) Every health practitioner who in the scope of professional practice, examines, attends, or treats a child and who reasonably } \\
\text { believes the child has been abused. }\end{array}$ \\
\hline $\begin{array}{l}\text { Reporting } \\
\text { Procedures } \\
\text { (Iowa) }\end{array}$ & $\begin{array}{l}\text { I.C.A. } § 232.69 \text { (West 2008) } \\
\text { (1) The report shall be made within } 24 \text { hours. } \\
\text { I.C.A. } § 232.70 \text { (West 2008) } \\
\text { 1. Each report made by a mandatory reporter shall be made both orally and in writing. } \\
\text { 2. The employer or supervisor of a person who is a mandatory or permissive reporter shall not apply a policy, work rule, or other } \\
\text { requirement that interferes with the person making a report of child abuse. } \\
\text { 3. The oral report shall be made by telephone or otherwise to the department of human services. If the person making the report } \\
\text { has reason to believe that immediate protection for the child is advisable, that person shall also make an oral report to an } \\
\text { appropriate law enforcement agency. } \\
\text { 4. The written report shall be made to the department of human services within forty-eight hours after such oral report. } \\
\text { 6. The oral and written reports shall contain the following information, or as much thereof as the person making the report is able } \\
\text { to furnish: } \\
\text { a. The names and home address of the child and the child's parents or other persons believed to be responsible for the child's } \\
\text { care; } \\
\text { b. The child's present whereabouts if not the same as the parent's or other person's home address; }\end{array}$ \\
\hline
\end{tabular}

** For purposes of this chart, corrections officers, police officers, peace officers, probation officers or "catch-all” phrases such as “all persons” have been bolded. However, many mandatory reporters include professionals who may have contact or work in correctional facilities. Such individuals include physicians, nurses, dentists, teachers and social workers. These statutes can be used as a tool to require staff other than correctional officers to report sexual misconduct with inmates.

This publication is developed by the NIC/WCL Project on Addressing Prison Rape under NIC Cooperative Agreement 06S20GJJ1.

This is not to be reproduced or cited without permission from the authors.

American University, Washington College of Law

Current as of May 7, 2009 


\section{Fifty State Survey of Mandatory Reporting Statutes}

\section{NIC/WCL Project on Addressing Prison Rape}

\begin{tabular}{|c|c|}
\hline $\begin{array}{l}\text { Reporting } \\
\text { Procedures Cont'd } \\
\text { (Iowa) }\end{array}$ & $\begin{array}{l}\text { c. The child's age; } \\
\text { d. The nature and extent of the child's injuries, including any evidence of previous injuries; } \\
\text { e. The name, age and condition of other children in the same home; } \\
\text { f. Any other information which the person making the report believes might be helpful in establishing the cause of the injury } \\
\text { to the child, the identity of the person or persons responsible for the injury, or in providing assistance to the child; and } \\
\text { g. The name and address of the person making the report. }\end{array}$ \\
\hline $\begin{array}{l}\text { Penalty for Failure to } \\
\text { Report } \\
\text { (Iowa) }\end{array}$ & $\begin{array}{l}\text { I.C.A. } \$ 232.75 \text { (West 2008) } \\
\text { (1) Any person, official, agency or institution required to report a suspected case of child abuse who knowingly and willfully } \\
\text { failed to do so is guilty of a simple misdemeanor. } \\
\text { (2) Any person, official, agency, or institution required to report a suspected case of child abuse who knowingly fails to do so or } \\
\text { who knowingly interferes with the making of such a report is civilly liable for the damages proximately caused by such failure or } \\
\text { interference. } \\
\text { I.C.A. } § 903.1 \text { (West 2008) } \\
\text { (a) For a simple misdemeanor, there shall be a fine of at least } \$ 65.00 \text { but not to exceed } \$ 625.00 \text {. The court may order } \\
\text { imprisonment not to exceed } 40 \text { days in lieu of a fine or in addition to a fine. }\end{array}$ \\
\hline $\begin{array}{l}\text { Mandatory } \\
\text { Reporting Statute } \\
\text { (Iowa) }\end{array}$ & $\begin{array}{l}\text { AGAINST AN ADULT } \\
\text { I.C.A. § 235B.3 (West 2008) }\end{array}$ \\
\hline
\end{tabular}

NOTE:

** For purposes of this chart, corrections officers, police officers, peace officers, probation officers or “catch-all” phrases such as “all persons” have been bolded. However, many mandatory reporters include professionals who may have contact or work in correctional facilities. Such individuals include physicians, nurses, dentists, teachers and social workers. These statutes can be used as a tool to require staff other than correctional officers to report sexual misconduct with inmates.

This publication is developed by the NIC/WCL Project on Addressing Prison Rape under NIC Cooperative Agreement 06S20GJJ1.

This is not to be reproduced or cited without permission from the authors.

American University, Washington College of Law

Current as of May 7, 2009 


\section{Fifty State Survey of Mandatory Reporting Statutes}

\section{NIC/WCL Project on Addressing Prison Rape}

\begin{tabular}{|c|c|}
\hline $\begin{array}{l}\text { What has to be } \\
\text { reported? } \\
(\text { Iowa) }\end{array}$ & $\begin{array}{l}\text { I.C.A. } § 235 B .3 \text { (West 2008) } \\
\text { (2) A person who, in the course of employment, examines, attends, counsels, or treats a dependent adult and reasonably believes } \\
\text { the dependent adult has suffered abuse. }\end{array}$ \\
\hline $\begin{array}{l}\text { Relevant Definitions } \\
\text { (Iowa) }\end{array}$ & $\begin{array}{l}\text { I.C.A. } § 235 B .3 \text { (West 2008) } \\
\text { 1. "Caretaker" means a related or nonrelated person who has the responsibility for the protection, care, or custody of a dependent } \\
\text { adult as a result of assuming the responsibility voluntarily, by contract, through employment, or by order of the court. } \\
\text { 4. "Dependent adult” means a person eighteen years of age or older who is unable to protect the person's own interests or unable to } \\
\text { adequately perform or obtain services necessary to meet essential human needs, as a result of a physical or mental condition which } \\
\text { requires assistance from another, or as defined by departmental rule. } \\
\text { 5. a. "Dependent adult abuse" means: } \\
\text { (1) Any of the following as a result of the willful or negligent acts or omissions of a caretaker: } \\
\text { (a) Physical injury to, or injury which is at a variance with the history given of the injury, or unreasonable confinement, } \\
\text { unreasonable punishment, or assault of a dependent adult. } \\
\text { (b) The commission of a sexual offense with or against a dependent adult. } \\
\text { (c) Exploitation of a dependent adult which means the act or process of taking unfair advantage of a dependent adult or } \\
\text { the adult's physical or financial resources for one's own personal or pecuniary profit, without the informed consent of the } \\
\text { dependent adult, including theft, by the use of undue influence, harassment, duress, deception, false representation, or } \\
\text { false pretenses. } \\
\text { (d) The deprivation of the minimum food, shelter, clothing, supervision, physical or mental health care, or other care } \\
\text { necessary to maintain a dependent adult's life or health. } \\
\text { (3) "Sexual exploitation” means any consensual or nonconsensual sexual conduct with a dependent adult for the purpose of }\end{array}$ \\
\hline
\end{tabular}

** For purposes of this chart, corrections officers, police officers, peace officers, probation officers or “catch-all” phrases such as “all persons” have been bolded. However, many mandatory reporters include professionals who may have contact or work in correctional facilities. Such individuals include physicians, nurses, dentists, teachers and social workers. These statutes can be used as a tool to require staff other than correctional officers to report sexual misconduct with inmates.

This publication is developed by the NIC/WCL Project on Addressing Prison Rape under NIC Cooperative Agreement 06S20GJJ1.

This is not to be reproduced or cited without permission from the authors.

American University, Washington College of Law

Current as of May 7, 2009 


\section{Fifty State Survey of Mandatory Reporting Statutes}

\section{NIC/WCL Project on Addressing Prison Rape}

\begin{tabular}{|c|c|}
\hline $\begin{array}{l}\text { Relevant Definitions } \\
\text { Cont'd } \\
\text { (Iowa) }\end{array}$ & $\begin{array}{l}\text { arousing or satisfying the sexual desires of the caretaker or dependent adult, which includes but is not limited to kissing; } \\
\text { touching of the clothed or unclothed inner thigh, breast, groin, buttock, anus, pubes, or genitals; or a sex act. Sexual } \\
\text { exploitation does not include touching which is part of a necessary examination, treatment, or care by a caretaker acting within } \\
\text { the scope of the practice or employment of the caretaker; the exchange of a brief touch or hug between the dependent adult and } \\
\text { a caretaker for the purpose of reassurance, comfort, or casual friendship; or touching between spouses. } \\
\text { (4) (c.) Sexual exploitation of a dependent adult who is a resident of a health care facility by a caretaker providing services to or } \\
\text { employed by the health care facility, whether within the health care facility or at a location outside of the health care facility. }\end{array}$ \\
\hline $\begin{array}{l}\text { Persons Required to } \\
\text { Report } \\
\text { (Iowa) }\end{array}$ & $\begin{array}{l}\text { I.C.A. } \$ 235 B .3 \text { (West 2008) } \\
\text { (2) Persons required to report include all of the following: } \\
\text { (a) A member of the staff of a community mental health center, a member of the staff of a hospital, a member of the staff or } \\
\text { employee of a public or private health care facility, a member of the staff or employee of an elder group home, a member of } \\
\text { the staff or employee of an assisted living program, and a member of the staff or employee of an adult day services program; } \\
\text { (b) A peace officer; } \\
\text { (1) An in-home homemaker-home health aide; } \\
\text { (2) An individual employed as an outreach person; } \\
\text { (3) A health practitioner; } \\
\text { (4) A member of the staff or an employee of a supported community living service, sheltered workshop, or work } \\
\text { (5) A social worker; } \\
\text { (6) A certified psychologist. }\end{array}$ \\
\hline $\begin{array}{l}\text { Reporting } \\
\text { Procedures } \\
\text { (Iowa) }\end{array}$ & $\begin{array}{l}\text { I.C.A. } \S 235 B .3 \text { (West 2008) } \\
\text { (2) Report the suspected dependent adult abuse to the department of human services. }\end{array}$ \\
\hline
\end{tabular}

NOTE:

** For purposes of this chart, corrections officers, police officers, peace officers, probation officers or “catch-all” phrases such as “all persons” have been bolded. However, many mandatory reporters include professionals who may have contact or work in correctional facilities. Such individuals include physicians, nurses, dentists, teachers and social workers. These statutes can be used as a tool to require staff other than correctional officers to report sexual misconduct with inmates.

This publication is developed by the NIC/WCL Project on Addressing Prison Rape under NIC Cooperative Agreement 06S20GJJ1.

This is not to be reproduced or cited without permission from the authors.

American University, Washington College of Law

Current as of May 7, 2009 


\section{Fifty State Survey of Mandatory Reporting Statutes}

\section{NIC/WCL Project on Addressing Prison Rape}

\begin{tabular}{|c|c|}
\hline $\begin{array}{l}\text { Penalty for Failure to } \\
\text { Report } \\
\text { (Iowa) }\end{array}$ & $\begin{array}{l}\text { I.C.A. } \S 235 \text { B. } 3 \text { (West 2008) } \\
\text { (12) A person required by this section to report a suspected case of dependent adult abuse who knowingly and willfully fails to do } \\
\text { so commits a simple misdemeanor.... A person required by this section to report a suspected case of dependent adult abuse who } \\
\text { knowingly fails to do so or who knowingly interferes with the making of such a report or applies a requirement that results in such } \\
\text { a failure is civilly liable for the damages proximately caused by the failure. } \\
\text { I.C.A. } \S 903.1 \text { (West } 2008 \text { ) } \\
\text { (1)(a) For a simple misdemeanor, there shall be a fine of at least } \$ 65.00 \text { but not to exceed } \$ 625.00 \text { dollars. The court may order } \\
\text { imprisonment not to exceed } 30 \text { days in lieu of a fine or in addition to a fine. }\end{array}$ \\
\hline \multicolumn{2}{|r|}{ KANSAS } \\
\hline $\begin{array}{l}\text { Mandatory } \\
\text { Reporting Statute } \\
\text { (Kansas) }\end{array}$ & $\begin{array}{l}\text { AGAINST A CHILD } \\
\text { KS ST § 38-2202 (West 2008) } \\
\text { Article 22. Revised Kansas Code for Care of Children }\end{array}$ \\
\hline $\begin{array}{l}\text { What has to be } \\
\text { reported? } \\
\text { (Kansas) }\end{array}$ & $\begin{array}{l}\text { KS ST § 38-2223 (West 2008) } \\
\text { (a) reason to suspect that a child has been harmed as a result of physical, mental or emotional abuse or neglect or sexual abuse.... }\end{array}$ \\
\hline $\begin{array}{l}\text { Relevant Definitions } \\
\text { (Kansas) }\end{array}$ & $\begin{array}{l}\text { KS ST § 38-2202 (West 2008) } \\
\text { (a) "Abandon" or "abandonment" means to forsake, desert or, without making appropriate provision for substitute care, cease } \\
\text { providing care for the child. }\end{array}$ \\
\hline
\end{tabular}

\section{NOTE:}

providing care for the child.

** For purposes of this chart, corrections officers, police officers, peace officers, probation officers or “catch-all” phrases such as “all persons” have been bolded. However, many mandatory reporters include professionals who may have contact or work in correctional facilities. Such individuals include physicians, nurses, dentists, teachers and social workers. These statutes can be used as a tool to require staff other than correctional officers to report sexual misconduct with inmates.

This publication is developed by the NIC/WCL Project on Addressing Prison Rape under NIC Cooperative Agreement 06S20GJJ1.

This is not to be reproduced or cited without permission from the authors.

American University, Washington College of Law

Current as of May 7, 2009 


\section{Fifty State Survey of Mandatory Reporting Statutes}

\section{NIC/WCL Project on Addressing Prison Rape}

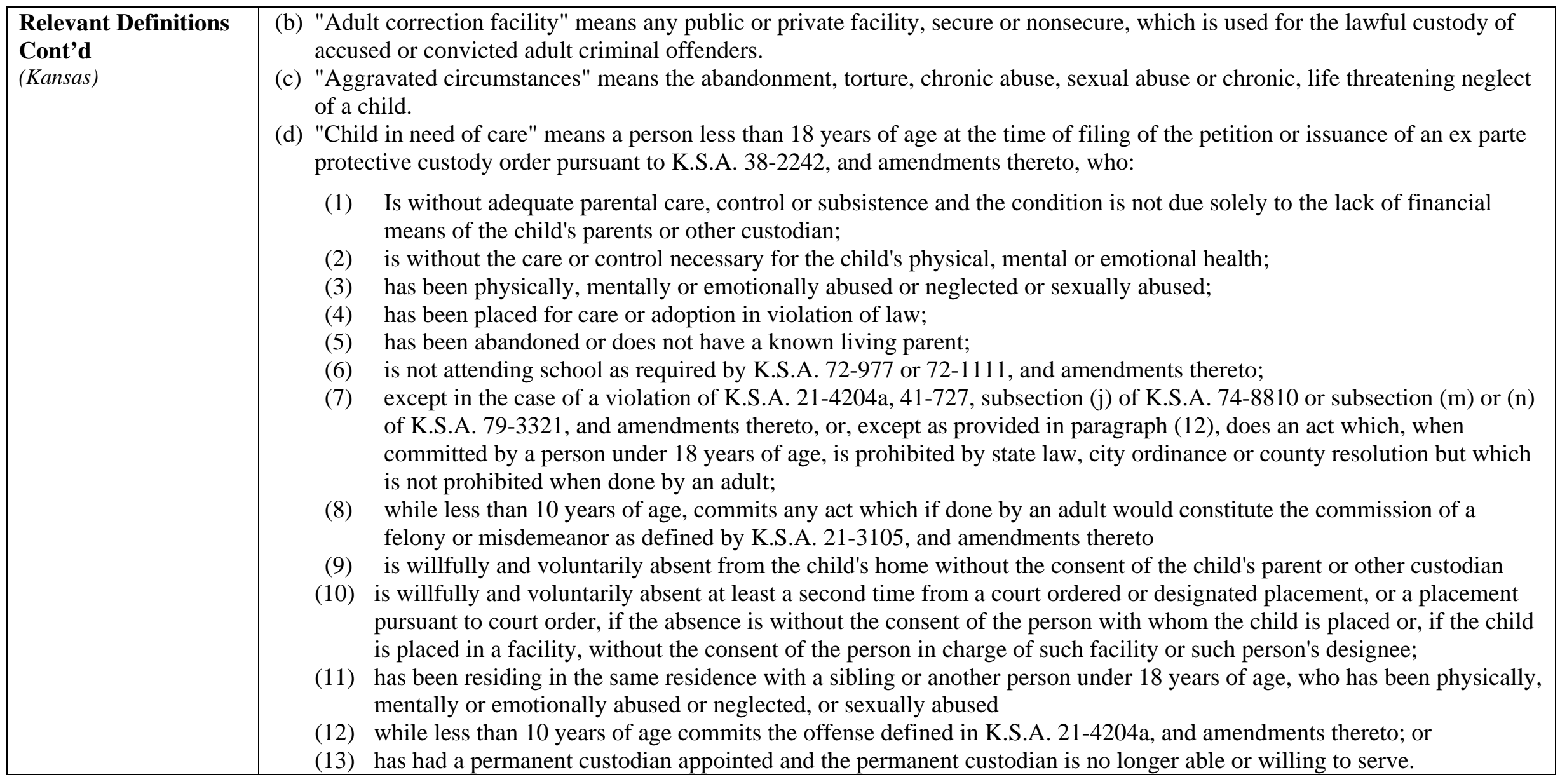

** For purposes of this chart, corrections officers, police officers, peace officers, probation officers or "catch-all” phrases such as “all persons” have been bolded. However, many mandatory reporters include professionals who may have contact or work in correctional facilities. Such individuals include physicians, nurses, dentists, teachers and social workers. These statutes can be used as a tool to require staff other than correctional officers to report sexual misconduct with inmates.

This publication is developed by the NIC/WCL Project on Addressing Prison Rape under NIC Cooperative Agreement 06S20GJJ1.

This is not to be reproduced or cited without permission from the authors.

American University, Washington College of Law

Current as of May 7, 2009 


\section{Fifty State Survey of Mandatory Reporting Statutes}

\section{NIC/WCL Project on Addressing Prison Rape}

\begin{tabular}{|c|c|}
\hline $\begin{array}{l}\text { Relevant Definitions } \\
\text { Cont'd } \\
\text { (Kansas) }\end{array}$ & 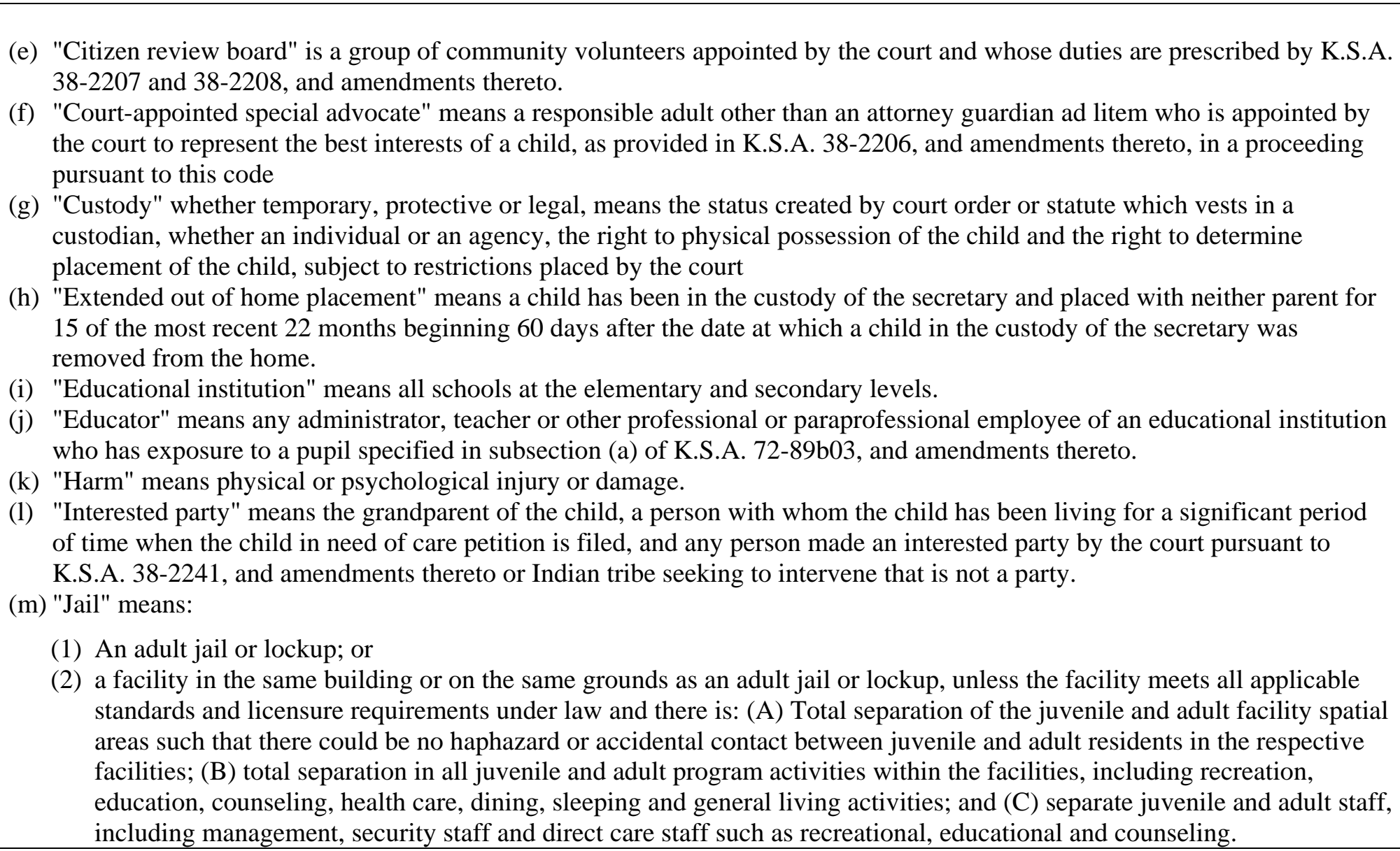 \\
\hline
\end{tabular}

NOTE:

** For purposes of this chart, corrections officers, police officers, peace officers, probation officers or “catch-all” phrases such as “all persons” have been bolded. However, many mandatory reporters include professionals who may have contact or work in correctional facilities. Such individuals include physicians, nurses, dentists, teachers and social workers. These statutes can be used as a tool to require staff other than correctional officers to report sexual misconduct with inmates.

This publication is developed by the NIC/WCL Project on Addressing Prison Rape under NIC Cooperative Agreement 06S20GJJ1.

This is not to be reproduced or cited without permission from the authors.

American University, Washington College of Law

Current as of May 7, 2009 


\title{
Fifty State Survey of Mandatory Reporting Statutes
}

\section{NIC/WCL Project on Addressing Prison Rape}

\begin{tabular}{|c|c|}
\hline $\begin{array}{l}\text { Relevant Definitions } \\
\text { Cont'd } \\
\text { (Kansas) }\end{array}$ & 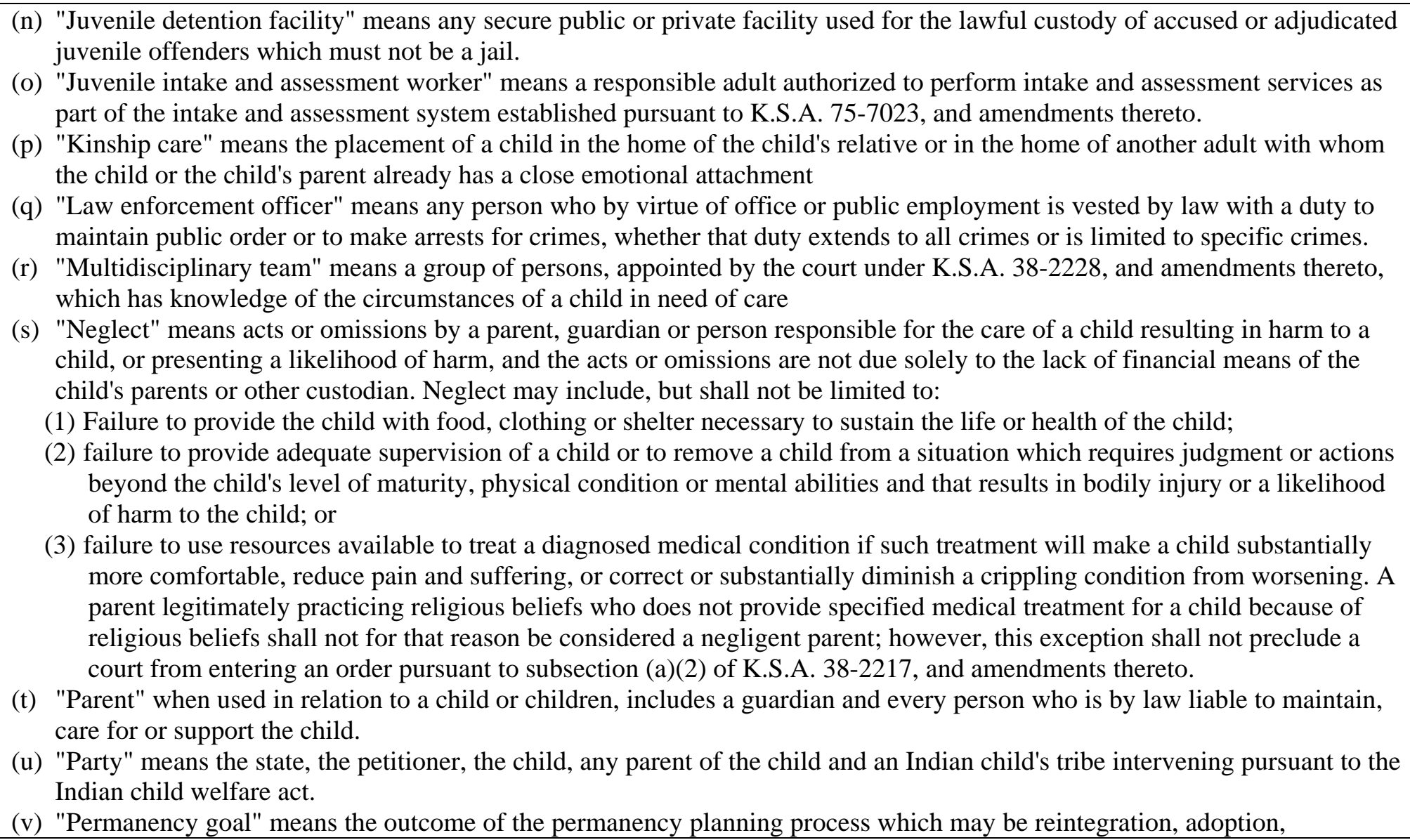 \\
\hline
\end{tabular}

NOTE:

\begin{abstract}
** For purposes of this chart, corrections officers, police officers, peace officers, probation officers or "catch-all” phrases such as “all persons” have been bolded. However, many mandatory reporters include professionals who may have contact or work in correctional facilities. Such individuals include physicians, nurses, dentists, teachers and social workers. These statutes can be used as a tool to require staff other than correctional officers to report sexual misconduct with inmates.
\end{abstract}

This publication is developed by the NIC/WCL Project on Addressing Prison Rape under NIC Cooperative Agreement 06S20GJJ1.

This is not to be reproduced or cited without permission from the authors.

American University, Washington College of Law

Current as of May 7, 2009 


\section{Fifty State Survey of Mandatory Reporting Statutes}

\section{NIC/WCL Project on Addressing Prison Rape}

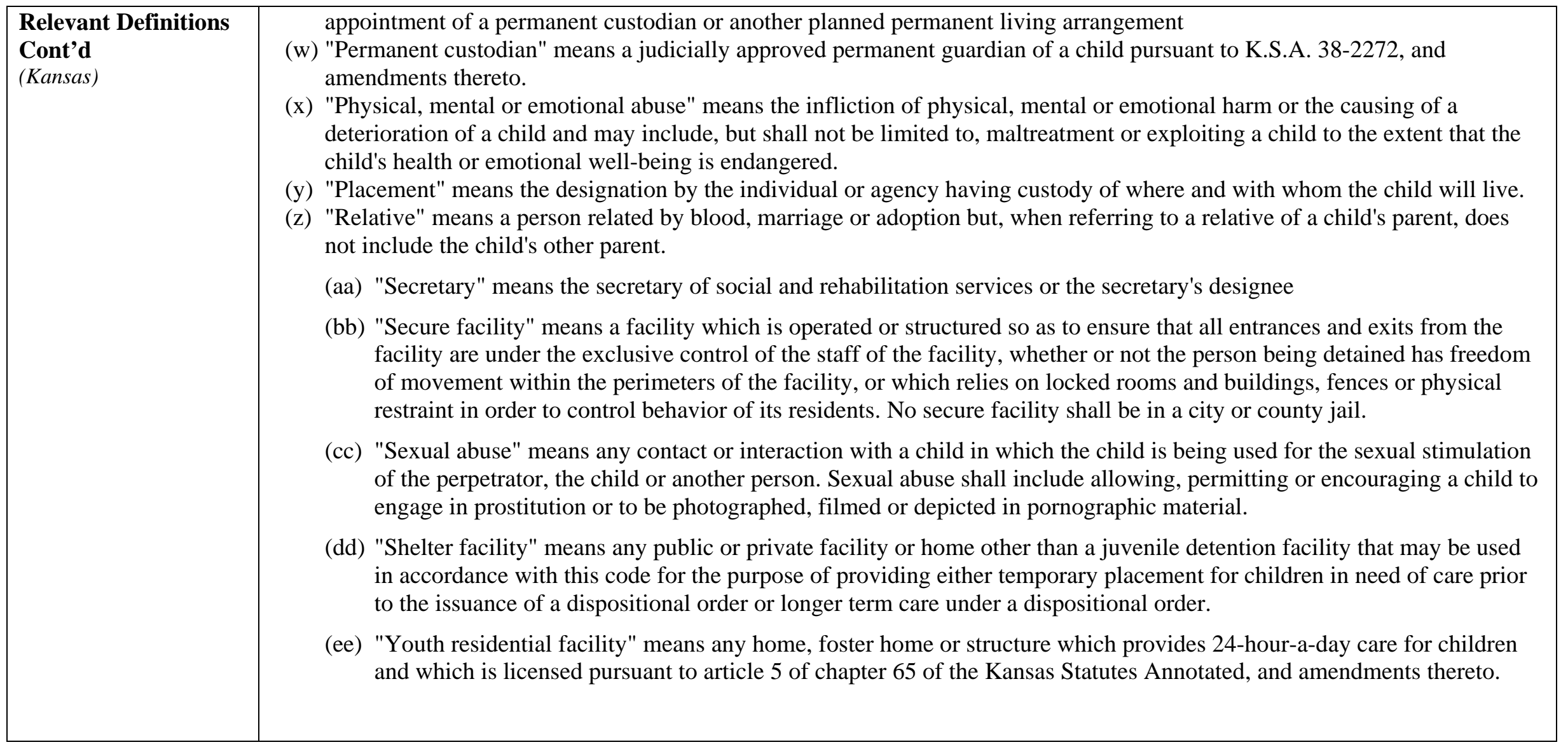

NOTE:

** For purposes of this chart, corrections officers, police officers, peace officers, probation officers or "catch-all” phrases such as “all persons” have been bolded. However, many mandatory reporters include professionals who may have contact or work in correctional facilities. Such individuals include physicians, nurses, dentists, teachers and social workers. These statutes can be used as a tool to require staff other than correctional officers to report sexual misconduct with inmates.

This publication is developed by the NIC/WCL Project on Addressing Prison Rape under NIC Cooperative Agreement 06S20GJJ1.

This is not to be reproduced or cited without permission from the authors.

American University, Washington College of Law

Current as of May 7, 2009 


\section{Fifty State Survey of Mandatory Reporting Statutes}

\section{NIC/WCL Project on Addressing Prison Rape}

\begin{tabular}{|c|c|}
\hline $\begin{array}{l}\text { Persons Required to } \\
\text { Report } \\
\text { (Kansas) }\end{array}$ & $\begin{array}{l}\text { KS ST § 38-2223 (West 2008) } \\
\text { (a) Persons making reports. (1) When any of the following persons has reason to suspect that a child has been harmed as a result } \\
\text { of physical, mental or emotional abuse or neglect or sexual abuse, the person shall report the matter promptly as provided in } \\
\text { subsections (b) and (c); } \\
\text { (A) The following persons providing medical care or treatment: Persons licensed to practice the healing arts, dentistry and } \\
\text { optometry; persons engaged in postgraduate training programs approved by the state board of healing arts; licensed } \\
\text { professional or practical nurses; and chief administrative officers of medical care facilities; } \\
\text { (B) The following persons licensed by the state to provide mental health services: Licensed psychologists, licensed masters } \\
\text { level psychologists, licensed clinical psychotherapists, licensed social workers, licensed marriage and family therapists, } \\
\text { licensed clinical marriage and family therapists, licensed professional counselors, licensed clinical professional counselors } \\
\text { and registered alcohol and drug abuse counselors; } \\
\text { (C) Teachers, school administrators or other employees of an educational institution which the child is attending and persons } \\
\text { licensed by the secretary of health and environment to provide child care services or the employees of persons so licensed at } \\
\text { the place where the child care services are being provided to the child; and } \\
\text { (D) Firefighters, emergency medical services personnel, law enforcement officers, juvenile intake and assessment workers, } \\
\text { court services officers and community corrections officers, case managers appointed under K.S.A. } 23-1001 \text { et seq., and } \\
\text { amendments thereto, and mediators appointed under K.S.A. 23- 602, and amendments thereto. } \\
\text { (2) In addition to the reports required under subsection (a)(1), any person who has reason to suspect that a child may be a child in } \\
\text { need of care may report the matter as provided in subsection (b) and (c). }\end{array}$ \\
\hline $\begin{array}{l}\text { Reporting } \\
\text { Procedures } \\
\text { (Kansas) }\end{array}$ & $\begin{array}{l}\text { KT ST § 38-2223 (West 2008) } \\
\text { (b) Form of report. (1) The report may be made orally and shall be followed by a written report if requested. Every report shall } \\
\text { contain, if known: The names and addresses of the child and the child's parents or other persons responsible for the child's care; }\end{array}$ \\
\hline
\end{tabular}

NOTE:

** For purposes of this chart, corrections officers, police officers, peace officers, probation officers or “catch-all” phrases such as “all persons” have been bolded. However, many mandatory reporters include professionals who may have contact or work in correctional facilities. Such individuals include physicians, nurses, dentists, teachers and social workers. These statutes can be used as a tool to require staff other than correctional officers to report sexual misconduct with inmates.

This publication is developed by the NIC/WCL Project on Addressing Prison Rape under NIC Cooperative Agreement 06S20GJJ1.

This is not to be reproduced or cited without permission from the authors.

American University, Washington College of Law

Current as of May 7, 2009 


\section{Fifty State Survey of Mandatory Reporting Statutes}

\section{NIC/WCL Project on Addressing Prison Rape}

\begin{tabular}{|c|c|}
\hline $\begin{array}{l}\text { Reporting } \\
\text { Procedures Cont'd } \\
\text { (Kansas) }\end{array}$ & $\begin{array}{l}\text { the location of the child if not at the child's residence; the child's gender, race and age; the reasons why the reporter suspects the } \\
\text { child may be a child in need of care; if abuse or neglect or sexual abuse is suspected, the nature and extent of the harm to the child, } \\
\text { including any evidence of previous harm; and any other information that the reporter believes might be helpful in establishing the } \\
\text { cause of the harm and the identity of the persons responsible for the harm. (2) When reporting a suspicion that a child may be in } \\
\text { need of care, the reporter shall disclose protected health information freely and cooperate fully with the secretary and law } \\
\text { enforcement throughout the investigation and any subsequent legal process. } \\
\text { (c) To whom made. Reports made pursuant to this section shall be made to the secretary, except as follows: } \\
\text { (1) When the department of social and rehabilitation services is not open for business, reports shall be made to the appropriate } \\
\text { law enforcement agency. On the next day that the department is open for business, the law enforcement agency shall report } \\
\text { to the department any report received and any investigation initiated pursuant to K.S.A. 38-2226, and amendments thereto. } \\
\text { The reports may be made orally or, on request of the secretary, in writing. } \\
\text { (2) Reports of child abuse or neglect occurring in an institution operated by the secretary of social and rehabilitation services or } \\
\text { the commissioner of juvenile justice shall be made to the attorney general. All other reports of child abuse or neglect by } \\
\text { persons employed by or of children of persons employed by the department of social and rehabilitation services shall be } \\
\text { made to the appropriate law enforcement agency. } \\
\text { (d) Death of child. Any person who is required by this section to report a suspicion that a child is in need of care and who knows } \\
\text { of information relating to the death of a child shall immediately notify the coroner as provided by K.S.A. } 22 a-242 \text {, and } \\
\text { amendments thereto. }\end{array}$ \\
\hline $\begin{array}{l}\text { Penalty for Failure to } \\
\text { Report } \\
\text { (Kansas) }\end{array}$ & 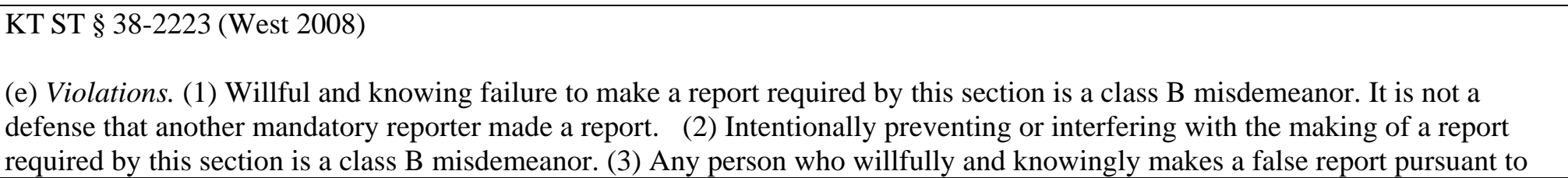 \\
\hline
\end{tabular}

NOTE:

** For purposes of this chart, corrections officers, police officers, peace officers, probation officers or “catch-all” phrases such as “all persons” have been bolded. However, many mandatory reporters include professionals who may have contact or work in correctional facilities. Such individuals include physicians, nurses, dentists, teachers and social workers. These statutes can be used as a tool to require staff other than correctional officers to report sexual misconduct with inmates.

This publication is developed by the NIC/WCL Project on Addressing Prison Rape under NIC Cooperative Agreement 06S20GJJ1.

This is not to be reproduced or cited without permission from the authors.

American University, Washington College of Law

Current as of May 7, 2009 


\section{Fifty State Survey of Mandatory Reporting Statutes}

\section{NIC/WCL Project on Addressing Prison Rape}

\begin{tabular}{|c|c|}
\hline $\begin{array}{l}\text { Penalty for Failure to } \\
\text { Report Cont'd } \\
\text { (Kansas) }\end{array}$ & $\begin{array}{l}\text { this section or makes a report that such person knows lacks factual foundation is guilty of a class B misdemeanor. } \\
\text { (f) Immunity from liability. Anyone who, without malice, participates in the making of a report to the secretary or a law } \\
\text { enforcement agency relating to a suspicion a child may be a child in need of care or who participates in any activity or } \\
\text { investigation relating to the report or who participates in any judicial proceeding resulting from the report shall have immunity } \\
\text { from any civil liability that might otherwise be incurred or imposed. } \\
\text { KAN. STAT. ANN. § 21-4502 (West 2008) } \\
\text { Class B Misdemeanor: Maximum of six months imprisonment. } \\
\text { KAN. STAT. ANN. § 21-4503 (West } 2008 \text { ) } \\
\text { Class B Misdemeanor: Maximum of } \$ 15,000 \text { fine }\end{array}$ \\
\hline $\begin{array}{l}\text { Mandatory } \\
\text { Reporting Statute } \\
\text { (Kansas) }\end{array}$ & $\begin{array}{l}\text { AGAINST AN ADULT } \\
\text { KT ST § 39-1431; KT ST § 39-1402 (West 2008) }\end{array}$ \\
\hline $\begin{array}{l}\text { What has to be } \\
\text { reported? } \\
\text { (Kansas) }\end{array}$ & $\begin{array}{l}\text { KT ST § 39-1431 (West 2008) } \\
\text { (a) Reasonable cause to believe that an adult is being or has been abused, neglected or exploited or is in need of protective } \\
\text { services; } \\
\text { KT ST § 39-1402 (West 2008) } \\
\text { (a) Mandatory reporters are also required to report abuse with respect to residents as defined by subsection (a)(1) of K.S.A. 39- }\end{array}$ \\
\hline
\end{tabular}

NOTE:

** For purposes of this chart, corrections officers, police officers, peace officers, probation officers or “catch-all” phrases such as “all persons” have been bolded. However, many mandatory reporters include professionals who may have contact or work in correctional facilities. Such individuals include physicians, nurses, dentists, teachers and social workers. These statutes can be used as a tool to require staff other than correctional officers to report sexual misconduct with inmates.

This publication is developed by the NIC/WCL Project on Addressing Prison Rape under NIC Cooperative Agreement 06S20GJJ1.

This is not to be reproduced or cited without permission from the authors.

American University, Washington College of Law

Current as of May 7, 2009 


\section{Fifty State Survey of Mandatory Reporting Statutes}

\section{NIC/WCL Project on Addressing Prison Rape}

\begin{tabular}{|c|c|}
\hline $\begin{array}{l}\text { What has to be } \\
\text { reported? Cont'd } \\
\text { (Kansas) }\end{array}$ & 1401 (West 2008) \\
\hline $\begin{array}{l}\text { Relevant Definitions } \\
\text { (Kansas) }\end{array}$ & $\begin{array}{l}\text { KT ST } § 39-1430 \text { (West 2008) } \\
\text { (a) “Adult” means an individual } 18 \text { years of age or older alleged to be unable to protect their own interest and who is harmed or } \\
\text { threatened with harm, whether financial, mental or physical in nature, through action or inaction by either another individual or } \\
\text { through their own action or inaction when (1) such person is residing in such person's own home, the home of a family member or } \\
\text { the home of a friend, (2) such person resides in an adult family home, or (3) such person is receiving services through a provider } \\
\text { of community services and affiliates thereof operated or funded by the department of social and rehabilitation services or the } \\
\text { department on aging or a residential facility. } \\
\text { (b) “Abuse” means any act or failure to act performed intentionally or recklessly that causes or is likely to cause harm to an adult, } \\
\text { including: } \\
\text { (1) Infliction of physical or mental injury; } \\
\text { (2) any sexual act with an adult when the adult does not consent or when the other person knows or should know that the adult } \\
\text { is incapable of resisting or declining consent to the sexual act due to mental deficiency or disease or due to fear of retribution or } \\
\text { hardship; } \\
\text { (3) unreasonable use of a physical restraint, isolation or medication that harms or is likely to harm an adult; } \\
\text { (4) unreasonable use of a physical or chemical restraint, medication or isolation as punishment, for convenience, in conflict } \\
\text { with a physician's orders or as a substitute for treatment, except where such conduct or physical restraint is in furtherance of the } \\
\text { health and safety of the adult; } \\
\text { (5) a threat or menacing conduct directed toward an adult that results or might reasonably be expected to result in fear or } \\
\text { emotional or mental distress to an adult; } \\
\text { (6) fiduciary abuse; or }\end{array}$ \\
\hline
\end{tabular}

** For purposes of this chart, corrections officers, police officers, peace officers, probation officers or "catch-all” phrases such as “all persons” have been bolded. However, many mandatory reporters include professionals who may have contact or work in correctional facilities. Such individuals include physicians, nurses, dentists, teachers and social workers. These statutes can be used as a tool to require staff other than correctional officers to report sexual misconduct with inmates.

This publication is developed by the NIC/WCL Project on Addressing Prison Rape under NIC Cooperative Agreement 06S20GJJ1.

This is not to be reproduced or cited without permission from the authors.

American University, Washington College of Law

Current as of May 7, 2009 


\section{Fifty State Survey of Mandatory Reporting Statutes}

\section{NIC/WCL Project on Addressing Prison Rape}

\begin{tabular}{|c|c|}
\hline $\begin{array}{l}\text { Relevant Definitions } \\
\text { Cont'd } \\
\text { (Kansas) }\end{array}$ & $\begin{array}{l}\text { (7) omission or deprivation by a caretaker or another person of goods or services which are necessary to avoid physical or } \\
\text { mental harm or illness. } \\
\text { KT ST § 39-1401 (West 2008) } \\
\text { (a) Resident means any resident in an adult care home such as a nursing facility, nursing facility for mental health, intermediate } \\
\text { care facility for the mentally retarded, assisted living facility, residential health care facility, home plus, boarding care home and } \\
\text { adult day care facility, all of which classifications of adult care homes are required to be licensed by the secretary of aging), any } \\
\text { individual kept, cared for, treated boarded or otherwise accommodated in a medical care facility; or any individual kept, cared for, } \\
\text { treated boarded or otherwise accommodated in a state psychiatric hospital or state institution for the mentally retarded. } \\
\text { (g) Neglect means the failure or omission by one's self, caretaker or another person with a duty to provide goods or services which } \\
\text { are reasonably necessary to ensure safety and well-being and to avoid physical or mental harm or illness. } \\
\text { (i) Exploitation means misappropriation of resident property or intentionally taking unfair advantage of an adult's physical or } \\
\text { financial resources for another individual's personal or financial advantage by the use of undue influence, coercion, harassment, } \\
\text { duress, deception, false representation or false pretense by a caretaker or another person. }\end{array}$ \\
\hline $\begin{array}{l}\text { Persons Required to } \\
\text { Report } \\
\text { (Kansas) }\end{array}$ & $\begin{array}{l}\text { KT ST } § 39-1431 \text { (West 2008) } \\
\text { (a) } \\
\text { • A law enforcement officer; } \\
\text { • Any person who is licensed to practice any branch of the healing arts; } \\
\text { - a licensed psychologist; } \\
\text { - A licensed master level psychologist; } \\
\text { - A licensed clinical psychotherapist; } \\
\text { - The chief administrative officer of a medical care facility; }\end{array}$ \\
\hline
\end{tabular}

\section{NOTE:}

** For purposes of this chart, corrections officers, police officers, peace officers, probation officers or "catch-all” phrases such as "all persons" have been bolded. However, many mandatory reporters include professionals who may have contact or work in correctional facilities. Such individuals include physicians, nurses, dentists, teachers and social workers. These statutes can be used as a tool to require staff other than correctional officers to report sexual misconduct with inmates.

This publication is developed by the NIC/WCL Project on Addressing Prison Rape under NIC Cooperative Agreement 06S20GJJ1.

This is not to be reproduced or cited without permission from the authors.

American University, Washington College of Law

Current as of May 7, 2009 


\section{Fifty State Survey of Mandatory Reporting Statutes}

\section{NIC/WCL Project on Addressing Prison Rape}

\begin{tabular}{|c|c|}
\hline $\begin{array}{l}\text { Persons Required to } \\
\text { Report Cont'd } \\
\text { (Kansas) }\end{array}$ & $\begin{array}{l}\text { - A teacher; } \\
\text { - A licensed social worker; } \\
\text { - A licensed professional nurse; } \\
\text { - A licensed practical nurse; } \\
\text { - A licensed dentist; } \\
\text { - A licensed marriage and family therapist; } \\
\text { - A licensed clinical marriage and family therapist; } \\
\text { - Licensed professional counselor; } \\
\text { - Licensed clinical professional counselor; } \\
\text { - Registered alcohol and drug abuse counselor; } \\
\text { - A case manager; } \\
\text { - A rehabilitation counselor; } \\
\text { - A bank trust officer or any other officers of financial institutions; } \\
\text { - A legal representative; } \\
\text { - A governmental assistance provider; } \\
\text { - An owner or operator of a residential care facility; } \\
\text { - An independent living counselor and the chief administrative officer of a licensed home health agency, the chief } \\
\text { administrative officer of an adult family home and the chief administrative officer of a provider of community services } \\
\text { and affiliates thereof operated or funded by the department of social and rehabilitation services. }\end{array}$ \\
\hline $\begin{array}{l}\text { Reporting } \\
\text { Procedures } \\
\text { (Kansas) }\end{array}$ & $\begin{array}{l}\text { KT ST } \S 39-1431 \text { (West 2008) } \\
\text { (a) Shall report, immediately from receipt of the information, such information or cause a report of such information to be made in } \\
\text { any reasonable manner... Reports shall be made to the department of social and rehabilitation services during the normal working } \\
\text { week days and hours of operation. Reports shall be made to law enforcement agencies during the time social and rehabilitation } \\
\text { services are not in operation. Law enforcement shall submit the report and appropriate information to the department of social and }\end{array}$ \\
\hline
\end{tabular}

NOTE:

** For purposes of this chart, corrections officers, police officers, peace officers, probation officers or “catch-all” phrases such as “all persons” have been bolded. However, many mandatory reporters include professionals who may have contact or work in correctional facilities. Such individuals include physicians, nurses, dentists, teachers and social workers. These statutes can be used as a tool to require staff other than correctional officers to report sexual misconduct with inmates.

This publication is developed by the NIC/WCL Project on Addressing Prison Rape under NIC Cooperative Agreement 06S20GJJ1.

This is not to be reproduced or cited without permission from the authors.

American University, Washington College of Law

Current as of May 7, 2009 


\section{Fifty State Survey of Mandatory Reporting Statutes}

\section{NIC/WCL Project on Addressing Prison Rape}

\begin{tabular}{|c|c|}
\hline $\begin{array}{l}\text { Reporting } \\
\text { Procedures Cont'd } \\
\text { (Kansas) }\end{array}$ & $\begin{array}{l}\text { rehabilitation services on the first working day that social and rehabilitation services is in operation after receipt of such } \\
\text { information. } \\
\text { (b) The report made pursuant to subsection (a) shall contain the name and address of the person making the report and of the } \\
\text { caretaker caring for the involved adult, the name and address of the involved adult, information regarding the nature and extent of } \\
\text { the abuse, neglect or exploitation, the name of the next of kin of the involved adult, if known, and any other information which the } \\
\text { person making the report believes might be helpful in the investigation of the case and the protection of the involved adult. }\end{array}$ \\
\hline $\begin{array}{l}\text { Penalty for Failure to } \\
\text { Report } \\
\text { (Kansas) }\end{array}$ & $\begin{array}{l}\text { KT ST } \S 39-1431 \text { (West 2008) } \\
\text { (e) Any person required to report information or cause a report of information to be made under subsection (a) who knowingly } \\
\text { fails to make such report or cause such report not to be made shall be guilty of a class B misdemeanor. } \\
\text { KT ST } § 21-4502 \text { (West 2008) } \\
\text { (b) Class B misdemeanor: } \\
\text { Maximum of six months imprisonment. } \\
\text { KT ST } \S 21-4503 \text { (West 2008) } \\
\text { (2) Class B Misdemeanor: Maximum of } \$ 1,000 \text { fine. }\end{array}$ \\
\hline & KENTUCKY \\
\hline
\end{tabular}

NOTE:

** For purposes of this chart, corrections officers, police officers, peace officers, probation officers or “catch-all” phrases such as “all persons” have been bolded. However, many mandatory reporters include professionals who may have contact or work in correctional facilities. Such individuals include physicians, nurses, dentists, teachers and social workers. These statutes can be used as a tool to require staff other than correctional officers to report sexual misconduct with inmates.

This publication is developed by the NIC/WCL Project on Addressing Prison Rape under NIC Cooperative Agreement 06S20GJJ1.

This is not to be reproduced or cited without permission from the authors.

American University, Washington College of Law

Current as of May 7, 2009 


\section{Fifty State Survey of Mandatory Reporting Statutes}

\section{NIC/WCL Project on Addressing Prison Rape}

\begin{tabular}{|c|c|}
\hline $\begin{array}{l}\text { Mandatory } \\
\text { Reporting Statute } \\
\text { (Kentucky) }\end{array}$ & $\begin{array}{l}\text { AGAINST A CHILD } \\
\text { KRS § } 620.030 \text { (West 2008) }\end{array}$ \\
\hline $\begin{array}{l}\text { What has to be } \\
\text { reported? } \\
\text { (Kentucky) }\end{array}$ & $\begin{array}{l}\text { KRS § } 620.030 \text { (West 2008) } \\
\text { (1) Knowledge or reasonable cause to believe that a child is dependent, neglected, or abused. }\end{array}$ \\
\hline $\begin{array}{l}\text { Relevant Definitions } \\
\text { (Kentucky) }\end{array}$ & $\begin{array}{l}\text { KRS § } 620.030 \text { (West 2008) } \\
\text { (8) Child means any person who has not reached his eighteenth birthday, unless otherwise provided. } \\
\text { KRS § } 620.030 \text { (West 2008) } \\
\text { (1) Abused or neglected child: a child whose health or welfare is harmed or threatened with harm when his parent, guardian, or } \\
\text { other person exercising custodial control or supervision of the child: } \\
\text { (ff) Inflicts or allows to be inflicted upon the child physical or emotional injury as defined in this section by other than } \\
\text { accidental means; } \\
\text { (gg) Creates or allows to be created a risk of physical or emotional injury as defined in this section to the child by other than } \\
\text { accidental means; } \\
\text { (hh) Engages in a pattern of conduct that renders the parent incapable of caring for the immediate and ongoing needs of the } \\
\text { child including, but not limited to, parental incapacity due to alcohol and other drug abuse; } \\
\text { (ii) Continuously or repeatedly fails or refuses to provide essential parental care and protection for the child, considering the } \\
\text { age of the child; } \\
\text { (jj) Commits or allows to be committed an act of sexual abuse, sexual exploitation, or prostitution upon the child; } \\
\text { (kk) Creates or allows to be created a risk that an act of sexual abuse, sexual exploitation, or prostitution will be committed }\end{array}$ \\
\hline
\end{tabular}

NOTE:

** For purposes of this chart, corrections officers, police officers, peace officers, probation officers or “catch-all” phrases such as “all persons” have been bolded. However, many mandatory reporters include professionals who may have contact or work in correctional facilities. Such individuals include physicians, nurses, dentists, teachers and social workers. These statutes can be used as a tool to require staff other than correctional officers to report sexual misconduct with inmates.

This publication is developed by the NIC/WCL Project on Addressing Prison Rape under NIC Cooperative Agreement 06S20GJJ1.

This is not to be reproduced or cited without permission from the authors.

American University, Washington College of Law

Current as of May 7, 2009 


\section{Fifty State Survey of Mandatory Reporting Statutes}

\section{NIC/WCL Project on Addressing Prison Rape}

\begin{tabular}{|c|c|}
\hline $\begin{array}{l}\text { Relevant Definitions } \\
\text { Cont'd } \\
\text { (Kentucky) }\end{array}$ & $\begin{array}{l}\text { upon the child; } \\
\text { (ll) Abandons or exploits the child; } \\
\text { (mm)Does not provide the child with adequate care, supervision, food, clothing, shelter, and education or medical care } \\
\text { necessary for the child's well-being. A parent or other person exercising custodial control or supervision of the child } \\
\text { legitimately practicing the person's religious beliefs shall not be considered a negligent parent solely because of failure to } \\
\text { provide specified medical treatment for a child for that reason alone. This exception shall not preclude a court from ordering } \\
\text { necessary medical services for a child; or } \\
\text { (nn) Fails to make sufficient progress toward identified goals as set forth in the court-approved case plan to allow for the safe } \\
\text { return of the child to the parent that results in the child remaining committed to the cabinet and remaining in foster care for } \\
\text { fifteen (15) of the most recent twenty-two (22) months. }\end{array}$ \\
\hline $\begin{array}{l}\text { Persons Required to } \\
\text { Report } \\
\text { (Kentucky) }\end{array}$ & $\begin{array}{l}\text { KRS § } 620.030 \text { (West 2008) } \\
\text { (2) Any person, including but not limited to: }{ }^{3} \\
\text { • Peace officer; } \\
\text { • Physician; } \\
\text { • Osteopathic physician; } \\
\text { • Nurse; } \\
\text { • Teacher; } \\
\text { • School personnel; } \\
\text { • Social worker; } \\
\text { • Coroner; } \\
\text { • Medical examiner; } \\
\text { • Child-caring personnel; } \\
\text { • Resident; }\end{array}$ \\
\hline
\end{tabular}

** For purposes of this chart, corrections officers, police officers, peace officers, probation officers or “catch-all” phrases such as “all persons” have been bolded. However, many mandatory reporters include professionals who may have contact or work in correctional facilities. Such individuals include physicians, nurses, dentists, teachers and social workers. These statutes can be used as a tool to require staff other than correctional officers to report sexual misconduct with inmates.

This publication is developed by the NIC/WCL Project on Addressing Prison Rape under NIC Cooperative Agreement 06S20GJJ1.

This is not to be reproduced or cited without permission from the authors.

American University, Washington College of Law

Current as of May 7, 2009 


\section{Fifty State Survey of Mandatory Reporting Statutes}

\section{NIC/WCL Project on Addressing Prison Rape}

\begin{tabular}{|c|c|}
\hline $\begin{array}{l}\text { Persons Required to } \\
\text { Report Cont'd } \\
\text { (Kentucky) }\end{array}$ & $\begin{array}{l}\text { - Intern; } \\
\text { - Chiropractor; } \\
\text { - Dentist; } \\
\text { - Optometrist; } \\
\text { - Emergency medical technician; } \\
\text { - Paramedic; } \\
\text { - Health professional; } \\
\text { - Mental health professional; or } \\
\text { - Any organization or agency for any of the above. }\end{array}$ \\
\hline $\begin{array}{l}\text { Reporting } \\
\text { Procedures } \\
\text { (Kentucky) }\end{array}$ & $\begin{array}{l}\text { KRS § } 620.030 \text { (West 2008) } \\
\text { (1) Immediately cause an oral or written report to be made to a local law enforcement agency or the Department of Kentucky State } \\
\text { Police; the cabinet or its designated representative; the Commonwealth's attorney or the county attorney; by telephone or } \\
\text { otherwise. Any supervisor who receives from an employee a report of suspected dependency, neglect or abuse shall promptly } \\
\text { make a report to the proper authorities for investigation. } \\
\text { (2) If requested, in addition to the report required in subsection (1), [a mandatory reporter shall] file with the local law } \\
\text { enforcement agency or the Department of Kentucky State Police or the Commonwealth's or county attorney, the cabinet or its } \\
\text { designated representative within forty-eight (48) hours of the original report a written report containing: } \\
\text { (a) The names and addresses of the child and his or her parents or other persons exercising custodial control or supervision; } \\
\text { (b) The child's age; } \\
\text { (c) The nature and extent of the child's alleged dependency, neglect or abuse (including any previous charges of dependency, } \\
\text { neglect or abuse) to this child or his or her siblings; } \\
\text { (d) The name and address of the person allegedly responsible for the abuse or neglect; and } \\
\text { (e) Any other information that the person making the report believes may be helpful in the furtherance of the purpose of this }\end{array}$ \\
\hline
\end{tabular}

(e) Any other information that the person making the report believes may be helpful in the furtherance of the purpose of this

** For purposes of this chart, corrections officers, police officers, peace officers, probation officers or “catch-all” phrases such as “all persons” have been bolded. However, many mandatory reporters include professionals who may have contact or work in correctional facilities. Such individuals include physicians, nurses, dentists, teachers and social workers. These statutes can be used as a tool to require staff other than correctional officers to report sexual misconduct with inmates.

This publication is developed by the NIC/WCL Project on Addressing Prison Rape under NIC Cooperative Agreement 06S20GJJ1.

This is not to be reproduced or cited without permission from the authors.

American University, Washington College of Law

Current as of May 7, 2009 


\section{Fifty State Survey of Mandatory Reporting Statutes}

\section{NIC/WCL Project on Addressing Prison Rape}

\begin{tabular}{|c|c|}
\hline $\begin{array}{l}\text { Reporting } \\
\text { Procedures } \\
\text { (Kentucky) }\end{array}$ & section. \\
\hline $\begin{array}{l}\text { Penalty for Failure to } \\
\text { Report } \\
\text { (Kentucky) }\end{array}$ & $\begin{array}{l}\text { KRS § } 620.990 \text { (West 2008) } \\
\text { (1) Any person intentionally violating the provisions of this chapter shall be guilty of a Class B misdemeanor. } \\
\text { KRS § } 532.090 \text { (West 2008) } \\
\text { Class B Misdemeanor: Maximum of } 90 \text { days } \\
\text { KRS § } 534.040 \text { (West 2008) } \\
\text { Class B Misdemeanor: Maximum of } \$ 250\end{array}$ \\
\hline $\begin{array}{l}\text { Mandatory } \\
\text { Reporting Statute } \\
\text { (Kentucky) }\end{array}$ & $\begin{array}{l}\text { AGAINST AN ADULT } \\
\text { KRS § } 209.030 \text { (West 2008) }\end{array}$ \\
\hline $\begin{array}{l}\text { What has to be } \\
\text { reported? } \\
\text { (Kentucky) }\end{array}$ & $\begin{array}{l}\text { KRS § } 209.030 \text { (West 2008) } \\
\text { (2) Reasonable cause to suspect that an adult has suffered abuse. }\end{array}$ \\
\hline $\begin{array}{l}\text { Relevant Definitions } \\
\text { (Kentucky) }\end{array}$ & $\begin{array}{l}\text { KRS § } 209.020 \text { (West 2008) } \\
\text { (4) Adult means a person eighteen (18) years of age or older who, because of mental or physical dysfunctioning, is unable to }\end{array}$ \\
\hline
\end{tabular}

NOTE:

** For purposes of this chart, corrections officers, police officers, peace officers, probation officers or “catch-all” phrases such as “all persons” have been bolded. However, many mandatory reporters include professionals who may have contact or work in correctional facilities. Such individuals include physicians, nurses, dentists, teachers and social workers. These statutes can be used as a tool to require staff other than correctional officers to report sexual misconduct with inmates.

This publication is developed by the NIC/WCL Project on Addressing Prison Rape under NIC Cooperative Agreement 06S20GJJ1.

This is not to be reproduced or cited without permission from the authors.

American University, Washington College of Law

Current as of May 7, 2009 


\section{Fifty State Survey of Mandatory Reporting Statutes}

\section{NIC/WCL Project on Addressing Prison Rape}

\begin{tabular}{|c|c|}
\hline $\begin{array}{l}\text { Relevant Definitions } \\
\text { Cont'd } \\
\text { (Kentucky) }\end{array}$ & $\begin{array}{l}\text { manage his or her own resources, carry out the activity of daily living, or protect himself or herself from neglect, exploitation, or a } \\
\text { hazardous or abusive situation without assistance from others, and who may be in need of protective services. } \\
\text { (8) Abuse means the infliction of injury, sexual abuse, unreasonable confinement, intimidation, or punishment that results in } \\
\text { physical pain or injury, including mental injury. } \\
\text { (9) Exploitation means obtaining or using another person's resources, including but not limited to funds, assets, or property, by } \\
\text { deception, intimidation, or similar means, with the intent to deprive the person of those resources; } \\
\text { (16) Neglect means a situation in which an adult is unable to perform or obtain for himself or herself the goods or services that are } \\
\text { necessary to maintain his or her health or welfare, or the deprivation of services by a caretaker that are necessary to maintain the } \\
\text { health and welfare of an adult. }\end{array}$ \\
\hline $\begin{array}{l}\text { Persons Required to } \\
\text { Report } \\
\text { (Kentucky) }\end{array}$ & $\begin{array}{l}\text { KRS § } 209.030 \text { (West 2008) } \\
\text { (2) Any person including, but not limited to: }{ }^{4} \\
\text { - Law enforcement officer; } \\
\text { - Physician; } \\
\text { - Nurse; } \\
\text { - social worker; } \\
\text { - Cabinet personnel; } \\
\text { - Coroner; } \\
\text { - Medical examiner; } \\
\text { - Alternate care facility employee; or } \\
\text { - Caretaker. }\end{array}$ \\
\hline
\end{tabular}

NOTE:

** For purposes of this chart, corrections officers, police officers, peace officers, probation officers or “catch-all” phrases such as “all persons” have been bolded. However, many mandatory reporters include professionals who may have contact or work in correctional facilities. Such individuals include physicians, nurses, dentists, teachers and social workers. These statutes can be used as a tool to require staff other than correctional officers to report sexual misconduct with inmates.

This publication is developed by the NIC/WCL Project on Addressing Prison Rape under NIC Cooperative Agreement 06S20GJJ1.

This is not to be reproduced or cited without permission from the authors.

American University, Washington College of Law

Current as of May 7, 2009 


\section{Fifty State Survey of Mandatory Reporting Statutes}

\section{NIC/WCL Project on Addressing Prison Rape}

\begin{tabular}{|c|c|}
\hline $\begin{array}{l}\text { Reporting } \\
\text { Procedures } \\
\text { (Kentucky) }\end{array}$ & $\begin{array}{l}\text { KRS § } 209.030 \text { (West 2008) } \\
\text { (3) An oral or written report shall be made immediately to the Cabinet for Health and Family Services upon knowledge of } \\
\text { suspected abuse, neglect, or exploitation of an adult. } \\
\text { (4) Any person making such a report shall provide the following information, if known: } \\
\text { (a) The name and address of the adult, or of any other person responsible for his care; } \\
\text { (b) The age of the adult; } \\
\text { (c) The nature and extent of the abuse, neglect, or exploitation, including any evidence of previous abuse, neglect, or } \\
\text { exploitation; } \\
\text { (d) The identity of the perpetrator, if known; } \\
\text { (e) The identity of the complainant, if possible; and } \\
\text { (f) Any other information that the person believes might be helpful in establishing the cause of abuse, neglect, or exploitation. }\end{array}$ \\
\hline $\begin{array}{l}\text { Penalty for Failure to } \\
\text { Report } \\
\text { (Kentucky) }\end{array}$ & $\begin{array}{l}\text { KRS § } 209.990 \text { (West 2008) } \\
\text { (1) Anyone knowingly or wantonly violating the provisions of this section shall be guilty of a Class B misdemeanor. Each } \\
\text { violation shall constitute a separate offense. } \\
\text { KRS § } 532.090 \text { (West 2008) } \\
\text { Class B Misdemeanor: Maximum of } 90 \text { days } \\
\text { KRS § } 534.040 \text { (West 2008) } \\
\text { Class B Misdemeanor: Maximum of } \$ 250\end{array}$ \\
\hline
\end{tabular}

NOTE:

** For purposes of this chart, corrections officers, police officers, peace officers, probation officers or “catch-all” phrases such as “all persons” have been bolded. However, many mandatory reporters include professionals who may have contact or work in correctional facilities. Such individuals include physicians, nurses, dentists, teachers and social workers. These statutes can be used as a tool to require staff other than correctional officers to report sexual misconduct with inmates.

This publication is developed by the NIC/WCL Project on Addressing Prison Rape under NIC Cooperative Agreement 06S20GJJ1.

This is not to be reproduced or cited without permission from the authors.

American University, Washington College of Law

Current as of May 7, 2009 


\section{Fifty State Survey of Mandatory Reporting Statutes}

\section{NIC/WCL Project on Addressing Prison Rape}

\begin{tabular}{|c|c|}
\hline \multicolumn{2}{|r|}{ LOUISIANA } \\
\hline $\begin{array}{l}\text { Mandatory } \\
\text { Reporting Statute } \\
\text { (Louisiana) }\end{array}$ & $\begin{array}{l}\text { AGAINST A CHILD } \\
\text { LSA-Ch.C. Art. } 609 \text { (West 2008) }\end{array}$ \\
\hline $\begin{array}{l}\text { What has to be } \\
\text { reported? } \\
\text { (Louisiana) }\end{array}$ & $\begin{array}{l}\text { LSA-Ch.C. Art. } 609 \text { (West 2008) } \\
\text { (A)(1) Cause to believe that a child's physical or mental health or welfare is endangered as a result of abuse or neglect or that } \\
\text { abuse or neglect was a contributing factor in a child's death. }\end{array}$ \\
\hline $\begin{array}{l}\text { Relevant Definitions } \\
\text { (Louisiana) }\end{array}$ & $\begin{array}{l}\text { LSA-Ch.C. Art. } 603 \text { (West 2008) } \\
\text { (5) “Child” means a person under eighteen years of age who, prior to juvenile proceedings, has not been judicially emancipated or } \\
\text { emancipated by marriage. } \\
\text { (1) "Abuse”: any one of the following acts which seriously endanger the physical, mental, or emotional health and safety of the } \\
\text { child: } \\
\text { (a) The infliction, attempted infliction, or, as a result of inadequate supervision, the allowance of the infliction or attempted } \\
\text { infliction of physical or mental injury upon the child by a parent or any other person. } \\
\text { (b) The exploitation or overwork of a child by a parent or any other person. } \\
\text { (c) The involvement of the child in any sexual act with a parent or any other person, or the aiding or toleration by the parent or } \\
\text { the caretaker of the child's sexual involvement with any other person or of the child's involvement in pornographic displays, } \\
\text { or any other involvement of a child in sexual activity constituting a crime under the laws of this state. }\end{array}$ \\
\hline
\end{tabular}

** For purposes of this chart, corrections officers, police officers, peace officers, probation officers or "catch-all” phrases such as "all persons" have been bolded. However, many mandatory reporters include professionals who may have contact or work in correctional facilities. Such individuals include physicians, nurses, dentists, teachers and social workers. These statutes can be used as a tool to require staff other than correctional officers to report sexual misconduct with inmates.

This publication is developed by the NIC/WCL Project on Addressing Prison Rape under NIC Cooperative Agreement 06S20GJJ1.

This is not to be reproduced or cited without permission from the authors.

American University, Washington College of Law

Current as of May 7, 2009 


\title{
Fifty State Survey of Mandatory Reporting Statutes
}

\section{NIC/WCL Project on Addressing Prison Rape}

\begin{tabular}{|c|c|}
\hline $\begin{array}{l}\text { Relevant Definitions } \\
\text { Cont'd } \\
\text { (Louisiana) }\end{array}$ & $\begin{array}{l}\text { (14) "Neglect" means the refusal or unreasonable failure of a parent or caretaker to supply the child with necessary food, clothing, } \\
\text { shelter, care, treatment, or counseling for any injury, illness, or condition of the child, as a result of which the child's physical, } \\
\text { mental, or emotional health and safety is substantially threatened or impaired. Neglect includes prenatal neglect. Consistent with } \\
\text { Article 606(B), the inability of a parent or caretaker to provide for a child due to inadequate financial resources shall not, for that } \\
\text { reason alone, be considered neglect. Whenever, in lieu of medical care, a child is being provided treatment in accordance with the } \\
\text { tenets of a well-recognized religious method of healing which has a reasonable, proven record of success, the child shall not, for } \\
\text { that reason alone, be considered to be neglected or maltreated. However, nothing herein shall prohibit the court from ordering } \\
\text { medical services for the child when there is substantial risk of harm to the child's health or welfare. }\end{array}$ \\
\hline $\begin{array}{l}\text { Persons Required to } \\
\text { Report } \\
\text { (Louisiana) }\end{array}$ & $\begin{array}{l}\text { LSA-Ch.C. Art. 603.1 (West 2008) } \\
\text { (15) "Mandatory Reporter” is any of the following individuals performing their occupational duties: } \\
\text { (a) Health practitioner is any individual who provides health care services, including a physician, surgeon, physical therapist, } \\
\text { dentist, resident, intern, hospital staff member, podiatrist, chiropractor, licensed nurse, nursing aide, dental hygienist, any } \\
\text { emergency medical technician, a paramedic, optometrist, medical examiner, or coroner, who diagnoses, examines, or } \\
\text { treats a child or his family; } \\
\text { (b) Mental health/social service practitioner: is any individual who provides mental health care or social service diagnosis, } \\
\text { assessment, counseling, or treatment, including a psychiatrist, psychologist, marriage or family counselor, social worker, } \\
\text { member of the clergy, aide, or other individual who provides counseling services to a child or his family; } \\
\text { (c) Member of the clergy any priest, rabbi, duly ordained clerical deacon or minister, Christian Science practitioner, or other } \\
\text { similarly situated functionary of a religious organization, except that he is not required to report a confidential } \\
\text { communication from a person to a member of the clergy who, in the course of the discipline or practice of that church, } \\
\text { denomination, or organization, is authorized or accustomed to hearing confidential communications, and under the } \\
\text { discipline or tenets of the church, denomination, or organization has a duty to keep such communications confidential. In } \\
\text { that instance, he shall encourage that person to report the allegations to the appropriate authorities; } \\
\text { (d) Teaching or child care provider is any person who provides training and supervision of a child, including any public or }\end{array}$ \\
\hline
\end{tabular}

\begin{abstract}
** For purposes of this chart, corrections officers, police officers, peace officers, probation officers or "catch-all” phrases such as “all persons” have been bolded. However, many mandatory reporters include professionals who may have contact or work in correctional facilities. Such individuals include physicians, nurses, dentists, teachers and social workers. These statutes can be used as a tool to require staff other than correctional officers to report sexual misconduct with inmates.
\end{abstract}

This publication is developed by the NIC/WCL Project on Addressing Prison Rape under NIC Cooperative Agreement 06S20GJJ1.

This is not to be reproduced or cited without permission from the authors.

American University, Washington College of Law

Current as of May 7, 2009 


\section{Fifty State Survey of Mandatory Reporting Statutes}

\section{NIC/WCL Project on Addressing Prison Rape}

\begin{tabular}{|c|c|}
\hline $\begin{array}{l}\text { Persons Required to } \\
\text { Report Cont'd } \\
\text { (Louisiana) }\end{array}$ & $\begin{array}{l}\text { private teacher, teacher's aide, instructional aide, school principal, school staff member, social worker, probation officer, } \\
\text { foster home parent, group home or other child care institutional staff member, personnel of residential home facilities, a } \\
\text { licensed or unlicensed day care provider, or any individual who provides such services to a child; } \\
\text { (e) Police officers or law enforcement officials; } \\
\text { (f) Commercial film and photographic print processor; } \\
\text { (g) Mediators appointed pursuant to Chapter } 6 \text { of Title IV; } \\
\text { (h) A parenting coordinator appointed pursuant to R.S. 9:358.1 et seq.; } \\
\text { (i) Court appointed special advocates (CASA) volunteers under the supervision of a (CASA) program appointed pursuant to } \\
\text { Chapter } 4 \text { of Title IV. }\end{array}$ \\
\hline $\begin{array}{l}\text { Reporting } \\
\text { Procedures } \\
\text { (Louisiana) }\end{array}$ & $\begin{array}{l}\text { LSA-Ch.C. Art. } 610 \text { (West 2008) } \\
\text { A. Reports of child abuse or neglect or that such was a contributing factor in a child's death, where the abuser is believed to be a } \\
\text { parent or caretaker, a person who maintains an interpersonal dating or engagement relationship with the parent or caretaker, or a } \\
\text { person living in the same residence with the parent or caretaker as a spouse whether married or not, shall be made immediately to } \\
\text { the local child protection unit of the department. Reports in which the abuse or neglect is believed to be perpetrated by someone } \\
\text { other than a caretaker, a person who maintains an interpersonal dating or engagement relationship with the parent or caretaker, or a } \\
\text { person living in the same residence with the parent or caretaker as a spouse whether married or not, and the caretaker is not } \\
\text { believed to have any responsibility for the abuse or neglect shall be made immediately to a local or state law enforcement agency. } \\
\text { Dual reporting to both the local child protection unit of the department and the local or state law enforcement agency is permitted. } \\
\text { B. The report shall contain the following information, if known: } \\
\text { (1) The name, address, age, sex, and race of the child. } \\
\text { (2) The nature, extent, and cause of the child's injuries or endangered condition, including any previous known or } \\
\text { (3) The name and address of the child's parent(s) or other caretaker. } \\
\text { (4) The names and ages of all other members of the child's household. }\end{array}$ \\
\hline
\end{tabular}

** For purposes of this chart, corrections officers, police officers, peace officers, probation officers or "catch-all” phrases such as “all persons” have been bolded. However, many mandatory reporters include professionals who may have contact or work in correctional facilities. Such individuals include physicians, nurses, dentists, teachers and social workers. These statutes can be used as a tool to require staff other than correctional officers to report sexual misconduct with inmates.

This publication is developed by the NIC/WCL Project on Addressing Prison Rape under NIC Cooperative Agreement 06S20GJJ1.

This is not to be reproduced or cited without permission from the authors.

American University, Washington College of Law

Current as of May 7, 2009 


\section{Fifty State Survey of Mandatory Reporting Statutes}

\section{NIC/WCL Project on Addressing Prison Rape}

\begin{tabular}{|c|c|}
\hline $\begin{array}{l}\text { Reporting } \\
\text { Procedures Cont'd } \\
\text { (Louisiana) }\end{array}$ & $\begin{array}{l}\text { (5) The name and address of the reporter. } \\
\text { (6) An account of how this child came to the reporter's attention. } \\
\text { (7) Any explanation of the cause of the child's injury or condition offered by the child, the caretaker, or any other } \\
\text { person. } \\
\text { (8) The number of times the reporter has filed a report on the child or the child's siblings. } \\
\text { (9) Any other information which the reporter believes might be important or relevant. }\end{array}$ \\
\hline $\begin{array}{l}\text { Penalty for Failure to } \\
\text { Report } \\
\text { (Louisiana) }\end{array}$ & $\begin{array}{l}\text { LSA-Ch.C. Art. } 609 \text { (West 2008) } \\
\text { (2) Violation of the duties imposed upon a mandatory reporter subjects the offender to criminal prosecution authorized by R.S. } \\
\text { 14:403(A)(1). } \\
\text { LSA-R.S. § 14:403 (West 2008) } \\
\text { A. (1) Any person who, under LA. CHILD. CODE ANN. art. } 609 \text { (2007). is required to report the abuse or neglect or sexual abuse of } \\
\text { a child and knowingly and willfully fails to do so report shall be guilty of a misdemeanor and upon conviction shall be fined not } \\
\text { more than } \$ 500.00 \text { or imprisoned for not more than } 6 \text { months, or both. }\end{array}$ \\
\hline $\begin{array}{l}\text { Mandatory } \\
\text { Reporting Statute } \\
\text { (Louisiana) }\end{array}$ & $\begin{array}{l}\text { AGAINST AN ADULT } \\
\text { LSA-R.S. § 14:403.2 (West 2008) }\end{array}$ \\
\hline $\begin{array}{l}\text { What has to be } \\
\text { reported? } \\
\text { (Louisiana) }\end{array}$ & $\begin{array}{l}\text { LSA-R.S. § 14:403.2 (West 2008) } \\
\text { (C) Having cause to believe that an adult's physical or mental health or welfare has been or may be further adversely affected by } \\
\text { abuse, neglect, or exploitation. }\end{array}$ \\
\hline
\end{tabular}

NOTE:

** For purposes of this chart, corrections officers, police officers, peace officers, probation officers or “catch-all” phrases such as “all persons” have been bolded. However, many mandatory reporters include professionals who may have contact or work in correctional facilities. Such individuals include physicians, nurses, dentists, teachers and social workers. These statutes can be used as a tool to require staff other than correctional officers to report sexual misconduct with inmates.

This publication is developed by the NIC/WCL Project on Addressing Prison Rape under NIC Cooperative Agreement 06S20GJJ1.

This is not to be reproduced or cited without permission from the authors.

American University, Washington College of Law

Current as of May 7, 2009 


\section{Fifty State Survey of Mandatory Reporting Statutes}

\section{NIC/WCL Project on Addressing Prison Rape}

\begin{tabular}{|c|c|}
\hline $\begin{array}{l}\text { Relevant Definitions } \\
\text { (Louisiana) }\end{array}$ & $\begin{array}{l}\text { LSA-R.S. } § 14: 403.2 \text { (West 2008) } \\
\text { (B)(1.1) Abuse is the infliction of physical or mental injury on an adult by other parties, including but not limited to such means as } \\
\text { sexual abuse, abandonment, isolation, exploitation, or extortion of funds or other things of value, to such an extent that his health, } \\
\text { self-determination, or emotional well-being is endangered. } \\
\text { (2) Adult is any person sixty years of age or older, any disabled person eighteen years of age or older, or an emancipated minor. } \\
\text { (6) Exploitation is the illegal or improper use or management of an aged person's or disabled adult's funds, assets, or property, } \\
\text { or the use of an aged person's or disabled adult's power of attorney or guardianship for one's own profit or advantage. } \\
\text { (8) Neglect is the failure, by a caregiver responsible for an adult's care or by other parties, to provide the proper or necessary } \\
\text { support or medical, surgical, or any other care necessary for his well-being. No adult who is being provided treatment in } \\
\text { accordance with a recognized religious method of healing in lieu of medical treatment shall for that reason alone be considered } \\
\text { to be neglected or abused. }\end{array}$ \\
\hline $\begin{array}{l}\text { Persons Required to } \\
\text { Report } \\
\text { (Louisiana) }\end{array}$ & $\begin{array}{l}\text { LSA-R.S. } § 14: 403 \text { (West 2008) } \\
\text { (C) Any person, including but not limited to a health, mental health, and social service practitioner. }\end{array}$ \\
\hline $\begin{array}{l}\text { Reporting } \\
\text { Procedures } \\
\text { (Louisiana) }\end{array}$ & $\begin{array}{l}\text { LSA-R.S. } \$ 14: 403.2 \text { (West 2008) } \\
\text { (D)(1) Reports reflecting the reporter's belief that an adult has been abused or neglected shall be made to any adult protection } \\
\text { agency or to any local or state law enforcement agency. These reports need not name the persons suspected of the alleged abuse or } \\
\text { neglect. } \\
\text { (D)(2) All reports shall contain the name and address of the adult, the name and address of the person responsible for the care of } \\
\text { the adult, if available, and any other pertinent information. }\end{array}$ \\
\hline
\end{tabular}

NOTE:

** For purposes of this chart, corrections officers, police officers, peace officers, probation officers or “catch-all” phrases such as “all persons” have been bolded. However, many mandatory reporters include professionals who may have contact or work in correctional facilities. Such individuals include physicians, nurses, dentists, teachers and social workers. These statutes can be used as a tool to require staff other than correctional officers to report sexual misconduct with inmates.

This publication is developed by the NIC/WCL Project on Addressing Prison Rape under NIC Cooperative Agreement 06S20GJJ1.

This is not to be reproduced or cited without permission from the authors.

American University, Washington College of Law

Current as of May 7, 2009 


\section{Fifty State Survey of Mandatory Reporting Statutes}

\section{NIC/WCL Project on Addressing Prison Rape}

\begin{tabular}{|c|c|}
\hline $\begin{array}{l}\text { Reporting } \\
\text { Procedures Cont'd } \\
\text { (Louisiana) }\end{array}$ & $\begin{array}{l}\text { (D)(3) All reports received by a local or state law enforcement agency shall be referred to the appropriate adult protection agency. } \\
\text { (D)(4) When the appropriate adult protection agency receives a report of sexual or physical abuse, whether directly or by referral, } \\
\text { the agency shall notify the chief law enforcement agency of the parish in which the incident is alleged to have occurred of such } \\
\text { report. Such notification shall be made prior to the end of the business day subsequent to the day on which the adult protection } \\
\text { agency received the report. For the purposes of this Paragraph, the chief law enforcement agency of Orleans Parish shall be the } \\
\text { New Orleans Police Department. }\end{array}$ \\
\hline $\begin{array}{l}\text { Penalty for Failure to } \\
\text { Report } \\
\text { (Louisiana) }\end{array}$ & $\begin{array}{l}\text { LSA-R.S. § 14:403.2(J(1) (West 2008) } \\
\text { Any person who knowingly and willfully fails to report as provided by Subsection C, shall be fined not more than } \$ 500.00 \text { or } \\
\text { imprisoned not more than 6months, or both. }\end{array}$ \\
\hline & MAINE \\
\hline $\begin{array}{l}\text { Mandatory } \\
\text { Reporting Statute } \\
\text { (Maine) }\end{array}$ & $\begin{array}{l}\text { AGAINST A CHILD } \\
22 \text { M.R.S.A. § 4011-A (West 2008) }\end{array}$ \\
\hline $\begin{array}{l}\text { What has to be } \\
\text { reported? } \\
\text { (Maine) }\end{array}$ & $\begin{array}{l}22 \text { M.R.S.A. § 4011-A (West 2008) } \\
\text { (1) When the person knows or has reasonable cause to suspect that a child has been or is likely to be abused or neglected. }\end{array}$ \\
\hline $\begin{array}{l}\text { Relevant Definitions } \\
\text { (Maine) }\end{array}$ & $\begin{array}{l}22 \text { M.R.S.A. § } 4002 \text { (West 2008) } \\
\text { (1) “Abuse” or “neglect” means a threat to a child's health or welfare by physical, mental or emotional injury or impairment, }\end{array}$ \\
\hline
\end{tabular}

NOTE:

** For purposes of this chart, corrections officers, police officers, peace officers, probation officers or “catch-all” phrases such as “all persons” have been bolded. However, many mandatory reporters include professionals who may have contact or work in correctional facilities. Such individuals include physicians, nurses, dentists, teachers and social workers. These statutes can be used as a tool to require staff other than correctional officers to report sexual misconduct with inmates.

This publication is developed by the NIC/WCL Project on Addressing Prison Rape under NIC Cooperative Agreement 06S20GJJ1.

This is not to be reproduced or cited without permission from the authors.

American University, Washington College of Law

Current as of May 7, 2009 


\section{Fifty State Survey of Mandatory Reporting Statutes}

\section{NIC/WCL Project on Addressing Prison Rape}

\begin{tabular}{|c|c|}
\hline $\begin{array}{l}\text { Relevant Definitions } \\
\text { Cont'd } \\
\text { (Maine) }\end{array}$ & $\begin{array}{l}\text { sexual abuse or exploitation, deprivation of essential needs or lack of protection from these or failure to ensure compliance with } \\
\text { school attendance requirements under Title 20-A, section 3272, subsection 2, paragraph B or section 5051-A, subsection } 1 \text {, } \\
\text { paragraph C, by a person responsible for the child. } \\
\text { (2) "Child” means any person who is less than } 18 \text { years of age. } \\
\text { (9) "Person responsible for the child” means a person with responsibility for a child's health or welfare, whether in the child's } \\
\text { home or another home or a facility which, as part of its function, provides for care of the child. It includes the child's custodian. }\end{array}$ \\
\hline $\begin{array}{l}\text { Persons Required to } \\
\text { Report } \\
\text { (Maine) }\end{array}$ & 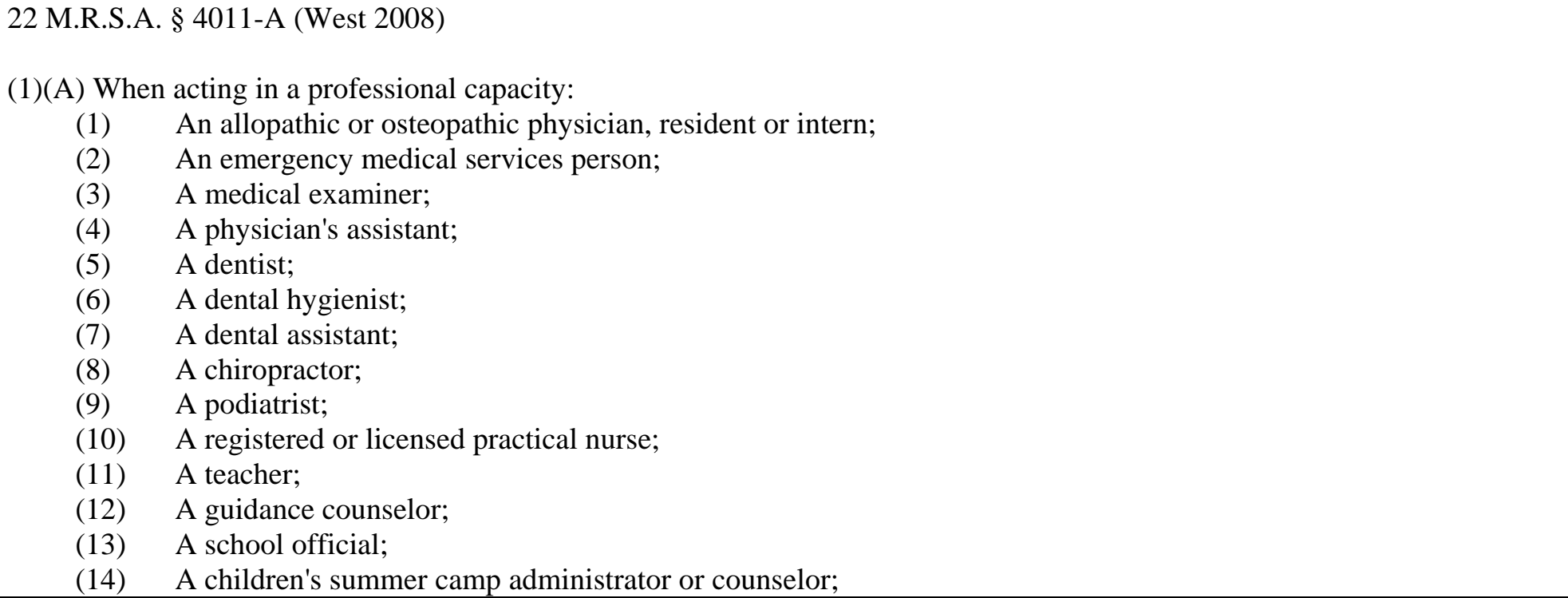 \\
\hline
\end{tabular}

NOTE:

** For purposes of this chart, corrections officers, police officers, peace officers, probation officers or “catch-all” phrases such as “all persons” have been bolded. However, many mandatory reporters include professionals who may have contact or work in correctional facilities. Such individuals include physicians, nurses, dentists, teachers and social workers. These statutes can be used as a tool to require staff other than correctional officers to report sexual misconduct with inmates.

This publication is developed by the NIC/WCL Project on Addressing Prison Rape under NIC Cooperative Agreement 06S20GJJ1.

This is not to be reproduced or cited without permission from the authors.

American University, Washington College of Law

Current as of May 7, 2009 


\section{Fifty State Survey of Mandatory Reporting Statutes}

\section{NIC/WCL Project on Addressing Prison Rape}

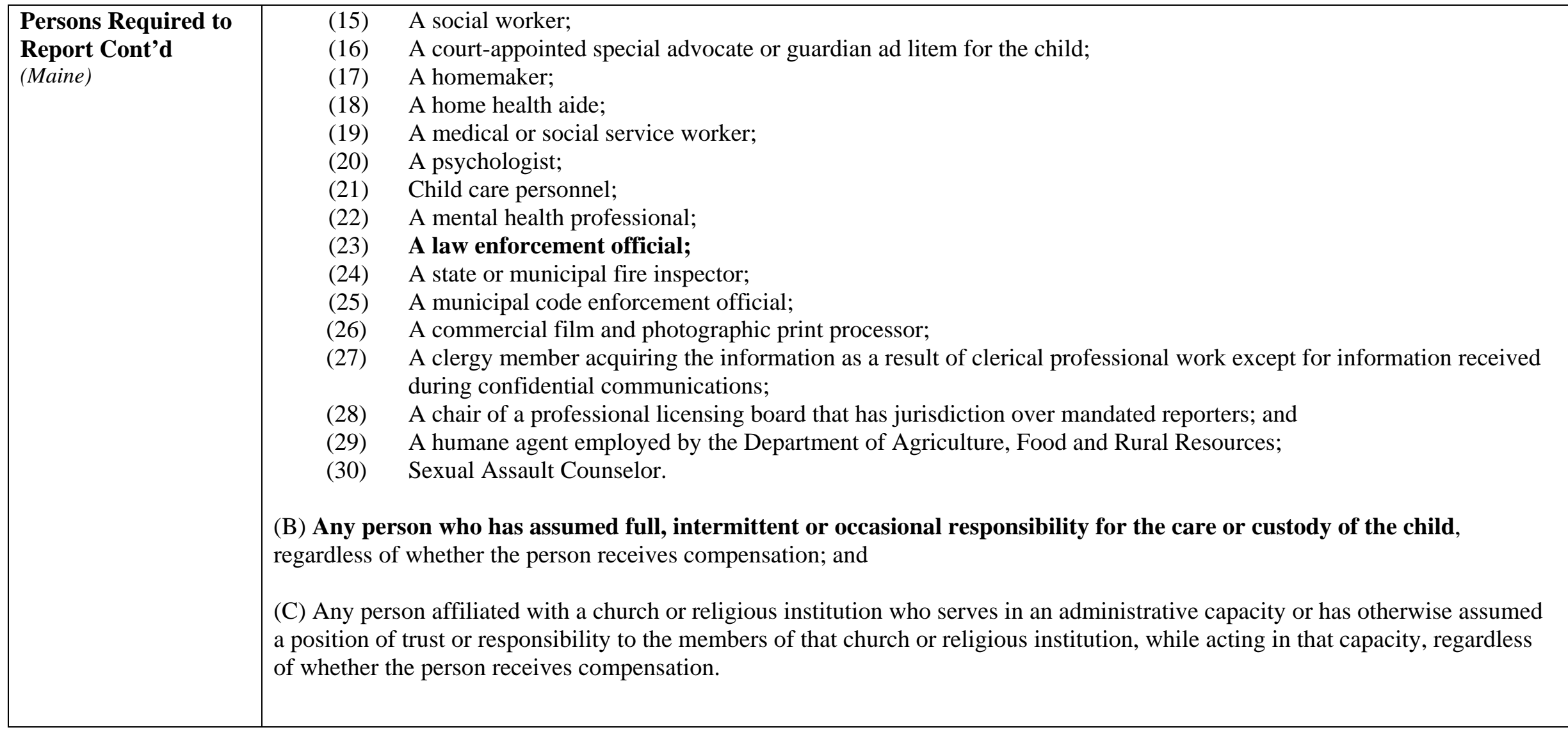

NOTE:

** For purposes of this chart, corrections officers, police officers, peace officers, probation officers or “catch-all” phrases such as “all persons” have been bolded. However, many mandatory reporters include professionals who may have contact or work in correctional facilities. Such individuals include physicians, nurses, dentists, teachers and social workers. These statutes can be used as a tool to require staff other than correctional officers to report sexual misconduct with inmates.

This publication is developed by the NIC/WCL Project on Addressing Prison Rape under NIC Cooperative Agreement 06S20GJJ1.

This is not to be reproduced or cited without permission from the authors.

American University, Washington College of Law

Current as of May 7, 2009 


\section{Fifty State Survey of Mandatory Reporting Statutes}

\section{NIC/WCL Project on Addressing Prison Rape}

\begin{tabular}{|c|c|}
\hline $\begin{array}{l}\text { Reporting } \\
\text { Procedures } \\
\text { (Maine) }\end{array}$ & $\begin{array}{l}22 \text { M.R.S.A. § 4011-A (West 2008) } \\
\text { (1) Immediately report or cause a report to be made to the department of human services. } \\
\text { Whenever a person is required to report in a capacity as a member of the staff of a medical or public or private institution, agency } \\
\text { or facility, that person immediately shall notify either the person in charge of the institution, agency or facility or a designated } \\
\text { agent who then shall cause a report to be made. The staff also may make a report directly to the department. } \\
22 \text { M.R.S.A. § } 4012 \text { (West 2008) } \\
\text { (1) Reports regarding abuse or neglect shall be made immediately by telephone to the department and shall be followed by a } \\
\text { written report within } 48 \text { hours if requested by the department. } \\
\text { (2) The reports shall include the following information if within the knowledge of the person reporting: } \\
\text { (A) The name and address of the child and the persons responsible for his care or custody; } \\
\text { (B) The child's age and sex; } \\
\text { (C) The nature and extent of abuse or neglect, including a description of injuries and any explanation given for them; } \\
\text { (D) A description of sexual abuse or exploitation; } \\
\text { (E) Family composition and evidence of prior abuse or neglect of the child or his siblings; } \\
\text { (F) The source of the report, the person making the report, his occupation and where he can be contacted; } \\
\text { (G) The actions taken by the reporting source, including a description of photographs or x rays taken; and } \\
\text { (H) Any other information that the person making the report believes may be helpful. }\end{array}$ \\
\hline $\begin{array}{l}\text { Penalty for Failure to } \\
\text { Report } \\
\text { (Maine) }\end{array}$ & $\begin{array}{l}22 \text { M.R.S.A. } § 4009 \text { (West 2008) } \\
\text { A person who knowingly violates a provision of this chapter commits a civil violation for which a forfeiture of not more than } \$ 500 \\
\text { may be adjudged. }\end{array}$ \\
\hline
\end{tabular}

** For purposes of this chart, corrections officers, police officers, peace officers, probation officers or “catch-all” phrases such as “all persons” have been bolded. However, many mandatory reporters include professionals who may have contact or work in correctional facilities. Such individuals include physicians, nurses, dentists, teachers and social workers. These statutes can be used as a tool to require staff other than correctional officers to report sexual misconduct with inmates.

This publication is developed by the NIC/WCL Project on Addressing Prison Rape under NIC Cooperative Agreement 06S20GJJ1.

This is not to be reproduced or cited without permission from the authors.

American University, Washington College of Law

Current as of May 7, 2009 


\section{Fifty State Survey of Mandatory Reporting Statutes}

\section{NIC/WCL Project on Addressing Prison Rape}

\begin{tabular}{|c|c|}
\hline $\begin{array}{l}\text { Mandatory } \\
\text { Reporting Statute } \\
\text { (Maine) }\end{array}$ & $\begin{array}{l}\text { AGAINST AN ADULT } \\
22 \text { M.R.S.A. } § 3477 \text { (West 2008) }\end{array}$ \\
\hline $\begin{array}{l}\text { What has to be } \\
\text { reported? } \\
\text { (Maine) }\end{array}$ & $\begin{array}{l}22 \text { M.R.S.A. § } 3477 \text { (West 2008) } \\
\text { (1) Reasonable cause to suspect that an incapacitated or dependent adult has been or is at substantial risk of abuse. }\end{array}$ \\
\hline $\begin{array}{l}\text { Relevant Definitions } \\
\text { (Maine) }\end{array}$ & $\begin{array}{l}\text { ME. REV. STAT. ANN. tit. } 22 \S 3472 \text { (West 2008) } \\
\text { (1) “Abuse” means the infliction of injury, unreasonable confinement, intimidation or cruel punishment that causes or is likely to } \\
\text { cause physical harm or pain or mental anguish; sexual abuse or sexual exploitation; or the intentional, knowing or reckless } \\
\text { deprivation of essential needs. "Abuse" includes acts and omissions. } \\
\text { (2) “Adult” means any person who has attained } 18 \text { years of age or who is a legally emancipated minor. } \\
\text { (6) “Dependent adult” means an adult who has a physical or mental condition that substantially impairs the adult's ability to } \\
\text { adequately provide for that adult's daily needs. "Dependent adult” includes, but is not limited to, any of the following: } \\
\text { A. A resident of a nursing home licensed or required to be licensed under section } 1817 \\
\text { B. A resident of a facility providing assisted living services licensed or required to be licensed pursuant to section } 7801 \text {; or } \\
\text { C. A person considered a dependent person under Title } 17-A \text {, section } 555 \text {. } \\
\text { (9) Exploitation means the illegal or improper use of an incapacitated or dependent adult or that adult's resources for another's } \\
\text { profit or advantage. }\end{array}$ \\
\hline
\end{tabular}

** For purposes of this chart, corrections officers, police officers, peace officers, probation officers or “catch-all” phrases such as “all persons” have been bolded. However, many mandatory reporters include professionals who may have contact or work in correctional facilities. Such individuals include physicians, nurses, dentists, teachers and social workers. These statutes can be used as a tool to require staff other than correctional officers to report sexual misconduct with inmates.

This publication is developed by the NIC/WCL Project on Addressing Prison Rape under NIC Cooperative Agreement 06S20GJJ1.

This is not to be reproduced or cited without permission from the authors.

American University, Washington College of Law

Current as of May 7, 2009 


\section{Fifty State Survey of Mandatory Reporting Statutes}

\section{NIC/WCL Project on Addressing Prison Rape}

\begin{tabular}{|c|c|}
\hline $\begin{array}{l}\text { Relevant Definitions } \\
\text { Cont'd } \\
\text { (Maine) }\end{array}$ & $\begin{array}{l}\text { (10) Incapacitated adult means any adult who is impaired by reason of mental illness, mental deficiency, physical illness or } \\
\text { disability to the extent that that individual lacks sufficient understanding or capacity to make or communicate responsible } \\
\text { decisions concerning that individual's person, or to the extent the adult can not effectively manage or apply that individual's estate } \\
\text { to necessary ends. } \\
\text { (11) Neglect means a threat to an adult's health or welfare by physical or mental injury or impairment, deprivation of essential } \\
\text { needs or lack of protection from these. } \\
\text { (15) Sexual abuse or sexual exploitation means contact or interaction of a sexual nature involving an incapacitated or dependent } \\
\text { adult without that adult's informed consent. }\end{array}$ \\
\hline $\begin{array}{l}\text { Persons Required to } \\
\text { Report } \\
\text { (Maine) }\end{array}$ & $\begin{array}{l}22 \text { M.R.S.A. § } 3477 \text { (West 2008) } \\
\text { (1)(A)While acting in a professional capacity: } \\
\text { (1) An allopathic or osteopathic physician; } \\
\text { (2) A medical intern; } \\
\text { (3) A medical examiner; } \\
\text { (4) A physician's assistant; } \\
\text { (5) A dentist; } \\
\text { (6) A chiropractor; } \\
\text { (7) A podiatrist; } \\
\text { (8) A registered or licensed practical nurse; } \\
\text { (9) A certified nursing assistant; } \\
\text { (10) A social worker; } \\
\text { (11) A psychologist; } \\
\text { (12) A pharmacist; }\end{array}$ \\
\hline
\end{tabular}

NOTE:

** For purposes of this chart, corrections officers, police officers, peace officers, probation officers or “catch-all” phrases such as “all persons” have been bolded. However, many mandatory reporters include professionals who may have contact or work in correctional facilities. Such individuals include physicians, nurses, dentists, teachers and social workers. These statutes can be used as a tool to require staff other than correctional officers to report sexual misconduct with inmates.

This publication is developed by the NIC/WCL Project on Addressing Prison Rape under NIC Cooperative Agreement 06S20GJJ1.

This is not to be reproduced or cited without permission from the authors.

American University, Washington College of Law

Current as of May 7, 2009 


\section{Fifty State Survey of Mandatory Reporting Statutes}

\section{NIC/WCL Project on Addressing Prison Rape}

\begin{tabular}{|c|c|}
\hline $\begin{array}{l}\text { Persons Required to } \\
\text { Report Cont'd } \\
\text { (Maine) }\end{array}$ & $\begin{array}{l}\text { (13) A physical therapist; } \\
\text { (14) A speech therapist; } \\
\text { (15) An occupational therapist; } \\
\text { (16) A mental health professional; } \\
\text { (17) A law enforcement official; } \\
\text { (18) Emergency room personnel; } \\
\text { (19) An ambulance attendant; } \\
\text { (20) An emergency medical technician; } \\
\text { (21) Unlicensed assistive personnel; } \\
\text { (22) A humane agent employed by the Department of Agriculture, Food and Rural Resources; or } \\
\text { (23) A clergy member acquiring the information as a result of clerical professional work except for information received } \\
\text { during confidential communications; } \\
\text { (B) Any person who has assumed full, intermittent or occasional -responsibility for the care or custody of the incapacitated } \\
\text { or dependent adult, regardless of whether the person receives compensation; or } \\
\text { (C) Any person affiliated with a church or religious institution who serves in an administrative capacity or has otherwise assumed } \\
\text { a position of trust or responsibility to the members of that church or religious institution, while acting in that capacity, regardless } \\
\text { of whether the person receives compensation. }\end{array}$ \\
\hline $\begin{array}{l}\text { Reporting } \\
\text { Procedures } \\
\text { (Maine) }\end{array}$ & $\begin{array}{l}22 \text { M.R.S.A. } § 3477 \text { (West 2008) } \\
\text { (2) Reports regarding abuse, neglect or exploitation must be made immediately by telephone to the department and must be } \\
\text { followed by a written report within } 48 \text { hours if requested by the department. The reports must contain the name and address of the } \\
\text { involved adult; information regarding the nature and extent of the abuse, neglect or exploitation; the source of the report; the } \\
\text { person making the report; that person's occupation; and where that person can be contacted. The report may contain any other } \\
\text { information that the reporter believes may be helpful. }\end{array}$ \\
\hline
\end{tabular}

** For purposes of this chart, corrections officers, police officers, peace officers, probation officers or “catch-all” phrases such as “all persons” have been bolded. However, many mandatory reporters include professionals who may have contact or work in correctional facilities. Such individuals include physicians, nurses, dentists, teachers and social workers. These statutes can be used as a tool to require staff other than correctional officers to report sexual misconduct with inmates.

This publication is developed by the NIC/WCL Project on Addressing Prison Rape under NIC Cooperative Agreement 06S20GJJ1.

This is not to be reproduced or cited without permission from the authors.

American University, Washington College of Law

Current as of May 7, 2009 


\section{Fifty State Survey of Mandatory Reporting Statutes}

\section{NIC/WCL Project on Addressing Prison Rape}

\begin{tabular}{|c|c|}
\hline $\begin{array}{l}\text { Reporting } \\
\text { Procedures Cont'd } \\
\text { (Maine) }\end{array}$ & $\begin{array}{l}\text { ME. REV. STAT. ANN. tit. } 22 \S 3477 \text { (West 2008) } \\
\text { (3) Confidentiality in case of treatment of individual suspected of causing abuse, neglect or exploitation: This section does not } \\
\text { require any person acting in that person's professional capacity to report when all of the following requirements are met: } \\
\text { (A) The factual basis for knowing or suspecting abuse, neglect or exploitation of an adult covered under this subchapter derives } \\
\text { from the professional's treatment of the individual suspected of causing the abuse, neglect or exploitation; } \\
\text { (B) The treatment was sought by the individual for a problem relating to the abuse, neglect or exploitation; and } \\
\text { (C) In the opinion of the person required to report, the abused, neglected or exploited adult's life or health is not immediately } \\
\text { threatened. }\end{array}$ \\
\hline $\begin{array}{l}\text { Penalty for Failure to } \\
\text { Report } \\
\text { (Maine) }\end{array}$ & $\begin{array}{l}22 \text { M.R.S.A. } \S 3475 \text { (West 2008) } \\
\text { A person who knowingly violates a provision of this chapter commits a civil violation for which a forfeiture of not more than } \$ 500 \\
\text { may be adjudged. Any licensed, registered, accredited or certified professional who has been adjudged to have violated a } \\
\text { provision of this chapter must, in addition to any financial penalty, be reported by the court or the department to the appropriate } \\
\text { professional licensing organization, registration board, accrediting unit or facility. }\end{array}$ \\
\hline \multicolumn{2}{|r|}{ MARYLAND } \\
\hline $\begin{array}{l}\text { Mandatory } \\
\text { Reporting Statute } \\
\text { (Maryland) }\end{array}$ & $\begin{array}{l}\text { AGAINST A CHILD } \\
\text { MD CODE, FAMILY LAW, § 5-704 (West 2008) }\end{array}$ \\
\hline
\end{tabular}

NOTE:

** For purposes of this chart, corrections officers, police officers, peace officers, probation officers or “catch-all” phrases such as “all persons” have been bolded. However, many mandatory reporters include professionals who may have contact or work in correctional facilities. Such individuals include physicians, nurses, dentists, teachers and social workers. These statutes can be used as a tool to require staff other than correctional officers to report sexual misconduct with inmates.

This publication is developed by the NIC/WCL Project on Addressing Prison Rape under NIC Cooperative Agreement 06S20GJJ1.

This is not to be reproduced or cited without permission from the authors.

American University, Washington College of Law

Current as of May 7, 2009 


\section{Fifty State Survey of Mandatory Reporting Statutes}

\section{NIC/WCL Project on Addressing Prison Rape}

\begin{tabular}{|c|c|}
\hline $\begin{array}{l}\text { What has to be } \\
\text { reported? } \\
\text { (Maryland) }\end{array}$ & $\begin{array}{l}\text { MD CODE, FAMILY LAW, } \S \text { 5-704 (West 2008) } \\
\text { (a)(1)(i) Reason to believe that a child has been subjected to abuse. }\end{array}$ \\
\hline $\begin{array}{l}\text { Relevant Definitions } \\
\text { (Maryland) }\end{array}$ & 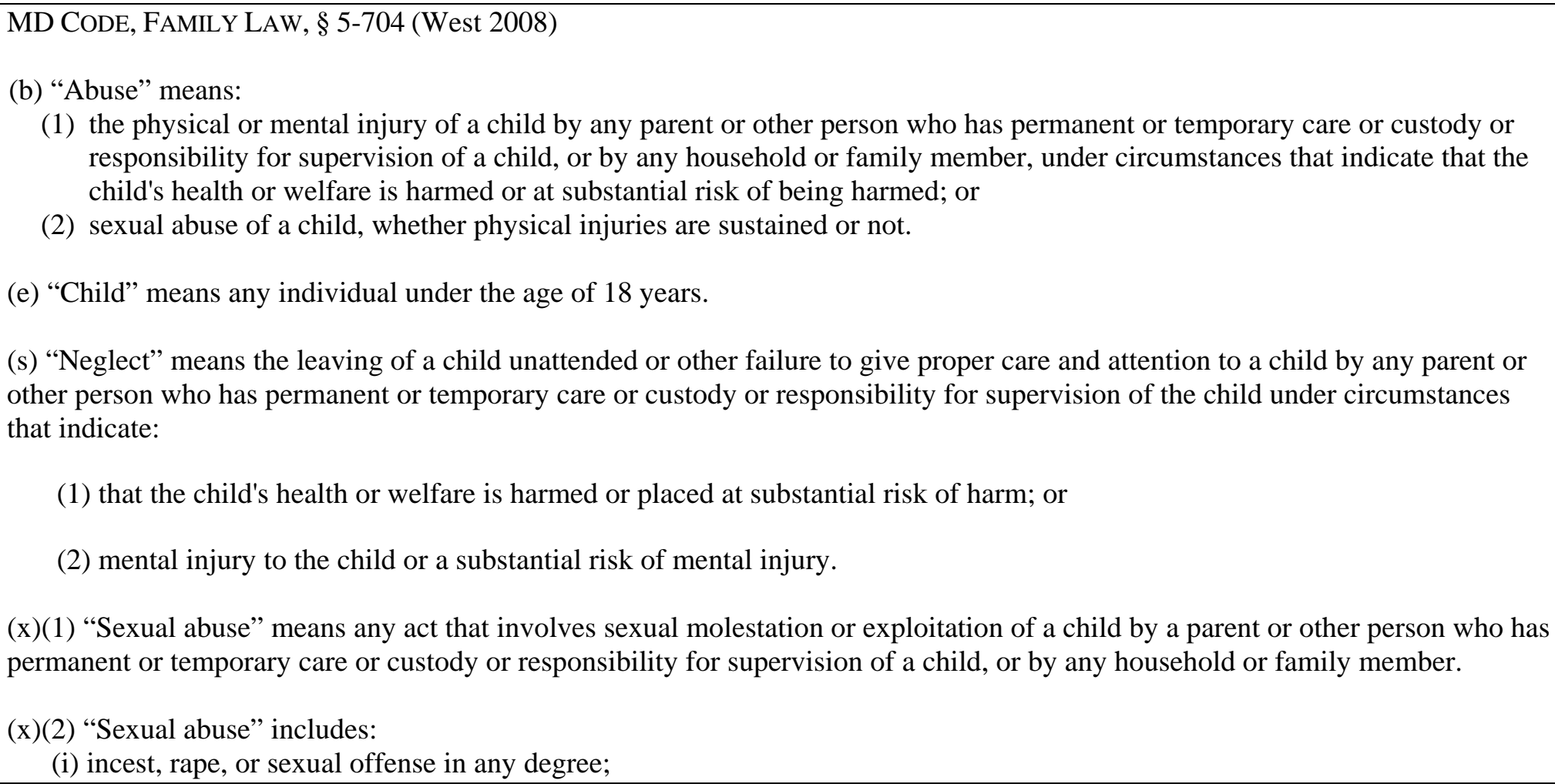 \\
\hline
\end{tabular}

NOTE:

** For purposes of this chart, corrections officers, police officers, peace officers, probation officers or “catch-all” phrases such as “all persons” have been bolded. However, many mandatory reporters include professionals who may have contact or work in correctional facilities. Such individuals include physicians, nurses, dentists, teachers and social workers. These statutes can be used as a tool to require staff other than correctional officers to report sexual misconduct with inmates.

This publication is developed by the NIC/WCL Project on Addressing Prison Rape under NIC Cooperative Agreement 06S20GJJ1.

This is not to be reproduced or cited without permission from the authors.

American University, Washington College of Law

Current as of May 7, 2009 


\section{Fifty State Survey of Mandatory Reporting Statutes}

\section{NIC/WCL Project on Addressing Prison Rape}

\begin{tabular}{|c|c|}
\hline $\begin{array}{l}\text { Relevant Definitions } \\
\text { Cont'd } \\
\text { (Maryland) }\end{array}$ & $\begin{array}{l}\text { (ii) sodomy; and } \\
\text { (iii) unnatural or perverted sexual practices. } \\
\text { (g)(1) Educator or human service worker means any provisional employee of any correctional, public, parochial or private } \\
\text { educational, health, juvenile service, social or social service agency, institution, or licensed facility. } \\
\text { (g)(2) Educator or human service worker includes: (i) any teacher; (ii) any counselor; (iii) any social worker; (iv) any caseworker; } \\
\text { and (v) any probation or parole officer. } \\
\text { (n)(1) Law enforcement agency means a State, county, or municipal police department, bureau, or agency. } \\
\text { (n)(2) Law enforcement agency includes (i) a State, county or municipal police department or agency; (ii) a sheriff's office; (iii) a } \\
\text { State’s Attorney’s office; and (iv) the Attorney General’s office. }\end{array}$ \\
\hline $\begin{array}{l}\text { Persons Required to } \\
\text { Report } \\
\text { (Maryland) }\end{array}$ & $\begin{array}{l}\text { MD CODE, FAMILY LAW, § 5-704 (West 2008) } \\
\text { (a) Each of the following acting in a professional capacity: } \\
\text { - Police officer; } \\
\text { - health practitioner; } \\
\text { - educator; } \\
\text { - human service worker. } \\
\text { (a)(2) If acting as a staff member of a: } \\
\text { - Juvenile detention center; } \\
\text { - Hospital; } \\
\text { - Public health agency; }\end{array}$ \\
\hline
\end{tabular}

** For purposes of this chart, corrections officers, police officers, peace officers, probation officers or “catch-all” phrases such as “all persons” have been bolded. However, many mandatory reporters include professionals who may have contact or work in correctional facilities. Such individuals include physicians, nurses, dentists, teachers and social workers. These statutes can be used as a tool to require staff other than correctional officers to report sexual misconduct with inmates.

This publication is developed by the NIC/WCL Project on Addressing Prison Rape under NIC Cooperative Agreement 06S20GJJ1.

This is not to be reproduced or cited without permission from the authors.

American University, Washington College of Law

Current as of May 7, 2009 


\section{Fifty State Survey of Mandatory Reporting Statutes}

\section{NIC/WCL Project on Addressing Prison Rape}

\begin{tabular}{|c|c|}
\hline $\begin{array}{l}\text { Persons Required to } \\
\text { Report } \\
\text { (Maryland) }\end{array}$ & $\begin{array}{l}\text { - Child care institution; } \\
\text { - School or similar institution } \\
\text { MD CODE, FAMILY LAW, § 5-705 (West 2008) } \\
\text { (a)(1) A person in this state other than a health practitioner, police officer, or educator or human service worker who has reason } \\
\text { to believe that a child has been subjected to abuse or neglect shall report. }\end{array}$ \\
\hline $\begin{array}{l}\text { Reporting } \\
\text { Procedures } \\
\text { (Maryland) }\end{array}$ & $\begin{array}{l}\text { MD CODE, FAMILY LAW, } \S 5-704 \text { (West 2008) } \\
\text { (b)(1) An individual who notifies the appropriate authorities shall make: } \\
\text { (i) an oral report, by telephone or direct communication, as soon as possible: } \\
\text { 1. to the local department or appropriate law enforcement agency if the person has reason to believe that the child has } \\
\text { been subjected to abuse; or } \\
\text { 2. to the local department if the person has reason to believe that the child has been subjected to neglect; and } \\
\text { (ii) a written report: } \\
\text { 1. to the local department not later than } 48 \text { hours after the contact, examination, attention, or treatment that caused the } \\
\text { individual to believe that the child had been subjected to abuse or neglect; and, } \\
\text { abuse. } \\
\text { (c) Insofar as is reasonably possible, an individual who makes a report shall include in the report the following information: } \\
\text { 1. the name, age, and home address of the child; } \\
\text { 2. the name and home address of the child's parent or other person who is responsible for the child's care; } \\
\text { 3. the whereabouts of the child; }\end{array}$ \\
\hline
\end{tabular}

NOTE:

** For purposes of this chart, corrections officers, police officers, peace officers, probation officers or “catch-all” phrases such as “all persons” have been bolded. However, many mandatory reporters include professionals who may have contact or work in correctional facilities. Such individuals include physicians, nurses, dentists, teachers and social workers. These statutes can be used as a tool to require staff other than correctional officers to report sexual misconduct with inmates.

This publication is developed by the NIC/WCL Project on Addressing Prison Rape under NIC Cooperative Agreement 06S20GJJ1.

This is not to be reproduced or cited without permission from the authors.

American University, Washington College of Law

Current as of May 7, 2009 


\section{Fifty State Survey of Mandatory Reporting Statutes}

\section{NIC/WCL Project on Addressing Prison Rape}

\begin{tabular}{|c|c|}
\hline $\begin{array}{l}\text { Reporting } \\
\text { Procedures } \\
\text { (Maryland) }\end{array}$ & $\begin{array}{l}\text { 4. the nature and extent of the abuse or neglect of the child, including any evidence or information available to the reporter } \\
\text { concerning possible previous instances of abuse or neglect; and } \\
\text { 5. any other information that would help to determine: } \\
\text { (i) the cause of the suspected abuse or neglect; and } \\
\text { (ii) the identity of any individual responsible for the abuse or neglect. }\end{array}$ \\
\hline $\begin{array}{l}\text { Penalty for Failure to } \\
\text { Report } \\
\text { (Maryland) }\end{array}$ & $\begin{array}{l}\text { MD CODE, PUBLIC SAFETY, § 3-212 (West 2008) } \\
\text { (a) Subject to the hearing provisions of subsection (b) of this section, the Commission may suspend or revoke the certification of a } \\
\text { police officer if the police officer: } \\
\text { (1) violates or fails to meet the Commission's standards; or } \\
\text { (2) knowingly fails to report suspected child abuse in violation of } \S 5-704 \text { of the Family Law Article. } \\
\text { MD CoDE, HEALTH OCCUPATIONS, § 19-311 (West 2008) } \\
\text { The Board may deny a license to any applicant, fine a licensee, reprimand any licensee, place any licensee on probation or suspect } \\
\text { or revoke a license if the applicant or licensee: } \\
\text { (15) Knowingly fails to report suspected child abuse in violation of } \S 5-704 \text { of the Family Law Article. (Social Workers) } \\
\text { MD CoDE, HEALTH OCCUPATIONS, § 14-404 (West 2008) } \\
\text { (a) The Board, on the affirmative vote of a majority of the quorum, may reprimand any licensee, place any licensee on probation } \\
\text { or suspend or revoke a license if the licensee: } \\
\text { (25) Knowingly fails to report suspected child abuse in violation of } \S 5-704 \text { of the Family Law Article. (Physicians) }\end{array}$ \\
\hline
\end{tabular}

NOTE:

** For purposes of this chart, corrections officers, police officers, peace officers, probation officers or "catch-all” phrases such as "all persons" have been bolded. However, many mandatory reporters include professionals who may have contact or work in correctional facilities. Such individuals include physicians, nurses, dentists, teachers and social workers. These statutes can be used as a tool to require staff other than correctional officers to report sexual misconduct with inmates.

This publication is developed by the NIC/WCL Project on Addressing Prison Rape under NIC Cooperative Agreement 06S20GJJ1.

This is not to be reproduced or cited without permission from the authors.

American University, Washington College of Law

Current as of May 7, 2009 


\section{Fifty State Survey of Mandatory Reporting Statutes}

\section{NIC/WCL Project on Addressing Prison Rape}

\begin{tabular}{|c|c|}
\hline $\begin{array}{l}\text { Mandatory } \\
\text { Reporting Statute } \\
\text { (Maryland) }\end{array}$ & $\begin{array}{l}\text { AGAINST AN ADULT } \\
\text { MD CODE, FAMILY LAW } \S 14-302 \text { (West 2008). }\end{array}$ \\
\hline $\begin{array}{l}\text { What has to be } \\
\text { reported? } \\
\text { (Maryland) } \\
\text { What has to be } \\
\text { reported? Cont'd } \\
\text { (Maryland) }\end{array}$ & $\begin{array}{l}\text { MD CODE, FAMILY LAW § 14-302 (West 2008) } \\
\text { (a) Each health practitioner, police officer, or human service worker who contacts, examines, attends, or treats an alleged } \\
\text { vulnerable adult, and who has reason to believe that the alleged vulnerable adult has been subjected to abuse, neglect, self-neglect, } \\
\text { or exploitation. }\end{array}$ \\
\hline $\begin{array}{l}\text { Relevant Definitions } \\
\text { (Maryland) }\end{array}$ & $\begin{array}{l}\text { MD CODE, FAMILY LAW } \S 14-101 \text { (West 2008) } \\
\text { (b) Abuse means the sustaining of any physical injury by a vulnerable adult as a result of cruel or inhumane treatment or as a result } \\
\text { of a malicious act by any person. } \\
\text { (f) Exploitation means any action which involves the misuse of a vulnerable adult's funds, property, or person. } \\
\text { (h)(1) Human service worker means any professional employee of any public or private health or social services agency or } \\
\text { provider. } \\
\text { (2) "Human service worker" includes: } \\
\text { (i) any social worker; and } \\
\text { (ii) any caseworker. } \\
\text { (i) Law enforcement agency means a State, county, or municipal police department, bureau, or agency. } \\
\text { (q) Vulnerable adult means an adult who lacks the physical or mental capacity to provide for the adult's daily needs. }\end{array}$ \\
\hline
\end{tabular}

NOTE:

** For purposes of this chart, corrections officers, police officers, peace officers, probation officers or "catch-all” phrases such as "all persons" have been bolded. However, many mandatory reporters include professionals who may have contact or work in correctional facilities. Such individuals include physicians, nurses, dentists, teachers and social workers. These statutes can be used as a tool to require staff other than correctional officers to report sexual misconduct with inmates.

This publication is developed by the NIC/WCL Project on Addressing Prison Rape under NIC Cooperative Agreement 06S20GJJ1.

This is not to be reproduced or cited without permission from the authors.

American University, Washington College of Law

Current as of May 7, 2009 


\section{Fifty State Survey of Mandatory Reporting Statutes}

\section{NIC/WCL Project on Addressing Prison Rape}

\begin{tabular}{|c|c|}
\hline $\begin{array}{l}\text { Relevant Definitions } \\
\text { Cont'd } \\
\text { (Maryland) }\end{array}$ & $\begin{array}{l}\text { (l)(1) Neglect means the willful deprivation of a vulnerable adult of adequate food, clothing, essential medical treatment or } \\
\text { habilitative therapy, shelter, or supervision. } \\
\text { (2) Neglect does not include the providing of nonmedical remedial care and treatment for the healing of injury or disease, with } \\
\text { the consent of the vulnerable adult, recognized by State law instead of medical treatment. } \\
\text { (p) Self-neglect means the inability of a vulnerable adult to provide the vulnerable adult with the services: } \\
\text { (1) that are necessary for the vulnerable adult's physical and mental health; and } \\
\text { (2) the absence of which impairs or threatens the vulnerable adult's well-being. }\end{array}$ \\
\hline $\begin{array}{l}\text { Persons Required to } \\
\text { Report } \\
\text { (Maryland) }\end{array}$ & $\begin{array}{l}\text { MD CODE, FAMILY LAW § 14-302 (West 2008) } \\
\text { (a) Health practitioner, police officer, or human service worker. }\end{array}$ \\
\hline $\begin{array}{l}\text { Reporting } \\
\text { Procedures } \\
\text { (Maryland) }\end{array}$ & $\begin{array}{l}\text { MD CODE, FAMILY LAW } \S 14-302 \text { (West 2008) } \\
\text { (a)(1) Notify the local department; and } \\
\text { (a)(2) If acting as a staff member of a hospital or public health agency, immediately notify and give all the information required by } \\
\text { this section to the head of the institution or the designee of the head. } \\
\text { MD CODE, FAMILY LAW } \S 14-302 \text { (West 2008) } \\
\text { (b) An individual who is required to make a report under subsection (a) of this section shall make the report by telephone, direct } \\
\text { communication, or in writing to the local department as soon as possible. }\end{array}$ \\
\hline
\end{tabular}

NOTE:

** For purposes of this chart, corrections officers, police officers, peace officers, probation officers or “catch-all” phrases such as “all persons” have been bolded. However, many mandatory reporters include professionals who may have contact or work in correctional facilities. Such individuals include physicians, nurses, dentists, teachers and social workers. These statutes can be used as a tool to require staff other than correctional officers to report sexual misconduct with inmates.

This publication is developed by the NIC/WCL Project on Addressing Prison Rape under NIC Cooperative Agreement 06S20GJJ1.

This is not to be reproduced or cited without permission from the authors.

American University, Washington College of Law

Current as of May 7, 2009 


\section{Fifty State Survey of Mandatory Reporting Statutes}

\section{NIC/WCL Project on Addressing Prison Rape}

\begin{tabular}{|c|c|}
\hline $\begin{array}{l}\text { Reporting } \\
\text { Procedures Cont'd } \\
\text { (Maryland) }\end{array}$ & $\begin{array}{l}\text { (d) Contents of report: Insofar as is reasonably possible, an individual who makes a report under this section shall include in the } \\
\text { report the following information: } \\
\text { (1) the name, age, and home address of the alleged vulnerable adult; } \\
\text { (2) the name and home address of the person responsible for the care of the alleged vulnerable adult; } \\
\text { (3) the whereabouts of the alleged vulnerable adult; } \\
\text { (4) the nature of the alleged vulnerable adult's incapacity; } \\
\text { (5) the nature and extent of the abuse, neglect, self-neglect, or exploitation of the alleged vulnerable adult, including evidence or } \\
\text { information available to the reporter concerning previous injury possibly resulting from abuse, neglect, self-neglect, or } \\
\text { exploitation; and } \\
\text { (6) any other information that would help to determine: } \\
\text { (i) the cause of the suspected abuse, neglect, self-neglect, or exploitation; and } \\
\text { (ii) the identity of any individual responsible for the abuse, neglect, self-neglect, or exploitation. }\end{array}$ \\
\hline $\begin{array}{l}\text { Penalty for Failure to } \\
\text { Report } \\
\text { (Maryland) }\end{array}$ & No enumerated sanctions. \\
\hline & MASSACHUSETTS \\
\hline $\begin{array}{l}\text { Mandatory } \\
\text { Reporting Statute } \\
\text { (Massachusetts) }\end{array}$ & $\begin{array}{l}\text { AGAINST A CHILD } \\
\text { M.G.L.A. } 119 \S 51 \text { A (West 2008) }\end{array}$ \\
\hline
\end{tabular}

NOTE:

** For purposes of this chart, corrections officers, police officers, peace officers, probation officers or "catch-all” phrases such as "all persons" have been bolded. However, many mandatory reporters include professionals who may have contact or work in correctional facilities. Such individuals include physicians, nurses, dentists, teachers and social workers. These statutes can be used as a tool to require staff other than correctional officers to report sexual misconduct with inmates.

This publication is developed by the NIC/WCL Project on Addressing Prison Rape under NIC Cooperative Agreement 06S20GJJ1.

This is not to be reproduced or cited without permission from the authors.

American University, Washington College of Law

Current as of May 7, 2009 


\section{Fifty State Survey of Mandatory Reporting Statutes}

\section{NIC/WCL Project on Addressing Prison Rape}

\begin{tabular}{|c|c|}
\hline $\begin{array}{l}\text { What has to be } \\
\text { reported? } \\
\text { (Massachusetts) }\end{array}$ & $\begin{array}{l}\text { M.G.L.A. } 119 \S 51 \text { A (West 2008) } \\
\text { Reasonable cause in their professional capacity to believe that a child under the age of } 18 \text { years is suffering physical or emotional } \\
\text { injury resulting from abuse inflicted upon him which causes harm or substantial risk of harm to the child's health or welfare } \\
\text { including sexual abuse. }\end{array}$ \\
\hline $\begin{array}{l}\text { Relevant Definitions } \\
\text { (Massachusetts) }\end{array}$ & $\begin{array}{l}\text { M.G.L.A. } 119 \S 51 \text { A (West 2008) } \\
\text { “Child” means under the age of eighteen years. } \\
\text { “Abuse” means causing harm or substantial risk of harm including sexual abuse caused by physical or emotional injury. }\end{array}$ \\
\hline $\begin{array}{l}\text { Persons Required to } \\
\text { Report } \\
\text { (Massachusetts) }\end{array}$ & $\begin{array}{l}\text { M.G.L.A. } 119 \text { § 51A (West 2008) } \\
\text { - Parole officer; } \\
\text { - Policeman or firefighter; } \\
\text { - Probation officer; } \\
\text { - Clerk/magistrate of the district courts; } \\
\text { - Any physician, medical intern, hospital personnel engaged in the examination, care or treatment of persons, medical } \\
\text { examiner, psychologist, emergency medical technician, dentist, nurse, chiropractor, podiatrist, optometrist, osteopath; } \\
\text { - Public or private school teacher, educational administrator, guidance or family counselor; } \\
\text { - Day care worker or any person paid to care for or work with a child in any public or private facility, or home or program } \\
\text { funded by the commonwealth or licensed pursuant to the provisions of chapter twenty-eight A, which provides day care } \\
\text { or residential services to children or which provides the services of child care resource and referral agencies, voucher } \\
\text { management agencies, family day care systems and child care food programs; }\end{array}$ \\
\hline
\end{tabular}

** For purposes of this chart, corrections officers, police officers, peace officers, probation officers or “catch-all” phrases such as “all persons” have been bolded. However, many mandatory reporters include professionals who may have contact or work in correctional facilities. Such individuals include physicians, nurses, dentists, teachers and social workers. These statutes can be used as a tool to require staff other than correctional officers to report sexual misconduct with inmates.

This publication is developed by the NIC/WCL Project on Addressing Prison Rape under NIC Cooperative Agreement 06S20GJJ1.

This is not to be reproduced or cited without permission from the authors.

American University, Washington College of Law

Current as of May 7, 2009 


\section{Fifty State Survey of Mandatory Reporting Statutes}

\section{NIC/WCL Project on Addressing Prison Rape}

\begin{tabular}{|c|c|}
\hline $\begin{array}{l}\text { Persons Required to } \\
\text { Report Cont'd } \\
\text { (Massachusetts) }\end{array}$ & $\begin{array}{l}\text { - Social worker; } \\
\text { - Foster parent; } \\
\text { - Licensor of the office of child care services or any successor agency; } \\
\text { - School attendance officer; } \\
\text { - Allied mental health and human services professional as licensed pursuant to the provisions of section one hundred and } \\
\text { sixty-five of chapter one hundred and twelve; } \\
\text { - Drug and alcoholism counselor; } \\
\text { - Psychiatrist, and clinical social worker; } \\
\text { - Priest, rabbi, clergy member, ordained or licensed minister, leader of any church or religious body, accredited Christian } \\
\text { Science practitioner, person performing official duties on behalf of a church or religious body that are recognized as the } \\
\text { duties of a priest, rabbi, clergy, ordained or licensed minister, leader of any church or religious body, or accredited } \\
\text { Christian Science practitioner, or person employed by a church or religious body to supervise, educate, coach, train or } \\
\text { counsel a child on a regular basis. }\end{array}$ \\
\hline $\begin{array}{l}\text { Reporting } \\
\text { Procedures } \\
\text { (Massachusetts) }\end{array}$ & $\begin{array}{l}\text { M.G.L.A. } 119 \S 51 \mathrm{~A} \text { (West 2008) } \\
\text { Immediately report such condition to the department by oral communication and by making a written report within forty-eight } \\
\text { hours after such oral communication; provided, however, that whenever such person so required to report is a member of the staff } \\
\text { of a medical or other public or private institution, school or facility, he shall immediately either notify the department or notify the } \\
\text { person in charge of such institution, school or facility, or that person's designated agent, whereupon such person in charge or his } \\
\text { said agent shall then become responsible to make the report in the manner required by this section. Any such hospital personnel } \\
\text { preparing such report, may take, or cause to be taken, photographs of the areas of trauma visible on a child who is the subject of } \\
\text { such report without the consent of the child's parents or guardians. All such photographs or copies thereof shall be sent to the } \\
\text { department together with such report. }\end{array}$ \\
\hline
\end{tabular}

** For purposes of this chart, corrections officers, police officers, peace officers, probation officers or “catch-all” phrases such as “all persons” have been bolded. However, many mandatory reporters include professionals who may have contact or work in correctional facilities. Such individuals include physicians, nurses, dentists, teachers and social workers. These statutes can be used as a tool to require staff other than correctional officers to report sexual misconduct with inmates.

This publication is developed by the NIC/WCL Project on Addressing Prison Rape under NIC Cooperative Agreement 06S20GJJ1.

This is not to be reproduced or cited without permission from the authors.

American University, Washington College of Law

Current as of May 7, 2009 


\section{Fifty State Survey of Mandatory Reporting Statutes}

\section{NIC/WCL Project on Addressing Prison Rape}

\begin{tabular}{|c|c|}
\hline $\begin{array}{l}\text { Penalty for Failure to } \\
\text { Report } \\
\text { (Massachusetts) }\end{array}$ & $\begin{array}{l}\text { M.G.L.A. } 119 \S 51 \mathrm{~A} \text { (West 2008) } \\
\text { Any such person so required to make such oral and written reports who fails to do so shall be punished by a fine of not more than } \\
\$ 1,000.00 \text {. }\end{array}$ \\
\hline $\begin{array}{l}\text { Mandatory } \\
\text { Reporting Statute } \\
\text { (Massachusetts) }\end{array}$ & $\begin{array}{l}\text { AGAINST AN ADULT } \\
\text { M.G.L.A. 19A, § } 15 \text { (West 2008) } \\
\text { M.G.L.A. 19C } \S 1 \text { (West 2008) }\end{array}$ \\
\hline $\begin{array}{l}\text { What has to be } \\
\text { reported? } \\
\text { (Massachusetts) }\end{array}$ & $\begin{array}{l}\text { M.G.L.A. 19A, } \S 15 \text { (West 2008) } \\
\text { (a) Reasonable cause to believe that an elderly person is suffering from or has died as a result of abuse. }\end{array}$ \\
\hline $\begin{array}{l}\text { Relevant Definitions } \\
\text { (Massachusetts) }\end{array}$ & $\begin{array}{l}\text { M.G.L.A. 19A, } \S 14 \text { (West 2008) } \\
\text { Abuse, an Act or omission which results in serious physical or emotional injury to an elderly person or financial exploitation of an } \\
\text { elderly person; or the failure, inability or resistance of an elderly person to provide for him one or more of the necessities essential } \\
\text { for physical and emotional well-being without which the elderly person would be unable to safely remain in the community; } \\
\text { provided, however, that no person shall be considered to be abused or neglected for the sole reason that such person is being } \\
\text { furnished or relies upon treatment in accordance with the tenets and teachings of a church or religious denomination by a duly } \\
\text { accredited practitioner thereof. }\end{array}$ \\
\hline
\end{tabular}

NOTE:

** For purposes of this chart, corrections officers, police officers, peace officers, probation officers or “catch-all” phrases such as “all persons” have been bolded. However, many mandatory reporters include professionals who may have contact or work in correctional facilities. Such individuals include physicians, nurses, dentists, teachers and social workers. These statutes can be used as a tool to require staff other than correctional officers to report sexual misconduct with inmates.

This publication is developed by the NIC/WCL Project on Addressing Prison Rape under NIC Cooperative Agreement 06S20GJJ1.

This is not to be reproduced or cited without permission from the authors.

American University, Washington College of Law

Current as of May 7, 2009 


\section{Fifty State Survey of Mandatory Reporting Statutes}

\section{NIC/WCL Project on Addressing Prison Rape}

\begin{tabular}{|c|c|}
\hline $\begin{array}{l}\text { Relevant Definitions } \\
\text { Cont'd } \\
\text { (Massachusetts) }\end{array}$ & Elderly person, an individual who is sixty years of age or over. \\
\hline $\begin{array}{l}\text { Persons Required to } \\
\text { Report } \\
\text { (Massachusetts) }\end{array}$ & 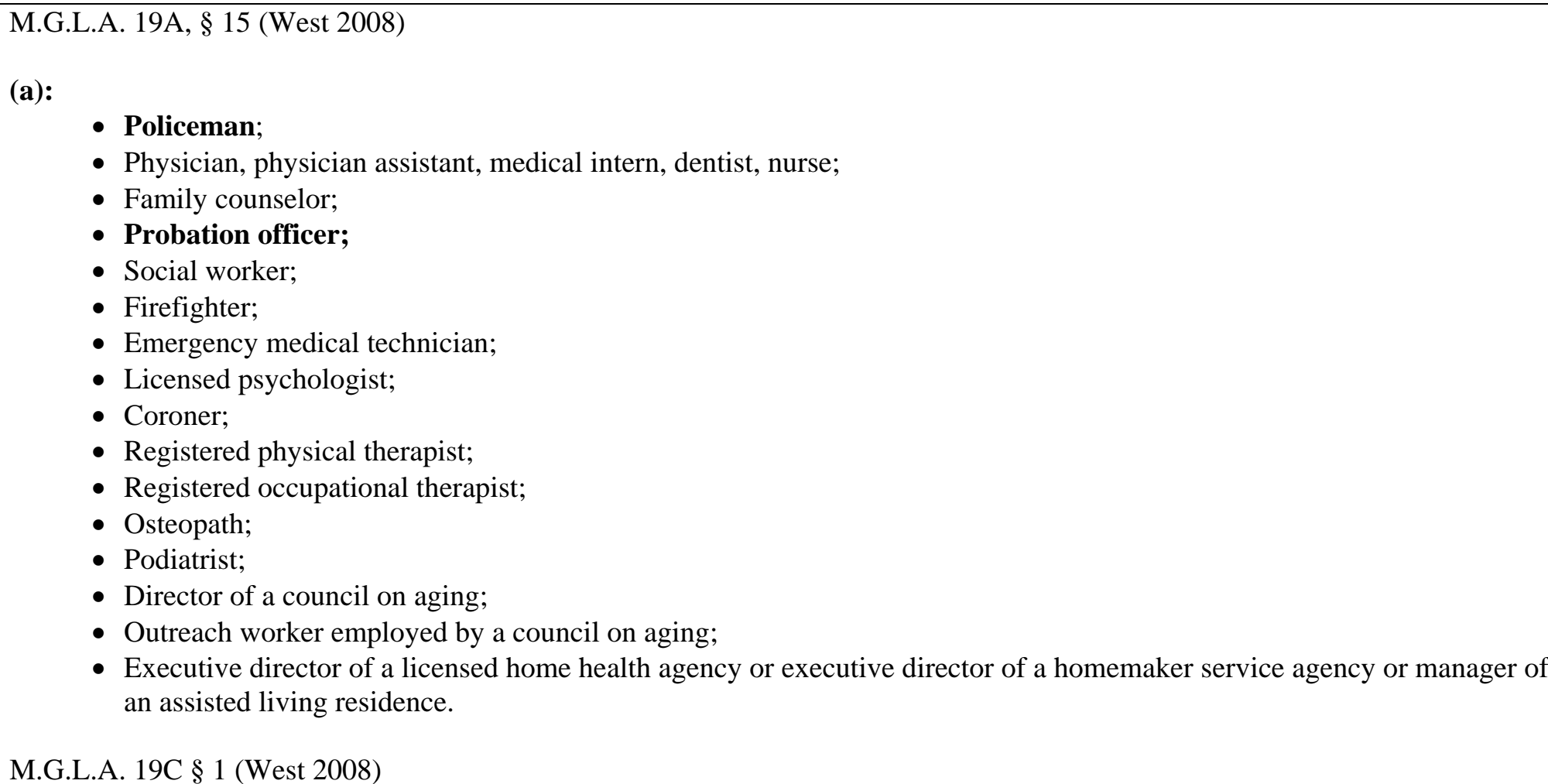 \\
\hline
\end{tabular}

NOTE:

** For purposes of this chart, corrections officers, police officers, peace officers, probation officers or "catch-all” phrases such as "all persons" have been bolded. However, many mandatory reporters include professionals who may have contact or work in correctional facilities. Such individuals include physicians, nurses, dentists, teachers and social workers. These statutes can be used as a tool to require staff other than correctional officers to report sexual misconduct with inmates.

This publication is developed by the NIC/WCL Project on Addressing Prison Rape under NIC Cooperative Agreement 06S20GJJ1.

This is not to be reproduced or cited without permission from the authors.

American University, Washington College of Law

Current as of May 7, 2009 


\section{Fifty State Survey of Mandatory Reporting Statutes}

\section{NIC/WCL Project on Addressing Prison Rape}

\begin{tabular}{|c|c|}
\hline $\begin{array}{l}\text { Persons Required to } \\
\text { Report Cont'd } \\
\text { (Massachusetts) }\end{array}$ & $\begin{array}{l}\text { “Mandated reporter”, any physician, medical intern, hospital personnel engaged in the examination, care or treatment of } \\
\text { persons, medical examiner, dentist, psychologist, nurse, chiropractor, podiatrist, osteopath, public or private school } \\
\text { teacher, educational administrator, guidance or family counselor, day care worker, probation officer, social worker, } \\
\text { foster parent, police officer or person employed by a state agency within the executive office of health and human } \\
\text { services as defined by section sixteen of chapter six A, or employed by a private agency providing services to disabled } \\
\text { persons who, in his professional capacity shall have reasonable cause to believe that a disabled person is suffering from } \\
\text { a reportable condition. }\end{array}$ \\
\hline $\begin{array}{l}\text { Reporting } \\
\text { Procedures } \\
\text { (Massachusetts) }\end{array}$ & $\begin{array}{l}\text { M.G.L.A. 19A, § } 15 \text { (West 2008) } \\
\text { (a) Immediately make a verbal report of such information or cause a report to be made to the department or its designated agency } \\
\text { and shall within forty-eight hours make a written report to the department or its designated agency. } \\
\text { (e) Reports made pursuant to subsections (a) and (b) shall contain the name, address and approximate age of the elderly person } \\
\text { who is the subject of the report, information regarding the nature and extent of the abuse, the name of the person's caretaker, if } \\
\text { known, any medical treatment being received or immediately required, if known, any other information the reporter believes to be } \\
\text { relevant to the investigation, and the name and address of the reporter and where said reporter may be contacted, if the reporter } \\
\text { wishes to provide said information. The department shall publicize the provisions of this section and the process by which reports } \\
\text { of abuse shall be made. }\end{array}$ \\
\hline $\begin{array}{l}\text { Penalty for Failure to } \\
\text { Report } \\
\text { (Massachusetts) }\end{array}$ & $\begin{array}{l}\text { M.G.L.A. 19A, } \S 15 \text { (West 2008) } \\
\text { (a) Any person so required to make such reports who fails to do so shall be punished by a fine of not more than } \$ 1,000.00 \text {. }\end{array}$ \\
\hline
\end{tabular}

NOTE:

** For purposes of this chart, corrections officers, police officers, peace officers, probation officers or “catch-all” phrases such as “all persons” have been bolded. However, many mandatory reporters include professionals who may have contact or work in correctional facilities. Such individuals include physicians, nurses, dentists, teachers and social workers. These statutes can be used as a tool to require staff other than correctional officers to report sexual misconduct with inmates.

This publication is developed by the NIC/WCL Project on Addressing Prison Rape under NIC Cooperative Agreement 06S20GJJ1.

This is not to be reproduced or cited without permission from the authors.

American University, Washington College of Law

Current as of May 7, 2009 


\section{Fifty State Survey of Mandatory Reporting Statutes}

\section{NIC/WCL Project on Addressing Prison Rape}

\begin{tabular}{|c|c|}
\hline \multicolumn{2}{|r|}{ MICHIGAN } \\
\hline $\begin{array}{l}\text { Mandatory } \\
\text { Reporting Statute } \\
\text { (Michigan) }\end{array}$ & $\begin{array}{l}\text { AGAINST A CHILD } \\
\text { M.C.L.A. § } 722.623 \text { (West 2008) }\end{array}$ \\
\hline $\begin{array}{l}\text { What has to be } \\
\text { reported? } \\
\text { (Michigan) }\end{array}$ & $\begin{array}{l}\text { M.C.L.A. } § 722.623 \text { (West 2008) } \\
\text { (1)(a) Reasonable cause to suspect child abuse or neglect. }\end{array}$ \\
\hline $\begin{array}{l}\text { Relevant Definitions } \\
\text { (Michigan) }\end{array}$ & $\begin{array}{l}\text { M.C.L.A. § } 722.622 \text { (West 2008) } \\
\text { (e) Child means a person under } 18 \text { years of age. } \\
\text { (f) Child abuse: harm or threatened harm to a child's health or welfare that occurs through nonaccidental physical or mental injury, } \\
\text { sexual abuse, sexual exploitation, or maltreatment, by a parent, a legal guardian, or any other person responsible for the child's } \\
\text { health or welfare or by a teacher, a teacher's aide, or a member of the clergy. } \\
\text { (j) Child neglect means harm or threatened harm to a child's health or welfare by a parent, legal guardian, or any other person } \\
\text { responsible for the child's health or welfare that occurs through either of the following: } \\
\text { (i) Negligent treatment, including the failure to provide adequate food, clothing, shelter, or medical care. } \\
\text { (ii) Placing a child at an unreasonable risk to the child's health or welfare by failure of the parent, legal guardian, or other } \\
\text { person responsible for the child's health or welfare to intervene to eliminate that risk when that person is able to do so and has, } \\
\text { or should have, knowledge of the risk. }\end{array}$ \\
\hline
\end{tabular}

** For purposes of this chart, corrections officers, police officers, peace officers, probation officers or "catch-all” phrases such as "all persons" have been bolded. However, many mandatory reporters include professionals who may have contact or work in correctional facilities. Such individuals include physicians, nurses, dentists, teachers and social workers. These statutes can be used as a tool to require staff other than correctional officers to report sexual misconduct with inmates.

This publication is developed by the NIC/WCL Project on Addressing Prison Rape under NIC Cooperative Agreement 06S20GJJ1.

This is not to be reproduced or cited without permission from the authors.

American University, Washington College of Law

Current as of May 7, 2009 


\section{Fifty State Survey of Mandatory Reporting Statutes}

\section{NIC/WCL Project on Addressing Prison Rape}

\begin{tabular}{|c|c|}
\hline $\begin{array}{l}\text { Relevant Definitions } \\
\text { Cont'd } \\
\text { (Michigan) }\end{array}$ & $\begin{array}{l}\text { (w) Sexual abuse means engaging in sexual contact or sexual penetration with a child. } \\
\text { (x) Sexual exploitation includes allowing, permitting, or encouraging a child to engage in prostitution, or allowing, permitting, } \\
\text { encouraging, or engaging in the photographing, filming, or depicting of a child engaged in a listed sexual act. }\end{array}$ \\
\hline $\begin{array}{l}\text { Persons Required to } \\
\text { Report } \\
\text { (Michigan) }\end{array}$ & $\begin{array}{l}\text { M.C.L.A. } § 722.623 \text { (West 2008) } \\
\text { (1)(a) An individual is required to report under this act as follows: } \\
\text { - Law enforcement officer; } \\
\text { - } \quad \text { Physician; } \\
\text { - Dentist; } \\
\text { - Physician's assistant; } \\
\text { - Registered dental hygienist; } \\
\text { - Medical examiner; } \\
\text { - Nurse; } \\
\text { - Person licensed to provide emergency medical care; } \\
\text { - } \quad \text { Audiologist; } \\
\text { - Psychologist; } \\
\text { - Marriage and family therapist; } \\
\text { - Licensed professional counselor; } \\
\text { - Licensed master social worker; } \\
\text { - Social worker; } \\
\text { - Social work technician; } \\
\text { - Licensed bachelor's social worker; } \\
\text { - School administrator; }\end{array}$ \\
\hline
\end{tabular}

NOTE:

** For purposes of this chart, corrections officers, police officers, peace officers, probation officers or “catch-all” phrases such as “all persons” have been bolded. However, many mandatory reporters include professionals who may have contact or work in correctional facilities. Such individuals include physicians, nurses, dentists, teachers and social workers. These statutes can be used as a tool to require staff other than correctional officers to report sexual misconduct with inmates.

This publication is developed by the NIC/WCL Project on Addressing Prison Rape under NIC Cooperative Agreement 06S20GJJ1.

This is not to be reproduced or cited without permission from the authors.

American University, Washington College of Law

Current as of May 7, 2009 


\section{Fifty State Survey of Mandatory Reporting Statutes}

\section{NIC/WCL Project on Addressing Prison Rape}

\begin{tabular}{|c|c|}
\hline $\begin{array}{l}\text { Persons Required to } \\
\text { Report Cont'd } \\
\text { (Michigan) }\end{array}$ & $\begin{array}{l}\text { - School counselor or teacher; } \\
\text { - } \text { Member of the clergy; } \\
\text { - } \text { Regulated child care provider; } \\
\text { - Eligibility specialist; } \\
\text { - Family independence manager; } \\
\text { - Samily independence specialist; } \\
\text { - Social services specialist; } \\
\text { - Social work specialist; } \\
\text { - Welfare services specialist. }\end{array}$ \\
\hline $\begin{array}{l}\text { Reporting } \\
\text { Procedures } \\
\text { (Michigan) }\end{array}$ & $\begin{array}{l}\text { M.C.L.A. } § 722.623 \text { (West 2008) } \\
\text { (1)(a) Immediately make by telephone or otherwise, an oral report, or cause an oral report to be made, of the suspected child abuse } \\
\text { or neglect to the department. Within } 72 \text { hours after making the oral report, the reporting person shall file a written report as } \\
\text { required in this act. If the reporting person is a member of the staff of a hospital, agency, or school, the reporting person shall } \\
\text { notify the person in charge of the hospital, agency, or school of his or her finding and that the report has been made, and shall } \\
\text { make a copy of the written report available to the person in charge. A notification to the person in charge of a hospital, agency, or } \\
\text { school does not relieve the member of the staff of the hospital, agency, or school of the obligation of reporting to the department as } \\
\text { required by this section. One report from a hospital, agency, or school shall be considered adequate to meet the reporting } \\
\text { requirement. A member of the staff of a hospital, agency, or school shall not be dismissed or otherwise penalized for making a } \\
\text { report required by this act or for cooperating in an investigation. } \\
\text { (1)(b) A department employee who is one of the following and has reasonable cause to suspect child abuse or neglect shall } \\
\text { make a report of suspected child abuse or neglect to the department in the same manner as required under subdivision (a): } \\
\text { (i) Eligibility specialist. }\end{array}$ \\
\hline
\end{tabular}

NOTE:

** For purposes of this chart, corrections officers, police officers, peace officers, probation officers or "catch-all” phrases such as "all persons" have been bolded. However, many mandatory reporters include professionals who may have contact or work in correctional facilities. Such individuals include physicians, nurses, dentists, teachers and social workers. These statutes can be used as a tool to require staff other than correctional officers to report sexual misconduct with inmates.

This publication is developed by the NIC/WCL Project on Addressing Prison Rape under NIC Cooperative Agreement 06S20GJJ1.

This is not to be reproduced or cited without permission from the authors.

American University, Washington College of Law

Current as of May 7, 2009 


\section{Fifty State Survey of Mandatory Reporting Statutes}

\section{NIC/WCL Project on Addressing Prison Rape}

\begin{tabular}{|c|c|}
\hline $\begin{array}{l}\text { Reporting } \\
\text { Procedures Cont'd } \\
\text { (Michigan) }\end{array}$ & $\begin{array}{l}\text { (ii) Family independence manager. } \\
\text { (iii) Family independence specialist. } \\
\text { (iv) Social services specialist. } \\
\text { (v) Social work specialist. } \\
\text { (vi) Social work specialist manager. } \\
\text { (vii) Welfare services specialist. } \\
\text { (2) The written report shall contain the name of the child and a description of the abuse or neglect. If possible, the report shall } \\
\text { contain the names and addresses of the child's parents, the child's guardian, the persons with whom the child resides, and the } \\
\text { child's age. The report shall contain other information available to the reporting person that might establish the cause of the abuse } \\
\text { or neglect, and the manner in which the abuse or neglect occurred. } \\
\text { (3) The department shall inform the reporting person of the required contents of the written report at the time the oral report is } \\
\text { made by the reporting person. } \\
\text { (4) The written report required in this section shall be mailed or otherwise transmitted to the county family independence agency } \\
\text { of the county in which the child suspected of being abused or neglected is found. }\end{array}$ \\
\hline $\begin{array}{l}\text { Penalty for Failure to } \\
\text { Report } \\
\text { (Michigan) }\end{array}$ & $\begin{array}{l}\text { M.C.L.A. } § 722.623 \text { (West 2008) } \\
\text { (l) A person who is required by this act to report an instance of suspected child abuse or neglect and who fails to do so is civilly } \\
\text { liable for the damages proximately caused by the failure. } \\
\text { (2) A person who is required by this act to report an instance of suspected child abuse or neglect and who knowingly fails to do so } \\
\text { is guilty of a misdemeanor punishable by imprisonment for not more than } 93 \text { days or a fine of not more than } \$ 500.00 \text {, or both. }\end{array}$ \\
\hline $\begin{array}{l}\text { Mandatory } \\
\text { Reporting Statute } \\
\text { (Michigan) }\end{array}$ & $\begin{array}{l}\text { AGAINST AN ADULT } \\
\text { M.C.L.A. § 400.11a (West 2008) }\end{array}$ \\
\hline
\end{tabular}

NOTE:

** For purposes of this chart, corrections officers, police officers, peace officers, probation officers or "catch-all” phrases such as “all persons” have been bolded. However, many mandatory reporters include professionals who may have contact or work in correctional facilities. Such individuals include physicians, nurses, dentists, teachers and social workers. These statutes can be used as a tool to require staff other than correctional officers to report sexual misconduct with inmates.

This publication is developed by the NIC/WCL Project on Addressing Prison Rape under NIC Cooperative Agreement 06S20GJJ1.

This is not to be reproduced or cited without permission from the authors.

American University, Washington College of Law

Current as of May 7, 2009 


\section{Fifty State Survey of Mandatory Reporting Statutes}

\section{NIC/WCL Project on Addressing Prison Rape}

\begin{tabular}{|c|c|}
\hline $\begin{array}{l}\text { What has to be } \\
\text { reported? } \\
\text { (Michigan) }\end{array}$ & $\begin{array}{l}\text { M.C.L.A. § 400.11a (West 2008) } \\
\text { (1) Suspects or has reasonable cause to believe that an adult has been abused. }\end{array}$ \\
\hline $\begin{array}{l}\text { Relevant Definitions } \\
\text { (Michigan) }\end{array}$ & $\begin{array}{l}\text { M.C.L.A. § 400.11a (West 2008) } \\
\text { (a) Abuse means harm or threatened harm to an adult's health or welfare caused by another person. Abuse includes, but is not } \\
\text { limited to, nonaccidental physical or mental injury, sexual abuse, or maltreatment. } \\
\text { (b) Adult in need of protective services or adult means a vulnerable person not less than } 18 \text { years of age who is suspected of being } \\
\text { or believed to be abused, neglected, or exploited. } \\
\text { (c) Exploitation means an action that involves the misuse of an adult's funds, property, or personal dignity by another person. } \\
\text { (d) Neglect means harm to an adult's health or welfare caused by the inability of the adult to respond to a harmful situation or by } \\
\text { the conduct of a person who assumes responsibility for a significant aspect of the adult's health or welfare. Neglect includes the } \\
\text { failure to provide adequate food, clothing, shelter, or medical care. A person shall not be considered to be abused, neglected, or in } \\
\text { need of emergency or protective services for the sole reason that the person is receiving or relying upon treatment by spiritual } \\
\text { means through prayer alone in accordance with the tenets and practices of a recognized church or religious denomination, and this } \\
\text { act shall not require any medical care or treatment in contravention of the stated or implied objection of that person. } \\
\text { (f) Vulnerable means a condition in which an adult is unable to protect himself or herself from abuse, neglect, or exploitation } \\
\text { because of a mental or physical impairment or because of advanced age. }\end{array}$ \\
\hline $\begin{array}{l}\text { Persons Required to } \\
\text { Report } \\
\text { (Michigan) }\end{array}$ & $\begin{array}{l}\text { M.C.L.A. § 400.11a (West 2008) } \\
\text { (1) A person who is employed, licensed, registered, or certified to provide health care, educational, social welfare, mental health, } \\
\text { or other human services; an employee of an agency licensed to provide health care, educational, social welfare, mental health, or } \\
\text { other human services; a law enforcement officer; or an employee of the office of the county medical examiner. }\end{array}$ \\
\hline
\end{tabular}

NOTE:

** For purposes of this chart, corrections officers, police officers, peace officers, probation officers or “catch-all” phrases such as “all persons” have been bolded. However, many mandatory reporters include professionals who may have contact or work in correctional facilities. Such individuals include physicians, nurses, dentists, teachers and social workers. These statutes can be used as a tool to require staff other than correctional officers to report sexual misconduct with inmates.

This publication is developed by the NIC/WCL Project on Addressing Prison Rape under NIC Cooperative Agreement 06S20GJJ1.

This is not to be reproduced or cited without permission from the authors.

American University, Washington College of Law

Current as of May 7, 2009 


\section{Fifty State Survey of Mandatory Reporting Statutes}

\section{NIC/WCL Project on Addressing Prison Rape}

\begin{tabular}{|c|c|}
\hline $\begin{array}{l}\text { Reporting } \\
\text { Procedures } \\
\text { (Michigan) }\end{array}$ & $\begin{array}{l}\text { M.C.L.A. § 400.11a (West 2008) } \\
\text { (1) Make immediately, by telephone or otherwise, an oral report to the county department of social services of the county in which } \\
\text { the abuse, neglect, or exploitation is suspected of having or believed to have occurred. After making the oral report, the reporting } \\
\text { person may file a written report with the county department. }\end{array}$ \\
\hline $\begin{array}{l}\text { Penalty for Failure to } \\
\text { Report } \\
\text { (Michigan) }\end{array}$ & $\begin{array}{l}\text { M.C.L.A. } \$ 400.11 \text { a (West 2008) } \\
\text { (e) A person required to make a report pursuant to section } 11 \text { a who fails to do so is liable civilly for the damages proximately } \\
\text { caused by the failure to report, and a civil fine of not more than } \$ 500.00 \text { for each failure to report. }\end{array}$ \\
\hline & MINNESOTA \\
\hline $\begin{array}{l}\text { Mandatory } \\
\text { Reporting Statute } \\
\text { (Minnesota) }\end{array}$ & $\begin{array}{l}\text { AGAINST A CHILD } \\
\text { M.S.A. § } 626.556 \text { (West 2008) }\end{array}$ \\
\hline $\begin{array}{l}\text { What has to be } \\
\text { reported? } \\
\text { (Minnesota) }\end{array}$ & $\begin{array}{l}\text { M.S.A. § } 626.556 \text { (West 2008) } \\
\text { Subd. } 3 \text { (a) A person who knows or has reason to believe a child is being neglected or physically or sexually abused, or has been } \\
\text { neglected or physically or sexually abused within the preceding three years. }\end{array}$ \\
\hline $\begin{array}{l}\text { Relevant Definitions } \\
\text { (Minnesota) }\end{array}$ & M.S.A. § 626.556 (West 2008) \\
\hline
\end{tabular}

NOTE:

** For purposes of this chart, corrections officers, police officers, peace officers, probation officers or “catch-all” phrases such as “all persons” have been bolded. However, many mandatory reporters include professionals who may have contact or work in correctional facilities. Such individuals include physicians, nurses, dentists, teachers and social workers. These statutes can be used as a tool to require staff other than correctional officers to report sexual misconduct with inmates.

This publication is developed by the NIC/WCL Project on Addressing Prison Rape under NIC Cooperative Agreement 06S20GJJ1.

This is not to be reproduced or cited without permission from the authors.

American University, Washington College of Law

Current as of May 7, 2009 


\title{
Fifty State Survey of Mandatory Reporting Statutes
}

\section{NIC/WCL Project on Addressing Prison Rape}

\begin{tabular}{|c|c|}
\hline $\begin{array}{l}\text { Relevant Definitions } \\
\text { Cont'd } \\
\text { (Minnesota) }\end{array}$ & 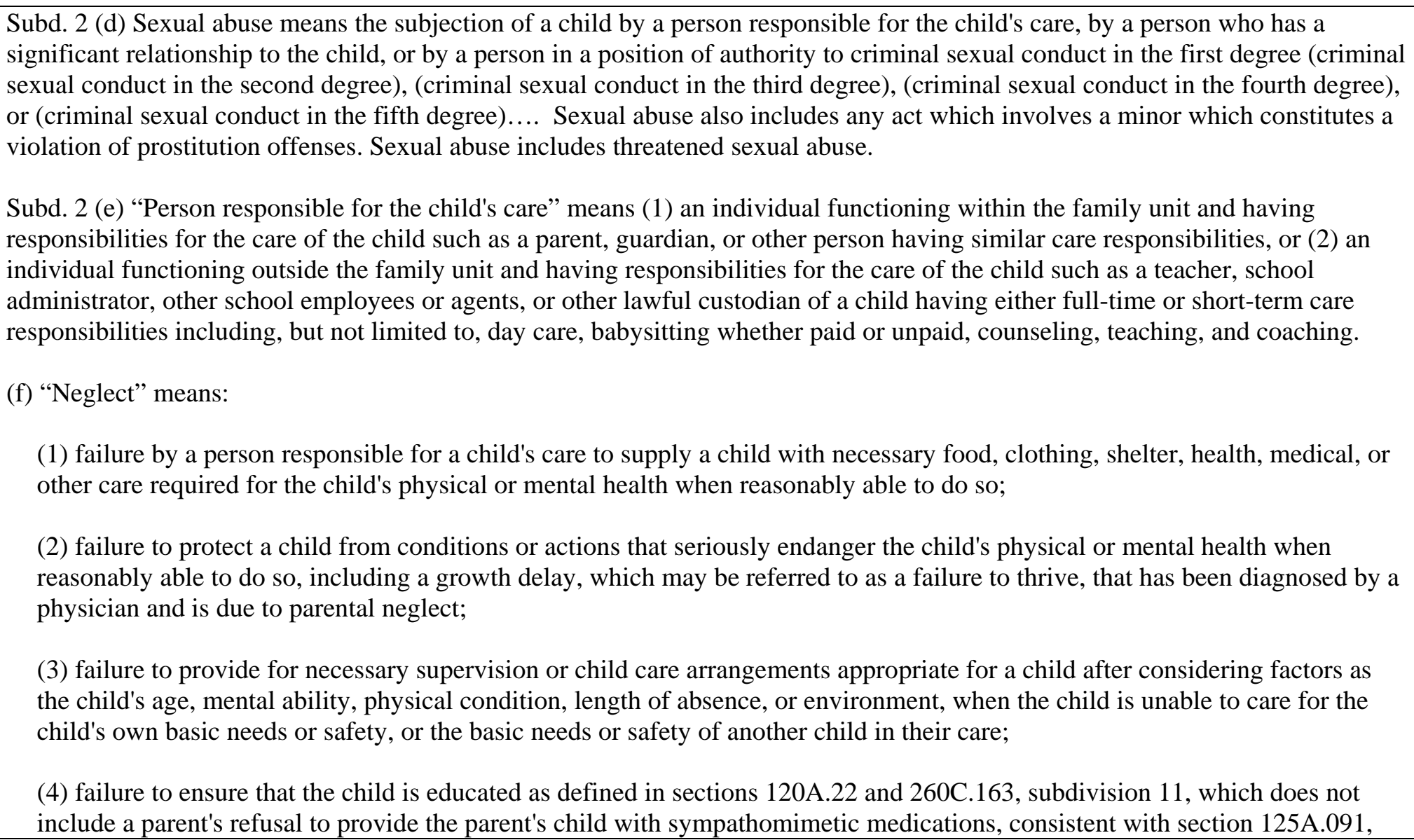 \\
\hline
\end{tabular}

NOTE:

\begin{abstract}
** For purposes of this chart, corrections officers, police officers, peace officers, probation officers or "catch-all” phrases such as “all persons” have been bolded. However, many mandatory reporters include professionals who may have contact or work in correctional facilities. Such individuals include physicians, nurses, dentists, teachers and social workers. These statutes can be used as a tool to require staff other than correctional officers to report sexual misconduct with inmates.
\end{abstract}

This publication is developed by the NIC/WCL Project on Addressing Prison Rape under NIC Cooperative Agreement 06S20GJJ1.

This is not to be reproduced or cited without permission from the authors.

American University, Washington College of Law

Current as of May 7, 2009 


\section{Fifty State Survey of Mandatory Reporting Statutes}

\section{NIC/WCL Project on Addressing Prison Rape}

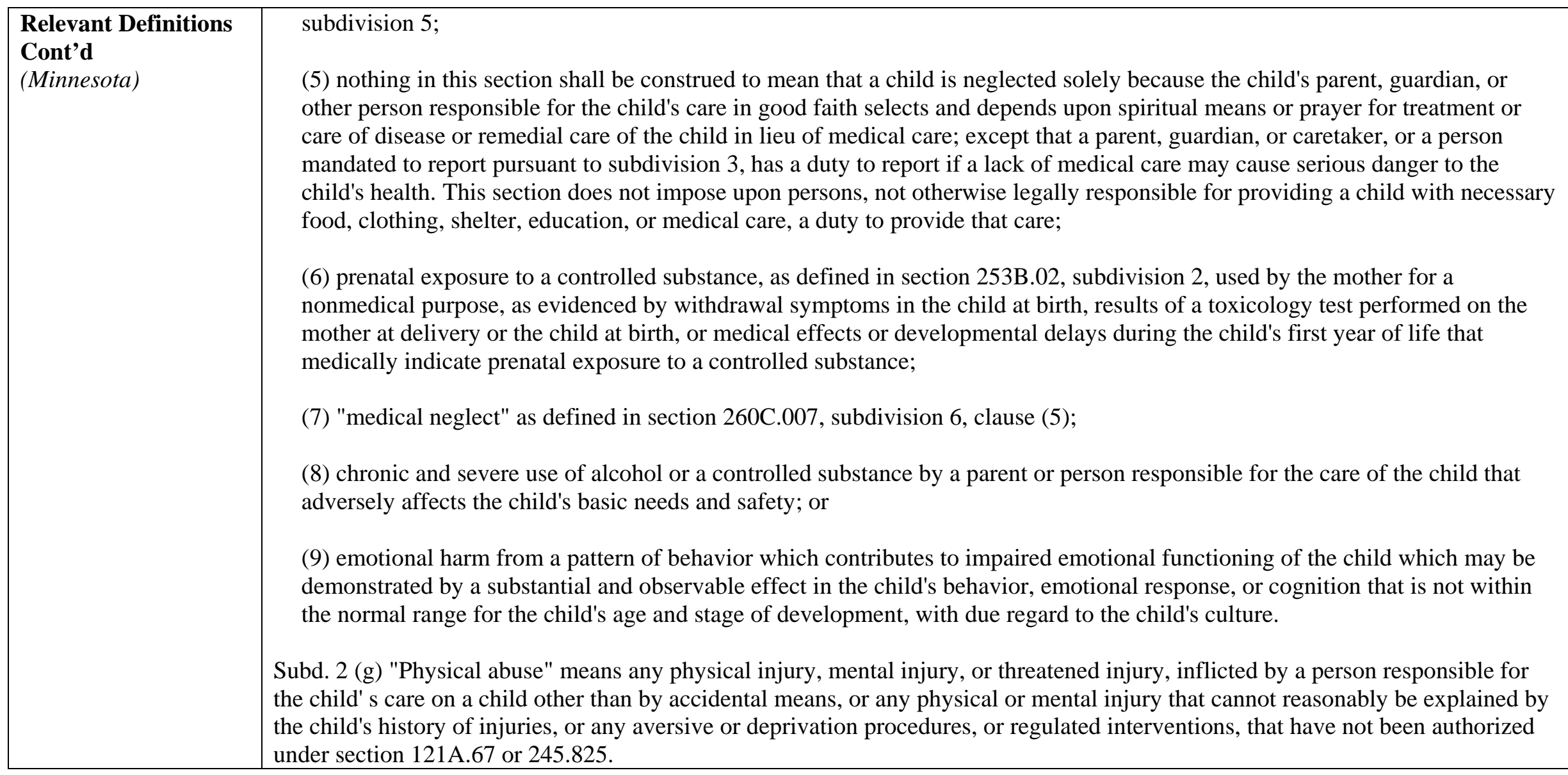

NOTE:

** For purposes of this chart, corrections officers, police officers, peace officers, probation officers or "catch-all” phrases such as “all persons” have been bolded. However, many mandatory reporters include professionals who may have contact or work in correctional facilities. Such individuals include physicians, nurses, dentists, teachers and social workers. These statutes can be used as a tool to require staff other than correctional officers to report sexual misconduct with inmates.

This publication is developed by the NIC/WCL Project on Addressing Prison Rape under NIC Cooperative Agreement 06S20GJJ1.

This is not to be reproduced or cited without permission from the authors.

American University, Washington College of Law

Current as of May 7, 2009 


\section{Fifty State Survey of Mandatory Reporting Statutes}

\section{NIC/WCL Project on Addressing Prison Rape}

\begin{tabular}{|c|c|}
\hline $\begin{array}{l}\text { Relevant Definitions } \\
\text { Cont'd } \\
\text { (Minnesota) }\end{array}$ & Subd. 3 (e) Immediately means as soon as possible but in no event longer than 24 hours. \\
\hline $\begin{array}{l}\text { Persons Required to } \\
\text { Report } \\
\text { (Minnesota) }\end{array}$ & $\begin{array}{l}\text { M.S.A. § } 626.556 \text { (West 2008) } \\
\text { Subd. } 3 \text { (a)(1) A professional or professional's delegate who is engaged in the practice of correctional supervision, correctional } \\
\text { services, or law enforcement, the healing arts, social services, hospital administration, psychological or psychiatric treatment, } \\
\text { child care, education, probation; or } \\
\text { Subd. } 3 \text { (a)(2) Employed as a member of the clergy and received the information while engaged in ministerial duties (except for } \\
\text { privileged communications). }\end{array}$ \\
\hline $\begin{array}{l}\text { Reporting } \\
\text { Procedures } \\
\text { (Minnesota) }\end{array}$ & $\begin{array}{l}\text { M.S.A. } \$ 626.556 \text { (West 2008) } \\
\text { Subd. } 3 \text { (a) Immediately report the information to the local welfare agency, agency responsible for assessing or investigating the } \\
\text { report. } \\
\text { Subd. } 3 \text { (c) A person mandated to report physical or sexual child abuse or neglect occurring within a licensed facility shall report } \\
\text { the information to the agency responsible for licensing the facility; or a nonlicensed personal care provider organization. A health } \\
\text { or corrections agency receiving a report may request the local welfare agency to provide assistance. A board or other entity } \\
\text { whose licensees perform work within a school facility, upon receiving a complaint of alleged maltreatment, shall provide } \\
\text { information about the circumstances of the alleged maltreatment to the commissioner of education. } \\
\text { Subd. } 7 . \text { Report. An oral report shall be made immediately by telephone or otherwise. An oral report made by a person required } \\
\text { under subdivision } 3 \text { to report shall be followed within } 72 \text { hours, exclusive of weekends and holidays, by a report in writing to the } \\
\text { appropriate police department, the county sheriff, the agency responsible for assessing or investigating the report, or the local }\end{array}$ \\
\hline
\end{tabular}

NOTE:

169

** For purposes of this chart, corrections officers, police officers, peace officers, probation officers or “catch-all” phrases such as “all persons” have been bolded. However, many mandatory reporters include professionals who may have contact or work in correctional facilities. Such individuals include physicians, nurses, dentists, teachers and social workers. These statutes can be used as a tool to require staff other than correctional officers to report sexual misconduct with inmates.

This publication is developed by the NIC/WCL Project on Addressing Prison Rape under NIC Cooperative Agreement 06S20GJJ1.

This is not to be reproduced or cited without permission from the authors.

American University, Washington College of Law

Current as of May 7, 2009 


\section{Fifty State Survey of Mandatory Reporting Statutes}

\section{NIC/WCL Project on Addressing Prison Rape}

\begin{tabular}{|c|c|}
\hline $\begin{array}{l}\text { Reporting } \\
\text { Procedures Cont'd } \\
\text { (Minnesota) }\end{array}$ & $\begin{array}{l}\text { welfare agency, unless the appropriate agency has informed the reporter that the oral information does not constitute a report under } \\
\text { subdivision 10. Any report shall be of sufficient content to identify the child, any person believed to be responsible for the abuse } \\
\text { or neglect of the child if the person is known, the nature and extent of the abuse or neglect and the name and address of the } \\
\text { reporter. }\end{array}$ \\
\hline $\begin{array}{l}\text { Penalty for Failure to } \\
\text { Report } \\
\text { (Minnesota) }\end{array}$ & $\begin{array}{l}\text { M.S.A. } \$ 626.556 \text { (West 2008) } \\
\text { Subd. 6(a) A person mandated by this section to report who knows or has reason to believe that a child is neglected or physically } \\
\text { or sexually abused or has been neglected or physically or sexually abused within the preceding three years, and fails to report is } \\
\text { guilty of a misdemeanor. } \\
\text { Subd. 6(b) A person mandated by this section to report who knows or has reason to believe that two or more children not related to } \\
\text { the perpetrator have been physically or sexually abused by the same perpetrator within the preceding ten years, and fails to report } \\
\text { is guilty of a gross misdemeanor. } \\
\text { Subd. } 6 \text { (c) A parent, guardian, or caretaker who knows or reasonably should know that the child's health is in serious danger and } \\
\text { who fails to report as required, is guilty of a gross misdemeanor if the child suffers substantial or great bodily harm because of the } \\
\text { lack of medical care. If the child dies because of the lack of medical care, the person is guilty of a felony and may be sentenced to } \\
\text { imprisonment for not more than two years or to payment of a fine of not more than } \$ 4,000 \text {, or both. } \\
\text { MiNN. STAT. ANN. } § 609.02 \text { (West } 2008 \text { ). } \\
\text { Subd. } 3 \text { Misdemeanor means a crime for which a sentence of not more than } 90 \text { days or a fine of not more than } \$ 1,000, \text { or both may } \\
\text { be imposed. } \\
\text { Subd. } 4 \text { Gross Misdemeanor means any crime which is not a felony or misdemeanor. The maximum fine which may be imposed } \\
\text { for a gross misdemeanor is } \$ 3,000 \text {. }\end{array}$ \\
\hline
\end{tabular}

NOTE:

** For purposes of this chart, corrections officers, police officers, peace officers, probation officers or “catch-all” phrases such as “all persons” have been bolded. However, many mandatory reporters include professionals who may have contact or work in correctional facilities. Such individuals include physicians, nurses, dentists, teachers and social workers. These statutes can be used as a tool to require staff other than correctional officers to report sexual misconduct with inmates.

This publication is developed by the NIC/WCL Project on Addressing Prison Rape under NIC Cooperative Agreement 06S20GJJ1.

This is not to be reproduced or cited without permission from the authors.

American University, Washington College of Law

Current as of May 7, 2009 


\section{Fifty State Survey of Mandatory Reporting Statutes}

\section{NIC/WCL Project on Addressing Prison Rape}

\begin{tabular}{|c|c|}
\hline $\begin{array}{l}\text { Mandatory } \\
\text { Reporting Statute } \\
\text { (Minnesota) }\end{array}$ & $\begin{array}{l}\text { AGAINST AN ADULT } \\
\text { M.S.A. § } 626.557 \text { (West 2008) }\end{array}$ \\
\hline $\begin{array}{l}\text { What has to be } \\
\text { reported? } \\
\text { (Minnesota) }\end{array}$ & $\begin{array}{l}\text { M.S.A. § } 626.557 \text { (West 2008) } \\
\text { Subd. 3(a) A mandated reporter who has reason to believe that a vulnerable adult is being or has been maltreated, or who has } \\
\text { knowledge that a vulnerable adult has sustained a physical injury which is not reasonably explained. }\end{array}$ \\
\hline $\begin{array}{l}\text { Relevant Definitions } \\
\text { (Minnesota) }\end{array}$ & $\begin{array}{l}\text { M.S.A. § } 626.5572 \text { (West 2008) } \\
\text { Subd. 2. Abuse. “Abuse” means: } \\
\text { (a) An act against a vulnerable adult that constitutes a violation of, an attempt to violate, or aiding and abetting a violation of: } \\
\text { (1) assault in the first through fifth degrees as defined in sections } 609.221 \text { to } 609.224 \text {; } \\
\text { (2) the use of drugs to injure or facilitate crime as defined in section } 609.235 \text {; } \\
\text { (3) the solicitation, inducement, and promotion of prostitution as defined in section } 609.322 \text {; and } \\
\text { (4) criminal sexual conduct in the first through fifth degrees as defined in sections } 609.342 \text { to } 609.3451 \text {. } \\
\text { A violation includes any action that meets the elements of the crime, regardless of whether there is a criminal proceeding or } \\
\text { conviction. } \\
\text { (c) Any sexual contact or penetration between a facility staff person or a person providing services in the facility and a resident, } \\
\text { patient, or client of that facility. } \\
\text { (d) The act of forcing, compelling, coercing, or enticing a vulnerable adult against the vulnerable adult's will to perform services } \\
\text { for the advantage of another. } \\
\text { (g) For purposes of this section, a vulnerable adult is not abused for the sole reason that the vulnerable adult, who is not impaired }\end{array}$ \\
\hline
\end{tabular}

NOTE:

** For purposes of this chart, corrections officers, police officers, peace officers, probation officers or “catch-all” phrases such as “all persons” have been bolded. However, many mandatory reporters include professionals who may have contact or work in correctional facilities. Such individuals include physicians, nurses, dentists, teachers and social workers. These statutes can be used as a tool to require staff other than correctional officers to report sexual misconduct with inmates.

This publication is developed by the NIC/WCL Project on Addressing Prison Rape under NIC Cooperative Agreement 06S20GJJ1.

This is not to be reproduced or cited without permission from the authors.

American University, Washington College of Law

Current as of May 7, 2009 


\section{Fifty State Survey of Mandatory Reporting Statutes}

\section{NIC/WCL Project on Addressing Prison Rape}

\begin{tabular}{|c|c|}
\hline $\begin{array}{l}\text { Relevant Definitions } \\
\text { Cont'd } \\
\text { (Minnesota) }\end{array}$ & 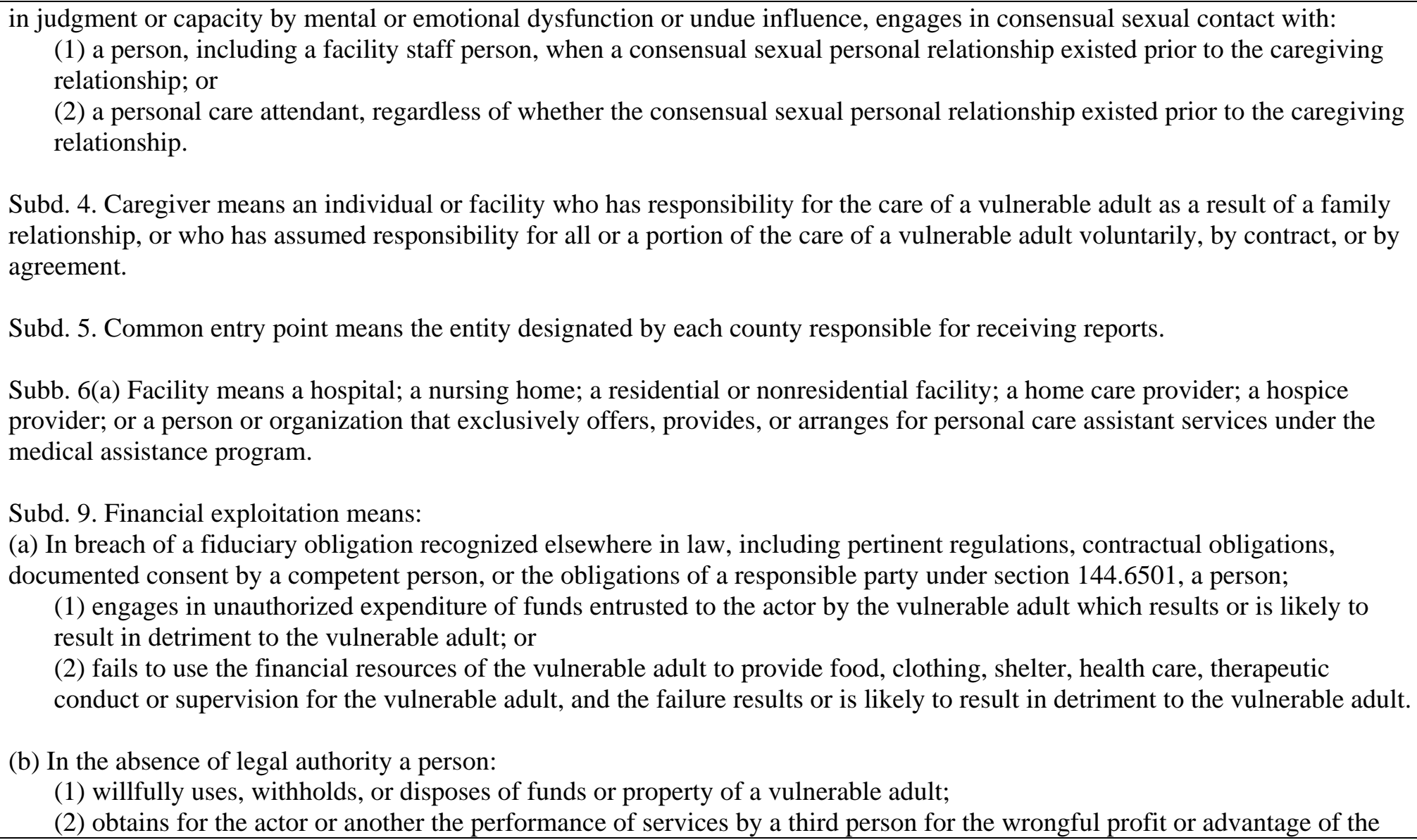 \\
\hline
\end{tabular}

NOTE:

** For purposes of this chart, corrections officers, police officers, peace officers, probation officers or “catch-all” phrases such as “all persons” have been bolded. However, many mandatory reporters include professionals who may have contact or work in correctional facilities. Such individuals include physicians, nurses, dentists, teachers and social workers. These statutes can be used as a tool to require staff other than correctional officers to report sexual misconduct with inmates.

This publication is developed by the NIC/WCL Project on Addressing Prison Rape under NIC Cooperative Agreement 06S20GJJ1.

This is not to be reproduced or cited without permission from the authors.

American University, Washington College of Law

Current as of May 7, 2009 


\section{Fifty State Survey of Mandatory Reporting Statutes}

\section{NIC/WCL Project on Addressing Prison Rape}

\begin{tabular}{|c|c|}
\hline $\begin{array}{l}\text { Relevant Definitions } \\
\text { Cont'd } \\
\text { (Minnesota) }\end{array}$ & 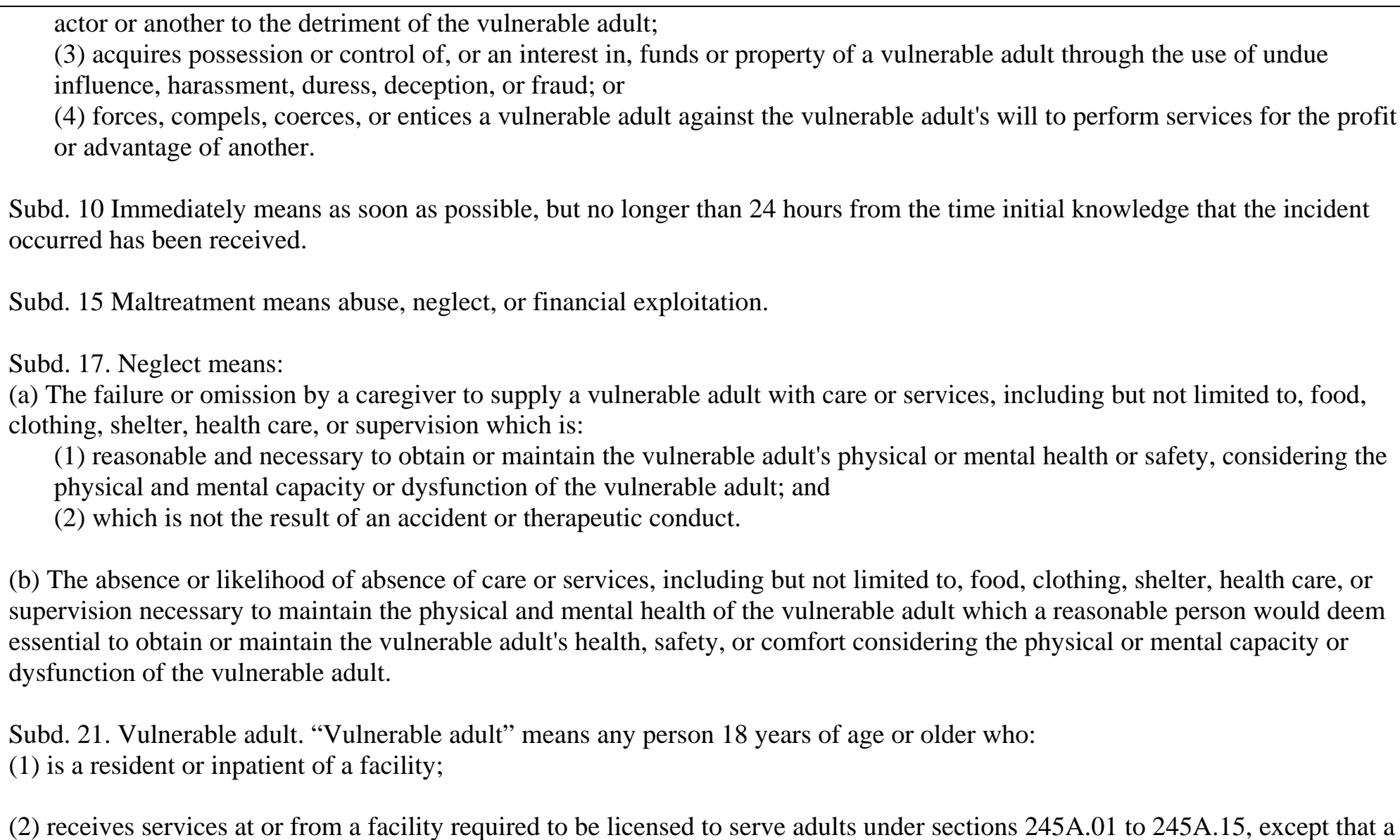 \\
\hline
\end{tabular}

NOTE:

** For purposes of this chart, corrections officers, police officers, peace officers, probation officers or “catch-all” phrases such as “all persons” have been bolded. However, many mandatory reporters include professionals who may have contact or work in correctional facilities. Such individuals include physicians, nurses, dentists, teachers and social workers. These statutes can be used as a tool to require staff other than correctional officers to report sexual misconduct with inmates.

This publication is developed by the NIC/WCL Project on Addressing Prison Rape under NIC Cooperative Agreement 06S20GJJ1.

This is not to be reproduced or cited without permission from the authors.

American University, Washington College of Law

Current as of May 7, 2009 


\section{Fifty State Survey of Mandatory Reporting Statutes}

\section{NIC/WCL Project on Addressing Prison Rape}

\begin{tabular}{|c|c|}
\hline $\begin{array}{l}\text { Relevant Definitions } \\
\text { Cont'd } \\
\text { (Minnesota) }\end{array}$ & $\begin{array}{l}\text { person receiving outpatient services for treatment of chemical dependency or mental illness, or one who is served in the Minnesota } \\
\text { sex offender program on a court-hold order for commitment, or is committed as a sexual psychopathic personality or as a sexually } \\
\text { dangerous person under chapter } 253 \mathrm{~B} \text {, is not considered a vulnerable adult unless the person meets the requirements of clause (4); } \\
\text { (3) receives services from a home care provider required to be licensed under section 144A.46; or from a person or organization } \\
\text { that exclusively offers, provides, or arranges for personal care assistant services under the medical assistance program as } \\
\text { authorized under sections 256B.04, subdivision 16, 256B.0625, subdivision 19a, 256B.0651, and 256B.0653 to 256B.0656; or } \\
\text { (4) regardless of residence or whether any type of service is received, possesses a physical or mental infirmity or other physical, } \\
\text { mental, or emotional dysfunction: } \\
\text { (i) that impairs the individual's ability to provide adequately for the individual's own care without assistance, including the } \\
\text { provision of food, shelter, clothing, health care, or supervision; and } \\
\text { (ii) because of the dysfunction or infirmity and the need for assistance, the individual has an impaired ability to protect the } \\
\text { individual from maltreatment. }\end{array}$ \\
\hline $\begin{array}{l}\text { Persons Required to } \\
\text { Report } \\
\text { (Minnesota) }\end{array}$ & $\begin{array}{l}\text { M.S.A. } § 626.5572 \text { (West 2008) } \\
\text { Subd. } 16 \text { Mandated reporter_means a "professional” or "professional's delegate” while engaged in: } \\
\text { (1) Social services; } \\
\text { (2) Law enforcement; } \\
\text { (3) Education; } \\
\text { (4) The care of vulnerable adults; } \\
\text { (5) Any of the occupations referred to in section 214.01, subdivision } 2 \text { [Board of Examiners of Nursing Home Administrators, } \\
\text { the Office of Unlicensed Complementary and Alternative Health Care Practice, the Board of Medical Practice, the Board } \\
\text { of Nursing, the Board of Chiropractic Examiners, the Board of Optometry, the Board of Physical Therapy, the Board of }\end{array}$ \\
\hline
\end{tabular}

NOTE:

** For purposes of this chart, corrections officers, police officers, peace officers, probation officers or “catch-all” phrases such as “all persons” have been bolded. However, many mandatory reporters include professionals who may have contact or work in correctional facilities. Such individuals include physicians, nurses, dentists, teachers and social workers. These statutes can be used as a tool to require staff other than correctional officers to report sexual misconduct with inmates.

This publication is developed by the NIC/WCL Project on Addressing Prison Rape under NIC Cooperative Agreement 06S20GJJ1.

This is not to be reproduced or cited without permission from the authors.

American University, Washington College of Law

Current as of May 7, 2009 


\section{Fifty State Survey of Mandatory Reporting Statutes}

\section{NIC/WCL Project on Addressing Prison Rape}

\begin{tabular}{|c|c|}
\hline $\begin{array}{l}\text { Persons Required to } \\
\text { Report Cont'd } \\
\text { (Minnesota) }\end{array}$ & $\begin{array}{l}\text { Psychology, the Board of Social Work, the Board of Marriage and Family Therapy, the Office of Mental Health Practice } \\
\text { established, the Board of Behavioral Health and Therapy, the Board of Dietetics and Nutrition Practice, the Board of } \\
\text { Dentistry, the Board of Pharmacy, the Board of Podiatric Medicine, and the Board of Veterinary Medicine]; } \\
\text { (6) An employee of a rehabilitation facility certified by the commissioner of jobs and training for vocational rehabilitation; } \\
\text { (7) An employee or person providing services in a facility; or } \\
\text { (8) A person that performs the duties of the medical examiner or coroner. }\end{array}$ \\
\hline $\begin{array}{l}\text { Reporting } \\
\text { Procedures } \\
\text { (Minnesota) }\end{array}$ & $\begin{array}{l}\text { M.S.A. § } 626.557 \text { (West 2008) } \\
\text { Subd. 3(a) Shall immediately report the information to the common entry point. } \\
\text { Subd. } 4 \text { To the extent possible, the report must be of sufficient content to identify the vulnerable adult, the caregiver, the nature } \\
\text { and extent of the suspected maltreatment, any evidence of previous maltreatment, the name and address of the reporter, the time, } \\
\text { date, and location of the incident, and any other information that the reporter believes might be helpful in investigating the } \\
\text { suspected maltreatment. } \\
\text { Subd. } 4 \text { (d) A facility may not prohibit a mandated reporter from reporting externally, and a facility is prohibited from retaliating } \\
\text { against a mandated reporter who reports an incident to the common entry point in good faith. The written notice by the facility } \\
\text { must inform the mandated reporter of this protection from retaliatory measures by the facility against the mandated reporter for } \\
\text { reporting externally. }\end{array}$ \\
\hline $\begin{array}{l}\text { Penalty for Failure to } \\
\text { Report } \\
\text { (Minnesota) }\end{array}$ & $\begin{array}{l}\text { M.S.A. § } 626.557 \text { (West 2008) } \\
\text { Subd. } 7 \text { A mandated reporter who negligently or intentionally fails to report is liable for damages caused by the failure. Nothing } \\
\text { in this subdivision imposes vicarious liability for the acts or omissions of others. }\end{array}$ \\
\hline
\end{tabular}

NOTE:

** For purposes of this chart, corrections officers, police officers, peace officers, probation officers or "catch-all” phrases such as “all persons” have been bolded. However, many mandatory reporters include professionals who may have contact or work in correctional facilities. Such individuals include physicians, nurses, dentists, teachers and social workers. These statutes can be used as a tool to require staff other than correctional officers to report sexual misconduct with inmates.

This publication is developed by the NIC/WCL Project on Addressing Prison Rape under NIC Cooperative Agreement 06S20GJJ1.

This is not to be reproduced or cited without permission from the authors.

American University, Washington College of Law

Current as of May 7, 2009 


\section{Fifty State Survey of Mandatory Reporting Statutes}

\section{NIC/WCL Project on Addressing Prison Rape}

\section{MISSISSIPPI}

\begin{tabular}{|c|c|}
\hline $\begin{array}{l}\text { Mandatory } \\
\text { Reporting Statute } \\
\text { (Mississippi) }\end{array}$ & $\begin{array}{l}\text { AGAINST A CHILD } \\
\text { Miss. Code Ann. } § 43-21-353 \text { (West 2008) }\end{array}$ \\
\hline $\begin{array}{l}\text { What has to be } \\
\text { reported? } \\
\text { (Mississippi) }\end{array}$ & $\begin{array}{l}\text { Miss. CODE ANN. § 43-21-353 (West 2008) } \\
\text { (1) Reasonable cause to suspect that a child is a neglected child or an abused child. }\end{array}$ \\
\hline $\begin{array}{l}\text { Relevant Definitions } \\
\text { (Mississippi) }\end{array}$ & $\begin{array}{l}\text { MiSS. CODE ANN. } § 43-21-105 \text { (West 2008) } \\
\text { (d) Child and youth are synonymous, and each means a person who has not reached his eighteenth birthday. A child who has not } \\
\text { reached his eighteenth birthday and is on active duty for a branch of the armed services or is married is not considered a "child" or } \\
\text { "youth" for the purposes of this chapter. } \\
\text { (k) “Child in need of supervision” means a child who has reached his seventh birthday and is in need of treatment or rehabilitation } \\
\text { because the child: } \\
\text { (i) Is habitually disobedient of reasonable and lawful commands of his parent, guardian or custodian and is ungovernable; or } \\
\text { (ii) While being required to attend school, willfully and habitually violates the rules thereof or willfully and habitually absents } \\
\text { himself therefrom; or } \\
\text { (iii) Runs away from home without good cause; or } \\
\text { (iv) Has committed a delinquent act or acts. } \\
\text { (l) "Neglected child” means a child: } \\
\text { (i) Whose parent, guardian or custodian or any person responsible for his care or support, neglects or refuses, when able so to } \\
\text { do, to provide for him proper and necessary care or support, or education as required by law, or medical, surgical, or other care } \\
\text { necessary for his well-being; provided, however, a parent who withholds medical treatment from any child who in good faith is }\end{array}$ \\
\hline
\end{tabular}

** For purposes of this chart, corrections officers, police officers, peace officers, probation officers or "catch-all” phrases such as “all persons” have been bolded. However, many mandatory reporters include professionals who may have contact or work in correctional facilities. Such individuals include physicians, nurses, dentists, teachers and social workers. These statutes can be used as a tool to require staff other than correctional officers to report sexual misconduct with inmates.

This publication is developed by the NIC/WCL Project on Addressing Prison Rape under NIC Cooperative Agreement 06S20GJJ1.

This is not to be reproduced or cited without permission from the authors.

American University, Washington College of Law

Current as of May 7, 2009 


\section{Fifty State Survey of Mandatory Reporting Statutes}

\section{NIC/WCL Project on Addressing Prison Rape}

\begin{tabular}{|c|c|}
\hline $\begin{array}{l}\text { Relevant Definitions } \\
\text { Cont'd } \\
\text { (Mississippi) }\end{array}$ & 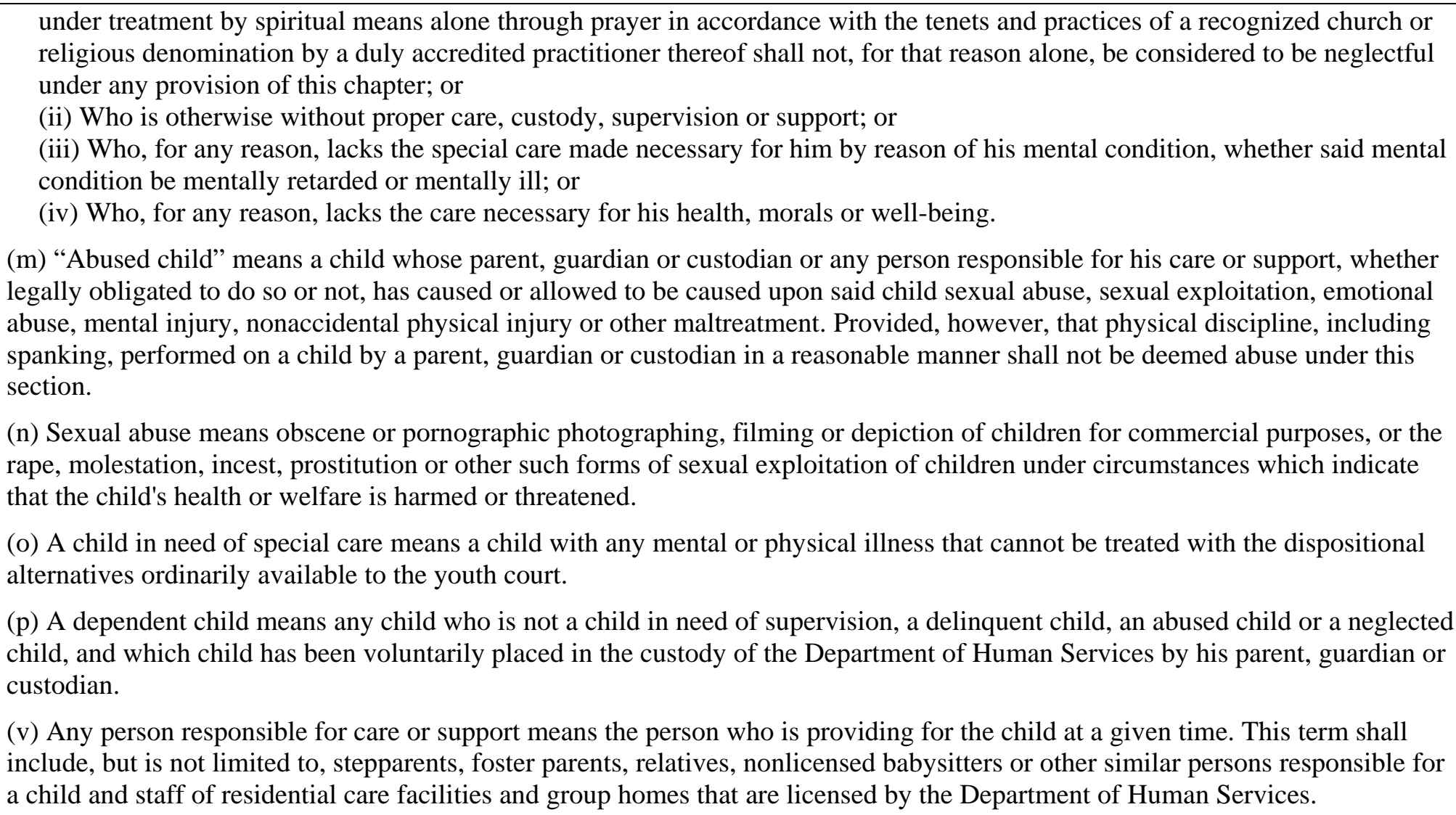 \\
\hline
\end{tabular}

NOTE:

** For purposes of this chart, corrections officers, police officers, peace officers, probation officers or "catch-all” phrases such as “all persons” have been bolded. However, many mandatory reporters include professionals who may have contact or work in correctional facilities. Such individuals include physicians, nurses, dentists, teachers and social workers. These statutes can be used as a tool to require staff other than correctional officers to report sexual misconduct with inmates.

This publication is developed by the NIC/WCL Project on Addressing Prison Rape under NIC Cooperative Agreement 06S20GJJ1.

This is not to be reproduced or cited without permission from the authors.

American University, Washington College of Law

Current as of May 7, 2009 


\section{Fifty State Survey of Mandatory Reporting Statutes}

\section{NIC/WCL Project on Addressing Prison Rape}

\begin{tabular}{|c|c|}
\hline $\begin{array}{l}\text { Persons Required to } \\
\text { Report } \\
\text { (Mississippi) }\end{array}$ & $\begin{array}{l}\text { MISS. CODE ANN. § 43-21-353 (West 2008) } \\
\text { (1) Any: } \\
\text { - Law enforcement officer; } \\
\text { - Attorney; } \\
\text { - Physician; } \\
\text { - Dentist; } \\
\text { - Intern; } \\
\text { - Resident; } \\
\text { - Nurse; } \\
\text { - Psychologist; } \\
\text { - Social worker; } \\
\text { - Family protection specialist; } \\
\text { - Child care giver; } \\
\text { - Minister; } \\
\text { - Public or private school employee; or } \\
\text { - Any other person having reasonable cause to suspect that a child is a neglected child or an abused child. }\end{array}$ \\
\hline $\begin{array}{l}\text { Reporting } \\
\text { Procedures } \\
\text { (Mississippi) }\end{array}$ & $\begin{array}{l}\text { MISS. CODE ANN. } § 43-21-353 \text { (West 2008). } \\
\text { (1) Shall cause an oral report to be made immediately by telephone or otherwise and followed as soon thereafter as possible by a } \\
\text { report in writing to the Department of Human Services and immediately a referral shall be made by the Department of Human } \\
\text { Services to the youth court intake unit, which unit shall promptly comply with Section 43-21-357. } \\
\text { (2) Any report to the Department of Human Services shall contain the names and addresses of the child and his parents or other } \\
\text { persons responsible for his care, if known, the child's age, the nature and extent of the child's injuries, including any evidence of }\end{array}$ \\
\hline
\end{tabular}

NOTE:

** For purposes of this chart, corrections officers, police officers, peace officers, probation officers or “catch-all” phrases such as “all persons” have been bolded. However, many mandatory reporters include professionals who may have contact or work in correctional facilities. Such individuals include physicians, nurses, dentists, teachers and social workers. These statutes can be used as a tool to require staff other than correctional officers to report sexual misconduct with inmates.

This publication is developed by the NIC/WCL Project on Addressing Prison Rape under NIC Cooperative Agreement 06S20GJJ1.

This is not to be reproduced or cited without permission from the authors.

American University, Washington College of Law

Current as of May 7, 2009 


\section{Fifty State Survey of Mandatory Reporting Statutes}

\section{NIC/WCL Project on Addressing Prison Rape}

\begin{tabular}{|c|c|}
\hline $\begin{array}{l}\text { Reporting } \\
\text { Procedures Cont'd } \\
\text { (Mississippi) }\end{array}$ & $\begin{array}{l}\text { previous injuries and any other information that might be helpful in establishing the cause of the injury and the identity of the } \\
\text { perpetrator. }\end{array}$ \\
\hline $\begin{array}{l}\text { Penalty for Failure to } \\
\text { Report } \\
\text { (Mississippi) }\end{array}$ & $\begin{array}{l}\text { Miss. CODE ANN. § 43-21-353 (West 2008) } \\
\text { (7) Anyone who willfully violates any provision of this section shall be, upon being found guilty, punished by a fine not to exceed } \\
\text { Five Thousand Dollars }(\$ 5,000.00) \text {, or by imprisonment in jail not to exceed one (1) year, or both. }\end{array}$ \\
\hline $\begin{array}{l}\text { Mandatory } \\
\text { Reporting Statute } \\
\text { (Mississippi) }\end{array}$ & $\begin{array}{l}\text { AGAINST AN ADULT } \\
\text { Miss. CODE ANN. § 43-47-7 (West 2008) }\end{array}$ \\
\hline $\begin{array}{l}\text { What has to be } \\
\text { reported? } \\
\text { (Mississippi) }\end{array}$ & $\begin{array}{l}\text { Miss. CODE ANN. § 43-47-7 (West 2008) } \\
\text { (1)(a) Knowledge or suspicion that a vulnerable adult has been or is being abused. }\end{array}$ \\
\hline $\begin{array}{l}\text { Relevant Definitions } \\
\text { (Mississippi) }\end{array}$ & $\begin{array}{l}\text { MisS. CODE ANN. § 43-47-5 (West 2008) } \\
\text { (a) "Abuse” means the willful or nonaccidental infliction of physical pain, injury or mental anguish on a vulnerable adult, the } \\
\text { unreasonable confinement of a vulnerable adult, or the willful deprivation by a caretaker of services which are necessary to } \\
\text { maintain the mental and physical health of a vulnerable adult. "Abuse" includes sexual abuse. "Abuse" shall not mean conduct } \\
\text { which is a part of the treatment and care of, and in furtherance of the health and safety of a patient or resident of a care facility. } \\
\text { "Abuse" includes, but is not limited to, a single incident. } \\
\text { (i) "Exploitation" means the illegal or improper use of a vulnerable adult or his resources for another's profit or advantage, with or } \\
\text { without the consent of the vulnerable adult, and includes acts committed pursuant to a power of attorney. "Exploitation" includes, }\end{array}$ \\
\hline
\end{tabular}

NOTE:

** For purposes of this chart, corrections officers, police officers, peace officers, probation officers or “catch-all” phrases such as “all persons” have been bolded. However, many mandatory reporters include professionals who may have contact or work in correctional facilities. Such individuals include physicians, nurses, dentists, teachers and social workers. These statutes can be used as a tool to require staff other than correctional officers to report sexual misconduct with inmates.

This publication is developed by the NIC/WCL Project on Addressing Prison Rape under NIC Cooperative Agreement 06S20GJJ1.

This is not to be reproduced or cited without permission from the authors.

American University, Washington College of Law

Current as of May 7, 2009 


\section{Fifty State Survey of Mandatory Reporting Statutes}

\section{NIC/WCL Project on Addressing Prison Rape}

\begin{tabular}{|c|c|}
\hline $\begin{array}{l}\text { Relevant Definitions } \\
\text { Cont'd } \\
\text { (Mississippi) }\end{array}$ & $\begin{array}{l}\text { but is not limited to, a single incident. } \\
\text { (k) "Neglect” means either the inability of a vulnerable adult who is living alone to provide for himself the food, clothing, shelter, } \\
\text { health care or other services which are necessary to maintain his mental and physical health, or failure of a caretaker to supply the } \\
\text { vulnerable adult with the food, clothing, shelter, health care, supervision or other services which a reasonably prudent person } \\
\text { would do to maintain the vulnerable adult's mental and physical health. "Neglect" includes, but is not limited to, a single incident. } \\
\text { (n) "Vulnerable adult" means a person whether minor or adult whose ability to perform the normal activities of daily living or to } \\
\text { provide for his or her own care or protection from abuse, neglect, exploitation or improper sexual contact is impaired due to a } \\
\text { mental, emotional, physical or developmental disability or dysfunction, or brain damage or the infirmities of aging. The term } \\
\text { "vulnerable adult" also includes all residents or patients, regardless of age, in a care facility. The department shall not be } \\
\text { prohibited from investigating, and shall have the authority and responsibility to fully investigate, in accordance with the provisions } \\
\text { of this chapter, any allegation of abuse, neglect, or exploitation regarding a patient in a care facility, if the alleged abuse, neglect or } \\
\text { exploitation occurred at a private residence. }\end{array}$ \\
\hline $\begin{array}{l}\text { Persons Required to } \\
\text { Report } \\
\text { (Mississippi) }\end{array}$ & $\begin{array}{l}\text { MISS. CODE ANN. § 43-47-7 (West 2008) } \\
\text { (1)(a) Any person including, but not limited to, the following, who knows or suspects that a vulnerable adult has been or is being } \\
\text { abused, neglected, or exploited: } \\
\text { (i) Attorney, physician, osteopathic physician, medical examiner, chiropractor or nurse engaged in the admission, } \\
\text { examination, care or treatment of vulnerable adults; } \\
\text { (ii) Health professional or mental health professional other than one listed above; } \\
\text { (iii) Practitioner who relies solely on spiritual means for healing; } \\
\text { (iv) Social worker, family protection worker, family protection specialist or other professional adult care, residential or } \\
\text { institutional staff; } \\
\text { (v) State, county or municipal criminal justice employee or law enforcement officer; } \\
\text { (vi) Human rights advocacy committee or long-term care ombudsman council member. }\end{array}$ \\
\hline
\end{tabular}

** For purposes of this chart, corrections officers, police officers, peace officers, probation officers or "catch-all” phrases such as “all persons” have been bolded. However, many mandatory reporters include professionals who may have contact or work in correctional facilities. Such individuals include physicians, nurses, dentists, teachers and social workers. These statutes can be used as a tool to require staff other than correctional officers to report sexual misconduct with inmates.

This publication is developed by the NIC/WCL Project on Addressing Prison Rape under NIC Cooperative Agreement 06S20GJJ1.

This is not to be reproduced or cited without permission from the authors.

American University, Washington College of Law

Current as of May 7, 2009 


\section{Fifty State Survey of Mandatory Reporting Statutes}

\section{NIC/WCL Project on Addressing Prison Rape}

\begin{tabular}{|c|c|}
\hline $\begin{array}{l}\text { Reporting } \\
\text { Procedures } \\
\text { (Mississippi) }\end{array}$ & $\begin{array}{l}\text { Miss. Code Ann. § 43-47-7 (West 2008) } \\
\text { (1)(a) Immediately report such knowledge or suspicion to the Department of Human Services or to the county department of } \\
\text { human services where the vulnerable adult is located. } \\
\text { (1)(b) To the extent possible, a report made pursuant to paragraph (a) must contain, but need not be limited to, the following } \\
\text { information: } \\
\text { (i) Name, age, race, sex, physical description and location of each vulnerable adult alleged to have been abused, neglected or } \\
\text { exploited. } \\
\text { (ii) Names, addresses and telephone numbers of the vulnerable adult's family members. } \\
\text { (iii) Name, address and telephone number of each alleged perpetrator. } \\
\text { (iv) Name, address and telephone number of the caregiver of the vulnerable adult, if different from the alleged perpetrator. } \\
\text { (v) Description of the neglect, exploitation, physical or psychological injuries sustained. } \\
\text { (vi) Actions taken by the reporter, if any, such as notification of the criminal justice agency. } \\
\text { (vii) Any other information available to the reporting person which may establish the cause of abuse, neglect or exploitation } \\
\text { that occurred or is occurring. }\end{array}$ \\
\hline $\begin{array}{l}\text { Penalty for Failure to } \\
\text { Report } \\
\text { (Mississippi) }\end{array}$ & $\begin{array}{l}\text { Miss. Code Ann. } § 43-47-7 \text { (West 2008) } \\
\text { (c) A person who fails to make a report as required under this subsection or who, because of the circumstances, should have } \\
\text { known or suspected beyond a reasonable doubt that a vulnerable adult suffers from exploitation, abuse, neglect or self-neglect but } \\
\text { who knowingly fails to comply with this section shall, upon conviction, be guilty of a misdemeanor and shall be punished by a } \\
\text { fine not exceeding Five Thousand Dollars ( } \$ 5,000.00) \text {, or by imprisonment in the county jail for not more than six (6) months, or } \\
\text { both such fine and imprisonment. }\end{array}$ \\
\hline
\end{tabular}

NOTE:

** For purposes of this chart, corrections officers, police officers, peace officers, probation officers or “catch-all” phrases such as “all persons” have been bolded. However, many mandatory reporters include professionals who may have contact or work in correctional facilities. Such individuals include physicians, nurses, dentists, teachers and social workers. These statutes can be used as a tool to require staff other than correctional officers to report sexual misconduct with inmates.

This publication is developed by the NIC/WCL Project on Addressing Prison Rape under NIC Cooperative Agreement 06S20GJJ1.

This is not to be reproduced or cited without permission from the authors.

American University, Washington College of Law

Current as of May 7, 2009 


\section{Fifty State Survey of Mandatory Reporting Statutes}

\section{NIC/WCL Project on Addressing Prison Rape}

\begin{tabular}{|c|c|}
\hline \multicolumn{2}{|r|}{ MISSOURI } \\
\hline $\begin{array}{l}\text { Mandatory } \\
\text { Reporting Statute } \\
\text { (Missouri) }\end{array}$ & $\begin{array}{l}\text { AGAINST A CHILD } \\
\text { V.A.M.S. § } 210.115 \text { (West 2008) }\end{array}$ \\
\hline $\begin{array}{l}\text { What has to be } \\
\text { reported? } \\
\text { (Missouri) }\end{array}$ & $\begin{array}{l}\text { V.A.M.S. § } 210.115 \text { (West 2008) } \\
\text { (1) Reasonable cause to suspect that a child has been or may be subjected to abuse or neglect or observes a child being subjected } \\
\text { to conditions or circumstances which would reasonably result in abuse or neglect. }\end{array}$ \\
\hline $\begin{array}{l}\text { Relevant Definitions } \\
\text { (Missouri) }\end{array}$ & $\begin{array}{l}\text { V.A.M.S. § } 210.115 \text { (West 2008) } \\
\text { (1) “Abuse” means, any physical injury, sexual abuse, or emotional abuse inflicted on a child other than by accidental means by } \\
\text { those responsible for the child's care, custody, and control, except that discipline including spanking, administered in a reasonable } \\
\text { manner, shall not be construed to be abuse. } \\
\text { (4)” Child” means any person, regardless of physical or mental condition, under eighteen years of age. } \\
\text { (11) “Jail” or “detention center” "personnel” means employees and volunteers working in any premises or institution where } \\
\text { incarceration, evaluation, care, treatment or rehabilitation is provided to persons who are being held under custody of the law. } \\
\text { (12) Neglect, failure to provide, by those responsible for the care, custody, and control of the child, the proper or necessary } \\
\text { support, education as required by law, nutrition or medical, surgical, or any other care necessary for the child's well-being; } \\
\text { (16) Those responsible for the care, custody, and control of the child, those included but not limited to the parents or guardian of a }\end{array}$ \\
\hline
\end{tabular}

** For purposes of this chart, corrections officers, police officers, peace officers, probation officers or “catch-all” phrases such as “all persons” have been bolded. However, many mandatory reporters include professionals who may have contact or work in correctional facilities. Such individuals include physicians, nurses, dentists, teachers and social workers. These statutes can be used as a tool to require staff other than correctional officers to report sexual misconduct with inmates.

This publication is developed by the NIC/WCL Project on Addressing Prison Rape under NIC Cooperative Agreement 06S20GJJ1.

This is not to be reproduced or cited without permission from the authors.

American University, Washington College of Law

Current as of May 7, 2009 


\section{Fifty State Survey of Mandatory Reporting Statutes}

\section{NIC/WCL Project on Addressing Prison Rape}

\begin{tabular}{|c|c|}
\hline $\begin{array}{l}\text { Relevant Definitions } \\
\text { Cont'd } \\
\text { (Missouri) }\end{array}$ & $\begin{array}{l}\text { child, other members of the child's household, or those exercising supervision over a child for any part of a twenty-four-hour day. } \\
\text { Those responsible for the care, custody and control shall also include any adult who, based on relationship to the parents of the } \\
\text { child, members of the child's household or the family, has access to the child. }\end{array}$ \\
\hline $\begin{array}{l}\text { Persons Required to } \\
\text { Report } \\
\text { (Missouri) }\end{array}$ & $\begin{array}{l}\text { V.A.M.S. § } 210.115 \text { (West 2008) } \\
\text { (1) When any: } \\
\text { - Peace officer or law enforcement official; } \\
\text { - Juvenile officer; } \\
\text { - Jail or detention center personnel; } \\
\text { - Physician, medical examiner, coroner, dentist, chiropractor, optometrist, podiatrist, resident, intern, nurse, hospital or } \\
\text { clinic personnel that are engaged in the examination, care, treatment or research of persons; } \\
\text { - Any other health practitioner; } \\
\text { - Psychologist; } \\
\text { - Mental health professional; } \\
\text { - Social worker; } \\
\text { - Day care center worker or other child-care worker; } \\
\text { - Probation or parole officer; } \\
\text { - Teacher; } \\
\text { - Principal or other school official; } \\
\text { - Minister as provided by section } 352.400, \text { RSMo; or } \\
\text { - Other person with responsibility for the care of children. }\end{array}$ \\
\hline
\end{tabular}

NOTE:

** For purposes of this chart, corrections officers, police officers, peace officers, probation officers or "catch-all” phrases such as "all persons" have been bolded. However, many mandatory reporters include professionals who may have contact or work in correctional facilities. Such individuals include physicians, nurses, dentists, teachers and social workers. These statutes can be used as a tool to require staff other than correctional officers to report sexual misconduct with inmates.

This publication is developed by the NIC/WCL Project on Addressing Prison Rape under NIC Cooperative Agreement 06S20GJJ1.

This is not to be reproduced or cited without permission from the authors.

American University, Washington College of Law

Current as of May 7, 2009 


\section{Fifty State Survey of Mandatory Reporting Statutes}

\section{NIC/WCL Project on Addressing Prison Rape}

\begin{tabular}{|c|c|}
\hline $\begin{array}{l}\text { Reporting } \\
\text { Procedures } \\
\text { (Missouri) }\end{array}$ & $\begin{array}{l}\text { V.A.M.S. § } 210.115 \text { (West 2008) } \\
\text { (1) Immediately report or cause a report to be made. } \\
\text { V.A.M.S. § } 210.130 \text { (West 2008) } \\
\text { (1) Oral reports of abuse or neglect shall be made to the division by telephone or otherwise. } \\
\text { (2) Such reports shall include the following information: The names and addresses of the child and his parents or other persons } \\
\text { responsible for his care, if known; the child's age, sex, and race; the nature and extent of the child's injuries, abuse or neglect, } \\
\text { including any evidence of previous injuries, abuse, or neglect to the child or his siblings; the name, age and address of the person } \\
\text { responsible for the injuries, abuse, or neglect, if known; family composition; the source of the report; the name and address of the } \\
\text { person making the report, his occupation, and where he can be reached; the actions taken by the reporting source, including the } \\
\text { taking of color photographs or the making of radiologic examinations... removal or keeping of the child... } \\
\text { (3) Evidence of sexual abuse or sexual molestation of any child under eighteen years of age shall be turned over to the division } \\
\text { within twenty-four hours by those mandated to report. }\end{array}$ \\
\hline $\begin{array}{l}\text { Penalty for Failure to } \\
\text { Report } \\
\text { (Missouri) }\end{array}$ & $\begin{array}{l}\text { V.A.M.S. } \S 210.165 \text { (West 2008) } \\
\text { (1) Any person violating any provision of sections } 210.110 \text { to } 210.165 \text { is guilty of a class A misdemeanor. } \\
\text { V.A.M.S. } § 588.011 \\
\text { The authorized terms of imprisonment for a class A misdemeanor is a term not to exceed one year Maximum of one (1) year } \\
\text { imprisonment. }\end{array}$ \\
\hline
\end{tabular}

NOTE:

** For purposes of this chart, corrections officers, police officers, peace officers, probation officers or “catch-all” phrases such as “all persons” have been bolded. However, many mandatory reporters include professionals who may have contact or work in correctional facilities. Such individuals include physicians, nurses, dentists, teachers and social workers. These statutes can be used as a tool to require staff other than correctional officers to report sexual misconduct with inmates.

This publication is developed by the NIC/WCL Project on Addressing Prison Rape under NIC Cooperative Agreement 06S20GJJ1.

This is not to be reproduced or cited without permission from the authors.

American University, Washington College of Law

Current as of May 7, 2009 


\section{Fifty State Survey of Mandatory Reporting Statutes}

\section{NIC/WCL Project on Addressing Prison Rape}

\begin{tabular}{|c|c|}
\hline $\begin{array}{l}\text { Penalty for Failure to } \\
\text { Report Cont'd } \\
\text { (Missouri) }\end{array}$ & $\begin{array}{l}\text { V.A.M.S. } \S 560.016 \text { (West 2008) } \\
\text { Except as otherwise provided for an offense outside this code, a person who has been convicted of a misdemeanor or infraction } \\
\text { may be sentenced to pay a fine which does not exceed } \$ 1,000 \text { for a class A misdemeanor, }\end{array}$ \\
\hline $\begin{array}{l}\text { Mandatory } \\
\text { Reporting Statute } \\
\text { (Missouri) }\end{array}$ & $\begin{array}{l}\text { AGAINST AN ADULT } \\
\text { V.A.M.S. § } 217.410 \text { (West 2008) } \\
\text { V.A.M.S. § } 198.070 \text { (West 2008) }\end{array}$ \\
\hline $\begin{array}{l}\text { What has to be } \\
\text { reported? } \\
\text { (Missouri) }\end{array}$ & $\begin{array}{l}\text { V.A.M.S. § } 217.410 \\
\text { (1) Reasonable cause to believe that an offender in a correctional center operated or funded by the department has been abused. } \\
\text { V.A.M.S. § } 198.070 \text { (West 2008) } \\
\text { 1. Reasonable cause to believe that a resident of a facility has been abused or neglected, he or she shall immediately report or cause } \\
\text { a report to be made to the department. }\end{array}$ \\
\hline $\begin{array}{l}\text { Relevant Definitions } \\
\text { (Missouri) }\end{array}$ & $\begin{array}{l}\text { V.A.M.S. § } 217.405 \text { (West 2008) } \\
\text { (1) Except as provided in subsection } 3 \text { of this section, a person commits the crime of "offender abuse" if he knowingly injures the } \\
\text { physical well-being of any offender under the jurisdiction of the department by beating, striking, wounding or by sexual contact } \\
\text { with such person. }\end{array}$ \\
\hline
\end{tabular}

NOTE:

** For purposes of this chart, corrections officers, police officers, peace officers, probation officers or "catch-all” phrases such as "all persons" have been bolded. However, many mandatory reporters include professionals who may have contact or work in correctional facilities. Such individuals include physicians, nurses, dentists, teachers and social workers. These statutes can be used as a tool to require staff other than correctional officers to report sexual misconduct with inmates.

This publication is developed by the NIC/WCL Project on Addressing Prison Rape under NIC Cooperative Agreement 06S20GJJ1.

This is not to be reproduced or cited without permission from the authors.

American University, Washington College of Law

Current as of May 7, 2009 


\section{Fifty State Survey of Mandatory Reporting Statutes}

\section{NIC/WCL Project on Addressing Prison Rape}

\begin{tabular}{|c|c|}
\hline $\begin{array}{l}\text { Persons Required to } \\
\text { Report } \\
\text { (Missouri) }\end{array}$ & 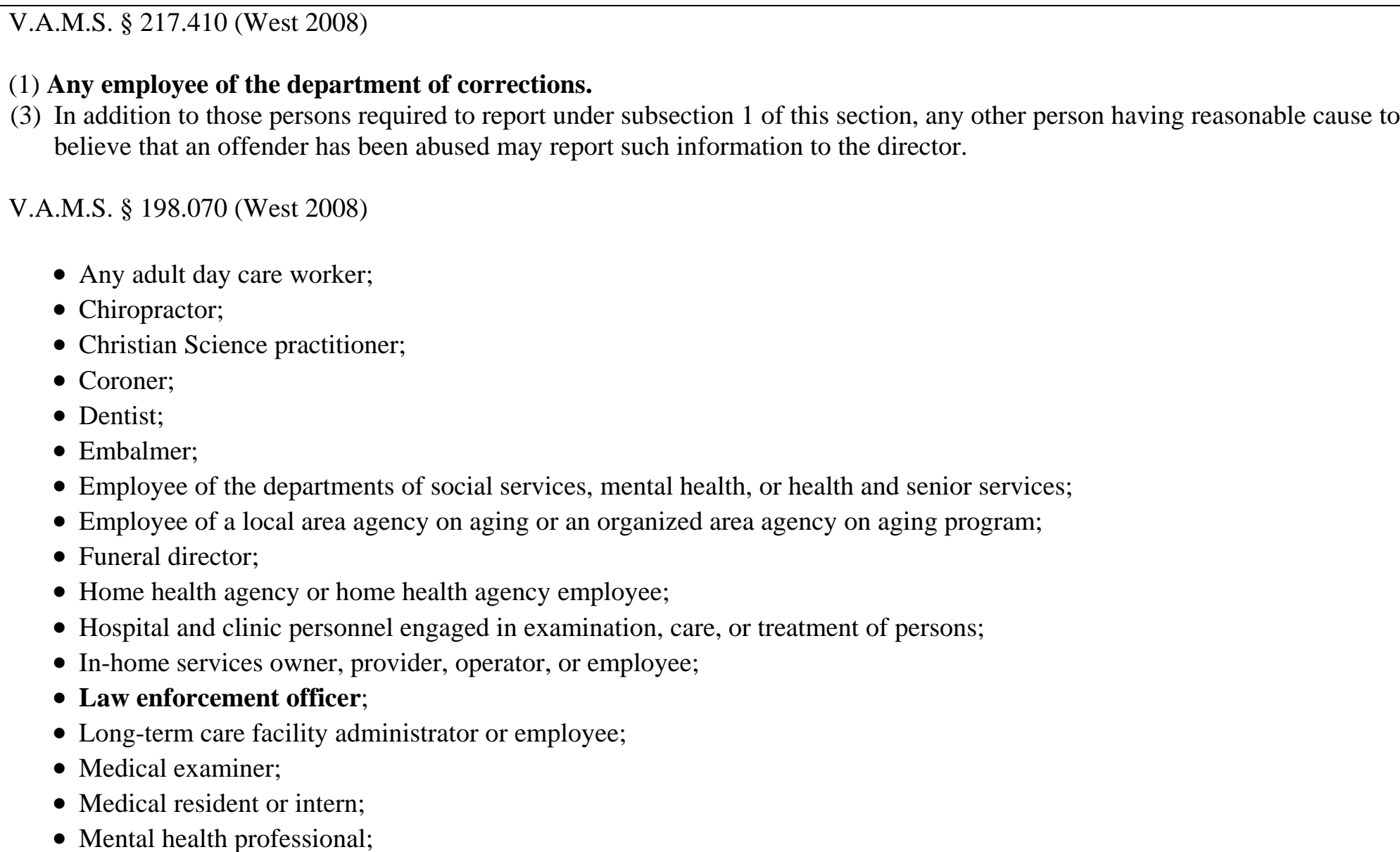 \\
\hline
\end{tabular}

** For purposes of this chart, corrections officers, police officers, peace officers, probation officers or "catch-all” phrases such as "all persons" have been bolded. However, many mandatory reporters include professionals who may have contact or work in correctional facilities. Such individuals include physicians, nurses, dentists, teachers and social workers. These statutes can be used as a tool to require staff other than correctional officers to report sexual misconduct with inmates.

This publication is developed by the NIC/WCL Project on Addressing Prison Rape under NIC Cooperative Agreement 06S20GJJ1.

This is not to be reproduced or cited without permission from the authors.

American University, Washington College of Law

Current as of May 7, 2009 


\section{Fifty State Survey of Mandatory Reporting Statutes}

\section{NIC/WCL Project on Addressing Prison Rape}

\begin{tabular}{|c|c|}
\hline $\begin{array}{l}\text { Persons Required to } \\
\text { Report Cont'd } \\
\text { (Missouri) }\end{array}$ & $\begin{array}{l}\text { - Minister; } \\
\text { - Nurse; } \\
\text { - Optome practitioner; } \\
\text { - Other health practitioner; } \\
\text { - Peace officer; } \\
\text { - Pharmacist; } \\
\text { - Physical therapist; } \\
\text { - Physician; } \\
\text { - Physician's assistant; } \\
\text { - Podiatrist; } \\
\text { - Probation or parole officer; } \\
\text { - Psychologist; } \\
\text { - Social worker; or } \\
\text { - Other person with the care of a person sixty years of age or older } \\
\text { 5. In addition to those persons required to report pursuant to subsection } 1 \text { of this section, any other person having } \\
\text { reasonable cause to believe that a resident has been abused or neglected may report such information to the } \\
\text { department. }\end{array}$ \\
\hline $\begin{array}{l}\text { Reporting } \\
\text { Procedures } \\
\text { (Missouri) }\end{array}$ & $\begin{array}{l}\text { V.A.M.S. § } 217.410 \text { (West 2008) } \\
\text { (1) Immediately report offender abuse in writing to the director. }\end{array}$ \\
\hline
\end{tabular}

NOTE:

** For purposes of this chart, corrections officers, police officers, peace officers, probation officers or "catch-all” phrases such as “all persons” have been bolded. However, many mandatory reporters include professionals who may have contact or work in correctional facilities. Such individuals include physicians, nurses, dentists, teachers and social workers. These statutes can be used as a tool to require staff other than correctional officers to report sexual misconduct with inmates.

This publication is developed by the NIC/WCL Project on Addressing Prison Rape under NIC Cooperative Agreement 06S20GJJ1.

This is not to be reproduced or cited without permission from the authors.

American University, Washington College of Law

Current as of May 7, 2009 


\section{Fifty State Survey of Mandatory Reporting Statutes}

\section{NIC/WCL Project on Addressing Prison Rape}

\begin{tabular}{|c|c|}
\hline $\begin{array}{l}\text { Reporting } \\
\text { Procedures Cont'd } \\
\text { (Missouri) }\end{array}$ & 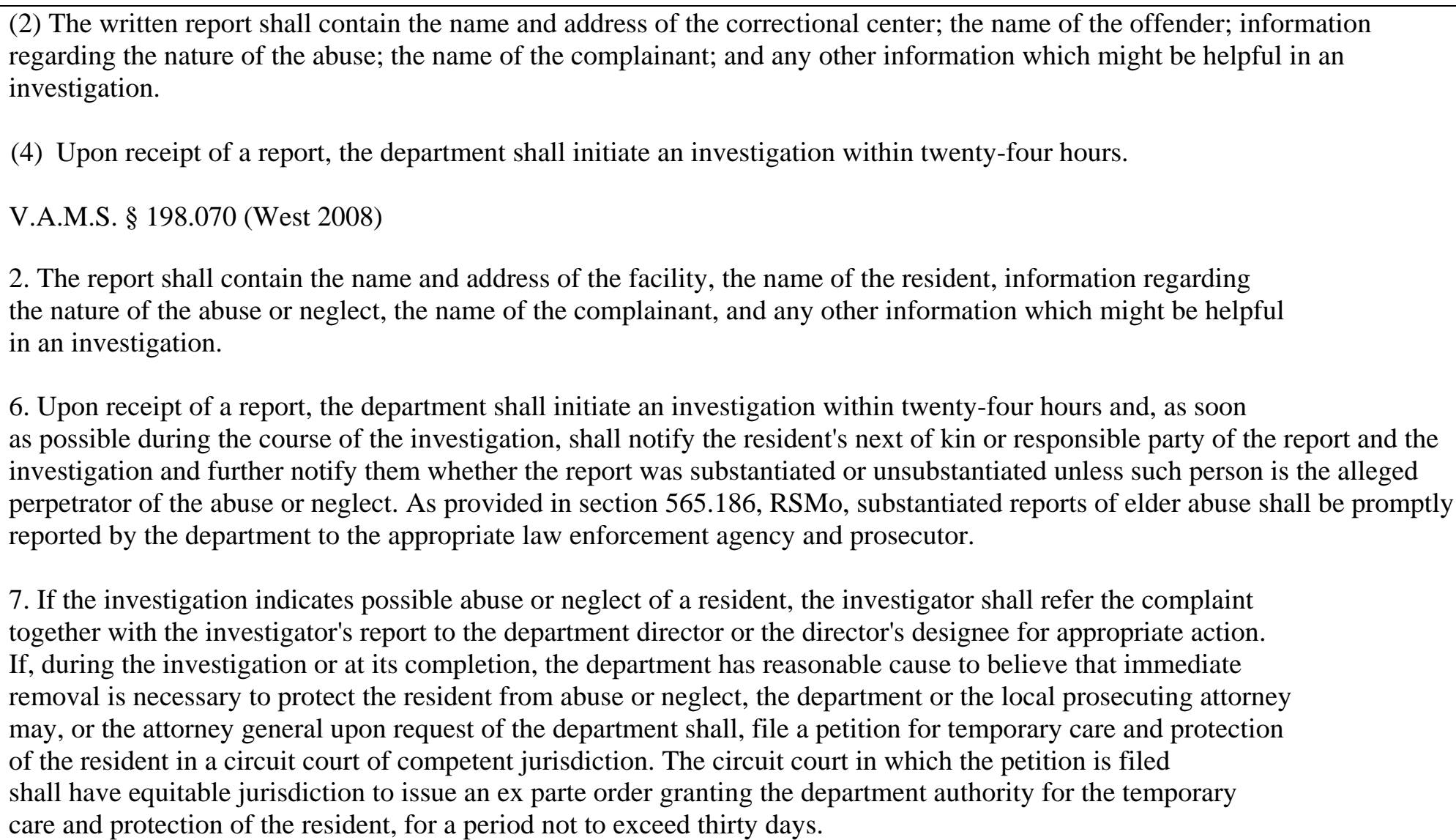 \\
\hline
\end{tabular}

NOTE:

** For purposes of this chart, corrections officers, police officers, peace officers, probation officers or "catch-all” phrases such as “all persons” have been bolded. However, many mandatory reporters include professionals who may have contact or work in correctional facilities. Such individuals include physicians, nurses, dentists, teachers and social workers. These statutes can be used as a tool to require staff other than correctional officers to report sexual misconduct with inmates.

This publication is developed by the NIC/WCL Project on Addressing Prison Rape under NIC Cooperative Agreement 06S20GJJ1.

This is not to be reproduced or cited without permission from the authors.

American University, Washington College of Law

Current as of May 7, 2009 


\section{Fifty State Survey of Mandatory Reporting Statutes}

\section{NIC/WCL Project on Addressing Prison Rape}

\begin{tabular}{|c|c|}
\hline $\begin{array}{l}\text { Reporting } \\
\text { Procedures Cont'd } \\
\text { (Missouri) }\end{array}$ & $\begin{array}{l}\text { 8. Reports shall be confidential, as provided pursuant to section 660.320, RSMo. } \\
\text { 10. Within five working days after a report required to be made pursuant to this section is received, the person } \\
\text { making the report shall be notified in writing of its receipt and of the initiation of the investigation. }\end{array}$ \\
\hline $\begin{array}{l}\text { Penalty for Failure to } \\
\text { Report } \\
\text { (Missouri) }\end{array}$ & $\begin{array}{l}\text { V.A.M.S. } \S 217.410 \text { (West 2008) } \\
\text { (3) Any person required by subsection } 1 \text { of this section to report or cause a report to be made, but who fails to do so within a } \\
\text { reasonable time after the act of abuse or neglect is guilty of a class A misdemeanor. } \\
\text { V.A.M.S. } § 558.011 \text { (West 2008) } \\
\text { Maximum of one (1) year imprisonment. } \\
\text { V.A.M.S. } § 560.016 \text { (West 2008) } \\
\text { Maximum fine of } \$ 1,000 \\
\text { V.A.M.S. } \S 198.070 \text { (West 2008) } \\
\text { 3. Any person required in subsection } 1 \text { of this section to report or cause a report to be made to the department who knowingly fails } \\
\text { to make a report within a reasonable time after the act of abuse or neglect as required in this subsection is guilty of a class A } \\
\text { misdemeanor. } \\
\text { 4. In addition to the penalties imposed by this section, any administrator who knowingly conceals any act of abuse or neglect } \\
\text { resulting in death or serious physical injury, as defined in section } 565.002 \text {, RSMo, is guilty of a class D felony. }\end{array}$ \\
\hline
\end{tabular}

NOTE:

** For purposes of this chart, corrections officers, police officers, peace officers, probation officers or "catch-all” phrases such as “all persons” have been bolded. However, many mandatory reporters include professionals who may have contact or work in correctional facilities. Such individuals include physicians, nurses, dentists, teachers and social workers. These statutes can be used as a tool to require staff other than correctional officers to report sexual misconduct with inmates.

This publication is developed by the NIC/WCL Project on Addressing Prison Rape under NIC Cooperative Agreement 06S20GJJ1.

This is not to be reproduced or cited without permission from the authors.

American University, Washington College of Law

Current as of May 7, 2009 


\section{Fifty State Survey of Mandatory Reporting Statutes}

\section{NIC/WCL Project on Addressing Prison Rape}

\begin{tabular}{|c|c|}
\hline \multicolumn{2}{|r|}{ MONTANA } \\
\hline $\begin{array}{l}\text { Mandatory } \\
\text { Reporting Statute } \\
\text { (Montana) }\end{array}$ & $\begin{array}{l}\text { AGAINST A CHILD } \\
\text { MCA § 41-3-201 (West 2008) }\end{array}$ \\
\hline $\begin{array}{l}\text { What has to be } \\
\text { reported? } \\
\text { (Montana) }\end{array}$ & $\begin{array}{l}\text { MCA § 41-3-201 (West 2008) } \\
\text { (1) Knowledge or reasonable cause to suspect, as a result of information they receive in their professional or official capacity, that } \\
\text { a child is abused or neglected. }\end{array}$ \\
\hline $\begin{array}{l}\text { Relevant Definitions } \\
\text { (Montana) }\end{array}$ & $\begin{array}{l}\text { MCA § 41-3-102 (West 2008) } \\
\text { (1) (a) “Abandon”, “abandoned”, and "abandonment” mean: } \\
\text { (i) leaving a child under circumstances that make reasonable the belief that the parent does not intend to resume care of the } \\
\text { child in the future; } \\
\text { (ii) willfully surrendering physical custody for a period of } 6 \text { months and during that period not manifesting to the child and the } \\
\text { person having physical custody of the child a firm intention to resume physical custody or to make permanent legal } \\
\text { arrangements for the care of the child; } \\
\text { (iii) that the parent is unknown and has been unknown for a period of } 90 \text { days and that reasonable efforts to identify and locate } \\
\text { the parent have failed; or } \\
\text { (iv) the voluntary surrender, by a parent of a newborn who is no more than } 30 \text { days old to an emergency services provider. } \\
\text { (1)(b) The terms do not include the voluntary surrender of a child to the department solely because of parental inability to access } \\
\text { publicly funded services. }\end{array}$ \\
\hline
\end{tabular}

** For purposes of this chart, corrections officers, police officers, peace officers, probation officers or "catch-all” phrases such as "all persons" have been bolded. However, many mandatory reporters include professionals who may have contact or work in correctional facilities. Such individuals include physicians, nurses, dentists, teachers and social workers. These statutes can be used as a tool to require staff other than correctional officers to report sexual misconduct with inmates.

This publication is developed by the NIC/WCL Project on Addressing Prison Rape under NIC Cooperative Agreement 06S20GJJ1.

This is not to be reproduced or cited without permission from the authors.

American University, Washington College of Law

Current as of May 7, 2009 


\section{Fifty State Survey of Mandatory Reporting Statutes}

\section{NIC/WCL Project on Addressing Prison Rape}

\begin{tabular}{|c|c|}
\hline $\begin{array}{l}\text { Relevant Definitions } \\
\text { Cont'd } \\
\text { (Montana) }\end{array}$ & 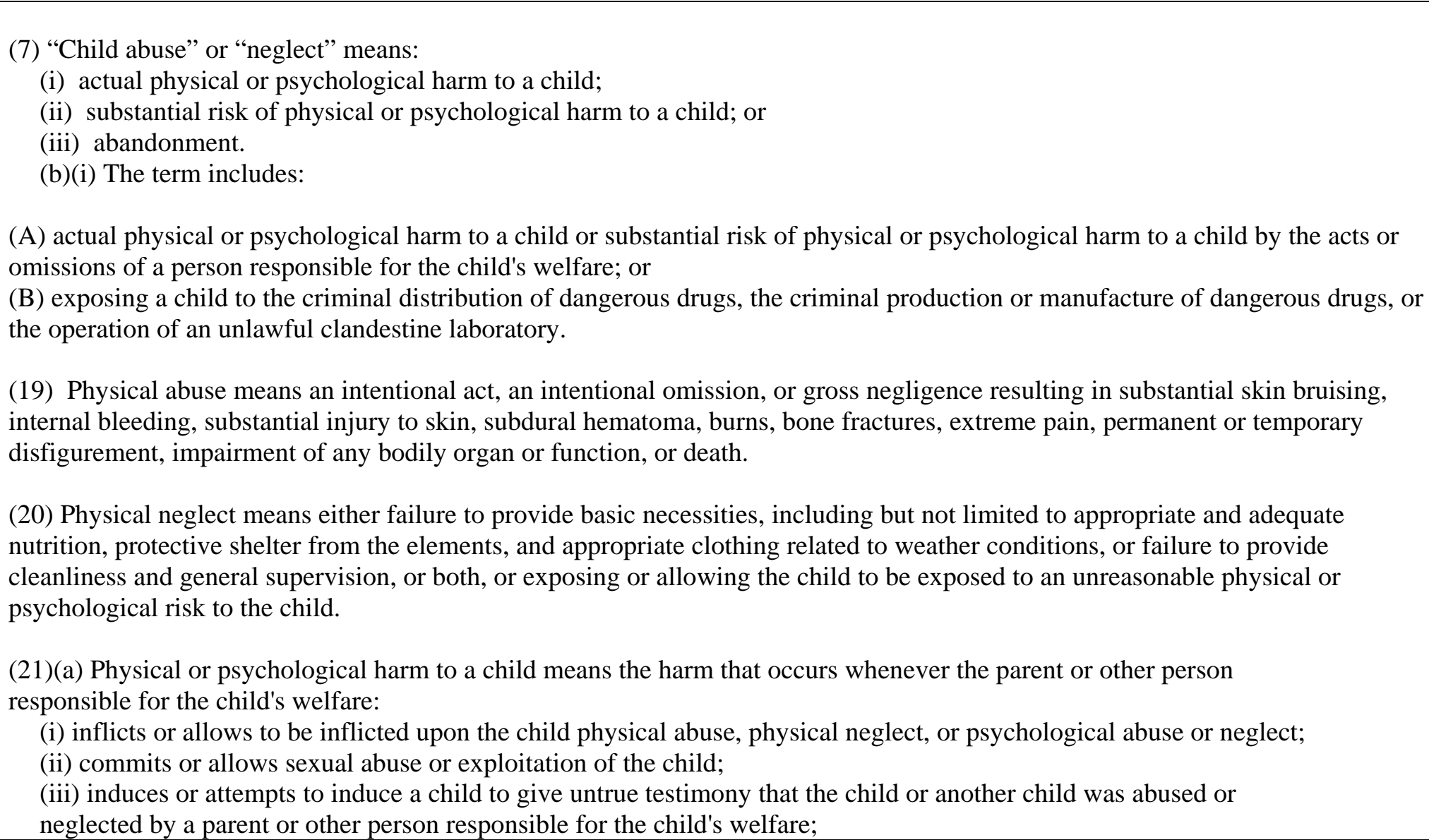 \\
\hline
\end{tabular}

NOTE:

** For purposes of this chart, corrections officers, police officers, peace officers, probation officers or “catch-all” phrases such as “all persons” have been bolded. However, many mandatory reporters include professionals who may have contact or work in correctional facilities. Such individuals include physicians, nurses, dentists, teachers and social workers. These statutes can be used as a tool to require staff other than correctional officers to report sexual misconduct with inmates.

This publication is developed by the NIC/WCL Project on Addressing Prison Rape under NIC Cooperative Agreement 06S20GJJ1.

This is not to be reproduced or cited without permission from the authors.

American University, Washington College of Law

Current as of May 7, 2009 


\section{Fifty State Survey of Mandatory Reporting Statutes}

\section{NIC/WCL Project on Addressing Prison Rape}

\begin{tabular}{|c|c|}
\hline $\begin{array}{l}\text { Relevant Definitions } \\
\text { Cont'd } \\
\text { (Montana) }\end{array}$ & $\begin{array}{l}\text { (iv) causes malnutrition or a failure to thrive or otherwise fails to supply the child with adequate food or fails to supply clothing, } \\
\text { shelter, education, or adequate health care, though financially able to do so or offered financial or other } \\
\text { reasonable means to do so; } \\
\text { (v) exposes or allows the child to be exposed to an unreasonable risk to the child's health or welfare by failing to } \\
\text { intervene or eliminate the risk; or } \\
\text { (vi) abandons the child. } \\
\text { (25) Reasonable cause to suspect means cause that would lead a reasonable person to believe that child abuse or neglect may have } \\
\text { occurred or is occurring, based on all the facts and circumstances known to the person. } \\
\text { (27)(a) Sexual abuse means the commission of sexual assault, sexual intercourse without consent, indecent exposure, deviate } \\
\text { sexual conduct, sexual abuse, ritual abuse, or incest. } \\
\text { (b) Sexual abuse does not include any necessary touching of an infant's or toddler's genital area while attending to the sanitary } \\
\text { or health care needs of that infant or toddler by a parent or other person responsible for the child's welfare. } \\
\text { (28) Sexual exploitation means allowing, permitting, or encouraging a child to engage in a prostitution offense, or allowing, } \\
\text { permitting, or encouraging sexual abuse of children. } \\
\text { MCA § } 45-2-101(\text { West 2008) } \\
\text { (6) Child or children means any individual or individuals under } 18 \text { years of age, unless a different age is specified. }\end{array}$ \\
\hline $\begin{array}{l}\text { Persons Required to } \\
\text { Report } \\
\text { (Montana) }\end{array}$ & $\begin{array}{l}\text { MCA § 41-3-201 (West 2008) } \\
\text { (2) Professionals and officials required to report are: } \\
\text { (a) A physician, resident, intern, or member of a hospital's staff engaged in the admission, examination, care, or treatment of } \\
\text { persons; }\end{array}$ \\
\hline
\end{tabular}

NOTE:

** For purposes of this chart, corrections officers, police officers, peace officers, probation officers or "catch-all” phrases such as “all persons” have been bolded. However, many mandatory reporters include professionals who may have contact or work in correctional facilities. Such individuals include physicians, nurses, dentists, teachers and social workers. These statutes can be used as a tool to require staff other than correctional officers to report sexual misconduct with inmates.

This publication is developed by the NIC/WCL Project on Addressing Prison Rape under NIC Cooperative Agreement 06S20GJJ1.

This is not to be reproduced or cited without permission from the authors.

American University, Washington College of Law

Current as of May 7, 2009 


\section{Fifty State Survey of Mandatory Reporting Statutes}

\section{NIC/WCL Project on Addressing Prison Rape}

\begin{tabular}{|c|c|}
\hline $\begin{array}{l}\text { Persons Required to } \\
\text { Report Cont'd } \\
\text { (Montana) }\end{array}$ & $\begin{array}{l}\text { (b) A nurse, osteopath, chiropractor, podiatrist, medical examiner, coroner, dentist, optometrist, or any other health or mental } \\
\text { health professional; } \\
\text { (c) Religious healers; } \\
\text { (d) School teachers, other school officials, and employees who work during regular school hours; } \\
\text { (e) A social worker, operator or employee of any registered or licensed day-care or substitute care facility, staff of a resource } \\
\text { and referral grant program or of a child and adult food care program, or an operator or employee of a child-care facility; } \\
\text { (f) A foster care, residential, or institutional worker; } \\
\text { (g) A peace officer or other law enforcement official; } \\
\text { (h) A member of the clergy; } \\
\text { (i) A guardian ad litem or a court-appointed advocate who is authorized to investigate a report of alleged abuse or neglect; or } \\
\text { (j) An employee of an entity that contracts with the department to provide direct services to children. } \\
\text { (3) A professional listed in subsection (2)(a) or (2)(b) involved in the delivery or care of an infant shall report to the department } \\
\text { any infant known to the professional to be affected by a dangerous drug, as defined in 50-32- } 101 \text {. }\end{array}$ \\
\hline $\begin{array}{l}\text { Reporting } \\
\text { Procedures } \\
\text { (Montana) }\end{array}$ & $\begin{array}{l}\text { MCA } \S \S 41-3-201 \text { (West 2008) } \\
\text { (1) Report the matter promptly to the department of public health and human services. } \\
\text { (5) The reports referred to under this section must contain: } \\
\text { (a) the names and addresses of the child and the child's parents or other persons responsible for the child's care; } \\
\text { (b) to the extent known, the child's age and the nature and extent of the child's injuries, including any evidence of previous } \\
\text { injuries; } \\
\text { (c) any other information that the maker of the report believes might be helpful in establishing the cause of the injuries or } \\
\text { showing the willful neglect and the identity of person or persons responsible for the injury or neglect; and } \\
\text { (d) the facts that led the person reporting to believe that the child has suffered injury or injuries or willful neglect, within the } \\
\text { meaning of this chapter. }\end{array}$ \\
\hline
\end{tabular}

NOTE:

** For purposes of this chart, corrections officers, police officers, peace officers, probation officers or “catch-all” phrases such as “all persons” have been bolded. However, many mandatory reporters include professionals who may have contact or work in correctional facilities. Such individuals include physicians, nurses, dentists, teachers and social workers. These statutes can be used as a tool to require staff other than correctional officers to report sexual misconduct with inmates.

This publication is developed by the NIC/WCL Project on Addressing Prison Rape under NIC Cooperative Agreement 06S20GJJ1.

This is not to be reproduced or cited without permission from the authors.

American University, Washington College of Law

Current as of May 7, 2009 


\section{Fifty State Survey of Mandatory Reporting Statutes}

\section{NIC/WCL Project on Addressing Prison Rape}

\begin{tabular}{|c|c|}
\hline $\begin{array}{l}\text { Penalty for Failure to } \\
\text { Report } \\
\text { (Montana) }\end{array}$ & $\begin{array}{l}\text { MCA } \S 41-3-207 \text { (West 2008) } \\
\text { (1) Any person, official, or institution required by law to report known or suspected child abuse or neglect who fails to do so or } \\
\text { who prevents another person from reasonably doing so is civilly liable for the damages proximately caused by such failure or } \\
\text { prevention. } \\
\text { (2) Any person or official required by law to report known or suspected child abuse or neglect who purposely or knowingly fails to } \\
\text { report known child abuse or neglect or purposely or knowingly prevents another person from doing so is guilty of a misdemeanor. } \\
\text { MONT. CODE ANN. } § 45-2-101 \text { (2008). } \\
\text { (42) Misdemeanor means an offense for which the sentence imposed upon conviction is imprisonment in the county jail for a term } \\
\text { of a fine, or both, or for which the sentence imposed is imprisonment in a state prison for a term of } 1 \text { year or less. }\end{array}$ \\
\hline $\begin{array}{l}\text { Mandatory } \\
\text { Reporting Statute } \\
\text { (Montana) }\end{array}$ & $\begin{array}{l}\text { AGAINST AN ADULT } \\
\text { MCA § 52-3-811 (West 2008) } \\
\text { 53-21-107. Abuse and neglect of persons admitted to mental health facility prohibited -- reporting -- investigations } \\
\quad \text { (1) Any form of abuse or neglect of a person admitted to a mental health facility is prohibited. }\end{array}$ \\
\hline $\begin{array}{l}\text { What has to be } \\
\text { reported? } \\
\text { (Montana) }\end{array}$ & $\begin{array}{l}\text { MCA § 52-3-811 (West 2008) } \\
\text { (1) Knowledge or a have reasonable cause to suspect that an older person or a person with a developmental disability known to } \\
\text { them in their professional or official capacities has been subjected to abuse, sexual abuse, neglect, or exploitation. }\end{array}$ \\
\hline
\end{tabular}

NOTE:

** For purposes of this chart, corrections officers, police officers, peace officers, probation officers or “catch-all” phrases such as “all persons” have been bolded. However, many mandatory reporters include professionals who may have contact or work in correctional facilities. Such individuals include physicians, nurses, dentists, teachers and social workers. These statutes can be used as a tool to require staff other than correctional officers to report sexual misconduct with inmates.

This publication is developed by the NIC/WCL Project on Addressing Prison Rape under NIC Cooperative Agreement 06S20GJJ1.

This is not to be reproduced or cited without permission from the authors.

American University, Washington College of Law

Current as of May 7, 2009 


\section{Fifty State Survey of Mandatory Reporting Statutes}

\section{NIC/WCL Project on Addressing Prison Rape}

\begin{tabular}{|c|c|}
\hline $\begin{array}{l}\text { What has to be } \\
\text { reported? Cont'd } \\
\text { (Montana) }\end{array}$ & 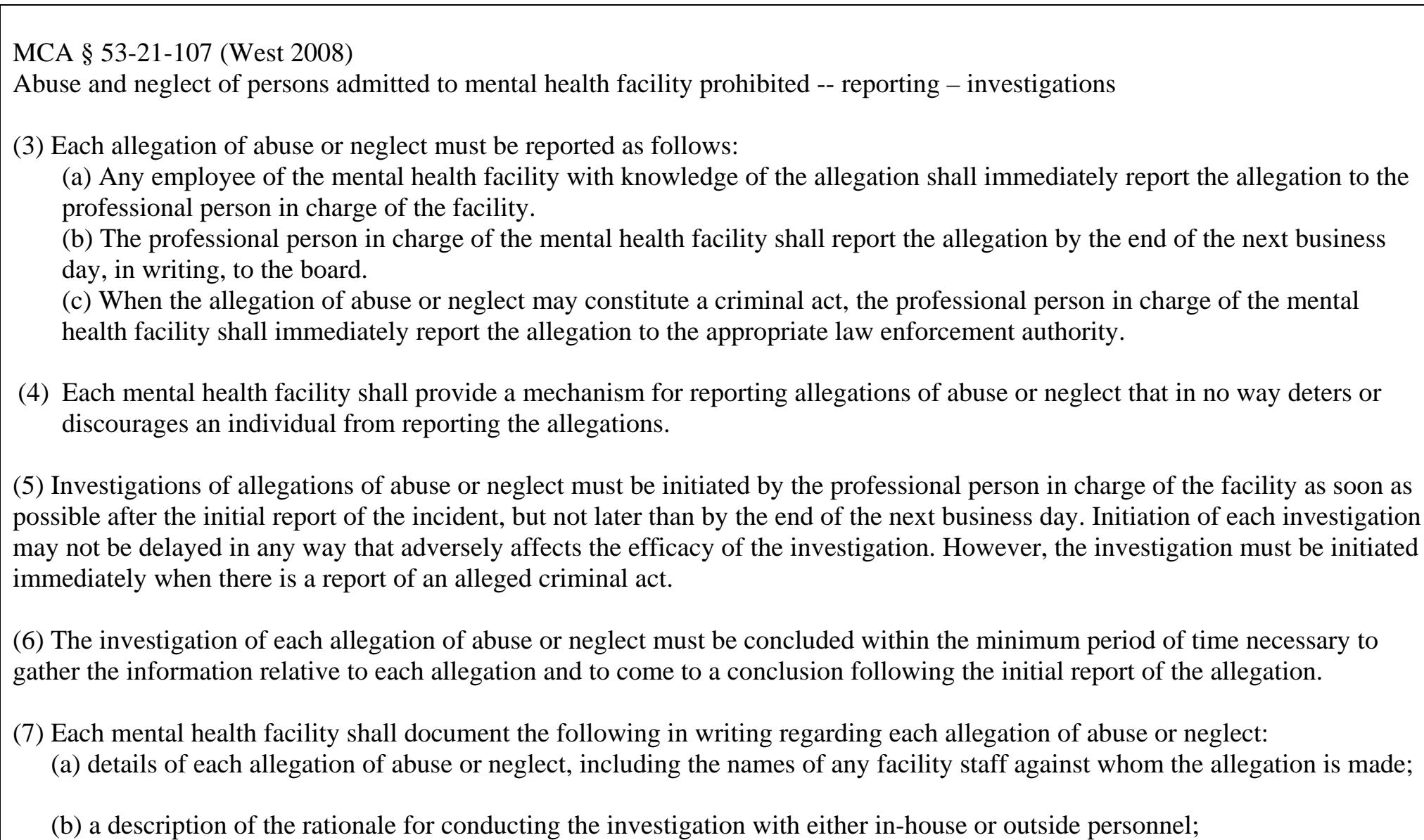 \\
\hline
\end{tabular}

NOTE:

** For purposes of this chart, corrections officers, police officers, peace officers, probation officers or “catch-all” phrases such as “all persons” have been bolded. However, many mandatory reporters include professionals who may have contact or work in correctional facilities. Such individuals include physicians, nurses, dentists, teachers and social workers. These statutes can be used as a tool to require staff other than correctional officers to report sexual misconduct with inmates.

This publication is developed by the NIC/WCL Project on Addressing Prison Rape under NIC Cooperative Agreement 06S20GJJ1.

This is not to be reproduced or cited without permission from the authors.

American University, Washington College of Law

Current as of May 7, 2009 


\section{Fifty State Survey of Mandatory Reporting Statutes}

\section{NIC/WCL Project on Addressing Prison Rape}

\begin{tabular}{|c|c|}
\hline $\begin{array}{l}\text { What has to be } \\
\text { reported? Cont'd } \\
\text { (Montana) }\end{array}$ & $\begin{array}{l}\text { (c) details of the process of the investigation of each allegation of abuse or neglect; } \\
\text { (d) details of the conclusions of the investigation; and } \\
\text { (e) details of corrective action taken. } \\
\text { (8) Mental health facilities shall provide a copy of the written report described in subsections (7)(a) through (7)(e) within } 5 \\
\text { working days of the completion of each investigation to the director of the department and to the board. }\end{array}$ \\
\hline $\begin{array}{l}\text { Relevant Definitions } \\
\text { (Montana) }\end{array}$ & $\begin{array}{l}\text { MCA } § 52-3-803 \text { (West 2008) } \\
\text { (1) “Abuse” means: } \\
\text { (b) the infliction of physical or mental injury; or } \\
\text { (c) the deprivation of food, shelter, clothing, or services necessary to maintain the physical or mental health of an older person } \\
\text { or a person with a developmental disability without lawful authority. A declaration made pursuant to 50-9-103 constitutes } \\
\text { lawful authority. } \\
\text { (3) Exploitation means: } \\
\text { (d) the unreasonable use of an older person or a person with a developmental disability or of a power of attorney, } \\
\text { conservatorship, or guardianship with regard to an older person or a person with a developmental disability in order to } \\
\text { obtain control of or to divert to the advantage of another the ownership, use, benefit, or possession of or interest in the } \\
\text { person's money, assets, or property by means of deception, duress, menace, fraud, undue influence, or intimidation with the } \\
\text { intent or result of permanently depriving the older person or person with a developmental disability of the ownership, use, } \\
\text { benefit, or possession of or interest in the person's money, assets, or property; } \\
\text { (e) an act taken by a person who has the trust and confidence of an older person or a person with a developmental disability to } \\
\text { obtain control of or to divert to the advantage of another the ownership, use, benefit, or possession of or interest in the } \\
\text { person's money, assets, or property by means of deception, duress, menace, fraud, undue influence, or intimidation with the } \\
\text { intent or result of permanently depriving the older person or person with a developmental disability of the ownership, use, } \\
\text { benefit, or possession of or interest in the person's money, assets, or property; }\end{array}$ \\
\hline
\end{tabular}

** For purposes of this chart, corrections officers, police officers, peace officers, probation officers or “catch-all” phrases such as “all persons” have been bolded. However, many mandatory reporters include professionals who may have contact or work in correctional facilities. Such individuals include physicians, nurses, dentists, teachers and social workers. These statutes can be used as a tool to require staff other than correctional officers to report sexual misconduct with inmates.

This publication is developed by the NIC/WCL Project on Addressing Prison Rape under NIC Cooperative Agreement 06S20GJJ1.

This is not to be reproduced or cited without permission from the authors.

American University, Washington College of Law

Current as of May 7, 2009 


\title{
Fifty State Survey of Mandatory Reporting Statutes
}

\section{NIC/WCL Project on Addressing Prison Rape}

\section{Relevant Definitions} Cont'd

(Montana) (f) the unreasonable use of an older person or a person with a developmental disability or of a power of attorney, conservatorship, or guardianship with regard to an older person or a person with a developmental disability done in the course of an offer or sale of insurance or securities in order to obtain control of or to divert to the advantage of another the ownership, use, benefit, or possession of the person's money, assets, or property by means of deception, duress, menace, fraud, undue influence, or intimidation with the intent or result of permanently depriving the older person or person with a developmental disability of the ownership, use, benefit, or possession of the person's money, assets, or property.

(7) Neglect means the failure of a person who has assumed legal responsibility or a contractual obligation for caring for an older person or a person with a developmental disability or who has voluntarily assumed responsibility for the person's care, including an employee of a public or private residential institution, facility, home, or agency, to provide food, shelter, clothing, or services necessary to maintain the physical or mental health of the older person or the person with a developmental disability.

(8) "Older person" means a person who is at least 60 years of age. For purposes of prosecution, the person 60 years of age or older must be unable to provide personal protection from abuse, sexual abuse, neglect, or exploitation because of a mental or physical impairment or because of frailties or dependencies brought about by advanced age.

(9) Person with a developmental disability means a person 18 years of age or older who has a developmental disability.

(11) Sexual abuse means the commission of sexual assault, sexual intercourse without consent, indecent exposure, deviate sexual conduct, or incest.

\section{Persons Required to}

\section{Report}

(Montana)
MCA § 52-3-811 (West 2008)

(3) Professionals and other persons required to report are:

(a) physician, resident, intern, professional or practical nurse, physician assistant, or member of a hospital staff engaged in the admission, examination, care, or treatment of persons;

(b) An osteopath, dentist, denturist, chiropractor, optometrist, podiatrist, medical examiner, coroner, or any other health or

\begin{abstract}
** For purposes of this chart, corrections officers, police officers, peace officers, probation officers or "catch-all” phrases such as “all persons” have been bolded. However, many mandatory reporters include professionals who may have contact or work in correctional facilities. Such individuals include physicians, nurses, dentists, teachers and social workers. These statutes can be used as a tool to require staff other than correctional officers to report sexual misconduct with inmates.
\end{abstract}

This publication is developed by the NIC/WCL Project on Addressing Prison Rape under NIC Cooperative Agreement 06S20GJJ1.

This is not to be reproduced or cited without permission from the authors.

American University, Washington College of Law

Current as of May 7, 2009 


\section{Fifty State Survey of Mandatory Reporting Statutes}

\section{NIC/WCL Project on Addressing Prison Rape}

\begin{tabular}{|c|c|}
\hline $\begin{array}{l}\text { Persons Required to } \\
\text { Report Cont'd } \\
\text { (Montana) }\end{array}$ & $\begin{array}{l}\text { mental health professional; } \\
\text { (c) An ambulance attendant; } \\
\text { (d) A social worker or other employee of the state, a county, or a municipality assisting an older person or a person with a } \\
\text { developmental disability in the application for or receipt of public assistance payments or services; } \\
\text { (e) A person who maintains or is employed by a rooming house, retirement home or complex, nursing home, group home, } \\
\text { adult foster care home, adult day-care center, or assisted living facility or an agency or individual that provides home health } \\
\text { services or personal care in the home; } \\
\text { (f) An attorney, unless the attorney acquired knowledge of the facts required to be reported from a client and the attorney- } \\
\text { client privilege applies; } \\
\text { (g) A peace officer or other law enforcement official; } \\
\text { (h) A person providing services to an older person or a person with a developmental disability pursuant to a contract with a } \\
\text { (i) An employee of the department while in the conduct of the employee's duties. }\end{array}$ \\
\hline $\begin{array}{l}\text { Reporting } \\
\text { Procedures } \\
\text { (Montana) }\end{array}$ & $\begin{array}{l}\text { MCA } \S 52-3-811 \text { (West 2008) } \\
\text { (1)(a) If the person is not a resident of a long-term care facility, report the matter to: } \\
\text { (i) the department or its local affiliate; or } \\
\text { (ii) the county attorney of the county in which the person resides or in which the acts that are the subject of the report occurred; } \\
\text { (1)(b) if the person is a resident of a long-term care facility, report the matter to the long-term care ombudsman appointed under } \\
\text { the provisions of } 42 \text { U.S.C. } 3027(\text { a)(12) and to the department. The department shall investigate the matter pursuant to its authority } \\
\text { in 50-5-204 and, if it finds any allegations of abuse, sexual abuse, neglect, or exploitation contained in the report to be } \\
\text { substantially true, forward a copy of the report to the county attorney as provided in subsection (1)(a)(ii). }\end{array}$ \\
\hline
\end{tabular}

NOTE:

** For purposes of this chart, corrections officers, police officers, peace officers, probation officers or "catch-all” phrases such as “all persons” have been bolded. However, many mandatory reporters include professionals who may have contact or work in correctional facilities. Such individuals include physicians, nurses, dentists, teachers and social workers. These statutes can be used as a tool to require staff other than correctional officers to report sexual misconduct with inmates.

This publication is developed by the NIC/WCL Project on Addressing Prison Rape under NIC Cooperative Agreement 06S20GJJ1.

This is not to be reproduced or cited without permission from the authors.

American University, Washington College of Law

Current as of May 7, 2009 


\section{Fifty State Survey of Mandatory Reporting Statutes}

\section{NIC/WCL Project on Addressing Prison Rape}

\begin{tabular}{|c|c|}
\hline $\begin{array}{l}\text { Penalty for Failure to } \\
\text { Report } \\
\text { (Montana) }\end{array}$ & $\begin{array}{l}\text { MCA } \S 52-3-825 \text { (West 2008) } \\
\text { (1) A person who purposely or knowingly fails to make a report or discloses or fails to disclose the contents of a case record or } \\
\text { report is guilty of an offense and upon conviction is punishable as provided in } 46-18-212 \text {. } \\
\text { MCA } \S 46-18-212 \text { (West } 2008 \text { ) } \\
\text { Imprisonment not to exceed } 6 \text { months in the county jail or a fine not to exceed } \$ 500 \text {, or both. }\end{array}$ \\
\hline & NEBRASKA \\
\hline $\begin{array}{l}\text { Mandatory } \\
\text { Reporting Statute } \\
\text { (Nebraska) }\end{array}$ & $\begin{array}{l}\text { AGAINST A CHILD } \\
\text { NEB. REV. ST. § 28-711 (West 2008) }\end{array}$ \\
\hline $\begin{array}{l}\text { What has to be } \\
\text { reported? } \\
\text { (Nebraska) }\end{array}$ & $\begin{array}{l}\text { NEB. REV. ST. } § 28-711 \text { (West 2008) } \\
\text { (1) Reasonable cause to believe that a child has been subjected to child abuse or neglect or observes such child being subjected to } \\
\text { conditions or circumstances which reasonably would result in child abuse or neglect. }\end{array}$ \\
\hline $\begin{array}{l}\text { Relevant Definitions } \\
(\text { Nebraska) }\end{array}$ & $\begin{array}{l}\text { NEB. REV. ST. § 28-707 (West 2008) } \\
\text { (1) A person commits child abuse if he or she knowingly, intentionally, or negligently causes or permits a minor child to be: } \\
\text { (a) Placed in a situation that endangers his or her life or physical or mental health; } \\
\text { (b) Cruelly confined or cruelly punished; } \\
\text { (c) Deprived of necessary food, clothing, shelter, or care; }\end{array}$ \\
\hline
\end{tabular}

NOTE:

** For purposes of this chart, corrections officers, police officers, peace officers, probation officers or “catch-all” phrases such as “all persons” have been bolded. However, many mandatory reporters include professionals who may have contact or work in correctional facilities. Such individuals include physicians, nurses, dentists, teachers and social workers. These statutes can be used as a tool to require staff other than correctional officers to report sexual misconduct with inmates.

This publication is developed by the NIC/WCL Project on Addressing Prison Rape under NIC Cooperative Agreement 06S20GJJ1.

This is not to be reproduced or cited without permission from the authors.

American University, Washington College of Law

Current as of May 7, 2009 


\section{Fifty State Survey of Mandatory Reporting Statutes}

\section{NIC/WCL Project on Addressing Prison Rape}

\begin{tabular}{|c|c|}
\hline $\begin{array}{l}\text { Relevant Definitions } \\
\text { Cont'd } \\
\text { (Nebraska) }\end{array}$ & $\begin{array}{l}\text { (d) Placed in a situation to be sexually exploited by allowing, encouraging, or forcing such minor child to solicit for or engage in } \\
\text { prostitution, debauchery, public indecency, or obscene or pornographic photography, films, or depictions; or } \\
\text { (e) Placed in a situation to be sexually abused as defined in section 28-319 or 28-320.01 or Section } 6 \text { of this Act. }\end{array}$ \\
\hline $\begin{array}{l}\text { Persons Required to } \\
\text { Report } \\
\text { (Nebraska) }\end{array}$ & $\begin{array}{l}\text { NEB. REV. ST. § 28-711 (West 2008) } \\
\text { (1) Any: } \\
\text { • Physician, medical institution, nurse; } \\
\text { • School employee; } \\
\text { • Social worker; or } \\
\text { - Other person. }\end{array}$ \\
\hline $\begin{array}{l}\text { Reporting } \\
\text { Procedures } \\
\text { (Nebraska) }\end{array}$ & $\begin{array}{l}\text { NEB. REV. ST. } § \text { 28-711 (West 2008) } \\
\text { (1) Shall report such incident or cause a report of child abuse or neglect to be made to the proper law enforcement agency or to the } \\
\text { department on the toll-free number.... Such report may be made orally by telephone with the caller giving his or her name and } \\
\text { address, shall be followed by a written report, and to the extent available shall contain the address and age of the abused or } \\
\text { neglected child, the address of the person or persons having custody of the abused or neglected child, the nature and extent of the } \\
\text { child abuse or neglect or the conditions and circumstances which would reasonably result in such child abuse or neglect, any } \\
\text { evidence of previous child abuse or neglect including the nature and extent, and any other information which in the opinion of the } \\
\text { person may be helpful in establishing the cause of such child abuse or neglect and the identity of the perpetrator or perpetrators. }\end{array}$ \\
\hline $\begin{array}{l}\text { Penalty for Failure to } \\
\text { Report } \\
(\text { Nebraska) }\end{array}$ & $\begin{array}{l}\text { NEB. REV. ST. § 28-717 (West 2008) } \\
\text { Any person who willfully fails to make any report of child abuse or neglect required by section 28-711 shall be guilty of a Class } \\
\text { III misdemeanor. }\end{array}$ \\
\hline
\end{tabular}

NOTE:

** For purposes of this chart, corrections officers, police officers, peace officers, probation officers or “catch-all” phrases such as “all persons” have been bolded. However, many mandatory reporters include professionals who may have contact or work in correctional facilities. Such individuals include physicians, nurses, dentists, teachers and social workers. These statutes can be used as a tool to require staff other than correctional officers to report sexual misconduct with inmates.

This publication is developed by the NIC/WCL Project on Addressing Prison Rape under NIC Cooperative Agreement 06S20GJJ1.

This is not to be reproduced or cited without permission from the authors.

American University, Washington College of Law

Current as of May 7, 2009 


\section{Fifty State Survey of Mandatory Reporting Statutes}

\section{NIC/WCL Project on Addressing Prison Rape}

\begin{tabular}{|c|c|}
\hline $\begin{array}{l}\text { Penalty for Failure to } \\
\text { Report Cont'd } \\
\text { (Nebraska) }\end{array}$ & $\begin{array}{l}\text { NEB. REV. ST. § 28-106 (West 2008) } \\
\text { Maximum of three months imprisonment or } \$ 500 \text { fine, or both. }\end{array}$ \\
\hline $\begin{array}{l}\text { Mandatory } \\
\text { Reporting Statute } \\
\text { (Nebraska) }\end{array}$ & $\begin{array}{l}\text { AGAINST AN ADULT } \\
\text { NEB. REV. ST. § 28-372 (West 2008) }\end{array}$ \\
\hline $\begin{array}{l}\text { What has to be } \\
\text { reported? } \\
\text { (Nebraska) }\end{array}$ & $\begin{array}{l}\text { NEB. REV. ST. § 28-372 (West 2008) } \\
\text { (1) Reasonable cause to believe that a vulnerable adult has been subjected to abuse or observes such adult being subjected to } \\
\text { conditions or circumstances which reasonably would result in abuse. }\end{array}$ \\
\hline $\begin{array}{l}\text { Relevant Definitions } \\
\text { (Nebraska) }\end{array}$ & $\begin{array}{l}\text { NEB. REV. ST. § 28-351 (West 2008) } \\
\text { Abuse shall mean any knowing, intentional, or negligent act or omission on the part of a caregiver, a vulnerable adult, or any other } \\
\text { person which results in physical injury, unreasonable confinement, cruel punishment, sexual abuse, exploitation, or denial of } \\
\text { essential services to a vulnerable adult. } \\
\text { NEB. REV. ST. § 28-371 (West 2008) } \\
\text { Vulnerable adult shall mean any person eighteen years of age or older who has a substantial mental or functional impairment or for } \\
\text { whom a guardian has been appointed under the Nebraska Probate Code. } \\
\text { NEB. REV. ST. } § 28-359 \text { (West 2008) }\end{array}$ \\
\hline
\end{tabular}

NOTE:

** For purposes of this chart, corrections officers, police officers, peace officers, probation officers or "catch-all” phrases such as “all persons” have been bolded. However, many mandatory reporters include professionals who may have contact or work in correctional facilities. Such individuals include physicians, nurses, dentists, teachers and social workers. These statutes can be used as a tool to require staff other than correctional officers to report sexual misconduct with inmates.

This publication is developed by the NIC/WCL Project on Addressing Prison Rape under NIC Cooperative Agreement 06S20GJJ1.

This is not to be reproduced or cited without permission from the authors.

American University, Washington College of Law

Current as of May 7, 2009 


\section{Fifty State Survey of Mandatory Reporting Statutes}

\section{NIC/WCL Project on Addressing Prison Rape}

\begin{tabular}{|c|c|}
\hline $\begin{array}{l}\text { Relevant Definitions } \\
\text { Cont'd } \\
\text { (Nebraska) }\end{array}$ & $\begin{array}{l}\text { Law enforcement agency shall mean the police department or the town marshal in incorporated municipalities, the office of the } \\
\text { sheriff in unincorporated areas, and the Nebraska State Patrol. }\end{array}$ \\
\hline $\begin{array}{l}\text { Persons Required to } \\
\text { Report } \\
\text { (Nebraska) }\end{array}$ & 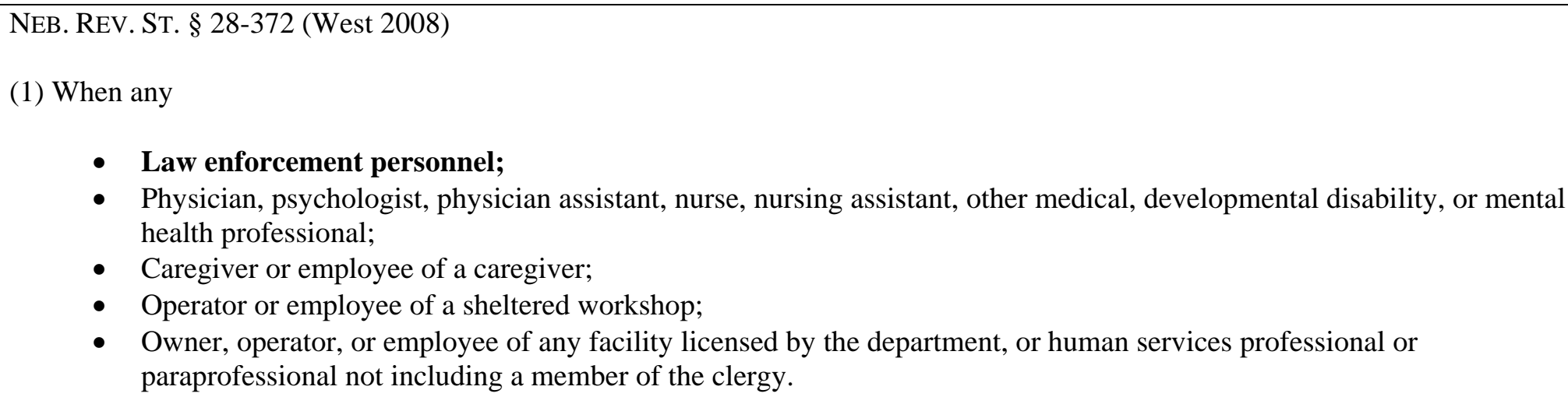 \\
\hline $\begin{array}{l}\text { Reporting } \\
\text { Procedures } \\
\text { (Nebraska) }\end{array}$ & $\begin{array}{l}\text { NEB. REV. ST. § 28-372 (West 2008) } \\
\text { (1) Report the incident or cause a report to be made to the appropriate law enforcement agency or to the department. } \\
\text { (2) Such report may be made by telephone, with the caller giving his or her name and address, and, if requested by the department, } \\
\text { shall be followed by a written report within forty-eight hours. To the extent available the report shall contain: (a) The name, } \\
\text { address, and age of the vulnerable adult; (b) the address of the caregiver or caregivers of the vulnerable adult; (c) the nature and } \\
\text { extent of the alleged abuse or the conditions and circumstances which would reasonably be expected to result in such abuse; (d) } \\
\text { any evidence of previous abuse including the nature and extent of the abuse; and (e) any other information which in the opinion of }\end{array}$ \\
\hline
\end{tabular}

** For purposes of this chart, corrections officers, police officers, peace officers, probation officers or “catch-all” phrases such as “all persons” have been bolded. However, many mandatory reporters include professionals who may have contact or work in correctional facilities. Such individuals include physicians, nurses, dentists, teachers and social workers. These statutes can be used as a tool to require staff other than correctional officers to report sexual misconduct with inmates.

This publication is developed by the NIC/WCL Project on Addressing Prison Rape under NIC Cooperative Agreement 06S20GJJ1.

This is not to be reproduced or cited without permission from the authors.

American University, Washington College of Law

Current as of May 7, 2009 


\section{Fifty State Survey of Mandatory Reporting Statutes}

\section{NIC/WCL Project on Addressing Prison Rape}

\begin{tabular}{|c|c|}
\hline $\begin{array}{l}\text { Reporting } \\
\text { Procedures Cont'd } \\
\text { (Nebraska) }\end{array}$ & $\begin{array}{l}\text { the person making the report may be helpful in establishing the cause of the alleged abuse and the identity of the perpetrator or } \\
\text { perpetrators. }\end{array}$ \\
\hline $\begin{array}{l}\text { Penalty for Failure to } \\
\text { Report } \\
\text { (Nebraska) }\end{array}$ & $\begin{array}{l}\text { NEB. REV. ST. } § 28-384 \text { (West 2008) } \\
\text { Any person who willfully fails to make any report required by the Adult Protective Services Act shall be guilty of a Class III } \\
\text { misdemeanor. } \\
\text { NEB. REV. ST. } § 28-106 \text { (West 2008) } \\
\text { Maximum of } 3 \text { months imprisonment or } \$ 500 \text { fine, or both. }\end{array}$ \\
\hline & NEVADA \\
\hline $\begin{array}{l}\text { Mandatory } \\
\text { Reporting Statute } \\
\text { (Nevada) }\end{array}$ & $\begin{array}{l}\text { AGAINST A CHILD } \\
\text { N.R.S. § 432B.220 (West 2008) }\end{array}$ \\
\hline $\begin{array}{l}\text { What has to be } \\
\text { reported? } \\
\text { (Nevada) }\end{array}$ & $\begin{array}{l}\text { N.R.S. § 432B.220 (West 2008) } \\
\text { (1) Any person who in his professional or occupational capacity, knows or has reasonable cause to believe that a child has been } \\
\text { abused or neglected. }\end{array}$ \\
\hline
\end{tabular}

NOTE:

** For purposes of this chart, corrections officers, police officers, peace officers, probation officers or “catch-all” phrases such as “all persons” have been bolded. However, many mandatory reporters include professionals who may have contact or work in correctional facilities. Such individuals include physicians, nurses, dentists, teachers and social workers. These statutes can be used as a tool to require staff other than correctional officers to report sexual misconduct with inmates.

This publication is developed by the NIC/WCL Project on Addressing Prison Rape under NIC Cooperative Agreement 06S20GJJ1.

This is not to be reproduced or cited without permission from the authors.

American University, Washington College of Law

Current as of May 7, 2009 


\section{Fifty State Survey of Mandatory Reporting Statutes}

\section{NIC/WCL Project on Addressing Prison Rape}

\begin{tabular}{|c|c|}
\hline $\begin{array}{l}\text { Relevant Definitions } \\
\text { (Nevada) }\end{array}$ & $\begin{array}{l}\text { N.R.S. § 28-707 (West 2008) } \\
\text { (1) A person commits child abuse if he or she knowingly, intentionally, or negligently causes or permits a minor child to be: } \\
\text { (a) Placed in a situation that endangers his or her life or physical or mental health; } \\
\text { (b) Cruelly confined or cruelly punished; } \\
\text { (c) Deprived of necessary food, clothing, shelter, or care; } \\
\text { (d) Placed in a situation to be sexually exploited by allowing, encouraging, or forcing such minor child to solicit for or engage } \\
\text { in prostitution, debauchery, public indecency, or obscene or pornographic photography, films, or depictions; or } \\
\text { (e) Placed in a situation to be sexually abused as defined in section } 28-319 \text { or } 28-320.01 \text { or Section } 6 \text { of this Act. }\end{array}$ \\
\hline $\begin{array}{l}\text { Persons Required to } \\
\text { Report } \\
\text { (Nevada) }\end{array}$ & $\begin{array}{l}\text { N.R.S. § 28-711 (West 2008) } \\
\text { (1) Any: } \\
\text { • Physician, medical institution, nurse; } \\
\text { • School employee; } \\
\text { • Social worker; or } \\
\text { - Other person. }\end{array}$ \\
\hline $\begin{array}{l}\text { Reporting } \\
\text { Procedures } \\
\text { (Nevada) }\end{array}$ & $\begin{array}{l}\text { N.R.S. } § \text { 28-711 (West 2008) } \\
\text { (1) Shall report such incident or cause a report of child abuse or neglect to be made to the proper law enforcement agency or to the } \\
\text { department on the toll-free number.... Such report may be made orally by telephone with the caller giving his or her name and } \\
\text { address, shall be followed by a written report, and to the extent available shall contain the address and age of the abused or } \\
\text { neglected child, the address of the person or persons having custody of the abused or neglected child, the nature and extent of the }\end{array}$ \\
\hline
\end{tabular}

NOTE:

** For purposes of this chart, corrections officers, police officers, peace officers, probation officers or "catch-all” phrases such as "all persons" have been bolded. However, many mandatory reporters include professionals who may have contact or work in correctional facilities. Such individuals include physicians, nurses, dentists, teachers and social workers. These statutes can be used as a tool to require staff other than correctional officers to report sexual misconduct with inmates.

This publication is developed by the NIC/WCL Project on Addressing Prison Rape under NIC Cooperative Agreement 06S20GJJ1.

This is not to be reproduced or cited without permission from the authors.

American University, Washington College of Law

Current as of May 7, 2009 


\section{Fifty State Survey of Mandatory Reporting Statutes}

\section{NIC/WCL Project on Addressing Prison Rape}

\begin{tabular}{|c|c|}
\hline $\begin{array}{l}\text { Reporting } \\
\text { Procedures Cont'd } \\
\text { (Nevada) }\end{array}$ & $\begin{array}{l}\text { child abuse or neglect or the conditions and circumstances which would reasonably result in such child abuse or neglect, any } \\
\text { evidence of previous child abuse or neglect including the nature and extent, and any other information which in the opinion of the } \\
\text { person may be helpful in establishing the cause of such child abuse or neglect and the identity of the perpetrator or perpetrators. }\end{array}$ \\
\hline $\begin{array}{l}\text { Penalty for Failure to } \\
\text { Report } \\
\text { (Nevada) }\end{array}$ & $\begin{array}{l}\text { N.R.S. § 28-717 (West 2008) } \\
\text { Any person who willfully fails to make any report of child abuse or neglect required by section 28-711 shall be guilty of a Class } \\
\text { III misdemeanor. } \\
\text { N.R.S. § 28-106 (West 2008) } \\
\text { Maximum of three months imprisonment or } \$ 500 \text { fine, or both. }\end{array}$ \\
\hline $\begin{array}{l}\text { Mandatory } \\
\text { Reporting Statute } \\
\text { (Nevada) }\end{array}$ & $\begin{array}{l}\text { AGAINST AN ADULT } \\
\text { N.R.S. § 28-372 (West 2008) }\end{array}$ \\
\hline $\begin{array}{l}\text { What has to be } \\
\text { reported? } \\
\text { (Nevada) }\end{array}$ & $\begin{array}{l}\text { N.R.S. § 28-372 (West 2008) } \\
\text { (1) Reasonable cause to believe that a vulnerable adult has been subjected to abuse or observes such adult being subjected to } \\
\text { conditions or circumstances which reasonably would result in abuse. }\end{array}$ \\
\hline $\begin{array}{l}\text { Relevant Definitions } \\
\text { (Nevada) }\end{array}$ & $\begin{array}{l}\text { N.R.S. § 28-351 (West 2008) } \\
\text { “Abuse” shall mean any knowing, intentional, or negligent act or omission on the part of a caregiver, a vulnerable adult, or any } \\
\text { other person which results in physical injury, unreasonable confinement, cruel punishment, sexual abuse, exploitation, or denial of }\end{array}$ \\
\hline
\end{tabular}

\section{NOTE:}

** For purposes of this chart, corrections officers, police officers, peace officers, probation officers or “catch-all” phrases such as “all persons” have been bolded. However, many mandatory reporters include professionals who may have contact or work in correctional facilities. Such individuals include physicians, nurses, dentists, teachers and social workers. These statutes can be used as a tool to require staff other than correctional officers to report sexual misconduct with inmates.

This publication is developed by the NIC/WCL Project on Addressing Prison Rape under NIC Cooperative Agreement 06S20GJJ1.

This is not to be reproduced or cited without permission from the authors.

American University, Washington College of Law

Current as of May 7, 2009 


\section{Fifty State Survey of Mandatory Reporting Statutes}

\section{NIC/WCL Project on Addressing Prison Rape}

\begin{tabular}{|c|c|}
\hline $\begin{array}{l}\text { Relevant Definitions } \\
\text { Cont'd } \\
\text { (Nevada) }\end{array}$ & $\begin{array}{l}\text { essential services to a vulnerable adult. } \\
\text { N.R.S. § 28-371 (West 2008) } \\
\text { "Vulnerable adult" shall mean any person eighteen years of age or older who has a substantial mental or functional impairment or } \\
\text { for whom a guardian has been appointed under the Nebraska Probate Code. } \\
\text { N.R.S. § 28-359 (West 2008) } \\
\text { "Law enforcement agency" shall mean the police department or the town marshal in incorporated municipalities, the office of the } \\
\text { sheriff in unincorporated areas, and the Nebraska State Patrol. }\end{array}$ \\
\hline $\begin{array}{l}\text { Persons Required to } \\
\text { Report } \\
\text { (Nevada) }\end{array}$ & $\begin{array}{l}\text { N.R.S. } § 28-372 \text { (West 2008) } \\
\text { (1) When any: } \\
\text { • Law enforcement personnel; }{ }^{6} \\
\text { - Physician, psychologist, physician assistant, nurse, nursing assistant, other medical, developmental disability, or mental } \\
\text { health professional, } \\
\text { - Caregiver or employee of a caregiver; } \\
\text { - Operator or employee of a sheltered workshop; } \\
\text { - Owner, operator, or employee of any facility licensed by the department, or human services professional or } \\
\text { paraprofessional not including a member of the clergy. }\end{array}$ \\
\hline $\begin{array}{l}\text { Reporting } \\
\text { Procedures } \\
\text { (Nevada) }\end{array}$ & $\begin{array}{l}\text { N.R.S. § 28-372 (West 2008) } \\
\text { (1) Report the incident or cause a report to be made to the appropriate law enforcement agency or to the department. }\end{array}$ \\
\hline
\end{tabular}

NOTE:

** For purposes of this chart, corrections officers, police officers, peace officers, probation officers or "catch-all” phrases such as "all persons" have been bolded. However, many mandatory reporters include professionals who may have contact or work in correctional facilities. Such individuals include physicians, nurses, dentists, teachers and social workers. These statutes can be used as a tool to require staff other than correctional officers to report sexual misconduct with inmates.

This publication is developed by the NIC/WCL Project on Addressing Prison Rape under NIC Cooperative Agreement 06S20GJJ1.

This is not to be reproduced or cited without permission from the authors.

American University, Washington College of Law

Current as of May 7, 2009 


\section{Fifty State Survey of Mandatory Reporting Statutes}

\section{NIC/WCL Project on Addressing Prison Rape}

\begin{tabular}{|c|c|}
\hline $\begin{array}{l}\text { Reporting } \\
\text { Procedures Cont'd } \\
\text { (Nevada) }\end{array}$ & $\begin{array}{l}\text { (2) Such report may be made by telephone, with the caller giving his or her name and address, and, if requested by the department, } \\
\text { shall be followed by a written report within forty-eight hours. To the extent available the report shall contain: (a) The name, } \\
\text { address, and age of the vulnerable adult; (b) the address of the caregiver or caregivers of the vulnerable adult; (c) the nature and } \\
\text { extent of the alleged abuse or the conditions and circumstances which would reasonably be expected to result in such abuse; (d) } \\
\text { any evidence of previous abuse including the nature and extent of the abuse; and (e) any other information which in the opinion of } \\
\text { the person making the report may be helpful in establishing the cause of the alleged abuse and the identity of the perpetrator or } \\
\text { perpetrators. }\end{array}$ \\
\hline $\begin{array}{l}\text { Penalty for Failure to } \\
\text { Report } \\
\text { (Nevada) }\end{array}$ & $\begin{array}{l}\text { N.R.S. § 28-384 (West 2008) } \\
\text { Any person who willfully fails to make any report required by the Adult Protective Services Act shall be guilty of a Class III } \\
\text { misdemeanor. } \\
\text { N.R.S. § 28-106 (West 2008) } \\
\text { Maximum of } 3 \text { months imprisonment or } \$ 500 \text { fine, or both. }\end{array}$ \\
\hline & NEW HAMPSHIRE \\
\hline $\begin{array}{l}\text { Mandatory } \\
\text { Reporting Statute } \\
\text { (New Hampshire) }\end{array}$ & $\begin{array}{l}\text { AGAINST A CHILD } \\
\text { N.H. REV. STAT. § 169-C:29 (West 2008) }\end{array}$ \\
\hline $\begin{array}{l}\text { What has to be } \\
\text { reported? } \\
\text { (New Hampshire) }\end{array}$ & $\begin{array}{l}\text { N.H. REV. STAT. § 169-C:29 (West 2008) } \\
\text { Reason to suspect that a child has been abused or neglected. }\end{array}$ \\
\hline
\end{tabular}

NOTE:

** For purposes of this chart, corrections officers, police officers, peace officers, probation officers or “catch-all” phrases such as “all persons” have been bolded. However, many mandatory reporters include professionals who may have contact or work in correctional facilities. Such individuals include physicians, nurses, dentists, teachers and social workers. These statutes can be used as a tool to require staff other than correctional officers to report sexual misconduct with inmates.

This publication is developed by the NIC/WCL Project on Addressing Prison Rape under NIC Cooperative Agreement 06S20GJJ1.

This is not to be reproduced or cited without permission from the authors.

American University, Washington College of Law

Current as of May 7, 2009 


\section{Fifty State Survey of Mandatory Reporting Statutes}

\section{NIC/WCL Project on Addressing Prison Rape}

\begin{tabular}{|c|c|}
\hline $\begin{array}{l}\text { Relevant Definitions } \\
\text { (New Hampshire) }\end{array}$ & 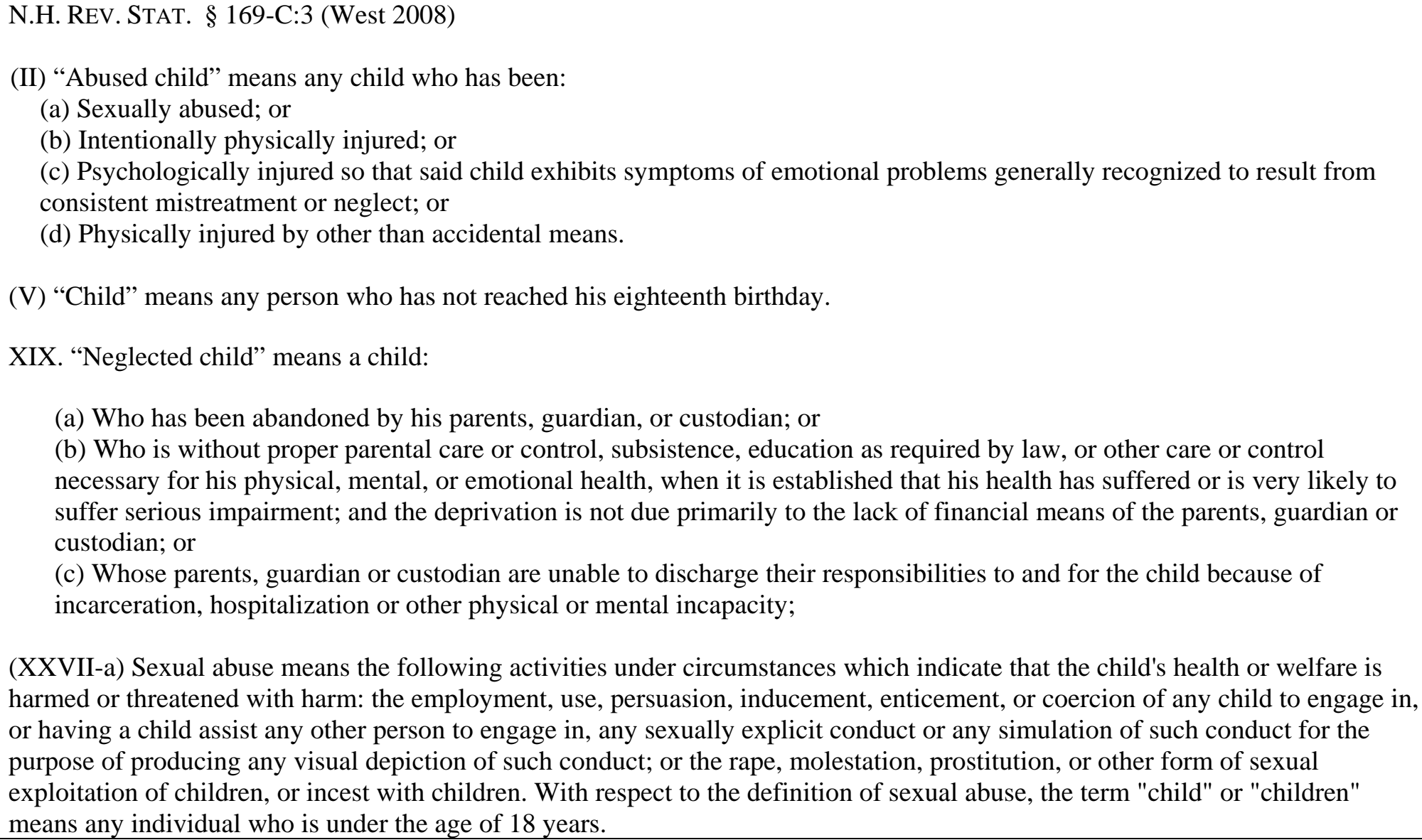 \\
\hline
\end{tabular}

NOTE:

** For purposes of this chart, corrections officers, police officers, peace officers, probation officers or "catch-all” phrases such as “all persons” have been bolded. However, many mandatory reporters include professionals who may have contact or work in correctional facilities. Such individuals include physicians, nurses, dentists, teachers and social workers. These statutes can be used as a tool to require staff other than correctional officers to report sexual misconduct with inmates.

This publication is developed by the NIC/WCL Project on Addressing Prison Rape under NIC Cooperative Agreement 06S20GJJ1.

This is not to be reproduced or cited without permission from the authors.

American University, Washington College of Law

Current as of May 7, 2009 


\section{Fifty State Survey of Mandatory Reporting Statutes}

\section{NIC/WCL Project on Addressing Prison Rape}

\begin{tabular}{|c|c|}
\hline $\begin{array}{l}\text { Persons Required to } \\
\text { Report } \\
\text { (New Hampshire) }\end{array}$ & $\begin{array}{l}\text { N.H. REV. STAT. } § 169-C: 29 \text { (West 2008) } \\
\text { Persons required to report: } \\
\text { - Law enforcement official; } \\
\text { - Physician, surgeon; } \\
\text { - County medical examiner; } \\
\text { - Psychiatrist; } \\
\text { - Resident; } \\
\text { - Intern; } \\
\text { - Dentist; } \\
\text { - Osteopath; } \\
\text { - Optometrist; } \\
\text { - Chiropractor; } \\
\text { - Psychologist; } \\
\text { - Therapist; } \\
\text { - Registered nurse; } \\
\text { - Hospital personnel (engaged in admission, examination, care and treatment of persons); } \\
\text { - Christian Science practitioner; } \\
\text { - Teacher, school official, school nurse, school counselor; } \\
\text { - Social worker; } \\
\text { - Day care worker, any other child or foster care worker; } \\
\text { - Priest, minister, or rabbi; or } \\
\text { - Any other person having reason to suspect that a child has been abused or neglected. }\end{array}$ \\
\hline
\end{tabular}

NOTE:

** For purposes of this chart, corrections officers, police officers, peace officers, probation officers or "catch-all” phrases such as "all persons" have been bolded. However, many mandatory reporters include professionals who may have contact or work in correctional facilities. Such individuals include physicians, nurses, dentists, teachers and social workers. These statutes can be used as a tool to require staff other than correctional officers to report sexual misconduct with inmates.

This publication is developed by the NIC/WCL Project on Addressing Prison Rape under NIC Cooperative Agreement 06S20GJJ1.

This is not to be reproduced or cited without permission from the authors.

American University, Washington College of Law

Current as of May 7, 2009 


\section{Fifty State Survey of Mandatory Reporting Statutes}

\section{NIC/WCL Project on Addressing Prison Rape}

\begin{tabular}{|c|c|}
\hline $\begin{array}{l}\text { Reporting } \\
\text { Procedures } \\
\text { (New Hampshire) }\end{array}$ & $\begin{array}{l}\text { N.H. REV. STAT. § 169-C:30 (West 2008) } \\
\text { An oral report shall be made immediately by telephone or otherwise, and followed within } 48 \text { hours by a report in writing, if so } \\
\text { requested, to the department. Such report shall, if known, contain the name and address of the child suspected of being neglected } \\
\text { or abused and the person responsible for the child's welfare, the specific information indicating neglect or the nature and extent of } \\
\text { the child's injuries (including any evidence of previous injuries), the identity of the person or persons suspected of being } \\
\text { responsible for such neglect or abuse, and any other information that might be helpful in establishing neglect or abuse or that may } \\
\text { be required by the department. }\end{array}$ \\
\hline $\begin{array}{l}\text { Penalty for Failure to } \\
\text { Report } \\
\text { (New Hampshire) }\end{array}$ & $\begin{array}{l}\text { N.H. REV. STAT. } § 169-C: 39 \text { (West 2008) } \\
\text { Anyone who knowingly violates any provision of this subdivision shall be guilty of a misdemeanor. } \\
\text { N.H. REV. STAT. § 651:2 } \\
\text { The maximum penalty for a class A misdemeanor shall not exceed one year. } \\
\text { The fine for a class A misdemeanor may not exceed } \$ 2,000 \text {. }\end{array}$ \\
\hline $\begin{array}{l}\text { Mandatory } \\
\text { Reporting Statute } \\
\text { (New Hampshire) }\end{array}$ & $\begin{array}{l}\text { AGAINST AN ADULT } \\
\text { N.H. REV. STAT. § 161-F:46 (West 2008) }\end{array}$ \\
\hline
\end{tabular}

NOTE:

** For purposes of this chart, corrections officers, police officers, peace officers, probation officers or “catch-all” phrases such as “all persons” have been bolded. However, many mandatory reporters include professionals who may have contact or work in correctional facilities. Such individuals include physicians, nurses, dentists, teachers and social workers. These statutes can be used as a tool to require staff other than correctional officers to report sexual misconduct with inmates.

This publication is developed by the NIC/WCL Project on Addressing Prison Rape under NIC Cooperative Agreement 06S20GJJ1.

This is not to be reproduced or cited without permission from the authors.

American University, Washington College of Law

Current as of May 7, 2009 


\section{Fifty State Survey of Mandatory Reporting Statutes}

\section{NIC/WCL Project on Addressing Prison Rape}

\begin{tabular}{|c|c|}
\hline $\begin{array}{l}\text { What has to be } \\
\text { reported? } \\
\text { (New Hampshire) }\end{array}$ & $\begin{array}{l}\text { N.H. REV. STAT. § 161-F:46 (West 2008) } \\
\text { Suspicion or belief in good faith that any adult who is or who is suspected to be incapacitated has been subjected to abuse, neglect, } \\
\text { self-neglect, or exploitation or is living in hazardous conditions }\end{array}$ \\
\hline $\begin{array}{l}\text { Relevant Definitions } \\
\text { (New Hampshire) }\end{array}$ & $\begin{array}{l}\text { N.H. REV. STAT. § 161-F:43 (West 2008) } \\
\text { (II) Abuse means any one of the following: } \\
\text { (a) "Emotional abuse" means the misuse of power, authority, or both, verbal harassment, or unreasonable confinement which } \\
\text { results or could result in the mental anguish or emotional distress of an incapacitated adult. } \\
\text { (b) "Physical abuse" means the use of physical force which results or could result in physical injury to an incapacitated adult. } \\
\text { (c) "Sexual abuse" means contact or interaction of a sexual nature involving an incapacitated adult without his or her informed } \\
\text { consent. } \\
\text { III. Neglect means an act or omission which results or could result in the deprivation of essential services or supports necessary to } \\
\text { maintain the minimum mental, emotional or physical health and safety of an incapacitated adult. } \\
\text { IV. Exploitation means the illegal use of an incapacitated adult's person or property for another person's profit or advantage, or the } \\
\text { breach of a fiduciary relationship through the use of a person or a person's property for any purpose not in the proper and lawful } \\
\text { execution of a trust, including, but not limited to, situations where a person obtains money, property, or services from an } \\
\text { incapacitated adult through the use of undue influence, harassment, duress, deception, or fraud. } \\
\text { VI. Self-neglect means an act or omission by an incapacitated adult which results or could result in the deprivation of essential } \\
\text { services or supports necessary to maintain his or her minimum mental, emotional or physical health and safety. }\end{array}$ \\
\hline
\end{tabular}

NOTE:

** For purposes of this chart, corrections officers, police officers, peace officers, probation officers or “catch-all” phrases such as “all persons” have been bolded. However, many mandatory reporters include professionals who may have contact or work in correctional facilities. Such individuals include physicians, nurses, dentists, teachers and social workers. These statutes can be used as a tool to require staff other than correctional officers to report sexual misconduct with inmates.

This publication is developed by the NIC/WCL Project on Addressing Prison Rape under NIC Cooperative Agreement 06S20GJJ1.

This is not to be reproduced or cited without permission from the authors.

American University, Washington College of Law

Current as of May 7, 2009 


\section{Fifty State Survey of Mandatory Reporting Statutes}

\section{NIC/WCL Project on Addressing Prison Rape}

\begin{tabular}{|c|c|}
\hline $\begin{array}{l}\text { Relevant Definitions } \\
\text { Cont'd } \\
\text { (New Hampshire) }\end{array}$ & $\begin{array}{l}\text { VII Incapacitated means that the physical, mental, or emotional ability of a person is such that he is unable to manage personal, } \\
\text { home, or financial affairs in his own best interest, or he is unable to act or unable to delegate responsibility to a responsible } \\
\text { caretaker or caregiver. }\end{array}$ \\
\hline $\begin{array}{l}\text { Persons Required to } \\
\text { Report } \\
\text { (New Hampshire) }\end{array}$ & $\begin{array}{l}\text { N.H. REV. STAT. } \S 161-F: 46 \text { (West 2008) } \\
\text { Any person, including, but not limited to: } \\
\text { • Law enforcement officials; } \\
\text { - Physicians; } \\
\text { - Other health care professionals; } \\
\text { - Social workers; and } \\
\text { - Clergy. } \\
\text { • }\end{array}$ \\
\hline $\begin{array}{l}\text { Reporting } \\
\text { Procedures } \\
\text { (New Hampshire) }\end{array}$ & $\begin{array}{l}\text { N.H. REV. STAT. } § 161-F: 46 \text { (West 2008) } \\
\text { (I) An oral report, by telephone or otherwise, shall be made immediately, followed by a written report, if so requested, to the } \\
\text { commissioner or his authorized representative. When oral reports are made after working hours of the department, or on weekends } \\
\text { or holidays, such reports shall be made to the police department of the appropriate political subdivision, or to the sheriff of the } \\
\text { county, in which the alleged abuse, neglect or exploitation occurred. Law enforcement officials receiving reports under this } \\
\text { paragraph shall notify the commissioner within } 72 \text { hours of receipt of such reports. }\end{array}$ \\
\hline $\begin{array}{l}\text { Penalty for Failure to } \\
\text { Report } \\
\text { (New Hampshire) }\end{array}$ & $\begin{array}{l}\text { N.H. REV. STAT. } § 161-F: 50 \text { (West 2008) } \\
\text { Any person who knowingly fails to make any report shall be guilty of a misdemeanor. } \\
\text { N.H. REV. STAT. § 651:2 (West 2008) }\end{array}$ \\
\hline
\end{tabular}

NOTE:

** For purposes of this chart, corrections officers, police officers, peace officers, probation officers or "catch-all” phrases such as “all persons” have been bolded. However, many mandatory reporters include professionals who may have contact or work in correctional facilities. Such individuals include physicians, nurses, dentists, teachers and social workers. These statutes can be used as a tool to require staff other than correctional officers to report sexual misconduct with inmates.

This publication is developed by the NIC/WCL Project on Addressing Prison Rape under NIC Cooperative Agreement 06S20GJJ1.

This is not to be reproduced or cited without permission from the authors.

American University, Washington College of Law

Current as of May 7, 2009 


\section{Fifty State Survey of Mandatory Reporting Statutes}

\section{NIC/WCL Project on Addressing Prison Rape}

\begin{tabular}{|c|c|}
\hline $\begin{array}{l}\text { Penalty for Failure to } \\
\text { Report Cont'd } \\
\text { (New Hampshire) }\end{array}$ & $\begin{array}{l}\text { (I) A person convicted of a felony or a Class A misdemeanor may be sentenced to imprisonment, probation, conditional or } \\
\text { unconditional discharge, or a fine. } \\
\text { (II) If a sentence of imprisonment is imposed, the court shall fix the maximum thereof which is not to exceed: } \\
\text { (c) One year for a class A misdemeanor }\end{array}$ \\
\hline & NEW JERSEY \\
\hline $\begin{array}{l}\text { Mandatory } \\
\text { Reporting Statute } \\
\text { (New Jersey) }\end{array}$ & $\begin{array}{l}\text { AGAINST A CHILD } \\
\text { N.J.S.A. § 9:6-8.10 (West 2008) }\end{array}$ \\
\hline $\begin{array}{l}\text { What has to be } \\
\text { reported? } \\
\text { (New Jersey) }\end{array}$ & $\begin{array}{l}\text { N.J.S.A. § 9:6-8.10 (West 2008) } \\
\text { Reasonable cause to believe that a child has been subjected to child abuse or acts of child abuse. }\end{array}$ \\
\hline $\begin{array}{l}\text { Relevant Definitions } \\
\text { (New Jersey) }\end{array}$ & $\begin{array}{l}\text { N.J.S.A. } § 9: 6-1 \text { (West 2008) } \\
\text { Abuse of a child shall consist in any of the following acts: (a) disposing of the custody of a child contrary to law; (b) employing or } \\
\text { permitting a child to be employed in any vocation or employment injurious to its health or dangerous to its life or limb, or contrary } \\
\text { to the laws of this State; (c) employing or permitting a child to be employed in any occupation, employment or vocation dangerous } \\
\text { to the morals of such child; (d) the habitual use by the parent or by a person having the custody and control of a child, in the } \\
\text { hearing of such child, of profane, indecent or obscene language; (e) the performing of any indecent, immoral or unlawful act or } \\
\text { deed, in the presence of a child, that may tend to debauch or endanger or degrade the morals of the child; (f) permitting or } \\
\text { allowing any other person to perform any indecent, immoral or unlawful act in the presence of the child that may tend to debauch }\end{array}$ \\
\hline
\end{tabular}

NOTE:

** For purposes of this chart, corrections officers, police officers, peace officers, probation officers or “catch-all” phrases such as “all persons” have been bolded. However, many mandatory reporters include professionals who may have contact or work in correctional facilities. Such individuals include physicians, nurses, dentists, teachers and social workers. These statutes can be used as a tool to require staff other than correctional officers to report sexual misconduct with inmates.

This publication is developed by the NIC/WCL Project on Addressing Prison Rape under NIC Cooperative Agreement 06S20GJJ1.

This is not to be reproduced or cited without permission from the authors.

American University, Washington College of Law

Current as of May 7, 2009 


\section{Fifty State Survey of Mandatory Reporting Statutes}

\section{NIC/WCL Project on Addressing Prison Rape}

\begin{tabular}{|c|c|}
\hline $\begin{array}{l}\text { Relevant Definitions } \\
\text { Cont'd } \\
\text { (New Jersey) }\end{array}$ & 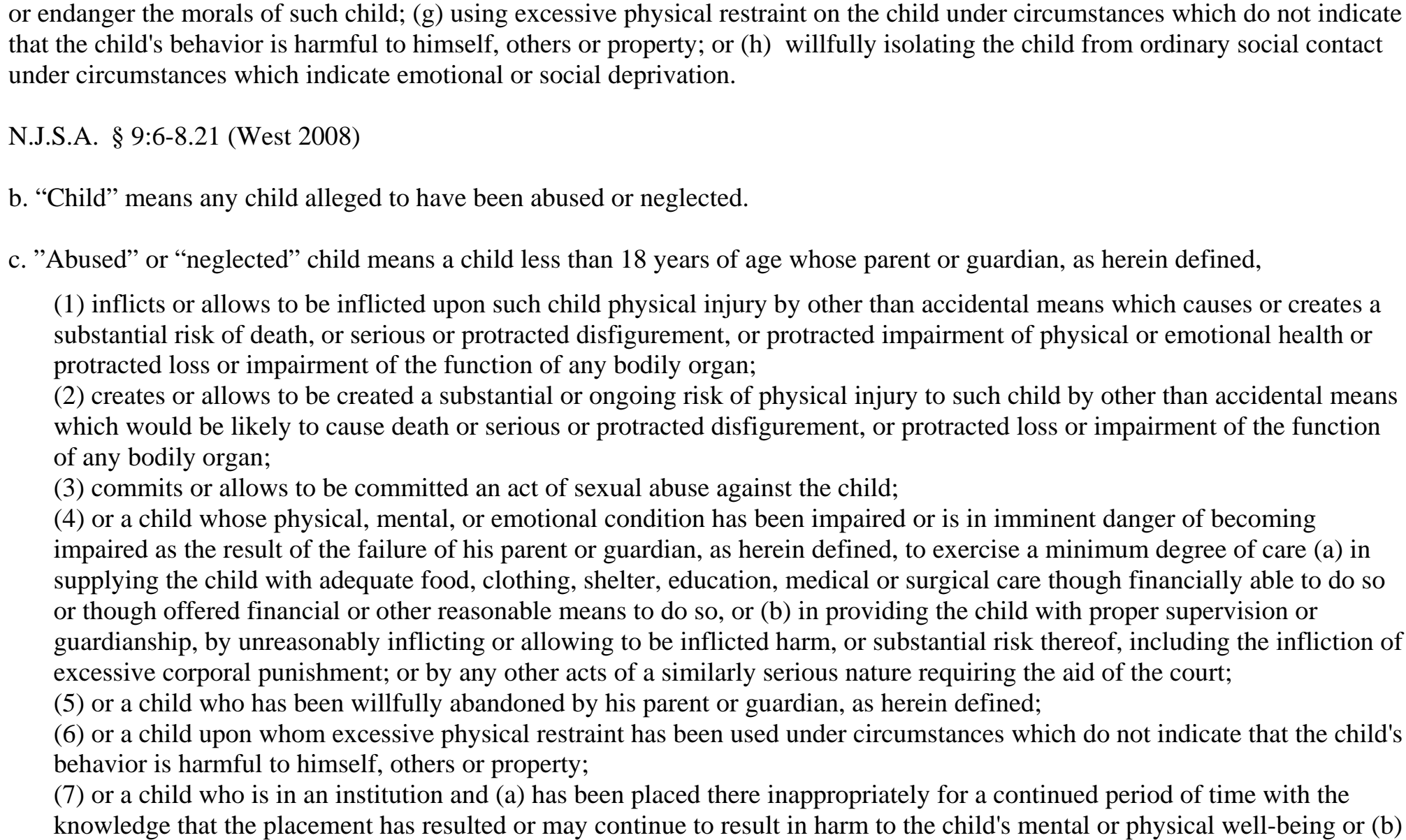 \\
\hline
\end{tabular}

** For purposes of this chart, corrections officers, police officers, peace officers, probation officers or "catch-all” phrases such as “all persons” have been bolded. However, many mandatory reporters include professionals who may have contact or work in correctional facilities. Such individuals include physicians, nurses, dentists, teachers and social workers. These statutes can be used as a tool to require staff other than correctional officers to report sexual misconduct with inmates.

This publication is developed by the NIC/WCL Project on Addressing Prison Rape under NIC Cooperative Agreement 06S20GJJ1.

This is not to be reproduced or cited without permission from the authors.

American University, Washington College of Law

Current as of May 7, 2009 


\section{Fifty State Survey of Mandatory Reporting Statutes}

\section{NIC/WCL Project on Addressing Prison Rape}

\begin{tabular}{|c|c|}
\hline $\begin{array}{l}\text { Relevant Definitions } \\
\text { Cont'd } \\
\text { (New Jersey) }\end{array}$ & $\begin{array}{l}\text { who has been willfully isolated from ordinary social contact under circumstances which indicate emotional or social } \\
\text { deprivation. }\end{array}$ \\
\hline $\begin{array}{l}\text { Persons Required to } \\
\text { Report } \\
\text { (New Jersey) }\end{array}$ & $\begin{array}{l}\text { N.J.S.A. } \S 9: 6-8.10 \text { (West 2008) } \\
\text { Any person having reasonable cause to believe that a child has been subjected to child abuse or acts of child abuse. }\end{array}$ \\
\hline $\begin{array}{l}\text { Reporting } \\
\text { Procedures } \\
\text { (New Jersey) }\end{array}$ & $\begin{array}{l}\text { N.J.S.A. § 9:6-8.10 (West 2008) } \\
\text { Individuals required to report shall report immediately to the Division of Youth and Family Services by telephone or otherwise. } \\
\text { Such reports, where possible, shall contain the names and addresses of the child and his parent, guardian, or other person having } \\
\text { custody and control of the child and, if known, the child's age, the nature and possible extent of the child's injuries, abuse or } \\
\text { maltreatment, including any evidence of previous injuries, abuse or maltreatment, and any other information that the person } \\
\text { believes may be helpful with respect to the child abuse and the identity of the perpetrator. }\end{array}$ \\
\hline $\begin{array}{l}\text { Penalty for Failure to } \\
\text { Report } \\
\text { (New Jersey) }\end{array}$ & $\begin{array}{l}\text { N.J.S.A. § 9:6-8.14 (West 2008) } \\
\text { Any person knowingly violating the provisions of this act including the failure to report an act of child abuse having reasonable } \\
\text { cause to believe that an act of child abuse has been committed is a disorderly person. } \\
\text { N.J.S.A. § 2C:43-8 (West 2008) } \\
\text { Maximum of } 6 \text { months imprisonment. } \\
\text { N.J.S.A. § } 2 \text { C: } 43-3 \text { (West 2008) } \\
\text { (d) Maximum fine of } \$ 1,000.00 \text {. }\end{array}$ \\
\hline
\end{tabular}

NOTE:

** For purposes of this chart, corrections officers, police officers, peace officers, probation officers or “catch-all” phrases such as “all persons” have been bolded. However, many mandatory reporters include professionals who may have contact or work in correctional facilities. Such individuals include physicians, nurses, dentists, teachers and social workers. These statutes can be used as a tool to require staff other than correctional officers to report sexual misconduct with inmates.

This publication is developed by the NIC/WCL Project on Addressing Prison Rape under NIC Cooperative Agreement 06S20GJJ1.

This is not to be reproduced or cited without permission from the authors.

American University, Washington College of Law

Current as of May 7, 2009 


\section{Fifty State Survey of Mandatory Reporting Statutes}

\section{NIC/WCL Project on Addressing Prison Rape}

\begin{tabular}{|c|c|}
\hline $\begin{array}{l}\text { Mandatory } \\
\text { Reporting Statute } \\
\text { (New Jersey) }\end{array}$ & $\begin{array}{l}\text { AGAINST AN ADULT } \\
\text { N.J.S.A. § 52:27D-419 (West 2008) }\end{array}$ \\
\hline $\begin{array}{l}\text { What has to be } \\
\text { reported? } \\
\text { (New Jersey) }\end{array}$ & $\begin{array}{l}\text { N.J.S.A. } § 52: 27 D-419 \text { (West 2008) } \\
\text { Reasonable cause to believe that a caretaker or other person has committed a criminal act against a vulnerable adult. }\end{array}$ \\
\hline $\begin{array}{l}\text { Relevant Definitions } \\
\text { (New Jersey) }\end{array}$ & $\begin{array}{l}\text { N.J.S.A. } § 52: 27 D-407 \text { (West 2008) } \\
\text { “County director means” the director of a county adult protective services provider. } \\
\text { "Vulnerable adult” means a person } 18 \text { years of age or older who resides in a community setting and who, because of a physical or } \\
\text { mental illness, disability or deficiency, lacks sufficient understanding or capacity to make, communicate, or carry out decisions } \\
\text { concerning his well-being and is the subject of abuse, neglect or exploitation. A person shall not be deemed to be the subject of } \\
\text { abuse, neglect or exploitation or in need of protective services for the sole reason that the person is being furnished nonmedical } \\
\text { remedial treatment by spiritual means through prayer alone or in accordance with a recognized religious method of healing in lieu } \\
\text { of medical treatment, and in accordance with the tenets and practices of the person's established religious tradition. } \\
\text { “Abuse means” the willful infliction of physical pain, injury or mental anguish, unreasonable confinement, or the willful } \\
\text { deprivation of services which are necessary to maintain a person's physical and mental health. } \\
\text { "Caretaker” means a person who has assumed the responsibility for the care of a vulnerable adult as a result of family relationship } \\
\text { or who has assumed responsibility for the care of a vulnerable adult voluntarily, by contract, or by order of a court of competent } \\
\text { jurisdiction, whether or not they reside together. } \\
\text { "Exploitation” means the act or process of illegally or improperly using a person or his resources for another person's profit or }\end{array}$ \\
\hline
\end{tabular}

NOTE:

** For purposes of this chart, corrections officers, police officers, peace officers, probation officers or “catch-all” phrases such as “all persons” have been bolded. However, many mandatory reporters include professionals who may have contact or work in correctional facilities. Such individuals include physicians, nurses, dentists, teachers and social workers. These statutes can be used as a tool to require staff other than correctional officers to report sexual misconduct with inmates.

This publication is developed by the NIC/WCL Project on Addressing Prison Rape under NIC Cooperative Agreement 06S20GJJ1.

This is not to be reproduced or cited without permission from the authors.

American University, Washington College of Law

Current as of May 7, 2009 


\section{Fifty State Survey of Mandatory Reporting Statutes}

\section{NIC/WCL Project on Addressing Prison Rape}

\begin{tabular}{|c|c|}
\hline $\begin{array}{l}\text { Relevant Definitions } \\
\text { Cont'd } \\
\text { (New Jersey) }\end{array}$ & $\begin{array}{l}\text { advantage. } \\
\text { "Neglect" means an act or failure to act by a vulnerable adult or his caretaker which results in the inadequate provision of care or } \\
\text { services necessary to maintain the physical and mental health of the vulnerable adult, and which places the vulnerable adult in a } \\
\text { situation which can result in serious injury or which is life-threatening. }\end{array}$ \\
\hline $\begin{array}{l}\text { Persons Required to } \\
\text { Report } \\
\text { (New Jersey) }\end{array}$ & $\begin{array}{l}\text { N.J.S.A. § 52:27D-419 (West 2008) } \\
\text { The county director or his designee. }\end{array}$ \\
\hline $\begin{array}{l}\text { Reporting } \\
\text { Procedures } \\
\text { (New Jersey) }\end{array}$ & $\begin{array}{l}\text { N.J.S.A. } § 52: 27 D-419 \text { (West 2008) } \\
\text { Immediately report the information to local law enforcement officials or the prosecutor of the county in which the alleged criminal } \\
\text { act was committed. If the report is made orally, a written report shall follow in a timely manner. }\end{array}$ \\
\hline $\begin{array}{l}\text { Penalty for Failure to } \\
\text { Report } \\
\text { (New Jersey) }\end{array}$ & $\begin{array}{l}\text { N.J.S.A. } § 52: 27 D-435 \text { (West 2008) } \\
\text { As an alternative, or in addition to the provisions of section } 21 \text { of P.L.1993, c. } 288 \text { (C. } 52: 27 D-434) \text { (pending before the } \\
\text { Legislature as this bill), the commissioner may, subject to notice and hearing, impose an administrative civil penalty for a violation } \\
\text { set forth in this section not to exceed } \$ 1,000 \text { for the first offense and } \$ 5,000 \text { for each subsequent offense. If the violation is of a } \\
\text { continuing nature, each day it continues constitutes an additional and separate violation. } \\
\text { The penalty may be sued for and recovered by and in the name of the commissioner in a civil action in a court of competent } \\
\text { jurisdiction by a summary proceeding under "the penalty enforcement law," N.J.S. } 2 A: 58-1 \text { et seq. For the purposes of this act, the } \\
\text { Superior Court and the municipal court shall have jurisdiction to enforce the provisions of "the penalty enforcement law." } \\
\text { The department may compromise and settle a claim for a penalty under this section in such amount as the department determines } \\
\text { to be appropriate and equitable. }\end{array}$ \\
\hline
\end{tabular}

NOTE:

** For purposes of this chart, corrections officers, police officers, peace officers, probation officers or “catch-all” phrases such as “all persons” have been bolded. However, many mandatory reporters include professionals who may have contact or work in correctional facilities. Such individuals include physicians, nurses, dentists, teachers and social workers. These statutes can be used as a tool to require staff other than correctional officers to report sexual misconduct with inmates.

This publication is developed by the NIC/WCL Project on Addressing Prison Rape under NIC Cooperative Agreement 06S20GJJ1.

This is not to be reproduced or cited without permission from the authors.

American University, Washington College of Law

Current as of May 7, 2009 


\section{Fifty State Survey of Mandatory Reporting Statutes}

\section{NIC/WCL Project on Addressing Prison Rape}

\begin{tabular}{|c|c|}
\hline \multicolumn{2}{|r|}{ NEW MEXICO } \\
\hline $\begin{array}{l}\text { Mandatory } \\
\text { Reporting Statute } \\
\text { (New Mexico) }\end{array}$ & $\begin{array}{l}\text { AGAINST A CHILD } \\
\text { N.M.S.A. } 1978 \S 32 \mathrm{~A}-4-3 \text { (West 2008) }\end{array}$ \\
\hline $\begin{array}{l}\text { What has to be } \\
\text { reported? } \\
\text { (New Mexico) }\end{array}$ & $\begin{array}{l}\text { N.M.S.A. } 1978 \S 32 \text { A-4-3 (West 2008) } \\
\text { (A) Knowledge or reasonable suspicion that a child is an abused or a neglected child. }\end{array}$ \\
\hline $\begin{array}{l}\text { Relevant Definitions } \\
\text { (New Mexico) }\end{array}$ & $\begin{array}{l}\text { N.M.S.A. } 1978 \text { § 32A-4-2 (West 2008) } \\
\text { (B) “Abused child” means a child: } \\
\text { (1) who has suffered or who is at risk of suffering serious harm because of the action or inaction of the child's parent, guardian } \\
\text { or custodian; } \\
\text { (2) who has suffered physical abuse, emotional abuse or psychological abuse inflicted or caused by the child's parent, guardian } \\
\text { or custodian; } \\
\text { (3) who has suffered sexual abuse or sexual exploitation inflicted by the child's parent, guardian or custodian; } \\
\text { (4) whose parent, guardian or custodian has knowingly, intentionally or negligently placed the child in a situation that may } \\
\text { endanger the child's life or health; or } \\
\text { (5) whose parent, guardian or custodian has knowingly or intentionally tortured, cruelly confined or cruelly punished the child; } \\
\text { (A) Abandonment includes instances when the parent, without justifiable cause: } \\
\text { (1) left the child without provision for the child's identification for a period of fourteen days; or } \\
\text { (2) left the child with others, including the other parent or an agency, without provision for support and without communication } \\
\text { for a period of: }\end{array}$ \\
\hline
\end{tabular}

\section{NOTE:}

** For purposes of this chart, corrections officers, police officers, peace officers, probation officers or "catch-all” phrases such as "all persons" have been bolded. However, many mandatory reporters include professionals who may have contact or work in correctional facilities. Such individuals include physicians, nurses, dentists, teachers and social workers. These statutes can be used as a tool to require staff other than correctional officers to report sexual misconduct with inmates.

This publication is developed by the NIC/WCL Project on Addressing Prison Rape under NIC Cooperative Agreement 06S20GJJ1.

This is not to be reproduced or cited without permission from the authors.

American University, Washington College of Law

Current as of May 7, 2009 


\section{Fifty State Survey of Mandatory Reporting Statutes}

\section{NIC/WCL Project on Addressing Prison Rape}

\begin{tabular}{|c|c|}
\hline $\begin{array}{l}\text { Relevant Definitions } \\
\text { Cont'd } \\
(\text { New Mexico) }\end{array}$ & 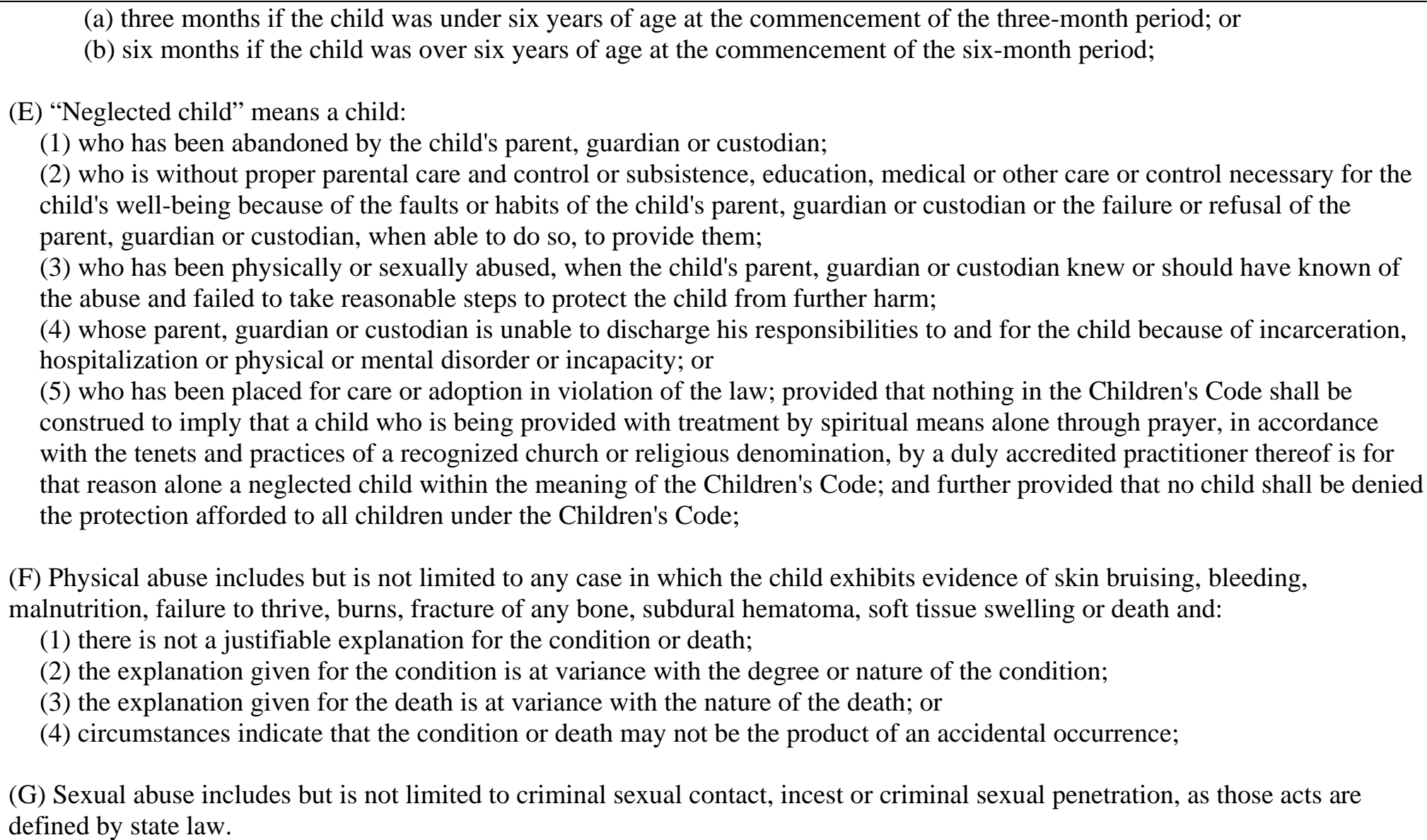 \\
\hline
\end{tabular}

NOTE:

** For purposes of this chart, corrections officers, police officers, peace officers, probation officers or “catch-all” phrases such as “all persons” have been bolded. However, many mandatory reporters include professionals who may have contact or work in correctional facilities. Such individuals include physicians, nurses, dentists, teachers and social workers. These statutes can be used as a tool to require staff other than correctional officers to report sexual misconduct with inmates.

This publication is developed by the NIC/WCL Project on Addressing Prison Rape under NIC Cooperative Agreement 06S20GJJ1.

This is not to be reproduced or cited without permission from the authors.

American University, Washington College of Law

Current as of May 7, 2009 


\section{Fifty State Survey of Mandatory Reporting Statutes}

\section{NIC/WCL Project on Addressing Prison Rape}

\begin{tabular}{|c|c|}
\hline $\begin{array}{l}\text { Relevant Definitions } \\
\text { Cont'd } \\
\text { (New Mexico) }\end{array}$ & $\begin{array}{l}\text { (H) Sexual exploitation includes but is not limited to: } \\
\text { (1) allowing, permitting or encouraging a child to engage in prostitution; } \\
\text { (2) allowing, permitting, encouraging or engaging a child in obscene or pornographic photographing; or } \\
\text { (3) filming or depicting a child for obscene or pornographic commercial purposes, as those acts are defined by state law. }\end{array}$ \\
\hline $\begin{array}{l}\text { Persons Required to } \\
\text { Report } \\
\text { (New Mexico) }\end{array}$ & $\begin{array}{l}\text { N.M.S.A. } 1978 \S 32 \text { A-4-3 (West 2008) } \\
\begin{array}{l}\text { (A) Every person, including: } \\
\text { - A law enforcement officer; } \\
\text { - A licensed physician; } \\
\text { - A resident or an intern examining, attending or treating a child; } \\
\text { - A judge presiding during a proceeding; } \\
\text { - A registered nurse; } \\
\text { - A visiting nurse; } \\
\text { - A schoolteacher; } \\
\text { - A school official; } \\
\text { - A social worker acting in an official capacity; or } \\
\text { - A member of the clergy who has information that is not privileged as a matter of law. }\end{array}\end{array}$ \\
\hline $\begin{array}{l}\text { Reporting } \\
\text { Procedures } \\
\text { (New Mexico) }\end{array}$ & $\begin{array}{l}\text { N.M.S.A. } 1978 \text { § 32A-4-3 (West 2008) } \\
\text { (A) Shall report the matter immediately to: } \\
\text { (1) a local law enforcement agency; } \\
\text { (2) the department; or } \\
\text { (3) a tribal law enforcement or social services agency for any Indian child residing in Indian country. }\end{array}$ \\
\hline
\end{tabular}

NOTE:

** For purposes of this chart, corrections officers, police officers, peace officers, probation officers or “catch-all” phrases such as “all persons” have been bolded. However, many mandatory reporters include professionals who may have contact or work in correctional facilities. Such individuals include physicians, nurses, dentists, teachers and social workers. These statutes can be used as a tool to require staff other than correctional officers to report sexual misconduct with inmates.

This publication is developed by the NIC/WCL Project on Addressing Prison Rape under NIC Cooperative Agreement 06S20GJJ1.

This is not to be reproduced or cited without permission from the authors.

American University, Washington College of Law

Current as of May 7, 2009 


\section{Fifty State Survey of Mandatory Reporting Statutes}

\section{NIC/WCL Project on Addressing Prison Rape}

\begin{tabular}{|c|c|}
\hline $\begin{array}{l}\text { Penalty for Failure to } \\
\text { Report } \\
\text { (New Mexico) }\end{array}$ & $\begin{array}{l}\text { N.M.S.A. } 1978 \S 32 \text { A-4-3 (West 2008) } \\
\text { (F) A person who violates the provisions of Subsection A of this section is guilty of a misdemeanor and shall be sentenced } \\
\text { pursuant to the provisions of Section 31-19-1 NMSA } 1978 \text {. } \\
\text { N.M.S.A. } 1978 \S 31-19-1 \text { (West 2008) } \\
\text { (A) Imprisonment in the county jail for a definite term less than } 1 \text { year or to the payment of a fine of not more than } \$ 1,000.00 \text { or to } \\
\text { both such imprisonment and fine in the discretion of the judge. }\end{array}$ \\
\hline $\begin{array}{l}\text { Mandatory } \\
\text { Reporting Statute } \\
\text { (New Mexico) }\end{array}$ & $\begin{array}{l}\text { AGAINST AN ADULT } \\
\text { N.M.S.A. } 1978 \S 27-7-30 \text { (West 2008) }\end{array}$ \\
\hline $\begin{array}{l}\text { What has to be } \\
\text { reported? } \\
\text { (New Mexico) }\end{array}$ & $\begin{array}{l}\text { N.M.S.A. } 1978 \text { § 27-7-30 (West 2008) } \\
\text { (A) Reasonable cause to believe that an incapacitated adult is being abused, neglected, or exploited. }\end{array}$ \\
\hline $\begin{array}{l}\text { Relevant Definitions } \\
\text { (New Mexico) }\end{array}$ & $\begin{array}{l}\text { N.M.S.A. } 1978 \S 27-7-16 \text { (West 2008) } \\
\text { (A) “Abuse” means: } \\
\text { (1) knowingly, intentionally or negligently and without justifiable cause inflicting physical pain, injury or mental anguish; or } \\
\text { (2) the intentional deprivation by a caretaker or other person of services necessary to maintain the mental and physical health of } \\
\text { an adult; or } \\
\text { (3) sexual abuse, including criminal sexual contact, incest and criminal sexual penetration. } \\
\text { (I) "Exploitation” means an unjust or improper use of an adult's money or property for another person's profit or advantage, }\end{array}$ \\
\hline
\end{tabular}

NOTE:

** For purposes of this chart, corrections officers, police officers, peace officers, probation officers or "catch-all” phrases such as "all persons" have been bolded. However, many mandatory reporters include professionals who may have contact or work in correctional facilities. Such individuals include physicians, nurses, dentists, teachers and social workers. These statutes can be used as a tool to require staff other than correctional officers to report sexual misconduct with inmates.

This publication is developed by the NIC/WCL Project on Addressing Prison Rape under NIC Cooperative Agreement 06S20GJJ1.

This is not to be reproduced or cited without permission from the authors.

American University, Washington College of Law

Current as of May 7, 2009 


\section{Fifty State Survey of Mandatory Reporting Statutes}

\section{NIC/WCL Project on Addressing Prison Rape}

\begin{tabular}{|c|c|}
\hline $\begin{array}{l}\text { Relevant Definitions } \\
\text { Cont'd } \\
\text { (New Mexico) }\end{array}$ & $\begin{array}{l}\text { pecuniary or otherwise. } \\
\text { (L) Incapacitated adult means any adult with a mental, physical, or developmental condition that substantially impairs the adult's } \\
\text { ability to provide adequately for the adult's own care or protection. } \\
\text { (N) Neglect means the failure of the caretaker of an adult to provide for the basic needs of the adult, such as clothing, food, shelter, } \\
\text { supervision and care for the physical and mental health of that adult; "neglect" includes self-neglect. }\end{array}$ \\
\hline $\begin{array}{l}\text { Persons Required to } \\
\text { Report } \\
\text { (New Mexico) }\end{array}$ & $\begin{array}{l}\text { N.M.S.A. } 1978 \S 27-7-30 \text { (West 2008) } \\
\text { (A) Any person, including financial institutions, having reasonable cause to believe that an incapacitated adult is being abused. }\end{array}$ \\
\hline $\begin{array}{l}\text { Reporting } \\
\text { Procedures } \\
(\text { New Mexico) }\end{array}$ & $\begin{array}{l}\text { N.M.S.A. } 1978 \S 27-7-30 \text { (West 2008) } \\
\text { (B) Immediately report that information to the department.... The report may be made orally or in writing. The report shall } \\
\text { include the name, age and address of the adult, the name and address of any other person responsible for the adult's care, the nature } \\
\text { and extent of the adult's condition, the basis of the reporter's knowledge and other relevant information. }\end{array}$ \\
\hline $\begin{array}{l}\text { Penalty for Failure to } \\
\text { Report } \\
(\mathrm{New} M e x i c o)\end{array}$ & $\begin{array}{l}\text { N.M.S.A. } 1978 \S 27-7-30 \text { (West 2008) } \\
\text { (C) Any person failing or refusing to report, or obstructing or impeding any investigation, as required by Subsection A of this } \\
\text { section is guilty of a misdemeanor. } \\
\text { N.M.S.A. } 1978 \S 31-19-1 \text { (West } 2008) \\
\text { (A) Imprisonment for a definite term less than one year or payment of a fine of not more than one thousand dollars }(\$ 1.000) \text { or to }\end{array}$ \\
\hline
\end{tabular}

NOTE:

** For purposes of this chart, corrections officers, police officers, peace officers, probation officers or “catch-all” phrases such as “all persons” have been bolded. However, many mandatory reporters include professionals who may have contact or work in correctional facilities. Such individuals include physicians, nurses, dentists, teachers and social workers. These statutes can be used as a tool to require staff other than correctional officers to report sexual misconduct with inmates.

This publication is developed by the NIC/WCL Project on Addressing Prison Rape under NIC Cooperative Agreement 06S20GJJ1.

This is not to be reproduced or cited without permission from the authors.

American University, Washington College of Law

Current as of May 7, 2009 


\section{Fifty State Survey of Mandatory Reporting Statutes}

\section{NIC/WCL Project on Addressing Prison Rape}

\begin{tabular}{|c|c|}
\hline $\begin{array}{l}\text { Penalty for Failure to } \\
\text { Report Cont'd } \\
(\text { New Mexico) }\end{array}$ & both such imprisonment and fine in the discretion of the judge. \\
\hline & NEW YORK \\
\hline $\begin{array}{l}\text { Mandatory } \\
\text { Reporting Statute } \\
\text { (New York) }\end{array}$ & $\begin{array}{l}\text { AGAINST A CHILD } \\
\text { N.Y. SOC. SERV. § } 413 \text { (West 2008) }\end{array}$ \\
\hline $\begin{array}{l}\text { What has to be } \\
\text { reported? } \\
\text { (New York) }\end{array}$ & $\begin{array}{l}\text { N.Y. SOC. SERV. § } 413 \text { (West 2008) } \\
\text { (1) Reasonable cause to suspect that a child coming before them in their professional or official capacity is an abused or maltreated } \\
\text { child, or when they have reasonable cause to suspect that a child is an abused or maltreated child where the parent, guardian, } \\
\text { custodian or other person legally responsible for such child comes before them in their professional or official capacity and states } \\
\text { from personal knowledge facts, conditions or circumstances which, if correct, would render the child an abused or maltreated } \\
\text { child. }\end{array}$ \\
\hline $\begin{array}{l}\text { Relevant Definitions } \\
\text { (New York) }\end{array}$ & $\begin{array}{l}\text { N.Y. SOC. SERV. § } 412 \text { (West 2008) } \\
\text { (1) “Abused child” means: } \\
\text { (a) a child under eighteen years of age defined as an abused child by the family court act; } \\
\text { (b) a child under the age of eighteen years who is defined as an abused child in residential care pursuant to subdivision eight of } \\
\text { this section; or } \\
\text { (c) a child with a handicapping condition, who is eighteen years of age or older, is in residential care in a school or facility, and } \\
\text { is defined as an abused child pursuant to subdivision eight of this section; provided that such term shall include a pupil with a }\end{array}$ \\
\hline
\end{tabular}

\section{NOTE:}

** For purposes of this chart, corrections officers, police officers, peace officers, probation officers or "catch-all” phrases such as "all persons" have been bolded. However, many mandatory reporters include professionals who may have contact or work in correctional facilities. Such individuals include physicians, nurses, dentists, teachers and social workers. These statutes can be used as a tool to require staff other than correctional officers to report sexual misconduct with inmates.

This publication is developed by the NIC/WCL Project on Addressing Prison Rape under NIC Cooperative Agreement 06S20GJJ1.

This is not to be reproduced or cited without permission from the authors.

American University, Washington College of Law

Current as of May 7, 2009 


\section{Fifty State Survey of Mandatory Reporting Statutes}

\section{NIC/WCL Project on Addressing Prison Rape}

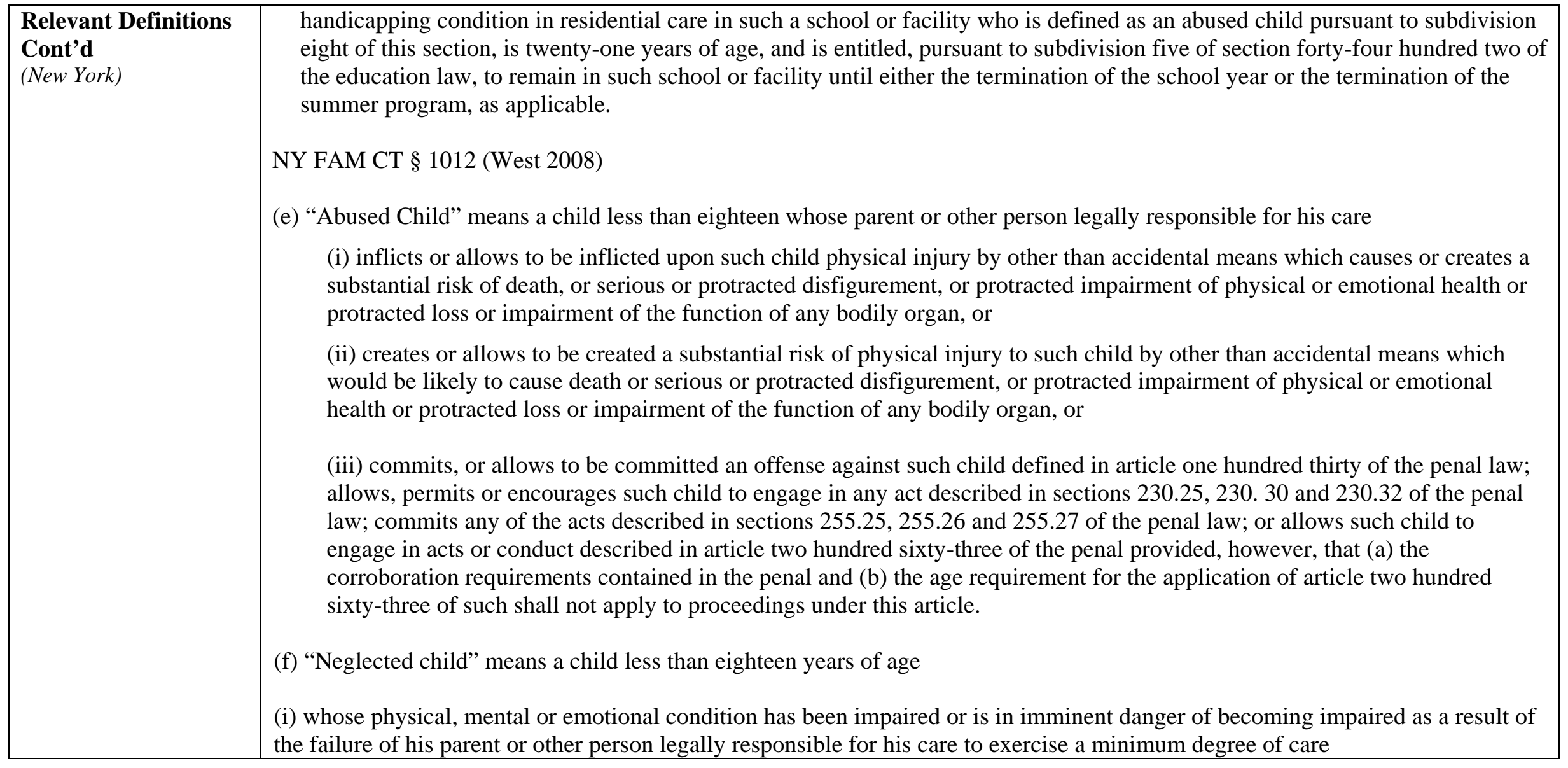

NOTE:

** For purposes of this chart, corrections officers, police officers, peace officers, probation officers or "catch-all” phrases such as “all persons” have been bolded. However, many mandatory reporters include professionals who may have contact or work in correctional facilities. Such individuals include physicians, nurses, dentists, teachers and social workers. These statutes can be used as a tool to require staff other than correctional officers to report sexual misconduct with inmates.

This publication is developed by the NIC/WCL Project on Addressing Prison Rape under NIC Cooperative Agreement 06S20GJJ1.

This is not to be reproduced or cited without permission from the authors.

American University, Washington College of Law

Current as of May 7, 2009 


\section{Fifty State Survey of Mandatory Reporting Statutes}

\section{NIC/WCL Project on Addressing Prison Rape}

\begin{tabular}{|c|c|}
\hline $\begin{array}{l}\text { Relevant Definitions } \\
\text { Cont'd } \\
\text { (New York) }\end{array}$ & $\begin{array}{l}\text { (A) in supplying the child with adequate food, clothing, shelter or education in accordance with the provisions of part } \\
\text { one of article sixty-five of the education law, or medical, dental, optometrical or surgical care, though financially able } \\
\text { to do so or offered financial or other reasonable means to do so; or } \\
\text { (B) in providing the child with proper supervision or guardianship, by unreasonably inflicting or allowing to be } \\
\text { inflicted harm, or a substantial risk thereof, including the infliction of excessive corporal punishment; or by misusing a } \\
\text { drug or drugs; or by misusing alcoholic beverages to the extent that he loses self-control of his actions; or by any other } \\
\text { acts of a similarly serious nature requiring the aid of the court; provided, however, that where the respondent is } \\
\text { voluntarily and regularly participating in a rehabilitative program, evidence that the respondent has repeatedly misused } \\
\text { a drug or drugs or alcoholic beverages to the extent that he loses self-control of his actions shall not establish that the } \\
\text { child is a neglected child in the absence of evidence establishing that the child's physical, mental or emotional condition } \\
\text { has been impaired or is in imminent danger of becoming impaired as set forth in paragraph (i) of this subdivision; or } \\
\text { (ii) who has been abandoned, in accordance with the definition and other criteria set forth in subdivision five of section } \\
\text { three hundred eighty-four-b of the social services law, by his parents or other person legally responsible for his care. } \\
\text { (g) Person legally responsible includes the child's custodian, guardian, any other person responsible for the child's care at the } \\
\text { relevant time. Custodian may include any person continually or at regular intervals found in the same household as the child when } \\
\text { the conduct of such person causes or contributes to the abuse or neglect of the child. }\end{array}$ \\
\hline $\begin{array}{l}\text { Persons Required to } \\
\text { Report } \\
\text { (New York) }\end{array}$ & $\begin{array}{l}\text { N.Y. SOC. SERV. § } 413 \text { (West 2008) } \\
\text { (1)(a) the following persons and officials are required to report or cause a report to be made } \\
\text { - Peace officer; } \\
\text { - Police officer; } \\
\text { - Other law enforcement official; } \\
\text { - Physician, registered physician assistant, surgeon, medical examiner, coroner; }\end{array}$ \\
\hline
\end{tabular}

NOTE:

** For purposes of this chart, corrections officers, police officers, peace officers, probation officers or "catch-all” phrases such as “all persons” have been bolded. However, many mandatory reporters include professionals who may have contact or work in correctional facilities. Such individuals include physicians, nurses, dentists, teachers and social workers. These statutes can be used as a tool to require staff other than correctional officers to report sexual misconduct with inmates.

This publication is developed by the NIC/WCL Project on Addressing Prison Rape under NIC Cooperative Agreement 06S20GJJ1.

This is not to be reproduced or cited without permission from the authors.

American University, Washington College of Law

Current as of May 7, 2009 


\section{Fifty State Survey of Mandatory Reporting Statutes}

\section{NIC/WCL Project on Addressing Prison Rape}

\begin{tabular}{|c|c|}
\hline $\begin{array}{l}\text { Persons Required to } \\
\text { Report Cont'd } \\
\text { (New York) }\end{array}$ & 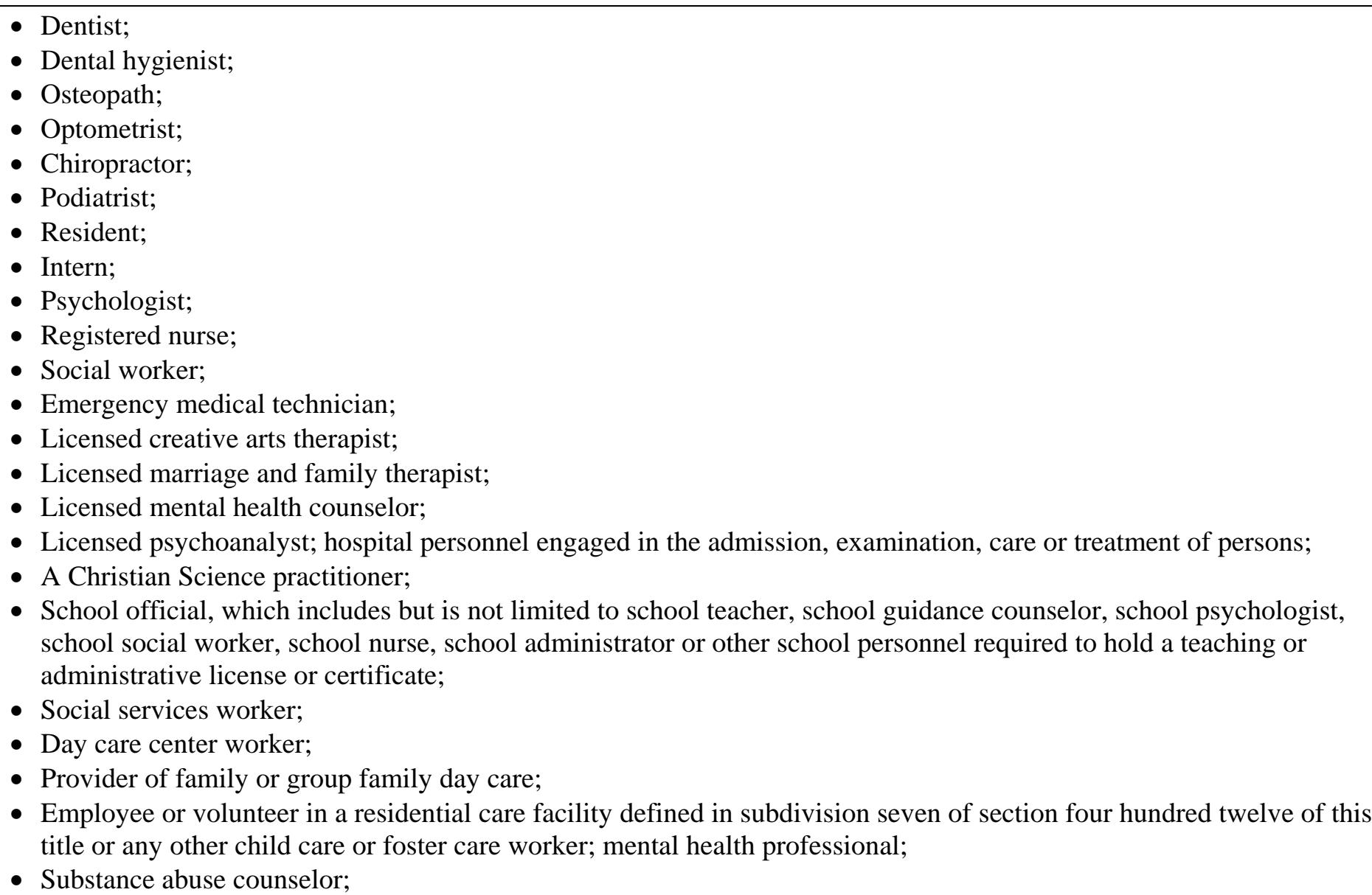 \\
\hline
\end{tabular}

** For purposes of this chart, corrections officers, police officers, peace officers, probation officers or "catch-all” phrases such as “all persons” have been bolded. However, many mandatory reporters include professionals who may have contact or work in correctional facilities. Such individuals include physicians, nurses, dentists, teachers and social workers. These statutes can be used as a tool to require staff other than correctional officers to report sexual misconduct with inmates.

This publication is developed by the NIC/WCL Project on Addressing Prison Rape under NIC Cooperative Agreement 06S20GJJ1.

This is not to be reproduced or cited without permission from the authors.

American University, Washington College of Law

Current as of May 7, 2009 


\section{Fifty State Survey of Mandatory Reporting Statutes}

\section{NIC/WCL Project on Addressing Prison Rape}

\begin{tabular}{|c|c|}
\hline $\begin{array}{l}\text { Persons Required to } \\
\text { Report Cont'd } \\
\text { (New York) }\end{array}$ & $\begin{array}{l}\text { - Alcoholism counselor; } \\
\text { - District attorney or assistant district attorney; or } \\
\text { - Investigator employed in the office of a district attorney. }\end{array}$ \\
\hline $\begin{array}{l}\text { Reporting } \\
\text { Procedures } \\
\text { (New York) }\end{array}$ & $\begin{array}{l}\text { N.Y. SOC. SERV. } § 413 \text { (West 2008) } \\
\text { (b) Whenever such person is required to report under this title in his or her capacity as a member of the staff of a medical or other } \\
\text { public or private institution, school, facility or agency, he or she shall make the report as required by this title and immediately } \\
\text { notify the person in charge of such institution, school, facility or agency, or his or her designated agent. Such person in charge, or } \\
\text { the designated agent of such person, shall be responsible for all subsequent administration necessitated by the report. Any report } \\
\text { shall include the name, title and contact information for every staff person of the institution who is believed to have direct } \\
\text { knowledge of the allegations in the report. }\end{array}$ \\
\hline $\begin{array}{l}\text { Penalty for Failure to } \\
\text { Report } \\
\text { (New York) }\end{array}$ & $\begin{array}{l}\text { N.Y. SOC. SERV. § } 420 \text { (West 2008) } \\
\text { (1) Any person, official or institution required by this title to report a case of suspected child abuse or maltreatment who willfully } \\
\text { fails to do so shall be guilty of a class A misdemeanor. } \\
\text { (2) Any person, official or institution required by this title to report a case of suspected child abuse or maltreatment who } \\
\text { knowingly and willfully fails to do so shall be civilly liable for the damages proximately caused by such failure. } \\
\text { N.Y. PENAL } \S 80.05 \\
\text { (1) A sentence to pay a fine for a class A misdemeanor shall be a sentence to pay an amount, fixed by the court, not exceeding } \\
\$ 1,000.00 \text {. } \\
\text { N.Y. PENAL } \S 70.15 \text { (West 2008) }\end{array}$ \\
\hline
\end{tabular}

NOTE:

** For purposes of this chart, corrections officers, police officers, peace officers, probation officers or “catch-all” phrases such as “all persons” have been bolded. However, many mandatory reporters include professionals who may have contact or work in correctional facilities. Such individuals include physicians, nurses, dentists, teachers and social workers. These statutes can be used as a tool to require staff other than correctional officers to report sexual misconduct with inmates.

This publication is developed by the NIC/WCL Project on Addressing Prison Rape under NIC Cooperative Agreement 06S20GJJ1.

This is not to be reproduced or cited without permission from the authors.

American University, Washington College of Law

Current as of May 7, 2009 


\section{Fifty State Survey of Mandatory Reporting Statutes}

\section{NIC/WCL Project on Addressing Prison Rape}

\begin{tabular}{|c|c|}
\hline $\begin{array}{l}\text { Penalty for Failure to } \\
\text { Report } \\
\text { (New York) }\end{array}$ & $\begin{array}{l}\text { ( } 1 \text { ) Class A misdemeanor. A sentence of imprisonment for a class A misdemeanor shall be a definite sentence. When such a } \\
\text { sentence is imposed the term shall be fixed by the court, and shall not exceed one year. }\end{array}$ \\
\hline $\begin{array}{l}\text { Mandatory } \\
\text { Reporting Statute } \\
\text { (New York) }\end{array}$ & $\begin{array}{l}\text { AGAINST AN ADULT } \\
\text { N/A There is no adult mandatory reporting statute in New York }\end{array}$ \\
\hline $\begin{array}{l}\text { What has to be } \\
\text { reported? } \\
\text { (New York) }\end{array}$ & N/A \\
\hline $\begin{array}{l}\text { Relevant Definitions } \\
\text { (New York) }\end{array}$ & N/A \\
\hline $\begin{array}{l}\text { Persons Required to } \\
\text { Report } \\
\text { (New York) }\end{array}$ & N/A \\
\hline $\begin{array}{l}\text { Reporting } \\
\text { Procedures } \\
\text { (New York) }\end{array}$ & N/A \\
\hline $\begin{array}{l}\text { Penalty for Failure to } \\
\text { Report } \\
\text { (New York) }\end{array}$ & N/A \\
\hline
\end{tabular}

NOTE:

** For purposes of this chart, corrections officers, police officers, peace officers, probation officers or "catch-all” phrases such as "all persons" have been bolded. However, many mandatory reporters include professionals who may have contact or work in correctional facilities. Such individuals include physicians, nurses, dentists, teachers and social workers. These statutes can be used as a tool to require staff other than correctional officers to report sexual misconduct with inmates.

This publication is developed by the NIC/WCL Project on Addressing Prison Rape under NIC Cooperative Agreement 06S20GJJ1.

This is not to be reproduced or cited without permission from the authors.

American University, Washington College of Law

Current as of May 7, 2009 


\section{Fifty State Survey of Mandatory Reporting Statutes}

\section{NIC/WCL Project on Addressing Prison Rape}

\begin{tabular}{|c|c|}
\hline \multicolumn{2}{|r|}{ NORTH CAROLINA } \\
\hline $\begin{array}{l}\text { Mandatory } \\
\text { Reporting Statute } \\
\text { (North Carolina) }\end{array}$ & $\begin{array}{l}\text { AGAINST A CHILD } \\
\text { N.C.G.S.A. § 7B-301 (West 2008) }\end{array}$ \\
\hline $\begin{array}{l}\text { What has to be } \\
\text { reported? } \\
\text { (North Carolina) }\end{array}$ & $\begin{array}{l}\text { N.C.G.S.A. § 7B-301 (West 2008) } \\
\text { Any person or institution that has cause to suspect that any juvenile is abused or neglected. }\end{array}$ \\
\hline $\begin{array}{l}\text { Relevant Definitions } \\
\text { (North Carolina) }\end{array}$ & $\begin{array}{l}\text { N.C.G.S.A. § 7B-101 (West 2008) } \\
\text { (1) Abused juveniles means any juvenile less than } 18 \text { years of age whose parent, guardian, custodian, or caretaker: } \\
\text { a. Inflicts or allows to be inflicted upon the juvenile a serious physical injury by other than accidental means } \\
\text { b. Creates or allows to be created a substantial risk of serious physical injury to the juvenile by other than accidental means; } \\
\text { c. Uses or allows to be used upon the juvenile cruel or grossly inappropriate procedures or cruel or grossly inappropriate } \\
\text { devices to modify behavior; } \\
\text { d. Commits, permits, or encourages the commission of a violation of the following laws by, with, or upon the juvenile: first- } \\
\text { degree rape, second degree rape, first-degree sexual offense, second degree sexual offense, sexual act by a custodian, crime } \\
\text { against nature, incest, preparation of obscene photographs, slides, or motion pictures of the juvenile; employing or } \\
\text { permitting the juvenile to assist in a violation of the obscenity laws; dissemination of obscene material to the juvenile; } \\
\text { displaying or disseminating material harmful to the juvenile, first and second degree sexual exploitation of the juvenile; } \\
\text { promoting the prostitution of the juvenile and taking indecent liberties with the juvenile, } \\
\text { e. Creates or allows to be created serious emotional damage to the juvenile; serious emotional damage is evidenced by a } \\
\text { juvenile's severe anxiety, depression, withdrawal, or aggressive behavior toward himself or others; o }\end{array}$ \\
\hline
\end{tabular}

NOTE:

** For purposes of this chart, corrections officers, police officers, peace officers, probation officers or "catch-all” phrases such as "all persons" have been bolded. However, many mandatory reporters include professionals who may have contact or work in correctional facilities. Such individuals include physicians, nurses, dentists, teachers and social workers. These statutes can be used as a tool to require staff other than correctional officers to report sexual misconduct with inmates.

This publication is developed by the NIC/WCL Project on Addressing Prison Rape under NIC Cooperative Agreement 06S20GJJ1.

This is not to be reproduced or cited without permission from the authors.

American University, Washington College of Law

Current as of May 7, 2009 


\section{Fifty State Survey of Mandatory Reporting Statutes}

\section{NIC/WCL Project on Addressing Prison Rape}

\begin{tabular}{|c|c|}
\hline $\begin{array}{l}\text { Relevant Definitions } \\
\text { Cont'd } \\
\text { (North Carolina) }\end{array}$ & $\begin{array}{l}\text { f. Encourages, directs, or approves of delinquent acts involving moral turpitude committed by the juvenile. } \\
\text { (15) Neglected juvenile means a juvenile who does not receive proper care, supervision, or discipline from the juvenile's parent, } \\
\text { guardian, custodian, or caretaker; or who has been abandoned; or who is not provided necessary medical care; or who is not } \\
\text { provided necessary remedial care; or who lives in an environment injurious to the juvenile's welfare; or who has been placed for } \\
\text { care or adoption in violation of law. In determining whether a juvenile is a neglected juvenile, it is relevant whether that juvenile } \\
\text { lives in a home where another juvenile has died as a result of suspected abuse or neglect or lives in a home where another juvenile } \\
\text { has been subjected to abuse or neglect by an adult who regularly lives in the home. }\end{array}$ \\
\hline $\begin{array}{l}\text { Persons Required to } \\
\text { Report } \\
\text { (North Carolina) }\end{array}$ & $\begin{array}{l}\text { N.C.G.S.A. § 7B-301 (West 2008) } \\
\text { Any person or institution that has cause to suspect that any juvenile is abused or neglected. }\end{array}$ \\
\hline $\begin{array}{l}\text { Reporting } \\
\text { Procedures } \\
\text { (North Carolina) }\end{array}$ & $\begin{array}{l}\text { N.C.G.S.A. § 7B-301 (West 2008) } \\
\text { Report should be made to the director of the department of social services in the county where the juvenile resides or is found. The } \\
\text { report may be made orally, by telephone, or in writing. The report shall include information as is known to the person making it } \\
\text { including the name and address of the juvenile; the name and address of the juvenile's parent, guardian, or caretaker; the age of the } \\
\text { juvenile; the names and ages of other juveniles in the home; the present whereabouts of the juvenile if not at the home address; the } \\
\text { nature and extent of any injury or condition resulting from abuse, neglect, or dependency; and any other information which the } \\
\text { person making the report believes might be helpful in establishing the need for protective services or court intervention. If the } \\
\text { report is made orally or by telephone, the person making the report shall give the person's name, address, and telephone number. } \\
\text { Refusal of the person making the report to give a name shall not preclude the department's assessment of the alleged abuse, } \\
\text { neglect, dependency, or death as a result of maltreatment. }\end{array}$ \\
\hline
\end{tabular}

NOTE:

** For purposes of this chart, corrections officers, police officers, peace officers, probation officers or "catch-all” phrases such as "all persons" have been bolded. However, many mandatory reporters include professionals who may have contact or work in correctional facilities. Such individuals include physicians, nurses, dentists, teachers and social workers. These statutes can be used as a tool to require staff other than correctional officers to report sexual misconduct with inmates.

This publication is developed by the NIC/WCL Project on Addressing Prison Rape under NIC Cooperative Agreement 06S20GJJ1.

This is not to be reproduced or cited without permission from the authors.

American University, Washington College of Law

Current as of May 7, 2009 


\section{Fifty State Survey of Mandatory Reporting Statutes}

\section{NIC/WCL Project on Addressing Prison Rape}

\begin{tabular}{|c|c|}
\hline $\begin{array}{l}\text { Penalty for Failure to } \\
\text { Report } \\
\text { (North Carolina) }\end{array}$ & $\begin{array}{l}\text { No statutory sanctions. } \\
\text { Note: Case law supports that a mandated reporter who failed to report was liable for damages. See Smith v. Jackson County Bd. } \\
\text { of Educ. } 168 \text { N.C. App. 452, } 608 \text { (2005). }\end{array}$ \\
\hline $\begin{array}{l}\text { Mandatory } \\
\text { Reporting Statute } \\
\text { (North Carolina) }\end{array}$ & $\begin{array}{l}\text { AGAINST AN ADULT } \\
\text { N.C.G.S.A. § 108A-102 (West 2008) }\end{array}$ \\
\hline $\begin{array}{l}\text { What has to be } \\
\text { reported? } \\
\text { (North Carolina) }\end{array}$ & $\begin{array}{l}\text { N.C.G.S.A. § 108A-102 (West 2008) } \\
\text { (a) Reasonable cause to believe that a disabled adult is in need of protective services. }\end{array}$ \\
\hline $\begin{array}{l}\text { Relevant Definitions } \\
\text { (North Carolina) }\end{array}$ & $\begin{array}{l}\text { N.C.G.S.A. § 108A-101 (West 2008) } \\
\text { (d) Disabled adult shall mean any person } 18 \text { years of age or over or any lawfully emancipated minor who is present in the State of } \\
\text { North Carolina and who is physically or mentally incapacitated due to mental retardation, cerebral palsy, epilepsy or autism; } \\
\text { organic brain damage caused by advanced age or other physical degeneration in connection therewith; or due to conditions } \\
\text { incurred at any age which are the result of accident, organic brain damage, mental or physical illness, or continued consumption or } \\
\text { absorption of substances. } \\
\text { (n) Protective services shall mean services provided by the State or other government or private organizations or individuals which } \\
\text { are necessary to protect the disabled adult from abuse, neglect, or exploitation. They shall consist of evaluation of the need for } \\
\text { service and mobilization of essential services on behalf of the disabled adult. } \\
\text { (m) The word "neglect" refers to a disabled adult who is either living alone and not able to provide for himself or herself the } \\
\text { services which are necessary to maintain the person's mental or physical health or is not receiving services from the person's } \\
\text { caretaker. }\end{array}$ \\
\hline
\end{tabular}

NOTE:

** For purposes of this chart, corrections officers, police officers, peace officers, probation officers or “catch-all” phrases such as “all persons” have been bolded. However, many mandatory reporters include professionals who may have contact or work in correctional facilities. Such individuals include physicians, nurses, dentists, teachers and social workers. These statutes can be used as a tool to require staff other than correctional officers to report sexual misconduct with inmates.

This publication is developed by the NIC/WCL Project on Addressing Prison Rape under NIC Cooperative Agreement 06S20GJJ1.

This is not to be reproduced or cited without permission from the authors.

American University, Washington College of Law

Current as of May 7, 2009 


\section{Fifty State Survey of Mandatory Reporting Statutes}

\section{NIC/WCL Project on Addressing Prison Rape}

\begin{tabular}{|c|c|}
\hline $\begin{array}{l}\text { Persons Required to } \\
\text { Report } \\
\text { (North Carolina) }\end{array}$ & $\begin{array}{l}\text { N.C.G.S.A. § 108A-102 (West 2008) } \\
\text { (a) Any person having reasonable cause to believe that a disabled adult is in need of protective services. }\end{array}$ \\
\hline $\begin{array}{l}\text { Reporting } \\
\text { Procedures } \\
\text { (North Carolina) }\end{array}$ & $\begin{array}{l}\text { N.C.G.S.A. § 108A-102 (West 2008) } \\
\text { (b) The report may be made orally or in writing. The report shall include the name and address of the disabled adult; the name and } \\
\text { address of the disabled adult's caretaker; the age of the disabled adult; the nature and extent of the disabled adult's injury or } \\
\text { condition resulting from abuse or neglect; and other pertinent information. }\end{array}$ \\
\hline $\begin{array}{l}\text { Penalty for Failure to } \\
\text { Report } \\
\text { (North Carolina) }\end{array}$ & No statutory sanctions. \\
\hline \multicolumn{2}{|r|}{ NORTH DAKOTA } \\
\hline $\begin{array}{l}\text { Mandatory } \\
\text { Reporting Statute } \\
\text { (North Dakota) }\end{array}$ & $\begin{array}{l}\text { AGAINST A CHILD } \\
\text { NDCC } \S 50-25.1-03 \text { (West 2008) }\end{array}$ \\
\hline $\begin{array}{l}\text { What has to be } \\
\text { reported? } \\
\text { (North Dakota) }\end{array}$ & $\begin{array}{l}\text { NDCC } \S 50-25.1-03 \text { (West 2008) } \\
\text { (1) Knowledge of or reasonable cause to suspect that a child is abused or neglected, or has died as a result of abuse or neglect. }\end{array}$ \\
\hline $\begin{array}{l}\text { Relevant Definitions } \\
\text { (North Dakota) }\end{array}$ & NDCC § 50-25.1-02 (West 2008) \\
\hline
\end{tabular}

NOTE:

** For purposes of this chart, corrections officers, police officers, peace officers, probation officers or “catch-all” phrases such as “all persons” have been bolded. However, many mandatory reporters include professionals who may have contact or work in correctional facilities. Such individuals include physicians, nurses, dentists, teachers and social workers. These statutes can be used as a tool to require staff other than correctional officers to report sexual misconduct with inmates.

This publication is developed by the NIC/WCL Project on Addressing Prison Rape under NIC Cooperative Agreement 06S20GJJ1.

This is not to be reproduced or cited without permission from the authors.

American University, Washington College of Law

Current as of May 7, 2009 


\section{Fifty State Survey of Mandatory Reporting Statutes}

\section{NIC/WCL Project on Addressing Prison Rape}

\begin{tabular}{|c|c|}
\hline $\begin{array}{l}\text { Relevant Definitions } \\
\text { Cont'd } \\
\text { (North Dakota) }\end{array}$ & 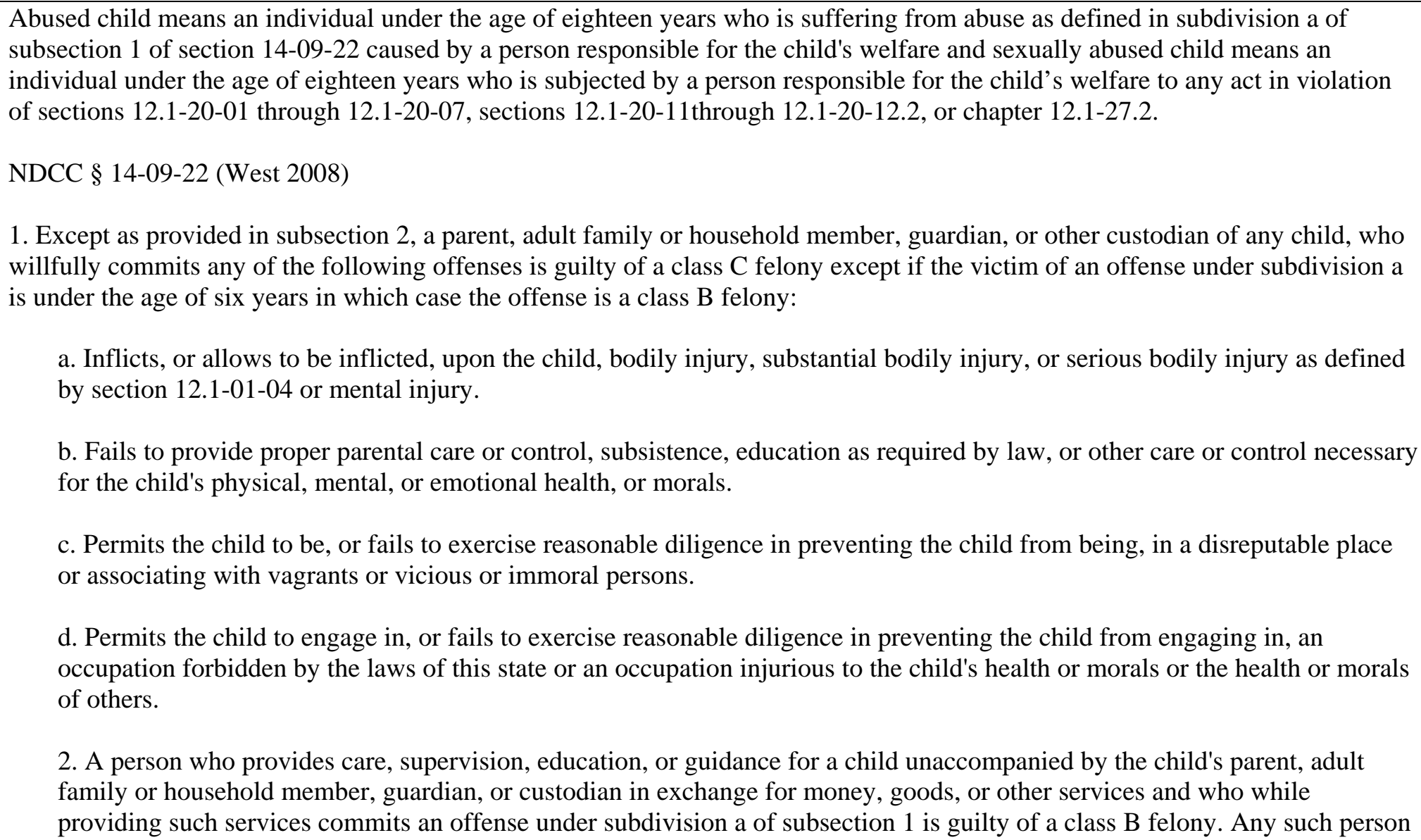 \\
\hline
\end{tabular}

NOTE:

** For purposes of this chart, corrections officers, police officers, peace officers, probation officers or “catch-all” phrases such as “all persons” have been bolded. However, many mandatory reporters include professionals who may have contact or work in correctional facilities. Such individuals include physicians, nurses, dentists, teachers and social workers. These statutes can be used as a tool to require staff other than correctional officers to report sexual misconduct with inmates.

This publication is developed by the NIC/WCL Project on Addressing Prison Rape under NIC Cooperative Agreement 06S20GJJ1.

This is not to be reproduced or cited without permission from the authors.

American University, Washington College of Law

Current as of May 7, 2009 


\section{Fifty State Survey of Mandatory Reporting Statutes}

\section{NIC/WCL Project on Addressing Prison Rape}

\begin{tabular}{|c|c|}
\hline $\begin{array}{l}\text { Relevant Definitions } \\
\text { Cont'd } \\
\text { (North Dakota) }\end{array}$ & $\begin{array}{l}\text { who commits, allows to be committed, or conspires to commit, against the child, a sex offense as defined in chapter } 12.1-20 \text { is } \\
\text { subject to the penalties provided in that chapter. }\end{array}$ \\
\hline $\begin{array}{l}\text { Persons Required to } \\
\text { Report } \\
\text { (North Dakota) }\end{array}$ & 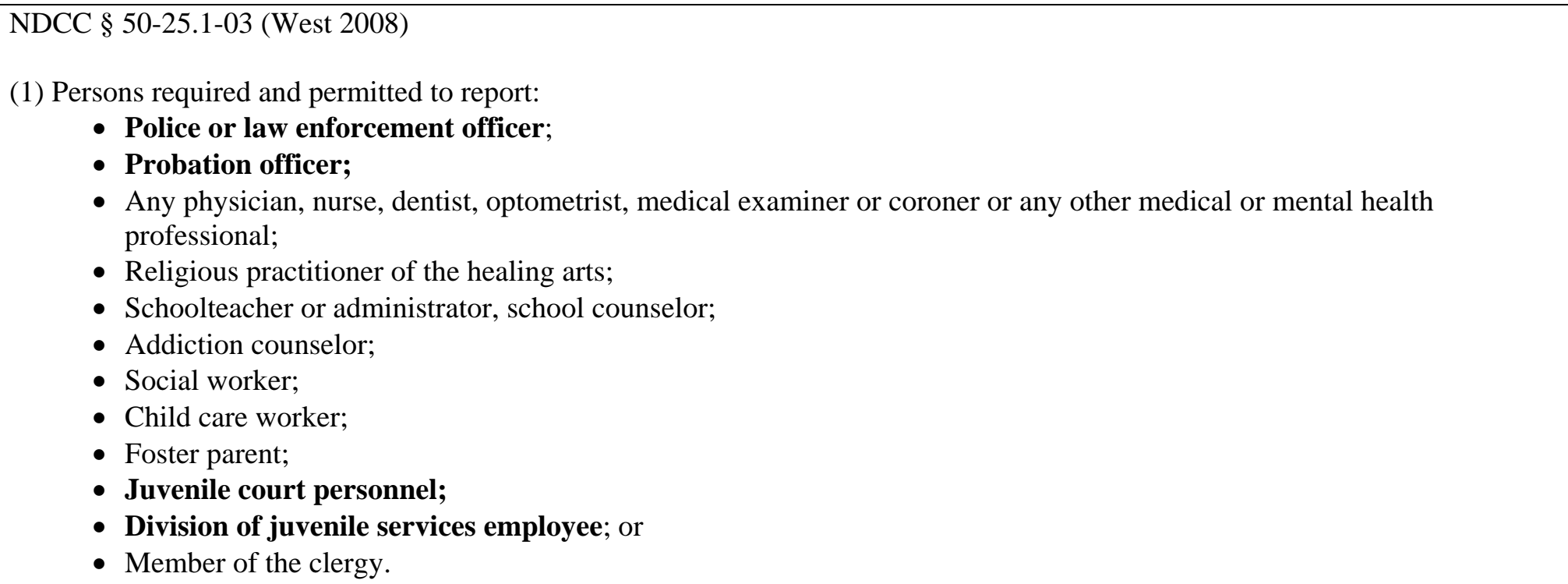 \\
\hline $\begin{array}{l}\text { Reporting } \\
\text { Procedures } \\
\text { (North Dakota) }\end{array}$ & $\begin{array}{l}\text { N.C.G.S.A. § 108A-102 (West 2008) } \\
\text { (b) The report may be made orally or in writing. The report shall include the name and address of the disabled adult; the name and } \\
\text { address of the disabled adult's caretaker; the age of the disabled adult; the nature and extent of the disabled adult's injury or } \\
\text { condition resulting from abuse or neglect; and other pertinent information. }\end{array}$ \\
\hline
\end{tabular}

NOTE:

** For purposes of this chart, corrections officers, police officers, peace officers, probation officers or "catch-all” phrases such as “all persons” have been bolded. However, many mandatory reporters include professionals who may have contact or work in correctional facilities. Such individuals include physicians, nurses, dentists, teachers and social workers. These statutes can be used as a tool to require staff other than correctional officers to report sexual misconduct with inmates.

This publication is developed by the NIC/WCL Project on Addressing Prison Rape under NIC Cooperative Agreement 06S20GJJ1.

This is not to be reproduced or cited without permission from the authors.

American University, Washington College of Law

Current as of May 7, 2009 


\section{Fifty State Survey of Mandatory Reporting Statutes}

\section{NIC/WCL Project on Addressing Prison Rape}

\begin{tabular}{|c|c|}
\hline $\begin{array}{l}\text { Penalty for Failure to } \\
\text { Report } \\
\text { (North Dakota) }\end{array}$ & $\begin{array}{l}\text { NDCC } \S 50 \text {-25.1-03 (West 2008) } \\
\text { A required reporter shall report the circumstances to the department if the knowledge or suspicion is derived from information } \\
\text { received by that person in that person's official or professional capacity. } \\
\text { NDCC § 50-25.1-04 (West 2008) } \\
\text { All persons mandated or permitted to report cases of known or suspected child abuse or neglect shall immediately cause oral or } \\
\text { written reports to be made to the department or the department's designee. Oral reports must be followed by written reports within } \\
\text { forty-eight hours if so requested by the department or the department's designee. A requested written report must include } \\
\text { information specifically sought by the department if the reporter possesses or has reasonable access to that information. Reports } \\
\text { involving known or suspected institutional child abuse or neglect must be made and received in the same manner as all other } \\
\text { reports made under this chapter. }\end{array}$ \\
\hline $\begin{array}{l}\text { Mandatory } \\
\text { Reporting Statute } \\
\text { (North Dakota) }\end{array}$ & $\begin{array}{l}\text { AGAINST AN ADULT } \\
\text { NDCC § 50-25.2-03 (West 2008) }\end{array}$ \\
\hline $\begin{array}{l}\text { What has to be } \\
\text { reported? } \\
\text { (North Dakota) }\end{array}$ & $\begin{array}{l}\text { NDCC } § 50-25.2-03 \text { (West 2008) } \\
\text { (1) Reasonable cause to believe that a vulnerable adult has been subjected to abuse or neglect, or who observes a vulnerable adult } \\
\text { being subjected to conditions or circumstances that reasonably would result in abuse or neglect. }\end{array}$ \\
\hline $\begin{array}{l}\text { Relevant Definitions } \\
\text { (North Dakota) }\end{array}$ & $\begin{array}{l}\text { NDCC } \S 50-25.2-01 \text { (West 2008) } \\
\text { (1) “Abuse” means any willful act or omission of a caregiver or any other person which results in physical injury, mental anguish, }\end{array}$ \\
\hline
\end{tabular}

NOTE:

** For purposes of this chart, corrections officers, police officers, peace officers, probation officers or “catch-all” phrases such as “all persons” have been bolded. However, many mandatory reporters include professionals who may have contact or work in correctional facilities. Such individuals include physicians, nurses, dentists, teachers and social workers. These statutes can be used as a tool to require staff other than correctional officers to report sexual misconduct with inmates.

This publication is developed by the NIC/WCL Project on Addressing Prison Rape under NIC Cooperative Agreement 06S20GJJ1.

This is not to be reproduced or cited without permission from the authors.

American University, Washington College of Law

Current as of May 7, 2009 


\section{Fifty State Survey of Mandatory Reporting Statutes}

\section{NIC/WCL Project on Addressing Prison Rape}

\begin{tabular}{|c|c|}
\hline $\begin{array}{l}\text { Relevant Definitions } \\
\text { Cont'd } \\
\text { (North Dakota) }\end{array}$ & $\begin{array}{l}\text { unreasonable confinement, sexual abuse or exploitation, or financial exploitation to or of a vulnerable adult. } \\
\text { (4) “Caregiver" means any person who has assumed the legal responsibility or a contractual obligation for the care of a vulnerable } \\
\text { adult or has voluntarily assumed responsibility for the care of a vulnerable adult. The term includes a facility operated by any } \\
\text { public or private agency, organization, or institution which provides services to, and has assumed responsibility for the care of, a } \\
\text { vulnerable adult. } \\
\text { (7) "Financial exploitation” means the taking or misuse of property or resources of a vulnerable adult by means of undue } \\
\text { influence, breach of a fiduciary relationship, deception, harassment, criminal coercion, theft, or other unlawful or improper means. } \\
\text { (11) “Neglect means” the failure of a caregiver to provide essential services necessary to maintain the physical and mental health } \\
\text { of a vulnerable adult, or the inability or lack of desire of the vulnerable adult to provide essential services necessary to maintain } \\
\text { and safeguard the vulnerable adult's own physical and mental health. } \\
\text { (17) "Vulnerable adult” means an adult who has a substantial mental or functional impairment. }\end{array}$ \\
\hline $\begin{array}{l}\text { Persons Required to } \\
\text { Report } \\
\text { (North Dakota) }\end{array}$ & $\begin{array}{l}\text { NDCC } \S 50-25.2-03 \text { (West 2008) } \\
\text { (1) A person who has reasonable cause to believe may report. }\end{array}$ \\
\hline $\begin{array}{l}\text { Reporting } \\
\text { Procedures } \\
\text { (North Dakota) }\end{array}$ & $\begin{array}{l}\text { NDCC } § 50-25.2-03 \text { (West 2008) } \\
\text { (2) A person reporting under this section may make an oral or written report, as soon as possible. To the extent reasonably } \\
\text { possible, a person who makes a report under this section shall include in the report: } \\
\text { (a) The name, age, and residence address of the alleged vulnerable adult; } \\
\text { (b) The name and residence address of the caregiver, if any; } \\
\text { (c) The nature and extent of the alleged abuse or neglect or the conditions and circumstances that would reasonably be } \\
\text { expected to result in abuse or neglect; }\end{array}$ \\
\hline
\end{tabular}

** For purposes of this chart, corrections officers, police officers, peace officers, probation officers or “catch-all” phrases such as “all persons” have been bolded. However, many mandatory reporters include professionals who may have contact or work in correctional facilities. Such individuals include physicians, nurses, dentists, teachers and social workers. These statutes can be used as a tool to require staff other than correctional officers to report sexual misconduct with inmates.

This publication is developed by the NIC/WCL Project on Addressing Prison Rape under NIC Cooperative Agreement 06S20GJJ1.

This is not to be reproduced or cited without permission from the authors.

American University, Washington College of Law

Current as of May 7, 2009 


\section{Fifty State Survey of Mandatory Reporting Statutes}

\section{NIC/WCL Project on Addressing Prison Rape}

\begin{tabular}{|c|c|}
\hline $\begin{array}{l}\text { Reporting } \\
\text { Procedures } \\
\text { (North Dakota) }\end{array}$ & $\begin{array}{l}\text { (d) Any evidence of previous abuse or neglect, including the nature and extent of the abuse or neglect; and } \\
\text { (e) Any other information that in the opinion of the person making the report may be helpful in establishing the cause of the } \\
\text { alleged abuse or neglect and the identity of the individual responsible for the alleged abuse or neglect. }\end{array}$ \\
\hline $\begin{array}{l}\text { Penalty for Failure to } \\
\text { Report } \\
\text { (North Dakota) }\end{array}$ & $\begin{array}{l}\text { NDCC } \S 50-25.2-03 \text { (West 2008) } \\
\text { (1) No enumerated sanctions; mandatory reporters may report but are not required. }\end{array}$ \\
\hline & OHIO \\
\hline $\begin{array}{l}\text { Mandatory } \\
\text { Reporting Statute } \\
\text { (Ohio) }\end{array}$ & $\begin{array}{l}\text { AGAINST A CHILD } \\
\text { R.C. } \S 2151.421 \text { (West 2008) }\end{array}$ \\
\hline $\begin{array}{l}\text { What has to be } \\
\text { reported? } \\
\text { (Ohio) }\end{array}$ & $\begin{array}{l}\text { R.C. } \S 2151.421 \text { (West 2008) } \\
\text { (A)(1)(a) No person acting in an official or professional capacity and knows or has reasonable cause to suspect that a child under } \\
\text { eighteen years of age or a mentally retarded, developmentally disabled, or physically impaired child under twenty-one years of age } \\
\text { has suffered or faces a threat of suffering any physical or mental wound, injury, disability, or condition of a nature that reasonably } \\
\text { indicates abuse or neglect of the child, shall fail to immediately report that knowledge or suspicion to the entity or persons } \\
\text { specified in this division. }\end{array}$ \\
\hline $\begin{array}{l}\text { Relevant Definitions } \\
\text { (Ohio) }\end{array}$ & $\begin{array}{l}\text { R.C. } § 2151.031 \text { (West 2008) } \\
\text { Abused child includes any child who: }\end{array}$ \\
\hline
\end{tabular}

NOTE:

** For purposes of this chart, corrections officers, police officers, peace officers, probation officers or “catch-all” phrases such as “all persons” have been bolded. However, many mandatory reporters include professionals who may have contact or work in correctional facilities. Such individuals include physicians, nurses, dentists, teachers and social workers. These statutes can be used as a tool to require staff other than correctional officers to report sexual misconduct with inmates.

This publication is developed by the NIC/WCL Project on Addressing Prison Rape under NIC Cooperative Agreement 06S20GJJ1.

This is not to be reproduced or cited without permission from the authors.

American University, Washington College of Law

Current as of May 7, 2009 


\section{Fifty State Survey of Mandatory Reporting Statutes}

\section{NIC/WCL Project on Addressing Prison Rape}

\begin{tabular}{|c|c|}
\hline $\begin{array}{l}\text { Relevant Definitions } \\
\text { Cont'd } \\
\text { (Ohio) }\end{array}$ & $\begin{array}{l}\text { (A) Is the victim of sexual activity except that the court need not find that any person has been convicted of the offense in order } \\
\text { to find that the child is an abused child; } \\
\text { (B) Is endangered, except that the court need not find that any person has been convicted under that section in order to find that } \\
\text { the child is an abused child; } \\
\text { (C) Exhibits evidence of any physical or mental injury or death, inflicted other than by accidental means, or an injury or death } \\
\text { which is at variance with the history given of it. Except as provided in division (D) of this section, a child exhibiting } \\
\text { evidence of corporal punishment or other physical disciplinary measure by a parent, guardian, custodian, person having } \\
\text { custody or control, or person in loco parentis of a child is not an abused child under this division. } \\
\text { (D) Because of the acts of his parents, guardian, or custodian, suffers physical or mental injury that harms or threatens to harm } \\
\text { the child's health or welfare } \\
\text { (E) Is subjected to out-of-home care child abuse. } \\
\text { R.C. } § 2151.425 \text { (West 2008) } \\
\text { (B) Sexual abuse of a child means unlawful sexual conduct or sexual contact with a person under eighteen years of age or a } \\
\text { mentally retarded, developmentally disabled, or physically impaired person under twenty-one years of age. }\end{array}$ \\
\hline $\begin{array}{l}\text { Persons Required to } \\
\text { Report } \\
\text { (Ohio) }\end{array}$ & $\begin{array}{l}\text { R.C. } § 2151.421 \text { (West 2008) } \\
\text { (A)(1)(b), Persons required to report injury or neglect: } \\
\text { - Attorney; } \\
\text { - Physician, including a hospital intern or resident; Dentist, Podiatrist, practitioner of a limited branch of medicine; } \\
\text { - Registered nurse, licensed practical nurse, visiting nurse, other health care professional; } \\
\text { - Licensed psychologist; } \\
\text { - Licensed school psychologist; } \\
\text { - Independent marriage and family therapist or marriage and family therapist; }\end{array}$ \\
\hline
\end{tabular}

** For purposes of this chart, corrections officers, police officers, peace officers, probation officers or "catch-all” phrases such as “all persons” have been bolded. However, many mandatory reporters include professionals who may have contact or work in correctional facilities. Such individuals include physicians, nurses, dentists, teachers and social workers. These statutes can be used as a tool to require staff other than correctional officers to report sexual misconduct with inmates.

This publication is developed by the NIC/WCL Project on Addressing Prison Rape under NIC Cooperative Agreement 06S20GJJ1.

This is not to be reproduced or cited without permission from the authors.

American University, Washington College of Law

Current as of May 7, 2009 


\section{Fifty State Survey of Mandatory Reporting Statutes}

\section{NIC/WCL Project on Addressing Prison Rape}

\begin{tabular}{|c|c|}
\hline $\begin{array}{l}\text { Persons Required to } \\
\text { Report Cont'd } \\
\text { (Ohio) }\end{array}$ & $\begin{array}{l}\text { - Speech pathologist or audiologist; } \\
\text { - Coroner; } \\
\text { - Administrator or employee of a child day-care center; } \\
\text { - Administrator or employee of a residential camp or child day camp; administrator or employee of a certified child care agency } \\
\text { or other public or private children services agency; } \\
\text { - School teacher; school employee; school authority; person engaged in social work or the practice of professional counseling; } \\
\text { - Agent of a county humane society; } \\
\text { - Person other than a cleric, rendering spiritual treatment through prayer in accordance with the tenets of a well-recognized } \\
\text { religion; } \\
\text { - Superintendent, board member, or employee of a county board of mental retardation; } \\
\text { - Investigative agent contracted with by a county board of mental retardation; ; } \\
\text { - Employee of the department of mental retardation and developmental disabilities; } \\
\text { - Employee of a facility or home that provides respite care in accordance with section 5123.171 of the Revised Code; } \\
\text { - Employee of an entity that provides homemaker services; } \\
\text { - A person performing the duties of an assessor pursuant to Chapter } 3107 \text { or } 5103 \text {. of the Revised Code; or third party employed } \\
\text { by a public children services agency to assist in providing child or family related services. }\end{array}$ \\
\hline $\begin{array}{l}\text { Reporting } \\
\text { Procedures } \\
\text { (Ohio) }\end{array}$ & $\begin{array}{l}\text { R.C. } \S 2151.421 \text { (West 2008) } \\
\text { (A)(1)(a) Except as provided in section 5120.173 [5120.17.3] of the Revised Code, the person making the report shall make it to } \\
\text { the public children services agency or a municipal or county peace officer in the county in which the child resides or in which the } \\
\text { abuse or neglect is occurring or has occurred. In the circumstances described in section } 5120.173 \text { [5120.17.3] of the Revised Code, } \\
\text { the person making the report shall make it to the entity specified in that section. } \\
\text { R.C. } \S 5120.173 \text { (West 2008) }\end{array}$ \\
\hline
\end{tabular}

NOTE:

** For purposes of this chart, corrections officers, police officers, peace officers, probation officers or “catch-all” phrases such as “all persons” have been bolded. However, many mandatory reporters include professionals who may have contact or work in correctional facilities. Such individuals include physicians, nurses, dentists, teachers and social workers. These statutes can be used as a tool to require staff other than correctional officers to report sexual misconduct with inmates.

This publication is developed by the NIC/WCL Project on Addressing Prison Rape under NIC Cooperative Agreement 06S20GJJ1.

This is not to be reproduced or cited without permission from the authors.

American University, Washington College of Law

Current as of May 7, 2009 


\title{
Fifty State Survey of Mandatory Reporting Statutes
}

\section{NIC/WCL Project on Addressing Prison Rape}

\begin{tabular}{|c|c|}
\hline $\begin{array}{l}\text { Reporting } \\
\text { Procedures Cont'd } \\
\text { (Ohio) }\end{array}$ & $\begin{array}{l}\text { Any person who is required to report abuse or neglect of a child under eighteen years of age that is reasonably suspected or } \\
\text { believed to have occurred or the threat of which is reasonably suspected or believed to exist, any person who is permitted to report } \\
\text { or cause a report to be made of reasonably suspected abuse or neglect of a child under eighteen years of age pursuant to division } \\
\text { (B) of that section, any person who is required to report suspected abuse or neglect of a person with mental retardation or a } \\
\text { developmental disability, and any person who is permitted to report suspected abuse or neglect of a person with mental retardation } \\
\text { or a developmental disability pursuant to division (F) of that section and who makes or causes the report to be made, shall direct } \\
\text { that report to the state highway patrol if the child or the person with mental retardation or a developmental disability is an inmate } \\
\text { in the custody of a state correctional institution. }\end{array}$ \\
\hline $\begin{array}{l}\text { Penalty for Failure to } \\
\text { Report } \\
\text { (Ohio) }\end{array}$ & $\begin{array}{l}\text { R.C. } § 2151.99 \text { (West 2008) } \\
\text { (C) Whoever violates division (A)(1) of section } 2151.421 \text { of the Revised Code shall be punished as follows: } \\
\text { (1) Except as otherwise provided in division }(\mathrm{C})(2) \text { of this section, the offender is guilty of a misdemeanor of the fourth degree. } \\
\text { (2) The offender is guilty of a misdemeanor of the first degree if the child who is the subject of the required report that the } \\
\text { offender fails to make suffers or faces the threat of suffering the physical or mental wound, injury, disability, or condition that } \\
\text { would be the basis of the required report when the child is under the direct care or supervision of the offender who is then acting } \\
\text { in the offender's official or professional capacity or when the child is under the direct care or supervision of another person over } \\
\text { whom the offender while acting in the offender's official or professional capacity has supervisory control. } \\
\text { R.C. §2929.24 (West 2008) } \\
\text { (A) Except as provided in section } 2929.22 \text { or } 2929.23 \text { of the Revised Code and unless another term is required or authorized } \\
\text { pursuant to law, if the sentencing court imposing a sentence upon an offender for a misdemeanor elects or is required to impose a } \\
\text { jail term on the offender pursuant to this chapter, the court shall impose a definite jail term that shall be one of the following: }\end{array}$ \\
\hline
\end{tabular}

NOTE:

\begin{abstract}
** For purposes of this chart, corrections officers, police officers, peace officers, probation officers or "catch-all” phrases such as “all persons” have been bolded. However, many mandatory reporters include professionals who may have contact or work in correctional facilities. Such individuals include physicians, nurses, dentists, teachers and social workers. These statutes can be used as a tool to require staff other than correctional officers to report sexual misconduct with inmates.
\end{abstract}

This publication is developed by the NIC/WCL Project on Addressing Prison Rape under NIC Cooperative Agreement 06S20GJJ1.

This is not to be reproduced or cited without permission from the authors.

American University, Washington College of Law

Current as of May 7, 2009 


\section{Fifty State Survey of Mandatory Reporting Statutes}

\section{NIC/WCL Project on Addressing Prison Rape}

\begin{tabular}{|c|c|}
\hline $\begin{array}{l}\text { Penalty for Failure to } \\
\text { Report Cont'd } \\
\text { (Ohio) }\end{array}$ & $\begin{array}{l}\text { (1) For a misdemeanor of the first degree, not more than one hundred eighty days; } \\
\text { (4) For a misdemeanor of the fourth degree, not more than thirty days. }\end{array}$ \\
\hline $\begin{array}{l}\text { Mandatory } \\
\text { Reporting Statute } \\
\text { (Ohio) }\end{array}$ & $\begin{array}{l}\text { AGAINST AN ADULT } \\
\text { R.C. } \S 5101.61 \text { (West 2008) }\end{array}$ \\
\hline $\begin{array}{l}\text { What has to be } \\
\text { reported? } \\
\text { (Ohio) }\end{array}$ & $\begin{array}{l}\text { R.C. } § 5101.61 \text { (West 2008) } \\
\text { Reasonable cause to believe that an adult is being abused, neglected, or exploited, or is in a condition which is the result of abuse, } \\
\text { neglect, or exploitation }\end{array}$ \\
\hline $\begin{array}{l}\text { Relevant Definitions } \\
\text { (Ohio) }\end{array}$ & $\begin{array}{l}\text { R.C. } \S 5101.60 \text { (West 2008) } \\
\text { (A) Abuse means the infliction upon an adult } \\
\text { by self or others of injury, unreasonable confinement, intimidation, or cruel punishment with resulting physical harm, pain, or } \\
\text { mental anguish. } \\
\text { R.C. } § 5101.60 \text { (West 2008) } \\
\text { (B) Adult means any person sixty years of age or older within this state who is handicapped by the infirmities of aging or who has } \\
\text { a physical or mental impairment which prevents the person from providing for the person's own care or protection, and who } \\
\text { resides in an independent living arrangement. } \\
\text { (G) Exploitation means the unlawful or improper act of a caretaker using an adult or an adult's resources for monetary or personal } \\
\text { benefit, profit, or gain. }\end{array}$ \\
\hline
\end{tabular}

NOTE:

** For purposes of this chart, corrections officers, police officers, peace officers, probation officers or “catch-all” phrases such as “all persons” have been bolded. However, many mandatory reporters include professionals who may have contact or work in correctional facilities. Such individuals include physicians, nurses, dentists, teachers and social workers. These statutes can be used as a tool to require staff other than correctional officers to report sexual misconduct with inmates.

This publication is developed by the NIC/WCL Project on Addressing Prison Rape under NIC Cooperative Agreement 06S20GJJ1.

This is not to be reproduced or cited without permission from the authors.

American University, Washington College of Law

Current as of May 7, 2009 


\section{Fifty State Survey of Mandatory Reporting Statutes}

\section{NIC/WCL Project on Addressing Prison Rape}

\begin{tabular}{|c|c|}
\hline $\begin{array}{l}\text { Relevant Definitions } \\
\text { Cont'd } \\
\text { (Ohio) }\end{array}$ & $\begin{array}{l}\text { (K) Neglect means the failure of an adult to provide for self the goods or services necessary to avoid physical harm, mental } \\
\text { anguish, or mental illness or the failure of a caretaker to provide such goods or services. }\end{array}$ \\
\hline $\begin{array}{l}\text { Persons Required to } \\
\text { Report } \\
\text { (Ohio) }\end{array}$ & 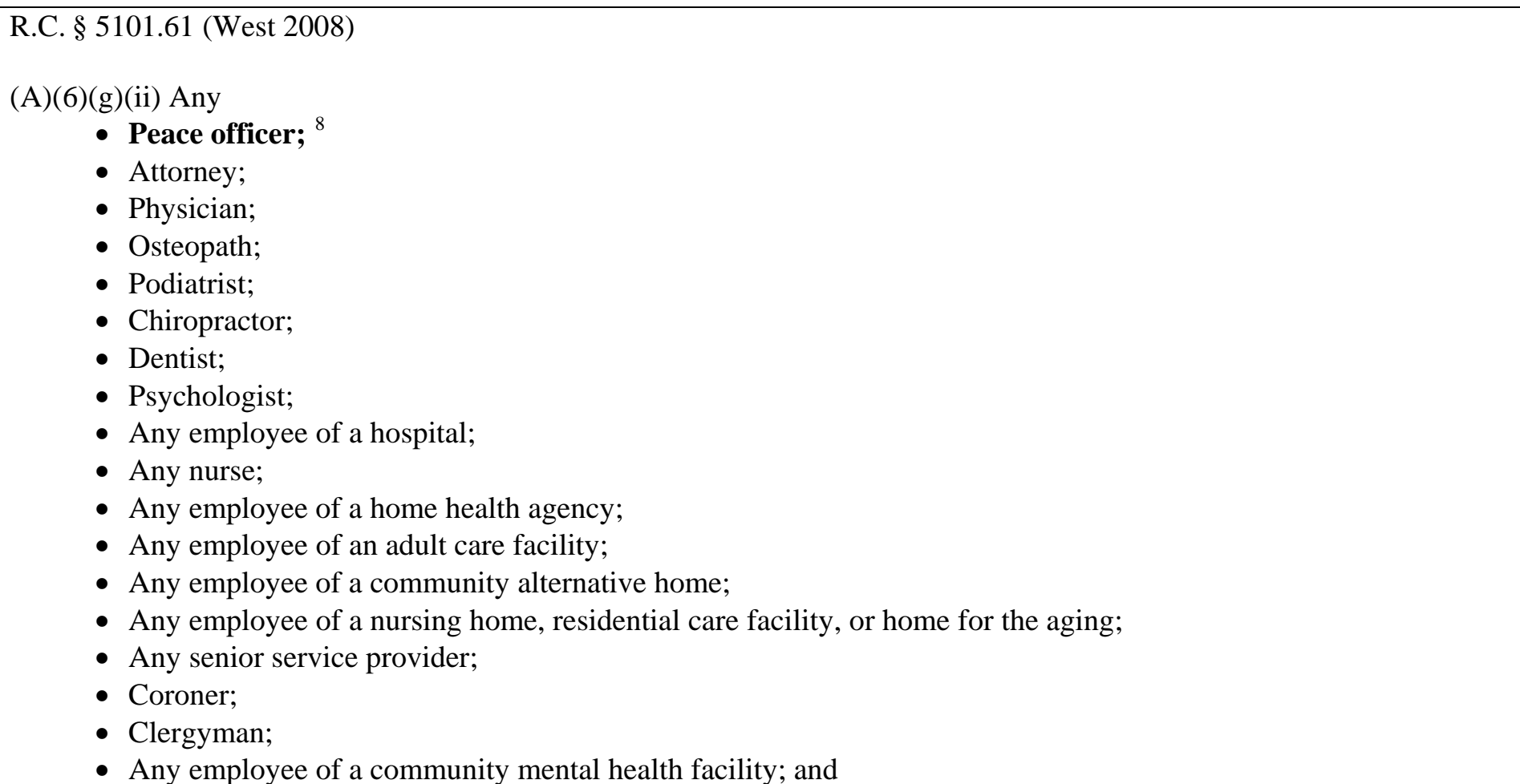 \\
\hline
\end{tabular}

NOTE:

** For purposes of this chart, corrections officers, police officers, peace officers, probation officers or "catch-all” phrases such as "all persons" have been bolded. However, many mandatory reporters include professionals who may have contact or work in correctional facilities. Such individuals include physicians, nurses, dentists, teachers and social workers. These statutes can be used as a tool to require staff other than correctional officers to report sexual misconduct with inmates.

This publication is developed by the NIC/WCL Project on Addressing Prison Rape under NIC Cooperative Agreement 06S20GJJ1.

This is not to be reproduced or cited without permission from the authors.

American University, Washington College of Law

Current as of May 7, 2009 


\section{Fifty State Survey of Mandatory Reporting Statutes}

\section{NIC/WCL Project on Addressing Prison Rape}

\begin{tabular}{|c|c|}
\hline $\begin{array}{l}\text { Persons Required to } \\
\text { Report Cont'd } \\
\text { (Ohio) }\end{array}$ & $\begin{array}{l}\text { - Any person engaged in social work or counseling; } \\
\text { - Any employee of an ambulatory health facility. }\end{array}$ \\
\hline $\begin{array}{l}\text { Reporting } \\
\text { Procedures } \\
\text { (Ohio) }\end{array}$ & $\begin{array}{l}\text { R.C. } \S 5101.61 \text { (West 2008) } \\
\text { Immediately report such belief to the county department of job and family services. } \\
\text { R.C. } § 5101.61 \text { (West 2008) } \\
\text { (C) The reports made under this section shall be made orally or in writing except that oral reports shall be followed by a written } \\
\text { report if a written report is requested by the department. Written reports shall include: } \\
\text { (1) The name, address, and approximate age of the adult who is the subject of the report; } \\
\text { (2) The name and address of the individual responsible for the adult's care, if any individual is, and if the individual is known; } \\
\text { (3) The nature and extent of the alleged abuse, neglect, or exploitation of the adult; } \\
\text { (4) The basis of the reporter's belief that the adult has been abused, neglected, or exploited. }\end{array}$ \\
\hline $\begin{array}{l}\text { Penalty for Failure to } \\
\text { Report } \\
\text { (Ohio) }\end{array}$ & No enumerated sanctions. \\
\hline & OKLAHOMA \\
\hline $\begin{array}{l}\text { Mandatory } \\
\text { Reporting Statute } \\
\text { (Oklahoma) }\end{array}$ & $\begin{array}{l}\text { AGAINST A CHILD } \\
10 \text { OKL. ST. ANN. } \S 7103 \text { (West 2008) }\end{array}$ \\
\hline
\end{tabular}

NOTE:

** For purposes of this chart, corrections officers, police officers, peace officers, probation officers or “catch-all” phrases such as “all persons” have been bolded. However, many mandatory reporters include professionals who may have contact or work in correctional facilities. Such individuals include physicians, nurses, dentists, teachers and social workers. These statutes can be used as a tool to require staff other than correctional officers to report sexual misconduct with inmates.

This publication is developed by the NIC/WCL Project on Addressing Prison Rape under NIC Cooperative Agreement 06S20GJJ1.

This is not to be reproduced or cited without permission from the authors.

American University, Washington College of Law

Current as of May 7, 2009 


\section{Fifty State Survey of Mandatory Reporting Statutes}

\section{NIC/WCL Project on Addressing Prison Rape}

\begin{tabular}{|c|c|}
\hline $\begin{array}{l}\text { What has to be } \\
\text { reported? } \\
(\text { Oklahoma) }\end{array}$ & $\begin{array}{l}10 \text { OKL. ST. ANN. } § 7103 \text { (West 2008) } \\
\text { (A)(1) Reason to believe that a child under the age of eighteen (18) years is a victim of abuse or neglect. } \\
\text { No privilege or contract shall relieve any person from the requirement of reporting pursuant to this section. }\end{array}$ \\
\hline $\begin{array}{l}\text { Relevant Definitions } \\
\text { (Oklahoma) }\end{array}$ & $\begin{array}{l}10 \text { OKL. ST. ANN. § } 7115 \text { (West 2008) } \\
\text { (A) Child abuse, as used in this subsection, means the willful or malicious abuse of a child under eighteen (18) years of age by } \\
\text { another, or the act of willfully or maliciously injuring, torturing or maiming a child under eighteen (18) years of age by another. } \\
10 \text { OKL. ST. ANN. § } 7102 \text { (West 2008) } \\
\text { (1) “Abuse” means harm or threatened harm to a child's health, safety or welfare by a person responsible for the child's health, } \\
\text { safety or welfare, including sexual abuse and sexual exploitation } \\
\text { (2) Harm or threatened harm to a child's health or safety" includes, but is not limited to: } \\
\text { a. nonaccidental physical or mental injury, } \\
\text { b. sexual abuse, } \\
\text { c. sexual exploitation, } \\
\text { d. neglect, } \\
\text { e. failure or omission to provide protection from harm or threatened harm, or } \\
\text { f. abandonment } \\
\text { (4) "Child” means any unmarried person under the age of eighteen (18) years. } \\
\text { (6) Sexual abuse includes, but is not limited to, rape, incest and lewd or indecent acts or proposals made to a child, as defined by }\end{array}$ \\
\hline
\end{tabular}

\section{NOTE:}

** For purposes of this chart, corrections officers, police officers, peace officers, probation officers or “catch-all” phrases such as “all persons” have been bolded. However, many mandatory reporters include professionals who may have contact or work in correctional facilities. Such individuals include physicians, nurses, dentists, teachers and social workers. These statutes can be used as a tool to require staff other than correctional officers to report sexual misconduct with inmates.

This publication is developed by the NIC/WCL Project on Addressing Prison Rape under NIC Cooperative Agreement 06S20GJJ1.

This is not to be reproduced or cited without permission from the authors.

American University, Washington College of Law

Current as of May 7, 2009 


\section{Fifty State Survey of Mandatory Reporting Statutes}

\section{NIC/WCL Project on Addressing Prison Rape}

\begin{tabular}{|c|c|}
\hline $\begin{array}{l}\text { Relevant Definitions } \\
\text { Cont'd } \\
(\text { Oklahoma })\end{array}$ & $\begin{array}{l}\text { law, by a person responsible for the child's health, safety or welfare. } \\
\text { (7) Sexual exploitation includes, but is not limited to, allowing, permitting, or encouraging a child to engage in prostitution, as } \\
\text { defined by law, by a person responsible for the child's health, safety or welfare or allowing, permitting, encouraging, or engaging } \\
\text { in the lewd, obscene, or pornographic photographing, filming, or depicting of a child in those acts as defined by the state law, by a } \\
\text { person responsible for the child's health, safety or welfare. }\end{array}$ \\
\hline $\begin{array}{l}\text { Persons Required to } \\
\text { Report } \\
\text { (Oklahoma) }\end{array}$ & $\begin{array}{l}\text { 10 OKL. ST. ANN. § } 7103 \text { (West 2008) } \\
\text { (A)(1) } \\
\text { a. Physician or surgeon, including doctors of medicine and dentistry, licensed osteopathic physicians, residents and interns, } \\
\text { examining, attending or treating a child under the age of eighteen (18) years; } \\
\text { b. Registered nurse examining, attending or treating such a child in the absence of a physician or surgeon; } \\
\text { c. Teacher of any child under the age of eighteen (18) years, and; } \\
\text { d. Other person. }\end{array}$ \\
\hline $\begin{array}{l}\text { Reporting } \\
\text { Procedures } \\
\text { (Oklahoma) }\end{array}$ & $\begin{array}{l}10 \text { OKL. ST. ANN. } § 7103 \text { (West 2008) } \\
\text { (A)(1) A mandatory reporter shall report the matter promptly to the Department of Human Services. Such reports may be made by } \\
\text { telephone, in writing, personally or by any other method prescribed by the Department. Any report of abuse or neglect made } \\
\text { pursuant to this section shall be made in good faith. }\end{array}$ \\
\hline $\begin{array}{l}\text { Penalty for Failure to } \\
\text { Report } \\
\text { (Oklahoma) }\end{array}$ & $\begin{array}{l}10 \text { OKL. ST. ANN. § } 7103 \text { (West 2008) } \\
\text { (D) Any person who knowingly and willfully fails to promptly report any incident as provided in this section may be reported by } \\
\text { the Department of Human Services to local law enforcement for criminal investigation and, upon conviction thereof, shall be }\end{array}$ \\
\hline
\end{tabular}

NOTE:

** For purposes of this chart, corrections officers, police officers, peace officers, probation officers or “catch-all” phrases such as “all persons” have been bolded. However, many mandatory reporters include professionals who may have contact or work in correctional facilities. Such individuals include physicians, nurses, dentists, teachers and social workers. These statutes can be used as a tool to require staff other than correctional officers to report sexual misconduct with inmates.

This publication is developed by the NIC/WCL Project on Addressing Prison Rape under NIC Cooperative Agreement 06S20GJJ1.

This is not to be reproduced or cited without permission from the authors.

American University, Washington College of Law

Current as of May 7, 2009 


\section{Fifty State Survey of Mandatory Reporting Statutes}

\section{NIC/WCL Project on Addressing Prison Rape}

\begin{tabular}{|c|c|}
\hline $\begin{array}{l}\text { Penalty for Failure to } \\
\text { Report Cont'd } \\
\text { (Oklahoma) }\end{array}$ & $\begin{array}{l}\text { guilty of a misdemeanor. } \\
21 \text { OKL. ST. ANN. } \S 10 \text { (West 2008) } \\
\text { Imprisonment in the county jail not exceeding one (1) year or by a fine not exceeding } \$ 500.00 \text {, or both such fine and } \\
\text { imprisonment. }\end{array}$ \\
\hline $\begin{array}{l}\text { Mandatory } \\
\text { Reporting Statute } \\
\text { (Oklahoma) }\end{array}$ & $\begin{array}{l}\text { AGAINST AN ADULT } \\
\text { 43A OKL. ST. ANN. § 10-104 (West 2008) }\end{array}$ \\
\hline $\begin{array}{l}\text { What has to be } \\
\text { reported? } \\
\text { (Oklahoma) }\end{array}$ & $\begin{array}{l}\text { 43A OKL. ST. ANN. § 10-104 (West 2008) } \\
\text { (A)(1) Reasonable cause to believe that a vulnerable adult is suffering from abuse, neglect, or exploitation. }\end{array}$ \\
\hline $\begin{array}{l}\text { Relevant Definitions } \\
\text { (Oklahoma) }\end{array}$ & $\begin{array}{l}\text { 43A OKL. ST. ANN. } § 10-103 \text { (West 2008) } \\
\text { (4) Incapacitated person means: } \\
\text { a. any person eighteen (18) years of age or older: } \\
\text { (1) who is impaired by reason of mental or physical illness or disability, dementia or related disease, mental retardation, } \\
\text { developmental disability or other cause, and } \\
\text { (2) whose ability to receive and evaluate information effectively or to make and to communicate responsible decisions is } \\
\text { impaired to such an extent that such person lacks the capacity to manage his or her financial resources or to meet } \\
\text { essential requirements for his or her mental or physical health or safety without assistance from others, or } \\
\text { b. a person for whom a guardian, limited guardian, or conservator has been appointed pursuant to the Oklahoma Guardianship } \\
\text { and Conservatorship Act; }\end{array}$ \\
\hline
\end{tabular}

** For purposes of this chart, corrections officers, police officers, peace officers, probation officers or "catch-all” phrases such as "all persons" have been bolded. However, many mandatory reporters include professionals who may have contact or work in correctional facilities. Such individuals include physicians, nurses, dentists, teachers and social workers. These statutes can be used as a tool to require staff other than correctional officers to report sexual misconduct with inmates.

This publication is developed by the NIC/WCL Project on Addressing Prison Rape under NIC Cooperative Agreement 06S20GJJ1.

This is not to be reproduced or cited without permission from the authors.

American University, Washington College of Law

Current as of May 7, 2009 


\section{Fifty State Survey of Mandatory Reporting Statutes}

\section{NIC/WCL Project on Addressing Prison Rape}

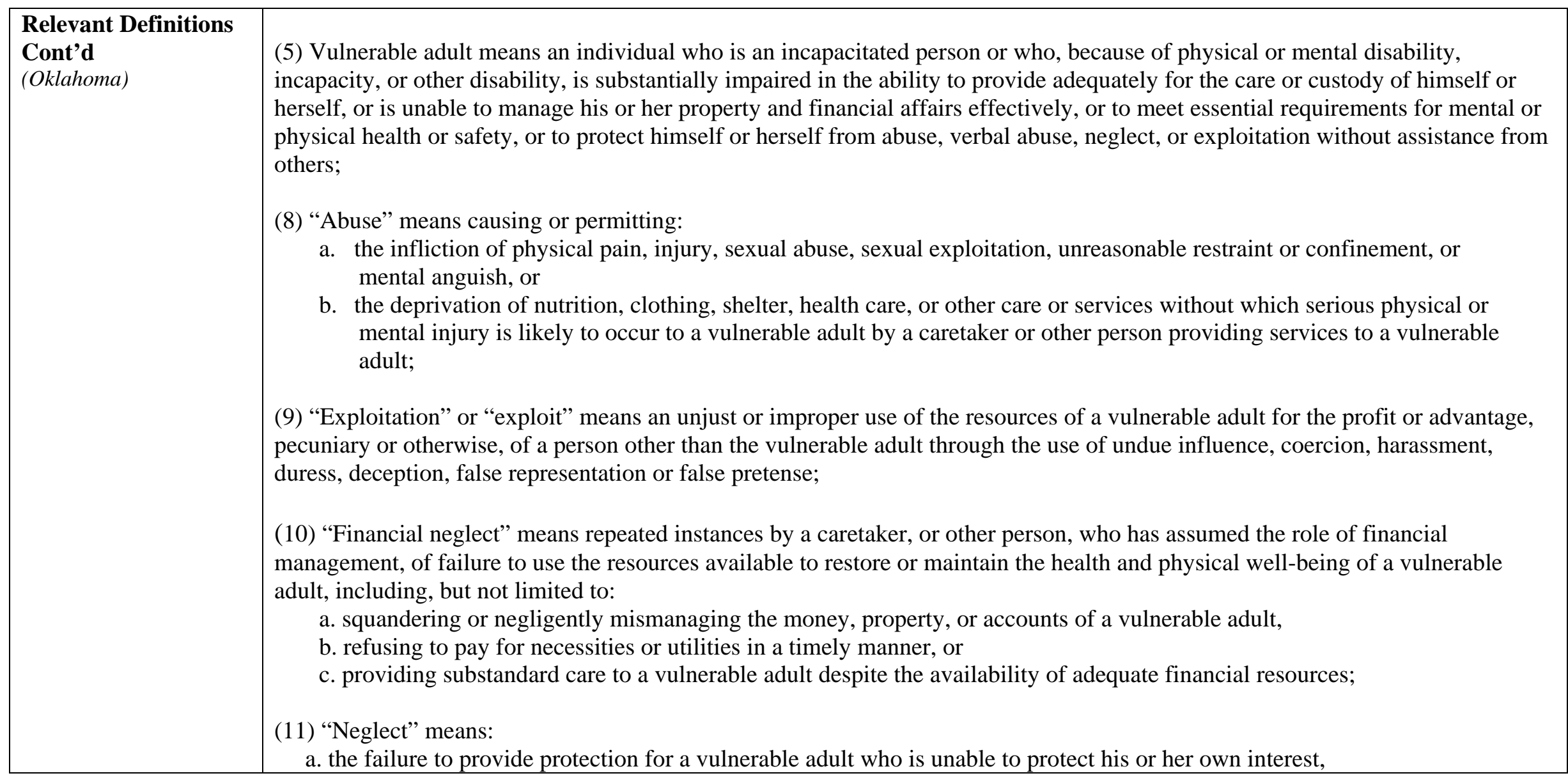

\section{NOTE:}

** For purposes of this chart, corrections officers, police officers, peace officers, probation officers or "catch-all” phrases such as “all persons” have been bolded. However, many mandatory reporters include professionals who may have contact or work in correctional facilities. Such individuals include physicians, nurses, dentists, teachers and social workers. These statutes can be used as a tool to require staff other than correctional officers to report sexual misconduct with inmates.

This publication is developed by the NIC/WCL Project on Addressing Prison Rape under NIC Cooperative Agreement 06S20GJJ1.

This is not to be reproduced or cited without permission from the authors.

American University, Washington College of Law

Current as of May 7, 2009 


\section{Fifty State Survey of Mandatory Reporting Statutes}

\section{NIC/WCL Project on Addressing Prison Rape}

\begin{tabular}{|c|c|}
\hline $\begin{array}{l}\text { Relevant Definitions } \\
\text { Cont'd } \\
\text { (Oklahoma) }\end{array}$ & $\begin{array}{l}\text { b. the failure to provide a vulnerable adult with adequate shelter, nutrition, health care, or clothing, or } \\
\text { c. negligent acts or omissions that result in harm or the unreasonable risk of harm to a vulnerable adult through the action, } \\
\text { inaction, or lack of supervision by a caretaker providing direct services; } \\
\text { (12) "Sexual abuse" means: } \\
\text { b. oral, anal, or vaginal penetration of a vulnerable adult by or through the union with the sexual organ of a caretaker or } \\
\text { other person providing services to the vulnerable adult, or the anal or vaginal penetration of a vulnerable adult by a } \\
\text { caretaker or other person providing services to the vulnerable adult with any other object, or } \\
\text { c. for the purpose of sexual gratification, the touching, feeling or observation of the body or private parts of a vulnerable } \\
\text { adult by a caretaker or other person providing services to the vulnerable adult, or } \\
\text { d. indecent exposure by a caretaker or other person providing services to the vulnerable adult. }\end{array}$ \\
\hline $\begin{array}{l}\text { Persons Required to } \\
\text { Report } \\
\text { (Oklahoma) }\end{array}$ & $\begin{array}{l}\text { 43A OKL. ST. ANN. § 10-104 (West 2008) } \\
\text { (A)(1) Any person having reasonable cause to believe that a vulnerable adult is suffering from abuse, neglect, or exploitation. } \\
\text { (B) Persons required to make reports pursuant to this section shall include, but not be limited to: } \\
\text { 1. Physicians; } \\
\text { 2. Operators of emergency response vehicles and other medical professionals; } \\
\text { 3. Social workers and mental health professionals; } \\
\text { 4. Law enforcement officials; } \\
\text { 5. Staff of domestic violence programs; } \\
\text { 6. Long-term care facility personnel, including staff of nursing facilities, intermediate care facilities for persons with mental } \\
\text { retardation, assisted living facilities, and residential care facilities; } \\
\text { 8. Other health care professionals; }\end{array}$ \\
\hline
\end{tabular}

NOTE:

** For purposes of this chart, corrections officers, police officers, peace officers, probation officers or “catch-all” phrases such as “all persons” have been bolded. However, many mandatory reporters include professionals who may have contact or work in correctional facilities. Such individuals include physicians, nurses, dentists, teachers and social workers. These statutes can be used as a tool to require staff other than correctional officers to report sexual misconduct with inmates.

This publication is developed by the NIC/WCL Project on Addressing Prison Rape under NIC Cooperative Agreement 06S20GJJ1.

This is not to be reproduced or cited without permission from the authors.

American University, Washington College of Law

Current as of May 7, 2009 


\section{Fifty State Survey of Mandatory Reporting Statutes}

\section{NIC/WCL Project on Addressing Prison Rape}

\begin{tabular}{|c|c|}
\hline $\begin{array}{l}\text { Persons Required to } \\
\text { Report Cont'd } \\
\text { (Oklahoma) }\end{array}$ & $\begin{array}{l}\text { vulnerable adult; } \\
\text { 9. Staff of residential care facilities, group homes, or employment settings for individuals with developmental disabilities; and } \\
\text { 10. Job coaches, community service workers, and personal care assistants. }\end{array}$ \\
\hline $\begin{array}{l}\text { Reporting } \\
\text { Procedures } \\
\text { (Oklahoma) }\end{array}$ & $\begin{array}{l}\text { 43A OKL. ST. ANN. } § 10-104 \text { (West 2008) } \\
\text { (A)(1) Shall make a report to either the Department of Human Services, the office of the district attorney in the county in which } \\
\text { the suspected abuse, neglect, or exploitation occurred or the local municipal police department or sheriff's department as soon as } \\
\text { the person is aware of the situation. } \\
\text { (C) The report shall contain the name and address of the vulnerable adult, the name and address of the caretaker, if any, and a } \\
\text { description of the current location and current condition of the vulnerable adult and of the situation which may constitute abuse, } \\
\text { neglect or exploitation of the vulnerable adult. }\end{array}$ \\
\hline $\begin{array}{l}\text { Penalty for Failure to } \\
\text { Report } \\
\text { (Oklahoma) }\end{array}$ & $\begin{array}{l}\text { 43A OKL. ST. ANN. § 10-104 (West 2008) } \\
\text { (D) Any person who knowingly and willfully fails to promptly report any abuse, neglect, or exploitation as required by the } \\
\text { provisions of subsections A and B of this section, upon conviction, shall be guilty of a misdemeanor punishable by imprisonment } \\
\text { in the county jail for a term not exceeding one (1) year or by a fine of not more than } \$ 1,000.00 \text {, or by both such fine and } \\
\text { imprisonment. }\end{array}$ \\
\hline & OREGON \\
\hline
\end{tabular}

NOTE:

** For purposes of this chart, corrections officers, police officers, peace officers, probation officers or “catch-all” phrases such as “all persons” have been bolded. However, many mandatory reporters include professionals who may have contact or work in correctional facilities. Such individuals include physicians, nurses, dentists, teachers and social workers. These statutes can be used as a tool to require staff other than correctional officers to report sexual misconduct with inmates.

This publication is developed by the NIC/WCL Project on Addressing Prison Rape under NIC Cooperative Agreement 06S20GJJ1.

This is not to be reproduced or cited without permission from the authors.

American University, Washington College of Law

Current as of May 7, 2009 


\section{Fifty State Survey of Mandatory Reporting Statutes}

\section{NIC/WCL Project on Addressing Prison Rape}

\begin{tabular}{|c|c|}
\hline $\begin{array}{l}\text { Mandatory } \\
\text { Reporting Statute } \\
\text { (Oregon) }\end{array}$ & $\begin{array}{l}\text { AGAINST A CHILD } \\
\text { O.R.S. § 419B.010 (West 2008) }\end{array}$ \\
\hline $\begin{array}{l}\text { What has to be } \\
\text { reported? } \\
\text { (Oregon) }\end{array}$ & $\begin{array}{l}\text { O.R.S. § 419B.010 (West 2008) } \\
\text { (1) Reasonable cause to believe that any child with whom the official comes in contact has suffered abuse or that any person with } \\
\text { whom the official comes in contact has abused a child. }\end{array}$ \\
\hline $\begin{array}{l}\text { Relevant Definitions } \\
\text { (Oregon) }\end{array}$ & $\begin{array}{l}\text { O.R.S. § } 419 B .005 \text { (West 2008) } \\
\text { (1)(a) “Abuse” means: } \\
\text { (A) Any assault, as defined in ORS chapter 163, of a child and any physical injury to a child which has been caused by other } \\
\text { than accidental means, including any injury which appears to be at variance with the explanation given of the injury. } \\
\text { (B) Any mental injury to a child, which shall include only observable and substantial impairment of the child's mental or } \\
\text { psychological ability to function caused by cruelty to the child, with due regard to the culture of the child. } \\
\text { (C) Rape of a child, which includes but is not limited to rape, sodomy, unlawful sexual penetration and incest. } \\
\text { (D) Sexual abuse. } \\
\text { (E) Sexual exploitation, including but not limited to: } \\
\text { (i) Contributing to the sexual delinquency of a minor, and any other conduct which allows, employs, authorizes, permits, } \\
\text { induces or encourages a child to engage in the performing for people to observe or the photographing, filming, tape } \\
\text { recording or other exhibition which, in whole or in part, depicts sexual conduct or contact, sexual abuse involving a child } \\
\text { or rape of a child, but not including any conduct which is part of any investigation which is designed to serve educational } \\
\text { or other legitimate purposes; and (ii) Allowing, permitting, encouraging or hiring a child to engage in prostitution. } \\
\text { (F) Negligent treatment or maltreatment of a child, including but not limited to the failure to provide adequate food, clothing, }\end{array}$ \\
\hline
\end{tabular}

NOTE:

** For purposes of this chart, corrections officers, police officers, peace officers, probation officers or “catch-all” phrases such as “all persons” have been bolded. However, many mandatory reporters include professionals who may have contact or work in correctional facilities. Such individuals include physicians, nurses, dentists, teachers and social workers. These statutes can be used as a tool to require staff other than correctional officers to report sexual misconduct with inmates.

This publication is developed by the NIC/WCL Project on Addressing Prison Rape under NIC Cooperative Agreement 06S20GJJ1.

This is not to be reproduced or cited without permission from the authors.

American University, Washington College of Law

Current as of May 7, 2009 


\section{Fifty State Survey of Mandatory Reporting Statutes}

\section{NIC/WCL Project on Addressing Prison Rape}

\begin{tabular}{|c|c|}
\hline $\begin{array}{l}\text { Relevant Definitions } \\
\text { Cont'd } \\
\text { (Oregon) }\end{array}$ & $\begin{array}{l}\text { shelter or medical care that is likely to endanger the health or welfare of the child. } \\
\text { (G) Threatened harm to a child, which means subjecting a child to a substantial risk of harm to the child's health or welfare. } \\
\text { (H) Buying or selling a person under } 18 \text { years of age as described in ORS } 163.537 \text {. } \\
\text { (I) Permitting a person under } 18 \text { years of age to enter or remain in or upon premises where methamphetamines are being } \\
\text { manufactured. } \\
\text { (J) Unlawful exposure to a controlled substance, as defined in ORS } 475.005 \text {, that subjects a child to a substantial risk of harm to } \\
\text { the child's health or safety. } \\
\text { (2) "Child" means an unmarried person who is under } 18 \text { years of age. }\end{array}$ \\
\hline $\begin{array}{l}\text { Persons Required to } \\
\text { Report } \\
\text { (Oregon) }\end{array}$ & $\begin{array}{l}\text { O.R.S. § 419B.010 (West 2008) } \\
\text { (1) Any public or private official having reasonable cause to believe that any child with whom the official comes in contact has } \\
\text { suffered abuse or that any person with whom the official comes in contact has abused a child. }\end{array}$ \\
\hline $\begin{array}{l}\text { Reporting } \\
\text { Procedures } \\
\text { (Oregon) }\end{array}$ & $\begin{array}{l}\text { O.R.S. § 419B.015 (West 2008) } \\
\text { (1)(a) A person making a report of child abuse, whether voluntarily or is required by ORS 419B.010, shall make an oral report by } \\
\text { telephone or otherwise to the local office of the Department of Human Services, to the designee of the department or to a law } \\
\text { enforcement agency within the county where the person making the report is located at the time of the contact. The report shall } \\
\text { contain, if known, the names and addresses of the child and the parents of the child or other persons responsible for care of the } \\
\text { child, the child's age, the nature and extent of the abuse, including any evidence of previous abuse, the explanation given for the } \\
\text { abuse and any other information that the person making the report believes might be helpful in establishing the cause of the abuse } \\
\text { and the identity of the perpetrator. }\end{array}$ \\
\hline
\end{tabular}

** For purposes of this chart, corrections officers, police officers, peace officers, probation officers or "catch-all” phrases such as "all persons" have been bolded. However, many mandatory reporters include professionals who may have contact or work in correctional facilities. Such individuals include physicians, nurses, dentists, teachers and social workers. These statutes can be used as a tool to require staff other than correctional officers to report sexual misconduct with inmates.

This publication is developed by the NIC/WCL Project on Addressing Prison Rape under NIC Cooperative Agreement 06S20GJJ1.

This is not to be reproduced or cited without permission from the authors.

American University, Washington College of Law

Current as of May 7, 2009 


\section{Fifty State Survey of Mandatory Reporting Statutes}

\section{NIC/WCL Project on Addressing Prison Rape}

\begin{tabular}{|c|c|}
\hline $\begin{array}{l}\text { Penalty for Failure to } \\
\text { Report } \\
\text { (Oregon) }\end{array}$ & $\begin{array}{l}\text { O.R.S. § 419B.010 (West 2008) } \\
\text { (3) Class A violation. } \\
\text { O.R.S. § } 153.018 \text { (West 2008) } \\
\text { Maximum fine of } \$ 720 . \\
\text { O.R.S. § } 161.545 \text { (West 2008) } \\
\text { Maximum sentence not to exceed one year. }\end{array}$ \\
\hline $\begin{array}{l}\text { Mandatory } \\
\text { Reporting Statute } \\
\text { (Oregon) }\end{array}$ & $\begin{array}{l}\text { AGAINST AN ADULT } \\
\text { O.R.S. § } 124.060 \text { (West 2008) }\end{array}$ \\
\hline $\begin{array}{l}\text { What has to be } \\
\text { reported? } \\
\text { (Oregon) }\end{array}$ & $\begin{array}{l}\text { O.R.S. § } 124.060 \text { (West 2008) } \\
\text { Reasonable cause to believe that any person } 65 \text { years of age or older with whom the official comes in contact, while acting in an } \\
\text { official capacity, has suffered abuse }\end{array}$ \\
\hline $\begin{array}{l}\text { Relevant Definitions } \\
\text { (Oregon) }\end{array}$ & $\begin{array}{l}\text { O.R.S. § } 124.050 \text { (West 2008) } \\
\text { (1) “Abuse” means one or more of the following: } \\
\text { (a) Any physical injury caused by other than accidental means, or which appears to be at variance with the explanation given of } \\
\text { the injury. }\end{array}$ \\
\hline
\end{tabular}

NOTE:

** For purposes of this chart, corrections officers, police officers, peace officers, probation officers or "catch-all” phrases such as "all persons" have been bolded. However, many mandatory reporters include professionals who may have contact or work in correctional facilities. Such individuals include physicians, nurses, dentists, teachers and social workers. These statutes can be used as a tool to require staff other than correctional officers to report sexual misconduct with inmates.

This publication is developed by the NIC/WCL Project on Addressing Prison Rape under NIC Cooperative Agreement 06S20GJJ1.

This is not to be reproduced or cited without permission from the authors.

American University, Washington College of Law

Current as of May 7, 2009 


\section{Fifty State Survey of Mandatory Reporting Statutes}

\section{NIC/WCL Project on Addressing Prison Rape}

\begin{tabular}{|c|c|}
\hline $\begin{array}{l}\text { Relevant Definitions } \\
\text { Cont'd } \\
\text { (Oregon) }\end{array}$ & $\begin{array}{l}\text { (b) Neglect, which leads to physical harm through withholding of services necessary to maintain health and well-being. } \\
\text { (c) Abandonment, including desertion or willful forsaking of an elderly person or a person with a disability the withdrawal or } \\
\text { neglect of duties and obligations owed an elderly person or a person with a disability by a caregiver or other person. } \\
\text { (d) Willful infliction of physical pain or injury. } \\
\text { (f) Causing any sweepstakes promotion to be mailed to an elderly person or a person with a disability who had received } \\
\text { sweepstakes promotional material in the United States mail, spent more than } \$ 500 \text { in the preceding year on any sweepstakes } \\
\text { promotions, or any combination of sweepstakes promotions from the same service, regardless of the identities of the } \\
\text { originators of the sweepstakes promotion and who represented to the court that the person felt the need for the court's } \\
\text { assistance to prevent the person from incurring further expense. } \\
\text { (g) Wrongfully taking or appropriating money or property, or knowingly subjecting an elderly person or person with a } \\
\text { disability to alarm by conveying a threat to wrongfully take or appropriate money or property, which threat reasonably } \\
\text { would be expected to cause the elderly person or person with a disability to believe that the threat will be carried out. } \\
\text { (h) Sexual contact with a nonconsenting elderly person or person with a disability or with an elderly person or person with a } \\
\text { disability considered incapable of consenting to a sexual act as described in ORS 163.315. As used in this paragraph, } \\
\text { "sexual contact" has the meaning given that term in ORS } 163.305 \text {. }\end{array}$ \\
\hline $\begin{array}{l}\text { Persons Required to } \\
\text { Report } \\
\text { (Oregon) }\end{array}$ & $\begin{array}{l}\text { O.R.S. } § 124.050 \text { (West 2008) } \\
\text { Any public or private official }{ }^{\mathbf{1 0}} \text { having reasonable cause to believe that any person } 65 \text { years of age or older with whom the } \\
\text { official comes in contact, while acting in an official capacity, has suffered abuse, or that any person with whom the official comes } \\
\text { in contact while acting in an official capacity has abused a person } 65 \text { years of age or older. }\end{array}$ \\
\hline $\begin{array}{l}\text { Reporting } \\
\text { Procedures } \\
\text { (Oregon) }\end{array}$ & $\begin{array}{l}\text { O.R.S. } \S 124.065 \text { (West 2008) } \\
\text { (1) When a report is required under ORS 124.060, an oral report shall be made immediately by telephone or otherwise to the local } \\
\text { office of the Department of Human Services or to a law enforcement agency within the county where the person making the report } \\
\text { is at the time of contact. If known, such reports shall contain the names and addresses of the elderly person and any persons }\end{array}$ \\
\hline
\end{tabular}

NOTE:

** For purposes of this chart, corrections officers, police officers, peace officers, probation officers or "catch-all” phrases such as “all persons” have been bolded. However, many mandatory reporters include professionals who may have contact or work in correctional facilities. Such individuals include physicians, nurses, dentists, teachers and social workers. These statutes can be used as a tool to require staff other than correctional officers to report sexual misconduct with inmates.

This publication is developed by the NIC/WCL Project on Addressing Prison Rape under NIC Cooperative Agreement 06S20GJJ1.

This is not to be reproduced or cited without permission from the authors.

American University, Washington College of Law

Current as of May 7, 2009 


\section{Fifty State Survey of Mandatory Reporting Statutes}

\section{NIC/WCL Project on Addressing Prison Rape}

\begin{tabular}{|c|c|}
\hline $\begin{array}{l}\text { Reporting } \\
\text { Procedures Cont'd } \\
\text { (Oregon) }\end{array}$ & $\begin{array}{l}\text { responsible for the care of the elderly person, the nature and the extent of the abuse (including any evidence of previous abuse), } \\
\text { the explanation given for the abuse and any other information which the person making the report believes might be helpful in } \\
\text { establishing the cause of the abuse and the identity of the perpetrator. }\end{array}$ \\
\hline $\begin{array}{l}\text { Penalty for Failure to } \\
\text { Report } \\
\text { (Oregon) }\end{array}$ & $\begin{array}{l}\text { O.R.S. § } 124.990 \text { (West 2008) } \\
\text { Class A violation } \\
\text { O.R.S. § } 153.018 \text { (West 2008). } \\
\text { Maximum fine of } \$ 720 . \\
\text { O.R.S. § } 161.545 \text { (West 2008). } \\
\text { Maximum sentence not to exceed one year. }\end{array}$ \\
\hline \multicolumn{2}{|r|}{ PENNSYLVANIA } \\
\hline $\begin{array}{l}\text { Mandatory } \\
\text { Reporting Statute } \\
\text { (Pennsylvania) }\end{array}$ & $\begin{array}{l}\text { AGAINST A CHILD } \\
23 \text { PA. C.S.A. § } 6311 \text { (West 2008) }\end{array}$ \\
\hline $\begin{array}{l}\text { What has to be } \\
\text { reported? } \\
\text { (Pennsylvania) }\end{array}$ & $\begin{array}{l}23 \text { PA. C.S.A. } \S 6311 \text { (West 2008) } \\
\text { (a) A person who, in the course of employment, occupation or practice of a profession, comes into contact with children shall }\end{array}$ \\
\hline
\end{tabular}

NOTE:

** For purposes of this chart, corrections officers, police officers, peace officers, probation officers or "catch-all” phrases such as "all persons" have been bolded. However, many mandatory reporters include professionals who may have contact or work in correctional facilities. Such individuals include physicians, nurses, dentists, teachers and social workers. These statutes can be used as a tool to require staff other than correctional officers to report sexual misconduct with inmates.

This publication is developed by the NIC/WCL Project on Addressing Prison Rape under NIC Cooperative Agreement 06S20GJJ1.

This is not to be reproduced or cited without permission from the authors.

American University, Washington College of Law

Current as of May 7, 2009 


\section{Fifty State Survey of Mandatory Reporting Statutes}

\section{NIC/WCL Project on Addressing Prison Rape}

\begin{tabular}{|c|c|}
\hline $\begin{array}{l}\text { What has to be } \\
\text { reported? Cont'd } \\
\text { (Pennsylvania) }\end{array}$ & $\begin{array}{l}\text { report or cause a report to be made when the person has reasonable cause to suspect, on the basis of medical, professional or } \\
\text { other training and experience, that a child under the care, supervision, guidance or training of that person or of an agency, } \\
\text { institution, organization or other entity with which that person is affiliated is a victim of child abuse, including child abuse by } \\
\text { an individual who is not a perpetrator. }\end{array}$ \\
\hline $\begin{array}{l}\text { Relevant Definitions } \\
\text { (Pennsylvania) }\end{array}$ & $\begin{array}{l}23 \text { PA. C.S.A. § } 6303 \text { (West 2008) } \\
\text { (a) “Child” includes a newborn. } \\
\text { (b)(1) the term "Child Abuse” shall mean any of the following: } \\
\text { (i) Any recent act or failure to act by a perpetrator which causes nonaccidental serious physical injury to a child under } 18 \text { years } \\
\text { of age. } \\
\text { (ii) An act or failure to act by a perpetrator which causes nonaccidental serious mental injury to or sexual abuse or sexual } \\
\text { exploitation of a child under } 18 \text { years of age. } \\
\text { (iii) Any recent act, failure to act or series of such acts or failures to act by a perpetrator which creates an imminent risk of serious } \\
\text { physical injury to or sexual abuse or sexual exploitation of a child under } 18 \text { years of age. } \\
\text { (iv) Serious physical neglect by a perpetrator constituting prolonged or repeated lack of supervision or the failure to provide } \\
\text { essentials of life, including adequate medical care, which endangers a child's life or development or impairs the child's } \\
\text { functioning. } \\
\text { (a) Sexual abuse or exploitation. Any of the following: } \\
\text { (1) The employment, use, persuasion, inducement, enticement or coercion of a child to engage in or assist another individual } \\
\text { to engage in sexually explicit conduct. } \\
\text { (2) The employment, use, persuasion, inducement, enticement or coercion of a child to engage in or assist another individual } \\
\text { to engage in simulation of sexually explicit conduct for the purpose of producing visual depiction, including } \\
\text { photographing, videotaping, computer depicting and filming. }\end{array}$ \\
\hline
\end{tabular}

NOTE:

** For purposes of this chart, corrections officers, police officers, peace officers, probation officers or "catch-all” phrases such as "all persons" have been bolded. However, many mandatory reporters include professionals who may have contact or work in correctional facilities. Such individuals include physicians, nurses, dentists, teachers and social workers. These statutes can be used as a tool to require staff other than correctional officers to report sexual misconduct with inmates.

This publication is developed by the NIC/WCL Project on Addressing Prison Rape under NIC Cooperative Agreement 06S20GJJ1.

This is not to be reproduced or cited without permission from the authors.

American University, Washington College of Law

Current as of May 7, 2009 


\section{Fifty State Survey of Mandatory Reporting Statutes}

\section{NIC/WCL Project on Addressing Prison Rape}

\begin{tabular}{|c|c|}
\hline $\begin{array}{l}\text { Relevant Definitions } \\
\text { Cont'd } \\
\text { (Pennsylvania) }\end{array}$ & $\begin{array}{l}\text { (3) Any of the following offenses committed against a child: } \\
\text { (i) Rape; } \\
\text { (ii) Sexual assault; } \\
\text { (iii) Involuntary deviate sexual intercourse; } \\
\text { (iv) Aggravated indecent assault; } \\
\text { (v) Molestation; } \\
\text { (vi) Incest; } \\
\text { (vii) Indecent exposure; } \\
\text { (viii) Prostitution; } \\
\text { (ix) Sexual abuse; } \\
\text { (x) Sexual exploitation. }\end{array}$ \\
\hline $\begin{array}{l}\text { Persons Required to } \\
\text { Report } \\
\text { (Pennsylvania) }\end{array}$ & $\begin{array}{l}23 \text { PA. C.S.A. } \S 6311 \text { (West 2008) } \\
\text { (a) Persons in the course of their employment, occupation or practice of their profession. } \\
\text { (b) Specific persons required to report under subsection (a) include, but are not limited to, any: } \\
\text { • Peace officer }{ }^{\mathbf{1 1}} \text { or law enforcement official; } \\
\text { • Licensed physician; osteopath, medical examiner, coroner, dentist, optometrist, chiropractor, podiatrist, intern, registered } \\
\text { nurse, licensed practical nurse, hospital personnel engaged in the admission, examination, care or treatment of persons; } \\
\text { • Funeral director; } \\
\text { • Christian Science practitioner; } \\
\text { - member of the clergy; } \\
\text { - School administrator, school teacher, school nurse; } \\
\text { - Social services worker; } \\
\text { • Day-care center worker or any other child-care or foster-care worker; or } \\
\text { • Mental health professional. }\end{array}$ \\
\hline
\end{tabular}

** For purposes of this chart, corrections officers, police officers, peace officers, probation officers or "catch-all” phrases such as “all persons” have been bolded. However, many mandatory reporters include professionals who may have contact or work in correctional facilities. Such individuals include physicians, nurses, dentists, teachers and social workers. These statutes can be used as a tool to require staff other than correctional officers to report sexual misconduct with inmates.

This publication is developed by the NIC/WCL Project on Addressing Prison Rape under NIC Cooperative Agreement 06S20GJJ1.

This is not to be reproduced or cited without permission from the authors.

American University, Washington College of Law

Current as of May 7, 2009 


\title{
Fifty State Survey of Mandatory Reporting Statutes
}

\section{NIC/WCL Project on Addressing Prison Rape}

\begin{tabular}{|c|c|}
\hline $\begin{array}{l}\text { Reporting } \\
\text { Procedures } \\
\text { (Pennsylvania) }\end{array}$ & 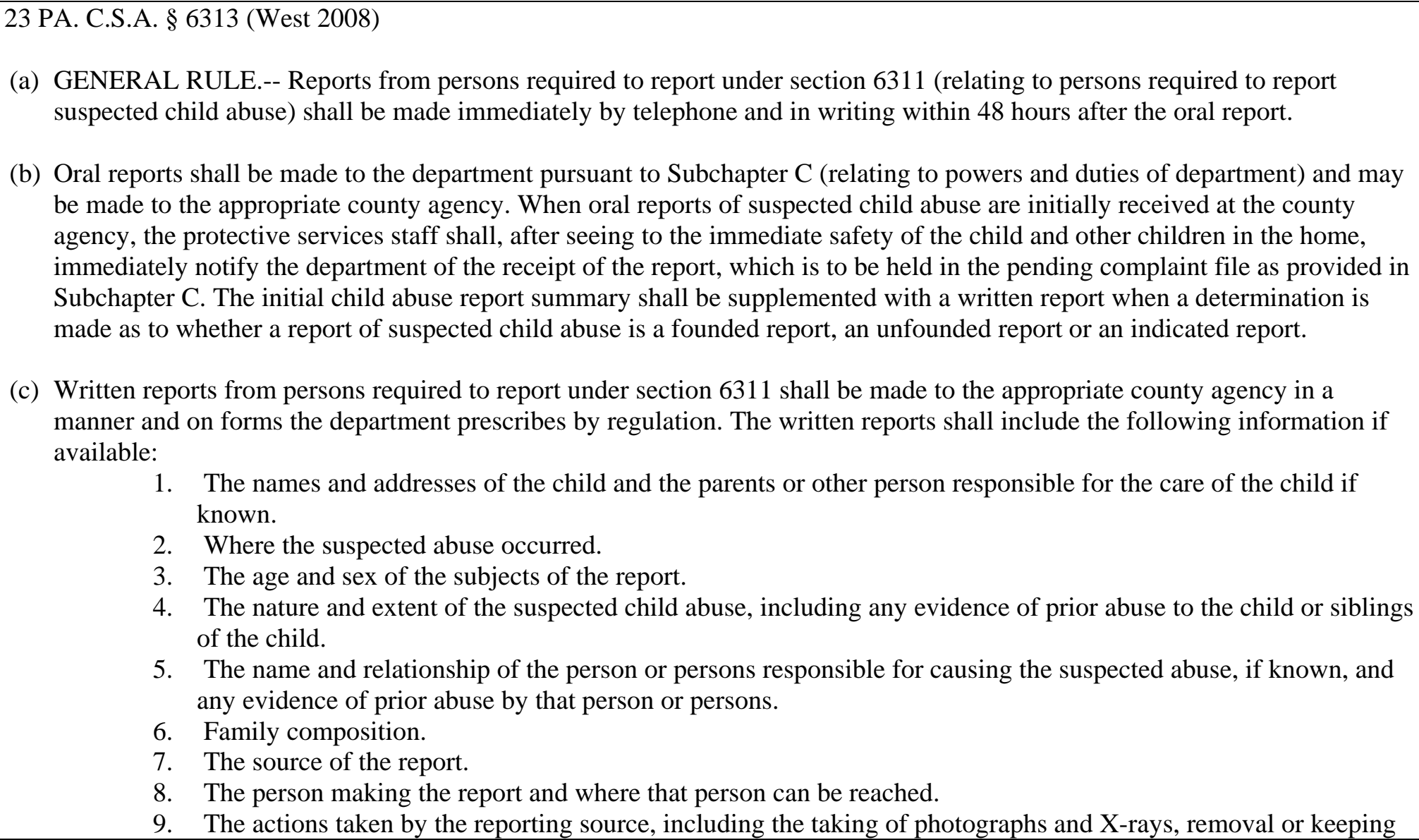 \\
\hline
\end{tabular}

\section{NOTE:}

\begin{abstract}
** For purposes of this chart, corrections officers, police officers, peace officers, probation officers or "catch-all” phrases such as "all persons" have been bolded. However, many mandatory reporters include professionals who may have contact or work in correctional facilities. Such individuals include physicians, nurses, dentists, teachers and social workers. These statutes can be used as a tool to require staff other than correctional officers to report sexual misconduct with inmates.
\end{abstract}

This publication is developed by the NIC/WCL Project on Addressing Prison Rape under NIC Cooperative Agreement 06S20GJJ1.

This is not to be reproduced or cited without permission from the authors.

American University, Washington College of Law

Current as of May 7, 2009 


\section{Fifty State Survey of Mandatory Reporting Statutes}

\section{NIC/WCL Project on Addressing Prison Rape}

\begin{tabular}{|c|c|}
\hline $\begin{array}{l}\text { Reporting } \\
\text { Procedures Cont'd } \\
\text { (Pennsylvania) }\end{array}$ & $\begin{array}{l}\text { of the child or notifying the medical examiner or coroner. } \\
\text { 10. Any other information which the department may require by regulation. }\end{array}$ \\
\hline $\begin{array}{l}\text { Penalty for Failure to } \\
\text { Report } \\
\text { (Pennsylvania) }\end{array}$ & $\begin{array}{l}23 \text { PA. C.S.A. § } 6319 \text { (West 2008) } \\
\text { A person or official required by this chapter to report a case of suspected child abuse or to make a referral to the appropriate } \\
\text { authorities who willfully fails to do so commits a misdemeanor of the third degree for the first violation and a misdemeanor of the } \\
\text { second degree for a second or subsequent violation. } \\
18 \text { PA. CONS. STAT. ANN. § } 106 \text { (West 2008) } \\
\text { (6) Misdemeanor of the second degree. } \\
\text { (7) Misdemeanor of the third degree. }\end{array}$ \\
\hline $\begin{array}{l}\text { Mandatory } \\
\text { Reporting Statute } \\
\text { (Pennsylvania) }\end{array}$ & $\begin{array}{l}\text { AGAINST AN ADULT } \\
35 \text { PA. C.S.A. § } 10225.701 \text { (West 2008) }\end{array}$ \\
\hline $\begin{array}{l}\text { What has to be } \\
\text { reported? } \\
\text { (Pennsylvania) }\end{array}$ & $\begin{array}{l}\text { 35 PA. C.S.A. } § 10225.701 \text { (West 2008) } \\
\text { (a)(1) Reasonable cause to suspect that a recipient is a victim of abuse. }\end{array}$ \\
\hline $\begin{array}{l}\text { Relevant Definitions } \\
\text { (Pennsylvania) }\end{array}$ & $\begin{array}{l}35 \text { PA. C.S.A. § } 10225.103 \text { (West 2008) } \\
\text { Abuse. } \\
\text { (1) The infliction of injury, unreasonable confinement, intimidation or punishment with resulting physical harm, pain or mental }\end{array}$ \\
\hline
\end{tabular}

NOTE:

** For purposes of this chart, corrections officers, police officers, peace officers, probation officers or “catch-all” phrases such as “all persons” have been bolded. However, many mandatory reporters include professionals who may have contact or work in correctional facilities. Such individuals include physicians, nurses, dentists, teachers and social workers. These statutes can be used as a tool to require staff other than correctional officers to report sexual misconduct with inmates.

This publication is developed by the NIC/WCL Project on Addressing Prison Rape under NIC Cooperative Agreement 06S20GJJ1.

This is not to be reproduced or cited without permission from the authors.

American University, Washington College of Law

Current as of May 7, 2009 


\section{Fifty State Survey of Mandatory Reporting Statutes}

\section{NIC/WCL Project on Addressing Prison Rape}

\begin{tabular}{|c|c|}
\hline $\begin{array}{l}\text { Relevant Definitions } \\
\text { Cont'd } \\
\text { (Pennsylvania) }\end{array}$ & 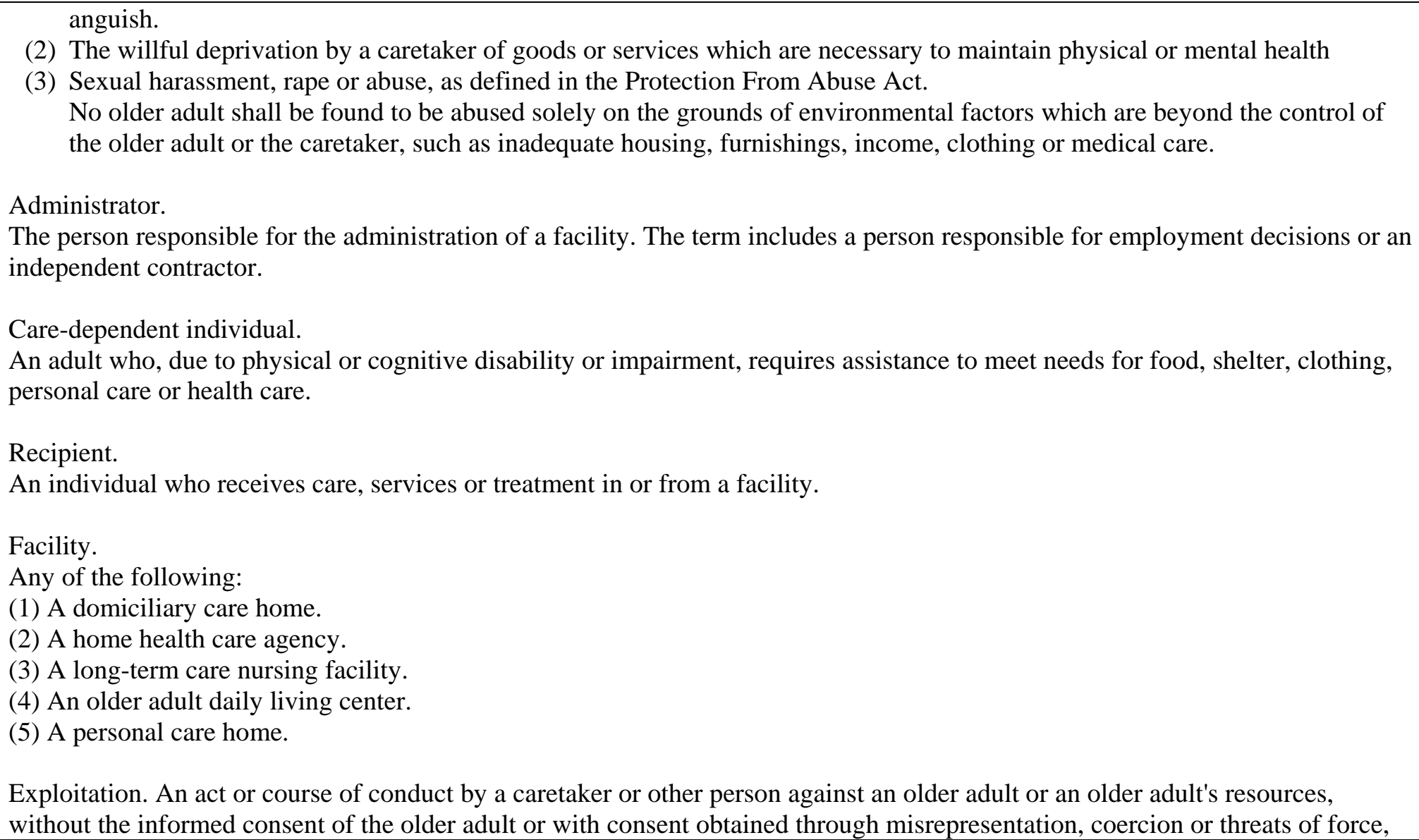 \\
\hline
\end{tabular}

NOTE:

** For purposes of this chart, corrections officers, police officers, peace officers, probation officers or “catch-all” phrases such as “all persons” have been bolded. However, many mandatory reporters include professionals who may have contact or work in correctional facilities. Such individuals include physicians, nurses, dentists, teachers and social workers. These statutes can be used as a tool to require staff other than correctional officers to report sexual misconduct with inmates.

This publication is developed by the NIC/WCL Project on Addressing Prison Rape under NIC Cooperative Agreement 06S20GJJ1.

This is not to be reproduced or cited without permission from the authors.

American University, Washington College of Law

Current as of May 7, 2009 


\section{Fifty State Survey of Mandatory Reporting Statutes}

\section{NIC/WCL Project on Addressing Prison Rape}

\begin{tabular}{|c|c|}
\hline $\begin{array}{l}\text { Relevant Definitions } \\
\text { Cont'd } \\
\text { (Pennsylvania) }\end{array}$ & $\begin{array}{l}\text { that results in monetary, personal or other benefit, gain or profit for the perpetrator or monetary or personal loss to the older adult. } \\
\text { Intimidation. An act or omission by any person or entity toward another person which is intended to, or with knowledge that the } \\
\text { act or omission will, obstruct, impede, impair, prevent or interfere with the administration of this act or any law intended to protect } \\
\text { older adults from mistreatment. } \\
\text { Neglect. The failure to provide for oneself or the failure of a caretaker to provide goods or services essential to avoid a clear and } \\
\text { serious threat to physical or mental health. No older adult who does not consent to the provision of protective services shall be } \\
\text { found to be neglected solely on the grounds of environmental factors which are beyond the control of the older adult or the } \\
\text { caretaker, such as inadequate housing, furnishings, income, clothing or medical care. } \\
\text { Older adult. A person within the jurisdiction of the Commonwealth who is } 60 \text { years of age or older. } \\
\text { Older adult in need of protective services. An incapacitated older adult who is unable to perform or obtain services that are } \\
\text { necessary to maintain physical or mental health, for whom there is no responsible caretaker and who is at imminent risk of danger } \\
\text { to his person or property. } \\
\text { Sexual abuse. Intentionally, knowingly or recklessly causing or attempting to cause rape, involuntary deviate sexual intercourse, } \\
\text { sexual assault, statutory sexual assault, aggravated indecent assault, indecent assault or incest. }\end{array}$ \\
\hline $\begin{array}{l}\text { Persons Required to } \\
\text { Report } \\
\text { (Pennsylvania) }\end{array}$ & $\begin{array}{l}35 \text { PA. C.S.A. § } 10225.701 \text { (West 2008) } \\
\text { (a)(1) Employee or Administrator. }\end{array}$ \\
\hline $\begin{array}{l}\text { Reporting } \\
\text { Procedures } \\
\text { (Pennsylvania) }\end{array}$ & $\begin{array}{l}35 \text { PA. C.S.A. } § 10225.701 \text { (West 2008) } \\
\text { (1) Shall immediately make an oral report to the agency. }\end{array}$ \\
\hline
\end{tabular}

NOTE:

** For purposes of this chart, corrections officers, police officers, peace officers, probation officers or “catch-all” phrases such as “all persons” have been bolded. However, many mandatory reporters include professionals who may have contact or work in correctional facilities. Such individuals include physicians, nurses, dentists, teachers and social workers. These statutes can be used as a tool to require staff other than correctional officers to report sexual misconduct with inmates.

This publication is developed by the NIC/WCL Project on Addressing Prison Rape under NIC Cooperative Agreement 06S20GJJ1.

This is not to be reproduced or cited without permission from the authors.

American University, Washington College of Law

Current as of May 7, 2009 


\section{Fifty State Survey of Mandatory Reporting Statutes}

\section{NIC/WCL Project on Addressing Prison Rape}

\begin{tabular}{|c|c|}
\hline $\begin{array}{l}\text { Reporting } \\
\text { Procedures Cont'd } \\
\text { (Pennsylvania) }\end{array}$ & $\begin{array}{l}\text { (c) A written report under this section shall be in a manner and on forms prescribed by the department. The report shall include, } \\
\text { at a minimum, the following information: } \\
\text { (1) Name, age and address of the recipient. } \\
\text { (2) Name and address of the recipient's guardian or next of kin. } \\
\text { (3) Name and address of the facility. } \\
\text { (4) Nature of the alleged offense. } \\
\text { (5) Any specific comments or observations that are directly related to the alleged incident and the individual involved. }\end{array}$ \\
\hline $\begin{array}{l}\text { Penalty for Failure to } \\
\text { Report } \\
\text { (Pennsylvania) }\end{array}$ & $\begin{array}{l}35 \text { PA. C.S.A. } \S 10225.706 \text { (West 2008) } \\
\text { (a) (3) The Commonwealth agency or Commonwealth agencies which regulate the facility have jurisdiction to determine } \\
\text { violations of this chapter and may issue an order assessing a civil penalty of not more than } \$ 2,500 \text {. } \\
\text { (b) (1) An administrator who intentionally or willfully fails to comply or obstructs compliance with this chapter commits a } \\
\text { misdemeanor of the third degree and shall, upon conviction, be sentenced to pay a fine of } \$ 2,500 \text { or to imprisonment for not more } \\
\text { than one year, or both. } \\
\text { (b) (2) A facility owner that intentionally or willfully fails to comply with or obstructs compliance with, this chapter commits a } \\
\text { misdemeanor of the third degree and shall, upon conviction, be sentenced to pay a fine of } \$ 2,500 \text { or to imprisonment for not more } \\
\text { than one year, or both. } \\
\text { (c) A person required under this chapter to report a case of suspected abuse who willfully fails to do so commits a summary } \\
\text { offense for the first violation and a misdemeanor of the third degree for a second or subsequent violation. } \\
\text { 18 PA. C.S.A. } § 106 \text { (West } 2008 \text { ) } \\
\text { (c) Summary offenses. An offense defined by this title constitutes a summary offense if: } \\
\text { (1) it is so designated in this title, or in a statute other than this title; or }\end{array}$ \\
\hline
\end{tabular}

NOTE:

** For purposes of this chart, corrections officers, police officers, peace officers, probation officers or “catch-all” phrases such as “all persons” have been bolded. However, many mandatory reporters include professionals who may have contact or work in correctional facilities. Such individuals include physicians, nurses, dentists, teachers and social workers. These statutes can be used as a tool to require staff other than correctional officers to report sexual misconduct with inmates.

This publication is developed by the NIC/WCL Project on Addressing Prison Rape under NIC Cooperative Agreement 06S20GJJ1.

This is not to be reproduced or cited without permission from the authors.

American University, Washington College of Law

Current as of May 7, 2009 


\section{Fifty State Survey of Mandatory Reporting Statutes}

\section{NIC/WCL Project on Addressing Prison Rape}

\begin{tabular}{|c|c|}
\hline $\begin{array}{l}\text { Penalty for Failure to } \\
\text { Report } \\
\text { (Pennsylvania) }\end{array}$ & (2) if a person convicted thereof may be sentenced to a term of imprisonment, the maximum of which is not more than 90 days. \\
\hline & PUERTO RICO \\
\hline $\begin{array}{l}\text { Mandatory } \\
\text { Reporting Statute } \\
\text { (Puerto Rico) }\end{array}$ & $\begin{array}{l}\text { AGAINST A CHILD } \\
8 \text { L.P.R.A. § } 446 \text { (West 2008) }\end{array}$ \\
\hline $\begin{array}{l}\text { What has to be } \\
\text { reported? } \\
\text { (Puerto Rico) }\end{array}$ & $\begin{array}{l}8 \text { L.P.R.A. § } 446 \text { (West 2008) } \\
\text { The following individuals and entities are under the obligation to report immediately in those cases where there is actual or } \\
\text { suspected abuse, institutional abuse, neglect, and/or institutional neglect of a minor: } \\
\text { Professionals or public officials, public, private, and privatized entities which, in their professional capacity and in the } \\
\text { performance of their duties, may learn of or come to suspect that a minor is, has been, or is at risk of becoming a victim of abuse, } \\
\text { institutional abuse, neglect, and/or institutional neglect. }\end{array}$ \\
\hline $\begin{array}{l}\text { Relevant Definitions } \\
\text { (Puerto Rico) }\end{array}$ & $\begin{array}{l}8 \text { L.P.R.A. § } 446 \text { (West 2008) } \\
\text { (b) Sexual abuse shall mean engaging in sexual conduct in the presence of a minor and/or using the minor, voluntarily or } \\
\text { otherwise, to engage in sexual conduct aimed at satisfying lasciviousness, or any other act that, if criminally prosecuted, would } \\
\text { constitute the crime of rape, sodomy, lewd or lascivious acts, indecent exposure, or obscene propositioning; remitting, } \\
\text { transporting, selling, distributing, publishing, exhibiting, or possessing obscene materials and obscene shows, }\end{array}$ \\
\hline
\end{tabular}

** For purposes of this chart, corrections officers, police officers, peace officers, probation officers or “catch-all” phrases such as “all persons” have been bolded. However, many mandatory reporters include professionals who may have contact or work in correctional facilities. Such individuals include physicians, nurses, dentists, teachers and social workers. These statutes can be used as a tool to require staff other than correctional officers to report sexual misconduct with inmates.

This publication is developed by the NIC/WCL Project on Addressing Prison Rape under NIC Cooperative Agreement 06S20GJJ1.

This is not to be reproduced or cited without permission from the authors.

American University, Washington College of Law

Current as of May 7, 2009 


\section{Fifty State Survey of Mandatory Reporting Statutes}

\section{NIC/WCL Project on Addressing Prison Rape}

\begin{tabular}{|c|c|}
\hline $\begin{array}{l}\text { Relevant Definitions } \\
\text { Cont'd } \\
\text { (Puerto Rico) }\end{array}$ & $\begin{array}{l}\text { (r) Abuse shall mean any intentional act or omission by the father, mother, or other person in charge of the minor of such a nature } \\
\text { that it causes or puts a minor at risk of suffering damage or harm to his or her health or physical, mental, and/or emotional } \\
\text { integrity, including sexual abuse as defined in this section. Abuse shall also mean to engage in obscene behavior and/or use the } \\
\text { minor to carry out obscene acts; to allow another person to cause or to put the minor at risk of suffering damage or harm to his or } \\
\text { her health or physical, mental, and/or emotional integrity; to abandon a minor willfully; to allow the father, mother, or other } \\
\text { person in charge of the wellbeing of the minor to exploit him or her; or to allow another person to do so by forcing or allowing the } \\
\text { minor to perform any act, including but not limited to using the minor to engage in obscene acts for profit or in order to receive } \\
\text { any other benefit, or to incur in any conduct that, if criminally prosecuted, would constitute a crime against the health, or physical, } \\
\text { mental, or emotional integrity of the minor, including sexual abuse of the minor. Minors will also be considered to be victims of } \\
\text { abuse if the father, mother, or person responsible for the minor has incurred in the conduct described above, or has engaged in acts } \\
\text { that constitute domestic violence in the presence of minors. } \\
\text { (s) Institutional abuse shall mean any act or omission by a foster parent or an employee or official of a public or private institution } \\
\text { that provides caregiving services, for twenty-four (24) hours a day or part thereof, who has control over or custody of a minor for } \\
\text { his or her care, education, treatment, or detention, who causes harm or endangers the health, or physical, mental, and/or emotional } \\
\text { integrity of the minor, including sexual abuse; engages in obscene conduct and/or uses the minor to perform obscene acts, known } \\
\text { or suspected, or which occur as a result of the prevailing policies, practices, and conditions in the institution in question; exploits } \\
\text { the minor or allows someone else to do so, including, but not limited to, using the minor to perform obscene acts for profit or in } \\
\text { order to receive any other benefit. }\end{array}$ \\
\hline $\begin{array}{l}\text { Persons Required to } \\
\text { Report } \\
\text { (Puerto Rico) }\end{array}$ & $\begin{array}{l}8 \text { L.P.R.A. } § 446 \text { (West 2008) } \\
\text { (a) Professionals or public officials } \\
\text { Public, private, and privatized entities who learn that a child has been abused or is at risk of abuse; } \\
\text { Professionals in the fields of health, the system of justice, education, social work, public order } \\
\text { Persons who administer or work in caregiving institutions or centers that provide care services for twenty-four (24) hours a day or } \\
\text { part thereof, or in rehabilitation institutions and centers for minors, or in foster homes; and all processors of film or photographs }\end{array}$ \\
\hline
\end{tabular}

NOTE:

** For purposes of this chart, corrections officers, police officers, peace officers, probation officers or "catch-all” phrases such as “all persons” have been bolded. However, many mandatory reporters include professionals who may have contact or work in correctional facilities. Such individuals include physicians, nurses, dentists, teachers and social workers. These statutes can be used as a tool to require staff other than correctional officers to report sexual misconduct with inmates.

This publication is developed by the NIC/WCL Project on Addressing Prison Rape under NIC Cooperative Agreement 06S20GJJ1.

This is not to be reproduced or cited without permission from the authors.

American University, Washington College of Law

Current as of May 7, 2009 


\section{Fifty State Survey of Mandatory Reporting Statutes}

\section{NIC/WCL Project on Addressing Prison Rape}

\begin{tabular}{|c|c|}
\hline $\begin{array}{l}\text { Persons Required to } \\
\text { Report Cont'd } \\
\text { (Puerto Rico) }\end{array}$ & $\begin{array}{l}\text { who have knowledge of or observe, in the performance of their professional responsibilities or employment, any motion picture, } \\
\text { photograph, videotape, negative, or slide that depicts a minor involved in a sexual activity. } \\
\text { (b) Any person who has knowledge of or suspects that a minor is a victim of abuse, institutional abuse, neglect, and/or institutional } \\
\text { neglect }\end{array}$ \\
\hline $\begin{array}{l}\text { Reporting } \\
\text { Procedures } \\
\text { (Puerto Rico) }\end{array}$ & $\begin{array}{l}8 \text { L.P.R.A. } \$ 446 \text { (West 2008) } \\
\text { (c) Persons bound to furnish information as set forth in subsection (a) shall subsequently fill out a form provided by the } \\
\text { Department, which shall be sent to the central registry, established hereunder, not later than forty-eight (48) hours after having } \\
\text { notified or referred the situation } \\
\text { Persons for subsection (b) shall report through the hotline of the Department, to the Puerto Rico Police, or to the local office of the } \\
\text { Department, as provided in this chapter. The information thus furnished, as well as the identity of the person who reported the } \\
\text { information shall be kept strictly confidential, except in the cases of unfounded reports in which false information has been } \\
\text { knowingly provided. }\end{array}$ \\
\hline $\begin{array}{l}\text { Penalty for Failure to } \\
\text { Report } \\
\text { (Puerto Rico) }\end{array}$ & No enumerated sanctions. \\
\hline $\begin{array}{l}\text { Mandatory } \\
\text { Reporting Statute } \\
\text { (Puerto Rico) }\end{array}$ & $\begin{array}{l}\text { AGAINST AN ADULT } \\
8 \text { L.P.R.A. § 346K (West 2008) }\end{array}$ \\
\hline
\end{tabular}

NOTE:

** For purposes of this chart, corrections officers, police officers, peace officers, probation officers or “catch-all” phrases such as “all persons” have been bolded. However, many mandatory reporters include professionals who may have contact or work in correctional facilities. Such individuals include physicians, nurses, dentists, teachers and social workers. These statutes can be used as a tool to require staff other than correctional officers to report sexual misconduct with inmates.

This publication is developed by the NIC/WCL Project on Addressing Prison Rape under NIC Cooperative Agreement 06S20GJJ1.

This is not to be reproduced or cited without permission from the authors.

American University, Washington College of Law

Current as of May 7, 2009 


\section{Fifty State Survey of Mandatory Reporting Statutes}

\section{NIC/WCL Project on Addressing Prison Rape}

\begin{tabular}{|c|c|}
\hline $\begin{array}{l}\text { What has to be } \\
\text { reported? } \\
\text { (Puerto Rico) }\end{array}$ & $\begin{array}{l}8 \text { L.P.R.A. } § 346 \mathrm{~K} \text { (West 2008) } \\
\text { Any person who learns or suspects that an elderly person is a victim of abuse, institutional abuse, abuse by negligence and/or } \\
\text { abuse by institutional negligence. }\end{array}$ \\
\hline $\begin{array}{l}\text { Relevant Definitions } \\
\text { (Puerto Rico) }\end{array}$ & $\begin{array}{l}8 \text { L.P.R.A. } § 353 \text { (West 2008) } \\
\text { (7) Elderly person. Means a human being sixty (60) years of age or older. }\end{array}$ \\
\hline $\begin{array}{l}\text { Persons Required to } \\
\text { Report } \\
\text { (Puerto Rico) }\end{array}$ & $\begin{array}{l}8 \text { L.P.R.A. } \S 346 K \text { (West 2008) } \\
\text { Any person who learns or suspects that an elderly person is a victim of abuse, institutional abuse, abuse by negligence and/or } \\
\text { abuse by institutional negligence. }\end{array}$ \\
\hline $\begin{array}{l}\text { Reporting } \\
\text { Procedures } \\
\text { (Puerto Rico) }\end{array}$ & $\begin{array}{l}8 \text { L.P.R.A. } § 346 K \text { (West 2008) } \\
\text { Shall report such a fact through the "Golden Hotline," to the Puerto Rico Police, and/or to the Office of Elderly Affairs, attached to } \\
\text { the Office of the Governor, in the manner provided for by this chapter. The information thus furnished shall be kept in strict } \\
\text { confidentiality, as well as the identity of the person who furnished the information. }\end{array}$ \\
\hline $\begin{array}{l}\text { Penalty for Failure to } \\
\text { Report } \\
\text { (Puerto Rico) }\end{array}$ & No enumerated sanctions. \\
\hline
\end{tabular}

NOTE:

** For purposes of this chart, corrections officers, police officers, peace officers, probation officers or “catch-all” phrases such as “all persons” have been bolded. However, many mandatory reporters include professionals who may have contact or work in correctional facilities. Such individuals include physicians, nurses, dentists, teachers and social workers. These statutes can be used as a tool to require staff other than correctional officers to report sexual misconduct with inmates.

This publication is developed by the NIC/WCL Project on Addressing Prison Rape under NIC Cooperative Agreement 06S20GJJ1.

This is not to be reproduced or cited without permission from the authors.

American University, Washington College of Law

Current as of May 7, 2009 


\section{Fifty State Survey of Mandatory Reporting Statutes}

\section{NIC/WCL Project on Addressing Prison Rape}

\section{RHODE ISLAND}

\begin{tabular}{|c|c|}
\hline $\begin{array}{l}\text { Mandatory } \\
\text { Reporting Statute } \\
\text { (Rhode Island) }\end{array}$ & $\begin{array}{l}\text { AGAINST A CHILD } \\
\text { R.I. GEN. LAWS } \S 40-11-3 \text { (West 2008) }\end{array}$ \\
\hline $\begin{array}{l}\text { What has to be } \\
\text { reported? } \\
\text { (Rhode Island) }\end{array}$ & $\begin{array}{l}\text { R.I. GEN. LAWS § 40-11-3 (West 2008) } \\
\text { Reasonable cause to know or suspect that any child has been abused or neglected or has been a victim of sexual abuse by another } \\
\text { child. }\end{array}$ \\
\hline $\begin{array}{l}\text { Relevant Definitions } \\
\text { (Rhode Island) }\end{array}$ & $\begin{array}{l}\text { R.I. GEN. LAWS § 40-11-2 (West 2008) } \\
\text { (1) Abused and/or neglected child means a child whose physical or mental health or welfare is harmed or threatened with harm } \\
\text { when his or her parent or other person responsible for his or her welfare: } \\
\text { i. Inflicts, or allows to be inflicted upon the child physical or mental injury, including excessive corporal punishment; or } \\
\text { ii. Creates or allows to be created a substantial risk of physical or mental injury to the child, including excessive corporal } \\
\text { punishment; or } \\
\text { iii. Commits or allows to be committed, against the child, an act of sexual abuse; o } \\
\text { iv. Fails to supply the child with adequate food, clothing, shelter, or medical care, though financially able to do so or offered } \\
\text { financial or other reasonable means to do so; or } \\
\text { v. Fails to provide the child with a minimum degree of care or proper supervision or guardianship because of his or her } \\
\text { unwillingness or inability to do so by situations or conditions such as, but not limited to, social problems, mental } \\
\text { incompetency, or the use of a drug, drugs, or alcohol to the extent that the parent or other person responsible for the } \\
\text { child's welfare loses his or her ability or is unwilling to properly care for the child; or } \\
\text { vi. Abandons or deserts the child; or }\end{array}$ \\
\hline
\end{tabular}

NOTE:

** For purposes of this chart, corrections officers, police officers, peace officers, probation officers or "catch-all” phrases such as “all persons” have been bolded. However, many mandatory reporters include professionals who may have contact or work in correctional facilities. Such individuals include physicians, nurses, dentists, teachers and social workers. These statutes can be used as a tool to require staff other than correctional officers to report sexual misconduct with inmates.

This publication is developed by the NIC/WCL Project on Addressing Prison Rape under NIC Cooperative Agreement 06S20GJJ1.

This is not to be reproduced or cited without permission from the authors.

American University, Washington College of Law

Current as of May 7, 2009 


\section{Fifty State Survey of Mandatory Reporting Statutes}

\section{NIC/WCL Project on Addressing Prison Rape}

\begin{tabular}{|c|c|}
\hline $\begin{array}{l}\text { Relevant Definitions } \\
\text { Cont'd } \\
\text { (Rhode Island) }\end{array}$ & $\begin{array}{l}\text { vii. Sexually exploits the child in that the person allows, permits or encourages the child to engage in prostitution; or } \\
\text { viii. Sexually exploits the child in that the person allows, permits, encourages or engages in the obscene or pornographic } \\
\text { photographing, filming or depiction of the child in a setting which taken as a whole suggests to the average person that the } \\
\text { child is about to engage in or has engaged in, any sexual act, or which depicts any such child under eighteen (18) years of } \\
\text { age, performing sodomy, oral copulation, sexual intercourse, masturbation, or bestiality; or } \\
\text { ix. Commits or allows to be committed any sexual offense against the child; or } \\
\text { x. Commits or allows to be committed against any child an act involving sexual penetration or sexual contact if the child is } \\
\text { under fifteen (15) years of age; or if the child is fifteen (15) years or older, and (1) force or coercion is used by the } \\
\text { perpetrator, or (2) the perpetrator knows or has reason to know that the victim is a severely impaired person, or physically } \\
\text { helpless. }\end{array}$ \\
\hline $\begin{array}{l}\text { Persons Required to } \\
\text { Report } \\
\text { (Rhode Island) }\end{array}$ & $\begin{array}{l}\text { R.I. GEN. LAWS § 40-11-2 (West 2008) } \\
\text { Any person. } \\
\text { R.I. GEN. LAWS § 40.1-27-2 (West 2008) } \\
\text { (a) Any person within the scope of their employment at a program or in their professional capacity who has knowledge of or } \\
\text { reasonable cause to believe that a participant in a program has been abused, mistreated or neglected shall make, within twenty-four } \\
\text { (24) hours or by the end of the next business day, a written report to the director of the department of mental health, retardation, } \\
\text { and hospitals or his or her designee. The report shall contain: } \\
\text { (1) The name, address, telephone number, occupation, and employer's address and the phone number of the person reporting; }\end{array}$ \\
\hline
\end{tabular}

NOTE:

** For purposes of this chart, corrections officers, police officers, peace officers, probation officers or "catch-all” phrases such as “all persons” have been bolded. However, many mandatory reporters include professionals who may have contact or work in correctional facilities. Such individuals include physicians, nurses, dentists, teachers and social workers. These statutes can be used as a tool to require staff other than correctional officers to report sexual misconduct with inmates.

This publication is developed by the NIC/WCL Project on Addressing Prison Rape under NIC Cooperative Agreement 06S20GJJ1.

This is not to be reproduced or cited without permission from the authors.

American University, Washington College of Law

Current as of May 7, 2009 


\section{Fifty State Survey of Mandatory Reporting Statutes}

\section{NIC/WCL Project on Addressing Prison Rape}

\begin{tabular}{|c|c|}
\hline $\begin{array}{l}\text { Persons Required to } \\
\text { Report Cont'd } \\
\text { (Rhode Island) }\end{array}$ & $\begin{array}{l}\text { (2) The name and address of the participant who is believed to be the victim of the abuse, mistreatment, or neglect; } \\
\text { (3) The details, observations, and beliefs concerning the incident(s } \\
\text { (4) Any statements regarding the incident made by the participant and to whom they were made; } \\
\text { (5) The date, time, and place of the incident; } \\
\text { (6) The name of any individual(s) believed to have knowledge of the incident; and } \\
\text { (7) The name of any individual(s) believed to have been responsible for the incident } \\
\text { (b) In addition to those persons required to report pursuant to this section, any other person may make a report if that person has } \\
\text { reasonable cause to believe that a participant has been abused, mistreated, or neglected. }\end{array}$ \\
\hline $\begin{array}{l}\text { Reporting } \\
\text { Procedures } \\
\text { (Rhode Island) }\end{array}$ & $\begin{array}{l}\text { R.I. GEN. LAWS § 40-11-3(a) (West 2008) } \\
\text { A mandatory reporter shall, within twenty-four (24) hours, transfer that information to the department of children, youth and } \\
\text { families or its agent who shall cause the report to be investigated immediately. }\end{array}$ \\
\hline $\begin{array}{l}\text { Penalty for Failure to } \\
\text { Report } \\
\text { (Rhode Island) }\end{array}$ & $\begin{array}{l}\text { R.I. GEN. LAWS } § 40-11-6.1 \text { (West 2008) } \\
\text { Any person, official, physician, or institution required by this chapter to report known or suspected child abuse or neglect or to } \\
\text { perform any other act who knowingly fails to do so or who knowingly prevents any person acting reasonably from doing so shall } \\
\text { be guilty of a misdemeanor and upon conviction thereof shall be subject to a fine of not more than five hundred dollars (\$500) or }\end{array}$ \\
\hline
\end{tabular}

NOTE:

** For purposes of this chart, corrections officers, police officers, peace officers, probation officers or “catch-all” phrases such as “all persons” have been bolded. However, many mandatory reporters include professionals who may have contact or work in correctional facilities. Such individuals include physicians, nurses, dentists, teachers and social workers. These statutes can be used as a tool to require staff other than correctional officers to report sexual misconduct with inmates.

This publication is developed by the NIC/WCL Project on Addressing Prison Rape under NIC Cooperative Agreement 06S20GJJ1.

This is not to be reproduced or cited without permission from the authors.

American University, Washington College of Law

Current as of May 7, 2009 


\section{Fifty State Survey of Mandatory Reporting Statutes}

\section{NIC/WCL Project on Addressing Prison Rape}

\begin{tabular}{|c|c|}
\hline $\begin{array}{l}\text { Penalty for Failure to } \\
\text { Report Cont'd } \\
\text { (Rhode Island) }\end{array}$ & $\begin{array}{l}\text { imprisonment for not more than one year or both. In addition, any person, official, physician, or institution who knowingly fails to } \\
\text { perform any act required by this chapter or who knowingly prevents another person from performing a required act shall be civilly } \\
\text { liable for the damages proximately caused by that failure. }\end{array}$ \\
\hline $\begin{array}{l}\text { Mandatory } \\
\text { Reporting Statute } \\
\text { (Rhode Island) }\end{array}$ & $\begin{array}{l}\text { AGAINST AN ADULT } \\
\text { R.I. GEN. LAWS § 42-66-8 (West 2008) }\end{array}$ \\
\hline $\begin{array}{l}\text { What has to be } \\
\text { reported? } \\
\text { (Rhode Island) }\end{array}$ & $\begin{array}{l}\text { R.I. GEN. LAWS § 42-66-8 (West 2008) } \\
\text { Reasonable cause to believe that any person sixty (60) years of age or older has been abused, neglected, exploited, or abandoned. }\end{array}$ \\
\hline $\begin{array}{l}\text { Relevant Definitions } \\
\text { (Rhode Island) }\end{array}$ & $\begin{array}{l}\text { R.I. GEN. LAWS § 42-66-4.1 (West 2008) } \\
\text { (8) “Elderly person” or “elder” means any person sixty (60) years of age or older. } \\
\text { (1) “Abuse” means physical abuse, sexual abuse, and/or emotional abuse of an elderly person by a caregiver as defined in } \\
\text { subsection } \\
\text { (a) "Physical Abuse” means the willful infliction of physical pain or injury (e.g. slapping, bruising or restraining) upon an } \\
\text { elderly person. } \\
\text { (b) "Sexual Abuse” means the infliction of non-consensual sexual contact of any kind upon an elderly person. Sexual abuse } \\
\text { includes, but is not limited to, sexual assault, rape, sexual misuse or exploitation of an elder, as well as threats of sexual abuse } \\
\text { where the perpetrator has the intent and the capacity to carry out the threatened abuse. } \\
\text { (c) "Emotional Abuse” means a pattern of willful infliction of mental or emotional harm upon an elder by threat, intimidation, } \\
\text { isolation or other abusive conduct. } \\
\text { (2) "Exploitation” means the fraudulent or otherwise illegal, unauthorized or improper act or process of an individual, including, }\end{array}$ \\
\hline
\end{tabular}

NOTE:

** For purposes of this chart, corrections officers, police officers, peace officers, probation officers or “catch-all” phrases such as “all persons” have been bolded. However, many mandatory reporters include professionals who may have contact or work in correctional facilities. Such individuals include physicians, nurses, dentists, teachers and social workers. These statutes can be used as a tool to require staff other than correctional officers to report sexual misconduct with inmates.

This publication is developed by the NIC/WCL Project on Addressing Prison Rape under NIC Cooperative Agreement 06S20GJJ1.

This is not to be reproduced or cited without permission from the authors.

American University, Washington College of Law

Current as of May 7, 2009 


\section{Fifty State Survey of Mandatory Reporting Statutes}

\section{NIC/WCL Project on Addressing Prison Rape}

\begin{tabular}{|c|c|}
\hline $\begin{array}{l}\text { Relevant Definitions } \\
\text { Cont'd } \\
\text { (Rhode Island) }\end{array}$ & $\begin{array}{l}\text { but not limited to, a caregiver or fiduciary, that uses the resources of an elder for monetary or personal benefit, profit, gain, or that } \\
\text { results in depriving an elder of rightful access to, or use of, benefits, resources, belongings, or assets by use of undue influence, } \\
\text { harassment, duress, deception, false representation or false pretenses. } \\
\text { (3) "Neglect” means the willful failure by a caregiver or other person with a duty of care to provide goods or services necessary to } \\
\text { avoid physical harm, mental harm or mental illness to an elderly person, including, but not limited to, "abandonment" (withdrawal } \\
\text { of necessary assistance) and denial of food or health related services. } \\
\text { (5) "Caregiver" means a person who has assumed the responsibility for the care of the elderly person voluntarily, by contract or by } \\
\text { order of a court of competent jurisdiction, or who is otherwise legally responsible for the care of the elderly person. } \\
\text { (6) "Self-Neglect" means a pattern of behavior in an elderly person that directly, imminently and significantly threatens his/her } \\
\text { own health and/or, safety. Self-neglect includes, but is not limited to, an inability or an incapacity to provide self with food, water, } \\
\text { shelter, or safety to the point of establishing imminent risk of any of the harm(s) described in the immediately preceding sentence. }\end{array}$ \\
\hline $\begin{array}{l}\text { Persons Required to } \\
\text { Report } \\
\text { (Rhode Island) }\end{array}$ & $\begin{array}{l}\text { R.I. GEN. LAWS § 42-66-8 (West 2008) } \\
\text { Any person who has reasonable cause to believe that any person sixty (60) years of age or older has been abused, neglected, } \\
\text { exploited, or abandoned }\end{array}$ \\
\hline $\begin{array}{l}\text { Reporting } \\
\text { Procedures } \\
\text { (Rhode Island) }\end{array}$ & $\begin{array}{l}\text { R.I. GEN. LAWS § 42-66-8 (West 2008) } \\
\text { Make an immediate report to the director of the department of elderly affairs or his or her designee. }\end{array}$ \\
\hline $\begin{array}{l}\text { Penalty for Failure to } \\
\text { Report } \\
\text { (Rhode Island) }\end{array}$ & $\begin{array}{l}\text { R.I. GEN. LAWS § 42-66-8 (West 2008) } \\
\text { Any person who fails to make the report shall be punished by a fine of not more than } \$ 1,000.00 \text {. }\end{array}$ \\
\hline
\end{tabular}

NOTE:

** For purposes of this chart, corrections officers, police officers, peace officers, probation officers or “catch-all” phrases such as “all persons” have been bolded. However, many mandatory reporters include professionals who may have contact or work in correctional facilities. Such individuals include physicians, nurses, dentists, teachers and social workers. These statutes can be used as a tool to require staff other than correctional officers to report sexual misconduct with inmates.

This publication is developed by the NIC/WCL Project on Addressing Prison Rape under NIC Cooperative Agreement 06S20GJJ1.

This is not to be reproduced or cited without permission from the authors.

American University, Washington College of Law

Current as of May 7, 2009 


\section{Fifty State Survey of Mandatory Reporting Statutes}

\section{NIC/WCL Project on Addressing Prison Rape}

\begin{tabular}{|c|c|}
\hline \multicolumn{2}{|r|}{ SOUTH CAROLINA } \\
\hline $\begin{array}{l}\text { Mandatory } \\
\text { Reporting Statute } \\
\text { (South Carolina) }\end{array}$ & $\begin{array}{l}\text { AGAINST A CHILD } \\
\text { CODE } 1976 \text { § 20-7-510 (West 2008) } \\
\text { CODE § 44-23-1150 (West 2008) }\end{array}$ \\
\hline $\begin{array}{l}\text { What has to be } \\
\text { reported? } \\
\text { (South Carolina) }\end{array}$ & $\begin{array}{l}\text { CODE } 1976 \text { § 20-7-510 (West 2008) } \\
\text { (A) When in the person's professional capacity the person has received information, which gives the person reason to believe that } \\
\text { a child has been or may be abused. }\end{array}$ \\
\hline $\begin{array}{l}\text { Relevant Definitions } \\
\text { (South Carolina) }\end{array}$ & $\begin{array}{l}\text { CODE } 1976 \text { § 20-7-490 (West 2008) } \\
\text { (1) "Child” means a person under the age of eighteen. } \\
\text { (2) Child abuse or neglect or harm occurs when the parent, guardian, or other person responsible for the child's welfare: } \\
\text { (a) inflicts or allows to be inflicted upon the child physical or mental injury or engages in acts or omissions which present a } \\
\text { substantial risk of physical or mental injury to the child, including injuries sustained as a result of excessive corporal } \\
\text { punishment, but excluding corporal punishment or physical discipline which: } \\
\text { (i) is administered by a parent or person in loco parentis; } \\
\text { (ii) is perpetrated for the sole purpose of restraining or correcting the child; } \\
\text { (iii) is reasonable in manner and moderate in degree; } \\
\text { (iv) has not brought about permanent or lasting damage to the child; and }\end{array}$ \\
\hline
\end{tabular}

\section{NOTE:}

** For purposes of this chart, corrections officers, police officers, peace officers, probation officers or "catch-all” phrases such as "all persons" have been bolded. However, many mandatory reporters include professionals who may have contact or work in correctional facilities. Such individuals include physicians, nurses, dentists, teachers and social workers. These statutes can be used as a tool to require staff other than correctional officers to report sexual misconduct with inmates.

This publication is developed by the NIC/WCL Project on Addressing Prison Rape under NIC Cooperative Agreement 06S20GJJ1.

This is not to be reproduced or cited without permission from the authors.

American University, Washington College of Law

Current as of May 7, 2009 


\section{Fifty State Survey of Mandatory Reporting Statutes}

\section{NIC/WCL Project on Addressing Prison Rape}

\section{Relevant Definitions} Cont'd

(South Carolina) (v) is not reckless or grossly negligent behavior by the parents.

(b) commits or allows to be committed against the child a sexual offense as defined by the laws of this State or engages in acts or omissions that present a substantial risk that a sexual offense as defined in the laws of this State would be committed against the child;

(c) fails to supply the child with adequate food, clothing, shelter, or education as required under Article 1 of Chapter 65 of Title 59, supervision appropriate to the child's age and development, or health care though financially able to do so or offered financial or other reasonable means to do so and the failure to do so has caused or presents a substantial risk of causing physical or mental injury. However, a child's absences from school may not be considered abuse or neglect unless the school has made efforts to bring about the child's attendance, and those efforts were unsuccessful because of the parents' refusal to cooperate. For the purpose of this chapter "adequate health care" includes any medical or nonmedical remedial health care permitted or authorized under state law;

(d) abandons the child;

(e) encourages, condones, or approves the commission of delinquent acts by the child and the commission of the acts are shown to be the result of the encouragement, condonation, or approval; o

(f) has committed abuse or neglect as described in subsections (a) through (e) such that a child who subsequently becomes part of the person's household is at substantial risk of one of those forms of abuse or neglect.

(4) Physical injury means death or permanent or temporary disfigurement or impairment of any bodily organ or function.

(5) Mental injury means an injury to the intellectual, emotional, or psychological capacity or functioning of a child as evidenced by a discernible and substantial impairment of the child's ability to function when the existence of that impairment is supported by the opinion of a mental health professional or medical professional.

** For purposes of this chart, corrections officers, police officers, peace officers, probation officers or "catch-all” phrases such as "all persons" have been bolded. However, many mandatory reporters include professionals who may have contact or work in correctional facilities. Such individuals include physicians, nurses, dentists, teachers and social workers. These statutes can be used as a tool to require staff other than correctional officers to report sexual misconduct with inmates.

This publication is developed by the NIC/WCL Project on Addressing Prison Rape under NIC Cooperative Agreement 06S20GJJ1.

This is not to be reproduced or cited without permission from the authors.

American University, Washington College of Law

Current as of May 7, 2009 


\section{Fifty State Survey of Mandatory Reporting Statutes}

\section{NIC/WCL Project on Addressing Prison Rape}

\begin{tabular}{|c|c|}
\hline $\begin{array}{l}\text { Relevant Definitions } \\
\text { Cont'd } \\
\text { (South Carolina) }\end{array}$ & $\begin{array}{l}\text { (19) Abandonment of a child means a parent or guardian willfully deserts a child or willfully surrenders physical possession of a } \\
\text { child without making adequate arrangements for the child's needs or the continuing care of the child. }\end{array}$ \\
\hline $\begin{array}{l}\text { Persons Required to } \\
\text { Report } \\
\text { (South Carolina) }\end{array}$ & 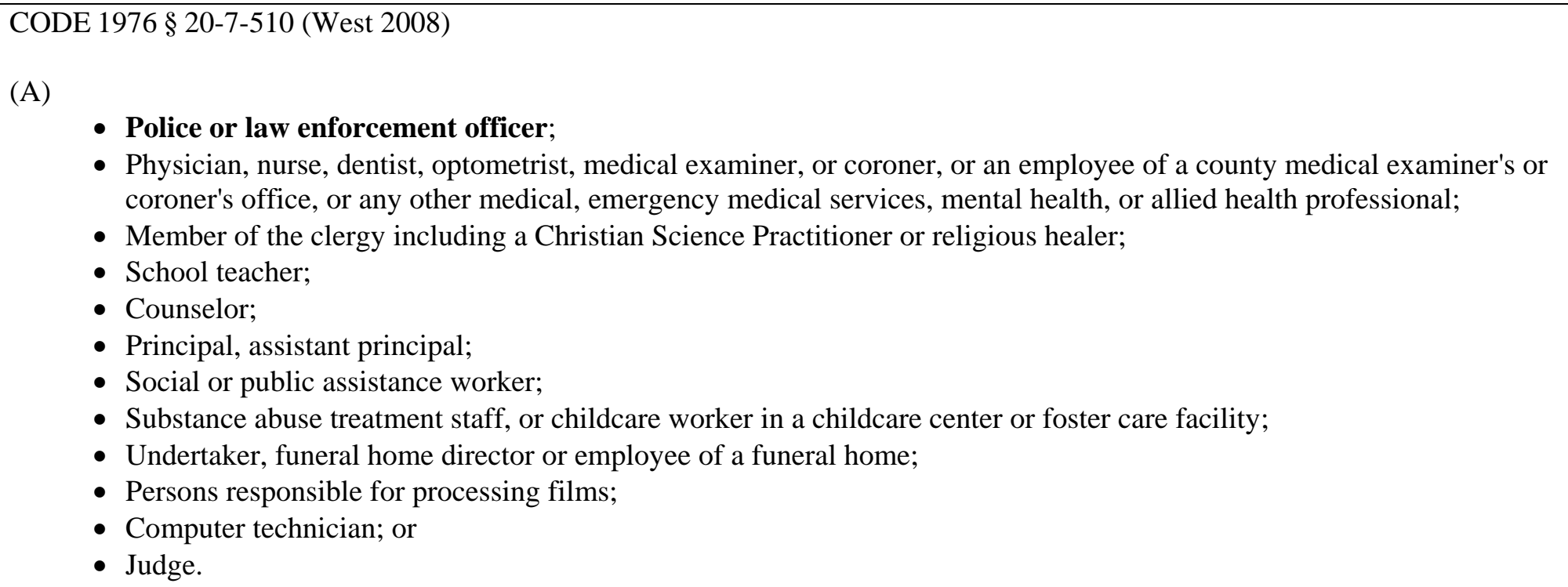 \\
\hline $\begin{array}{l}\text { Reporting } \\
\text { Procedures } \\
\text { (South Carolina) }\end{array}$ & $\begin{array}{l}\text { CODE } 1976 \text { § 20-7-510 (West 2008) } \\
\text { (D) Reports of child abuse or neglect may be made orally by telephone or otherwise to the county department of social services or } \\
\text { to a law enforcement agency in the county where the child resides or is found. }\end{array}$ \\
\hline
\end{tabular}

NOTE:

** For purposes of this chart, corrections officers, police officers, peace officers, probation officers or "catch-all” phrases such as “all persons” have been bolded. However, many mandatory reporters include professionals who may have contact or work in correctional facilities. Such individuals include physicians, nurses, dentists, teachers and social workers. These statutes can be used as a tool to require staff other than correctional officers to report sexual misconduct with inmates.

This publication is developed by the NIC/WCL Project on Addressing Prison Rape under NIC Cooperative Agreement 06S20GJJ1.

This is not to be reproduced or cited without permission from the authors.

American University, Washington College of Law

Current as of May 7, 2009 


\section{Fifty State Survey of Mandatory Reporting Statutes}

\section{NIC/WCL Project on Addressing Prison Rape}

\begin{tabular}{|c|c|}
\hline $\begin{array}{l}\text { Penalty for Failure to } \\
\text { Report } \\
\text { (South Carolina) }\end{array}$ & $\begin{array}{l}\text { CODE } 1976 \text { § 20-7-560 (West 2008) } \\
\text { A person required to report a case of child abuse or neglect or a person required to perform any other function under this article } \\
\text { who knowingly fails to do so, must be fined not more than } \$ 500.00 \text { or imprisoned not more than } 6 \text { months, or both. }\end{array}$ \\
\hline $\begin{array}{l}\text { Mandatory } \\
\text { Reporting Statute } \\
\text { (South Carolina) }\end{array}$ & $\begin{array}{l}\text { AGAINST AN ADULT } \\
\text { CODE } 1976 \text { § 43-35-25 (West 2008) } \\
\text { CODE § 44-23-1150 (West 2008) }\end{array}$ \\
\hline $\begin{array}{l}\text { What has to be } \\
\text { reported? } \\
\text { (South Carolina) }\end{array}$ & $\begin{array}{l}\text { CODE } 1976 \text { § 63-7-310 (West 2008) } \\
\text { (A) Reason to believe that a vulnerable adult has been or is likely to be abused, neglected, or exploited }\end{array}$ \\
\hline $\begin{array}{l}\text { Relevant Definitions } \\
\text { (South Carolina) }\end{array}$ & $\begin{array}{l}\text { CODE } 1976 \text { § 43-35-10 (West 2008) } \\
\text { (1) “Abuse” means physical abuse or psychological abuse. } \\
\text { (3) "Exploitation” means: } \\
\text { (a) causing or requiring a vulnerable adult to engage in activity or labor which is improper, unlawful, or against the reasonable } \\
\text { and rational wishes of the vulnerable adult. Exploitation does not include requiring a vulnerable adult to participate in an } \\
\text { activity or labor which is a part of a written plan of care or which is prescribed or authorized by a licensed physician } \\
\text { attending the patient; } \\
\text { (b) an improper, unlawful, or unauthorized use of the funds, assets, property, power of attorney, guardianship, or }\end{array}$ \\
\hline
\end{tabular}

NOTE:

** For purposes of this chart, corrections officers, police officers, peace officers, probation officers or "catch-all” phrases such as "all persons" have been bolded. However, many mandatory reporters include professionals who may have contact or work in correctional facilities. Such individuals include physicians, nurses, dentists, teachers and social workers. These statutes can be used as a tool to require staff other than correctional officers to report sexual misconduct with inmates.

This publication is developed by the NIC/WCL Project on Addressing Prison Rape under NIC Cooperative Agreement 06S20GJJ1.

This is not to be reproduced or cited without permission from the authors.

American University, Washington College of Law

Current as of May 7, 2009 


\title{
Fifty State Survey of Mandatory Reporting Statutes
}

\section{NIC/WCL Project on Addressing Prison Rape}

\section{Relevant Definitions}

Cont'd

(South Carolina)

conservatorship of a vulnerable adult by a person for the profit or advantage of that person or another person; or

(c) causing a vulnerable adult to purchase goods or services for the profit or advantage of the seller or another person through: (i) undue influence, (ii) harassment, (iii) duress, (iv) force, (v) coercion, or (vi) swindling by overreaching, cheating, or defrauding the vulnerable adult through cunning arts or devices that delude the vulnerable adult and cause him to lose money or other property.

(6) "Neglect" means the failure or omission of a caregiver to provide the care, goods, or services necessary to maintain the health or safety of a vulnerable adult including, but not limited to, food, clothing, medicine, shelter, supervision, and medical services. Neglect may be repeated conduct or a single incident which has produced or can be proven to result in serious physical or psychological harm or substantial risk of death. Noncompliance with regulatory standards alone does not constitute neglect. Neglect includes the inability of a vulnerable adult, in the absence of a caretaker, to provide for his or her own health or safety which produces or could reasonably be expected to produce serious physical or psychological harm or substantial risk of death.

(8) "Physical abuse" means intentionally inflicting or allowing to be inflicted physical injury on a vulnerable adult by an act or failure to act. Physical abuse includes, but is not limited to, slapping, hitting, kicking, biting, choking, pinching, burning, actual or attempted sexual battery, use of medication outside the standards of reasonable medical practice for the purpose of controlling behavior, and unreasonable confinement. Physical abuse also includes the use of a restrictive or physically intrusive procedure to control behavior for the purpose of punishment except that a therapeutic procedure prescribed by a licensed physician or other qualified professional or that is part of a written plan of care by a licensed physician or other qualified professional is not considered physical abuse. Physical abuse does not include altercations or acts of assault between vulnerable adults.

(10) "Psychological abus”e means deliberately subjecting a vulnerable adult to threats or harassment or other forms of intimidating behavior causing fear, humiliation, degradation, agitation, confusion, or other forms of serious emotional distress.

(11) "Vulnerable adult" means a person eighteen years of age or older who has a physical or mental condition which substantially impairs the person from adequately providing for his or her own care or protection. This includes a person who is impaired in the

\begin{abstract}
** For purposes of this chart, corrections officers, police officers, peace officers, probation officers or “catch-all” phrases such as “all persons” have been bolded. However, many mandatory reporters include professionals who may have contact or work in correctional facilities. Such individuals include physicians, nurses, dentists, teachers and social workers. These statutes can be used as a tool to require staff other than correctional officers to report sexual misconduct with inmates.
\end{abstract}

This publication is developed by the NIC/WCL Project on Addressing Prison Rape under NIC Cooperative Agreement 06S20GJJ1.

This is not to be reproduced or cited without permission from the authors.

American University, Washington College of Law

Current as of May 7, 2009 


\section{Fifty State Survey of Mandatory Reporting Statutes}

\section{NIC/WCL Project on Addressing Prison Rape}

\begin{tabular}{|c|c|}
\hline $\begin{array}{l}\text { Relevant Definitions } \\
\text { Cont'd } \\
\text { (South Carolina) }\end{array}$ & $\begin{array}{l}\text { ability to adequately provide for the person's own care or protection because of the infirmities of aging including, but not limited } \\
\text { to, organic brain damage, advanced age, and physical, mental, or emotional dysfunction. A resident of a facility is a vulnerable } \\
\text { adult. }\end{array}$ \\
\hline $\begin{array}{l}\text { Persons Required to } \\
\text { Report } \\
\text { (South Carolina) }\end{array}$ & $\begin{array}{l}\text { CODE } 1976 \S 63-7-310 \text { (West 2008) } \\
\text { (A) Law enforcement officer; } \\
\text { - Physician, nurse; } \\
\text { - Dentist; } \\
\text { - Optometrist, medical examiner; } \\
\text { - Coroner; } \\
\text { - Other medical; } \\
\text { - Mental health or allied health professional; } \\
\text { - Christian Science practitioner; } \\
\text { - Religious healer; } \\
\text { - School teacher; } \\
\text { - Counselor, psychologist; } \\
\text { - Mental health or mental retardation specialist; } \\
\text { - Social or public assistance worker; or } \\
\text { - Caregiver, staff or volunteer of an adult day care center or of a facility. } \\
\text { Any other person who has actual knowledge that a vulnerable adult has been abused, neglected, or exploited shall report the } \\
\text { incident in accordance with this section. }\end{array}$ \\
\hline
\end{tabular}

NOTE:

** For purposes of this chart, corrections officers, police officers, peace officers, probation officers or "catch-all” phrases such as "all persons" have been bolded. However, many mandatory reporters include professionals who may have contact or work in correctional facilities. Such individuals include physicians, nurses, dentists, teachers and social workers. These statutes can be used as a tool to require staff other than correctional officers to report sexual misconduct with inmates.

This publication is developed by the NIC/WCL Project on Addressing Prison Rape under NIC Cooperative Agreement 06S20GJJ1.

This is not to be reproduced or cited without permission from the authors.

American University, Washington College of Law

Current as of May 7, 2009 


\section{Fifty State Survey of Mandatory Reporting Statutes}

\section{NIC/WCL Project on Addressing Prison Rape}

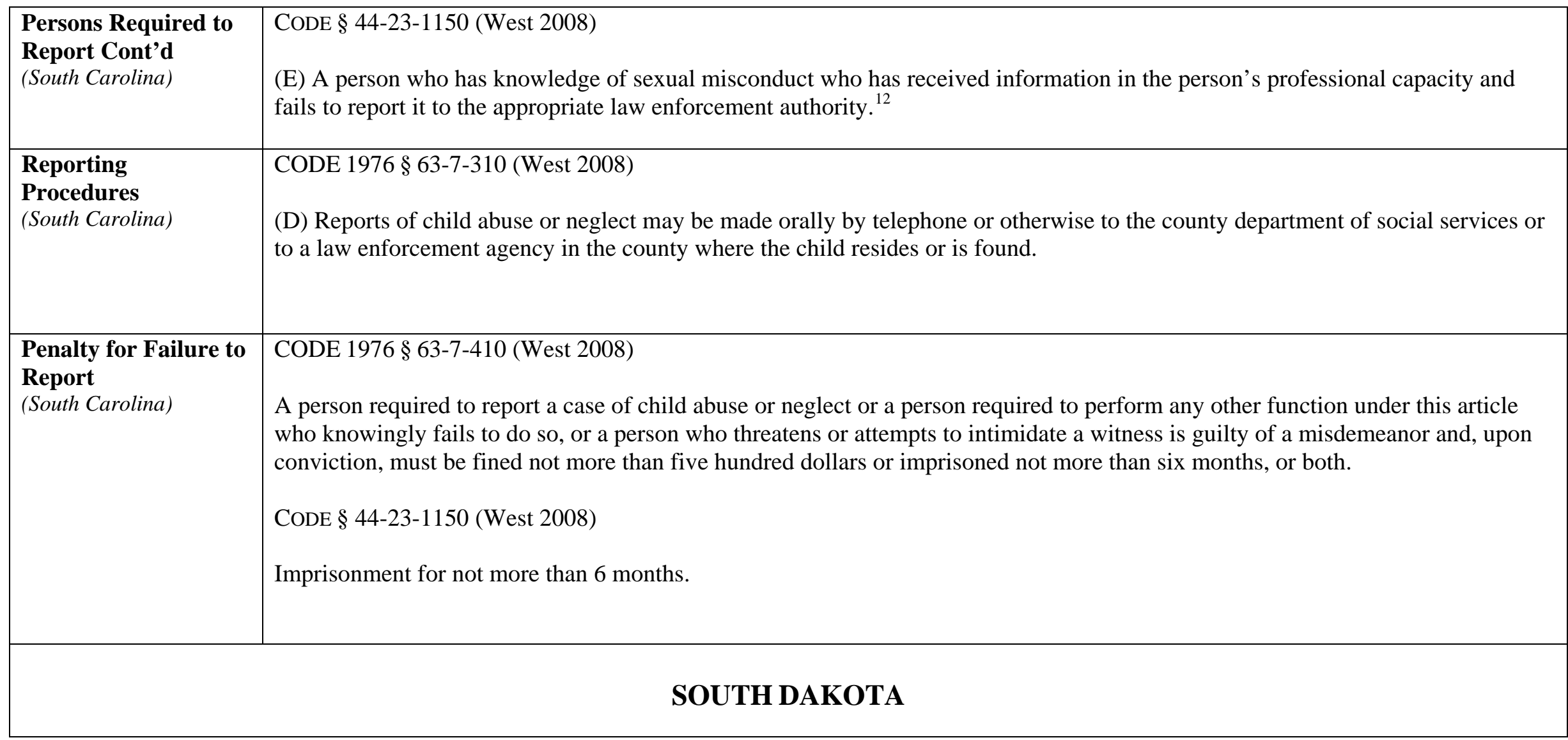

NOTE:

** For purposes of this chart, corrections officers, police officers, peace officers, probation officers or "catch-all” phrases such as "all persons" have been bolded. However, many mandatory reporters include professionals who may have contact or work in correctional facilities. Such individuals include physicians, nurses, dentists, teachers and social workers. These statutes can be used as a tool to require staff other than correctional officers to report sexual misconduct with inmates.

This publication is developed by the NIC/WCL Project on Addressing Prison Rape under NIC Cooperative Agreement 06S20GJJ1.

This is not to be reproduced or cited without permission from the authors.

American University, Washington College of Law

Current as of May 7, 2009 


\section{Fifty State Survey of Mandatory Reporting Statutes}

\section{NIC/WCL Project on Addressing Prison Rape}

\begin{tabular}{|c|c|}
\hline $\begin{array}{l}\text { Mandatory } \\
\text { Reporting Statute } \\
\text { (South Dakota) }\end{array}$ & 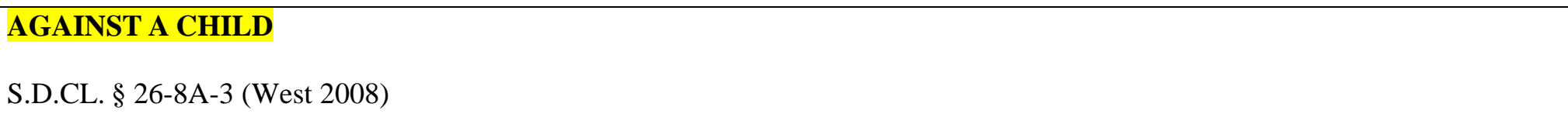 \\
\hline $\begin{array}{l}\text { What has to be } \\
\text { reported? } \\
\text { (South Dakota) }\end{array}$ & $\begin{array}{l}\text { S.D.CL. § 26-8A-3 (West 2008) } \\
\text { Reasonable cause to suspect that a child under the age of eighteen has been abused or neglected. }\end{array}$ \\
\hline $\begin{array}{l}\text { Relevant Definitions } \\
\text { (South Dakota) }\end{array}$ & $\begin{array}{l}\text { S.D.CL. § 26-8A-2 (West 2008) } \\
\text { “Abused” or “neglected child” means a child: } \\
\text { (1) Whose parent, guardian, or custodian has abandoned the child or has subjected the child to mistreatment or abuse } \\
\text { (2) Who lacks proper parental care through the actions or omissions of the child's parent, guardian, or custodian; } \\
\text { (3) Whose environment is injurious to the child's welfare; } \\
\text { (4) Whose parent, guardian, or custodian fails or refuses to provide proper or necessary subsistence, supervision, education, } \\
\text { medical care, or any other care necessary for the child's health, guidance, or well-being; } \\
\text { (5) Who is homeless, without proper care, or not domiciled with the child's parent, guardian, or custodian through no fault of } \\
\text { the child's parent, guardian, or custodian; } \\
\text { (6) Who is threatened with substantial harm; } \\
\text { (7) Who has sustained emotional harm or mental injury as indicated by an injury to the child's intellectual or psychological } \\
\text { capacity evidenced by an observable and substantial impairment in the child's ability to function within the child's normal } \\
\text { range of performance and behavior, with due regard to the child's culture; } \\
\text { (8) Who is subject to sexual abuse, sexual molestation, or sexual exploitation by the child's parent, guardian, custodian, or any } \\
\text { other person responsible for the child's care; } \\
\text { (9) Who was subject to prenatal exposure to abusive use of alcohol or any controlled drug or substance not lawfully } \\
\text { prescribed by a practitioner; or }\end{array}$ \\
\hline
\end{tabular}

NOTE:

** For purposes of this chart, corrections officers, police officers, peace officers, probation officers or "catch-all” phrases such as "all persons" have been bolded. However, many mandatory reporters include professionals who may have contact or work in correctional facilities. Such individuals include physicians, nurses, dentists, teachers and social workers. These statutes can be used as a tool to require staff other than correctional officers to report sexual misconduct with inmates.

This publication is developed by the NIC/WCL Project on Addressing Prison Rape under NIC Cooperative Agreement 06S20GJJ1.

This is not to be reproduced or cited without permission from the authors.

American University, Washington College of Law

Current as of May 7, 2009 


\section{Fifty State Survey of Mandatory Reporting Statutes}

\section{NIC/WCL Project on Addressing Prison Rape}

\begin{tabular}{|c|c|}
\hline $\begin{array}{l}\text { Relevant Definitions } \\
\text { Cont'd } \\
\text { (South Dakota) }\end{array}$ & $\begin{array}{l}\text { (10) Whose parent, guardian, or custodian knowingly exposes the child to an environment that is being used for the } \\
\text { manufacture, use, or distribution of methamphetamines or any other unlawfully manufactured controlled drug or substance. }\end{array}$ \\
\hline $\begin{array}{l}\text { Persons Required to } \\
\text { Report } \\
\text { (South Dakota) }\end{array}$ & 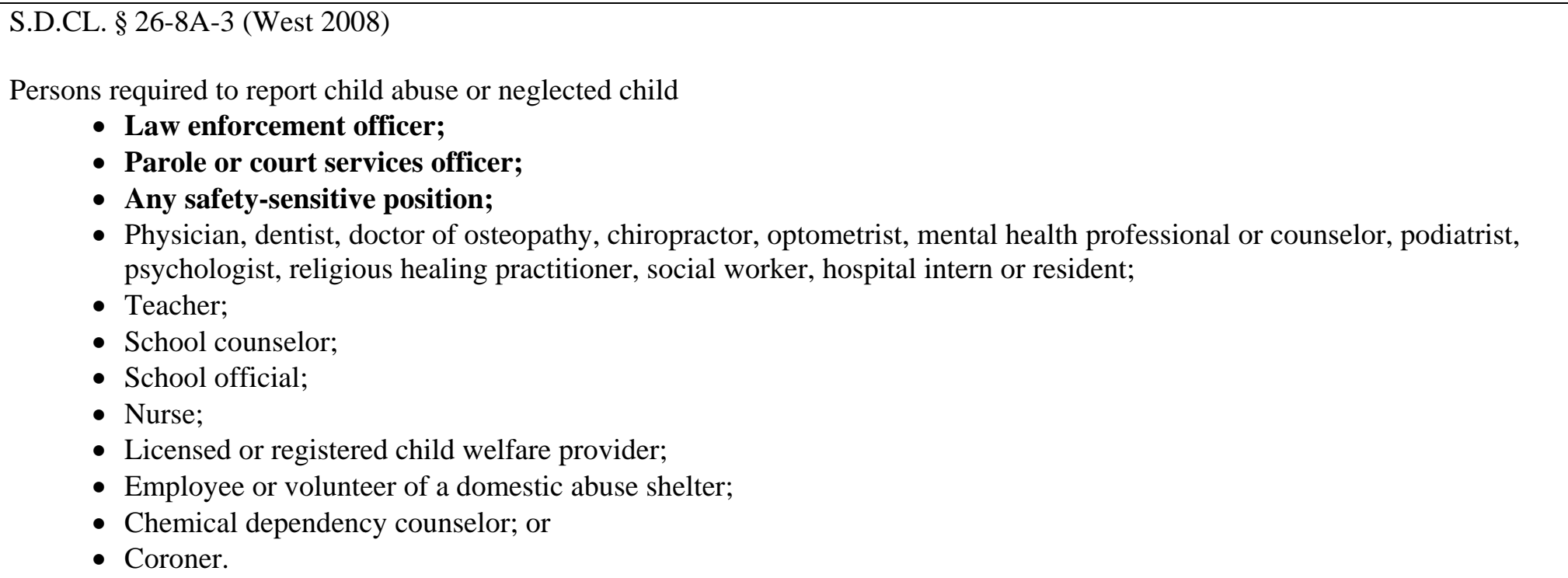 \\
\hline $\begin{array}{l}\text { Reporting } \\
\text { Procedures } \\
\text { (South Dakota) }\end{array}$ & $\begin{array}{l}\text { S.D.CL. } § \text { 26-8A-8 (West 2008) } \\
\text { The reports required shall be made orally and immediately by telephone or otherwise to the state's attorney of the county in which } \\
\text { the child resides or is present, to the department of social services or to law enforcement officers. }\end{array}$ \\
\hline
\end{tabular}

NOTE:

** For purposes of this chart, corrections officers, police officers, peace officers, probation officers or “catch-all” phrases such as “all persons” have been bolded. However, many mandatory reporters include professionals who may have contact or work in correctional facilities. Such individuals include physicians, nurses, dentists, teachers and social workers. These statutes can be used as a tool to require staff other than correctional officers to report sexual misconduct with inmates.

This publication is developed by the NIC/WCL Project on Addressing Prison Rape under NIC Cooperative Agreement 06S20GJJ1.

This is not to be reproduced or cited without permission from the authors.

American University, Washington College of Law

Current as of May 7, 2009 


\section{Fifty State Survey of Mandatory Reporting Statutes}

\section{NIC/WCL Project on Addressing Prison Rape}

\begin{tabular}{|c|c|}
\hline $\begin{array}{l}\text { Penalty for Failure to } \\
\text { Report } \\
\text { (South Dakota) }\end{array}$ & $\begin{array}{l}\text { S.D.CL. } \S 26-8 \text { A-3 (West 2008) } \\
\text { Any person who intentionally fails to make the required report is guilty of a Class } 1 \text { misdemeanor. } \\
\text { S.D.CL. } § 23 A-45-9 \text { (West 2008) } \\
\text { (1) Class } 1 \text { misdemeanor is any misdemeanor which has been classified as a Class } 1 \text { misdemeanor or any unclassified } \\
\text { misdemeanor which may be punished by a maximum imprisonment of more than } 30 \text { days. } \\
\text { S.D.CL. } \S 26-8 \text { A-6 (West 2008) } \\
\text { Any person who has contact with a child through the performance of services as a member of a staff of a hospital or similar } \\
\text { institution shall immediately notify the person in charge of the institution or his designee of suspected abuse or neglect. Any } \\
\text { person who knowingly and intentionally fails to make a required report and to submit copies of records is guilty of a Class } 1 \\
\text { misdemeanor. }\end{array}$ \\
\hline $\begin{array}{l}\text { Mandatory } \\
\text { Reporting Statute } \\
\text { (South Dakota) }\end{array}$ & $\begin{array}{l}\text { AGAINST AN ADULT } \\
\text { N/A There is no adult mandatory reporting statute in South Dakota }\end{array}$ \\
\hline $\begin{array}{l}\text { What has to be } \\
\text { reported? } \\
\text { (South Dakota) }\end{array}$ & $\mathbf{N} / \mathbf{A}$ \\
\hline $\begin{array}{l}\text { Relevant Definitions } \\
\text { (South Dakota) }\end{array}$ & N/A \\
\hline
\end{tabular}

NOTE:

** For purposes of this chart, corrections officers, police officers, peace officers, probation officers or “catch-all” phrases such as “all persons” have been bolded. However, many mandatory reporters include professionals who may have contact or work in correctional facilities. Such individuals include physicians, nurses, dentists, teachers and social workers. These statutes can be used as a tool to require staff other than correctional officers to report sexual misconduct with inmates.

This publication is developed by the NIC/WCL Project on Addressing Prison Rape under NIC Cooperative Agreement 06S20GJJ1.

This is not to be reproduced or cited without permission from the authors.

American University, Washington College of Law

Current as of May 7, 2009 


\section{Fifty State Survey of Mandatory Reporting Statutes}

\section{NIC/WCL Project on Addressing Prison Rape}

\begin{tabular}{|c|c|}
\hline $\begin{array}{l}\text { Persons Required to } \\
\text { Report } \\
\text { (South Dakota) }\end{array}$ & N/A \\
\hline $\begin{array}{l}\text { Reporting } \\
\text { Procedures } \\
\text { (South Dakota) }\end{array}$ & N/A \\
\hline $\begin{array}{l}\text { Penalty for Failure to } \\
\text { Report } \\
\text { (South Dakota) }\end{array}$ & N/A \\
\hline & TENNESSEE \\
\hline $\begin{array}{l}\text { Mandatory } \\
\text { Reporting Statute } \\
\text { (Tennessee) }\end{array}$ & $\begin{array}{l}\text { AGAINST A CHILD } \\
\text { T.C.A. § 37-1-403 (West 2008) }\end{array}$ \\
\hline $\begin{array}{l}\text { What has to be } \\
\text { reported? } \\
\text { (Tennessee) }\end{array}$ & $\begin{array}{l}\text { T.C.A. } \S 37-1-403 \text { (West 2008) } \\
\text { (a)(1) A person who has knowledge of or is called upon to render aid to any child who is suffering from or has sustained any } \\
\text { wound, injury, disability, or physical or mental condition and if the harm is of such a nature as to reasonably indicate that it has } \\
\text { been caused by brutality, abuse or neglect or that, on the basis of available information, reasonably appears to have been caused by } \\
\text { brutality, abuse or neglect. }\end{array}$ \\
\hline
\end{tabular}

NOTE:

** For purposes of this chart, corrections officers, police officers, peace officers, probation officers or "catch-all” phrases such as "all persons" have been bolded. However, many mandatory reporters include professionals who may have contact or work in correctional facilities. Such individuals include physicians, nurses, dentists, teachers and social workers. These statutes can be used as a tool to require staff other than correctional officers to report sexual misconduct with inmates.

This publication is developed by the NIC/WCL Project on Addressing Prison Rape under NIC Cooperative Agreement 06S20GJJ1.

This is not to be reproduced or cited without permission from the authors.

American University, Washington College of Law

Current as of May 7, 2009 


\section{Fifty State Survey of Mandatory Reporting Statutes}

\section{NIC/WCL Project on Addressing Prison Rape}

\begin{tabular}{|c|c|}
\hline $\begin{array}{l}\text { Relevant Definitions } \\
\text { (Tennessee) }\end{array}$ & $\begin{array}{l}\text { T.C.A. § 37-1-102 (West 2008) } \\
\text { (b)(1) Abuse exists when a person under the age of eighteen (18) is suffering from, has sustained, or may be in immediate danger } \\
\text { of suffering from or sustaining a wound, injury, disability or physical or mental condition caused by brutality, neglect or other } \\
\text { actions or inactions of a parent, relative, guardian or caretaker. } \\
\text { (b)(4) Child means: } \\
\text { (A) A person under eighteen (18) years of age; or } \\
\text { (B) A person under nineteen (19) years of age for the limited purpose of: } \\
\text { (i) Remaining under the continuing jurisdiction of the juvenile court to enforce a non-custodial order of disposition entered } \\
\text { prior to the person's eighteenth birthday; or } \\
\text { (ii) Remaining under the jurisdiction of the juvenile court for the purpose of being committed, or completing commitment } \\
\text { including completion of home placement supervision, to the department of children's services with such commitment based on an } \\
\text { adjudication of delinquency for an offense that occurred prior to the person's eighteenth birthday; or } \\
\text { (iii) Remaining under the jurisdiction of the juvenile court for resolution of delinquent offense or offenses committed prior } \\
\text { to a person's eighteenth birthday but considered by the juvenile court after a person's eighteenth birthday with the court having the } \\
\text { option of retaining jurisdiction for adjudication and disposition or transferring the person to criminal court. }\end{array}$ \\
\hline $\begin{array}{l}\text { Persons Required to } \\
\text { Report } \\
\text { (Tennessee) }\end{array}$ & $\begin{array}{l}\text { T.C.A. § 37-1-403 (West 2008) } \\
\text { Any person who has knowledge of or is called upon to render aid to any child who is suffering from or has sustained any wound, } \\
\text { injury, disability, or physical or mental condition. } \\
\text { T.C.A. § 37-1-605 (West 2008) } \\
\text { (a) Any person includes, but is not limited to, any: }\end{array}$ \\
\hline
\end{tabular}

NOTE:

** For purposes of this chart, corrections officers, police officers, peace officers, probation officers or "catch-all” phrases such as “all persons” have been bolded. However, many mandatory reporters include professionals who may have contact or work in correctional facilities. Such individuals include physicians, nurses, dentists, teachers and social workers. These statutes can be used as a tool to require staff other than correctional officers to report sexual misconduct with inmates.

This publication is developed by the NIC/WCL Project on Addressing Prison Rape under NIC Cooperative Agreement 06S20GJJ1.

This is not to be reproduced or cited without permission from the authors.

American University, Washington College of Law

Current as of May 7, 2009 


\section{Fifty State Survey of Mandatory Reporting Statutes}

\section{NIC/WCL Project on Addressing Prison Rape}

\begin{tabular}{|c|c|}
\hline $\begin{array}{l}\text { Persons Required to } \\
\text { Report Cont'd } \\
\text { (Tennessee) }\end{array}$ & $\begin{array}{l}\text { (1) Physician, osteopathic physician, medical examiner, chiropractor, nurse or hospital personnel engaged in the admission, } \\
\text { examination, care or treatment of persons; } \\
\text { (2) Health or mental health professional other than one listed in subdivision; } \\
\text { (3) Practitioner who relies solely on spiritual means for healing; } \\
\text { (4) School teacher or other school official or personnel; } \\
\text { (5) Judge of any court of the state; } \\
\text { (6) Social worker, day care center worker, or other professional child care, foster care, residential or institutional worker; } \\
\text { (7) Law enforcement officer; or } \\
\text { (8) Neighbor, relative, friend or any other person. }\end{array}$ \\
\hline $\begin{array}{l}\text { Reporting } \\
\text { Procedures } \\
\text { (Tennessee) }\end{array}$ & $\begin{array}{l}\text { T.C.A. } § 37-1-403 \text { (West 2008) } \\
\text { (a)(1) A mandatory reporter shall report such harm immediately if the harm is of such a nature as to reasonably indicate that it has } \\
\text { been caused by brutality, abuse or neglect or that, on the basis of available information, reasonably appears to have been caused by } \\
\text { brutality, abuse or neglect. } \\
\text { (a)(2) Any such person with knowledge of the type of harm described in this subsection (a) shall report it, by telephone or } \\
\text { otherwise, to the: } \\
\text { (A) Judge having juvenile jurisdiction over the child; } \\
\text { (B) Department, in a manner specified by the department, either by contacting a local representative of the department or by } \\
\text { utilizing the department's centralized intake procedure, where applicable; } \\
\text { (C) Sheriff of the county where the child resides; or } \\
\text { (D) Chief law enforcement official of the municipality where the child resides. } \\
\text { (3) If any such person knows or has reasonable cause to suspect that a child has been sexually abused, the person shall report } \\
\text { such information in accordance with } \S 37-1-605 \text {, relative to the sexual abuse of children, regardless of whether such person } \\
\text { knows or believes that the child has sustained any apparent injury as a result of such abuse. }\end{array}$ \\
\hline
\end{tabular}

** For purposes of this chart, corrections officers, police officers, peace officers, probation officers or "catch-all” phrases such as “all persons” have been bolded. However, many mandatory reporters include professionals who may have contact or work in correctional facilities. Such individuals include physicians, nurses, dentists, teachers and social workers. These statutes can be used as a tool to require staff other than correctional officers to report sexual misconduct with inmates.

This publication is developed by the NIC/WCL Project on Addressing Prison Rape under NIC Cooperative Agreement 06S20GJJ1.

This is not to be reproduced or cited without permission from the authors.

American University, Washington College of Law

Current as of May 7, 2009 


\section{Fifty State Survey of Mandatory Reporting Statutes}

\section{NIC/WCL Project on Addressing Prison Rape}

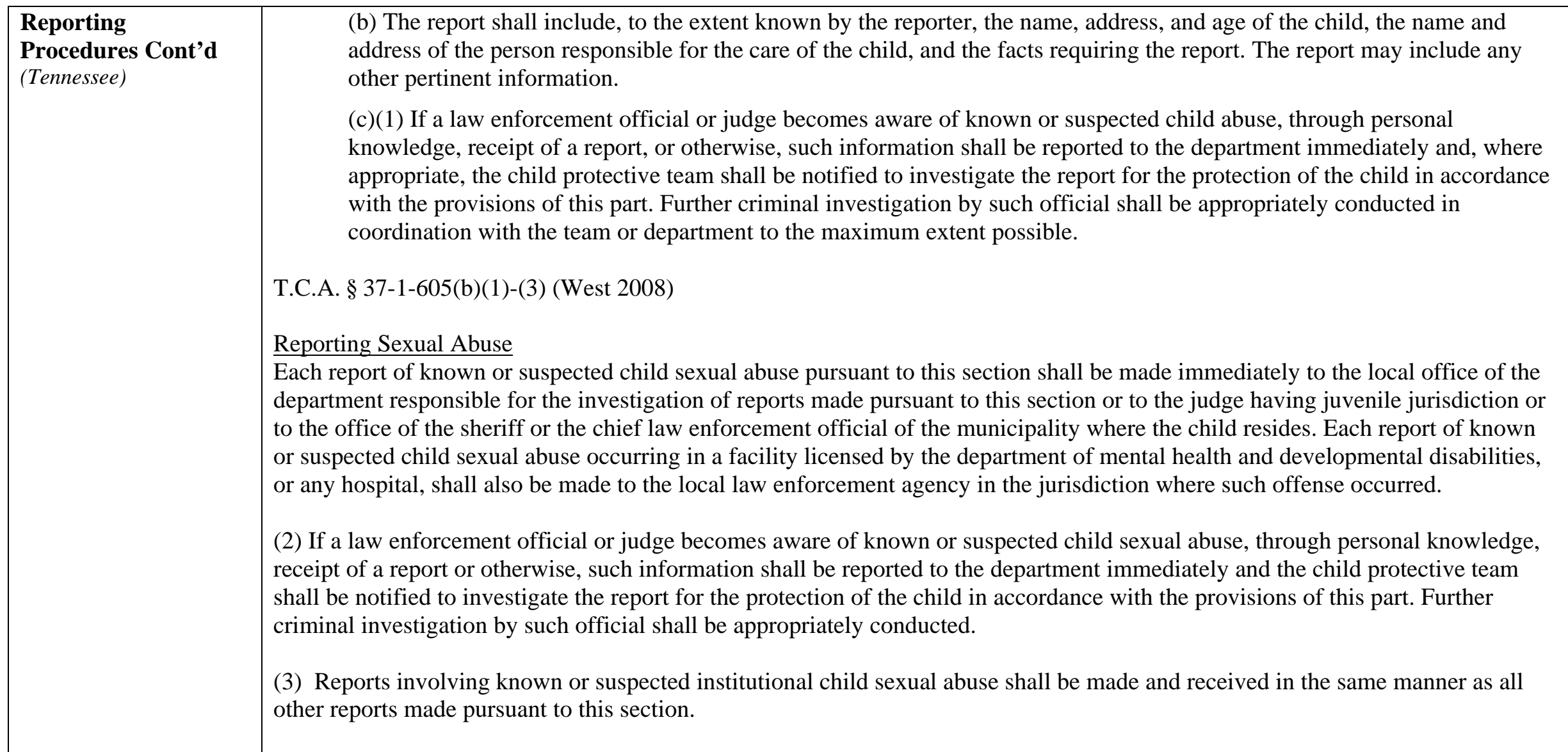

** For purposes of this chart, corrections officers, police officers, peace officers, probation officers or “catch-all” phrases such as “all persons” have been bolded. However, many mandatory reporters include professionals who may have contact or work in correctional facilities. Such individuals include physicians, nurses, dentists, teachers and social workers. These statutes can be used as a tool to require staff other than correctional officers to report sexual misconduct with inmates.

This publication is developed by the NIC/WCL Project on Addressing Prison Rape under NIC Cooperative Agreement 06S20GJJ1.

This is not to be reproduced or cited without permission from the authors.

American University, Washington College of Law

Current as of May 7, 2009 


\section{Fifty State Survey of Mandatory Reporting Statutes}

\section{NIC/WCL Project on Addressing Prison Rape}

\begin{tabular}{|c|c|}
\hline $\begin{array}{l}\text { Penalty for Failure to } \\
\text { Report } \\
\text { (Tennessee) }\end{array}$ & $\begin{array}{l}\text { T.C.A. } \S 37-1-412 \text { (West 2008) } \\
\text { (a) Any person who knowingly fails to make a report required by } \S 37-1-403 \text { commits a Class A misdemeanor. } \\
\text { (b) A juvenile court having reasonable cause to believe that a person is guilty of violating this section may have the person brought } \\
\text { before the court either by summons or by warrant. If the defendant pleads not guilty, the juvenile court judge shall bind the } \\
\text { defendant over to the grand jury. If the defendant pleads guilty and waives, in writing, indictment, presentment, grand jury } \\
\text { investigation, and trial by jury, the juvenile court judge shall sentence the defendant under this section with a fine not to exceed } \\
\text { two thousand five hundred dollars }(\$ 2,500) \text {. }\end{array}$ \\
\hline $\begin{array}{l}\text { Mandatory } \\
\text { Reporting Statute } \\
\text { (Tennessee) }\end{array}$ & $\begin{array}{l}\text { AGAINST AN ADULT } \\
\text { T.C.A. § 71-6-103 (West 2008) }\end{array}$ \\
\hline $\begin{array}{l}\text { What has to be } \\
\text { reported? } \\
\text { (Tennessee) }\end{array}$ & $\begin{array}{l}\text { T.C.A. } \S 71-6-103 \text { (West 2008) } \\
\text { A mandated reporter having reasonable cause to suspect that an adult has suffered abuse, neglect, or exploitation. }\end{array}$ \\
\hline $\begin{array}{l}\text { Relevant Definitions } \\
\text { (Tennessee) }\end{array}$ & $\begin{array}{l}\text { T.C.A. § 71-6-102 (West 2008) } \\
\text { (1) Abuse or neglect means the infliction of physical pain, injury, or mental anguish, or the deprivation of services by a caretaker } \\
\text { that are necessary to maintain the health and welfare of an adult or a situation in which an adult is unable to provide or obtain the } \\
\text { services that are necessary to maintain that person's health or welfare. Nothing in this part shall be construed to require or } \\
\text { authorize the provision of medical care to any terminally ill person if such person has executed an unrevoked living will in } \\
\text { accordance with the provisions of the Tennessee Right to Natural Death Act, and if the provisions of such medical care would } \\
\text { conflict with the terms of such living will. }\end{array}$ \\
\hline
\end{tabular}

NOTE:

** For purposes of this chart, corrections officers, police officers, peace officers, probation officers or “catch-all” phrases such as “all persons” have been bolded. However, many mandatory reporters include professionals who may have contact or work in correctional facilities. Such individuals include physicians, nurses, dentists, teachers and social workers. These statutes can be used as a tool to require staff other than correctional officers to report sexual misconduct with inmates.

This publication is developed by the NIC/WCL Project on Addressing Prison Rape under NIC Cooperative Agreement 06S20GJJ1.

This is not to be reproduced or cited without permission from the authors.

American University, Washington College of Law

Current as of May 7, 2009 


\section{Fifty State Survey of Mandatory Reporting Statutes}

\section{NIC/WCL Project on Addressing Prison Rape}

\begin{tabular}{|c|c|}
\hline $\begin{array}{l}\text { Relevant Definitions } \\
\text { Cont'd } \\
\text { (Tennessee) }\end{array}$ & $\begin{array}{l}\text { (2) Adult means a person eighteen (18) years of age or older who because of mental or physical dysfunctioning or advanced age is } \\
\text { unable to manage such person's own resources, carry out the activities of daily living, or protect such person from neglect, } \\
\text { hazardous or abusive situations without assistance from others and who has no available, willing, and responsibly able person for } \\
\text { assistance and who may be in need of protective services. } \\
\text { (3) Advanced age means sixty (60) years of age or older. } \\
\text { (8) Exploitation means the improper use by a caretaker of funds that have been paid by a governmental agency to an adult or to the } \\
\text { caretaker for the use or care of the adult. } \\
\text { (12) Sexual abuse occurs when an adult, as defined in this chapter, is forced, tricked, threatened or otherwise coerced by a person } \\
\text { into sexual activity, involuntary exposure to sexually explicit material or language, or sexual contact against such adult's will. } \\
\text { Sexual abuse also occurs when an "adult," as defined in this chapter, is unable to give consent to such sexual activities or contact } \\
\text { and is engaged in such activities or contact with another person. }\end{array}$ \\
\hline $\begin{array}{l}\text { Persons Required to } \\
\text { Report } \\
\text { (Tennessee) }\end{array}$ & $\begin{array}{l}\text { T.C.A. } § 71-6-103 \text { (West 2008) } \\
\text { (b)(1) Any person, including, but not limited to: } \\
\text { - A physician; } \\
\text { - Nurse; } \\
\text { - Social Worker; } \\
\text { - Department personnel; } \\
\text { - Coroner; } \\
\text { - Medical examiner; } \\
\text { - Alternate care facility employee; or caretaker. }\end{array}$ \\
\hline
\end{tabular}

NOTE:

** For purposes of this chart, corrections officers, police officers, peace officers, probation officers or "catch-all” phrases such as "all persons" have been bolded. However, many mandatory reporters include professionals who may have contact or work in correctional facilities. Such individuals include physicians, nurses, dentists, teachers and social workers. These statutes can be used as a tool to require staff other than correctional officers to report sexual misconduct with inmates.

This publication is developed by the NIC/WCL Project on Addressing Prison Rape under NIC Cooperative Agreement 06S20GJJ1.

This is not to be reproduced or cited without permission from the authors.

American University, Washington College of Law

Current as of May 7, 2009 


\section{Fifty State Survey of Mandatory Reporting Statutes}

\section{NIC/WCL Project on Addressing Prison Rape}

\begin{tabular}{|c|c|}
\hline $\begin{array}{l}\text { Reporting } \\
\text { Procedures } \\
\text { (Tennessee) }\end{array}$ & $\begin{array}{l}\text { T.C.A. } § 71-6-103 \text { (West 2008) } \\
\text { (C) An oral or written report shall be made immediately to the department of human services upon knowledge of the occurrence of } \\
\text { suspected abuse, neglect, or exploitation of an adult. Any person making such a report shall provide the following information, if } \\
\text { known: the name and address of the adult, or of any other person responsible for the adult's care; the age of the adult; the nature } \\
\text { and extent of the abuse, neglect, or exploitation, including any evidence of previous abuse, neglect, or exploitation; the identity of } \\
\text { the perpetrator, if known; the identity of the complainant, if possible; and any other information that the person believes might be } \\
\text { helpful in establishing the cause of abuse, neglect, or exploitation. Each report of known or suspected abuse of an adult involving a } \\
\text { sexual offense that is a violation of } \S \S 39-13-501--39-13-506 \text { that occurs in a facility licensed by the department of mental health } \\
\text { and developmental disabilities as defined in } \S 33-5-402 \text {, or any hospital shall also be made to the local law enforcement agency in } \\
\text { the jurisdiction where such offense occurred. }\end{array}$ \\
\hline $\begin{array}{l}\text { Penalty for Failure to } \\
\text { Report } \\
\text { (Tennessee) }\end{array}$ & $\begin{array}{l}\text { T.C.A. } § 71-6-110 \text { (West 2008) } \\
\text { Any person who knowingly fails to make a report required by this chapter commits a class A misdemeanor. } \\
\text { T.C.A. } § 40-35-111 \text { (West } 2008) \\
\text { (e)(1) Class A misdemeanor, not greater than eleven (11) months, twenty-nine (29) days or a fine not to exceed two thousand five } \\
\text { hundred dollars }(\$ 2,500) \text {, or both, unless otherwise provided by statute. }\end{array}$ \\
\hline \multicolumn{2}{|r|}{ TEXAS } \\
\hline $\begin{array}{l}\text { Mandatory } \\
\text { Reporting Statute } \\
\text { (Texas) }\end{array}$ & $\begin{array}{l}\text { AGAINST A CHILD } \\
\text { V.T.C.A., FAMILY CODE } \S 261.101 \text { (West 2008) }\end{array}$ \\
\hline
\end{tabular}

NOTE:

** For purposes of this chart, corrections officers, police officers, peace officers, probation officers or “catch-all” phrases such as “all persons” have been bolded. However, many mandatory reporters include professionals who may have contact or work in correctional facilities. Such individuals include physicians, nurses, dentists, teachers and social workers. These statutes can be used as a tool to require staff other than correctional officers to report sexual misconduct with inmates.

This publication is developed by the NIC/WCL Project on Addressing Prison Rape under NIC Cooperative Agreement 06S20GJJ1.

This is not to be reproduced or cited without permission from the authors.

American University, Washington College of Law

Current as of May 7, 2009 


\section{Fifty State Survey of Mandatory Reporting Statutes}

\section{NIC/WCL Project on Addressing Prison Rape}

\begin{tabular}{|c|c|}
\hline $\begin{array}{l}\text { What has to be } \\
\text { reported? } \\
\text { (Texas) }\end{array}$ & $\begin{array}{l}\text { V.T.C.A., FAMILY CODE } \S 261.101 \text { (West 2008) } \\
\text { (a) A person having cause to believe that a child's physical or mental health or welfare has been adversely affected by abuse or } \\
\text { neglect. } \\
\text { V.T.C.A., FAMILY CODE } \S 261.101(\text { c) (West 2008) } \\
\text { The requirement to report under this section applies without exception to an individual whose personal communications may } \\
\text { otherwise be privileged, including an attorney, a member of the clergy, a medical practitioner, a social worker, a mental health } \\
\text { professional, and an employee of a clinic or health care facility that provides reproductive services. }\end{array}$ \\
\hline $\begin{array}{l}\text { Relevant Definitions } \\
\text { (Texas) }\end{array}$ & $\begin{array}{l}\text { V V.T.C.A., FAMILY CODE } \S 100.003 \text { (West 2008) } \\
\text { (a) Child or minor means a person under } 18 \text { years of age who is not and has not been married or who has not had the disabilities } \\
\text { of minority removed for general purposes. } \\
\text { V.T.C.A., FAMILY CODE } § 261.001 \text { (West 2008) } \\
\text { (1) Abuse includes the following acts or omissions by a person: } \\
\text { (A) mental or emotional injury to a child that results in an observable and material impairment in the child's } \\
\text { growth, development, or psychological functioning; } \\
\text { (B) causing or permitting the child to be in a situation in which the child sustains a mental or emotional injury that results in } \\
\text { an observable and material impairment in the child's growth, development, or psychological functioning; } \\
\text { (C) physical injury that results in substantial harm to the child, or the genuine threat of substantial harm from physical injury } \\
\text { to the child, including an injury that is at variance with the history or explanation given and excluding an accident or } \\
\text { reasonable discipline by a parent, guardian, or managing or possessory conservator that does not expose the child to a }\end{array}$ \\
\hline
\end{tabular}

NOTE:

** For purposes of this chart, corrections officers, police officers, peace officers, probation officers or “catch-all” phrases such as “all persons” have been bolded. However, many mandatory reporters include professionals who may have contact or work in correctional facilities. Such individuals include physicians, nurses, dentists, teachers and social workers. These statutes can be used as a tool to require staff other than correctional officers to report sexual misconduct with inmates.

This publication is developed by the NIC/WCL Project on Addressing Prison Rape under NIC Cooperative Agreement 06S20GJJ1.

This is not to be reproduced or cited without permission from the authors.

American University, Washington College of Law

Current as of May 7, 2009 


\section{Fifty State Survey of Mandatory Reporting Statutes}

\section{NIC/WCL Project on Addressing Prison Rape}

\begin{tabular}{|c|c|}
\hline $\begin{array}{l}\text { Relevant Definitions } \\
\text { Cont'd } \\
\text { (Texas) }\end{array}$ & 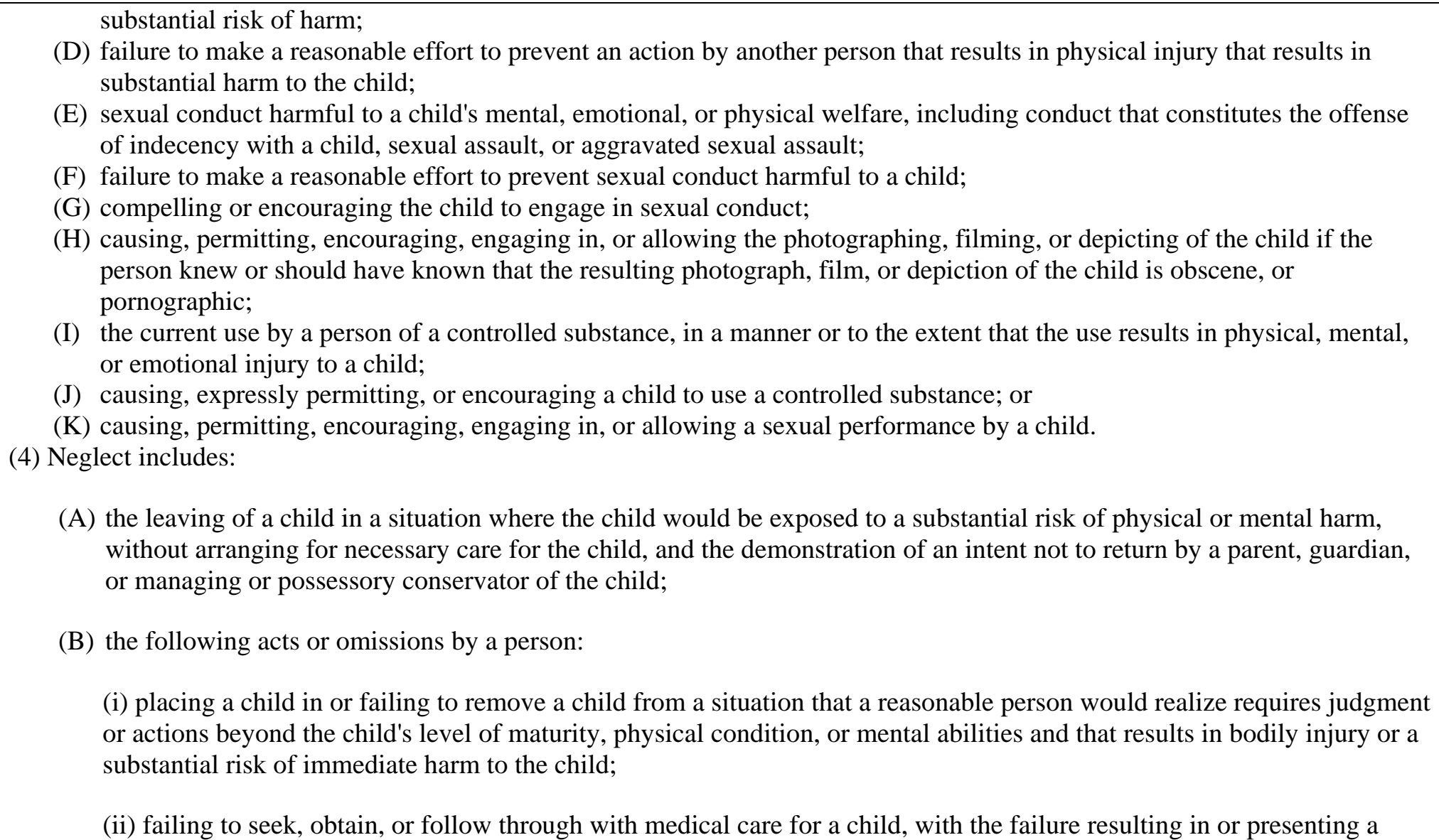 \\
\hline
\end{tabular}

NOTE:

** For purposes of this chart, corrections officers, police officers, peace officers, probation officers or “catch-all” phrases such as “all persons” have been bolded. However, many mandatory reporters include professionals who may have contact or work in correctional facilities. Such individuals include physicians, nurses, dentists, teachers and social workers. These statutes can be used as a tool to require staff other than correctional officers to report sexual misconduct with inmates.

This publication is developed by the NIC/WCL Project on Addressing Prison Rape under NIC Cooperative Agreement 06S20GJJ1.

This is not to be reproduced or cited without permission from the authors.

American University, Washington College of Law

Current as of May 7, 2009 


\section{Fifty State Survey of Mandatory Reporting Statutes}

\section{NIC/WCL Project on Addressing Prison Rape}

\begin{tabular}{|c|c|}
\hline $\begin{array}{l}\text { Relevant Definitions } \\
\text { Cont'd } \\
\text { (Texas) }\end{array}$ & $\begin{array}{l}\text { substantial risk of death, disfigurement, or bodily injury or with the failure resulting in an observable and material } \\
\text { impairment to the growth, development, or functioning of the child; } \\
\text { (iii) the failure to provide a child with food, clothing, or shelter necessary to sustain the life or health of the child, } \\
\text { excluding failure caused primarily by financial inability unless relief services had been offered and refused; } \\
\text { (iv) placing a child in or failing to remove the child from a situation in which the child would be exposed to a substantial } \\
\text { risk of sexual conduct harmful to the child; or } \\
\text { (v) placing a child in or failing to remove the child from a situation in which the child would be exposed to acts or } \\
\text { omissions that constitute abuse under Subdivision (1)(E), (F), (G), (H), or (K) committed against another child; or } \\
\text { (C) the failure by the person responsible for a child's care, custody, or welfare to permit the child to return to the child's home } \\
\text { without arranging for the necessary care for the child after the child has been absent from the home for any reason, } \\
\text { including having been in residential placement or having run away } \\
\text { V.T.C.A., FAMILY CoDE } \S 261.101 \text { (West } 2008 \text { ) } \\
\text { (b) Professional means an individual who is licensed or certified by the state or who is an employee of a facility licensed, } \\
\text { certified, or operated by the state and who, in the normal course of official duties or duties for which a license or } \\
\text { certification is required, has direct contact with children. }\end{array}$ \\
\hline $\begin{array}{l}\text { Persons Required to } \\
\text { Report } \\
\text { (Texas) }\end{array}$ & $\begin{array}{l}\text { V.T.C.A., FAMILY CODE } § 261.101 \text { (West 2008) } \\
\text { (a) A person having cause to believe that a child's physical or mental health or welfare has been adversely affected by abuse } \\
\text { or neglect by any person }\end{array}$ \\
\hline
\end{tabular}

NOTE:

** For purposes of this chart, corrections officers, police officers, peace officers, probation officers or “catch-all” phrases such as “all persons” have been bolded. However, many mandatory reporters include professionals who may have contact or work in correctional facilities. Such individuals include physicians, nurses, dentists, teachers and social workers. These statutes can be used as a tool to require staff other than correctional officers to report sexual misconduct with inmates.

This publication is developed by the NIC/WCL Project on Addressing Prison Rape under NIC Cooperative Agreement 06S20GJJ1.

This is not to be reproduced or cited without permission from the authors.

American University, Washington College of Law

Current as of May 7, 2009 


\section{Fifty State Survey of Mandatory Reporting Statutes}

\section{NIC/WCL Project on Addressing Prison Rape}

\begin{tabular}{|c|c|}
\hline $\begin{array}{l}\text { Persons Required to } \\
\text { Report Cont'd } \\
\text { (Texas) }\end{array}$ & $\begin{array}{l}\text { is a victim of an offense.... Including: } \\
\text { - Juvenile detention or correctional officers; } \\
\text { - Juvenile probation officers; } \\
\text { - Teachers; } \\
\text { - Nurses; } \\
\text { - Doctors; } \\
\text { - Day-care employees; } \\
\text { - Employees of a clinic or health care facility that provides reproductive services. }\end{array}$ \\
\hline $\begin{array}{l}\text { Reporting } \\
\text { Procedures } \\
\text { (Texas) }\end{array}$ & $\begin{array}{l}\text { V.T.C.A., FAMILY CODE } \S 261.101 \text { (West 2008) } \\
\text { (a) A person shall immediately make a report. } \\
\text { V.T.C.A. FAMILY CODE } \S 261.101 \text { (West 2008) } \\
\text { (b) A professional shall make a report not later than the } 48^{\text {th }} \text { hour after the hour the professional first suspects that the child has } \\
\text { been or may be abused or neglected or is a victim of an offense. A professional may not delegate to or rely on another person } \\
\text { to make the report. }\end{array}$ \\
\hline $\begin{array}{l}\text { Penalty for Failure to } \\
\text { Report } \\
\text { (Texas) }\end{array}$ & $\begin{array}{l}\text { V.T.C.A., FAMILY CODE } § 261.109 \text { (West 2008) } \\
\text { (a) A person commits an offense if the person has cause to believe that a child's physical or mental health or welfare has been or } \\
\text { may be adversely affected by abuse or neglect and knowingly fails to report as provided in this chapter. } \\
\text { (b) An offense under this section is a Class B misdemeanor. }\end{array}$ \\
\hline
\end{tabular}

NOTE:

** For purposes of this chart, corrections officers, police officers, peace officers, probation officers or “catch-all” phrases such as “all persons” have been bolded. However, many mandatory reporters include professionals who may have contact or work in correctional facilities. Such individuals include physicians, nurses, dentists, teachers and social workers. These statutes can be used as a tool to require staff other than correctional officers to report sexual misconduct with inmates.

This publication is developed by the NIC/WCL Project on Addressing Prison Rape under NIC Cooperative Agreement 06S20GJJ1.

This is not to be reproduced or cited without permission from the authors.

American University, Washington College of Law

Current as of May 7, 2009 


\section{Fifty State Survey of Mandatory Reporting Statutes}

\section{NIC/WCL Project on Addressing Prison Rape}

\begin{tabular}{|c|c|}
\hline $\begin{array}{l}\text { Penalty for Failure to } \\
\text { Report Cont'd } \\
\text { (Texas) }\end{array}$ & $\begin{array}{l}\text { V.T.C.A. PENAL CODE } § 12.22 \text { (West 2008) } \\
\text { An individual adjudged guilty of a Class B misdemeanor shall be punished by: } \\
\text { (1) a fine not to exceed } \$ 2,000 \text {; } \\
\text { (2) confinement in jail for a term not to exceed } 180 \text { days; or } \\
\text { (3) both such fine and confinement. }\end{array}$ \\
\hline $\begin{array}{l}\text { Mandatory } \\
\text { Reporting Statute } \\
\text { (Texas) }\end{array}$ & $\begin{array}{l}\text { AGAINST AN ADULT } \\
\text { TEX. HUM. RES. § } 48.051 \text { (West 2008) }\end{array}$ \\
\hline $\begin{array}{l}\text { What has to be } \\
\text { reported? } \\
\text { (Texas) }\end{array}$ & $\begin{array}{l}\text { TEX. HUM. RES. } § 48.051 \text { (West 2008) } \\
\text { (a) A person who has cause to believe that an elderly or disabled person is in the state of abuse, neglect, or exploitation shall report } \\
\text { the information required by Subsection (d) immediately to the department. } \\
\text { (b) A person who has cause to believe that an elderly or disabled person has been abused, neglected, or exploited in a facility } \\
\text { operated, licensed, certified, or registered by a state agency other than the Texas Department of Mental Health and Mental } \\
\text { Retardation. }\end{array}$ \\
\hline $\begin{array}{l}\text { Relevant Definitions } \\
\text { (Texas) }\end{array}$ & $\begin{array}{l}\text { TEX. HUM. RES. CODE ANN. § } 48.002 \text { (West 2008) } \\
\text { (1) “Elderly person” means a person } 65 \text { years of age or older. } \\
\text { (2) “Abuse” means: }\end{array}$ \\
\hline
\end{tabular}

NOTE:

** For purposes of this chart, corrections officers, police officers, peace officers, probation officers or “catch-all” phrases such as “all persons” have been bolded. However, many mandatory reporters include professionals who may have contact or work in correctional facilities. Such individuals include physicians, nurses, dentists, teachers and social workers. These statutes can be used as a tool to require staff other than correctional officers to report sexual misconduct with inmates.

This publication is developed by the NIC/WCL Project on Addressing Prison Rape under NIC Cooperative Agreement 06S20GJJ1.

This is not to be reproduced or cited without permission from the authors.

American University, Washington College of Law

Current as of May 7, 2009 


\section{Fifty State Survey of Mandatory Reporting Statutes}

\section{NIC/WCL Project on Addressing Prison Rape}

\begin{tabular}{|c|c|}
\hline $\begin{array}{l}\text { Relevant Definitions } \\
\text { Cont'd } \\
\text { (Texas) }\end{array}$ & $\begin{array}{l}\text { (A) the negligent or wilful infliction of injury, unreasonable confinement, intimidation, or cruel punishment with resulting } \\
\text { physical or emotional harm or pain to an elderly or disabled person by the person's caretaker, family member, or other } \\
\text { individual who has an ongoing relationship with the person; or } \\
\text { (B) sexual abuse of an elderly or disabled person, including any involuntary or nonconsensual sexual conduct such as indecent } \\
\text { exposure or assaultive offenses, committed by the person's caretaker, family member, or other individual who has } \\
\text { an ongoing relationship with the person. } \\
\text { (3) Exploitation means the illegal or improper act or process of a caretaker, family member, or other individual who has an } \\
\text { ongoing relationship with the elderly or disabled person using the resources of an elderly or disabled person for monetary or } \\
\text { personal benefit, profit, or gain without the informed consent of the elderly or disabled person. } \\
\text { (8) Disabled person means a person with a mental, physical, or developmental disability that substantially impairs the person's } \\
\text { ability to provide adequately for the person's care or protection and who is: } \\
\text { (A) } 18 \text { years of age or older; or } \\
\text { (B) under } 18 \text { years of age and who has had the disabilities of minority removed. }\end{array}$ \\
\hline $\begin{array}{l}\text { Persons Required to } \\
\text { Report } \\
\text { (Texas) }\end{array}$ & $\begin{array}{l}\text { TEX. HUM. RES. § } 48.051 \text { (West 2008) } \\
\text { (c) The duty imposed applies without exception to a person whose knowledge concerning possible abuse, neglect, or exploitation } \\
\text { is obtained during the scope of the person's employment or whose professional communications are generally confidential, } \\
\text { including an attorney, clergy member, medical practitioner, social worker, and mental health professional. }\end{array}$ \\
\hline
\end{tabular}

NOTE:

** For purposes of this chart, corrections officers, police officers, peace officers, probation officers or “catch-all” phrases such as “all persons” have been bolded. However, many mandatory reporters include professionals who may have contact or work in correctional facilities. Such individuals include physicians, nurses, dentists, teachers and social workers. These statutes can be used as a tool to require staff other than correctional officers to report sexual misconduct with inmates.

This publication is developed by the NIC/WCL Project on Addressing Prison Rape under NIC Cooperative Agreement 06S20GJJ1.

This is not to be reproduced or cited without permission from the authors.

American University, Washington College of Law

Current as of May 7, 2009 


\section{Fifty State Survey of Mandatory Reporting Statutes}

\section{NIC/WCL Project on Addressing Prison Rape}

\begin{tabular}{|c|c|}
\hline $\begin{array}{l}\text { Reporting } \\
\text { Procedures } \\
\text { (Texas) }\end{array}$ & $\begin{array}{l}\text { TEX. HUM. RES. § } 48.051 \text { (West 2008) } \\
\text { (a) Shall report immediately to the department. } \\
\text { (b) If a person has cause to believe that an elderly or disabled person has been abused, neglected, or exploited in a facility } \\
\text { operated, licensed, certified, or registered by a state agency other than the Texas Department of Mental Health and Mental } \\
\text { Retardation, the person shall report the information to the state agency that operates, licenses, certifies, or registers the facility for } \\
\text { investigation by that agency. } \\
\text { (d) The report may be made orally or in writing. It shall include: } \\
\text { (1) the name, age, and address of the elderly or disabled person; } \\
\text { (2) the name and address of any person responsible for the elderly or disabled person's care; } \\
\text { (3) the nature and extent of the elderly or disabled person's condition; } \\
\text { (4) the basis of the reporter's knowledge; and } \\
\text { (5) any other relevant information. }\end{array}$ \\
\hline $\begin{array}{l}\text { Penalty for Failure to } \\
\text { Report } \\
\text { (Texas) }\end{array}$ & $\begin{array}{l}\text { TEX. HUM. RES. } § 48.052 \text { (West 2008) } \\
\text { (a) A person commits an offense if the person has cause to believe that an elderly or disabled person has been abused, neglected, } \\
\text { or exploited or is in the state of abuse, neglect, or exploitation and knowingly fails to report in accordance with this chapter. An } \\
\text { offense under this subsection is a Class A misdemeanor. } \\
\text { TEX. PENAL } § 12.21 \text { (West 2008) } \\
\text { An individual adjudged guilty of a Class A misdemeanor shall be punished by: } \\
\text { (1) a fine not to exceed } \$ 4,000 \text {; } \\
\text { (2) confinement in jail for a term not to exceed one year; or } \\
\text { (3) both such fine and confinement. }\end{array}$ \\
\hline
\end{tabular}

NOTE:

** For purposes of this chart, corrections officers, police officers, peace officers, probation officers or “catch-all” phrases such as “all persons” have been bolded. However, many mandatory reporters include professionals who may have contact or work in correctional facilities. Such individuals include physicians, nurses, dentists, teachers and social workers. These statutes can be used as a tool to require staff other than correctional officers to report sexual misconduct with inmates.

This publication is developed by the NIC/WCL Project on Addressing Prison Rape under NIC Cooperative Agreement 06S20GJJ1.

This is not to be reproduced or cited without permission from the authors.

American University, Washington College of Law

Current as of May 7, 2009 


\section{Fifty State Survey of Mandatory Reporting Statutes}

\section{NIC/WCL Project on Addressing Prison Rape}

\begin{tabular}{|c|c|}
\hline \multicolumn{2}{|r|}{ UTAH } \\
\hline $\begin{array}{l}\text { Mandatory } \\
\text { Reporting Statute } \\
\text { (Utah) }\end{array}$ & $\begin{array}{l}\text { AGAINST A CHILD } \\
\text { U.C.A. } 1953 \S 62 \mathrm{a}-4 \mathrm{a}-403 \text { (West 2008) }\end{array}$ \\
\hline $\begin{array}{l}\text { What has to be } \\
\text { reported? } \\
\text { (Utah) }\end{array}$ & $\begin{array}{l}\text { U.C.A. } 1953 \S 62 a-4 a-403 \text { (West 2008) } \\
\text { Reason to believe that a child has been subjected to incest, molestation, sexual exploitation, sexual abuse, physical abuse, or } \\
\text { neglect, or who observes a child being subjected to conditions or circumstances which would reasonably result in sexual abuse, } \\
\text { physical abuse, or neglect, he shall immediately notify the nearest peace officer, law enforcement agency, or office of the division. }\end{array}$ \\
\hline $\begin{array}{l}\text { Relevant Definitions } \\
\text { (Utah) }\end{array}$ & $\begin{array}{l}\text { U.C.A. } 1953 \text { § 62a-4a-101 (West 2008) } \\
\text { (4) “Child” means, except as provided in Part 7, Interstate Compact on Placement of Children, a person under } 18 \text { years of age. } \\
\text { (1)(a) “Abuse” means: } \\
\text { (i) actual or threatened nonaccidental physical or mental harm; } \\
\text { (ii) negligent treatment; } \\
\text { (iii) sexual exploitation; or } \\
\text { (iv) any sexual abuse. } \\
\text { (18)(a) “Neglect” means: } \\
\text { (i) abandonment of a child, except as provided in Part 8, Safe Relinquishment of a Newborn Child; } \\
\text { (ii) subjecting a child to mistreatment or abuse; } \\
\text { (iii) lack of proper parental care by reason of the fault or habits of the parent, guardian, or custodian; }\end{array}$ \\
\hline
\end{tabular}

NOTE:

** For purposes of this chart, corrections officers, police officers, peace officers, probation officers or "catch-all” phrases such as "all persons" have been bolded. However, many mandatory reporters include professionals who may have contact or work in correctional facilities. Such individuals include physicians, nurses, dentists, teachers and social workers. These statutes can be used as a tool to require staff other than correctional officers to report sexual misconduct with inmates.

This publication is developed by the NIC/WCL Project on Addressing Prison Rape under NIC Cooperative Agreement 06S20GJJ1.

This is not to be reproduced or cited without permission from the authors.

American University, Washington College of Law

Current as of May 7, 2009 


\section{Fifty State Survey of Mandatory Reporting Statutes}

\section{NIC/WCL Project on Addressing Prison Rape}

\begin{tabular}{|c|c|}
\hline $\begin{array}{l}\text { Relevant Definitions } \\
\text { Cont'd } \\
\text { (Utah) }\end{array}$ & 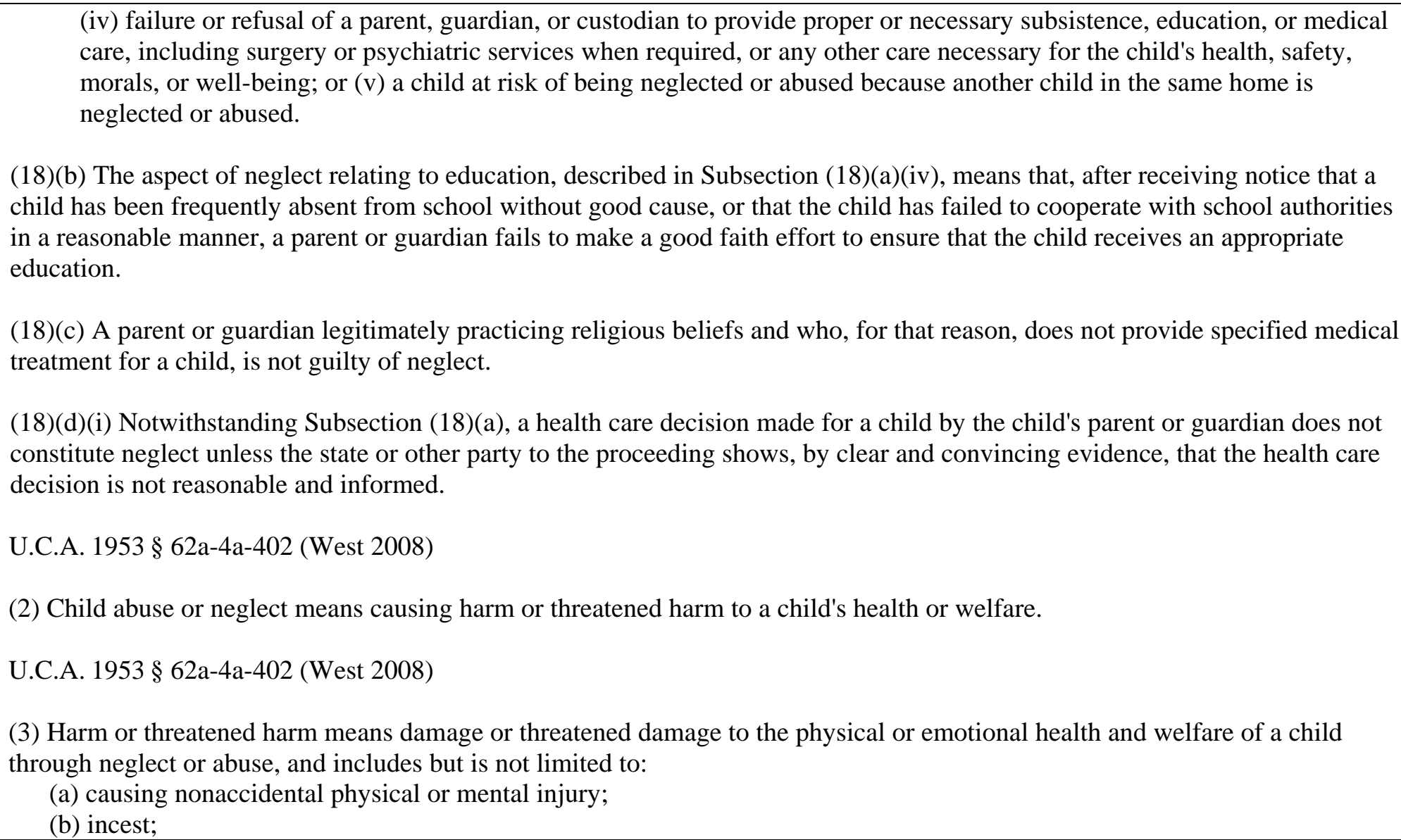 \\
\hline
\end{tabular}

NOTE:

** For purposes of this chart, corrections officers, police officers, peace officers, probation officers or "catch-all” phrases such as “all persons” have been bolded. However, many mandatory reporters include professionals who may have contact or work in correctional facilities. Such individuals include physicians, nurses, dentists, teachers and social workers. These statutes can be used as a tool to require staff other than correctional officers to report sexual misconduct with inmates.

This publication is developed by the NIC/WCL Project on Addressing Prison Rape under NIC Cooperative Agreement 06S20GJJ1.

This is not to be reproduced or cited without permission from the authors.

American University, Washington College of Law

Current as of May 7, 2009 


\section{Fifty State Survey of Mandatory Reporting Statutes}

\section{NIC/WCL Project on Addressing Prison Rape}

\begin{tabular}{|c|c|}
\hline $\begin{array}{l}\text { Relevant Definitions } \\
\text { Cont'd } \\
\text { (Utah) }\end{array}$ & $\begin{array}{l}\text { (c) sexual abuse; } \\
\text { (d) sexual exploitation; } \\
\text { (e) molestation; or } \\
\text { (f) repeated negligent treatment or maltreatment. } \\
\text { (4) Incest means having sexual intercourse with a person whom the perpetrator knows to be his or her ancestor, descendant, } \\
\text { brother, sister, uncle, aunt, nephew, niece, or first cousin. The relationships referred to in this subsection include blood } \\
\text { relationships of the whole or half blood without regard to legitimacy, and include relationships of parent and child by adoption, } \\
\text { and relationships of stepparent and stepchild while the marriage creating the relationship of a stepparent and stepchild exists. } \\
\text { (5) Molestation means touching the anus or any part of the genitals of a child or otherwise taking indecent liberties with a child, or } \\
\text { causing a child to take indecent liberties with the perpetrator or another with the intent to arouse or gratify the sexual desire of any } \\
\text { person. } \\
\text { (6) Sexual abuse means acts or attempted acts of sexual intercourse, sodomy, or molestation directed towards a child. } \\
\text { (7) Sexual exploitation of a child means knowingly employing, using, persuading, inducing, enticing, or coercing any child to pose } \\
\text { in the nude for the purpose of sexual arousal of any person or for profit, or to engage in any sexual or simulated sexual conduct for } \\
\text { the purpose of photographing, filming, recording, or displaying in any way the sexual or simulated sexual conduct, and includes } \\
\text { displaying, distributing, possessing for the purpose of distribution, or selling material depicting a child in the nude or engaging in } \\
\text { sexual or simulated sexual conduct. }\end{array}$ \\
\hline $\begin{array}{l}\text { Persons Required to } \\
\text { Report } \\
\text { (Utah) }\end{array}$ & $\begin{array}{l}\text { U.C.A. } 1953 \text { § 62a-4a-403 (West 2008) } \\
\text { Any person (except clergy unless consent from the confessor is secured). }\end{array}$ \\
\hline
\end{tabular}

NOTE:

** For purposes of this chart, corrections officers, police officers, peace officers, probation officers or "catch-all” phrases such as "all persons" have been bolded. However, many mandatory reporters include professionals who may have contact or work in correctional facilities. Such individuals include physicians, nurses, dentists, teachers and social workers. These statutes can be used as a tool to require staff other than correctional officers to report sexual misconduct with inmates.

This publication is developed by the NIC/WCL Project on Addressing Prison Rape under NIC Cooperative Agreement 06S20GJJ1.

This is not to be reproduced or cited without permission from the authors.

American University, Washington College of Law

Current as of May 7, 2009 


\section{Fifty State Survey of Mandatory Reporting Statutes}

\section{NIC/WCL Project on Addressing Prison Rape}

\begin{tabular}{|c|c|}
\hline $\begin{array}{l}\text { Reporting } \\
\text { Procedures } \\
\text { (Utah) }\end{array}$ & $\begin{array}{l}\text { U.C.A. } 1953 \text { § 62a-4a-403 (West 2008) } \\
\text { (1) Immediately notify the nearest peace officer, law enforcement agency, or office of the division. }\end{array}$ \\
\hline $\begin{array}{l}\text { Penalty for Failure to } \\
\text { Report } \\
\text { (Utah) }\end{array}$ & $\begin{array}{l}\text { U.C.A. } 1953 \text { § 62a-4a-411 (West 2008) } \\
\text { Willful failure to report when required to do so is guilty of a class B misdemeanor. }\end{array}$ \\
\hline $\begin{array}{l}\text { Mandatory } \\
\text { Reporting Statute } \\
\text { (Utah) }\end{array}$ & $\begin{array}{l}\text { AGAINST AN ADULT } \\
\text { U.C.A. } 1953 \text { § 62A-3-305 (West 2008) }\end{array}$ \\
\hline $\begin{array}{l}\text { What has to be } \\
\text { reported? } \\
\text { (Utah) }\end{array}$ & $\begin{array}{l}\text { U.C.A. } 1953 \text { § 62A-3-305 (West 2008) } \\
\text { Reason to believe that any vulnerable adult has been the subject of abuse, neglect, or exploitation. }\end{array}$ \\
\hline $\begin{array}{l}\text { Relevant Definitions } \\
\text { (Utah) }\end{array}$ & $\begin{array}{l}\text { U.C.A. } 1953 \S 62 \mathrm{~A}-3-301 \text { (West 2008) } \\
\text { (2) “Abuse” means: } \\
\text { (a) attempting to cause harm, intentionally or knowingly causing harm, or intentionally or knowingly placing another in fear of } \\
\text { imminent harm; } \\
\text { (b) unreasonable or inappropriate use of physical restraint, medication, or isolation that causes or is likely to cause harm to a } \\
\text { vulnerable adult that is in conflict with a physician's orders or used as an unauthorized substitute for treatment, unless that conduct } \\
\text { furthers the health and safety of the adult; } \\
\text { (c) emotional or psychological abuse; } \\
\text { (d) sexual offense; or } \\
\text { (e) deprivation of life sustaining treatment, except: }\end{array}$ \\
\hline
\end{tabular}

NOTE:

** For purposes of this chart, corrections officers, police officers, peace officers, probation officers or “catch-all” phrases such as “all persons” have been bolded. However, many mandatory reporters include professionals who may have contact or work in correctional facilities. Such individuals include physicians, nurses, dentists, teachers and social workers. These statutes can be used as a tool to require staff other than correctional officers to report sexual misconduct with inmates.

This publication is developed by the NIC/WCL Project on Addressing Prison Rape under NIC Cooperative Agreement 06S20GJJ1.

This is not to be reproduced or cited without permission from the authors.

American University, Washington College of Law

Current as of May 7, 2009 


\section{Fifty State Survey of Mandatory Reporting Statutes}

\section{NIC/WCL Project on Addressing Prison Rape}

\begin{tabular}{|c|c|}
\hline $\begin{array}{l}\text { Relevant Definitions } \\
\text { Cont'd } \\
\text { (Utah) }\end{array}$ & 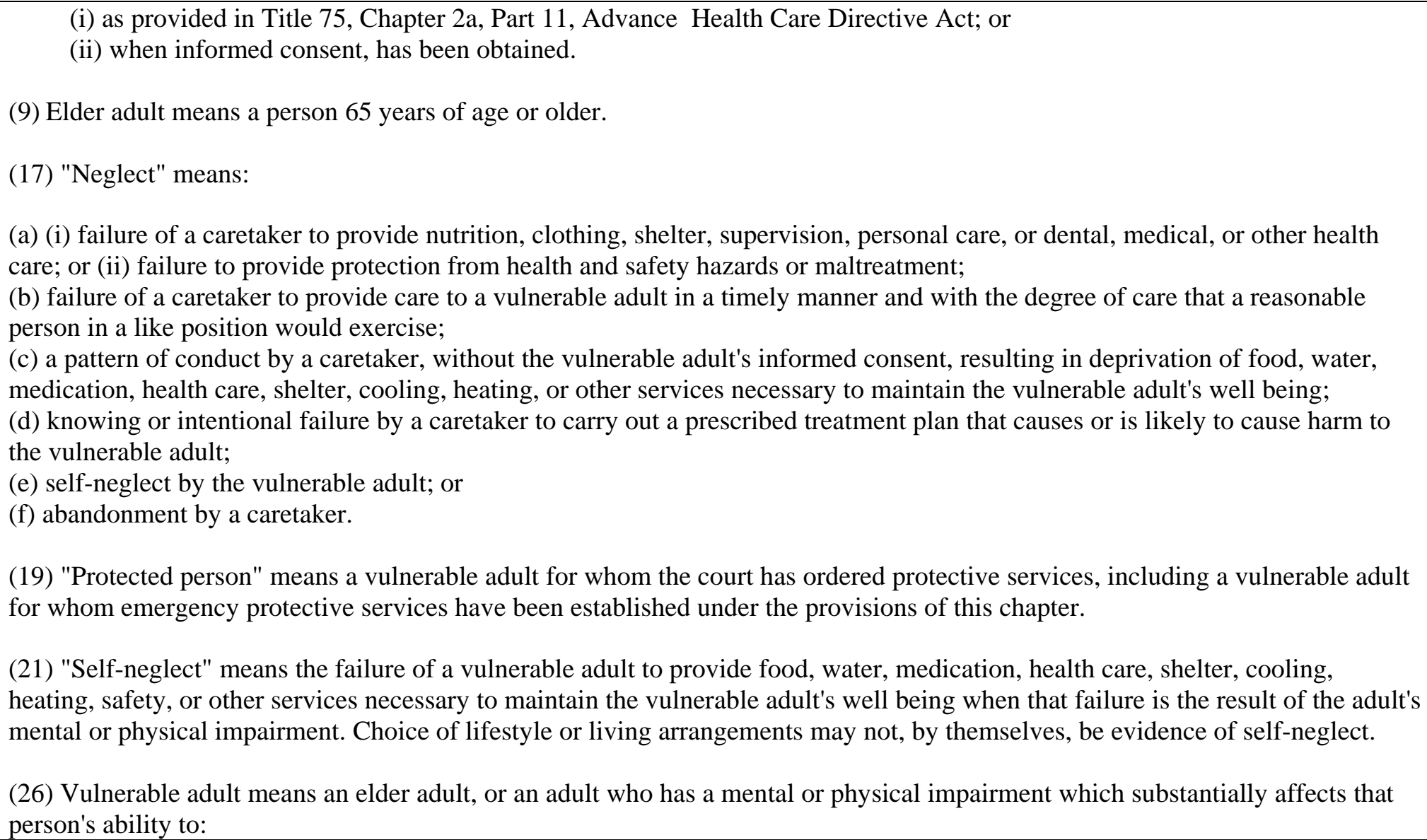 \\
\hline
\end{tabular}

NOTE:

** For purposes of this chart, corrections officers, police officers, peace officers, probation officers or “catch-all” phrases such as “all persons” have been bolded. However, many mandatory reporters include professionals who may have contact or work in correctional facilities. Such individuals include physicians, nurses, dentists, teachers and social workers. These statutes can be used as a tool to require staff other than correctional officers to report sexual misconduct with inmates.

This publication is developed by the NIC/WCL Project on Addressing Prison Rape under NIC Cooperative Agreement 06S20GJJ1.

This is not to be reproduced or cited without permission from the authors.

American University, Washington College of Law

Current as of May 7, 2009 


\section{Fifty State Survey of Mandatory Reporting Statutes}

\section{NIC/WCL Project on Addressing Prison Rape}

\begin{tabular}{|c|c|}
\hline $\begin{array}{l}\text { Relevant Definitions } \\
\text { Cont'd } \\
\text { (Utah) }\end{array}$ & 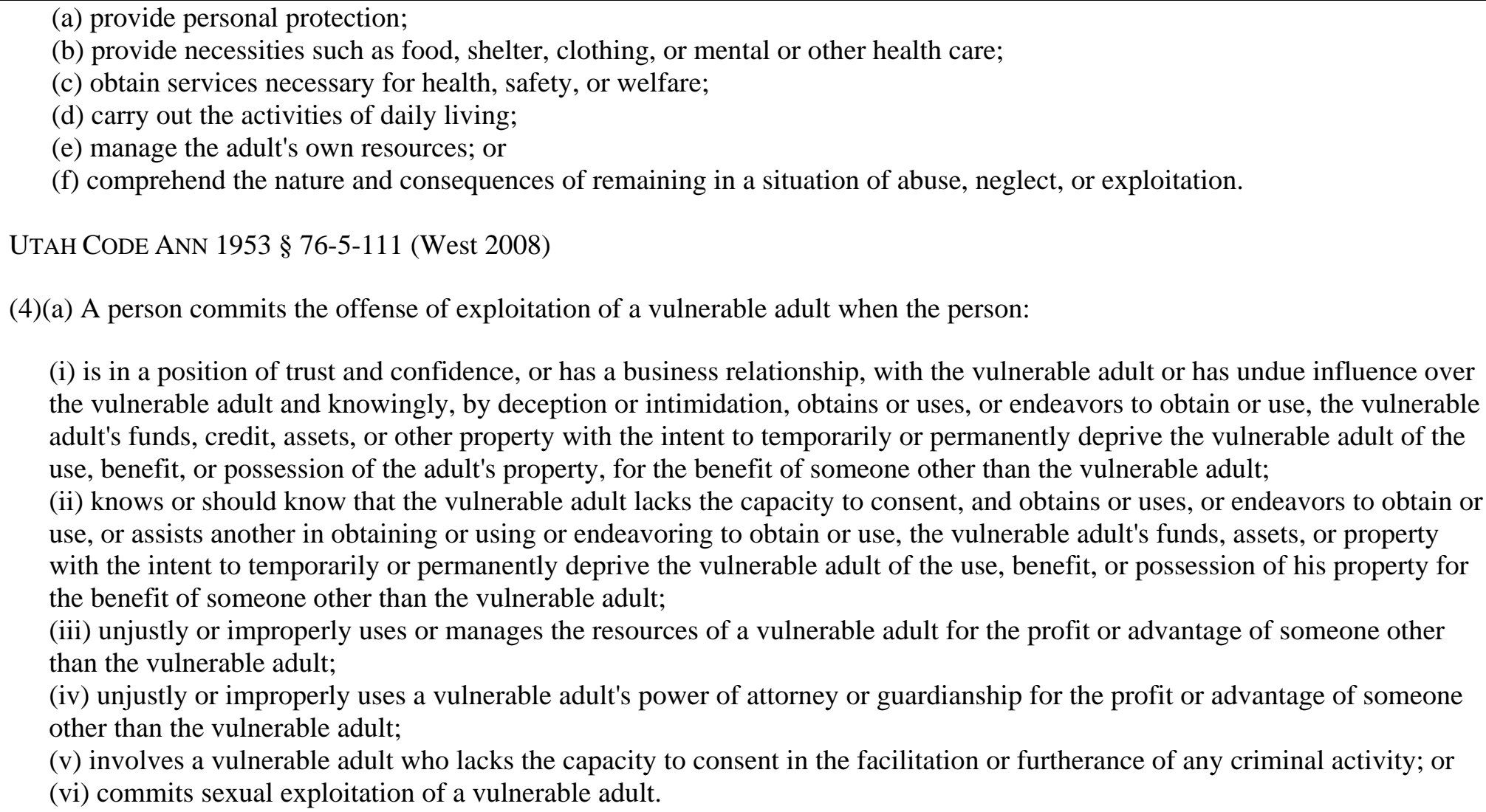 \\
\hline
\end{tabular}

NOTE:

** For purposes of this chart, corrections officers, police officers, peace officers, probation officers or "catch-all” phrases such as “all persons” have been bolded. However, many mandatory reporters include professionals who may have contact or work in correctional facilities. Such individuals include physicians, nurses, dentists, teachers and social workers. These statutes can be used as a tool to require staff other than correctional officers to report sexual misconduct with inmates.

This publication is developed by the NIC/WCL Project on Addressing Prison Rape under NIC Cooperative Agreement 06S20GJJ1.

This is not to be reproduced or cited without permission from the authors.

American University, Washington College of Law

Current as of May 7, 2009 


\section{Fifty State Survey of Mandatory Reporting Statutes}

\section{NIC/WCL Project on Addressing Prison Rape}

\begin{tabular}{|c|c|}
\hline $\begin{array}{l}\text { Persons Required to } \\
\text { Report } \\
\text { (Utah) }\end{array}$ & $\begin{array}{l}\text { U.C.A. } 1953 \S 62 \text { A-3-305 (West 2008) } \\
\text { (1) Any person who has reason to believe that any vulnerable adult has been the subject of abuse, neglect, or exploitation. }\end{array}$ \\
\hline $\begin{array}{l}\text { Reporting } \\
\text { Procedures } \\
\text { (Utah) }\end{array}$ & $\begin{array}{l}\text { U.C.A. } 1953 \text { § 62A-3-305 (West 2008) } \\
\text { (1) Immediately notify Adult Protective Services intake or the nearest law enforcement agency. }\end{array}$ \\
\hline $\begin{array}{l}\text { Penalty for Failure to } \\
\text { Report } \\
\text { (Utah) }\end{array}$ & $\begin{array}{l}\text { U.C.A. } 1953 \text { § 62A-3-305 (West 2008) } \\
\text { (4) Any person who willfully fails to report suspected abuse, neglect, or exploitation of a vulnerable adult is guilty of a class B } \\
\text { misdemeanor. }\end{array}$ \\
\hline & VERMONT \\
\hline $\begin{array}{l}\text { Mandatory } \\
\text { Reporting Statute } \\
\text { (Vermont) }\end{array}$ & $\begin{array}{l}\text { AGAINST A CHILD } \\
33 \text { V.S.A. § } 4913 \text { (West 2008) }\end{array}$ \\
\hline $\begin{array}{l}\text { What has to be } \\
\text { reported? } \\
\text { (Vermont) }\end{array}$ & $\begin{array}{l}33 \text { V.S.A. § } 4913 \text { (West 2008) } \\
\text { (a) Reasonable cause to believe that any child has been abused or neglected. }\end{array}$ \\
\hline $\begin{array}{l}\text { Relevant Definitions } \\
\text { (Vermont) }\end{array}$ & 33 V.S.A. § 4912 (West 2008) \\
\hline
\end{tabular}

** For purposes of this chart, corrections officers, police officers, peace officers, probation officers or “catch-all” phrases such as “all persons” have been bolded. However, many mandatory reporters include professionals who may have contact or work in correctional facilities. Such individuals include physicians, nurses, dentists, teachers and social workers. These statutes can be used as a tool to require staff other than correctional officers to report sexual misconduct with inmates.

This publication is developed by the NIC/WCL Project on Addressing Prison Rape under NIC Cooperative Agreement 06S20GJJ1.

This is not to be reproduced or cited without permission from the authors.

American University, Washington College of Law

Current as of May 7, 2009 


\section{Fifty State Survey of Mandatory Reporting Statutes}

\section{NIC/WCL Project on Addressing Prison Rape}

\begin{tabular}{|c|c|}
\hline $\begin{array}{l}\text { Relevant Definitions } \\
\text { Cont'd } \\
\text { (Vermont) }\end{array}$ & $\begin{array}{l}\text { (1) “Child” means an individual under the age of majority. } \\
\text { (2) “Abused” or "neglected child” means a child whose physical health, psychological growth and development or welfare is } \\
\text { harmed or is at substantial risk of harm by the acts or omissions of his or her parent or other person responsible for the child's } \\
\text { welfare. An "abused or neglected child” also means a child who is sexually abused or at substantial risk of sexual abuse by any } \\
\text { person. } \\
\text { (8) Sexual abuse consists of any act or acts by any person involving sexual molestation or exploitation of a child including but not } \\
\text { limited to incest, prostitution, rape, sodomy, or any lewd and lascivious conduct involving a child. Sexual abuse also includes the } \\
\text { aiding, abetting, counseling, hiring, or procuring of a child to perform or participate in any photograph, motion picture, exhibition, } \\
\text { show, representation, or other presentation which, in whole or in part, depicts a sexual conduct, sexual excitement or } \\
\text { sadomasochistic abuse involving a child. }\end{array}$ \\
\hline $\begin{array}{l}\text { Persons Required to } \\
\text { Report } \\
\text { (Vermont) }\end{array}$ & $\begin{array}{l}33 \text { V.S.A. § } 4913 \text { (West 2008) } \\
\text { (a) } \\
\text { - Police officer; } \\
\text { - Probation officer; } \\
\text { - Physician, surgeon, osteopath, chiropractor, or physician's assistant, any resident physician, intern, or any hospital } \\
\text { administrator in any hospital in this state, whether or not so registered, and any registered nurse, licensed practical nurse, } \\
\text { medical examiner, dentist, psychologist, any other health care provider; } \\
\text { - School superintendent, school teacher, school librarian, school principal, school guidance counselor; } \\
\text { - Child care worker; } \\
\text { - Mental health professional; } \\
\text { - Social worker; } \\
\text { - Camp owner, camp administrator, camp counselor; or } \\
\text { - Member of the clergy. }\end{array}$ \\
\hline
\end{tabular}

** For purposes of this chart, corrections officers, police officers, peace officers, probation officers or "catch-all” phrases such as “all persons” have been bolded. However, many mandatory reporters include professionals who may have contact or work in correctional facilities. Such individuals include physicians, nurses, dentists, teachers and social workers. These statutes can be used as a tool to require staff other than correctional officers to report sexual misconduct with inmates.

This publication is developed by the NIC/WCL Project on Addressing Prison Rape under NIC Cooperative Agreement 06S20GJJ1.

This is not to be reproduced or cited without permission from the authors.

American University, Washington College of Law

Current as of May 7, 2009 


\section{Fifty State Survey of Mandatory Reporting Statutes}

\section{NIC/WCL Project on Addressing Prison Rape}

\begin{tabular}{|c|c|}
\hline $\begin{array}{l}\text { Persons Required to } \\
\text { Report Cont'd } \\
\text { (Vermont) }\end{array}$ & $\begin{array}{l}\text { (b) Any other concerned person not listed in subsection (a) of this section who has reasonable cause to believe that any child has } \\
\text { been abused or neglected may report or cause a report to be made in accordance with the provisions of section } 4914 \text { of this title. }\end{array}$ \\
\hline $\begin{array}{l}\text { Reporting } \\
\text { Procedures } \\
\text { (Vermont) }\end{array}$ & $\begin{array}{l}33 \text { V.S.A. § } 4913 \text { (West 2008) } \\
\text { (a) Report or cause a report to be made in accordance with the provisions of section } 4914 \text { of this title within } 24 \text { hours. } \\
33 \text { V.S.A. § } 4913 \text { (West 2008) } \\
\text { A report shall be made orally or in writing to the commissioner of social and rehabilitation services or designee. The commissioner } \\
\text { or designee shall request the reporter to follow the oral report with a written report, unless the reporter is anonymous. Reports shall } \\
\text { contain the name and address of the reporter as well as the names and addresses of the child and the parents or other persons } \\
\text { responsible for the child's care, if known; the age of the child; the nature and extent of the child's injuries together with any } \\
\text { evidence of previous abuse and neglect of the child or the child's siblings; and any other information that the reporter believes } \\
\text { might be helpful in establishing the cause of the injuries or reasons for the neglect as well as in protecting the child and assisting } \\
\text { the family. If a report of child abuse or neglect involves the acts or omissions of the commissioner for children and families or } \\
\text { employees of that department, then the report shall be directed to the secretary of the agency of human services who shall cause } \\
\text { the report to be investigated by other appropriate agency staff other than staff of the department for children and families. If the } \\
\text { report is substantiated, services shall be offered to the child and to his or her family or caretaker according to the requirements of } \\
\text { section } 4915 \text { of this title. }\end{array}$ \\
\hline
\end{tabular}

NOTE:

** For purposes of this chart, corrections officers, police officers, peace officers, probation officers or "catch-all” phrases such as "all persons" have been bolded. However, many mandatory reporters include professionals who may have contact or work in correctional facilities. Such individuals include physicians, nurses, dentists, teachers and social workers. These statutes can be used as a tool to require staff other than correctional officers to report sexual misconduct with inmates.

This publication is developed by the NIC/WCL Project on Addressing Prison Rape under NIC Cooperative Agreement 06S20GJJ1.

This is not to be reproduced or cited without permission from the authors.

American University, Washington College of Law

Current as of May 7, 2009 


\section{Fifty State Survey of Mandatory Reporting Statutes}

\section{NIC/WCL Project on Addressing Prison Rape}

\begin{tabular}{|c|c|}
\hline $\begin{array}{l}\text { Penalty for Failure to } \\
\text { Report } \\
\text { (Vermont) }\end{array}$ & $\begin{array}{l}33 \text { V.S.A. } § 4913 \text { (West 2008) } \\
\text { (e)(1) A person who violates this section shall be fined not more than } \$ 500.00 \text {. } \\
\text { (e)(2) A person who violates this section with the intent to conceal abuse or neglect of a child shall be imprisoned not more than } \\
\text { six months or fined not more than } \$ 1,000.00 \text {, or both. } \\
\text { This section shall not be construed to prohibit a prosecution under any other provision of law. }\end{array}$ \\
\hline $\begin{array}{l}\text { Mandatory } \\
\text { Reporting Statute } \\
\text { (Vermont) }\end{array}$ & $\begin{array}{l}\text { AGAINST AN ADULT } \\
33 \text { V.S.A. § } 6903 \text { (West 2008) }\end{array}$ \\
\hline $\begin{array}{l}\text { What has to be } \\
\text { reported? } \\
\text { (Vermont) }\end{array}$ & $\begin{array}{l}33 \text { V.S.A. § } 6903 \text { (West 2008) } \\
\text { (a) Knows of or has received information of abuse, neglect or exploitation of a vulnerable adult or who has reason to suspect that } \\
\text { any vulnerable adult has been abused, neglected or exploited. }\end{array}$ \\
\hline $\begin{array}{l}\text { Relevant Definitions } \\
\text { (Vermont) }\end{array}$ & $\begin{array}{l}33 \text { V.S.A. § } 6902 \text { (West 2008) } \\
\text { (1) “Abuse” means: } \\
\text { (E) Any treatment of a vulnerable adult which places life, health or welfare in jeopardy or which is likely to result in } \\
\text { impairment of health; } \\
\text { (F) Any conduct committed with an intent or reckless disregard that such conduct is likely to cause unnecessary harm, } \\
\text { unnecessary pain or unnecessary suffering to a vulnerable adult; } \\
\text { (G) Unnecessary or unlawful confinement or unnecessary or unlawful restraint of a vulnerable adult; } \\
\text { (H) Any sexual activity with a vulnerable adult by a caregiver who volunteers for or is paid by a caregiving facility or program. } \\
\text { This definition shall not apply to a consensual relationship between a vulnerable adult and a spouse, nor to a consensual } \\
\text { relationship between a vulnerable adult and a caregiver hired, supervised, and directed by the vulnerable adult; }\end{array}$ \\
\hline
\end{tabular}

NOTE:

** For purposes of this chart, corrections officers, police officers, peace officers, probation officers or “catch-all” phrases such as “all persons” have been bolded. However, many mandatory reporters include professionals who may have contact or work in correctional facilities. Such individuals include physicians, nurses, dentists, teachers and social workers. These statutes can be used as a tool to require staff other than correctional officers to report sexual misconduct with inmates.

This publication is developed by the NIC/WCL Project on Addressing Prison Rape under NIC Cooperative Agreement 06S20GJJ1.

This is not to be reproduced or cited without permission from the authors.

American University, Washington College of Law

Current as of May 7, 2009 


\title{
Fifty State Survey of Mandatory Reporting Statutes
}

\section{NIC/WCL Project on Addressing Prison Rape}

\begin{tabular}{|c|c|}
\hline $\begin{array}{l}\text { Relevant Definitions } \\
\text { Cont'd } \\
\text { (Vermont) }\end{array}$ & 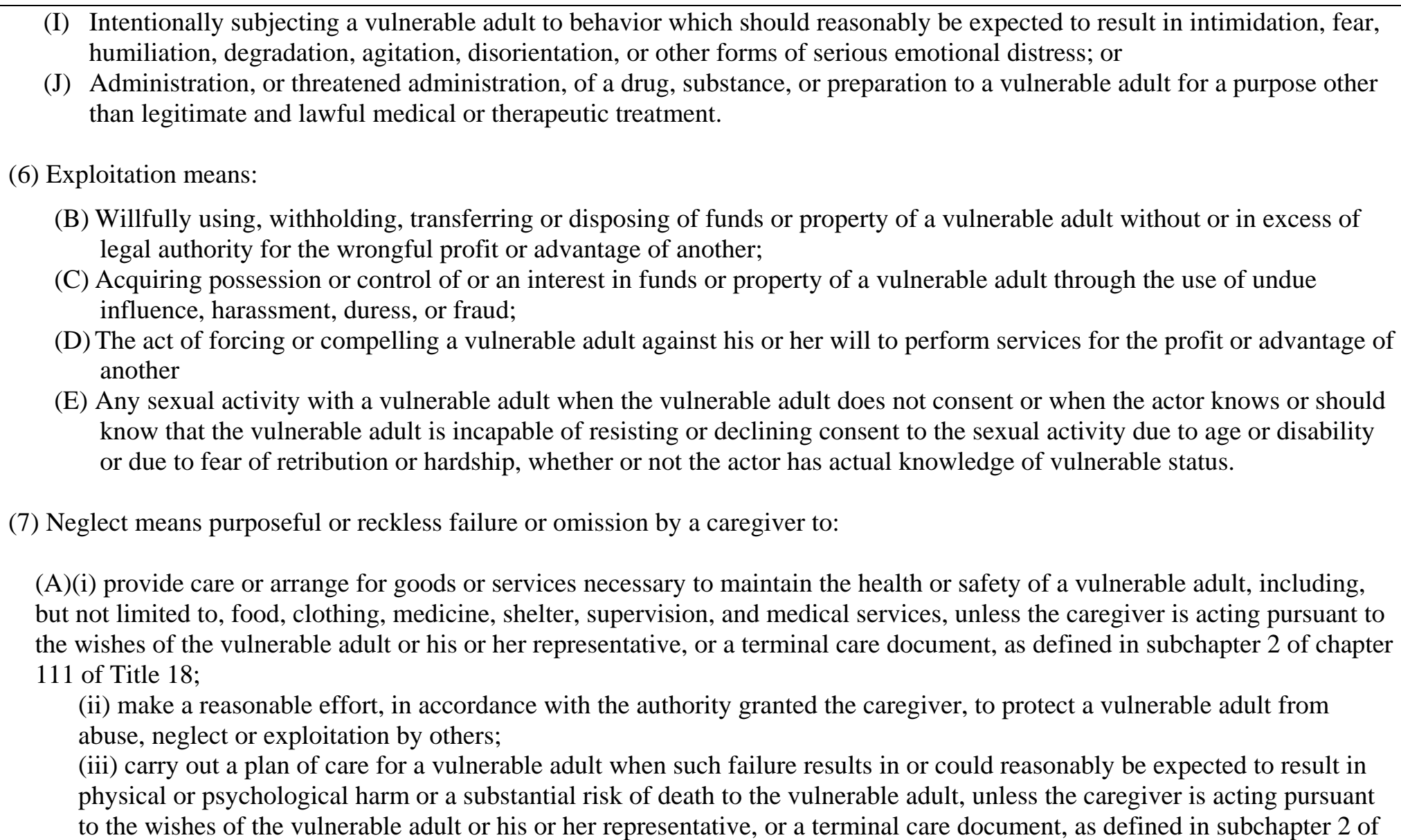 \\
\hline
\end{tabular}

NOTE:

\begin{abstract}
** For purposes of this chart, corrections officers, police officers, peace officers, probation officers or "catch-all” phrases such as “all persons” have been bolded. However, many mandatory reporters include professionals who may have contact or work in correctional facilities. Such individuals include physicians, nurses, dentists, teachers and social workers. These statutes can be used as a tool to require staff other than correctional officers to report sexual misconduct with inmates.
\end{abstract}

This publication is developed by the NIC/WCL Project on Addressing Prison Rape under NIC Cooperative Agreement 06S20GJJ1.

This is not to be reproduced or cited without permission from the authors.

American University, Washington College of Law

Current as of May 7, 2009 


\section{Fifty State Survey of Mandatory Reporting Statutes}

\section{NIC/WCL Project on Addressing Prison Rape}

\begin{tabular}{|c|c|}
\hline $\begin{array}{l}\text { Relevant Definitions } \\
\text { Cont'd } \\
\text { (Vermont) }\end{array}$ & $\begin{array}{l}\text { chapter } 111 \text { of Title 18; or } \\
\text { (iv) report significant changes in the health status of a vulnerable adult to a physician, nurse, or immediate supervisor, when } \\
\text { the caregiver is employed by an organization that offers, provides or arranges for personal care. } \\
\text { (11) "Sexual activity" means a sexual act, other than appropriate medical care or personal hygiene, or lewd and lascivious conduct. } \\
\text { (14) "Vulnerable adult" means any person } 18 \text { years of age or older who: } \\
\text { (A) is a resident of a facility required to be license; } \\
\text { (B) is a resident of a psychiatric hospital or a psychiatric unit of a hospital; } \\
\text { (C) has been receiving personal care services for more than one month from a home health agency certified by the Vermont } \\
\text { department of health or from a person or organization that offers, provides, or arranges for personal care; or } \\
\text { (D) regardless of residence or whether any type of service is received, is impaired due to brain damage, infirmities of aging, or } \\
\text { a physical, mental, or developmental disability: } \\
\text { (i) that results in some impairment of the individual's ability to provide for his or her own care without assistance, } \\
\text { including the provision of food, shelter, clothing, health care, supervision, or management of finances; or } \\
\text { (ii) because of the disability or infirmity, the individual has an impaired ability to protect himself or herself from abuse, } \\
\text { neglect, or exploitation. }\end{array}$ \\
\hline $\begin{array}{l}\text { Persons Required to } \\
\text { Report } \\
\text { (Vermont) }\end{array}$ & $\begin{array}{l}33 \text { V.S.A. § } 6903 \text { (West 2008) } \\
\text { (a) Any of the following, other than a crisis worker acting pursuant to section } 1614 \text { of Title 12, who knows of or has received } \\
\text { information of abuse, neglect or exploitation of a vulnerable adult or who has reason to suspect that any vulnerable adult has } \\
\text { been abused, neglected or exploited shall report or cause a report to be made } \\
\text { (1) All employees, contractors and grantees of the agency of human services who are involved in caregiving; }\end{array}$ \\
\hline
\end{tabular}

NOTE:

** For purposes of this chart, corrections officers, police officers, peace officers, probation officers or “catch-all” phrases such as “all persons” have been bolded. However, many mandatory reporters include professionals who may have contact or work in correctional facilities. Such individuals include physicians, nurses, dentists, teachers and social workers. These statutes can be used as a tool to require staff other than correctional officers to report sexual misconduct with inmates.

This publication is developed by the NIC/WCL Project on Addressing Prison Rape under NIC Cooperative Agreement 06S20GJJ1.

This is not to be reproduced or cited without permission from the authors.

American University, Washington College of Law

Current as of May 7, 2009 


\section{Fifty State Survey of Mandatory Reporting Statutes}

\section{NIC/WCL Project on Addressing Prison Rape}

\begin{tabular}{|c|c|}
\hline $\begin{array}{l}\text { Persons Required to } \\
\text { Report Cont'd } \\
\text { (Vermont) }\end{array}$ & $\begin{array}{l}\text { (2) A physician, osteopath, chiropractor or physician's assistant, nurse, medical examiner, licensed nursing assistant, emergency } \\
\text { medical services personnel, dentist, or psychologist; } \\
\text { (3) A school teacher, school librarian, school administrator, school guidance counselor, school aide, school bus driver, or school } \\
\text { employee or school contractor who works regularly with students; } \\
\text { (4) A mental health professional, social worker, person or organization that offers, provides, or arranges for personal care for } \\
\text { vulnerable adults, a caregiver employed by a vulnerable adult, employee of or contractor involved in caregiving for a } \\
\text { community mental health center, law enforcement officer, and an individual who works regularly with vulnerable adults and } \\
\text { who is an employee of an adult day care center, area agency on aging, senior center, or meal program designed primarily to } \\
\text { serve vulnerable adults; } \\
\text { (5) A hospital, nursing home, residential care home, home health agency or any entity providing nursing or nursing related } \\
\text { services for remuneration, intermediate care facility for adults with mental retardation, therapeutic community residence, } \\
\text { group home, developmental home, school or contractor involved in caregiving, operator or employee of any of these } \\
\text { facilities or agencies. }\end{array}$ \\
\hline $\begin{array}{l}\text { Reporting } \\
\text { Procedures } \\
\text { (Vermont) }\end{array}$ & $\begin{array}{l}33 \text { V.S.A. § } 6903 \text { (West 2008) } \\
\text { (a) Report or cause a report to be made within } 48 \text { hours. } \\
33 \text { V.S.A. § } 6904 \text { (West 2008) } \\
\text { A report shall be made orally or in writing to the commissioner or designee as soon as possible, but in no event later than } 48 \text { hours } \\
\text { thereafter. The report may also be made to a law enforcement officer. If an oral report is made by telephone or otherwise, the } \\
\text { commissioner or designee shall request that it be followed within one week by a report in writing. Reports shall contain the name } \\
\text { and address of the reporter as well as the names and addresses of the vulnerable adult and persons responsible for his or her care, if } \\
\text { known; the age of the vulnerable adult; the nature of his or her disability, the nature and extent of the vulnerable adult's abuse, } \\
\text { neglect or exploitation together with any evidence of previous abuse, neglect or exploitation of the vulnerable adult; and any other } \\
\text { information that the reporter believes might be helpful in establishing the cause of any injuries or reasons for the abuse, neglect or } \\
\text { exploitation as well as in protecting the vulnerable adult. If a report of abuse, neglect, or exploitation involves the acts or }\end{array}$ \\
\hline
\end{tabular}

NOTE:

** For purposes of this chart, corrections officers, police officers, peace officers, probation officers or “catch-all” phrases such as “all persons” have been bolded. However, many mandatory reporters include professionals who may have contact or work in correctional facilities. Such individuals include physicians, nurses, dentists, teachers and social workers. These statutes can be used as a tool to require staff other than correctional officers to report sexual misconduct with inmates.

This publication is developed by the NIC/WCL Project on Addressing Prison Rape under NIC Cooperative Agreement 06S20GJJ1.

This is not to be reproduced or cited without permission from the authors.

American University, Washington College of Law

Current as of May 7, 2009 


\section{Fifty State Survey of Mandatory Reporting Statutes}

\section{NIC/WCL Project on Addressing Prison Rape}

\begin{tabular}{|c|c|}
\hline $\begin{array}{l}\text { Reporting } \\
\text { Procedures Cont'd } \\
\text { (Vermont) }\end{array}$ & $\begin{array}{l}\text { omissions of the commissioner or employees of that department, then such reports shall be directed to the secretary of the agency } \\
\text { of human services who shall cause the report to be investigated by appropriate staff other than staff of the department. }\end{array}$ \\
\hline $\begin{array}{l}\text { Penalty for Failure to } \\
\text { Report } \\
\text { (Vermont) }\end{array}$ & $\begin{array}{l}33 \text { V.S.A. } § 6913 \text { (West 2008) } \\
\text { (b) Whenever the commissioner finds, after notice and hearing, that a mandatory reporter, as defined in subdivisions } 6903(\mathrm{a})(1) \text {, } \\
\text { (2), (3), (4), and (5) of this title, has willfully violated the provisions of subsection } 6903(\mathrm{a}) \text {, the commissioner may impose an } \\
\text { administrative penalty not to exceed } \$ 500.00 \text { per violation. For purposes of this subsection, every } 24 \text { hours that a report is not } \\
\text { made beyond the period for reporting required by subsection } 6903(\mathrm{a}) \text { shall constitute a new and separate violation, and a } \\
\text { mandatory reporter shall be liable for an administrative penalty of not more than } \$ 500.00 \text { for each } 24 \text {-hour period, not to exceed a } \\
\text { maximum penalty of } \$ 5,000.00 \text { per reportable incident. }\end{array}$ \\
\hline \multicolumn{2}{|r|}{ VIRGIN ISLANDS } \\
\hline $\begin{array}{l}\text { Mandatory } \\
\text { Reporting Statute } \\
\text { (Virgin Islands) }\end{array}$ & $\begin{array}{l}\text { AGAINST A CHILD } \\
\text { V.I. CODE ANN. tit. 5, § 5/2533 (West 2008) }\end{array}$ \\
\hline $\begin{array}{l}\text { What has to be } \\
\text { reported? } \\
\text { (Virgin Islands) }\end{array}$ & $\begin{array}{l}\text { V.I. CODE ANN. tit. 5, } \$ 5 / 2533 \text { (West 2008) } \\
\text { (a) Reasonable cause to suspect that a child has been subjected to abuse, sexual abuse or neglect, or observes the child being } \\
\text { subjected to conditions or circumstances that would reasonably result in abuse or neglect. }\end{array}$ \\
\hline
\end{tabular}

NOTE:

** For purposes of this chart, corrections officers, police officers, peace officers, probation officers or “catch-all” phrases such as “all persons” have been bolded. However, many mandatory reporters include professionals who may have contact or work in correctional facilities. Such individuals include physicians, nurses, dentists, teachers and social workers. These statutes can be used as a tool to require staff other than correctional officers to report sexual misconduct with inmates.

This publication is developed by the NIC/WCL Project on Addressing Prison Rape under NIC Cooperative Agreement 06S20GJJ1.

This is not to be reproduced or cited without permission from the authors.

American University, Washington College of Law

Current as of May 7, 2009 


\section{Fifty State Survey of Mandatory Reporting Statutes}

\section{NIC/WCL Project on Addressing Prison Rape}

\begin{tabular}{|c|c|}
\hline $\begin{array}{l}\text { Relevant Definitions } \\
\text { (Virgin Islands) }\end{array}$ & $\begin{array}{l}\text { V.I. CODE ANN. tit. 5, } \S 5 / 2502 \text { (West 2008) } \\
\text { (2) “Abuse” means any physical or mental injury inflicted on a child, other than by accidental means, by those responsible for the } \\
\text { care and maintenance of the child, which injury causes or creates a substantial risk of death, serious or protracted disfigurement, } \\
\text { protracted impairment of physical or emotional health or loss or protracted impairment of the function of any bodily organ. Abuse } \\
\text { includes the sexual abuse of a child, as defined by law, or the sexual exploitation, including the prostituting of a child and the } \\
\text { photographing or other depiction of a child for pornographic purposes, or a persistent course of sexual conduct that causes a child's } \\
\text { health or welfare to be harmed or threatened. } \\
\text { (7) “Child” means an individual under the age of } 18 \text { years. } \\
\text { (20) "Neglect” means the failure by those responsible for the care and maintenance of the child to provide the necessary support, } \\
\text { maintenance, education as required by law; and medical or mental health care, to the extent that the child's health or welfare is } \\
\text { harmed or threatened thereby. It shall also mean an abandoned child as defined in this chapter. }\end{array}$ \\
\hline $\begin{array}{l}\text { Persons Required to } \\
\text { Report } \\
\text { (Virgin Islands) }\end{array}$ & 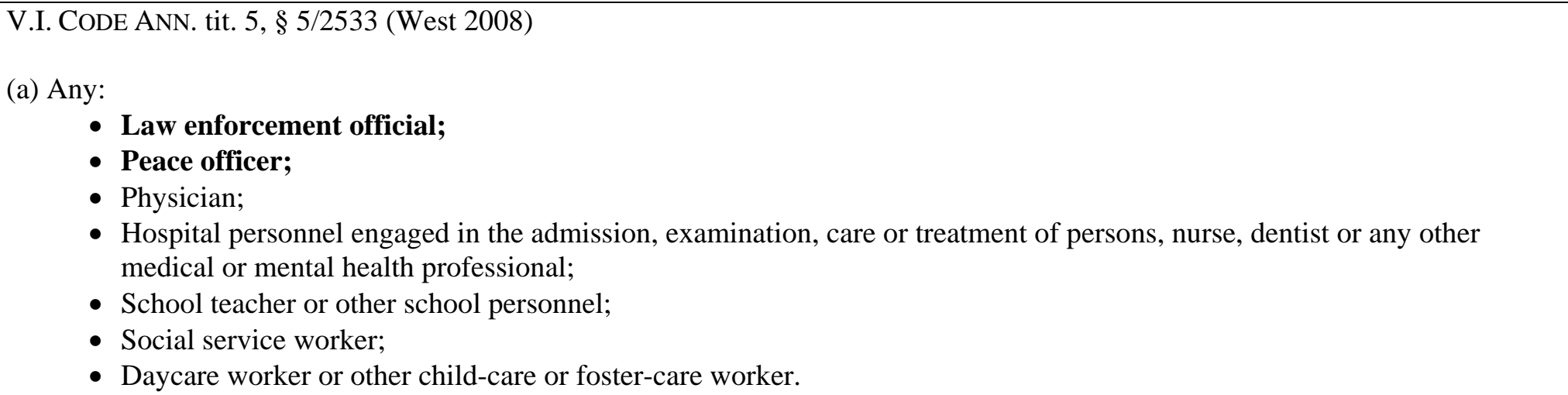 \\
\hline
\end{tabular}

NOTE:

** For purposes of this chart, corrections officers, police officers, peace officers, probation officers or “catch-all” phrases such as “all persons” have been bolded. However, many mandatory reporters include professionals who may have contact or work in correctional facilities. Such individuals include physicians, nurses, dentists, teachers and social workers. These statutes can be used as a tool to require staff other than correctional officers to report sexual misconduct with inmates.

This publication is developed by the NIC/WCL Project on Addressing Prison Rape under NIC Cooperative Agreement 06S20GJJ1.

This is not to be reproduced or cited without permission from the authors.

American University, Washington College of Law

Current as of May 7, 2009 


\section{Fifty State Survey of Mandatory Reporting Statutes}

\section{NIC/WCL Project on Addressing Prison Rape}

\begin{tabular}{|c|c|}
\hline $\begin{array}{l}\text { Reporting } \\
\text { Procedures } \\
\text { (Virgin Islands) }\end{array}$ & $\begin{array}{l}\text { V.I. CODE ANN. tit. 5, § 5/ } 2533 \text { (West 2008) } \\
\text { (a) Immediately report it or cause a report to be made. } \\
\text { V.I. CoDE ANN. tit. 5, §5/2534 (West 2008) } \\
\text { (a) Reports of child abuse, sexual abuse or neglect made pursuant to this subchapter shall be made immediately by telephone or } \\
\text { otherwise to the U.S. Virgin Islands Police Department (V.I.P.D.) or to the Department of Social Welfare. The U.S. Virgin Islands } \\
\text { Police Department (V.I.P.D.) shall relay such reports to the Department of Social Welfare immediately or, at the latest, at the } \\
\text { commencement of the next regular office hours of the Department of Social Welfare. At the request of the Department of Social } \\
\text { Welfare, an oral report shall be followed by a written report within } 48 \text { hours. } \\
\text { (b) To the extent possible, such reports shall include the following information: the names and addresses of the child and his } \\
\text { parents or other persons responsible for his care; the child's age and sex; the nature and extent of the child's injuries, sexual abuse } \\
\text { or neglect to the child or any other child in the same home; the name and address of the person responsible for the injuries, sexual } \\
\text { abuse or neglect, the family composition, the source of the report, including the name of the person making the report, his } \\
\text { occupation and his address; any action taken by the reporting source, including the taking of X-rays or color photographs or filing } \\
\text { for temporary custody; and any other information that the person making the report believes may further the purpose of this } \\
\text { subchapter. }\end{array}$ \\
\hline $\begin{array}{l}\text { Penalty for Failure to } \\
\text { Report } \\
\text { (Virgin Islands) }\end{array}$ & $\begin{array}{l}\text { V.I. CODE ANN. tit. } 5, \S 5 / 2539 \text { (West 2008) } \\
\text { Any person, official or institution required by this subchapter to report a case of alleged child abuse, sexual abuse or neglect, or to } \\
\text { perform any other act, who knowingly fails to do so, shall be guilty of a misdemeanor and shall be fined not more than } \\
\$ 500 \text { or imprisoned not more than one year, or both. }\end{array}$ \\
\hline
\end{tabular}

NOTE:

** For purposes of this chart, corrections officers, police officers, peace officers, probation officers or "catch-all” phrases such as "all persons" have been bolded. However, many mandatory reporters include professionals who may have contact or work in correctional facilities. Such individuals include physicians, nurses, dentists, teachers and social workers. These statutes can be used as a tool to require staff other than correctional officers to report sexual misconduct with inmates.

This publication is developed by the NIC/WCL Project on Addressing Prison Rape under NIC Cooperative Agreement 06S20GJJ1.

This is not to be reproduced or cited without permission from the authors.

American University, Washington College of Law

Current as of May 7, 2009 


\section{Fifty State Survey of Mandatory Reporting Statutes}

\section{NIC/WCL Project on Addressing Prison Rape}

\begin{tabular}{|c|c|}
\hline $\begin{array}{l}\text { Mandatory } \\
\text { Reporting Statute } \\
\text { (Virgin Islands) }\end{array}$ & $\begin{array}{l}\text { AGAINST AN ADULT } \\
\text { V.I. CODE ANN. tit. 34, § 34/453 (West 2008) }\end{array}$ \\
\hline $\begin{array}{l}\text { What has to be } \\
\text { reported? } \\
\text { (Virgin Islands) }\end{array}$ & $\begin{array}{l}\text { V.I. CODE ANN. tit. 34, } \S 34 / 453 \text { (West 2008) } \\
\text { (a) Reasonable cause to believe that an elderly person or disabled adult is suffering from or has died as result of abuse, neglect, } \\
\text { abandonment or exploitation. }\end{array}$ \\
\hline $\begin{array}{l}\text { Relevant Definitions } \\
\text { (Virgin Islands) } \\
\text { Relevant Definitions } \\
\text { Cont'd } \\
\text { (Virgin Islands) }\end{array}$ & $\begin{array}{l}\text { V.I. CoDE ANN. tit. 34, § 34/452 (West 2008) } \\
\text { (2) Abuse means the infliction of verbal, psychological or physical pain, injury or harm, mental anguish or harm, or unreasonable } \\
\text { confinement. } \\
\text { (6) Elderly person means an individual who is sixty (60) years of age or over. } \\
\text { (5) Disabled adult means a person eighteen (18) years of age or older who because of mental or physical dysfunctioning or } \\
\text { advanced age is unable to manage his own resources, carry out the activities of daily living or protect himself from neglect, } \\
\text { hazardous or abusive situations without assistance from others and who has no available, willing and responsibly able person to } \\
\text { assist him. } \\
\text { (8) Exploitation means an act or course of conduct to influence or interfere by misrepresentation, coercion or threats of force } \\
\text { whether for monetary, personal, or other benefit, gain or profit. } \\
\text { (9) Neglect means failure or refusal to provide treatment or services necessary to maintain physical or mental health. }\end{array}$ \\
\hline
\end{tabular}

NOTE:

** For purposes of this chart, corrections officers, police officers, peace officers, probation officers or "catch-all” phrases such as "all persons" have been bolded. However, many mandatory reporters include professionals who may have contact or work in correctional facilities. Such individuals include physicians, nurses, dentists, teachers and social workers. These statutes can be used as a tool to require staff other than correctional officers to report sexual misconduct with inmates.

This publication is developed by the NIC/WCL Project on Addressing Prison Rape under NIC Cooperative Agreement 06S20GJJ1.

This is not to be reproduced or cited without permission from the authors.

American University, Washington College of Law

Current as of May 7, 2009 


\section{Fifty State Survey of Mandatory Reporting Statutes}

\section{NIC/WCL Project on Addressing Prison Rape}

\begin{tabular}{|c|c|}
\hline $\begin{array}{l}\text { Persons Required to } \\
\text { Report } \\
\text { (Virgin Islands) }\end{array}$ & 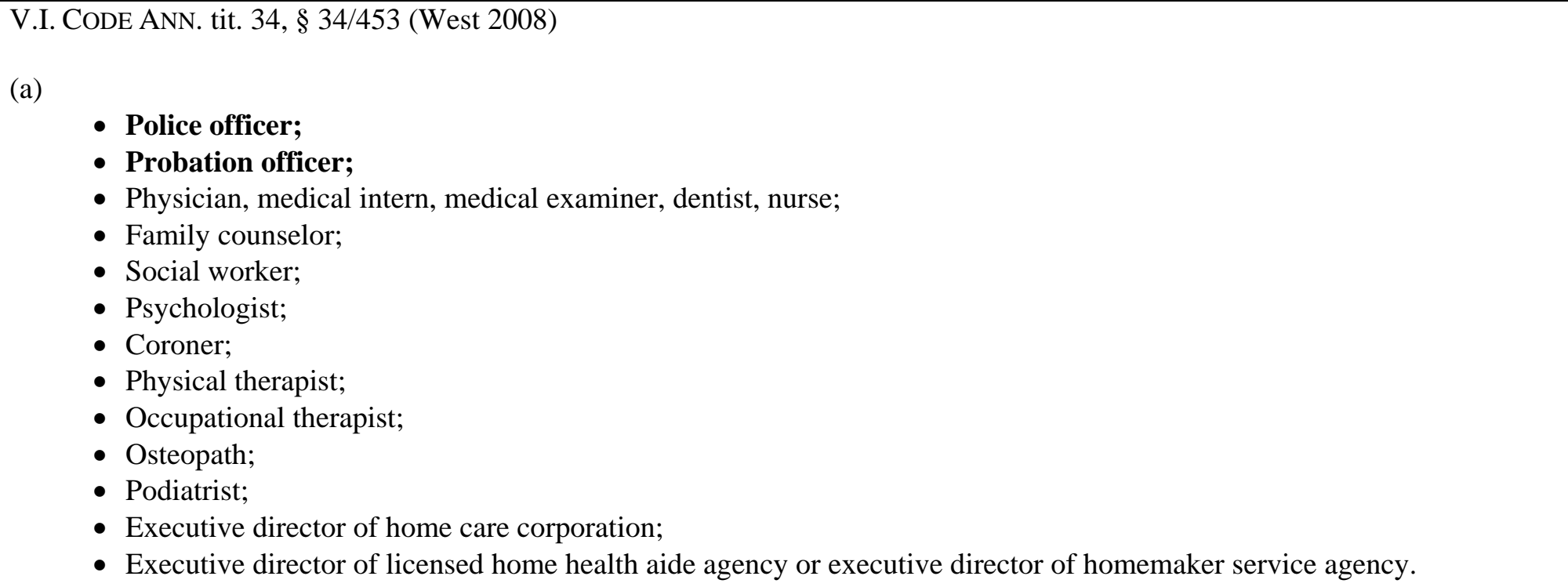 \\
\hline $\begin{array}{l}\text { Reporting } \\
\text { Procedures } \\
\text { (Virgin Islands) }\end{array}$ & $\begin{array}{l}\text { V.I. CoDE ANN. tit. 34, § 34/453 (West 2008) } \\
\text { (a) Immediately make a verbal report of such information or cause a report to be made to the Department of Human Services, and } \\
\text { shall within forty-eight (48) hours make a written report to the Department. } \\
\text { (e) Reports made under subsections (a) and (b) shall contain: } \\
\text { (1) the name, address and approximate age of the elderly person or disabled adult who is the subject of the report; } \\
\text { (2) information regarding the nature and extent of the abuse, neglect, exploitation, or abandonment; }\end{array}$ \\
\hline
\end{tabular}

NOTE:

** For purposes of this chart, corrections officers, police officers, peace officers, probation officers or "catch-all” phrases such as "all persons" have been bolded. However, many mandatory reporters include professionals who may have contact or work in correctional facilities. Such individuals include physicians, nurses, dentists, teachers and social workers. These statutes can be used as a tool to require staff other than correctional officers to report sexual misconduct with inmates.

This publication is developed by the NIC/WCL Project on Addressing Prison Rape under NIC Cooperative Agreement 06S20GJJ1.

This is not to be reproduced or cited without permission from the authors.

American University, Washington College of Law

Current as of May 7, 2009 


\section{Fifty State Survey of Mandatory Reporting Statutes}

\section{NIC/WCL Project on Addressing Prison Rape}

\begin{tabular}{|c|c|}
\hline $\begin{array}{l}\text { Reporting } \\
\text { Procedures Cont'd } \\
\text { (Virgin Islands) }\end{array}$ & $\begin{array}{l}\text { (3) the name of the person's caretaker, if known; } \\
\text { (4) any medical treatment being received or immediately required, if known; } \\
\text { (5) any other information the reporter believes to be relevant to the investigation; and } \\
\text { (6) the name and address of the reporter and where said reporter may be contacted, if the reporter wishes to provide said } \\
\text { information. }\end{array}$ \\
\hline $\begin{array}{l}\text { Penalty for Failure to } \\
\text { Report } \\
\text { (Virgin Islands) }\end{array}$ & $\begin{array}{l}\text { V.I. CODE ANN. tit. 34, } \$ 34 / 453 \text { (West 2008) } \\
\text { (a) Any person required to make a report under this subsection who fails to do so shall be punished by a fine of not more than one } \\
\text { thousand dollars }(\$ 1,000) \text {. }\end{array}$ \\
\hline & VIRGINIA \\
\hline $\begin{array}{l}\text { Mandatory } \\
\text { Reporting Statute } \\
\text { (Virginia) }\end{array}$ & $\begin{array}{l}\text { AGAINST A CHILD } \\
\text { VA. CODE ANN. § 63.2-1509 (West 2008) }\end{array}$ \\
\hline $\begin{array}{l}\text { What has to be } \\
\text { reported? } \\
\text { (Virginia) }\end{array}$ & $\begin{array}{l}\text { VA. CODE ANN. § 63.2-1509 (West 2008) } \\
\text { (A) Specified persons who, in their professional or official capacity, have reason to suspect that a child is an abused or neglected } \\
\text { child. }\end{array}$ \\
\hline
\end{tabular}

NOTE:

** For purposes of this chart, corrections officers, police officers, peace officers, probation officers or “catch-all” phrases such as “all persons” have been bolded. However, many mandatory reporters include professionals who may have contact or work in correctional facilities. Such individuals include physicians, nurses, dentists, teachers and social workers. These statutes can be used as a tool to require staff other than correctional officers to report sexual misconduct with inmates.

This publication is developed by the NIC/WCL Project on Addressing Prison Rape under NIC Cooperative Agreement 06S20GJJ1.

This is not to be reproduced or cited without permission from the authors.

American University, Washington College of Law

Current as of May 7, 2009 


\section{Fifty State Survey of Mandatory Reporting Statutes}

\section{NIC/WCL Project on Addressing Prison Rape}

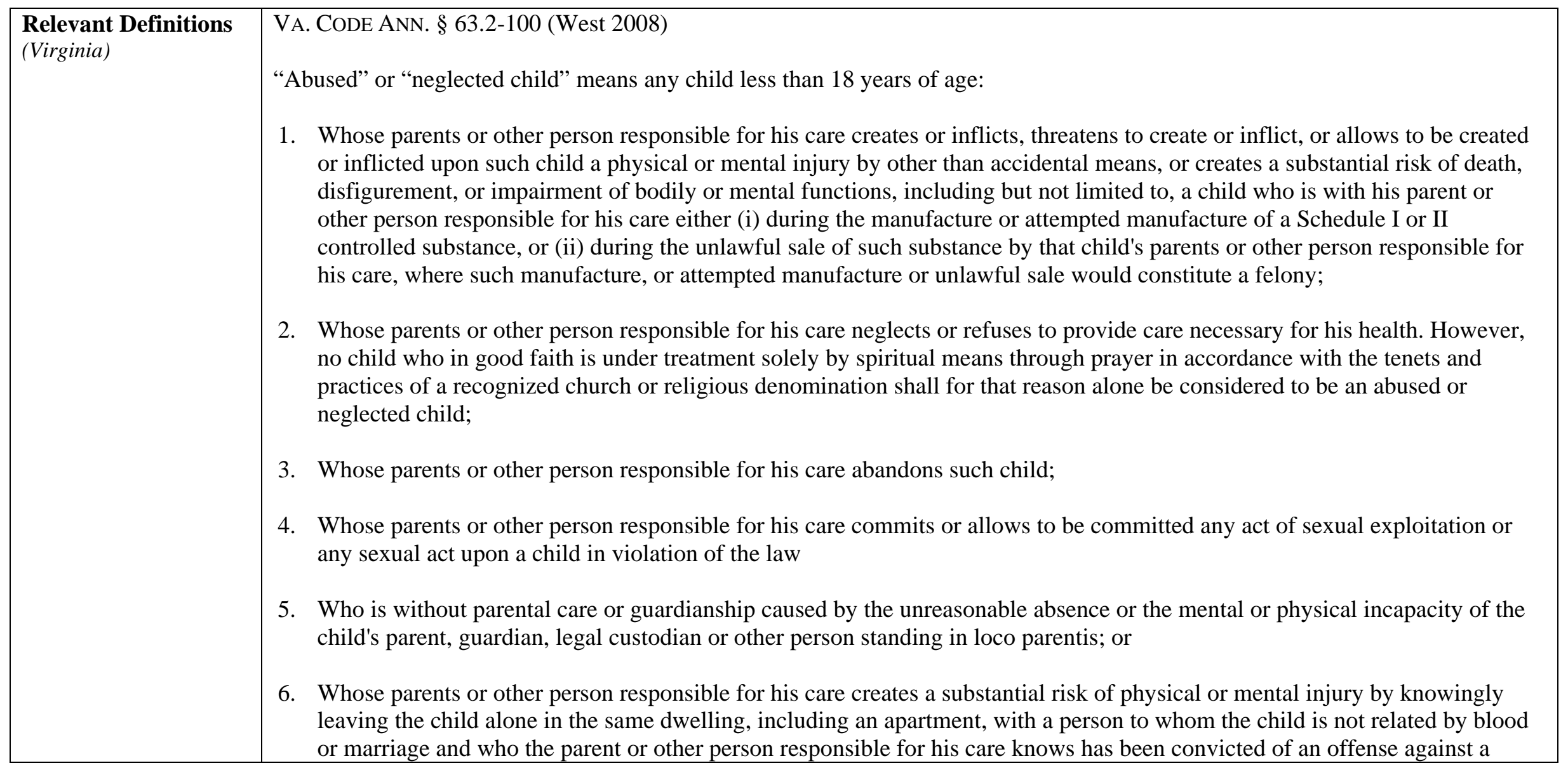

NOTE:

** For purposes of this chart, corrections officers, police officers, peace officers, probation officers or “catch-all” phrases such as “all persons” have been bolded. However, many mandatory reporters include professionals who may have contact or work in correctional facilities. Such individuals include physicians, nurses, dentists, teachers and social workers. These statutes can be used as a tool to require staff other than correctional officers to report sexual misconduct with inmates.

This publication is developed by the NIC/WCL Project on Addressing Prison Rape under NIC Cooperative Agreement 06S20GJJ1.

This is not to be reproduced or cited without permission from the authors.

American University, Washington College of Law

Current as of May 7, 2009 


\section{Fifty State Survey of Mandatory Reporting Statutes}

\section{NIC/WCL Project on Addressing Prison Rape}

\begin{tabular}{|c|c|}
\hline $\begin{array}{l}\text { Relevant Definitions } \\
\text { Cont'd } \\
\text { (Virginia) }\end{array}$ & $\begin{array}{l}\text { minor for which registration is required as a violent sexual offender.... If a civil proceeding under this title is based solely on } \\
\text { the parent having left the child at a hospital or rescue squad, it shall be an affirmative defense that such parent safely delivered } \\
\text { the child to a hospital that provides } 24 \text {-hour emergency services or to an attended rescue squad that employs emergency } \\
\text { medical technicians, within } 14 \text { days of the child's birth. For purposes of terminating parental rights and placement for } \\
\text { adoption, the court may find such a child is a neglected child upon the ground of abandonment. }\end{array}$ \\
\hline $\begin{array}{l}\text { Persons Required to } \\
\text { Report } \\
\text { (Virginia) }\end{array}$ & $\begin{array}{l}\text { VA. CODE ANN. § 63.2-1509 (West 2008) } \\
\text { A. The following persons who, in their professional or official capacity, have reason to suspect that a child is an abused or } \\
\text { neglected child, shall report the matter immediately: } \\
\text { (1) Any person licensed to practice medicine or any of the healing arts; } \\
\text { (2) Any hospital resident or intern, and any person employed in the nursing profession; } \\
\text { (3) Any person employed as a social worker; } \\
\text { (4) Any probation officer; } \\
\text { (5) Any teacher or other person employed in a public or private school, kindergarten or nursery school; } \\
\text { (6) Any person providing full-time or part-time child care for pay on a regularly planned basis; } \\
\text { (7) Any mental health professional; } \\
\text { (8) Any law--enforcement officer; } \\
\text { (9) Any mediator eligible to receive court referrals; } \\
\text { (10)Any professional staff person, not previously enumerated, employed by a private or state-operated hospital, } \\
\text { institution or facility to which children have been committed or where children have been placed for care } \\
\text { and treatment; } \\
\text { (11)Any person associated with or employed by any private organization responsible for the care, custody or } \\
\text { control of children; } \\
\text { (12)Any person who is designated a court--appointed special advocate; } \\
\text { (13)Any mediator eligible to receive court referrals; } \\
\text { (14)Any person, over the age of } 18 \text { years, who has received training approved by the Department of Social Services }\end{array}$ \\
\hline
\end{tabular}

** For purposes of this chart, corrections officers, police officers, peace officers, probation officers or “catch-all” phrases such as “all persons” have been bolded. However, many mandatory reporters include professionals who may have contact or work in correctional facilities. Such individuals include physicians, nurses, dentists, teachers and social workers. These statutes can be used as a tool to require staff other than correctional officers to report sexual misconduct with inmates.

This publication is developed by the NIC/WCL Project on Addressing Prison Rape under NIC Cooperative Agreement 06S20GJJ1.

This is not to be reproduced or cited without permission from the authors.

American University, Washington College of Law

Current as of May 7, 2009 


\section{Fifty State Survey of Mandatory Reporting Statutes}

\section{NIC/WCL Project on Addressing Prison Rape}

\begin{tabular}{|c|c|}
\hline $\begin{array}{l}\text { Persons Required to } \\
\text { Report Cont'd } \\
\text { (Virginia) }\end{array}$ & $\begin{array}{l}\text { for the purposes of recognizing and reporting child abuse and neglect; and } \\
\text { (15) Any person employed by a local department as defined in } \S 63.2-100 \text { who determines eligibility for public } \\
\text { assistance. }\end{array}$ \\
\hline $\begin{array}{l}\text { Reporting } \\
\text { Procedures } \\
\text { (Virginia) }\end{array}$ & $\begin{array}{l}\text { VA. CODE ANN. § 63.2-1509 (West 2008) } \\
\text { (A) Report the matter immediately to the local department of the county or city wherein the child resides or wherein the abuse or } \\
\text { neglect is believed to have occurred or to the Department's toll--free child abuse and neglect hotline. } \\
\text { If neither the locality in which the child resides nor where the abuse or neglect is believed to have occurred is known, then such } \\
\text { report shall be made to the local department of the county or city where the abuse or neglect was discovered or to the Department's } \\
\text { toll-free child abuse and neglect hotline. If an employee of the local department is suspected of abusing or neglecting a child, the } \\
\text { report shall be made to the court of the county or city where the abuse or neglect was discovered. Upon receipt of such a report by } \\
\text { the court, the judge shall assign the report to a local department that is not the employer of the suspected employee for } \\
\text { investigation or family assessment. The judge may consult with the Department in selecting a local department to respond to the } \\
\text { report or the complaint. } \\
\text { If the information is received by a teacher, staff member, resident, intern or nurse in the course of professional services in a } \\
\text { hospital, school or similar institution, such person may, in place of said report, immediately notify the person in charge of the } \\
\text { institution or department, or his designee, who shall make such report forthwith. } \\
\text { The initial report may be an oral report but such report shall be reduced to writing by the child abuse coordinator of the } \\
\text { local department on a form prescribed by the Board. Any person required to make the report pursuant to this subsection shall } \\
\text { disclose all information that is the basis for his suspicion of abuse or neglect of the child and, upon request, shall make available to } \\
\text { the child-protective services coordinator and the local department, which is the agency of jurisdiction, any information, records or } \\
\text { reports that document the basis for the report. All persons required by this subsection to report suspected abuse or neglect who }\end{array}$ \\
\hline
\end{tabular}

NOTE:

** For purposes of this chart, corrections officers, police officers, peace officers, probation officers or “catch-all” phrases such as “all persons” have been bolded. However, many mandatory reporters include professionals who may have contact or work in correctional facilities. Such individuals include physicians, nurses, dentists, teachers and social workers. These statutes can be used as a tool to require staff other than correctional officers to report sexual misconduct with inmates.

This publication is developed by the NIC/WCL Project on Addressing Prison Rape under NIC Cooperative Agreement 06S20GJJ1.

This is not to be reproduced or cited without permission from the authors.

American University, Washington College of Law

Current as of May 7, 2009 


\section{Fifty State Survey of Mandatory Reporting Statutes}

\section{NIC/WCL Project on Addressing Prison Rape}

\begin{tabular}{|c|c|}
\hline $\begin{array}{l}\text { Reporting } \\
\text { Procedures Cont'd } \\
\text { (Virginia) }\end{array}$ & $\begin{array}{l}\text { maintain a record of a child who is the subject of such a report shall cooperate with the investigating agency and shall make related } \\
\text { information, records and reports available to the investigating agency unless such disclosure violates the federal Family } \\
\text { Educational Rights and Privacy Act. Provision of such information, records and reports by a health care provider shall not be } \\
\text { prohibited. Criminal investigative reports received from law--enforcement agencies shall not be further disseminated by the } \\
\text { investigating agency nor shall they be subject to public disclosure. }\end{array}$ \\
\hline $\begin{array}{l}\text { Penalty for Failure to } \\
\text { Report } \\
\text { (Virginia) }\end{array}$ & $\begin{array}{l}\text { VA. CODE ANN. § 63.2-1509 (West 2008) } \\
\text { (D) Any person required to file a report pursuant to this section who fails to do so within } 72 \text { hours of his first suspicion of child } \\
\text { abuse or neglect shall be fined not more than } \$ 500 \text { for the first failure and for any subsequent failures not less than } \$ 100 \text { nor more } \\
\text { than } \$ 1,000 \text {. }\end{array}$ \\
\hline $\begin{array}{l}\text { Mandatory } \\
\text { Reporting Statute } \\
\text { (Virginia) }\end{array}$ & $\begin{array}{l}\text { AGAINST AN ADULT } \\
\text { VA. CODE ANN. § 63.2-1606 (West 2008) }\end{array}$ \\
\hline $\begin{array}{l}\text { What has to be } \\
\text { reported? } \\
\text { (Virginia) }\end{array}$ & $\begin{array}{l}\text { VA. CODE ANN. § 63.2-1606 (West 2008) } \\
\text { Matters giving reason to suspect the abuse, neglect or exploitation of adults. }\end{array}$ \\
\hline $\begin{array}{l}\text { Relevant Definitions } \\
\text { (Virginia) }\end{array}$ & $\begin{array}{l}\text { VA. CODE ANN. § 63.2-1603 (West 2008) } \\
\text { "Adult” means any person } 60 \text { years of age or older, or any person } 18 \text { years of age or older who is incapacitated and who resides in } \\
\text { the Commonwealth; provided, however, "adult" may include qualifying nonresidents who are temporarily in the Commonwealth } \\
\text { and who are in need of temporary or emergency protective services. } \\
\text { "Incapacitated person” means any adult who is impaired by reason of mental illness, mental retardation, physical illness or }\end{array}$ \\
\hline
\end{tabular}

NOTE:

** For purposes of this chart, corrections officers, police officers, peace officers, probation officers or “catch-all” phrases such as “all persons” have been bolded. However, many mandatory reporters include professionals who may have contact or work in correctional facilities. Such individuals include physicians, nurses, dentists, teachers and social workers. These statutes can be used as a tool to require staff other than correctional officers to report sexual misconduct with inmates.

This publication is developed by the NIC/WCL Project on Addressing Prison Rape under NIC Cooperative Agreement 06S20GJJ1.

This is not to be reproduced or cited without permission from the authors.

American University, Washington College of Law

Current as of May 7, 2009 


\section{Fifty State Survey of Mandatory Reporting Statutes}

\section{NIC/WCL Project on Addressing Prison Rape}

\begin{tabular}{|c|c|}
\hline $\begin{array}{l}\text { Relevant Definitions } \\
\text { Cont'd } \\
\text { (Virginia) }\end{array}$ & $\begin{array}{l}\text { disability, advanced age or other causes to the extent that the adult lacks sufficient understanding or capacity to make, } \\
\text { communicate or carry out responsible decisions concerning his or her well-being. }\end{array}$ \\
\hline $\begin{array}{l}\text { Persons Required to } \\
\text { Report } \\
\text { (Virginia) }\end{array}$ & $\begin{array}{l}\text { VA. CODE ANN. § 63.2-1606 (West 2008) } \\
\text { (a) The following persons acting in their professional capacity: } \\
\text { (1) Any person licensed, certified, or registered by health regulatory boards with the exception of persons licensed by the } \\
\text { Board of Veterinary Medicine; } \\
\text { (2) Any mental health services provider; } \\
\text { (3) Any emergency medical services personnel certified by the Board of Health; } \\
\text { (4) Any guardian or conservator of an adult; } \\
\text { (5) Any person employed by or contracted with a public or private agency or facility and working with adults in an } \\
\text { (6) Any person providing full, intermittent or occasional care to an adult for compensation, including but not limited to, } \\
\text { companion, chore, homemaker, and personal care workers; } \\
\text { (7) Any law-enforcement officer. }\end{array}$ \\
\hline $\begin{array}{l}\text { Reporting } \\
\text { Procedures } \\
\text { (Virginia) }\end{array}$ & $\begin{array}{l}\text { VA. CODE ANN. § 63.2-1606 (West 2008) } \\
\text { (A) Reported immediately upon the reporting person's determination that there is such reason to suspect. } \\
\text { Reports shall be made to the local department or the adult protective services hotline. } \\
\text { (B) The report shall be made in accordance with subsection A to the local department of the county or city wherein the adult } \\
\text { resides or wherein the adult abuse, neglect or exploitation is believed to have occurred or to the adult protective services hotline. } \\
\text { Nothing in this section shall be construed to eliminate or supersede any other obligation to report as required by law. If a person }\end{array}$ \\
\hline
\end{tabular}

** For purposes of this chart, corrections officers, police officers, peace officers, probation officers or “catch-all” phrases such as “all persons” have been bolded. However, many mandatory reporters include professionals who may have contact or work in correctional facilities. Such individuals include physicians, nurses, dentists, teachers and social workers. These statutes can be used as a tool to require staff other than correctional officers to report sexual misconduct with inmates.

This publication is developed by the NIC/WCL Project on Addressing Prison Rape under NIC Cooperative Agreement 06S20GJJ1.

This is not to be reproduced or cited without permission from the authors.

American University, Washington College of Law

Current as of May 7, 2009 


\section{Fifty State Survey of Mandatory Reporting Statutes}

\section{NIC/WCL Project on Addressing Prison Rape}

\begin{tabular}{|c|c|}
\hline $\begin{array}{l}\text { Reporting } \\
\text { Procedures Cont'd } \\
\text { (Virginia) }\end{array}$ & $\begin{array}{l}\text { required to report under this section receives information regarding abuse, neglect or exploitation while providing professional } \\
\text { services in a hospital, nursing facility or similar institution, then he may, in lieu of reporting, notify the person in charge of the } \\
\text { institution or his designee, who shall report such information, in accordance with the institution's policies and procedures for } \\
\text { reporting such matters, immediately upon his determination that there is reason to suspect abuse, neglect or exploitation. Any } \\
\text { person required to make the report or notification required by this subsection shall do so either orally or in writing and shall } \\
\text { disclose all information that is the basis for the suspicion of adult abuse, neglect or exploitation. Upon request, any person required } \\
\text { to make the report shall make available to the adult protective services worker and the local department investigating the reported } \\
\text { case of adult abuse, neglect or exploitation any information, records or reports which document the basis for the report. All } \\
\text { persons required to report suspected adult abuse, neglect or exploitation shall cooperate with the investigating adult protective } \\
\text { services worker of a local department and shall make information, records and reports which are relevant to the investigation } \\
\text { available to such worker to the extent permitted by state and federal law. Criminal investigative reports received from law- } \\
\text { enforcement agencies shall not be further disseminated by the investigating agency nor shall they be subject to public disclosure. }\end{array}$ \\
\hline $\begin{array}{l}\text { Penalty for Failure to } \\
\text { Report } \\
\text { (Virginia) }\end{array}$ & $\begin{array}{l}\text { VA. CODE ANN. } § 63.2-1606 \text { (West 2008) } \\
\text { (H) Any person who fails to make a required report or notification pursuant to subsection A shall be subject to a civil penalty of } \\
\text { not more than } \$ 500 \text { for the first failure and not less than } \$ 100 \text { nor more than } \$ 1,000 \text { for any subsequent failures. Civil penalties } \\
\text { under subdivision A } 7 \text { shall be determined by a court of competent jurisdiction, in its discretion. All other civil penalties under this } \\
\text { section shall be determined by the Commissioner or his designee. }\end{array}$ \\
\hline & WASHINGTON \\
\hline
\end{tabular}

NOTE:

** For purposes of this chart, corrections officers, police officers, peace officers, probation officers or “catch-all” phrases such as “all persons” have been bolded. However, many mandatory reporters include professionals who may have contact or work in correctional facilities. Such individuals include physicians, nurses, dentists, teachers and social workers. These statutes can be used as a tool to require staff other than correctional officers to report sexual misconduct with inmates.

This publication is developed by the NIC/WCL Project on Addressing Prison Rape under NIC Cooperative Agreement 06S20GJJ1.

This is not to be reproduced or cited without permission from the authors.

American University, Washington College of Law

Current as of May 7, 2009 


\section{Fifty State Survey of Mandatory Reporting Statutes}

\section{NIC/WCL Project on Addressing Prison Rape}

\begin{tabular}{|c|c|}
\hline $\begin{array}{l}\text { Mandatory } \\
\text { Reporting Statute } \\
\text { (Washington) }\end{array}$ & $\begin{array}{l}\text { AGAINST A CHILD } \\
\text { W.A. S.T. § } 26.44 .030 \text { (West 2008) }\end{array}$ \\
\hline $\begin{array}{l}\text { What has to be } \\
\text { reported? } \\
\text { (Washington) }\end{array}$ & $\begin{array}{l}\text { W.A. S.T. § } 26.44 .030 \text { (West 2008) } \\
\text { (1)(a) Reasonable cause to believe that a child has suffered abuse or neglect. }\end{array}$ \\
\hline $\begin{array}{l}\text { Relevant Definitions } \\
\text { (Washington) }\end{array}$ & $\begin{array}{l}\text { W.A. S.T. § } 26.44 .020 \text { (West 2008) } \\
\text { (6) Child or children means any person under the age of eighteen years of age. } \\
\text { (12) Abuse or neglect means sexual abuse, sexual exploitation, or injury of a child by any person under circumstances which cause } \\
\text { harm to the child's health, welfare, or safety, excluding conduct permitted under RCW 9A.16.100; or the negligent treatment or } \\
\text { maltreatment of a child by a person responsible for or providing care to the child. An abused child is a child who has been } \\
\text { subjected to child abuse or neglect as defined in this section. } \\
\text { (14) Sexual exploitation includes: (a) Allowing, permitting, or encouraging a child to engage in prostitution by any person; or (b) } \\
\text { allowing, permitting, encouraging, or engaging in the obscene or pornographic photographing, filming, or depicting of a child by } \\
\text { any person. } \\
\text { (15) Negligent treatment or maltreatment means an act or a failure to act, or the cumulative effects of a pattern of conduct, } \\
\text { behavior, or inaction, that evidences a serious disregard of consequences of such magnitude as to constitute a clear and present } \\
\text { danger to a child's health, welfare, or safety, including but not limited to conduct prohibited under RCW } 9 \text { A.42.100. When } \\
\text { considering whether a clear and present danger exists, evidence of a parent's substance abuse as a contributing factor to negligent } \\
\text { treatment or maltreatment shall be given great weight. The fact that siblings share a bedroom is not, in and of itself, negligent } \\
\text { treatment or maltreatment. Poverty, homelessness, or exposure to domestic violence as defined in RCW } 26.50 .010 \text { that is }\end{array}$ \\
\hline
\end{tabular}

NOTE:

** For purposes of this chart, corrections officers, police officers, peace officers, probation officers or “catch-all” phrases such as “all persons” have been bolded. However, many mandatory reporters include professionals who may have contact or work in correctional facilities. Such individuals include physicians, nurses, dentists, teachers and social workers. These statutes can be used as a tool to require staff other than correctional officers to report sexual misconduct with inmates.

This publication is developed by the NIC/WCL Project on Addressing Prison Rape under NIC Cooperative Agreement 06S20GJJ1.

This is not to be reproduced or cited without permission from the authors.

American University, Washington College of Law

Current as of May 7, 2009 


\section{Fifty State Survey of Mandatory Reporting Statutes}

\section{NIC/WCL Project on Addressing Prison Rape}

\begin{tabular}{|c|c|}
\hline $\begin{array}{l}\text { Relevant Definitions } \\
\text { Cont'd } \\
\text { (Washington) }\end{array}$ & perpetrated against someone other than the child does not constitute negligent treatment or maltreatment in and of itself. \\
\hline $\begin{array}{l}\text { Persons Required to } \\
\text { Report } \\
\text { (Washington) }\end{array}$ & 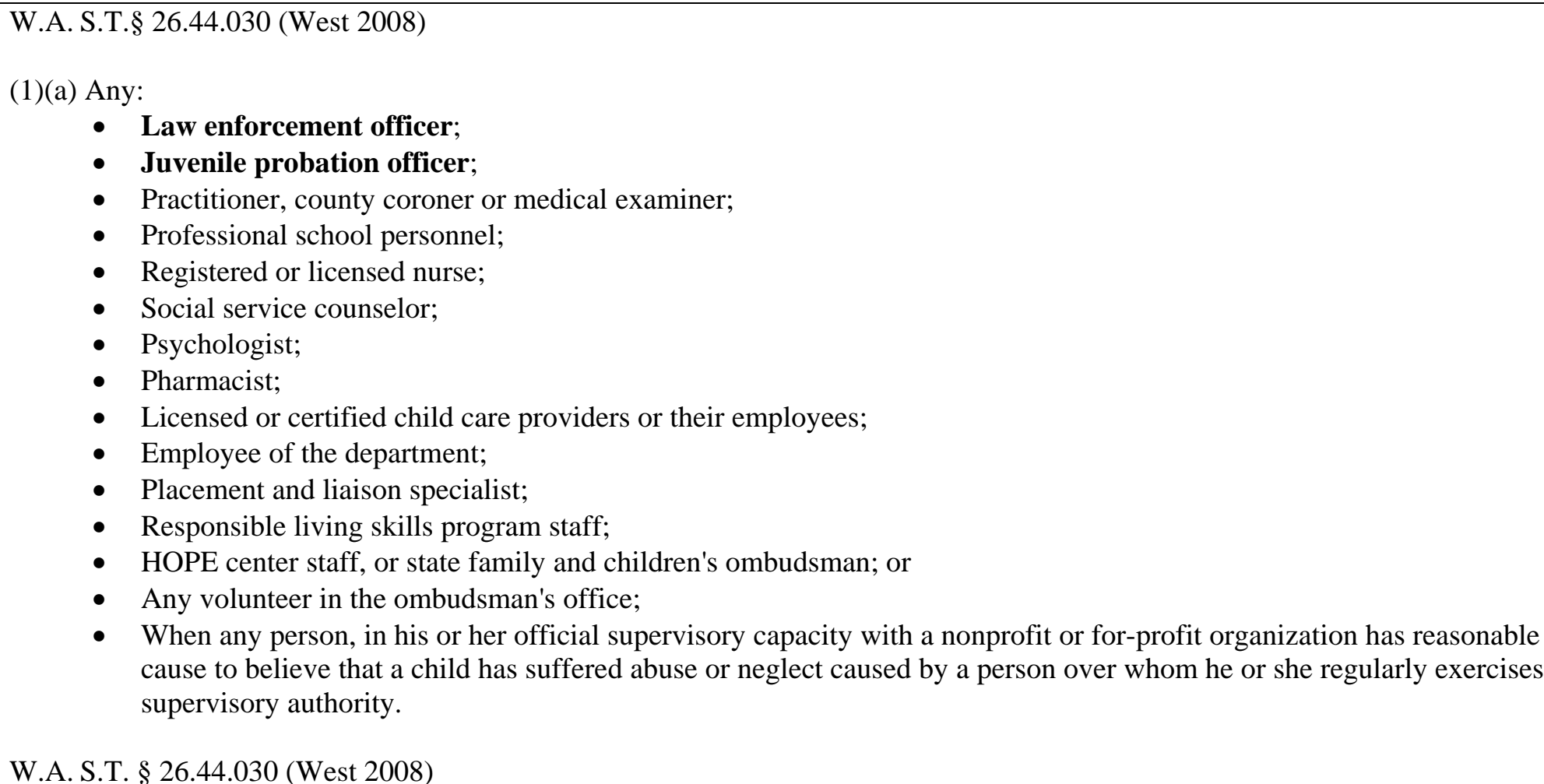 \\
\hline
\end{tabular}

NOTE:

** For purposes of this chart, corrections officers, police officers, peace officers, probation officers or "catch-all” phrases such as "all persons" have been bolded. However, many mandatory reporters include professionals who may have contact or work in correctional facilities. Such individuals include physicians, nurses, dentists, teachers and social workers. These statutes can be used as a tool to require staff other than correctional officers to report sexual misconduct with inmates.

This publication is developed by the NIC/WCL Project on Addressing Prison Rape under NIC Cooperative Agreement 06S20GJJ1.

This is not to be reproduced or cited without permission from the authors.

American University, Washington College of Law

Current as of May 7, 2009 


\section{Fifty State Survey of Mandatory Reporting Statutes}

\section{NIC/WCL Project on Addressing Prison Rape}

\begin{tabular}{|c|c|}
\hline $\begin{array}{l}\text { Persons Required to } \\
\text { Report Cont'd } \\
\text { (Washington) }\end{array}$ & $\begin{array}{l}\text { (1)(c) The reporting requirement also applies to department of corrections personnel who, in the course of their employment, } \\
\text { observe offenders or the children with whom the offenders are in contact. If, as a result of observations or information received } \\
\text { in the course of his or her employment, any department of corrections personnel has reasonable cause to believe that a child has } \\
\text { suffered abuse or neglect, he or she shall report the incident, or cause a report to be made, to the proper law enforcement agency or } \\
\text { to the department. }\end{array}$ \\
\hline $\begin{array}{l}\text { Reporting } \\
\text { Procedures } \\
\text { (Washington) }\end{array}$ & $\begin{array}{l}\text { W.A. S.T. } § 26.44 .040 \text { (West 2008) } \\
\text { An immediate oral report must be made by telephone or otherwise to the proper law enforcement agency or the department of } \\
\text { social and health services and, upon request, must be followed by a report in writing. Such reports must contain the following } \\
\text { information, if known: } \\
\text { (1) The name, address, and age of the child; } \\
\text { (2) The name and address of the child's parents, stepparents, guardians, or other persons having custody of the child; } \\
\text { (3) The nature and extent of the alleged injury or injuries; } \\
\text { (4) The nature and extent of the alleged neglect; } \\
\text { (5) The nature and extent of the alleged sexual abuse; } \\
\text { (6) Any evidence of previous injuries, including their nature and extent; and } \\
\text { (7) Any other information that may be helpful in establishing the cause of the child's death, injury, or injuries and the identity of } \\
\text { the alleged perpetrator or perpetrators. }\end{array}$ \\
\hline $\begin{array}{l}\text { Penalty for Failure to } \\
\text { Report } \\
\text { (Washington) }\end{array}$ & $\begin{array}{l}\text { W.A. S.T. § } 26.44 .080 \text { (West 2008) } \\
\text { Every person who is required to make, or to cause to be made, a report pursuant to RCW } 26.44 .030 \text { and } 26.44 .040 \text {, and who } \\
\text { knowingly fails to make, or fails to cause to be made, such report, shall be guilty of a gross misdemeanor. } \\
\text { W.A.S.T. § 9.92.020 (West 2008) }\end{array}$ \\
\hline
\end{tabular}

NOTE:

** For purposes of this chart, corrections officers, police officers, peace officers, probation officers or "catch-all” phrases such as “all persons” have been bolded. However, many mandatory reporters include professionals who may have contact or work in correctional facilities. Such individuals include physicians, nurses, dentists, teachers and social workers. These statutes can be used as a tool to require staff other than correctional officers to report sexual misconduct with inmates.

This publication is developed by the NIC/WCL Project on Addressing Prison Rape under NIC Cooperative Agreement 06S20GJJ1.

This is not to be reproduced or cited without permission from the authors.

American University, Washington College of Law

Current as of May 7, 2009 


\section{Fifty State Survey of Mandatory Reporting Statutes}

\section{NIC/WCL Project on Addressing Prison Rape}

\begin{tabular}{|c|c|}
\hline $\begin{array}{l}\text { Penalty for Failure to } \\
\text { Report Cont'd } \\
\text { (Washington) }\end{array}$ & $\begin{array}{l}\text { Imprisonment in the county jail for a maximum term fixed by the court of not more than one year, or by a fine in an amount fixed } \\
\text { by the court of not more than five thousand dollars, or by both such imprisonment and fine. }\end{array}$ \\
\hline $\begin{array}{l}\text { Mandatory } \\
\text { Reporting Statute } \\
\text { (Washington) }\end{array}$ & $\begin{array}{l}\text { AGAINST AN ADULT } \\
\text { W.A. S.T. § } 74.34 .035 \text { (West 2008) }\end{array}$ \\
\hline $\begin{array}{l}\text { What has to be } \\
\text { reported? } \\
\text { (Washington) }\end{array}$ & $\begin{array}{l}\text { W.A. S.T. } § 74.34 .035 \text { (West 2008) } \\
\text { (1) When there is reasonable cause to believe that abandonment, abuse, financial exploitation, or neglect of a vulnerable adult has } \\
\text { occurred, mandated reporters shall immediately report to the department. } \\
\text { (2) When there is reason to suspect that sexual assault has occurred, mandated reporters shall immediately report to the appropriate } \\
\text { law enforcement agency and to the department. } \\
\text { (3) When there is reason to suspect that physical assault has occurred or there is reasonable cause to believe that an act has caused } \\
\text { fear of imminent harm. }\end{array}$ \\
\hline $\begin{array}{l}\text { Relevant Definitions } \\
\text { (Washington) }\end{array}$ & $\begin{array}{l}\text { W.A. S.T. } § 74.34 .021 \text { (West 2008) } \\
\text { (15) Vulnerable adult includes persons receiving services from any individual who for compensation serves as a personal aide to a } \\
\text { person who self-directs his or her own care in his or her home. } \\
\text { W.A. S.T. } § 74.34 .020 \text { (West 2008) } \\
\text { (2) Abuse means the willful action or inaction that inflicts injury, unreasonable confinement, intimidation, or punishment on a } \\
\text { vulnerable adult. In instances of abuse of a vulnerable adult who is unable to express or demonstrate physical harm, pain, or }\end{array}$ \\
\hline
\end{tabular}

NOTE:

** For purposes of this chart, corrections officers, police officers, peace officers, probation officers or “catch-all” phrases such as “all persons” have been bolded. However, many mandatory reporters include professionals who may have contact or work in correctional facilities. Such individuals include physicians, nurses, dentists, teachers and social workers. These statutes can be used as a tool to require staff other than correctional officers to report sexual misconduct with inmates.

This publication is developed by the NIC/WCL Project on Addressing Prison Rape under NIC Cooperative Agreement 06S20GJJ1.

This is not to be reproduced or cited without permission from the authors.

American University, Washington College of Law

Current as of May 7, 2009 


\section{Fifty State Survey of Mandatory Reporting Statutes}

\section{NIC/WCL Project on Addressing Prison Rape}

\begin{tabular}{|c|c|}
\hline $\begin{array}{l}\text { Relevant Definitions } \\
\text { Cont'd } \\
\text { (Washington) }\end{array}$ & $\begin{array}{l}\text { mental anguish, the abuse is presumed to cause physical harm, pain, or mental anguish. Abuse includes sexual abuse, mental } \\
\text { abuse, physical abuse, and exploitation of a vulnerable adult, which have the following meanings: } \\
\text { (a) Sexual abuse means any form of nonconsensual sexual contact, including but not limited to unwanted or inappropriate } \\
\text { touching, rape, sodomy, sexual coercion, sexually explicit photographing, and sexual harassment. Sexual abuse includes } \\
\text { any sexual contact between a staff person, who is not also a resident or client, and a vulnerable adult living in that facility } \\
\text { or receiving service from a program, whether or not it is consensual. } \\
\text { (b) Physical abuse means the willful action of inflicting bodily injury or physical mistreatment. Physical abuse includes, but is } \\
\text { not limited to, striking with or without an object, slapping, pinching, choking, kicking, shoving, prodding, or the use of } \\
\text { chemical restraints or physical restraints unless the restraints are consistent with licensing requirements, and includes } \\
\text { restraints that are otherwise being used inappropriately } \\
\text { (c) Mental abuse means any willful action or inaction of mental or verbal abuse. Mental abuse includes, but is not limited to, } \\
\text { coercion, harassment, inappropriately isolating a vulnerable adult from family, friends, or regular activity, and verbal } \\
\text { assault that includes ridiculing, intimidating, yelling, or swearing. } \\
\text { (d) Exploitation means an act of forcing, compelling, or exerting undue influence over a vulnerable adult causing the } \\
\text { vulnerable adult to act in a way that is inconsistent with relevant past behavior, or causing the vulnerable adult to perform } \\
\text { services for the benefit of another. }\end{array}$ \\
\hline $\begin{array}{l}\text { Persons Required to } \\
\text { Report } \\
\text { (Washington) }\end{array}$ & $\begin{array}{l}\text { W.A. S.T. § } 74.34 .020 \text { (West 2008) } \\
\text { (10) Employee of the department; law enforcement officer; social worker; professional school personnel; individual provider; an } \\
\text { employee of a facility; an operator of a facility; an employee of a social service, welfare, mental health, adult day health, adult day } \\
\text { care, home health, home care, or hospice agency; county coroner or medical examiner; Christian Science practitioner; or health } \\
\text { care provider. }\end{array}$ \\
\hline
\end{tabular}

** For purposes of this chart, corrections officers, police officers, peace officers, probation officers or "catch-all” phrases such as "all persons" have been bolded. However, many mandatory reporters include professionals who may have contact or work in correctional facilities. Such individuals include physicians, nurses, dentists, teachers and social workers. These statutes can be used as a tool to require staff other than correctional officers to report sexual misconduct with inmates.

This publication is developed by the NIC/WCL Project on Addressing Prison Rape under NIC Cooperative Agreement 06S20GJJ1.

This is not to be reproduced or cited without permission from the authors.

American University, Washington College of Law

Current as of May 7, 2009 


\section{Fifty State Survey of Mandatory Reporting Statutes}

\section{NIC/WCL Project on Addressing Prison Rape}

\begin{tabular}{|c|c|}
\hline $\begin{array}{l}\text { Reporting } \\
\text { Procedures } \\
\text { (Washington) }\end{array}$ & $\begin{array}{l}\text { W.A. S.T. } § 74.34 .035 \text { (West 2008) } \\
\text { (3)(a)-(b) Mandated reporters shall immediately report to the department of social and health services. } \\
\text { (1) When there is reason to suspect that sexual assault has occurred, mandated reporters shall immediately report to the appropriate } \\
\text { law enforcement agency and to the department. } \\
\text { (2) When there is reason to suspect that sexual assault has occurred, mandated reporters shall immediately report to the appropriate } \\
\text { law enforcement agency and to the department. } \\
\text { (7) Each report, oral or written, must contain as much as possible of the following information: } \\
\text { (a) The name and address of the person making the report; } \\
\text { (b) The name and address of the vulnerable adult and the name of the facility or agency providing care for the vulnerable adult; } \\
\text { (c) The name and address of the legal guardian or alternate decision maker; } \\
\text { (d) The nature and extent of the abandonment, abuse, financial exploitation, neglect, or self-neglect; } \\
\text { (e) Any history of previous abandonment, abuse, financial exploitation, neglect, or self-neglect; } \\
\text { (f) The identity of the alleged perpetrator, if known; and } \\
\text { (g) Other information that may be helpful in establishing the extent of abandonment, abuse, financial exploitation, neglect, or the } \\
\text { cause of death of the deceased vulnerable adult. }\end{array}$ \\
\hline $\begin{array}{l}\text { Penalty for Failure to } \\
\text { Report } \\
\text { (Washington) }\end{array}$ & $\begin{array}{l}\text { W.A. S.T. } \S 74.34 .053 \text { (West 2008) } \\
\text { (1) A person who is required to make a report under this chapter and who knowingly fails to make the report is guilty of a gross } \\
\text { misdemeanor. }\end{array}$ \\
\hline
\end{tabular}

NOTE:

** For purposes of this chart, corrections officers, police officers, peace officers, probation officers or “catch-all” phrases such as “all persons” have been bolded. However, many mandatory reporters include professionals who may have contact or work in correctional facilities. Such individuals include physicians, nurses, dentists, teachers and social workers. These statutes can be used as a tool to require staff other than correctional officers to report sexual misconduct with inmates.

This publication is developed by the NIC/WCL Project on Addressing Prison Rape under NIC Cooperative Agreement 06S20GJJ1.

This is not to be reproduced or cited without permission from the authors.

American University, Washington College of Law

Current as of May 7, 2009 


\section{Fifty State Survey of Mandatory Reporting Statutes}

\section{NIC/WCL Project on Addressing Prison Rape}

\begin{tabular}{|c|c|}
\hline \multicolumn{2}{|r|}{ WEST VIRGINIA } \\
\hline $\begin{array}{l}\text { Mandatory } \\
\text { Reporting Statute } \\
\text { (West Virginia) }\end{array}$ & $\begin{array}{l}\text { AGAINST A CHILD } \\
\text { W. VA. CODE } \S 49-6 A-2 \text { (West 2008) }\end{array}$ \\
\hline $\begin{array}{l}\text { What has to be } \\
\text { reported? } \\
\text { (West Virginia) }\end{array}$ & $\begin{array}{l}\text { W. VA. CODE § 49-6A-2 (West 2008) } \\
\text { Reasonable cause to suspect that a child is neglected or abused or observes the child being subjected to conditions that are likely to } \\
\text { result in abuse or neglect. }\end{array}$ \\
\hline $\begin{array}{l}\text { Relevant Definitions } \\
\text { (West Virginia) }\end{array}$ & $\begin{array}{l}\text { W. VA. CODE § 49-1-3 (West 2008) } \\
\text { (a) “Abused child” means a child whose health or welfare is harmed or threatened by: } \\
\text { 1. A parent, guardian or custodian who knowingly or intentionally inflicts, attempts to inflict or knowingly allows another } \\
\text { person to inflict, physical injury or mental or emotional injury, upon the child or another child in the home; o } \\
\text { 2. Sexual abuse or sexual exploitation; or } \\
\text { 3. The sale or attempted sale of a child by a parent, guardian or custodian; } \\
\text { 4. Domestic violence as defined in section two hundred two, article twenty-seven, chapter forty-eight of this code. } \\
\text { (j)(1) "Neglected child” means a child: } \\
\text { (A) Whose physical or mental health is harmed or threatened by a present refusal, failure or inability of the child's parent, } \\
\text { guardian or custodian to supply the child with necessary food, clothing, shelter, supervision, medical care or education, when } \\
\text { such refusal, failure or inability is not due primarily to a lack of financial means on the part of the parent, guardian or }\end{array}$ \\
\hline
\end{tabular}

NOTE:

** For purposes of this chart, corrections officers, police officers, peace officers, probation officers or "catch-all” phrases such as "all persons" have been bolded. However, many mandatory reporters include professionals who may have contact or work in correctional facilities. Such individuals include physicians, nurses, dentists, teachers and social workers. These statutes can be used as a tool to require staff other than correctional officers to report sexual misconduct with inmates.

This publication is developed by the NIC/WCL Project on Addressing Prison Rape under NIC Cooperative Agreement 06S20GJJ1.

This is not to be reproduced or cited without permission from the authors.

American University, Washington College of Law

Current as of May 7, 2009 


\section{Fifty State Survey of Mandatory Reporting Statutes}

\section{NIC/WCL Project on Addressing Prison Rape}

\begin{tabular}{|c|c|}
\hline $\begin{array}{l}\text { Relevant Definitions } \\
\text { Cont'd } \\
\text { (West Virginia) }\end{array}$ & 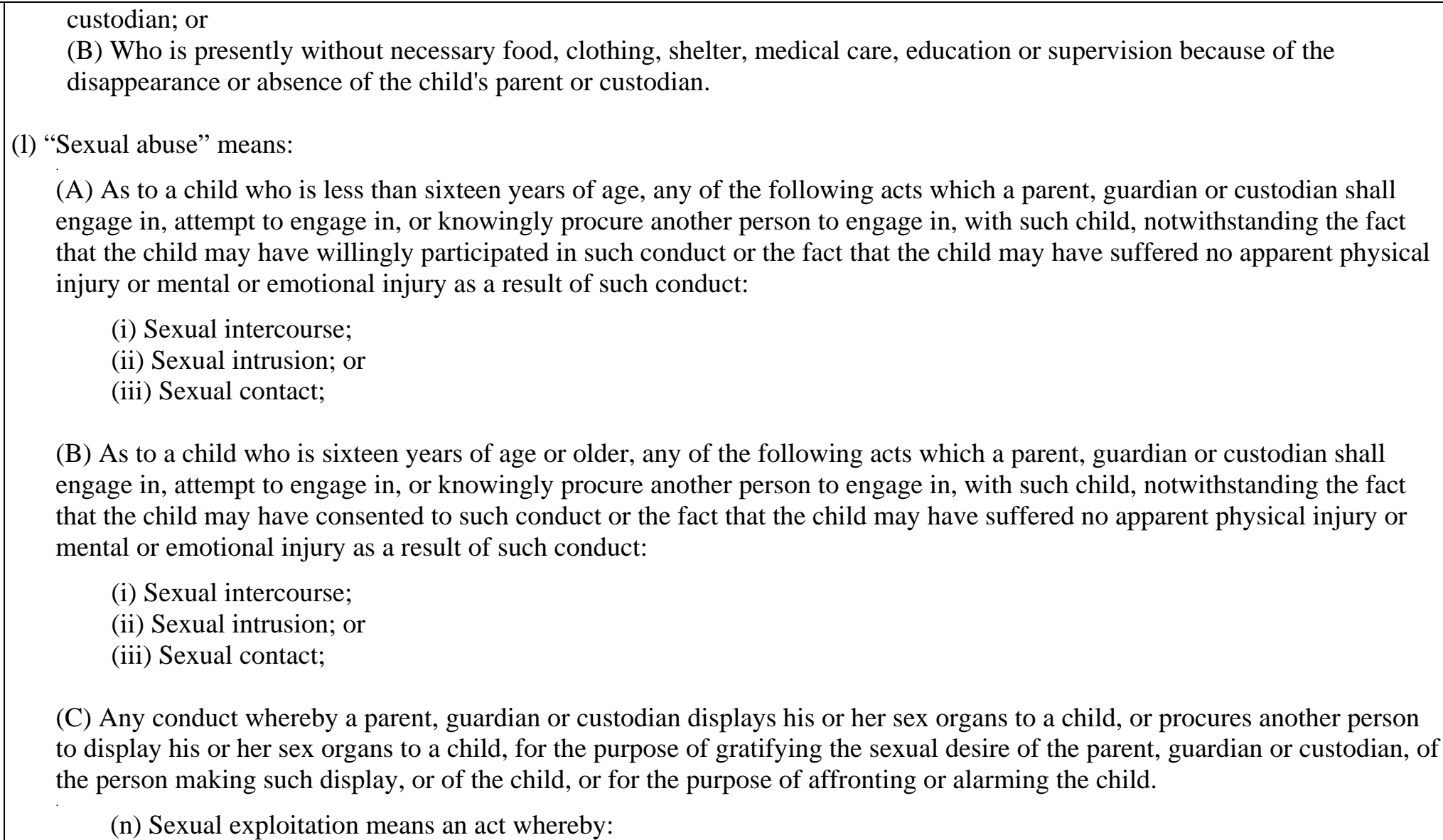 \\
\hline
\end{tabular}

NOTE:

** For purposes of this chart, corrections officers, police officers, peace officers, probation officers or "catch-all” phrases such as “all persons” have been bolded. However, many mandatory reporters include professionals who may have contact or work in correctional facilities. Such individuals include physicians, nurses, dentists, teachers and social workers. These statutes can be used as a tool to require staff other than correctional officers to report sexual misconduct with inmates.

This publication is developed by the NIC/WCL Project on Addressing Prison Rape under NIC Cooperative Agreement 06S20GJJ1.

This is not to be reproduced or cited without permission from the authors.

American University, Washington College of Law

Current as of May 7, 2009 


\title{
Fifty State Survey of Mandatory Reporting Statutes
}

\section{NIC/WCL Project on Addressing Prison Rape}

\begin{tabular}{|c|c|}
\hline $\begin{array}{l}\text { Relevant Definitions } \\
\text { Cont'd } \\
\text { (West Virginia) }\end{array}$ & $\begin{array}{l}\text { (1) A parent, custodian or guardian, whether for financial gain or not, persuades, induces, entices or coerces a child to } \\
\text { engage in sexually explicit conduct as that term is defined in section one, article eight-c, chapter sixty-one of this code; } \\
\text { (2) A parent, guardian or custodian persuades, induces, entices or coerces a child to display his or her sex organs for the } \\
\text { sexual gratification of the parent, guardian, custodian or a third person, or to display his or her sex organs under } \\
\text { circumstances in which the parent, guardian or custodian knows such display is likely to be observed by others who } \\
\text { would be affronted or alarmed }\end{array}$ \\
\hline $\begin{array}{l}\text { Persons Required to } \\
\text { Report } \\
\text { (West Virginia) }\end{array}$ & $\begin{array}{l}\text { W. VA. CODE } § 49-6 A-2 \text { (West 2008) } \\
\text { • Peace officer or law-enforcement official; } \\
\text { - } \quad \text { Medical, dental or mental health professional, Christian science practitioner, religious healer, emergency medical } \\
\text { - } \\
\text { - Services personnel; } \\
\text { - Social service worker, child care or foster care worker; } \\
\text { - } \quad \text { Member of the clergy; } \\
\text { - Circuit court judge, family law master, employee of the division of juvenile services or magistrate. }\end{array}$ \\
\hline $\begin{array}{l}\text { Reporting } \\
\text { Procedures } \\
\text { (West Virginia) }\end{array}$ & $\begin{array}{l}\text { W. VA. CODE } § 49-6 A-2 \text { (West 2008) } \\
\text { Shall immediately, and not more than } 48 \text { hours after suspecting this abuse, report the circumstances or cause a report to be made to } \\
\text { the state department of human services: Provided, That in any case where the reporter believes that the child suffered serious } \\
\text { physical abuse or sexual abuse or sexual assault, the reporter shall also immediately report, or cause a report to be made, to the } \\
\text { division of public safety and any law-enforcement agency having jurisdiction to investigate the complaint: Provided, however, } \\
\text { That any person required to report under this article who is a member of the staff of a public or private institution, school, facility } \\
\text { or agency shall immediately notify the person in charge of such institution, school, facility or agency, or a designated agent }\end{array}$ \\
\hline
\end{tabular}

\section{NOTE:}

\begin{abstract}
** For purposes of this chart, corrections officers, police officers, peace officers, probation officers or "catch-all” phrases such as "all persons" have been bolded. However, many mandatory reporters include professionals who may have contact or work in correctional facilities. Such individuals include physicians, nurses, dentists, teachers and social workers. These statutes can be used as a tool to require staff other than correctional officers to report sexual misconduct with inmates.
\end{abstract}

This publication is developed by the NIC/WCL Project on Addressing Prison Rape under NIC Cooperative Agreement 06S20GJJ1.

This is not to be reproduced or cited without permission from the authors.

American University, Washington College of Law

Current as of May 7, 2009 


\section{Fifty State Survey of Mandatory Reporting Statutes}

\section{NIC/WCL Project on Addressing Prison Rape}

\begin{tabular}{|c|c|}
\hline $\begin{array}{l}\text { Reporting } \\
\text { Procedures Cont'd } \\
\text { (West Virginia) }\end{array}$ & thereof, who shall report or cause a report to be made. \\
\hline $\begin{array}{l}\text { Penalty for Failure to } \\
\text { Report } \\
\text { (West Virginia) }\end{array}$ & $\begin{array}{l}\text { W. VA. CODE } § 49-6 A-8 \text { (West 2008) } \\
\text { Any person, official or institution required by this article to report a case involving a child known or suspected to be abused or } \\
\text { neglected, or required by section five of this article to forward a copy of a report of serious injury, who knowingly fails to do so or } \\
\text { knowingly prevents another person acting reasonably from doing so, shall be guilty of a misdemeanor, and, upon conviction } \\
\text { thereof, shall be confined in the county jail not more than } 10 \text { days or fined not more than } \$ 100.00 \text {, or both. }\end{array}$ \\
\hline $\begin{array}{l}\text { Mandatory } \\
\text { Reporting Statute } \\
\text { (West Virginia) }\end{array}$ & $\begin{array}{l}\text { AGAINST AN ADULT } \\
\text { W. VA. CODE } \S 9-6-9 \text { (West 2008) }\end{array}$ \\
\hline $\begin{array}{l}\text { What has to be } \\
\text { reported? } \\
\text { (West Virginia) }\end{array}$ & $\begin{array}{l}\text { W. VA. CODE } § 9-6-9 \text { (West 2008) } \\
\text { (a) Reasonable cause to believe that an incapacitated adult or facility resident is or has been neglected, abused or placed in an } \\
\text { emergency situation, or if such person observes an incapacitated adult or facility resident being subjected to conditions that are } \\
\text { likely to result in abuse, neglect or an emergency situation. }\end{array}$ \\
\hline $\begin{array}{l}\text { Relevant Definitions } \\
\text { (West Virginia) }\end{array}$ & $\begin{array}{l}\text { W. VA. CODE § 9-6-1 (West 2008) } \\
\text { (2) “Abuse” means the infliction or threat to inflict physical pain or injury on or the imprisonment of any incapacitated adult or } \\
\text { facility resident. }\end{array}$ \\
\hline
\end{tabular}

NOTE:

** For purposes of this chart, corrections officers, police officers, peace officers, probation officers or "catch-all” phrases such as "all persons" have been bolded. However, many mandatory reporters include professionals who may have contact or work in correctional facilities. Such individuals include physicians, nurses, dentists, teachers and social workers. These statutes can be used as a tool to require staff other than correctional officers to report sexual misconduct with inmates.

This publication is developed by the NIC/WCL Project on Addressing Prison Rape under NIC Cooperative Agreement 06S20GJJ1.

This is not to be reproduced or cited without permission from the authors.

American University, Washington College of Law

Current as of May 7, 2009 


\section{Fifty State Survey of Mandatory Reporting Statutes}

\section{NIC/WCL Project on Addressing Prison Rape}

\begin{tabular}{|c|c|}
\hline $\begin{array}{l}\text { Persons Required to } \\
\text { Report } \\
\text { (West Virginia) }\end{array}$ & 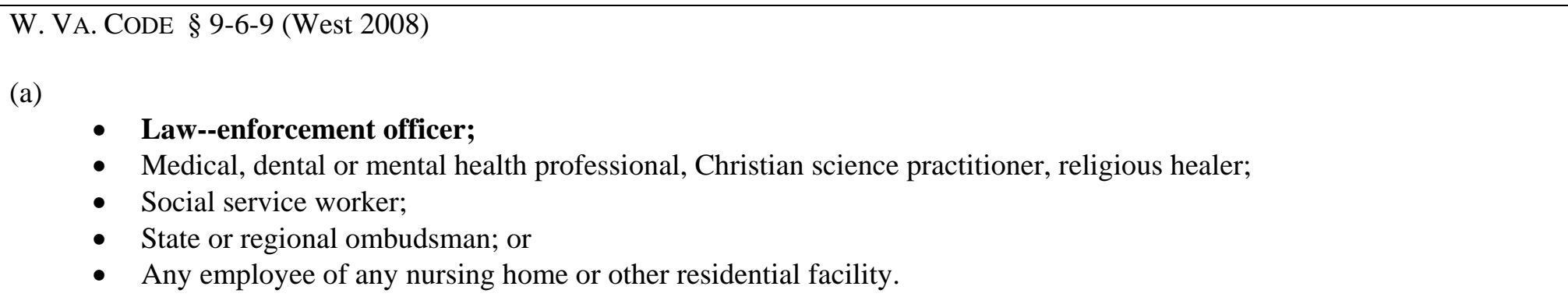 \\
\hline $\begin{array}{l}\text { Reporting } \\
\text { Procedures } \\
\text { (West Virginia) }\end{array}$ & $\begin{array}{l}\text { W. VA. CODE } \S 9-6-9 \text { (West 2008) } \\
\text { (a) Shall immediately report the circumstances pursuant to the provisions of section eleven [§ 9-6-11]. } \\
\text { W. VA. CODE ANN. § 9-6-11 (West 2008) } \\
\text { (a) A report of neglect or abuse of an incapacitated adult or facility resident or of an emergency situation involving such an adult } \\
\text { shall be made immediately by telephone to the department's local adult protective services agency and shall be followed by a } \\
\text { written report by the complainant or the receiving agency within } 48 \text { hours. }\end{array}$ \\
\hline $\begin{array}{l}\text { Penalty for Failure to } \\
\text { Report } \\
\text { (West Virginia) }\end{array}$ & $\begin{array}{l}\text { W. VA. CODE § 9-6-14 (West 2008) } \\
\text { Any person subject to the mandatory reporting provisions of this article who knowingly fails to make any report required herein or } \\
\text { any person who knowingly prevents another person from making such a report is guilty of a misdemeanor, and, upon conviction } \\
\text { thereof, shall be fined not more than one hundred dollars or imprisoned in the county jail for not more than ten days, or both fined } \\
\text { and imprisoned. }\end{array}$ \\
\hline
\end{tabular}

NOTE:

** For purposes of this chart, corrections officers, police officers, peace officers, probation officers or “catch-all” phrases such as “all persons” have been bolded. However, many mandatory reporters include professionals who may have contact or work in correctional facilities. Such individuals include physicians, nurses, dentists, teachers and social workers. These statutes can be used as a tool to require staff other than correctional officers to report sexual misconduct with inmates.

This publication is developed by the NIC/WCL Project on Addressing Prison Rape under NIC Cooperative Agreement 06S20GJJ1.

This is not to be reproduced or cited without permission from the authors.

American University, Washington College of Law

Current as of May 7, 2009 


\section{Fifty State Survey of Mandatory Reporting Statutes}

\section{NIC/WCL Project on Addressing Prison Rape}

\begin{tabular}{|c|c|}
\hline \multicolumn{2}{|r|}{ WISCONSIN } \\
\hline $\begin{array}{l}\text { Mandatory } \\
\text { Reporting Statute } \\
\text { (Wisconsin) }\end{array}$ & $\begin{array}{l}\text { AGAINST A CHILD } \\
\text { W.S.A. § } 48.981 \text { (West 2008) }\end{array}$ \\
\hline $\begin{array}{l}\text { What has to be } \\
\text { reported? } \\
\text { (Wisconsin) }\end{array}$ & $\begin{array}{l}\text { W.S.A. } § 48.981 \text { (West 2008) } \\
\text { (2) Reasonable cause to suspect that a child seen by the person in the course of professional duties has been abused or neglected or } \\
\text { who has reason to believe that a child seen by the person in the course of professional duties has been threatened with abuse or } \\
\text { neglect and that abuse or neglect of the child will occur. }\end{array}$ \\
\hline $\begin{array}{l}\text { Relevant Definitions } \\
\text { (Wisconsin) }\end{array}$ & $\begin{array}{l}\text { W.S.A. § } 48.02 \text { (West 2008) } \\
\text { (1) “Abuse” other than when used in referring to abuse of alcohol beverages or other drugs, means any of the following: } \\
\text { (a) Physical injury inflicted on a child by other than accidental means: } \\
\text { (am) When used in referring to an unborn child, serious physical harm inflicted on the unborn child, and the risk of serious } \\
\text { physical harm to the child when born, caused by the habitual lack of self-control of the expectant mother of the unborn child } \\
\text { in the use of alcohol beverages, controlled substances or controlled substance analogs, exhibited to a severe degree. } \\
\text { (b) Sexual intercourse sexual contact } \\
\text { (c) Sexual Exploitation of a child } \\
\text { (d) Permitting, allowing or encouraging a child to commit prostitution } \\
\text { (e) Intentionally causes a child under the age of } 18 \text { to view or listen to sexually explicit conduct if the viewing or listening is } \\
\text { for the purpose of sexually arousing or gratifying the actor or humiliating or degrading the child. } \\
\text { (f) Causes a child to expose genitals or pubic area or exposes genitals or pubic area to a child for purposes of sexual arousal or } \\
\text { sexual gratification }\end{array}$ \\
\hline
\end{tabular}

NOTE:

** For purposes of this chart, corrections officers, police officers, peace officers, probation officers or "catch-all” phrases such as "all persons" have been bolded. However, many mandatory reporters include professionals who may have contact or work in correctional facilities. Such individuals include physicians, nurses, dentists, teachers and social workers. These statutes can be used as a tool to require staff other than correctional officers to report sexual misconduct with inmates.

This publication is developed by the NIC/WCL Project on Addressing Prison Rape under NIC Cooperative Agreement 06S20GJJ1.

This is not to be reproduced or cited without permission from the authors.

American University, Washington College of Law

Current as of May 7, 2009 


\section{Fifty State Survey of Mandatory Reporting Statutes}

\section{NIC/WCL Project on Addressing Prison Rape}

\begin{tabular}{|c|c|}
\hline $\begin{array}{l}\text { Relevant Definitions } \\
\text { Cont'd } \\
\text { (Wisconsin) }\end{array}$ & 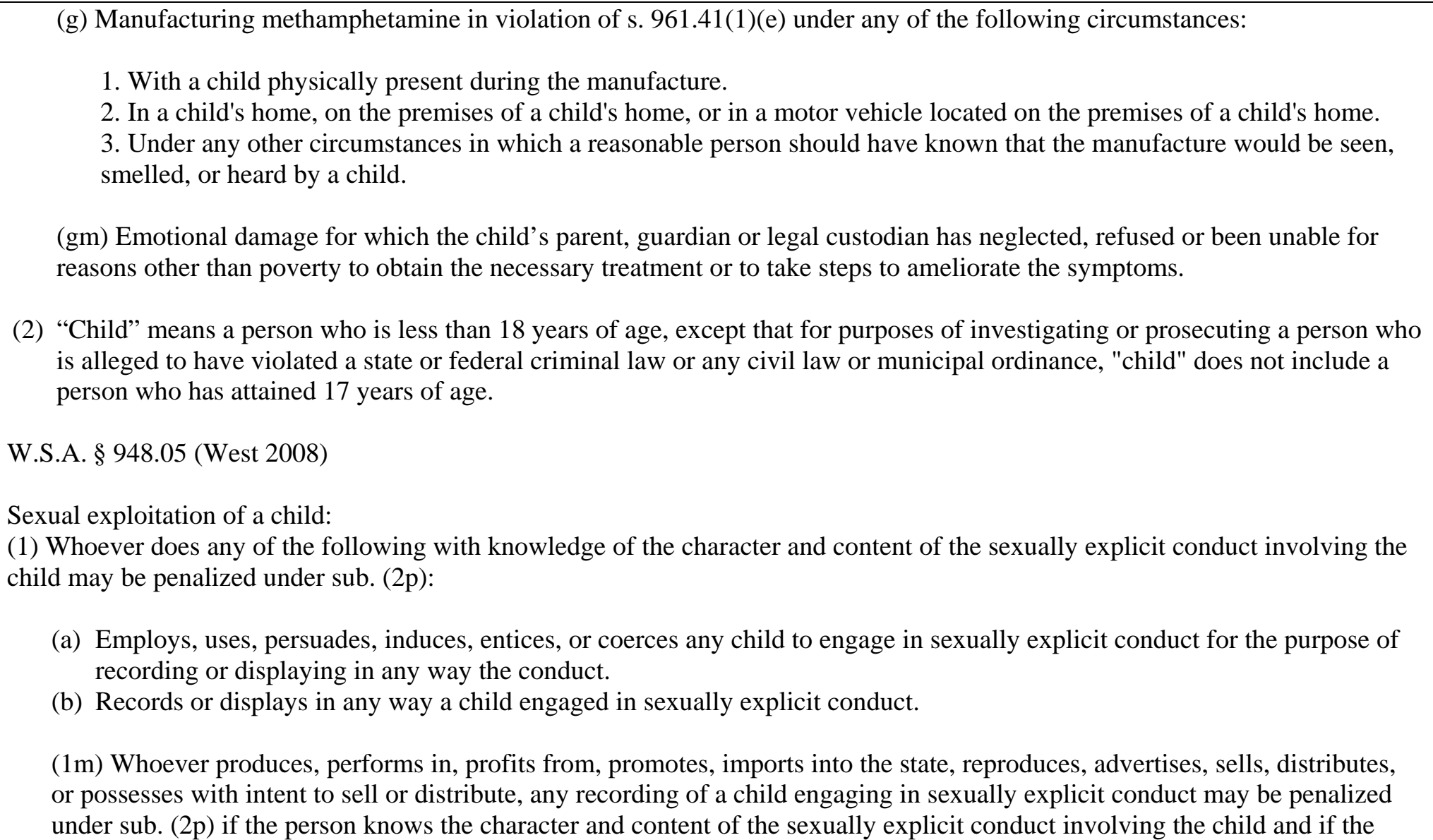 \\
\hline
\end{tabular}

NOTE:

** For purposes of this chart, corrections officers, police officers, peace officers, probation officers or “catch-all” phrases such as “all persons” have been bolded. However, many mandatory reporters include professionals who may have contact or work in correctional facilities. Such individuals include physicians, nurses, dentists, teachers and social workers. These statutes can be used as a tool to require staff other than correctional officers to report sexual misconduct with inmates.

This publication is developed by the NIC/WCL Project on Addressing Prison Rape under NIC Cooperative Agreement 06S20GJJ1.

This is not to be reproduced or cited without permission from the authors.

American University, Washington College of Law

Current as of May 7, 2009 


\section{Fifty State Survey of Mandatory Reporting Statutes}

\section{NIC/WCL Project on Addressing Prison Rape}

\begin{tabular}{|c|c|}
\hline $\begin{array}{l}\text { Relevant Definitions } \\
\text { Cont'd } \\
\text { (Wisconsin) }\end{array}$ & $\begin{array}{l}\text { person knows or reasonably should know that the child engaging in the sexually explicit conduct has not attained the age of } 18 \\
\text { years. } \\
\text { (2) A person responsible for a child's welfare who knowingly permits, allows or encourages the child to engage in sexually } \\
\text { explicit conduct for a purpose proscribed in sub. (1)(a) or (b) or (1m) may be penalized under sub. ( } 2 \text { p). } \\
\text { (2p)(a) Except as provided in par. (b), a person who violates sub. (1), (1m), or ( } 2 \text { ) is guilty of a Class C felony. } \\
\text { (b) A person who violates sub. (1), (1m), or (2) is guilty of a Class F felony if the person is under } 18 \text { years of age when the } \\
\text { offense occurs. } \\
\text { (3) It is an affirmative defense to prosecution for violation of sub. (1)(a) or (b) or (2) if the defendant had reasonable cause to } \\
\text { believe that the child had attained the age of } 18 \text { years. A defendant who raises this affirmative defense has the burden of } \\
\text { proving this defense by a preponderance of the evidence. } \\
\text { W.S.A. § } 48.981 \text { (West 2008) } \\
\text { "Neglect” means failure, refusal or inability on the part of a caregiver, for reasons other than poverty, to provide necessary care, } \\
\text { food, clothing, medical or dental care or shelter so as to seriously endanger the physical health of the child. }\end{array}$ \\
\hline $\begin{array}{l}\text { Persons Required to } \\
\text { Report } \\
\text { (Wisconsin) }\end{array}$ & $\begin{array}{l}\text { W.S.A. } § 48.981 \text { (West 2008) } \\
\text { 1. A child-care worker in a day care center, group home, or residential care center for children and youth; } \\
\text { (2)(a) Any of the following persons who has reasonable cause to suspect that a child seen by the person in the course of } \\
\text { professional duties has been abused or neglected or who has reason to believe that a child seen by the person in the course of } \\
\text { professional duties has been threatened with abuse or neglect and that abuse or neglect of the child will occur shall, except as } \\
\text { provided under sub. (2m), report as provided in sub. (3): }\end{array}$ \\
\hline
\end{tabular}

NOTE:

** For purposes of this chart, corrections officers, police officers, peace officers, probation officers or “catch-all” phrases such as “all persons” have been bolded. However, many mandatory reporters include professionals who may have contact or work in correctional facilities. Such individuals include physicians, nurses, dentists, teachers and social workers. These statutes can be used as a tool to require staff other than correctional officers to report sexual misconduct with inmates.

This publication is developed by the NIC/WCL Project on Addressing Prison Rape under NIC Cooperative Agreement 06S20GJJ1.

This is not to be reproduced or cited without permission from the authors.

American University, Washington College of Law

Current as of May 7, 2009 


\section{Fifty State Survey of Mandatory Reporting Statutes}

\section{NIC/WCL Project on Addressing Prison Rape}

\begin{tabular}{|c|c|}
\hline $\begin{array}{l}\text { Persons Required to } \\
\text { Report Cont'd } \\
\text { (Wisconsin) }\end{array}$ & 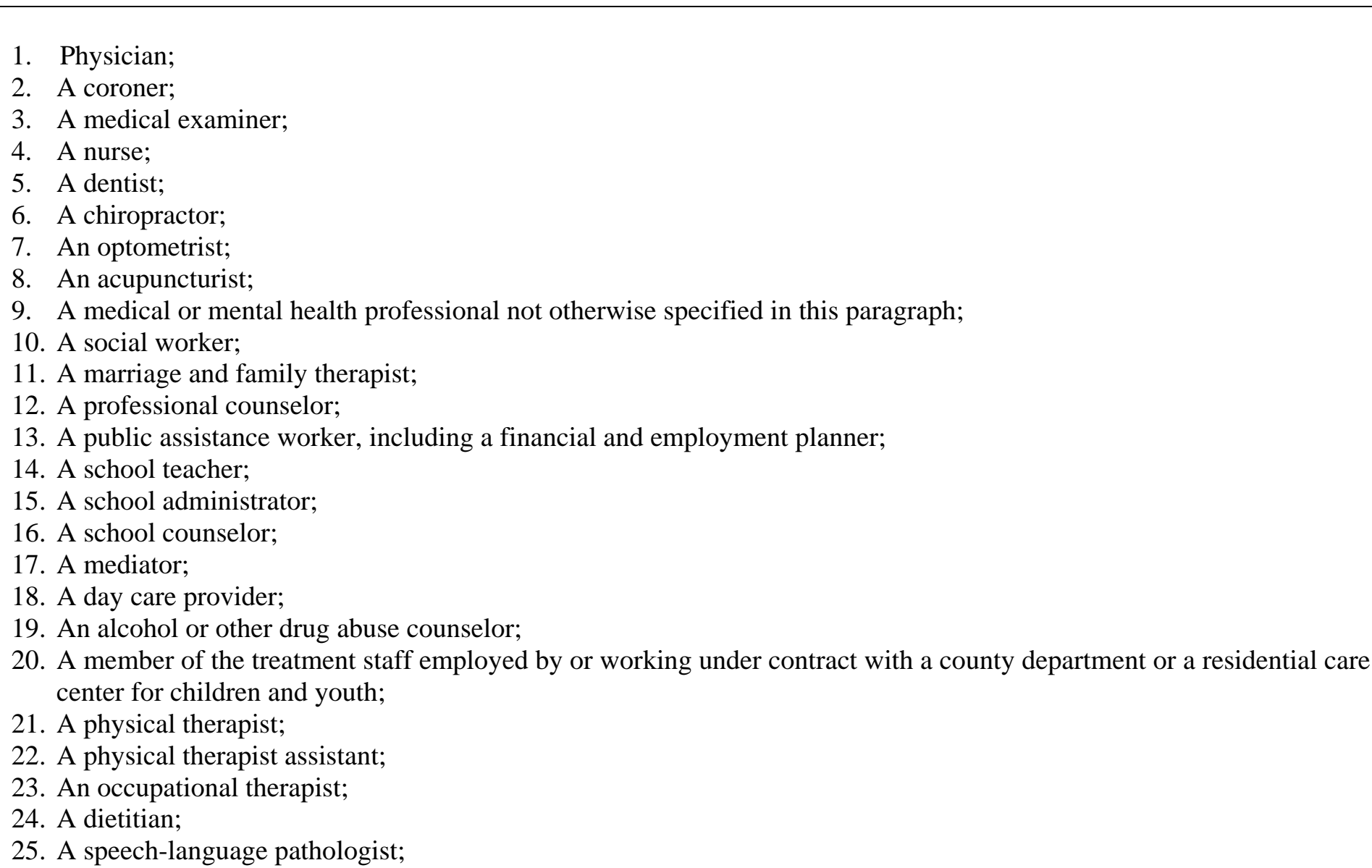 \\
\hline
\end{tabular}

NOTE:

** For purposes of this chart, corrections officers, police officers, peace officers, probation officers or "catch-all” phrases such as “all persons” have been bolded. However, many mandatory reporters include professionals who may have contact or work in correctional facilities. Such individuals include physicians, nurses, dentists, teachers and social workers. These statutes can be used as a tool to require staff other than correctional officers to report sexual misconduct with inmates.

This publication is developed by the NIC/WCL Project on Addressing Prison Rape under NIC Cooperative Agreement 06S20GJJ1.

This is not to be reproduced or cited without permission from the authors.

American University, Washington College of Law

Current as of May 7, 2009 


\section{Fifty State Survey of Mandatory Reporting Statutes}

\section{NIC/WCL Project on Addressing Prison Rape}

\begin{tabular}{|c|c|}
\hline $\begin{array}{l}\text { Persons Required to } \\
\text { Report Cont'd } \\
\text { (Wisconsin) }\end{array}$ & $\begin{array}{l}\text { 26. An audiologist; } \\
\text { 27. An emergency medical technician; } \\
\text { 28. A first responder; } \\
\text { 29. A law enforcement officer; } \\
\text { 30. Member of the clergy (except for privileged communication). }\end{array}$ \\
\hline $\begin{array}{l}\text { Reporting } \\
\text { Procedures } \\
\text { (Wisconsin) }\end{array}$ & $\begin{array}{l}\text { W.S.A. } \S 48.981 \text { (West 2008) } \\
\text { (3)(a)(1) A person required to report shall immediately inform, by telephone or personally, the county department or, in a county } \\
\text { having a population of 500,000 or more, the department or a licensed child welfare agency under contract with the department or } \\
\text { the sheriff or city, village, or town police department of the facts and circumstances contributing to a suspicion of child abuse or } \\
\text { neglect or of unborn child abuse or to a belief that abuse or neglect will occur. }\end{array}$ \\
\hline $\begin{array}{l}\text { Penalty for Failure to } \\
\text { Report } \\
\text { (Wisconsin) }\end{array}$ & $\begin{array}{l}\text { W.S.A. } § 48.981 \text { (West 2008) } \\
\text { (6) Whoever intentionally violates this section by failure to report as required may be fined not more than } \$ 1,000 \text { or imprisoned } \\
\text { not more than } 6 \text { months or both. }\end{array}$ \\
\hline $\begin{array}{l}\text { Mandatory } \\
\text { Reporting Statute } \\
\text { (Wisconsin) }\end{array}$ & $\begin{array}{l}\text { AGAINST AN ADULT } \\
\text { W.S.A. § } 46.90 \text { (West 2008) }\end{array}$ \\
\hline $\begin{array}{l}\text { What has to be } \\
\text { reported? } \\
\text { (Wisconsin) }\end{array}$ & $\begin{array}{l}\text { W.S.A. } § 46.90 \text { (West 2008) } \\
\text { (4)(ad) A mandated reporter who has seen an elder adult at risk in the course of the person's professional duties. }\end{array}$ \\
\hline
\end{tabular}

NOTE:

** For purposes of this chart, corrections officers, police officers, peace officers, probation officers or “catch-all” phrases such as “all persons” have been bolded. However, many mandatory reporters include professionals who may have contact or work in correctional facilities. Such individuals include physicians, nurses, dentists, teachers and social workers. These statutes can be used as a tool to require staff other than correctional officers to report sexual misconduct with inmates.

This publication is developed by the NIC/WCL Project on Addressing Prison Rape under NIC Cooperative Agreement 06S20GJJ1.

This is not to be reproduced or cited without permission from the authors.

American University, Washington College of Law

Current as of May 7, 2009 


\section{Fifty State Survey of Mandatory Reporting Statutes}

\section{NIC/WCL Project on Addressing Prison Rape}

\begin{tabular}{|c|c|}
\hline $\begin{array}{l}\text { Relevant Definitions } \\
\text { (Wisconsin) }\end{array}$ & $\begin{array}{l}\text { W.S.A. § } 46.90 \text { (West 2008) } \\
\text { (a) Abuse means any of the following: } \\
\text { 1. Physical abuse. } \\
\text { 2. Emotional abuse. } \\
\text { 3. Sexual abuse. } \\
\text { 4. Treatment without consent. } \\
\text { 5. Unreasonable confinement or restraint. } \\
\text { (br) Elder adult at risk means any person age } 60 \text { or older who has experienced, is currently experiencing, or is at risk of } \\
\text { experiencing abuse, neglect, self-neglect, or financial exploitation. } \\
\text { (cm) Emotional abuse means language or behavior that serves no legitimate purpose and is intended to be intimidating, } \\
\text { humiliating, threatening, frightening, or otherwise harassing, and that does or reasonably could intimidate, humiliate, threaten, } \\
\text { frighten, or otherwise harass the individual to whom the conduct or language is directed. } \\
\text { (ed) Financial exploitation means any of the following: } \\
\text { 1. Obtaining an individual's money or property by deceiving or enticing the individual, or by forcing, compelling, or coercing } \\
\text { the individual to give, sell at less than fair market value, or in other ways convey money or property against his or her will } \\
\text { without his or her informed consent. } \\
\text { 2. Theft } \\
\text { 3. The substantial failure or neglect of a fiscal agent to fulfill his or her responsibilities. } \\
\text { 4. Unauthorized use of an individual's personal identifying information or documents } \\
\text { 5. Unauthorized use of an entity's identifying information or documents } \\
\text { 6. Forgery } \\
\text { 7. Financial transaction card crimes }\end{array}$ \\
\hline
\end{tabular}

NOTE:

** For purposes of this chart, corrections officers, police officers, peace officers, probation officers or "catch-all” phrases such as "all persons" have been bolded. However, many mandatory reporters include professionals who may have contact or work in correctional facilities. Such individuals include physicians, nurses, dentists, teachers and social workers. These statutes can be used as a tool to require staff other than correctional officers to report sexual misconduct with inmates.

This publication is developed by the NIC/WCL Project on Addressing Prison Rape under NIC Cooperative Agreement 06S20GJJ1.

This is not to be reproduced or cited without permission from the authors.

American University, Washington College of Law

Current as of May 7, 2009 


\section{Fifty State Survey of Mandatory Reporting Statutes}

\section{NIC/WCL Project on Addressing Prison Rape}

\begin{tabular}{|c|c|}
\hline $\begin{array}{l}\text { Relevant Definitions } \\
\text { Cont'd } \\
\text { (Wisconsin) }\end{array}$ & $\begin{array}{l}\text { (f) Neglect means the failure of a caregiver, as evidenced by an act, omission, or course of conduct, to endeavor to secure or } \\
\text { maintain adequate care, services, or supervision for an individual, including food, clothing, shelter, or physical or mental health } \\
\text { care, and creating significant risk or danger to the individual's physical or mental health. "Neglect" does not include a decision that } \\
\text { is made to not seek medical care for an individual, if that decision is consistent with the individual's previously executed } \\
\text { declaration or do-not-resuscitate order under ch. 154, a power of attorney for health care under ch. 155, or as otherwise authorized } \\
\text { by law. } \\
\text { (fg) Physical abuse means the intentional or reckless infliction of bodily harm. } \\
\text { (g) Self-neglect means a significant danger to an individual's physical or mental health because the individual is responsible for his } \\
\text { or her own care but fails to obtain adequate care, including food, shelter, clothing, or medical or dental care. }\end{array}$ \\
\hline $\begin{array}{l}\text { Persons Required to } \\
\text { Report } \\
\text { (Wisconsin) }\end{array}$ & $\begin{array}{l}\text { W.S.A. § } 46.90 \text { (West 2008) } \\
\text { 4) Reporting. (ab) The following persons shall file reports: } \\
\text { (1) An employee of any entity that is licensed, certified, or approved by or registered with the department; } \\
\text { (3) A health care provider; } \\
\text { (4) A social worker, professional counselor, or marriage and family therapist. }\end{array}$ \\
\hline $\begin{array}{l}\text { Reporting } \\
\text { Procedures } \\
\text { (Wisconsin) }\end{array}$ & $\begin{array}{l}\text { W.S.A. § } 46.90 \text { (West 2008) } \\
\text { Mandated Reporters shall file a report with the county department, the elder-adult-at-risk agency, a state or local law enforcement } \\
\text { agency, the department, or the board on aging and long-term care if the elder adult at risk has requested the person to make the } \\
\text { report, or if the person has reasonable cause to believe the abuse has occurred. }\end{array}$ \\
\hline
\end{tabular}

NOTE:

** For purposes of this chart, corrections officers, police officers, peace officers, probation officers or “catch-all” phrases such as “all persons” have been bolded. However, many mandatory reporters include professionals who may have contact or work in correctional facilities. Such individuals include physicians, nurses, dentists, teachers and social workers. These statutes can be used as a tool to require staff other than correctional officers to report sexual misconduct with inmates.

This publication is developed by the NIC/WCL Project on Addressing Prison Rape under NIC Cooperative Agreement 06S20GJJ1.

This is not to be reproduced or cited without permission from the authors.

American University, Washington College of Law

Current as of May 7, 2009 


\title{
Fifty State Survey of Mandatory Reporting Statutes
}

\section{NIC/WCL Project on Addressing Prison Rape}

\begin{tabular}{|c|c|}
\hline $\begin{array}{l}\text { Penalty for Failure to } \\
\text { Report } \\
\text { (Wisconsin) }\end{array}$ & $\begin{array}{l}\text { W.S.A. } § 46.90 \text { (West 2008) } \\
\text { (9)(e) Whoever intentionally violates sub. (4)(ad) by failure to report as required may be fined not more than } \$ 500 \text { or imprisoned } \\
\text { not more than } 6 \text { months or both. }\end{array}$ \\
\hline & WYOMING \\
\hline $\begin{array}{l}\text { Mandatory } \\
\text { Reporting Statute } \\
\text { (Wyoming) }\end{array}$ & $\begin{array}{l}\text { AGAINST A CHILD } \\
\text { W.S. } 1977 \S 14-3-205 \text { (West 2008) }\end{array}$ \\
\hline $\begin{array}{l}\text { What has to be } \\
\text { reported? } \\
\text { (Wyoming) }\end{array}$ & $\begin{array}{l}\text { W.S. } 1977 \text { § 14-3-205 (West 2008) } \\
\text { (a) A person who knows or has reasonable cause to believe or suspect that a child has been abused or neglected or who observes } \\
\text { any child being subjected to conditions or circumstances that would reasonably result in abuse or neglect. }\end{array}$ \\
\hline $\begin{array}{l}\text { Relevant Definitions } \\
\text { (Wyoming) }\end{array}$ & $\begin{array}{l}\text { W.S. } 1977 \S 14-3-202 \text { (West 2008) } \\
\text { (ii) “Abuse” means inflicting or causing physical or mental injury, harm or imminent danger to the physical or mental health or } \\
\text { welfare of a child other than by accidental means, including abandonment, unless the abandonment is a relinquishment } \\
\text { substantially in accordance with W.S. 14-11-101 through 14-11-109, excessive or unreasonable corporal punishment, malnutrition } \\
\text { or substantial risk thereof by reason of intentional or unintentional neglect, and the commission or allowing the commission of a } \\
\text { sexual offense against a child as defined by law: } \\
\text { (A) “Mental injury” means an injury to the psychological capacity or emotional stability of a child as evidenced by an } \\
\text { observable or substantial impairment in his ability to function within a normal range of performance and behavior with due }\end{array}$ \\
\hline
\end{tabular}

\section{NOTE:}

observable or substantial impairment in his ability to function within a normal range of performance and behavior with due

\begin{abstract}
** For purposes of this chart, corrections officers, police officers, peace officers, probation officers or "catch-all” phrases such as "all persons" have been bolded. However, many mandatory reporters include professionals who may have contact or work in correctional facilities. Such individuals include physicians, nurses, dentists, teachers and social workers. These statutes can be used as a tool to require staff other than correctional officers to report sexual misconduct with inmates.
\end{abstract}

This publication is developed by the NIC/WCL Project on Addressing Prison Rape under NIC Cooperative Agreement 06S20GJJ1.

This is not to be reproduced or cited without permission from the authors.

American University, Washington College of Law

Current as of May 7, 2009 


\section{Fifty State Survey of Mandatory Reporting Statutes}

\section{NIC/WCL Project on Addressing Prison Rape}

\begin{tabular}{|c|c|}
\hline $\begin{array}{l}\text { Relevant Definitions } \\
\text { Cont'd } \\
\text { (Wyoming) }\end{array}$ & $\begin{array}{l}\text { regard to his culture; } \\
\text { (B) "Physical injury" means any harm to a child including but not limited to disfigurement, impairment of any bodily organ, } \\
\text { skin bruising if greater in magnitude than minor bruising associated with reasonable corporal punishment, bleeding, burns, } \\
\text { fracture of any bone, subdural hematoma or substantial malnutrition; } \\
\text { (C) "Substantial risk" means a strong possibility as contrasted with a remote or insignificant possibility; } \\
\text { (D) Imminent danger includes threatened harm and means a statement, overt act, condition or status which represents an } \\
\text { immediate and substantial risk of sexual abuse or physical or mental injury. } \\
\text { (iii) “Child” means any person under the age of eighteen (18) } \\
\text { (vii) "Neglect" means a failure or refusal by those responsible for the child's welfare to provide adequate care, maintenance, } \\
\text { supervision, education or medical, surgical or any other care necessary for the child's well being. Treatment given in good faith by } \\
\text { spiritual means alone, through prayer, by a duly accredited practitioner in accordance with the tenets and practices of a recognized } \\
\text { church or religious denomination is not child neglect for that reason alone. }\end{array}$ \\
\hline $\begin{array}{l}\text { Persons Required to } \\
\text { Report } \\
\text { (Wyoming) }\end{array}$ & $\begin{array}{l}\text { W.S. } 1977 \text { § 14-3-205 (West 2008) } \\
\text { (a) Any person. }\end{array}$ \\
\hline $\begin{array}{l}\text { Reporting } \\
\text { Procedures } \\
\text { (Wyoming) }\end{array}$ & $\begin{array}{l}\text { W.S. } 1977 \S 14-3-205 \text { (West 2008) } \\
\text { (a) Immediately report to the child protective agency or local law enforcement agency or cause a report to be made. } \\
\text { (b) If a person reporting child abuse or neglect is a member of the staff of a medical or other public or private institution, school, } \\
\text { facility or agency, he shall notify the person in charge or his designated agent as soon as possible, who is thereupon also } \\
\text { responsible to make the report or cause the report to be made. }\end{array}$ \\
\hline
\end{tabular}

NOTE:

** For purposes of this chart, corrections officers, police officers, peace officers, probation officers or “catch-all” phrases such as “all persons” have been bolded. However, many mandatory reporters include professionals who may have contact or work in correctional facilities. Such individuals include physicians, nurses, dentists, teachers and social workers. These statutes can be used as a tool to require staff other than correctional officers to report sexual misconduct with inmates.

This publication is developed by the NIC/WCL Project on Addressing Prison Rape under NIC Cooperative Agreement 06S20GJJ1.

This is not to be reproduced or cited without permission from the authors.

American University, Washington College of Law

Current as of May 7, 2009 


\section{Fifty State Survey of Mandatory Reporting Statutes}

\section{NIC/WCL Project on Addressing Prison Rape}

\begin{tabular}{|c|c|}
\hline $\begin{array}{l}\text { Penalty for Failure to } \\
\text { Report } \\
\text { (Wyoming) }\end{array}$ & $\begin{array}{l}\text { W.S. } 1977 \S 14-3-205 \text { (West 2008) } \\
\text { (c) Any employer, public or private, who discharges, suspends, disciplines or penalizes an employee solely for making a report of } \\
\text { neglect or abuse under W.S. 14-3-201 through } 14-3-216 \text { is guilty of a misdemeanor punishable by imprisonment for not more than } \\
\text { six (6) months, a fine of not more than seven hundred fifty dollars ( } \$ 750.00) \text {, or both. } \\
\text { (d) Any person who knowingly and intentionally makes a false report of child abuse or neglect, or who encourages or coerces } \\
\text { another person to make a false report of child abuse or neglect, is guilty of a misdemeanor punishable by imprisonment for not } \\
\text { more than six (6) months, a fine of not more than seven hundred fifty dollars ( } \$ 750.00) \text {, or both. }\end{array}$ \\
\hline $\begin{array}{l}\text { Mandatory } \\
\text { Reporting Statute } \\
\text { (Wyoming) }\end{array}$ & $\begin{array}{l}\text { AGAINST AN ADULT } \\
\text { W.S. } 1977 \S 35-20-111 \text { (West 2008) }\end{array}$ \\
\hline $\begin{array}{l}\text { What has to be } \\
\text { reported? } \\
\text { (Wyoming) }\end{array}$ & $\begin{array}{l}\text { W.S. } 1977 \S 35-20-111 \text { (West 2008) } \\
\text { (a) Without exception to a person or agency who knows, or has sufficient knowledge which a prudent and cautious man in similar } \\
\text { circumstances would have to believe, that a vulnerable adult has been or is being abused, neglected, exploited or abandoned, or is } \\
\text { committing self neglect. }\end{array}$ \\
\hline $\begin{array}{l}\text { Relevant Definitions } \\
\text { (Wyoming) }\end{array}$ & $\begin{array}{l}\text { W.S. } 1977 \text { § 35-20-102 (West 2008) } \\
\text { (a)(ii) “Abuse” means the intentional or reckless infliction, by the vulnerable adult's caregiver, family member or other individual } \\
\text { of: } \\
\text { (A) Injury; } \\
\text { (B) Unreasonable confinement which threatens the welfare and well being of a vulnerable adult; or } \\
\text { (C) Intimidation or cruel punishment with resulting physical or emotional harm or pain to a vulnerable adult. }\end{array}$ \\
\hline
\end{tabular}

NOTE:

** For purposes of this chart, corrections officers, police officers, peace officers, probation officers or "catch-all” phrases such as "all persons" have been bolded. However, many mandatory reporters include professionals who may have contact or work in correctional facilities. Such individuals include physicians, nurses, dentists, teachers and social workers. These statutes can be used as a tool to require staff other than correctional officers to report sexual misconduct with inmates.

This publication is developed by the NIC/WCL Project on Addressing Prison Rape under NIC Cooperative Agreement 06S20GJJ1.

This is not to be reproduced or cited without permission from the authors.

American University, Washington College of Law

Current as of May 7, 2009 


\section{Fifty State Survey of Mandatory Reporting Statutes}

\section{NIC/WCL Project on Addressing Prison Rape}

\begin{tabular}{|c|c|}
\hline $\begin{array}{l}\text { Relevant Definitions } \\
\text { Cont'd } \\
\text { (Wyoming) }\end{array}$ & 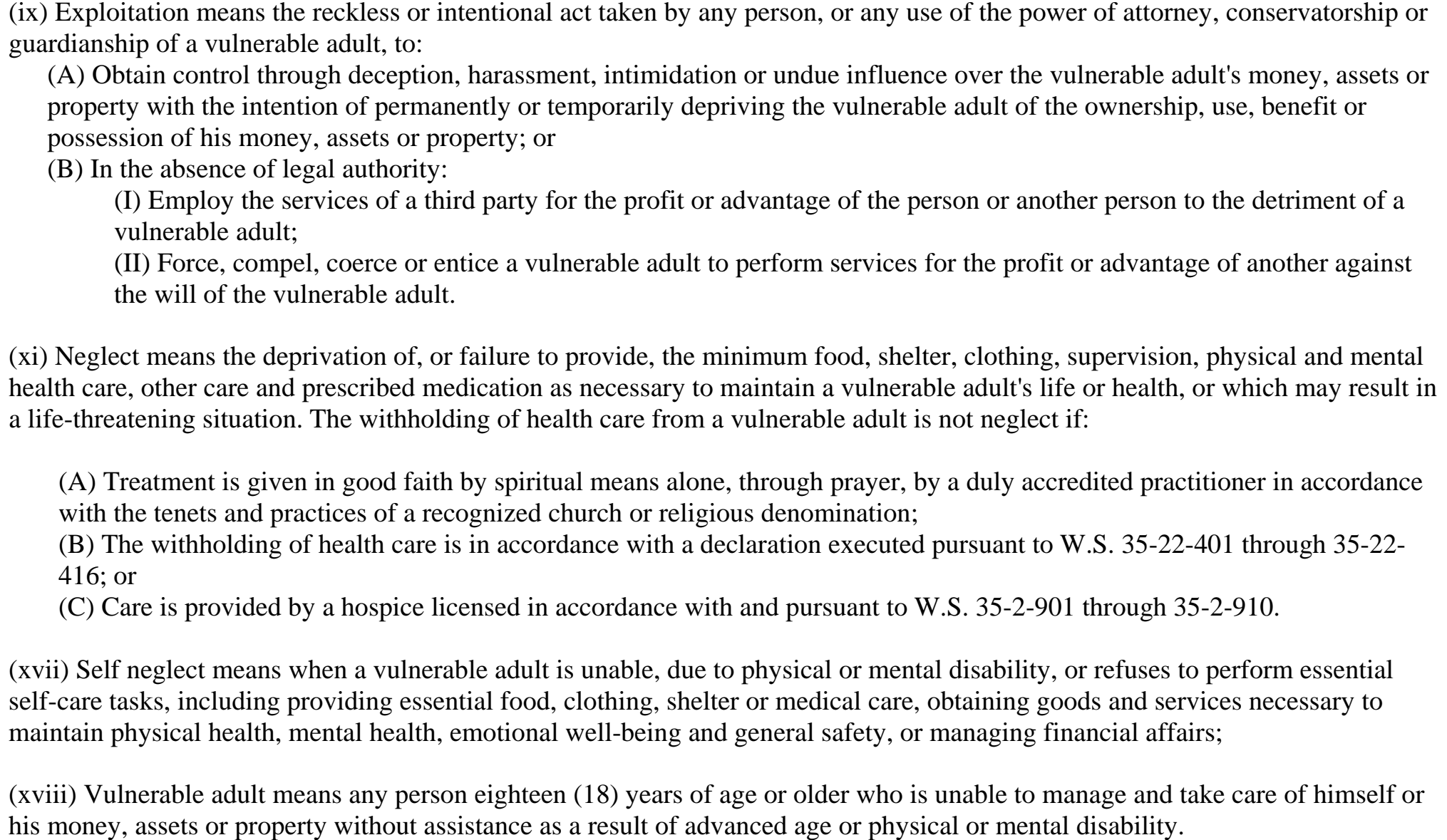 \\
\hline
\end{tabular}

NOTE:

** For purposes of this chart, corrections officers, police officers, peace officers, probation officers or “catch-all” phrases such as “all persons” have been bolded. However, many mandatory reporters include professionals who may have contact or work in correctional facilities. Such individuals include physicians, nurses, dentists, teachers and social workers. These statutes can be used as a tool to require staff other than correctional officers to report sexual misconduct with inmates.

This publication is developed by the NIC/WCL Project on Addressing Prison Rape under NIC Cooperative Agreement 06S20GJJ1.

This is not to be reproduced or cited without permission from the authors.

American University, Washington College of Law

Current as of May 7, 2009 


\section{Fifty State Survey of Mandatory Reporting Statutes}

\section{NIC/WCL Project on Addressing Prison Rape}

\begin{tabular}{|c|c|}
\hline $\begin{array}{l}\text { Persons Required to } \\
\text { Report } \\
\text { (Wyoming) }\end{array}$ & $\begin{array}{l}\text { W.S. } 1977 \S 35-20-111 \text { (West 2008) } \\
\text { (a) Any person or agency. }\end{array}$ \\
\hline $\begin{array}{l}\text { Reporting } \\
\text { Procedures } \\
\text { (Wyoming) }\end{array}$ & $\begin{array}{l}\text { W.S. } 1977 \S 35-20-103 \text { (West 2008) } \\
\text { (a) Report the information immediately to a law enforcement agency or the department. } \\
\text { (b) The report may be made orally or in writing. The report shall provide to law enforcement or the department the following, to } \\
\text { the extent available: } \\
\text { (i) The name, age and address of the vulnerable adult; } \\
\text { (ii) The name and address of any person responsible for the vulnerable adult's care; } \\
\text { (iii) The nature and extent of the vulnerable adult's condition; } \\
\text { (iv) The basis of the reporter's knowledge; } \\
\text { (v) The names and conditions of the other residents, if the vulnerable adult resides in a facility with other vulnerable adults; } \\
\text { (vi) An evaluation of the persons responsible for the care of the residents, if the vulnerable adult resides in a facility with other } \\
\text { vulnerable adults; } \\
\text { (vii) The adequacy of the facility environment; } \\
\text { (viii) Any evidence of previous injuries; } \\
\text { (ix) Any collaborative information; and } \\
\text { (x) Any other relevant information. }\end{array}$ \\
\hline $\begin{array}{l}\text { Penalty for Failure to } \\
\text { Report } \\
\text { (Wyoming) }\end{array}$ & $\begin{array}{l}\text { W.S. } 1977 \S 35-20-111 \text { (West 2008) } \\
\text { (b) Any person or agency who knows or has sufficient knowledge which a prudent and cautious man in similar } \\
\text { circumstances would have to believe that a vulnerable adult is being or has been abused, neglected, exploited or abandoned, or is } \\
\text { committing self neglect, and knowingly fails to report in accordance with this act is guilty of a misdemeanor punishable by } \\
\text { imprisonment for not more than one (1) year, a fine of not more than one thousand dollars }(\$ 1,000.00) \text {, or both. }\end{array}$ \\
\hline
\end{tabular}

NOTE:

** For purposes of this chart, corrections officers, police officers, peace officers, probation officers or “catch-all” phrases such as “all persons” have been bolded. However, many mandatory reporters include professionals who may have contact or work in correctional facilities. Such individuals include physicians, nurses, dentists, teachers and social workers. These statutes can be used as a tool to require staff other than correctional officers to report sexual misconduct with inmates.

This publication is developed by the NIC/WCL Project on Addressing Prison Rape under NIC Cooperative Agreement 06S20GJJ1.

This is not to be reproduced or cited without permission from the authors.

American University, Washington College of Law

Current as of May 7, 2009 


\section{Fifty State Survey of Mandatory Reporting Statutes}

\section{NIC/WCL Project on Addressing Prison Rape}

\begin{tabular}{|l|l|}
\hline \multicolumn{1}{|l|}{} \\
UNITED STATES \\
\hline $\begin{array}{l}\text { Mandatory } \\
\text { Reporting Statute } \\
\text { (Federal Law) }\end{array}$ & AGAINST A CHILD \\
\hline $\begin{array}{l}\text { Mandatory } \\
\text { Reporting Statute } \\
\text { (Federal Law) }\end{array}$ & $\begin{array}{l}\text { AGAINST AN ADULT } \\
\text { There is no federal mandatory reporting law. }\end{array}$ \\
\hline
\end{tabular}

${ }^{1}$ Consistent with original research through a NIC/WCL Project on Addressing Prison Rape listserv query, peace officers are NOT considered detention or correctional officers in Arizona.

${ }^{2}$ Consistent with original research through a NIC/WCL Project on Addressing Prison Rape listserv query, correctional officers ARE considered law enforcement officials in the District of Columbia.

${ }^{3}$ Consistent with original research through a NIC/WCL Project on Addressing Prison Rape listserv query, youth workers at the Kentucky Department of Juvenile Justice ARE mandatory reporters.

NOTE:

** For purposes of this chart, corrections officers, police officers, peace officers, probation officers or "catch-all” phrases such as "all persons" have been bolded. However, many mandatory reporters include professionals who may have contact or work in correctional facilities. Such individuals include physicians, nurses, dentists, teachers and social workers. These statutes can be used as a tool to require staff other than correctional officers to report sexual misconduct with inmates.

This publication is developed by the NIC/WCL Project on Addressing Prison Rape under NIC Cooperative Agreement 06S20GJJ1.

This is not to be reproduced or cited without permission from the authors.

American University, Washington College of Law

Current as of May 7, 2009 


\section{Fifty State Survey of Mandatory Reporting Statutes}

\section{NIC/WCL Project on Addressing Prison Rape}

${ }^{4}$ Consistent with original research through a NIC/WCL Project on Addressing Prison Rape listserv query, staff from the community corrections division are mandatory reporters. Kentucky is a unified corrections system; the Department of Community Corrections is a division under the Department of Corrections DOC staff are also mandatory reporters.

${ }^{5}$ Consistent with original research through a NIC/WCL Project on Addressing Prison Rape listserv query, correctional officers are public safety officers and are considered mandatory reporters in Montana.

${ }^{6}$ Consistent with original research through a NIC/WCL Project on Addressing Prison Rape listserv query, a correctional officer is not considered a law enforcement or a peace officer in Nebraska.

${ }^{7}$ Consistent with original research through a NIC/WCL Project on Addressing Prison Rape listserv query, a correctional officer is considered law enforcement and is a mandatory reporter in New Hampshire.

${ }^{8}$ Consistent with original research through a NIC/WCL Project on Addressing Prison Rape listserv query, peace officer does not include corrections officers in Ohio.

${ }^{9}$ Consistent with original research through a NIC/WCL Project on Addressing Prison Rape listserv query, a small number of correctional officers in Oklahoma are peace officers.

${ }^{10}$ Consistent with original research through a NIC/WCL Project on Addressing Prison Rape listserv query, in Oregon, whether correctional staff are peace officers depends on the county. If a Sherriff decides to make the jail staff peace officers, then they would be mandatory reporters. However, if the Sheriff does not consider correctional staff peace officers, they are not considered mandatory reporters.

${ }^{11}$ Consistent with original research through a NIC/WCL Project on Addressing Prison Rape listserv query, correctional officers are peace officers in Pennsylvania.

NOTE:

** For purposes of this chart, corrections officers, police officers, peace officers, probation officers or "catch-all” phrases such as "all persons" have been bolded. However, many mandatory reporters include professionals who may have contact or work in correctional facilities. Such individuals include physicians, nurses, dentists, teachers and social workers. These statutes can be used as a tool to require staff other than correctional officers to report sexual misconduct with inmates.

This publication is developed by the NIC/WCL Project on Addressing Prison Rape under NIC Cooperative Agreement 06S20GJJ1.

This is not to be reproduced or cited without permission from the authors.

American University, Washington College of Law

Current as of May 7, 2009 